\title{
Bruno Gonçalves Zeni
}

\section{Sinuca de malandro}

Narradores, protagonistas e figuras paternas

em João Antônio 


\section{Bruno Gonçalves Zeni}

\section{Sinuca de malandro}

\section{Narradores, protagonistas e figuras paternas em João Antônio}

Tese de doutorado apresentada ao Departamento de Teoria Literária e Literatura Comparada da Faculdade de Filosofia, Letras e Ciências Humanas da Universidade de São Paulo, sob orientação do Prof. Dr. Joaquim Alves de Aguiar 
Ao mеи pai, Marcio Zeni, que involuntariamente inspirou este trabalho. À minha mãe, Maria Rosa Gonçalves Zeni (in memoriam).

A Sílvia de Moraes Nastari Zeni, pelo dia a dia, pelas conversas, pela companhia, pelo amor. 


\section{Agradecimentos}

Agradeço a Joaquim Alves de Aguiar pela orientação, pelo apoio, pela confiança e pela amizade, em diálogos sobre literatura e vida que já passam de dez anos.

À Silvia, por tudo.

A Manuel da Costa Pinto e Paloma Vidal, pela amizade, pela troca intelectual e pelas indicações de leitura.

A Tatiana Couto, Suzana Couto, Andrew Loar, Lucas e Lina, pela alegria, pela vizinhança e por San Francisco.

Aos companheiros de pesquisa acadêmica Rodrigo Lacerda, Luciana Araújo Marques e Simone Paulino dos Santos.

À Capes (Coordenação de Aperfeiçoamento de Pessoal de Nível Superior), pela bolsa concedida.

A todos os funcionários do Departamento de Teoria Literária e Literatura Comparada (DTLLC), da Letras da USP, em especial a Luiz de Mattos Alves.

Aos pesquisadores e funcionários do Cedap (Centro de Documentação e Apoio à Pesquisa) da Faculdade de Ciências e Letras da Unesp de Assis, especialmente a Rodrigo Fukuhara, Carolina D.B. Monteiro e Denise Rosa, pela ajuda em minha pesquisa no Acervo João Antônio. 


\section{RESUMO}

Este trabalho analisa os contos e textos autobiográficos de João Antônio (19371996) nos quais as figuras paternas exercem papel decisivo para os protagonistas. A análise literária parte da identificação de elementos fundamentais do texto de ficção (tais como narrador, personagens e ação) e de como eles se articulam e interagem. As interpretações combinam elementos da crítica literária, da historiografia, de pesquisas bibliográfica e biográfica, apontando ainda para questões da sociologia e da psicanálise. O estudo parte das reflexões de Antonio Candido, crítico que formulou conceitos importantes para o autor em foco, para a crítica literária e para a linha de pesquisa que relaciona literatura e sociedade. As análises conduzem a questões sobre a trajetória dos personagens ficcionais, sobre o conceito de malandragem, sobre o conto na obra de João Antônio e sobre as relações entre biografia e literatura na vida do autor.

\section{Palavras-chave}

Literatura contemporânea; conto brasileiro; autobiografia; figuras paternas; narrativa urbana; malandragem e marginalidade; literatura e sociedade.

\section{Abstract}

This thesis analyses João Antonio's short stories and autobiographical narratives where father figures are crucial and intimately related to main characters. The critical work identifies essential elements of fiction (such as narrator, characters and plot) and the way they interact. Our research is based upon Antonio Candido's essays on João Antônio and on literature and society. The effort of interpretation combines literary criticism, history of literature, biographical approach and bibliographic research, also including psychoanalysis and sociological theoretical references. The interpretations lead to conclusions about the journey of the main characters, the concept of trickery (malandragem), the short story form in João Antonio and the relationship between life and work of this Brazilian writer.

\section{Keywords}

Contemporary literature; Brazilian short stories; autobiography; father figures; urban narrative; trickery (malandragem) and social marginality; literature and society. 


\section{SUMÁRIO}

SIGLAS, ABREVIAÇÕES E EDIÇÕES DE REFERÊNCIA............................................... 7

INTRODUÇÃ

CAPÍTULO 1 EU SOU UM OUTRO - Três contos autobiográficos de João Antônio............. 45

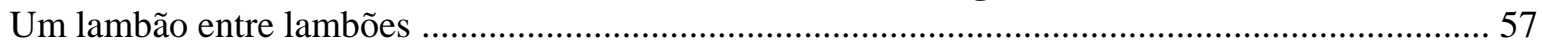

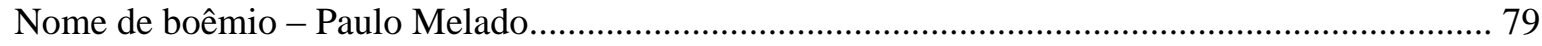

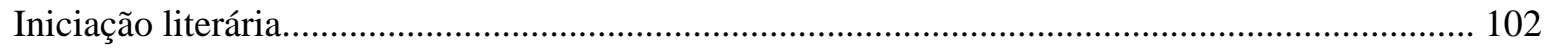

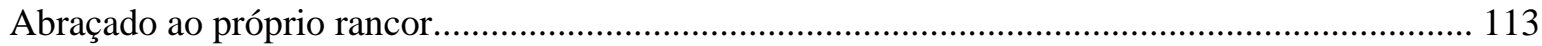

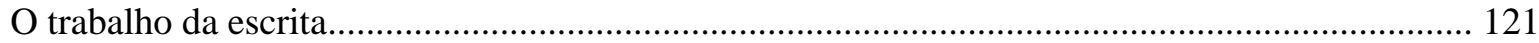

CAPÍTULO 2 AFINANDO A MALANDRAGEM - Dos “Contos Gerais” à sinuca............. 139

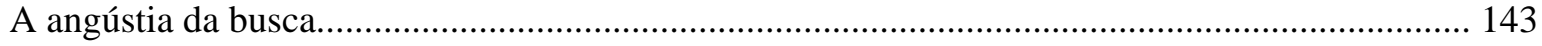

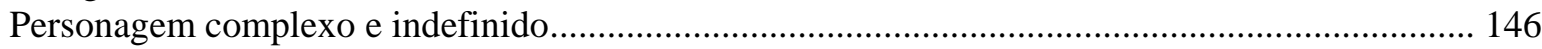

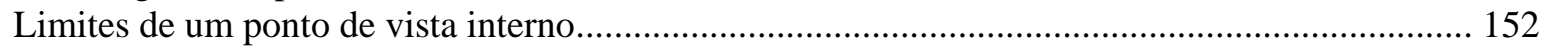

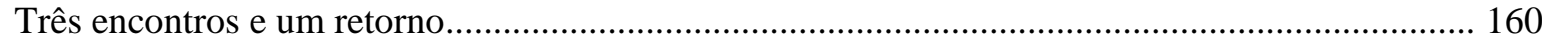

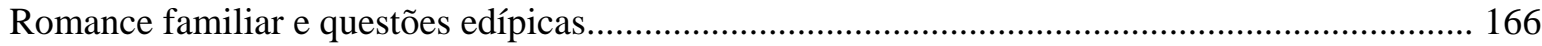

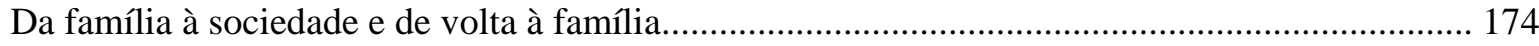

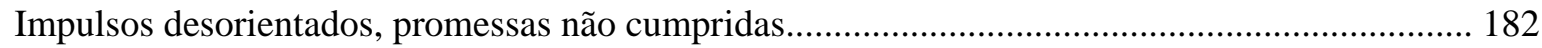

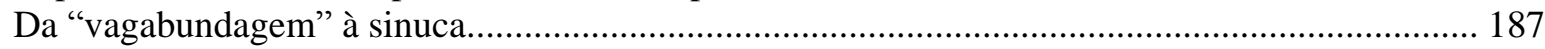

CAPÍTULO 3 DESTINO DE MALANDRO É VIRAR LENDA - Sobre "Malagueta, Perus e

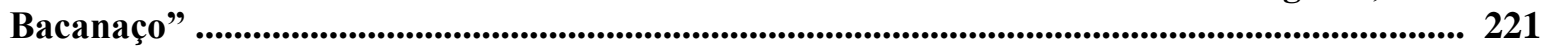

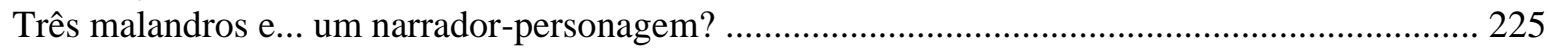

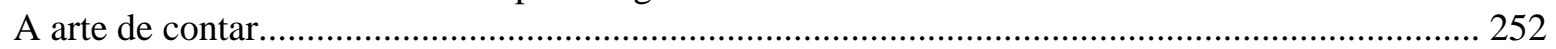

Malandragem: tipicidade e situação narrada.............................................................................. 266

Ponto de fuga: Perus, um infante entre velhos malandros......................................................... 282

\section{CAPÍTULO 4 ASCENSÃO E QUEDA DO MALANDRO - Sobre "Paulinho Perna}

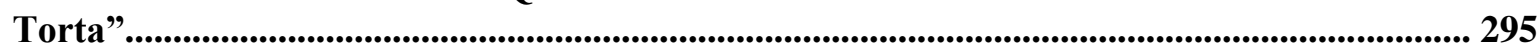

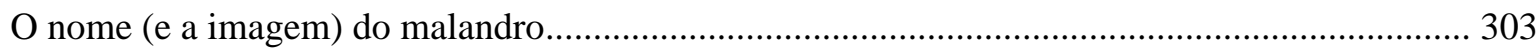

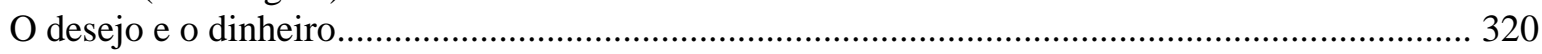

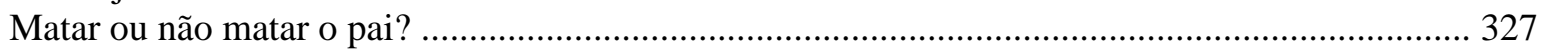

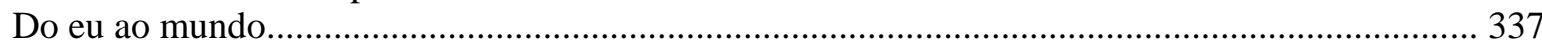

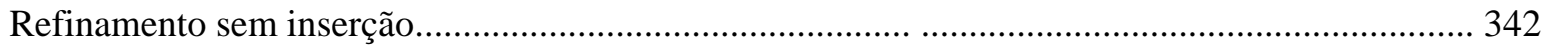

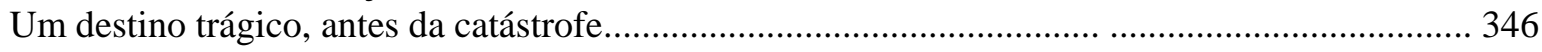

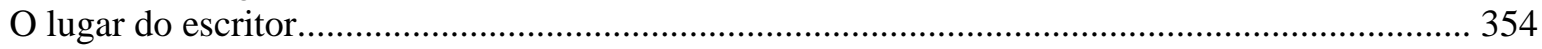

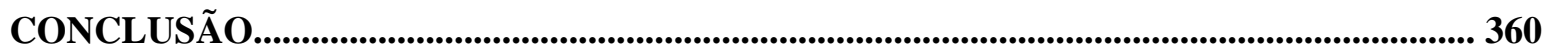

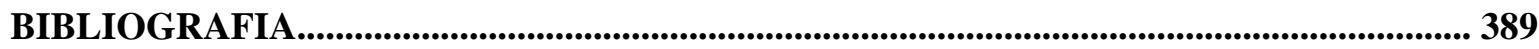

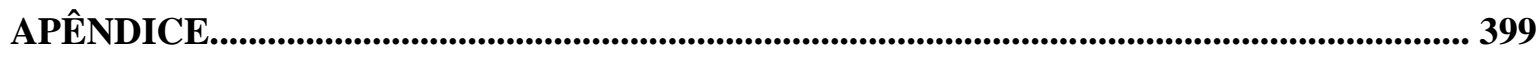

Livros de João Antônio e contos que os constituem

Imagens e documentos 


\section{SIGLAS, ABREVIAÇÕES E EDIÇÕES DE REFERÊNCIA UTILIZADAS}

"Aact": o conto "Afinação da arte de chutar tampinhas".

Amr: o livro Abraçado ao meu rancor. A edição de referência utilizada neste trabalho é a primeira. São Paulo: Guanabara, 1986.

"Amr": o conto "Abraçado ao meu rancor".

Dedo-duro: o livro. A edição de referência é a primeira. Rio de Janeiro: Record, 1982.

"Dedo-duro": o conto.

MPB: o livro Malagueta Perus e Bacanaço. A edição de referência utilizada neste trabalho é a da Cosac Naify. São Paulo, 2004.

"MPB", o conto "Malagueta Perus e Bacanaço".

Lambões: o livro e o texto de Lambões de caçarola (Trabalhadores do Brasil!'). Porto Alegre: L\&PM, 1977.

$L d c$ : o livro Leão-de-chácara. A edição de referência utilizada neste trabalho é a da Cosac Naify. São Paulo, 2002.

"Ldc": o conto "Leão-de-chácara".

Lima Barreto: o livro Calvário e porres do pingente Afonso Henriques de Lima Barreto. "PMCMS": o conto "Paulo Melado do Chapéu Mangueira Serralha", de Dedo-duro. "PPT": o conto "Paulinho Perna Torta", de $L d c$. 


\section{Introdução}


Ao surgir no panorama da literatura brasileira dos anos 60, João Antônio foi visto como um autor incomum, e sua obra foi, desde o começo, acolhida como novidade na tradição das nossas letras. Em 1963, a recepção ao seu livro de estreia, Malagueta, Perus e Bacanaço foi calorosa e marcada pela celebração. No ano mesmo do seu lançamento, Sérgio Milliet o saudava: “Algumas das cenas que nos apresenta são pequenas obrasprimas, são de antologia, são de causar inveja a escritores bem mais experientes”. O crítico destaca "o mundo de simpatia e de ternura que o contista tem para com seus heróis", "picaretas rabelaisianos", "boêmios que deambulam como bons sujeitos, que se viram”, em textos narrados em linguagem popular, "sem fazer ópera", "sem dós de peito", com simplicidade, em linguagem popular. ${ }^{1}$

O livro foi recebido com entusiasmo também por João Alexandre Barbosa. Como bem leu o crítico, no calor da hora:

(...) o campo do autor é a sociedade de São Paulo pelo avesso, isto é, o pequeno mundo de marginais, malandros, soldados rasos, jogadores de sinuca ou de judô. O mundo miúdo e rico da vida de expedientes por sob a organização industrial e burguesa. Vida e mundo, entretanto, onde não falta a veia da humanidade em seus aspectos trágicos ou cômicos que João Antônio sabe ferir com a sua estranha e coerente sintaxe: linguagem coloquial amarrando esperanças, fracassos e espertezas. ${ }^{2}$

Para João Alexandre, o autor "agarra pela raiz o significado dessas pequenas vidas miseráveis que a organização social põe de lado, em um louco processo de desumanização e morte lenta. Mas sem cair na lamentação chorosa ou no panegírico das frustrações. Tudo limpo, com picardia, para usar de uma palavra que lhe é muito querida". ${ }^{3}$ Com o conto que dá título ao livro, o escritor "vem desde muito cedo firmar-se entre o que existe de melhor na nossa ficção urbana. Na linha de um Manuel Antônio de Almeida, de um Lima Barreto, de um Alcântara Machado, de um Mário de Andrade, de um Marques Rebelo, de um Gastão de Holanda". ${ }^{4}$

\footnotetext{
${ }^{1}$ MiLliet, Sérgio. "Alguns malandros". Recorte de jornal preservado no Acervo João Antônio, no Cedap (Centro de Documentação e Apoio à Pesquisa) da Faculdade de Ciências e Letras da Unesp de Assis, com a seguinte indicação a máquina de escrever: O Estado de S. Paulo, 23 jul 1963.

2 Barbosa, João Alexandre. "Malagueta, Perus e Bacanaço", in Opus 60 - Ensaios de crítica, São Paulo, Duas Cidades, 1980, pp. 137-140. A resenha sobre o livro de João Antônio foi originalmente publicada no Jornal do Comércio do Recife, em 17 nov. 1963.

${ }^{3}$ Idem, ibidem, p. 138.

${ }^{4}$ Idem, ibidem, p. 139.
} 
Além da filiação à tradição da literatura urbana, outro aspecto que sobressai na recepção crítica inicial é a valorização da ambientação paulistana dos contos e as comparações com Alcântara Machado - Mário de Andrade, surpreendentemente, não é muito citado neste momento de estreia de João Antônio. Aos olhos dos comentadores, na obra do jovem autor, São Paulo não se resume a mero cenário e assume estatuto de personagem. Segundo Arnaldo Mendes, do Última Hora, no livro de João Antônio "São Paulo passa, pela primeira vez em nossa história literária, a funcionar como autêntico personagem e não como mero ambiente ou cenário da composição". 5 Para Bráulio Pedroso, de $O$ Estado de S. Paulo, "no caso de João Antônio podemos afirmar, mesmo que permaneça neste livro Malagueta, Perus e Bacanaço, que São Paulo tem seu romancista, que São Paulo pela primeira vez surge dramaticamente na expressão acanhada de seus bairros afastados, na promiscuidade de sua aglutinação central, no traço convincente de seus personagens típicos e na contribuição lingüística de sua fala particular". 6 A promessa de um grande escritor em São Paulo fez o jornalista da revista Visão comemorar no título da matéria: "Enfim uma esperança". 7

Rodrigo Lacerda reconstituiu recentemente a recepção crítica imediata do primeiro livro de João Antônio, e não apenas do ponto de vista da teoria literária, mas também no contexto editorial e de afinidades políticas da década de $1960 .^{8}$ Além disso, recompôs as estratégias de inserção no meio literário brasileiro de que o escritor lançou mão: no início de sua carreira, João Antônio enviou seus contos a críticos e jornalistas; conquistou, assim, o apadrinhamento de nomes influentes na imprensa e nas melhores editoras do Rio e de São Paulo. "Durante aqueles anos, entre vários contatos que o jovem escritor conseguira fazer, destacavam-se, no Rio de Janeiro, o genial Paulo Rónai; em São Paulo, o crítico e escritor

\footnotetext{
${ }^{5}$ Mendes, A. "Um cronista de São Paulo". In: Última Hora, São Paulo, 13/07/63. Apud LACERDA, Rodrigo. João Antônio: uma biografia literária. Tese de doutoramento. Orientação de Joaquim Alves de Aguiar. São Paulo: Departamento de Teoria Literária e Literatura Comparada (DTLLC), FFLCH-USP, 2006, p. 212.

${ }^{6}$ Pedroso, Bráulio: "São Paulo tem seu romancista", In: O Estado de São Paulo, 16 ago 1963. Apud LACERDA, Rodrigo. João Antônio: uma biografia literária. op.cit, p. 212.

7 "Enfim uma esperança". Revista Visão. Vol. 23, no 11, 13 set. 1963. Reprodução de recorte de jornal consultada no Acervo João Antônio, no Cedap (Centro de Documentação e Apoio à Pesquisa), Unesp, Assis.

${ }^{8}$ Além da tese de doutorado de Rodrigo Lacerda, ver do mesmo autor: "O primeiro amor de João Antônio". In: Malagueta, Perus e Bacanaço. João Antônio. $4^{\text {a }}$ edição rev. Cosac Naify, 2004, encarte anexado ao livro, em separata.
} 
Mário da Silva Brito, também envolvido no mundo editorial; e, claro, Ricardo Ramos. Eles foram, efetivamente, os seus três padrinhos literários".9

Doze anos depois, quando do lançamento do seu segundo livro, Leão-de-chácara, em 1975, a primeira coletânea do autor foi reeditada, e João Antônio experimentou uma espécie de renascimento literário, acompanhado de uma reanimação da literatura e das práticas literárias no período, depois dos tempos mais sombrios da ditadura. ${ }^{10}$ Em carta de 1974 a Fábio Lucas, João Antônio fala em “dez anos de congelamento literário”. Segundo o

${ }^{9}$ Segundo Rodrigo Lacerda, Ricardo Ramos, filho de Graciliano Ramos, foi diretor da Civilização Brasileira,
editora que viria a publicar a primeira edição de Malagueta, Perus e Bacanaço. A partir de 1958, além disso,
Ramos publicou nas páginas do Última Hora, onde tinha uma coluna, vários dos primeiros contos de João
Antônio: "Afinação da Arte de Chutar Tampinhas", "Fujie", "Retalhos de Fome Numa Tarde de G.C." e
"Natal na Cafua". Mário da Silva Brito, por sua vez, era articulista de O Estado de S. Paulo. No Suplemento
Literário do Estadão, saíram alguns dos primeiros contos do autor: "Índios" (1 $1^{\circ}$ ago 1959), "Frio" (6 fev.
1960), "Visita" (26 nov. 1960). Foi por iniciativa de Mário da Silva Brito que João Antônio conseguiu usar
uma cabine da Biblioteca Mário de Andrade para reescrever o conto que dá título ao livro, quando do
incêndio que destruiu a casa da família, em 12 de agosto de 1960. Mário da Silvia Brito, que assina a orelha
das primeiras edições de MPB e de Ldc, foi ainda quem levou João Antônio para a Civilização Brasileira (o
autor negociava publicar dois livros, um com a Edições Autores Reunidos e outro com a Editora das
Américas). Para um panorama do início da carreira de João Antônio e sobre as primeiras publicações em
jornais, ver LACERDA, R. João Antônio: uma biografia literária, op.cit., cap. 2. No Apêndice desta tese,
reproduzimos alguns dos contos publicados originalmente na imprensa. ${ }^{10}$ As cartas de João Antônio a Caio Porfírio Carneiro registram este momento de intensa atividade literária e novo reconhecimento. A segunda edição de $M P B$ esgotou-se rapidamente, $L d c$ chegou ao primeiro lugar entre os livros de ficção mais vendidos no país, o autor trabalhava como editor do Livro de Cabeceira do Homem, revista da Civilização Brasileira, preparava a edição de outros livros, como Malhação do Judas carioca, Casa de loucos e Lima Barreto, e fazia frequentes viagens pelo país, divulgando os seus livros e participando de eventos literários e universitários. Ver Cartas aos amigos Caio Porfírio Carneiro e Fábio Lucas. Cotia/SP: Ateliê Editorial. São Paulo: Oficina do Livro Rubens Borba de Moraes, 2004. Flávio Aguiar, em texto de 1978, relembra o momento de renascimento literário experimentado nos anos de 1974-75: "A partir daí nascem e renascem revistas literárias, surgem seções de literatura em jornais de circulação nacional ou regional, inclusive diários; as edições de estreantes crescem em número e tiragem. Mas é claro que a literatura nunca 'morrera', ou defendera o obscurantismo, para ter um 'renascimento'. Naquele momento (74/75) o que reapareceu, e que justificou um interesse editorial mais intenso pela literatura, foi a prática de debatê-la em público. (...) Percebeu-se que literatura atraía um público muito mais amplo do que a expectativa usual, e houve margem para muita coisa, que dormia na gaveta, ir pelo menos dormir na gaveta alheia. (...) A partir de 74/75 o conto amplia sua presença, na imprensa e nas edições. Quanto à poesia, descobria-se que o fenômeno das edições 'marginais', vendidas de mão em mão, atinge proporções de epidemia. (...) No conto, aparecia constantemente uma outra marginalidade: a dos desempregados, dos fora-da-lei, os perseguidos e humilhados: denúncia direta da violência oficial ou oficiosa, do desvario de um crescimento urbano premeditado mas desplanejado. Não por acaso o carro-chefe da divulgação do conto brasileiro, naquela época, foi a reedição de Malagueta, Perus e Bacanaço, de João Antônio. O poeta desprezado, peregrino das faculdades, portas de teatro e cinema; os marginais desesperançados que peregrinam pelas ruas e pela violência das macrocidades: eis um cartão de apresentação do conto e da poesia, nos anos em apreço. Ao lado, um cidadão de classe média contempla, um pouco perplexo, o 'milagre brasileiro' revelar-se circo de horrores." AGUIAR, Flávio. "Os mensageiros de Jó", In: A palavra no purgatório. Literatura e cultura nos anos 70. São Paulo: Boitempo Editorial, 1997, pp. 179-180. No final da década de 1990, Aguiar voltaria ao tema da redescoberta do autor e da realidade dos marginalizados em: AGUiAR, F. "Evocação de João Antônio ou do purgatório ao inferno". Remate de Males, $\mathrm{n}^{\circ}$ 19. Revista do Departamento de Teoria Literária do Instituto de Estudos da Linguagem. Unicamp, Campinas, 1999. 
próprio autor esse congelamento foi "determinado por vários fatores", "inclusive de editores". 11

O longo período de mais de uma década sem publicar em livro intriga ainda hoje críticos e leitores. Tania Macêdo tenta resumir os variados motivos que explicariam o hiato entre o primeiro e o segundo livro: “(...) a difícil situação editorial brasileira para o jovem escritor, a sua mudança para o Rio de Janeiro (que seria responsável por um grande impacto no escritor), o trabalho em vários jornais, na revista Manchete, o internamento em um sanatório. Provavelmente cada um desses motivos tenha tido o seu peso nesse silêncio. (...) Um exame retrospectivo de sua obra permite dizer que, muito possivelmente, esse intervalo deveu-se ao alto grau de exigência do autor em relação a seu trabalho, exigência essa potencializada, sem dúvida, pelas expectativas e pressões que o segundo livro sempre carrega". 12

Como bem ressalta Tania Macêdo, a mudança para o Rio de Janeiro, problemas de saúde, questões profissionais, pessoais e políticas devem ter contribuído para o longo silêncio, ainda que o período, como também assinala a autora, tenha sido marcado pela atividade intensa como jornalista, que lhe renderia matéria para pelo menos dois livros da década de 70: Malhação do Judas carioca (1975) e Casa de loucos (1976).

O ambiente político desfavorável que se seguiu ao golpe militar de 64, um ano depois do lançamento de Malagueta, Perus e Bacanaço, deve ter contribuído para os doze anos sem livros de João Antônio, ainda que não se tenha notícia de que o autor tenha sido censurado. ${ }^{13}$ Apesar de sua publicação durante a ditadura, a obra de João Antônio traz

\footnotetext{
${ }^{11}$ Carta a Fábio Lucas datada de 29 set. 1974. Em carta de 1976 a Caio Porfírio Carneiro, diz ele: "Estive doze anos na Sibéria literária e agora não posso perder mais tempo". In: João Antônio. Cartas aos amigos Caio Porfírio Carneiro e Fábio Lucas. Cotia/SP: Ateliê Editorial. São Paulo: Oficina do Livro Rubens Borba de Moraes, 2004, respectivamente, p. 96 e 73. Depois do "congelamento literário", em 1975 e 1976 Leão-dechácara e Malhação do Judas Carioca frequentaram a lista da revista Veja de livros mais vendidos no país.

${ }^{12}$ MACÊDO, T. "Malandros e merdunchos". In: $L d c$, p. 6.

${ }^{13}$ Sandra Reimão, em estudo recente, reconstituiu os casos mais significativos de livros censurados a partir da edição do AI-5, em dezembro de 1968. Especialmente na ficção, a autora comenta a censura a Feliz ano novo, de Rubem Fonseca, e Zero, de Ignácio de Loyola, ambos censurados em 1976. Dentre outros autores que tiveram textos ou livros de ficção censurados estão Álvaro Alves de Faria, Aguinaldo Silva, Cassandra Rios, Dalton Trevisan, José Louzeiro, Renato Tapajós. A autora indica que, curiosamente, a censura foi mais rígida com os livros durante o governo Geisel (1974-1979) e não durante os Anos de Chumbo (1968-1974). REIMÃo, Sandra. Repressão e resistência. São Paulo: Edusp/Fapesp, 2011. No caso de João Antônio, nenhum de seus livros foi censurado, mas sofreu censura prévia a revista Extra - Realidade Brasileira, especial Malditos Escritores! (no. 4, ano I, março de 1977, número organizado por João Antônio), como assinala Mylton Severiano, que fala também numa espécie de censura interna na redação de Realidade, onde João
} 
poucas referências ao regime militar, ainda que o tema dos marginalizados e a atividade do escritor como jornalista na imprensa nanica permitam situá-lo como um autor dissonante em relação ao regime. Flávio Aguiar, que, como João Antônio, também atuou na imprensa alternativa, destaca entretanto a dimensão simbólica de sua literatura, acentuando o caráter universal da obra do autor, desvinculada das lutas e debates políticos mais imediatos. Num momento de violência política e marginalização dos escritores e dos "deserdados da terra", dos "humildes", da "gente simples", Aguiar chama a atenção para a singularidade de seus personagens e para a dimensão subjetiva de um realismo que vai além da representação objetiva: "O essencial é que nenhum personagem de João Antônio está em sua medida. Um sopro transformador os desengonça a todos: eles se fazem símbolos, ao invés de 'retrato fiel' à la naturalismo do século XIX. São símbolos de uma peregrinação universal, daqueles que não têm nas mãos o próprio destino." ${ }^{14}$

Ao estrear em livro, nos anos 60, com Malagueta, Perus e Bacanaço, e pelo menos até o final da década seguinte, quando lançou, além de Leão-de-chácara, também Malhação do Judas carioca, Casa de loucos, Lima Barreto e Lambões de caçarola (Trabalhadores do Brasil!), a obra de João Antônio foi vista como uma grande novidade na literatura brasileira e - como não poderia deixar de ser depois de um volume de estreia tão poderoso - sob o signo da promessa, daquela esperança de que se assistia ao surgimento de um grande escritor. ${ }^{15}$

Já nos anos 1970 a obra do autor foi incorporada pela crítica não apenas à produção de maior relevância à época, mas também à corrente da tradição realista brasileira, bastante caudalosa, como se sabe. A literatura do autor foi vista por Antonio Candido como inauguradora de um "realismo feroz" na literatura nacional, ao lado da ficção de Rubem Fonseca, tendo ambos como precursor, especialmente, Dalton Trevisan. Candido deu destaque a João Antônio em seu texto "A nova narrativa", escrito em 1979, em que o crítico apresenta um período de intensa renovação da prosa de ficção brasileira - de "legitimação da pluralidade" —, quando a literatura passou a incorporar com regularidade recursos

Antônio trabalhou - e sofreu com um diretor de redação que era censor disfarçado, "homem camuflado do Golbery”. Severiano, M. Paixão de João Antônio. São Paulo: Editora Casa Amarela, 2005, pp. 58 e 59.

${ }^{14}$ AGUIAR, Flávio. “A palavra no purgatório". In: A palavra no purgatório. op.cit., p. 91.

${ }^{15} \mathrm{O}$ final do texto de João Alexandre Barbosa aposta nisso: "Enfim, todo o conto — todo o livro, melhor — é dessa espécie rara: de um criador que sabe o peso de suas armas e utiliza-o. Por isso, creio que João Antônio, que a orelha do livro informa moço, tem muito ainda para dizer. Felizmente.”. João Alexandre Barbosa, op. cit., p. 140. 
experimentais de composição e procedimentos típicos do jornalismo, do cinema, da autobiografia e da crônica. Para Candido, o realismo feroz de Rubem Fonseca e João Antônio realiza-se melhor quando autor e narrador diminuem as distâncias em relação a seus personagens, desestabilizando a objetividade do realismo tradicional, em que o escritor "se encastelava na terceira pessoa". Por isso, Candido valoriza os relatos em primeira pessoa, foco narrativo que permite diminuir as distâncias sociais, fazendo o autor se identificar com a matéria narrada, adotando a primeira pessoa como "recurso para confundir autor e personagem, adotando uma espécie de discurso direto permanente e desconvencionalizado, que permite fusão maior que a do indireto livre". ${ }^{16}$ No caso de João Antônio, tece elogios a "Paulinho Perna Torta", definido como uma "obra-prima em nossa ficção". ${ }^{17}$

No começo da década de 1980, João Antônio foi incluído por Alfredo Bosi entre os mais representativos contistas brasileiros da época. Bosi destacou no autor a capacidade de "reconhecer as lesões de vários graus que a sociedade de classes não cessa de produzir no tecido moral do anti-herói contemporâneo". ${ }^{18}$ No volume de ensaios Os pobres na literatura brasileira, Jesus Antônio Durigan procurou driblar os lugares-comuns que já haviam se cristalizado a respeito do autor ${ }^{19}$ e chamou a atenção para a "necessidade de aprendizagem" de seus personagens, algo que contamina o narrador, que "não apenas valoriza e incorpora como seu o ponto de vista dos atores marginais, como também procura assumir de fato a sua própria representação de "narrador malandro"”. Durigan estende essa dinâmica aos contos autobiográficos, como "Paulo Melado do Chapéu Mangueira Serralha", no qual esse narrador "realiza definitivamente a sua formação". O crítico define a dinâmica da obra do autor com uma imagem interessante: ciranda da malandragem, na qual solidão e medo aproximam “"os otários’ (integrados) e os 'malandros’ (marginais)

\footnotetext{
${ }^{16}$ CANDIDO, Antonio. "A nova narrativa", in: A educação pela noite \& outros ensaios. $3^{a}$ edição. São Paulo: Ática, 2003, p. 213.

${ }_{18}^{17}$ idem, ibidem, p. 210.

18 BOSI, Alfredo. "Situações e formas do conto brasileiro contemporâneo". In: O conto brasileiro contemporâneo. São Paulo: Cultrix, 1981, $4^{\mathrm{a}}$ edição, p. 10. O conto do autor incluído na antologia foi "Frio". Em tempos mais recentes, nos Cem melhores contos brasileiros do século (Objetiva, 2000), Italo Moriconi selecionou "Guardador", publicado em livro em Amr, mas com primeira versão escrita em 1975 e publicada em Panorama, como indica os trabalhos de Carlos Alberto Farias de Azevedo Filho, Hibridismo e ruptura de gêneros em João Antônio (Unesp, Assis, 2008) e Renata Ribeiro de Moraes, João Antônio de pés vermelhos: a atuação do escritor-jornalista em Panorama (UEL, Londrina, 2005).

${ }^{19}$ Alguns epítetos colados em João Antônio, mencionados por Durigan: "o clássico velhaco", "escritor do submundo", "autor da marginalidade", "que trabalha com o livro da vida", "que escreve como um soco".
} 
confrontando-se de maneira sistemática e agressiva". A roda-viva da malandragem mantém os "atores girando em torno de si próprios, dentro de uma realidade gerenciada pela violência". 20

Apesar da recepção inicial amplamente favorável, com o lançamento de Dedo-duro, em 1982, porém, começam a aparecer textos um pouco mais críticos à obra do autor, como uma resenha de Leo Gilson Ribeiro, ${ }^{21}$ sobre a qual o próprio João Antônio expressou descontentamento, ${ }^{22}$ e as considerações de Flora Süssekind sobre as condições favoráveis que o projeto literário nacionalista do autor teria encontrado na ideologia ufanista do regime militar. ${ }^{23}$ Algumas críticas já haviam aparecido antes, desde a época do lançamento do livro, ${ }^{24}$ mas nunca haviam sido tão duras.

${ }^{20}$ DuRigAn, Jesus Antonio. "João Antônio e a ciranda da malandragem”, In: Roberto Schwarz (org.), Os pobres na literatura brasileira. São Paulo: Brasiliense, 1983, pp. 214-218.

${ }^{21}$ Leo Gilson Ribeiro resenha Dedo-duro, no Jornal da Tarde: "João Antônio, neste seu momento de pausa indefinida, acumula de modo excessivo centenas de palavras que, se têm a expressividade que deseja, paralelamente tornam o mundo que elas querem descrever hermético, barroco, no sentido pejorativo do termo, palavroso demais, obtendo, não a comunhão do leitor com os propósitos evidentemente nobres e idealistas do autor, mas sim sua incompreensão e, no pior dos casos, seu enfado e desinteresse pela obra." Apud Rodrigo Lacerda. Pingentes: João Antônio e Lima Barreto. Disponível em: http://www.rodrigolacerda.com.br/pingentes-joao-antonio-e-lima-barreto. Último acesso: 2 jul. 2012.

${ }^{22}$ João Antônio reage assim à crítica de Leo Gilson Ribeiro: "O crítico que um dia me botou nos cornos da lua, agora acha que não passo de machista, barroco, exagerado, fascinado pelas palavras e por mim mesmo, correndo o perigo de me tornar um ultrapassado stalinista. Agora, um troço ficou chato para ele, penso eu. Eu não sou um alto inventor de palavras. Não tenho capacidades à Mário de Andrade ou à J. Guimarães Rosa. E certos termos que ele aponta como de difícil compreensão e gírias de código fechado estão dicionarizadas e bem. Exemplo: mundrungueiro, capiongo, cafofo. Também não me lambuzo com as palavras, são os meus personagens que as utilizam. Como Wilson Martins, no Jornal do Brasil, Leo Gilson ficou num chove-não-molha, num morde-e-sopra, para concluir, meio culposo, que não pode 'bitolar um dos quatro ou cinco talentos mais vivos do Brasil de hoje'. Mas deixemos isso pra lá. O importante é que Dedo-Duro vai recebendo algum espaço e, falando honestamente, acho até natural que leve alguns esporros. Afinal, quem sai à chuva é pra se molhar." Carta a Caio Porfírio Carneiro, datada de 22 nov. 1982, incluída em ANTÔNIO, João. Cartas aos amigos Caio Porfírio Carneiro e Fábio Lucas, op.cit., p. 76.

${ }^{23}$ SÜSSEKIND, Flora. Literatura e vida literária: Polêmicas, diários \& retratos. Rio de Janeiro: Jorge Zahar Editor, 1985.

${ }^{24} \mathrm{O}$ trabalho de levantamento da recepção crítica da obra de João Antônio feito por Jane Christina Pereira registra as críticas de Assis Brasil e Celso Cunha no ano de lançamento do livro de estreia: "Assis Brasil, em 26 de junho de 1963, no Jornal do Brasil, ressalta em Malagueta, Perus e Bacanaço a 'ausência de uma unidade qualificativa no livro e a narração em $1^{\text {a }}$ pessoa, que denuncia um memorialismo e uma repetição da psicologia das ações'. Em 1975, em sua História Crítica da Literatura Brasileira volta a apontar os mesmos aspectos como negativos em relação àquela obra, sem deixar de salientar, como fez no primeiro texto, os aspectos positivos ligados aos contos em $3^{\text {a }}$ pessoa. Também apontando falhas, Fausto Cunha, em 12 de outubro de 1963, no Correio da Manhã, comenta que ao escrever uma obra visando apenas o público paulista, João Antônio deixa o leitor de outros estados um pouco indiferente. Diz, ainda, que seus contos tendem ao episódico e ao incidental por falta de um estilo próprio. Entretanto, acaba elogiando sua autenticidade vivencial que, segundo ele, contrabalança tudo." PEREIRA, Jane Christina. Estudo crítico da bibliografia sobre João Antônio (1963-1976). Dissertação de mestrado. Orientação de Ana Maria Domingues de Oliveira. Assis: Faculdade de Ciências e Letras da Universidade Estadual Paulista, Unesp, 2001, pp. 24-25. 
Ainda que o autor tenha sido agraciado com uma consagração precoce, como se vê, João Antônio não tardou a experimentar o sabor das críticas e das limitações de alcance de sua obra, que dizem respeito não apenas a problemas individuais, mas também à literatura brasileira. As numerosas cartas e entrevistas de João Antônio expressam sua contrariedade com relação à falta de reconhecimento do escritor profissional no Brasil e à fragilidade própria do sistema literário nacional — os escritores sempre à procura de bons editores e de um público-leitor —, insatisfação combinada a um inconformismo e a um espírito irrequieto e irritadiço, cuja intensidade de inconformismo se acentuou ao longo dos anos e ganhou expressão crispada, com reflexos na obra do autor. Abraçado ao meu rancor, de 1986, seu último grande livro, traz a marca amarga de um autor fiel a suas origens e, ao mesmo tempo, inconformado com as transformações que fizeram desaparecer a boemia e a cidade de outrora, tomada pelo brilho falso do turismo, da finança e do trabalho alienado, cooptado pelo mercado - inclusive o trabalho jornalístico e literário, o trabalho dele próprio, João Antônio.

Como bem apontou à época João Luiz Lafetá, a "estética do rancor" 25 de João Antônio expressa um paradoxo experimentado pelo escritor que é similar ao de Lima Barreto: resolver o impasse que se impõe no artifício de unir, de um lado, o "recato" da representação literária e, de outro, os "sentimentos e ressentimentos" do vivido. José Paulo Paes, por sua vez, lembrou que João Antônio, ao colocar-se sob o signo do rancor, não estava sendo original, mas, ao contrário, estava inserido em longa tradição das letras nacionais, pois "foi afinal sob esse signo que nasceu, há trezentos anos, a própria literatura brasileira". ${ }^{26}$ José Paulo Paes analisa o rancor de João Antônio, exteriorizado em "confusão de sentimentos", ligando-o à culpa: "Se o rancor se volta principalmente contra um progresso que só beneficia os donos da vida, nos Jardins, jamais os humilhados e ofendidos nos Morros da Geada, nem por isso é menos perceptível o sentimento de culpa que, ao longo de sua elegíaca visita à casa paterna, o narrador experimenta”.

\footnotetext{
${ }^{25}$ LAFETÁ, João Luiz. "João Antônio e sua estética do rancor". In: de Antonio Arnoni Prado. Duas Cidades/Editora 34. São Paulo: 2004.

${ }^{26} \mathrm{O}$ crítico refere-se ao rancor de Gregório de Matos, "reconhecidamente nosso primeiro escritor digno do nome”. PAES, José Paulo. "Ilustração e defesa do rancor". In: O Estado de S. Paulo, 21 mar. 1987. Recorte de jornal consultado no Acervo João Antônio, Cedap, Unesp de Assis. Paes alude a Gregório de Matos porque versos do poeta servem de epígrafe a "Abraçado ao meu rancor", conto que dá título ao volume de João Antônio: "Carregado de mim ando no mundo,/ E o grande peso embarga-me as passadas,/ Que como ando por vias desusadas,/ Faço o peso crescer, e vou-me ao fundo". A outra epígrafe ao texto é de Lima Barreto: "A minha alma é de bandido tímido".
} 
Ainda na década de 1980, Alfredo Bosi voltaria a debruçar-se sobre a literatura do autor, a propósito de Abraçado ao meu rancor. No prefácio ao livro, Bosi também comenta a dificuldade da volta à casa da família: "Ele não volta para sempre: parece impossível o retorno a quem já transpôs o limiar da classe. Mas volta sempre que o chamado é mais forte do que tudo e a consciência da separação dói acima da medida". ${ }^{27}$

O final da carreira literária de João Antônio, da segunda metade da década de 1980 até o fim da vida, foi de fato marcado pela culpa e pela melancolia de um autor que não conseguiu levar adiante projetos de maior fôlego e passou a reeditar textos e livros antigos, além de recuperar textos escritos muitos anos antes, transformando-os em contos, crônicas e perfis literários, incorporados aos seus últimos livros. A variedade de estilos e formas dos últimos anos de sua carreira aponta para um autor inquieto e inconformado, mas também para um escritor que talvez não tenha encontrado a medida exata de seu talento e de sua vocação de ficcionista. A morte precoce e inesperada, em outubro de 1996, aos 59 anos, e as circunstâncias da descoberta do corpo do autor, em estado de putrefação, dias depois de seu falecimento, contribuíram para acentuar ainda mais a impressão de melancolia dos últimos anos do autor.

A importância de sua obra, entretanto, tem sido reconhecida, encontrando lugar de destaque na literatura brasileira contemporânea, graças às análises críticas relevantes, às reedições recentes de seus livros e à permanência do interesse dos leitores e admiradores. A apreciação crítica da obra de João Antônio tem se adensado nos últimos anos graças ao trabalho de jovens críticos e estudantes que vêm se debruçando sobre sua obra e ao carinho com que seus contemporâneos ainda se lembram dele, muitos dos quais privaram da amizade com o autor, outros tantos - professores, escritores, jornalistas, críticos - que registraram em ensaios e textos memorialísticos suas considerações sobre autor e obra, elaboraram leituras críticas e afetivas de seus livros, divulgaram cartas trocadas com ele, retomaram lembranças de época e impressões sobre João Antônio.

Em 1999, a revista Remate de Males, do Departamento de Teoria Literária do IEL (Instituto de Estudos da Linguagem) da Unicamp, dedicou um número inteiro a João Antônio, que reúne amigos, críticos e professores que abordam temas específicos de sua obra. Dentre os autores que integram a edição estão Antonio Candido, Antonio Arnoni

\footnotetext{
${ }^{27}$ BosI, Alfredo, "Um boêmio entre duas cidades". Prefácio a Amr.
} 
Prado, Vilma Arêas, Fábio Lucas, Caio Porfírio Carneiro, Fernando Paixão, Flávio Aguiar e Ilka Brunhilde Laurito, esta uma das mais fiéis correspondentes do autor, com quem João Antônio trocou cartas desde antes de publicar Malagueta, Perus e Bacanaço.

Alguns dos estudos mais recentes sobre o autor ganharam divulgação no volume Papéis de escritor: Leituras sobre João Antônio. ${ }^{28}$ Outros trabalhos vinculados ao Acervo João Antônio, depositado no Cedap (Centro de Documentação e Apoio à Pesquisa) da Unesp de Assis, podem ser consultados on-line. ${ }^{29}$ No que se refere à biografia do autor, o trabalho de Rodrigo Lacerda, tese de doutorado que empreendeu uma biografia literária do autor, e o livro do jornalista Mylton Severiano, escrito a partir da memória de amigo e da correspondência trocada com João Antônio, são referência para quem se interessa pelas relações entre vida e obra do escritor. O livro de Severiano, por sinal, traz o que provavelmente é a última carta de João Antônio, datada de 10 de outubro de $1996 .{ }^{30}$

As cartas - e João Antônio escreveu muitas, para muita gente, como se sabe sempre reservam novas informações sobre episódios da vida e sobre as ideias do autor, quando vêm a público. ${ }^{31}$ Mas, como bem ressaltam Ana Maria Domingues e Telma Maciel da Silva, as cartas do autor nem sempre eram pensadas enquanto comunicação pessoal, de interação particular com a outra pessoa, destinatária das missivas. Antes, eram mais um espaço de experimentação literária e "escrita de si":

João Antônio se relacionava com a sua correspondência de modo muito particular. De um lado, ela é espaço de experimentação linguística, que culmina em um trabalho estético; sob essa perspectiva, algumas das cartas (ou trechos delas) irmanam-se a textos literários de sua lavra. Por outro lado, há também a assumida estratégia de preservação da memória e construção de um

\footnotetext{
${ }^{28}$ Oliveira, Ana Maria Domingues de, ORnellas, Clara Ávila, Silva, Telma Maciel da (orgs.). Papéis de escritor: Leituras sobre João Antônio. Assis: FCL - Assis - Unesp Publicações, 2008.

${ }^{29} \mathrm{http}: / / \mathrm{www} . c e d a p . a s s i s . u n e s p . b r / a c e r v o$ joao antonio/Acervo.htm

${ }^{30}$ Severiano, M. Paixão de João Antônio. São Paulo: Editora Casa Amarela, 2005, pp. 28-30.

${ }^{31}$ Exemplo disso é a forte ligação que o autor diz ter desenvolvido, na juventude, com o lunfardo, o modo de falar popular e amalandrado dos portenhos, linguajar que compõe muitas letras de tangos. Em carta a Fernando Paixão, ao comentar o trabalho de tradução para o alemão das gírias utilizadas em seus textos, João Antônio comenta que se interessou por gírias e aprendeu muitas delas ao tomar contato com o lunfardo (por meio de um amigo argentino, Victor Taphanel, e a esposa dele, Luzia). Na mesma carta, cita também, nesse sentido, ressalta a importância da leitura da obra do escritor argentino Roberto Arlt. PAIXÃO, F. "João Antônio: cartas de desabafo". Revista IEB, n. 51, mar/set 2010, p. 164.
} 
imaginário, o que acaba por permitir a leitura do conjunto como uma espécie de autobiografia fragmentária, associada às estratégias discursivas do diário íntimo. ${ }^{32}$

As autoras dão como exemplo uma carta enviada a Jácomo Mandatto em 1963, quase idêntica a carta enviada na mesma época a Ilka Brunhilde Laurito, cartas que darão origem ao texto de fíç̧ão autobiográfico "Uma força", incluído em livro vinte anos depois, em Amr (1986).

Recentemente, o poeta e professor Fernando Paixão, que foi editor de João Antônio na Ática, de São Paulo, publicou três longas cartas que recebeu no último ano de vida do escritor. ${ }^{33}$ Apesar de anotar que o autor "tornara-se um tanto amargo, desencantado com as rodas literárias em que via predominar a vaidade dos escritores sobre a discussão de ideias e valores literários", Fernando Paixão registra a energia e a animação com que o autor abraçou o projeto então proposto pelo editor: escrever um ensaio sobre a arte literária, inspirado em livro de Julien Gracq, A literatura no estômago.

(...)

Julien Gracq convida a profundar a impostura toda da mentiralhada em que nos meteram até a alma do nosso horizonte.

Talvez ele chegue com algum ressentimento, sabe-se lá, outros ocupavam a cena quando publicou e estavam entrincheirados em grupo, debaixo de algum ismo ou bandeira. Havia uniões pouco naturais mas passavam por uniões e ganhavam a cena. Ele terá chegado só. Não interessa, seu panfleto é de uma sinceridade respeitável e aplica-se, em atualidade, ao exame e cotejo do próprio sistema, ao carneirismo dos prêmios, certames, conferências, grupelhos, coquetéis e, em principal, a esta corja de gente feia, chata, desinteressada, que se repete e não muda um milímetro, culturesca e beócia que rodeia a chamada vida literária num país ágrafo. A sua nota final de autor em $A$ Literatura no Estômago mata a pau. Melhormente: mata e mostra o pau.

Grato por tudo, mande-me notícias e perdoe meus humores. A título de que não sei, em nome de quem também não sei, mas vá perdoando.

Haveremos de topar com um bem topado Tchaikovsky, com um telefonema de morena na tarde e, quem sabe, com algum fiapo de verdade, acima das incertezas da filosofia. Afinal, nossa literatura não é a que pensa, ela se compraz com algumas certezas da beleza, mesmo que passageira. $\mathrm{Na}$ primeira leitura, o panfleto de Julien Gracq me deprimiu mais; ainda assim é um escritor de bom porte. E, claro, também estava no ponto, já não aguentava mais. Saturou-se ou saturaram-no. Vomitou, mas vomitou com elegância subida. Um ponto a favor.

Abraços,

JOÃO ANTÔNIO ${ }^{34}$

\footnotetext{
32 OliveIRA, Ana Maria Domingues de; Silva, Telma Maciel da. "Memória e ficção na correspondência do escritor João Antônio". Teresa. Revista de literatura brasileira [8] [9]; São Paulo, p. 356-371, 2008.

${ }^{33}$ PAIXÃO, F. "João Antônio: cartas de desabafo". op.cit., pp. 157-180.

${ }^{34}$ Carta de João Antônio a Fernando Paixão, datada de 26 abr. de 1996. PAIXÃO, F. "João Antônio: cartas de desabafo", op.cit., pp. 171-172.
} 
Como se vê, a considerar suas últimas correspondências, trocadas com Fernando Paixão, e também aquelas com o amigo Mylton Severiano, o autor ainda mantinha, mesmo nos últimos tempos, o temperamento inquieto, irritadiço, combativo e insatisfeito, um tanto amargo, mas espirituoso e mobilizado pela literatura.

Apesar do final de vida melancólico e súbito, a personalidade contraditória e a obra desafiadora do escritor permanecem despertando interesse, inclusive de críticos e escritores jovens, muitos dos quais, como é o nosso caso, não chegaram a conhecer o autor pessoalmente.

Nosso trabalho parte da inquietação, da admiração e do apreço pela obra de João Antônio - já se vão quase vinte anos, desde que tivemos o primeiro contato com a literatura do autor, durante a graduação em Jornalismo, no começo da década de 1990. O interesse persistente como leitor conduziu ao desafio analítico de compreensão dos alcances e limites de uma obra múltipla e poderosa, mas também dispersiva, cuja potência criativa arrefeceu ao longo dos anos, especialmente se considerarmos a incidência cada vez menor da ficção na obra do autor e a ausência de obras de fôlego na maturidade.

João Antônio se notabilizou como contista, apesar de ter escrito também crônicas, reportagem e até conto-reportagem, gênero no qual é celebrado, ainda que seu propalado pioneirismo nessa área seja relativo. ${ }^{35} \mathrm{O}$ autor não chegou a escrever nenhum romance, e se conhecem poucos poemas de sua autoria, como os versos de "Choros - Para pintagol e cuíca". ${ }^{36}$ Sabe-se, porém, que na juventude o autor cultivou o desejo de escrever narrativas longas: um romance intitulado Jordão, que o autor gostaria de ter retomado nos últimos anos de sua carreira, como informa Rodrigo Lacerda, ${ }^{37}$ e Irmãos Raccatti Ltda., projeto de

\footnotetext{
${ }^{35}$ Sobre a atividade de João Antônio na revista Realidade, onde ele exercitou o formato do conto-reportagem, ver o trabalho de Carlos Alberto Farias de Azevedo Filho. João Antônio: Repórter de Realidade. João Pessoa: Idéia, 2002. Nessa área, lembrem-se de antecessores como Lima Barreto ( $O$ subterrâneo do Morro do Castelo) e João do Rio (A alma encantadora das ruas).

${ }^{36} \mathrm{O}$ poema pode ser lido em Severiano, M. Paixão de João Antônio. op.cit., pp. 83-92. No Acervo João Antônio, na Unesp de Assis, consultamos também uma pasta com haicais de autoria do escritor, Sete haicais de pés quebrados, provavelmente inéditos.

37 Jordão foi um amigo muito próximo de João Antônio, "personagem misterioso", "amizade da noite malandra e das ruas de luzes vermelhas que o jovem escritor freqüentava" (como se refere a ele Rodrigo Lacerda), com quem o escritor travou intimidade. O escritor cogitou transformar a história de Jordão em romance, o que nunca aconteceu. A amizade com esse rapaz é citada por João Antônio nas cartas a Ilka Brunhilde Laurito, com que João Antônio trocou extensa correspondência. Ver o capítulo 2 e a conclusão do trabalho de Rodrigo Lacerda. João Antônio: uma biografia literária,op.cit..
} 
romance sobre o universo da propaganda em que trabalhou durante o ano de 1963, mas que não chegou a publicar. ${ }^{38}$

Ainda que não tenha escrito romances, os contos do autor apresentam elementos que são típicos do gênero romanesco. Seus protagonistas são personagens que se caracterizam por elementos que marcam o herói de romance, tal como definido por Lukács: a busca, o contato áspero com o mundo e o impulso de conquista da realidade. Por serem contos que têm forte características do romance, os textos mais relevantes de João Antônio são contos longos, que tendem à forma distendida, o que permite classificá-los como novela, forma intermediária entre o conto e o romance. Talvez por isso ele tenha sido comparado tanto a contistas como a romancistas, e ao final da carreira, ainda que intentasse retomar o projeto de um romance, se mostrasse tão ligado aos contos de juventude, onde, como veremos, estão o manancial de toda a sua obra.

Apesar do sucesso de contos como "Malagueta, Perus e Bacanaço" e "Paulinho Perna Torta" e de continuar muito ligado a esses contos maiores de sua carreira, João Antônio se mostrava incomodado com o rótulo de intérprete da malandragem, de cronista da marginalidade, de "clássico velhaco" e outros epítetos pelos quais ficou conhecido. Já em 1964 o autor desconfiava de si próprio como retratista da malandragem. Em carta a Ilka Brunhilde, citada por Rodrigo Lacerda, o autor dizia querer retomar o espírito universal e essencial dos primeiros contos.

Vou-lhe fazer uma confissão, Ilka. Cá entre nós, fique claro. Eu não sou o escritor dos malandros. Já estou cansado desse slogan que certos jornais, revistas e repórteres andaram pespegando por aí. (...) Meu futuro literário, a meu ver e sentir de agora, é continuar a linha iniciada pelos contos mais universais e de análise de certas essências do homem, como 'Busca' e 'Afinação da arte de chutar tampinhas'. Lembra-se? Aquela me parece agora ser a minha verdadeira rota. Um corte vertical na alma dos personagens, botando-os para fora sem prosas moles, porém, não exagerando nunca o tamanho de seus vazios interiores. ${ }^{39}$

Estes contos iniciais de sua carreira, cujo espírito o autor, assim, gostaria de ter retomado como sua "verdadeira rota" foram os textos que o fizeram ser comparado, de

\footnotetext{
${ }^{38}$ A referência a este projeto de ficção está em OliveIRA, Ana Maria Domingues de; SILVA, Telma Maciel da. "Memória e ficção na correspondência do escritor João Antônio", op. cit.

${ }^{39}$ Carta a Ilka Brunhilde Laurito de 8 jun. 1964, apud LACERDA, R. João Antônio: uma biografia literária. op.cit., p. 448.
} 
início, a autores como Alcântara Machado e Lima Barreto. As referências ao parentesco de João Antônio e Alcântara Machado foram muito presentes na recepção crítica inicial de $M P B$, como mencionamos. Já com relação a Lima Barreto, as comparações críticas foram ensejadas, em larga medida, pela insistência com que João Antônio procurou homenagear o autor e reafirmar sua dívida literária para com Lima. ${ }^{40} \mathrm{E}$, de fato, as andanças dos protagonistas fazem lembrar os personagens de Lima Barreto, sobretudo Isaías Caminha, quando jovem. Como semelhança entre os dois autores, Antonio Arnoni Prado vê a observação da gente simples e dos tipos comuns, o sentimento de indignação pelo beletrismo, as ruas e os bares como espaços de ficção privilegiados, a "disponibilidade para o conflito" de uma existência à margem, a "dissonância da visão de mundo". 41

É curioso, porém, que as comparações de João Antônio tenham recaído pouco sobre um autor como Mário de Andrade. Talvez isso tenha se dado em função do caráter francamente mítico, rapsódico, de Macunaíma, em contraste com o realismo chão de $M P B$, ou talvez por conta do registro sentimental e lírico da obra de Mário, mesmo nos poemas ou contos em que a cidade de São Paulo avulta como personagem principal, caso de Pauliceia desvairada ou Contos de Belazarte, em oposição à objetividade, algumas vezes beirando o jornalístico, dos textos de João Antônio. Mas a comparação com alguns dos contos mais maduros de Mário de Andrade indica como João Antônio se relacionou e levou adiante conquistas da literatura de Mário que vinham se depurando na prosa curta de ficção que tinha São Paulo como cenário e os personagens pobres ou pequeno burgueses como protagonistas. $^{42}$

Continuadora de Alcântara e Mário de Andrade, a obra de João Antônio também guarda relação com a antropofagia de Oswald de Andrade e com as obras de Graciliano Ramos e Guimarães Rosa no que se refere ao tema da oposição entre "barbárie" e “civilização", conceitos que, como Oswald, Graciliano e Rosa, João Antônio trata de

\footnotetext{
${ }^{40}$ Além das dedicatórias a Lima, João Antônio escreveu um livro sobre o autor: Calvário e porres do pingente Afonso Henriques de Lima Barreto. Recentemente, Clara Ávila Ornellas publicou estudo sobre os dois autores: ORNELLAS, Clara Ávila. João Antônio, leitor de Lima Barreto. São Paulo: Edusp, 2011.

${ }^{41}$ PRADO, Antonio Arnoni. "Lima Barreto personagem de João Antônio". In: Remate de males $\mathrm{n}^{\mathrm{o}}$ 19, op.cit., pp. 147-167.

${ }_{42}$ Além de Macunaíma e dos Contos de Belazarte, no conjunto dos Contos novos, por exemplo, sobressaem muitas semelhanças entre contos de João Antônio e os textos de Mário protagonizados pelo personagem Juca: "Vestida de preto", "O peru de Natal", "Frederico Paciência" e "Tempo da camisolinha" (o protagonismo de Juca, neste último texto é indeterminado, ainda que o texto se comunique fortemente com os demais contos citados, um pouco como acontece com os "Contos Gerais" de João Antônio).
} 
desestabilizar e questionar, quando não inverter, mostrando que os integrantes do polo social positivo - os protagonistas da ordem burguesa em que se inserem os personagens - definem, segregam e marginalizam quem é "bárbaro" aos seus olhos pretensamente "civilizados". O retorno ao "bárbaro" e ao "primitivo", que a obra de Oswald propõe e que João Antônio atualiza no campo da malandragem, lembra também a valorização daquela "barbárie positiva", resultante da pobreza da experiência, tal como a formula Benjamin. ${ }^{43}$

Dizer que João Antônio levou adiante as conquistas dos modernistas e de autores posteriores não significa, obviamente, dizer que o autor é melhor que Mário, Oswald, Alcântara, Graça e Rosa ou que a literatura evoluiu de um momento a outro. Significa dizer que no contexto dos anos 1950 João Antônio retomou um espírito semelhante aos de seus antecessores, compondo, em ficção realista, um retrato imaginativo e complexo da realidade, por meio de personagens e situações exemplares e também surpreendentes e inventivas. Ao mesmo tempo que elaborou ficcionalmente contradições históricas que já estavam anunciadas no modernismo, deu expressão ainda mais acirrada ao drama social e psicológico dos moradores pobres de São Paulo. Se o retrato dos "intalianinhos" feitos por Alcântara tinha por parâmetro dar contornos ficcionais à ascensão social dos "novos mamalucos", no contexto da incipiente industrialização paulistana, flagrando esse movimento no cotidiano dos bairros operários - o Brás, o Bexiga e a Barra Funda —, em João Antônio, o momento histórico posterior apresenta novos desafios de composição. ${ }^{44}$

A modernização, que se anunciava no momento heroico do modernismo com tintas da euforia e da ingenuidade sobre um futuro de prosperidade e progresso, ${ }^{45}$ no limiar dos anos 60 ganha representação mais dramática nos contos de João Antônio - e "dramático", aqui, não é apenas força de expressão, pois diz respeito ao caráter trágico da trajetória dos personagens do autor, como veremos. O espírito de otimismo do pós-guerra e da democratização que sobreveio ao fim do Estado Novo reeditava, de certa forma, aquela crença num progresso e numa modernidade a que o Brasil e São Paulo especialmente

\footnotetext{
${ }^{43}$ Benjamin, W. "Pobreza e experiência". In: Documentos de cultura, documentos de barbárie. Sel. de Willi Bolle. São Paulo: Cultrix/Edusp, 1986.

${ }^{44}$ Em pesquisa anterior, analisamos as obras de Alcântara e João Antônio. ZENI, B. Fachada, sinuca e afasia. Alcântara Machado, João Antônio e Fernando Bonassi. São Paulo, ficção no século XX. Dissertação de mestrado em Teoria Literária e Literatura Comparada. Orientação de Joaquim Alves de Aguiar. São Paulo, FFLCH-USP, 2004. Disponível em: http://www.spap.fflch.usp.br/node/27.

${ }^{45}$ Roberto Schwarz lê o Pau-brasil de Oswald de Andrade como uma poesia que "perseguia a miragem de um progresso inocente", em "A carroça, o bonde e o poeta modernista". In: SchWARZ, R. Que horas são? São Paulo: Companhia das Letras, 1997.
} 
estavam pretensamente destinados. Maria Arminda do Nascimento Arruda, autora que estudou os projetos artísticos e institucionais de tentativa de metropolização e modernização de São Paulo nos anos 1950, observa: "Na vivência de muitos de seus contemporâneos, o Brasil, nos meados do século xx, ensaiava trilhar um alvissareiro caminho histórico, anunciador do efetivo rompimento com as peias que o atavam ao passado, passado este que se recusava a morrer. É como se a débâcle do Estado Novo, a instauração das instituições democráticas e a emergência de um surto desenvolvimentista sem paralelos descortinassem a possibilidade de 'forjar nos trópicos este suporte de civilização moderna"." ${ }^{46}$ A citação da autora refere-se entre aspas à formulação de Florestan Fernandes, que aponta para o caráter incompleto, atrasado e muitas vezes retrógrado do projeto de civilização brasileira, que em São Paulo ganha ares de modernização econômica, tecnológica, urbanística e artística muitas vezes enganosos.

A juventude de João Antônio transcorreu no contexto desenvolvimentista, mas o autor viveu o processo histórico do lado marginal, daqueles que sofreram os efeitos excludentes dessa modernização. A origem humilde da família e a inclinação de esquerda dos textos do autor - de caráter antiburguês e de proximidade aos marginais, malandros e merdunchos - faz com que sua trajetória e sua literatura localizem-se historicamente de maneira complexa. Publicada inicialmente no limiar do golpe de 1964, sua obra se relaciona com um contexto social que é anterior - o da conquista de direitos e da incipiente industrialização da era Vargas e a modernização e o desenvolvimentismo dos anos JK -, mas já anuncia a permanência da dominação e da espoliação das classes populares no contexto social posterior, de acirramento e radicalização à direita da política e da economia, em prol do capital.

A localização histórico-ideológica da literatura do autor ajuda a entender seus alcances e ambiguidades. $\mathrm{O}$ contexto, com suas implicações para a cultura e as artes, foi bem definido por Roberto Schwarz, que apontou a hegemonia da produção artística de esquerda nos primeiros anos de ditadura, hegemonia, entretanto, acompanhada de seus limites de circulação:

\footnotetext{
${ }^{46}$ ArrudA, M. Metrópole e cultura. São Paulo no meio século XX. Bauru, SP: Edusc, 2001.
} 
O seu domínio, salvo engano, concentra-se nos grupos diretamente ligados à produção ideológica, tais como estudantes, artistas, jornalistas, parte dos sociólogos e economistas, a parte raciocinante do clero, arquitetos etc., - mas daí não sai, nem pode sair, por razões policiais. Os intelectuais são de esquerda, e as matérias que preparam de um lado para as comissões do governo ou do grande capital, e do outro para as rádios, televisões e os jornais do país, não são. É de esquerda somente a matéria que o grupo - numeroso a ponto de formar um bom mercado produz para consumo próprio. Esta situação cristalizou-se em 64, quando grosso modo a intelectualidade socialista, já pronta para prisão, desemprego e exílio, foi poupada. Torturados e longamente presos foram somente aqueles que haviam organizado o contato com operários, camponeses, marinheiros e soldados. Cortadas naquela ocasião as pontes entre o movimento cultural e as massas, o governo Castelo Branco não impediu a circulação teórica ou artística do ideário esquerdista, que embora em área restrita floresceu extraordinariamente. ${ }^{47}$

Talvez por conta dessas contradições bem apontadas por Roberto Schwarz a literatura do autor não tenha sofrido reveses durante o período, mas, ao contrário, tenha experimentado grande popularidade, inclusive durante a ditadura militar e principalmente depois do endurecimento de 1968, ainda que uma autora como Flora Süssekind veja no sucesso da literatura de João Antônio uma espécie de afinação com o ideário nacionalista do regime militar.

Este trabalho não se ocupa das razões sociais ou ideológicas pelas quais a obra do autor desfrutou de tamanha popularidade na década de 1970, mas entende que sua relação com o jornalismo e com a situação de arbitrariedade e repressão política tenha se dado de maneira ambígua e torturada, como, aliás, os textos do autor vão registrar, com grande elaboração literária, nos anos 1980, numa espécie de ressaca pela sobrevivência aos anos de chumbo e ao chamado milagre econômico - o que alguns de seus textos, como "Abraçado ao meu rancor", expressam de maneira evidente e dramática.

A obra de João Antônio coloca em cena o avesso - o lado residual e negativo — da modernização dos anos 1950 e 1960. E depois, a partir dos anos 70, aponta para a permanência e o acirramento da exclusão social e da violência urbana que marcariam a segunda metade do século XX, especialmente em São Paulo. O cenário é o de uma cidade urbanizada e industrial, vista $n a$ e $d a$ periferia, com protagonistas que vivem afastados do

\footnotetext{
47 SChwARZ, R. “Cultura e política 1964-1969. Alguns esquemas”. In: estudos. $2^{\text {a }}$ edição. Rio de Janeiro: Paz e Terra, 1978, p. 62. . O pai de família e outros
} 
centro da cidade e dos bairros "bons". Os personagens são trabalhadores proletários e marginais sempre ameaçados de cair ainda mais um degrau na escala de classes, rumo ao lumpesinato, à exclusão. Nos termos que o próprio escritor consagrou para se referir ao seus personagens, são os "sem-eira-nem-beira", "pingentes", "merdunchos". Além deles, João Antônio criou uma galeria de boêmios e malandros, alguns deles construídos como tipos, com todos os cacoetes, com o linguajar e a indumentária fixados no imaginário brasileiro pelo samba: os sapatos finos e lustrosos, as camisas bem passadas, as mãos manicuradas, a gíria característica, o rebolado no caminhar e a pisada macia. Os boêmios e malandros encarnam fantasias e estratégias de sobrevivência que se mostram necessárias num ambiente histórico e social que a todo momento os ameaça espoliar, excluir e, no limite, eliminar.

Perseguir o sentido da malandragem em "MPB" pressupõe considerá-la sob duplo viés: tipo malandro e funcionamento amalandrado, caráter mítico e atualizado, em sua permanência e em ação. A contradição é própria da obra ficcional de João Antônio, em que se combinam o arquétipo e a situação. Em outras palavras, trata-se essencialmente de uma ficção da ação e do mito (na acepção de relato mítico, oral, atemporal, circular e de explicação das origens, aproximando-se da lenda, ${ }^{48}$ e de mythos, "imitação secundária da ação"49 ou, simplesmente, trama, narrativa de uma ação). Isso não significa que no caso de João Antônio, um autor, por excelência, interessado na ação, esteja ausente a reflexão ou pensamento crítico. Como anota Frye: "o mythos é a dianoia em movimento; a dianoia é o mythos em paralisação. Uma causa por que tendemos a pensar no simbolismo literário apenas em termos de sentido é que não temos ordinariamente palavra para o corpo em movimento das imagens numa obra literária". 50

Os personagens de João Antônio são expressão de realismo e de certo arcabouço mítico, atravessados pelos ritos contemporâneos: as passagens de uma fase a outra da vida, os costumes sociais, as lutas, artes e os jogos. Os protagonistas se ligam, por exemplo, aos arquétipos do Édipo, do phármakon (ou bode expiatório) e do pobre-diabo — mas um pobre-diabo que é ainda mais rebaixado na escala social que aquele pequeno funcionário

\footnotetext{
${ }^{48}$ No sentido que Jolles e Vernant dão a mito. Ver Jolles, André. Formas simples. São Paulo: Cultrix, 1976; e Vernant, Jean-Pierre. O universo, os deuses, o homem. São Paulo: Companhia das Letras, 2000, p. 11.

${ }^{49} \mathrm{Na}$ definição de Northrop Frye, inspirada no conceito de mímese de Aristóteles. FrYE, N. Anatomia da crítica. Trad. de Péricles Eugênio da Silva Ramos. São Paulo: Cultrix, 1973, p. 86.

${ }^{50}$ FRYE, N. Anatomia da crítica. op.cit. p. 87, grifo do autor.
} 
público ou amanuense que José Paulo Paes tão bem identificou como um dos anti-heróis recorrentes da literatura brasileira. Os personagens de João Antônio guardam características semelhantes às desse pobre-diabo como a humilhação, o deslocamento, o desengonço, o temor do rebaixamento social, mas estão ainda mais abaixo na escala social, mais para o lumpemproletariado ou, nos termos que o próprio autor utilizava, para "merdunchos". E talvez se possam ver esses personagens - dada a ubiquidade do dinheiro no contexto social em que vivem - como precursores daquilo que Roberto Schwarz, recorrendo a expressão de Robert Kurz, chama de "sujeitos monetários sem dinheiro". 51

Na obra de João Antônio se faz sentir a tensão entre os universos da barbárie e da civilização, como se disse. A malandragem que os contos do autor encena são expressão de uma "barbárie" que nasce do próprio funcionamento da "civilização" brasileira. Como a ficção do autor evidencia, trata-se de uma sociedade, o Brasil de meados do século XX, que se industrializa - são os anos do desenvolvimentismo de JK — mas que se moderniza atualizando elementos antigos, arcaicos e persistentes do funcionamento social brasileiro, uma sociedade pautada pela ambiguidade entre ordem e desordem, público e privado. É uma sociedade dividida, como ainda o é, entre classes sociais que se imaginam distantes e apartadas uma da outra, mas que se ligam por uma lógica excludente, em que os trabalhadores e o povo de modo geral — malandros, merdunchos, trouxas, otários "correm todos os riscos", como diz Roberto Damatta, ${ }^{52}$ em que momentos acirrados de conflitos viram caso de polícia, com prejuízo para os mais pobres, de origem nebulosa, desconhecida ou não reconhecida, como a literatura de João Antônio atesta e encena. "Paulinho Perna Torta", como veremos, é testemunho - literário, artístico — enfático desta lógica exploradora e humilhante.

A obra de João Antônio relaciona-se de maneira crítica com esse dado concreto de realidade. Na ficção, o autor mostra o quanto há de artifício e dominação no esquema que opõe as "famílias" e a malandragem, a sociedade dita "de bem" e os marginais. Como mostra a sua literatura, o lado pretensamente "civilizado", na verdade, submete os excluídos, merdunchos, malandros, pingentes, considerando-os o lado "bárbaro" dessa mesma sociedade. O instrumento pelo qual esse esquema se dá é o da violência social,

\footnotetext{
51 Schwarz, R. "Agregados antigos e modernos. (Entrevista)". In: Martinha versus Lucrécia. Ensaios e entrevistas. São Paulo: Companhia das Letras, 2012.

${ }^{52}$ DaMatTA, R. Carnavais, malandros e heróis. Rio de Janeiro: Rocco, 1997, p. 16.
} 
através da polícia, e econômica, por meio da espoliação, da exploração da força de trabalho, de ocupações informais e desemprego.

A malandragem, nesse quadro, é comportamento que desestabiliza as convicções sobre quem é quem. A estratégia, como veremos, se relaciona com uma certa perspectiva antropofágica, mas ao final se revela autofágica: os malandros tendem a se devorar uns aos outros, a se autoconsumir e não a devorar o outro.

A contradição é expressa, nos contos mais longos do autor, em uma espécie de formação na malandragem, cujo objetivo é a picardia e não o aprendizado formal ou o desenvolvimento humanístico das potencialidades dos personagens. A picardia, esta sabedoria amalandrada, é aquisição e desenvolvimento de capacidade e habilidade, mas também é trapaça, golpe e disfarce. Os personagens, assim, recusam o aprendizado formal para adquirir picardia, afirmando-se no universo da boemia, da sinuca, da malandragem. Eles se lançam à aventura, ganham nome, fama e status, mas empreendem uma ascensão para a queda, como veremos na análise de "Malagueta, Perus e Bacanaço" e, especialmente, de "Paulinho Perna Torta".

Este trabalho procura, assim, definir a sinuca dos malandros: as contradições alcances e limites - dos principais personagens e da obra do autor.

Os malandros representados com mais nitidez em sua obra são Bacanaço e Paulinho Perna Torta. Apesar de João Antônio ter, com razão, se mostrado incomodado com o rótulo de retratista da malandragem e ter expressado o desejo de retomar o espírito de seus primeiros textos (os “Contos Gerais", que constituem a primeira parte de $M P B$ ), é inegável que o sucesso do autor e a excelência de alguns de seus contos se devem, justamente, à representação inventiva desse universo, que o autor logrou realizar. Como pretendemos mostrar, entretanto, João Antônio escreveu sobre o tema de maneira complexa, segundo um viés duplo e imprevisto, retratando a malandragem como um comportamento individual na figura do personagem malandro, o tipo que antes dele o samba consagrou - e também como um mecanismo de funcionamento social, que expressa modos de ser, existir e interagir característicos da sociabilidade brasileira.

O comportamento malandro percorre diferentes produções culturais e artísticas, mas tem na literatura um campo privilegiado de experimentação. A malandragem na literatura brasileira, como se sabe, é de tradição antiga, arraigada na oralidade popular. O 
personagem mais conhecido desta linhagem é Pedro Malasartes, que protagoniza contos populares e inspirou obras posteriores, produzidas já no contexto da cultura letrada. Câmara Cascudo reuniu seis histórias protagonizadas por Malasartes em seu Contos tradicionais do Brasil. ${ }^{53}$ Mário de Andrade, em Contos de Belazarte, criou um narrador que se relaciona em negativo com o personagem da literatura popular, conservando traços da cultura oral e da vida comunitária. O momento em que Mário de Andrade escreve já é, porém, de assimilação social de novos protagonistas sociais, como descendentes de escravos, imigrantes e operários, de urbanização e industrialização, com permanência do atraso e da desigualdade brutal de classes convivendo com elementos de modernidade, como mostram textos como "Túmulo, túmulo, túmulo", "Jaburu malandro" e "Nízia Figueira, sua criada".

Além de Malasartes, paradigma de todos os malandros, como observa Roberto Damatta, ${ }^{54}$ e seus sucedâneos e releituras, a literatura popular brasileira também registra um ciclo de histórias de espertezas e artimanhas protagonizadas por animais, com destaque para o jabuti. Câmara Cascudo define o jabuti como "o herói invencível das estórias indígenas no Extremo Norte, cheio de astúcia e habilidade, vencendo os animais fortes e violentos". Ele é "inofensivo e retraído", mas "aparece nos mitos da língua geral como vingativo, astucioso, ativo, cheio de humor e amigo de discussão". O autor liga o jabuti a outros animais dotados da mesma capacidade de esperteza, como a raposa na mitologia do Velho Mundo. ${ }^{55}$ Em sua Antologia do folclore brasileiro, Câmara Cascudo inclui dois contos deste bicho, recolhidos por Couto de Magalhães: "O jabuti e o veado" e "O jabuti e o gigante". ${ }^{56}$ Em Contos tradicionais do Brasil, consta "O cágado e o teiú", seguido de uma

\footnotetext{
${ }^{53}$ CASCudo, Luís da Câmara. Contos tradicionais do Brasil. $8^{a}$ edição. São Paulo: Global, 2000.

${ }^{54}$ DAMATTA, R. Carnavais, malandros e heróis. op.cit. Ver especialmente o capítulo V, "Pedro Malasartes e o paradoxo da malandragem".

${ }^{55}$ CASCUDO, Luís da Câmara. Dicionário do folclore brasileiro. $5^{\mathrm{a}}$ ed. Belo Horizonte: Itatiaia, 1984. Verbete "Jabuti". Não se tem notícia se João Antônio leu histórias populares ou lendas brasileiras, como as do ciclo do Jabuti. Mas se sabe que as fábulas de Esopo foram leituras que marcaram a juventude do autor, como indica o conto autobiográfico "PMCMS". A pesquisa de Clara Ávila Ornellas na biblioteca pessoal de João Antônio, analisando a marginália e as anotações do autor em alguns dos livros que possuía, aponta para outras leituras relevantes: Alcântara Machado, Machado de Assis, Manuel Antônio de Almeida, Lima Barreto, Marques Rebelo, Graciliano Ramos, Herman Hesse, Dostoiévski, Tchékov, Górki, Pratolini. ORnellas, Clara Ávila. "João Antônio, leitor". In: Papéis de escritor, op.cit., pp. 33-60. A leitura de Esopo, precoce e relevante para a sua formação, pode ter relação com a profusão de animais que povoam a ficção de João Antônio. Não é o nosso tema e não o abordaremos, mas vale registrar que uma profunda zoomorfização dos personagens percorre toda a sua obra. Os malandros são "piranhas", "cobras" do joguinho. Os policiais são "ratos". Os porteiros de boate são "leões". E, num livro de maturidade, Abraçado ao meu rancor, o autor publicaria um texto de juventude, "Uma força", em que o narrador se depara com um "cágado de domingo".

${ }^{56}$ CASCUDO, Luís da Câmara. Antologia do folclore brasileiro. $5^{\mathrm{a}}$ edição. São Paulo: Global, 2001.
} 
nota em que Câmara Cascudo relembra outras versões da história, "substituindo-se a compareceria" pela dupla onça e macaco, e aponta para as origens africanas do conto, em que os protagonistas são tartaruga e elefante, tartaruga e veado, rã e elefante. ${ }^{57}$ Além do jabuti, sua variante, o cágado, também é protagonista de destaque nos contos populares. Silvio Romero reuniu em Contos populares do Brasil, ${ }^{58}$ pelo menos cinco contos de cágado e seis contos de jabuti.

Lembre-se que dentre os personagens zoomórficos de João Antônio — além dos “cobras do joguinho" e "piranhas", como os malandros são alcunhados — está o cágado do conto "Uma força", incluído em Abraçado ao meu rancor, "réptil quelônio" com que o autor depara num domingo, "pelos subúrbios lá longe das minhas chateações”, e se torna uma espécie de duplo. Diz o narrador do conto: "Tinha um não sei quê de sabedoria e sofrimento, e isto me encantou. De pronto lhe quis bem, e era como se já o tivesse conhecido lá antes, antes e depois das lendas dos jabutis. Ah, cágado, passa a viver como pessoa da família e a ser vivente meu". 59

Câmara Cascudo discute as origens do Ciclo do Jabuti e também examina o Ciclo do Gado e o "prestígio do valente" em seu Literatura oral no Brasil. As proezas ligadas à apartação do gado, ao aboio, à ferra e à vaquejada deram ensejo a cantigas, gestas e romances populares, alguns recolhidos por estudiosos, outros registrados em folhetos de feira: “Onde a pastorícia fixa a população a estória do gado é a primeira estória geral. Todos os moradores têm um episódio evocador de valentia ante a ferocidade do bruto. (...) Os poetas anônimos, autores desses poemas, encarnam a defesa do animal perseguido e vitimado. Não há ABC e 'verso' de elogio ao vaqueiro vencedor ou ao cavalo veloz, orgulho da fazenda, derrubador no limpo e no fechado. O estro dos poetas populares haloa o derrotado, trazendo-o sempre vivo para um ambiente de simpatia, dando despedidas irônicas ou líricas aos vaqueiros falhados ou aos recantos em que nascera, pastara e vivera." ${ }^{60} \mathrm{O}$ elogio da coragem e das proezas é característico da "Gesta dos valentes": “O prestígio do valente determina o ciclo para o encantamento popular. Soldado regular ou guerrilheiro, tem seus admiradores. É a coragem pessoal a sugestão suprema, motivo do

\footnotetext{
${ }^{57}$ CAscudo, C. Contos tradicionais do Brasil. op.cit., pp. 194-195.

${ }^{58}$ Romero, Sílvio. Contos populares do Brasil. São Paulo: Landy, 2000.

${ }^{59}$ Amr, p. 160.

${ }^{60}$ CAscudo, Luís da Câmara. Literatura oral no Brasil. $3^{\mathrm{a}}$ ed. Belo Horizonte: Itatiaia/ São Paulo: Edusp, 1984 , pp. 357 e 359.
} 
comentário poético. São, nos Estados Unidos, os cangaceiros, killers, Wild Bill Hickok, Billy the Kid, Jesse James, Sam Bass, ou os free lances, francos-atiradores, Roy Bean, Buffalo Bill, Big-Foot Wallace, com estórias, cantos, lendas. Esse halo admirativo não significa solidarismo com as atitudes do herói mas compreensão humana pela energia, irradiante coragem, resistência, destemor. Esse é o clima inglês para Robin Hood e francês para Louis Mandrin (...) A ousadia pessoal seduz e os corsos louvam seus valentes como os sertanejos historiam as andanças dos cangaceiros. $" 61$

As lendas em torno das gestas populares e a literatura do cangaço têm forte penetração na cultura brasileira ainda hoje e deitam raízes em um período histórico anterior ao seu momento de maior definição, o final do século XIX e o começo do século XX, quando se destacam as figuras de Cabeleira, Lampião, Corisco. Na literatura considerada erudita, o tema do cangaço e da jagunçagem, como mostrou Antonio Candido, é expressão de um funcionamento social pelo qual "a ordem privada desempenha funções que em princípio caberiam ao poder público". Historicamente, remonta à incipiente urbanização da região das Minas. A vida comunitária e a violência nas zonas rurais, permeadas de elementos de caráter urbano, ainda que influenciadas em menor grau pela "civilização urbana", deu ensejo no Brasil a uma literatura do cangaço e da jagunçagem que canta, em prosa e verso, a "tropelia" e a "violência grupal e individual, normais de certo modo nas sociedades rústicas do passado". 62 Desde os poetas mineiros até Guimarães Rosa e depois, a literatura da jagunçagem representou e problematizou a ousadia e a notoriedade, a violência e a dimensão constestatória, a ação e a resistência, persistindo como traço cultural forte não apenas na literatura mas na cultura brasileiras.

A literatura de João Antônio tem como antecedente essa longa tradição da literatura popular e da literatura erudita, brasileira e universal, na qual a proeza, a valentia, a façanha e a violência expressam contextos comunitários e sociais, limites e enfrentamentos pessoais, desejos humanos de reconhecimento, fama, realização e conquista.

\footnotetext{
${ }^{61}$ CASCUDO, Luís da Câmara. Literatura oral no Brasil. op.cit., pp. 362-363.

${ }^{62}$ CANDIDO, Antonio. "Jagunços mineiros de Cláudio a Guimarães Rosa”. In: Vários escritos. 4" edição. São Paulo/Rio de Janeiro: Duas Cidades/Ouro sobre azul, 2004, p. 99.
} 
No entanto, os personagens de João Antônio aqui contemplados não são jagunços; são malandros ou bandidos. ${ }^{63}$ No caso dos personagens iniciais do autor, os protagonistas dos "Contos Gerais" e de "Visita", por exemplo, nem se pode dizer que sejam malandros, ainda que a lógica da malandragem já atue em seu comportamento e informe seus devaneios e angústias. Os personagens dos contos mais desenvolvidos, sobretudo Perus, Malagueta, Bacanaço e Paulinho Perna Torta, sim, são malandros e até criminosos (os dois últimos, sobretudo), mas alguns deles, em especial o último, Perna Torta, como veremos, é mais que isso: é jovem de origem desconhecida, moleque de rua, malandro e bandido, além de "rei". Avultam como exceção no quadro de personagens do autor os dois leões, Jaime, o Pirraça, e Joãozinho da Babilônia, personagens de $L d c$ (livro publicado em 1975). Ambos são guarda-costas, "forma branda de jaguncismo", como define Candido. Nenhum dos dois contos, "Ldc" e "Joãozinho da Babilônia", porém, será analisado neste trabalho, que se concentra na ficção inicial de João Antônio e delimita seu corpus a partir de uma questão que, se não está ausente nestas duas narrativas, não é decisiva para a constituição de personagens e entrecho. Ao contrário, justamente porque o jagunço pressupõe relações de mando e dependência, ligadas à posse da terra, às disputas políticas e a um funcionamento social arcaico, ainda que persistente, ele não é, nos limites desta tese, um tipo que nos interesse como o malandro e o criminoso.

Se na tradição popular a figura do malandro e do valente são representadas por personagens que são bichos antropomorfizados ou anti-heróis que expressam o ponto de vista dos oprimidos, na literatura moderna a malandragem também ensejou obras relevantes, com personagens que se comportam como malandros, oscilando entre ordem e desordem, entre norma e transgressão, moralidade e boemia, sociedade instituída e práticas consideradas ilícitas e criminosas. As Memórias de um sargento de milícias, que Antonio Candido analisou em "Dialética da malandragem", 64 é o texto de referência para a localização do funcionamento social que informa toda uma linhagem de obras literárias, à

\footnotetext{
${ }^{63}$ Segundo Candido, "o nome de jagunço pode ser dado tanto ao valentão assalariado e ao camarada em armas, quanto ao próprio mandante que os utiliza para fins de transgressão consciente, ou para impor a ordem privada que faz as vezes de ordem pública. De qualquer forma, não se consideram jagunços os ladrões de gado, os contrabandistas, os bandidos independentes. Embora haja flutuação do termo, a idéia de jaguncismo está ligada à ideia de prestação de serviço, de mandante e mandatário, sendo típica nas situações de luta política, disputa de famílias ou grupos". idem, ibidem, p. 105.

${ }^{64}$ CANDIDO, Antonio. "Dialética da malandragem". In: $O$ discurso e a cidade. São Paulo: Duas Cidades, $2^{\text {a }}$ edição, 1998. Ver também SCHWARZ, Roberto. "Pressupostos, salvo engano, de Dialética da malandragem." In: Que horas são? op.cit.
} 
qual pertencem também Macunaíma ${ }^{65}$ Brás, Bexiga e Barra Funda ${ }^{66}$ Desabrigo, de Antonio Fraga, alguns romances de Jorge Amado, o Auto da Compadecida, de Ariano Suassuna, todo o samba, mas em especial o samba malandro, ${ }^{67}$ a obra de Chico Buarque, com destaque para Ópera do malandro, e os contos de João Antônio, dentre outras obras.

Apesar de ser um traço forte da obra de João Antônio, a malandragem, porém, não é o tema desta tese, ainda que ela seja expressão de algo que nosso trabalho define como seu objeto de análise: as relações entre personagens e figuras paternas. As indicações comparativas sobre outros autores - os modernistas, mas também Lima Barreto, Guimarães Rosa, Graciliano Ramos e Rubem Fonseca - cujas obras se relacionam com a de João Antônio também não constituem o cerne de nosso trabalho, apesar de sugerirem caminhos historiográficos que pedem desenvolvimento.

Este trabalho se propõe a analisar a literatura de João Antônio a partir de uma questão que atravessa sua obra, do princípio ao fim: a relação dos protagonistas com as figuras paternas. O corpus do presente trabalho se delimita, assim, de acordo com essa premissa: analisar os textos literários de João Antônio em que os protagonistas se relacionem com seus pais e sucedâneos ou com outros personagens que assumam lugares de autoridade e posições de hierarquia vertical relevantes para a compreensão dos textos.

\footnotetext{
${ }^{65}$ A obra de Mário de Andrade é toda ela atravessada pelo folclore e pela cultura popular, por sua influência e pela pesquisa estética que o autor desenvolveu em torno desse tema. Macunaíma é apenas a obra de maior fôlego nessa direção, mas a música, a narrativa oral, a cultura popular e a malandragem são temas na pesquisa etnográfica e na crônica ( $O$ turista aprendiz), na poesia (Clã do jabuti, Remate de males, Lira paulistana), no ensaio ( $O$ empalhador de passarinho), na ficção (Contos de Belazarte, como "Jaburu malandro"), dentre outros). Gilda de Mello e Souza, partindo da ideia de que a novidade estética radical de Macunaíma reside no seu descompromisso com a mímese e no procedimento de bricolagem (montagem lúdica e seletiva de fragmentos, o que pressupõem boa dose de invenção), chega na fórmula de $O$ tupi e o alaúde, segundo a qual a obra de Mário de Andrade combina análise do fenômeno musical e processo criador popular, "duas obsessões fundamentais" que informam a "meditação estética" do autor e sugerem formas universais de compor (a suíte e a variação). SouZA, G. M. e. O tupi e o alaúde. Uma interpretação de Macunaíma. $2^{a}$ edição. São Paulo: Livaria Duas Cidades/Editora 34, 2003.

${ }^{66}$ Já tivemos oportunidade de analisar o livro de Alcântara Machado no que ele encena de modernidade de "fachada", num momento de transformação e renovação aceleradas, não apenas na literatura, mas também na sociedade brasileira. Em trabalho anterior, tentamos mostrar que a prosa de Alcântara é renovadora da linguagem e seu retrato dos bairros operários de São Paulo é objetivo e distanciado, mas sua ficção deixa entrever, por detrás da fachada de modernidade e integração étnica, a permanência e a eclosão de práticas de favorecimento e corrupção típicas da mistura de público e privado do cordialismo brasileiro, tal como estudado por Sergio Buarque de Holanda. ZENI, B. Fachada, sinuca e afasia. Alcântara Machado, João Antônio e Fernando Bonassi. São Paulo, ficção no século XX. op.cit. Disponível em: http://www.spap.fflch.usp.br/node/27.

${ }^{67}$ Sigo aqui a tipologia de Claudia Matos: o samba apologético-nacionalista ou samba-exaltação, cujo representante maior é Ary Barroso, o samba-lírico amoroso, de Cartola e Nelson Cavaquinho, entre outros, e o samba-malandro de Geraldo Pereira e Wilson Batista. MATos, Claudia Neiva de. Acertei no milhar: samba e malandragem no tempo de Getúlio. Rio de Janeiro: Paz e Terra, 1982.
} 
A partir dessa delimitação - interação entre protagonistas e figuras paternas (pais ou pais substitutos) - , portanto, escolhemos os textos de João Antônio aqui analisados. O trabalho contempla sobretudo textos de ficção, mas examina também os três principais textos autobiográficos do autor. Assim, nossas análises compreendem: no capítulo 1, os contos autobiográficos Lambões de caçarola (Trabalhadores do Brasil!), "Paulo Melado do Chapéu Mangueira Serralha" e "Abraçado ao meu rancor"; no capítulo 2, os "Contos Gerais", especialmente "Busca", incluindo alguns comentários sobre os demais textos de $M P B$, primeiro livro de João Antônio; no capítulo 3, o conto "Malagueta, Perus e Bacanaço", que dá título ao livro de mesmo nome; no capítulo 4, "Paulinho Perna Torta", conto escrito em meados dos anos 1960, mas incluído em volume do autor apenas dez anos depois, em $L d c$ (1975).

Nossas leituras dos contos autobiográficos, que compõem o capítulo 1, partem do pressuposto de que, apesar de biográficos, são textos essencialmente literários, que compõem a obra literária do autor assim como os textos ficcionais. A construção e a estrutura dos relatos os tornam realizações artísticas singulares, equilibradas entre a autobiografia e a ficção. Esta ambiguidade, que é característica de todo texto memorialístico, dado que a experiência vivida é reelaborada na rememoração e sobretudo na sua transformação em linguagem verbal, em narrativa, é acentuada no caso dos textos de João Antônio por conta mesmo de certa indefinição no pacto que estes relatos estabelecem com o leitor.

Recorremos aqui à ideias de Phillipe Lejeune a respeito do pacto autobiográfico, definido pelo autor francês de acordo com os procedimentos textuais e paratextuais por meio dos quais se apresenta o narrador autobiográfico e se estabelecem os gêneros dos textos ou livros. Como veremos no capítulo 1, apesar do conteúdo biográfico dos relatos, que trazem correspondências com episódios da vida do autor, neles o pacto autobiográfico não é inequívoco. Em nenhum dos três textos, narrados todos em primeira pessoa, o personagem-narrador se identifica claramente ou informa o seu nome, ainda que muitos outros personagens, reais ou ficcionais, reais $e$ ficcionais, sejam claramente nomeados, assim como outros também não sejam nomeados. Além da ambiguidade que cerca a identidade dos protagonistas, também o gênero dos textos é indeterminado, como 
procuramos mostrar por meio da análise de paratextos, como dedicatórias, prefácios e fichas catalográficas, textos de orelha e de quartas capas (ou contracapas).

Assim, esses três contos de João Antônio, segundo nossa interpretação, não se adequam com justeza à classificação de textos autobiográficos e não são tomados, aqui, como fonte sobre a vida do autor. Os contos autobiográficos são analisados em função, justamente, da relação que os protagonistas-narradores estabelecem com os pais e seus sucedâneos, para compreender como a construção literária desses textos se relaciona à construção da identidade dos narradores e também à identidade de João Antônio como escritor - e não apenas do homem João Antônio, ser empírico, nascido na periferia de São Paulo em 1937 e morto em Copacabana, Rio de Janeiro, em 1996. Em outras palavras, entendemos que os textos autobiográficos são parte da obra literária do autor, cumprem função decisiva em sua constituição enquanto indivíduo autônomo e escritor e, por fim, também expressam os limites literários de João Antônio, ligados, como não poderia deixar de ser, a questões de sua biografia.

A atenção detida e a análise dos textos autobiográficos, assim, não conferem viés biográfico à nossa leitura. Bem ao contrário, procuramos mostrar que mesmo os textos autobiográficos compreendem um trabalho de elaboração e construção literárias que incluem recursos típicos da ficção. As ambiguidades inerentes a essa combinação contribuem para enriquecer a literatura do autor, pois fazem parte de sua estratégia de se afirmar como escritor, definir suas opções literárias e então, no momento da maturidade, expressar os impasses dessas escolhas, de vida e de profissão, entre o jornalismo e a literatura, entre a fidelidade às origens e a ascensão social.

É por isso que insistimos em ler o contos analisados no capítulo 1 com desconfiança em relação ao seu caráter essencialmente autobiográfico. Acreditamos que essa estratégia interpretativa permite, assim, entrever o sentido profundamente artístico desses contos, em que a encenação da autobiografia revela um escritor consciente de seus alcances e das contradições advindas de suas conquistas. Isso não significa que consideramos os textos autobiográficos de maneira ficcional ou que desconfiamos do que se narra ali, mas que, de novo, bem ao contrário, entendemos que a autobiografia pressupõe uma arte narrativa. Como diz Lejeune: 
O fato de a identidade individual, na escrita como na vida, passar pela narrativa não significa de modo algum que ela seja uma ficção. Ao me colocar por escrito, apenas prolongo aquele trabalho de criação de "identidade narrativa", com diz Paul Ricouer, em que consiste qualquer vida. É claro que, ao tentar me ver melhor, continuo me criando, passo a limpo os rascunhos de minha identidade, e esse movimento vai provisoriamente estilizá-los ou simplificá-los. Mas não brinco de me inventar. Ao seguir as vias da narrativa, ao contrário, sou fiel a minha verdade: todos os homens que andam na rua são homens-narrativas, é por isso que conseguem parar em pé. Se a identidade é um imaginário, a autobiografia que corresponde a esse imaginário está do lado da verdade. Nenhuma relação com o jogo deliberado da ficção. ${ }^{68}$

A partir do capítulo 2, passamos às análises dos textos ficcionais.

Nossa concepção de análise literária se pauta pela ideia de que o texto ficcional é constituído de três elementos essenciais: narrador, personagens e ação. Esse conceito inspira-se na Poética de Aristóteles, ainda hoje central para os estudos literários, e onde, como se sabe, valorizam-se as noções de mimese (imitação) e de mythos (ação). A poética aristotélica, porém, também como é notório, se refere a obras de caráter dramático comédias e tragédias da Antiguidade - , em que não se encontra a figura do narrador, instância fundante e decisiva para a narrativa de ficção e, consequentemente, para a análise literária das obras aqui apreciadas.

Se o personagem constitui a ficção, como assinala Anatol Rosenfeld, ${ }^{69}$ o narrador é o elemento da ficção que, se não a instaura, ao menos, a conduz, dispondo os demais elementos de acordo com sua posição, o foco em terceira ou primeira pessoa, com seu ponto de vista em relação aos personagens, com o tom que imprime ao relato e com a sua relação com o leitor. O ponto de vista, o foco narrativo e a maneira com que narradores e personagens se relacionam nos parecem, portanto, boas entradas para a análise literária da ficção do autor.

João Antônio escreveu contos em terceira e em primeira pessoa, atingindo resultados notáveis em ambas as modalidades de foco narrativo. Dos contos analisados neste trabalho, apenas "Malagueta, Perus e Bacanaço" é narrado em terceira pessoa. Os

\footnotetext{
${ }^{68}$ LEJEUNE, Philippe. "Autobiografia e ficção". In: O pacto autobiográfico. De Rousseau à internet. Trad. de Jovira Maria Gerheim Noronha e Maria Inês Coimbra Neves. Belo Horizonte: Editora UFMG, 2008.

${ }^{69}$ Rosenfeld, Anatol. "Literatura e personagem". In: Antonio Candido et al. A personagem de ficção. São Paulo: Perspectiva, 1976. $5^{\text {a }}$ edição, p. 27.
} 
demais, "Contos Gerais", "Paulinho Perna Torta" e os contos autobiográficos, são todos narrados em primeira pessoa.

Antonio Candido, ao comentar "Malagueta, Perus e Bacanaço", destaca justamente a capacidade do autor de dar voz aos marginais, diminuindo as distâncias entre narrador culto e mundo narrado, fundindo narrador e protagonistas. Trata-se de um artifício literário que tem relação com a posição do narrador e com o ponto de vista deste em relação aos demais personagens. Como diz Candido, João Antônio “inventou uma espécie de uniformização da escrita, de tal maneira que tanto o narrador quanto os personagens, ou seja, tanto os momentos de estilo indireto quanto os de estilo direto, parecem brotar da mesma fonte". 70

Como veremos no capítulo 3, o narrador deste conto, além de se aproximar e talvez participar da ação como personagem, também sabe tomar distância quando necessário, para apontar as brutalidades e os limites da aventura malandra. Apesar da cisão do protagonista em três, em "MPB” é possível verificar que as relações de parceria e hierarquia que se estabelecem entre os jogadores já apontam para o dilema, a sinuca, em que os malandros vivem: eles precisam de outros jogadores para suas trampolinagens, mas também dependem de uma relação vertical de mando, de chefia, que os permite se lançar à aventura mas também os torna reféns da lógica da malandragem. Em nossa leitura, por sinal, a malandragem é pautada, justamente, pela contradição entre as relações a um só tempo horizontais e verticais que se estabelecem entre os personagens, no que ela, portanto, expressa contradições da relação entre pais e filhos.

O tema da malandragem ganha, neste conto, um retrato excepcional, pois João Antônio o abordou duplamente, como dissemos: enquanto tipologia de personagem, sobretudo na figura de Bacanaço, o típico malandro à moda antiga, e enquanto conceito, comportamento e estratégia de sobrevivência. Fez isso de maneira habilidosa, expondo a reversibilidade entre malandros e trouxas, algo, aliás, bem apontado anteriormente por

\footnotetext{
${ }^{70}$ CANDIDO, Antonio. "Na noite enxovalhada". In: $M P B$, pp. 10-11. O texto de Candido, escrito em 1995 como prefácio a uma edição de $M P B$ que não saiu, foi originalmente publicado na citada revista Remate de males, $\mathrm{n}^{0} 19$, op.cit. O texto foi republicado como prefácio da edição mais recente de Malagueta, Perus e Bacanaço (Cosac e Naify, 2004).
} 
Antonio Hohlfedt ${ }^{71}$ e por Jesus Antônio Durigan, que fala em "ciranda da malandragem", 72 para definir o funcionamento vicioso de perde e ganha com que os personagens comportam.

Aqui, tentamos mostrar como a fantasia de malandro também é uma estratégia ambígua: ela revela e esconde a identidade do personagem. A fantasia, por um lado, é disfarce: é fantasia de malandro e, a um só tempo, de burguês e de nobre, o que permite viver e sobreviver sem se inserir socialmente, mas dependendo dessa mesma ordem social, que o malandro despreza; por outro, é devaneio, fantasia de grandeza e façanha que faz com que o malandro sonhe com golpes de sorte, com a fortuna, mas se veja o tempo inteiro confrontado com as marés de sorte e azar, com a vulnerabilidade que lhe é própria, com a exploração promíscua a que se submete e é submetido pela polícia, com a violência com que o poder instituído o trata quando ele se torna um sintoma da barbárie que a civilização traz entranhada em si mesma.

O ponto de vista interno, que é admiravelmente conduzido em aproximações e distanciamento por meio do discurso indireto livre nos contos em terceira pessoa, como em "Malagueta, Perus e Bacanaço", ganha nas narrativas em primeira pessoa, por sua vez, soluções também notáveis. Narrador e personagem são, por princípio e por definição, coincidentes nos contos em primeira pessoa. Nesses textos é o protagonista quem narra, o que acarreta um ponto de vista interno que é constitutivo da história narrada e que limita a ação, justamente, à perspectiva do personagem-narrador. Na ficção de João Antônio, o foco em primeiro pessoa é responsável por criar alguns de seus personagens mais complexos e contraditórios, porque eles são, justamente, personagens e narradores - e alguns deles se confundem com o próprio autor.

O duplo papel, de personagem e narrador, dos seus protagonistas ganha realização maior em "Paulinho Perna Torta", conto que concentra os principais temas e questões da literatura de João Antônio. O texto indica que, da malandragem dos primeiros relatos (os “Contos Gerais", primeira parte de $M P B$, e os contos de "Sinuca", última seção do mesmo livro) passou-se à criminalidade desabrida do protagonista Perna Torta.

"Paulinho Perna Torta" narra a história de um criminoso assim alcunhado por um malandro mais velho, Laércio Arrudão, por conta de um machucado na perna, adquirido

\footnotetext{
${ }^{71}$ Hohlfeldt, A. "Para lá de Bagdá", prefácio a Os melhores contos. João Antônio. $2^{\mathrm{a}}$ edição. São Paulo: Global, 1997.

${ }^{72}$ DuRIGAN, J. "João Antônio e a ciranda da malandragem”, op.cit.
} 
depois de uma briga entre uma prostituta e um travesti que se desentenderam por conta de Paulinho. O personagem carrega a fama de ter matado o próprio pai, crime que ele enuncia, para negar, duas vezes ao longo da narrativa. Como lhe falta o pai, o jovem malandro encontra em Laércio Arrudão um pai substituto. É o malandro mais velho, seu "padrinho", que irá orientá-lo nas atividades ilícitas. O conto narra a trajetória desse malandro criminoso desde o começo de sua vida de virações, como engraxate nas estações da Luz e Julio Prestes, ao mesmo tempo em que descreve a constituição da Boca do Lixo paulistana, cujo marco é 1953, ano que dá eixo à narrativa. Ali, na Boca, Perna Torta vira "rei", impondo-se como empresário do jogo, cafetão e traficante, depois de inúmeros percalços, dentre os quais uma passagem pela Casa de Detenção. A falta do pai, o possível parricídio e o encontro com o malandro mais velho, o padrinho, apontam para consequências negativas — e, talvez por isso mesmo, de alto potencial crítico - que a trajetória do personagemnarrador evidencia. Sua crise existencial profunda, ao final do conto, relaciona-se com sua formação individual, com a relação com outros personagens, com o contexto social em que ele vive e com sua constituição como personagem-narrador.

Nossa abordagem da obra de João Antônio tem por orientação a análise dos elementos literários do texto ficcional, mas se abre também para os aspectos sociais, psicológicos e paraliterários que compõem as obras. Partindo da escolha de textos em que os protagonistas se deparam e se confrontam com figuras paternas, empreendemos um caminho de análise que localiza na presença e na ausência paternas situações decisivas para a ficção do autor. Essa aproximação crítica permite ver como os contos de João Antônio têm um forte pathos comum e, de maneira recorrente, colocam em cena um romance familiar que revisita e atualiza algumas as questões decisivas para os personagens principais, como o desafio de crescer, de deixar o terreno da infância e projetar-se no mundo adulto, de deixar a casa e ganhar a rua, passar da família à sociedade, ganhando então autonomia, movimento que tem formulações cruciais para a literatura de João Antônio nos conceitos de aprendizado, malandragem e narração. Como veremos, a obra do autor se relaciona não apenas com a lenda de Édipo tal como relida por Freud e por teóricos da literatura como Marthe Robert, mas também de maneira arquetípica, com a lenda de Édipo, pois sua obra reedita a história do herói que está sujeito às garras do destino, que a certa altura, toma consciência disso, mas não pode escapar à condenação a que foi 
destinado. A relação ambivalente dos protagonistas com o pai é a questão de base nos textos de João Antônio e nos conduz, assim, aos demais temas, sobretudo à malandragem, à necessidade de narrativa e à dificuldade de narrar. E, por fỉm, à posição artística e pessoal do escritor, que ao final da carreira ganhou modulação diversa daquela dos primeiros livros — uma certa "estética do rancor", como a definiu João Luiz Lafetá ${ }^{73}$ —, ainda que coerente com a trajetória do autor e dotada de alto grau de reflexão e consciência de seu lugar social.

Procuramos, aqui, seguir as indicações críticas formuladas por Antonio Candido, tentando levar adiante a caracterização e a apreciação que o crítico faz das obras de João Antônio. Nosso método se ampara na atenção detida aos elementos essenciais da ficção, com destaque para narrador, personagens e ação narrativa. As análises se baseiam na paráfrase e nos comentários a trechos significativos dos contos, destacando a interação entre os elementos, sobretudo narradores e personagens, atentando também para o manejo e para a invenção da linguagem, que em João Antônio é fundamental na combinação de oralidade e elaboração culta — marca de origem e experiência do autor e de seus personagens, reinventada por este escritor de talento e de ouvido afinado para a música cotidiana das palavras, especialmente para a "charla" dos "merdunchos".

Acreditamos que a escolha dos contos aqui analisados permite localizar questões críticas relevantes para a obra de João Antônio: a constituição de narradores e personagens, a trajetória dos personagens ficcionais, a forma do conto, o conceito de malandragem e as relações entre a literatura e a biografia do autor. Ainda que grandes críticos literários brasileiros, como Antonio Candido, Alfredo Bosi, João Alexandre Barbosa, José Paulo Paes, João Luiz Lafetá e Antonio Arnoni Prado, entre outros, tenham se debruçado sobre sua literatura, a obra do autor ainda pede olhar de conjunto e análises mais detidas.

Nosso trabalho partiu da leitura integral da obra de João Antônio publicada em livro. Para tanto, escolhemos certa abordagem da obra do autor, não de acordo com os gêneros literários praticados por ele nem segundo a cronologia de publicação ou da vida do escritor, mas de acordo com certa visada crítica, que procuramos aqui desenvolver, atentando sobretudo para a trajetória de seus protagonistas.

Nos contos do autor, sobressai certo tipo recorrente de personagem: o jovem brasileiro pobre do sexo masculino. E o grande tema da obra de João Antônio será

\footnotetext{
${ }^{73}$ LAFETÁ, João Luiz. “João Antônio e sua estética do rancor”. In:
} . A dimensão da noite. op.cit. 
protagonizado por esse personagem, que assume diferentes feições ao longo de sua carreira literária. O drama de família que aparece nos contos do autor em geral é protagonizado por um jovem rapaz que se descobre, justamente, nesse momento decisivo em que é preciso deixar para trás certas amarras e fixações, para lutar contra o destino a que se foi destinado (com o perdão do jogo de palavras) por seu contexto histórico, social e, claro, familiar. O conflito se expressa por meio de sofrimento e angústia, daí o forte conteúdo psicológico manifesto das narrativas, mas se desenrola num contexto social bem específico, ainda que nunca claramente enunciado nos contos. $\mathrm{O}$ drama que vivem esses rapazes de origem social modesta é um só: o desejo e a dificuldade de se estabelecer na sociedade brasileira de meados do século XX - e a recusa a se inserir socialmente nos termos "positivos" desta sociedade urbana, burguesa, católica e de moralidade convencional.

As narrativas desse personagem recorrente mostram que sua inserção problemática os impele à ação. É conhecida a inclinação dos personagens para o deslocamento, para as longas andanças pela cidade e para a movimentação incessante, comportamento que Alfredo Bosi chamou de "ânsia deambulatória"," Esse impulso horizontal de ampliação do espaço é complementado por um vetor vertical, que faz com que os protagonistas estejam sempre ocupados com a promessa de ascensão social, mas também assombrados pela ameaça iminente da queda.

As contradições dos jovens pobres e sonhadores, protagonistas dos contos do autor, divididos entre o desejo de ascensão, de aventura e o temor da derrota e da queda ganha metáfora exemplar no jogo de sinuca:

Sonhei que voltara às grandes paradas. Eu e Carlinhos.

Desprezando para sempre nossos empregos, sozinhos no mundo e conluiados, malandros perigosos, agora. Vagabundeávamos, finos na habilidade torpe de qualquer exploração. E fisgávamos mulheres, donos de bar, zeladores de prédios, engraxates, porteiros de hotel, meninos que vendem amendoim...

Era quando a branca caía.

No jogo, no quente jogo aberto das parceiradas duras, partidas caríssimas, eu tropicava, tropicava, repetidamente. Aquilo não se explicava! A tacada final era dolorosa e era invariável — era a minha - e eu me perdia. Aquilo, aquilo nos arruinava. Quem me visse e não soubesse diria

\footnotetext{
${ }^{74}$ BosI, A. "Um boêmio entre duas cidades". Prefácio a Amr.
} 
que eu estava traindo. O ótimo Carlinhos não se desnorteava, fazia fé, dava-me o embalo, imprimia moral.

— Firma e joga o jogo!

Mas nada. Ajeitasse giz no taco, estudasse os efeitos das tabelas, caçasse combinações, lavasse o rosto para a tacada — não me salvava. A bola branca caía.

Como se depreende dos "Contos gerais" e alguns outros contos iniciais do autor, como "Visita", acima citado, o empuxo que atua sobre os personagens tem sentido contrafamiliar, isto é, os personagens querem sair de casa e ganhar a rua. Sonham em se emancipar do domínio da família e ingressar na ordem social, ainda que em negativo — na boemia, no jogo, na malandragem e, no limite, no crime - , para além dos limites do convívio da família nuclear e da comunidade, para além das origens, sempre sonhando com as "grandes paradas", com a aventura. O movimento é espacial e social, mas também psicológico. Como bem observa Vima Lia Martin acerca dos “Contos Gerais”:

As personagens que protagonizam os três contos são "otários" que rejeitam os valores burgueses cultivados por seu meio social e sofrem de uma insatisfação profunda advinda de uma certa consciência que possuem acerca das contradições sociais e das limitações inerentes ao lugar social que ocupam. São personagens masculinas que, ao sofrerem a experiência do deslocamento psíquico ou social, acabam por ser porta-vozes da angústia daqueles que não incorporam a ideologia burguesa, pautada em valores como o trabalho e a família. ${ }^{75}$

Do ponto de vista da crítica e da teoria literária, nossa leitura busca, portanto, unir conteúdos sociais, familiares e psicológicos, por entender que esses componentes estão não apenas presentes nas narrativas mas muitas vezes relacionados, quando não confundidos e consubstanciados. Trata-se, no caso da ficção de João Antônio, portanto, de mostrar como conteúdo psicológico e conteúdo social estão não apenas unidos, mas imbricados, e como o autor expressa por meio da forma literária essa condição existencial de seus protagonistas. Trata-se de mostrar, ainda, como esses elementos ganham retrato dramático, trágico, na ficção do autor, que encena e reencena a mesma história — a aventura e seus limites —, num contexto social e numa trajetória individual precisa: o jovem rapaz de origem pobre, no Brasil de meados do século XX.

\footnotetext{
${ }^{75}$ MARTin, Vima Lia. Literatura e marginalidade: um estudo sobre João Antônio e Luandino Vieira. São Paulo: Alameda Editorial, 2008, p. 73.
} 
A caracterização dos textos de João Antônio permite inseri-lo, como acreditamos, em certa tradição que tem raízes no século XIX, tributária da ficção realista e naturalista, do romance burguês e do conto moderno. Em linhas gerais, é um autor que se liga à linhagem daquilo que Frye chamou de "ficção trágica" e mais especificamente de "tragédia imitativa baixa", 76 com origem no novecentos e continuidade no século seguinte. O momento histórico brasileiro em que esse drama se desenvolve, no caso de João Antônio, situa-se entre a revolução de 1930 e o golpe militar de 1964; esse contexto, como indica a obra do autor, é marcado, sobretudo para os mais pobres, mais por uma promessa de mudança e modernização que por uma transformação social consolidada, e a trajetória de seus personagens, sempre flertando com a marginalidade, expressa contradições da história e da sociedade que vêm do passado brasileiro e que continuam atuando em nosso tempo.

A vitalidade da obra do autor continua a surpreender, apontando para uma solução formal singular que faz de João Antônio um autor de grande interesse e influência para a literatura brasileira contemporânea. O ponto de vista interno com que o autor escreveu seus textos, além de estabelecer uma perspectiva privilegiada, já que permite narrar desde o coração das paixões e dos problemas de seus personagens, também constitui limites, como a de se manter fiel a seu universo e suas origens, ao mesmo tempo que deles apartado e destacado, já que se trata de um escritor contemporâneo e consciente, que retrata mas também reflete sobre o que vê e sobre o que cria.

Em seus melhores momentos, os textos de João Antônio não são mero reflexo de uma dada realidade. ${ }^{77}$ São recriações literárias complexas, em que personagens e ambiente social interagem e contribuem para se definir um ao outro. Isolados, alguns personagens constituem figuras ricas, cujas trajetórias revelam-se histórias de grande complexidade literária e interesse psicológico e social. Aqui, trata-se, aliás, de estabelecer uma visada crítica que conjugue justamente esses aspectos, literário, paraliterário, psicológico e sóciohistórico, arcabouço teórico que adotamos não por convicção apriorística, mas por sugestão ou exigência da obra em quadro.

\footnotetext{
${ }^{76}$ FRYE, N. Anatomia da crítica. op.cit., p. 44.

${ }^{77}$ Para tanto, pensamos no conceito de reflexo e reflexão propostos por Alfredo Bosi, mas também na leitura de Antonio Candido a respeito do autor. Bosi, A. "Reflexo e reflexão em história literária", in: Literatura e resistência. São Paulo: Companhia das Letras, 2002. CANDIDO, A. "Na noite enxovalhada”, in: MPB.
} 
Para compreender de que maneira sua literatura se sustenta sobre esses pilares, escolhemos estudar a obra de João Antônio de acordo com um eixo de análise particular, que relaciona vida e literatura, atentando para os desdobramentos e os reflexos da experiência pessoal na sua obra publicada, mas partindo sempre dos textos do escritor e com ênfase e interesse principal em sua literatura. Em outras palavras, o que nos interessa são os textos do escritor, mas também a vida de João Antônio na medida em que ela esclarece (ainda que não explique ou solucione) aspectos de sua literatura. $\mathrm{Na}$ verdade, neste caso, talvez a obra ilumine a vida e não o contrário. Em outros termos, em João Antônio vida e obra se atravessam, sem correspondências mecânicas, mas em relação complexa e contraditória, ainda que coerente: o escritor escreveu sobre o que viveu, reinventando a própria biografia, e viveu os desejos que animavam sua escrita e as consequências de sua própria literatura. Nesta "contradança promíscua", como diz Antonio Candido, ${ }^{78}$ neste jogo entre vida e literatura, uma não explica a outra, ainda que estejam ambas intimamente relacionadas e se alimentem mutuamente.

O cerne da investigação crítica, em nossa concepção, está em identificar as questões e soluções literárias elaboradas por João Antônio. Elas foram a um só tempo inovadoras, mas se construíram sobre alicerces sólidos da tradição brasileira e da literatura ocidental, sobre os quais talvez o autor mesmo não tivesse consciência da amplidão e profundidade. A leitura crítica que desenvolvemos aqui conjuga conteúdo psicológico, social, biográfico e elementos literários e paraliterários. Mas ela não é uma leitura psicológica, sociológica, temática nem biográfica. Trata-se em essência de uma interpretação literária, pois parte da estrutura dos relatos e da constituição de seus personagens e narradores. Apontar questões críticas relevantes e localizar a produção de ficção de João na tradição brasileira, assim, pressupõe mostrar o caráter ao mesmo tempo inovador e tradicional de sua literatura e os próprios limites que sua obra encontrou e expressou. Nosso trabalho pretende analisar a obra de João Antônio segundo essa concepção crítica e empreender uma visão mais completa de sua literatura, contribuindo para estabelecer a dimensão do autor e de sua obra na literatura brasileira contemporânea.

\footnotetext{
${ }^{78}$ CANDIDO, A. "Um banho incrível de humanidade". In: Dedo-duro, Rio de Janeiro: Record, 1982. Texto de orelha da primeira edição do livro.
} 


\section{Capítulo 1}

\section{EU SOU UM OUTRO}

\section{Três contos autobiográficos de João Antônio}


Os primeiros contos de João Antônio se baseiam largamente na experiência pessoal do próprio autor. São textos que o autor escreveu a partir do que viveu na juventude, como ele próprio declarou e reafirmou, desde as primeiras entrevistas e os primeiros textos que publicou sobre sua obra - e assim até o fim da vida. Em um texto que escreveu em 1963, no ano mesmo de lançamento de seu primeiro livro, diz ele a respeito dos personagens Malagueta, Perus e Bacanaço: "No trajeto comprido da noite e da madrugada eu os sofro e sofro a cidade. Porque vão em muitos ritmos de marcha. O que se passa com eles e dentro deles, o que se passa na cidade é o que este aqui quis contar". E no mesmo texto, mais adiante, fechando-o: "Não quero detalhar minhas amizades malandras, que isto não é novela. E tem mais duas propriedades — não sou besta e nem delator. Mas foi lá. Nas beiradas das estações, nos salões do joguinho, nos goles dos botecos, que vi Malagueta, Perus e Bacanaço". 79

A combinação entre vivido e imaginado se afirma desde o ano do lançamento e persiste, mas a importância da experiência pessoal ganha ênfase ao longo do tempo. No texto "Corpo-a-corpo com a vida", uma declaração de princípios literários, o autor reafirma o caráter essencialmente biográfico do conto "MPB": "Eu vivi a aventura de Malagueta, Perus e Bacanaço um pote de vezes. Um tufo de vezes. Sair da Lapa, catar a Barra Funda, desguiar para o centro da cidade, pegar os lados de Pinheiros, procurando jogo e acabar na Lapa, era a aventura diária de quem estava naquele fogo". 80

Como se não fosse suficiente, em entrevista publicada em livro, em 1987, o autor declarou:

"Malagueta, Perus e Bacanaço" é simplesmente uma aventura noturna que cansei de viver logo depois que saí do quartel, e que consistia em tentar arranjar algum dinheiro em andanças pelos salões de sinuca. Isso, em geral, era feito pelas últimas horas da tarde, entrando pela noite e madrugada. Assim, não imaginei nada na história de Malagueta. Simplesmente foi a coleta de uma experiência vivida numerosas vezes e que ainda hoje se vive. O roteiro do livro é exatamente aquele que nós

\footnotetext{
${ }^{79}$ AnTÔNIO, J. “De Malagueta, Perus e Bacanaço”. In: $M P B$, pp. 15 e 17.

80 “Corpo-a-corpo com a vida". In: AnTÔNIO, J. Malagueta, Perus e Bacanaço incluindo Malhação do Judas carioca. São Paulo: Clube do Livro, 1987, p. 323.
} 
fazíamos: saíamos da Lapa, íamos à Água Branca, depois Barra Funda, depois cidade, a seguir Pinheiros e novamente tornávamos à Lapa. ${ }^{81}$

O apreço pelos primeiros livros e pelos textos de juventude também é confirmado pela opção em reeditar, no final da carreira, contos como "Busca", "Afinação da arte de chutar tampinhas", "Fujie", "Índios", 82 "Frio", "Meninão do Caixote", "MPB" e "PPT”, em coletâneas direcionadas ao público infanto-juvenil, como Meninão do caixote (Record, 1983; Atual, 1991), Malagueta, Perus e Bacanaço (Ática, 1987), Paulinho Perna Torta (Mercado Aberto, 1993), Afinação da Arte de Chutar Tampinhas (Formato Editorial, 1993), Patuléia (Ática, 1996), Sete vezes rua (Scipione, 1996).

Assim como no ano de estreia, trinta anos depois o autor voltaria a dizer que gostava mesmo era de seus contos de juventude: "Gosto de todos os meus contos. Foram escritos com a mesma fidelidade que tenho para comigo. Foram reescritos até chegar ao ponto, ou àquilo a que chamo de o ponto; trabalhados até ficarem prontos. Gosto, creio que seja natural, um pouco mais dos filhos da minha juventude, no caso os contos extraídos do livro Malagueta, Perus e Bacanaço. Mas gosto também do 'Paulinho Perna Torta'. Se eu não amasse esses contos não os estaria publicando". ${ }^{83}$

A experiência pessoal e a criação ficcional apoiada nesses anos de iniciação literária e de vida se tornaram indissociáveis na produção de João Antônio. Seus contos são recorrentes em apresentar protagonistas que remetem ao próprio autor: jovens do sexo masculino, de origem humilde, divididos entre o trabalho e a boemia, inadaptados aos valores do mundo operário/pequeno burguês em que nasceram e se criaram, amantes da música, da sinuca, das lutas, dos jogos e das transgressões - um universo viril e áspero que é, em muitos casos, contrabalanceado por sensibilidade, lirismo e certa desorientação. É o caso de Vicente e dos demais protagonistas dos "Contos Gerais" (seção inicial de $M P B)$, de Paulinho Perna Torta, de Perus e, em certa medida, também dos outros malandros

\footnotetext{
81 "O leitor é um parceiro que eu vou procurar". Entrevista com João Antônio. In: . Malagueta, Perus e Bacanaço, São Paulo, Ática, 1987. No mesmo sentido, ver "O leitor como parceiro", in $L d c$, pp. 159-162.

82 "Índios" foi um dos primeiros contos publicados pelo autor, em 6 fev. 1960, no "Suplemento Literário" de $O$ Estado de S. Paulo. No Apêndice desta tese, reproduzimos a página do jornal com o conto (que seria renomeado para "Bolo na garganta" e incluído em Meninão do caixote).

83 "João Antônio: 'Escrevo de dentro para fora". In: Patuléia. Gentes da rua. São Paulo: Ática, 1996, p. 3. Os textos de $M P B$ incluídos nesse volume de contos, todos publicados anteriormente, são: "Meninão do caixote", "Fujie", "Natal na cafua" e "Afinação da arte de chutar tampinhas".
} 
protagonistas de "MPB" - estes três personagens, o autor os considerava seus "conluiados irmãozinhos da noite e da gandaia". ${ }^{84}$

Além da ficção de inspiração autobiográfica, porém, o autor produziu também boa quantidade de textos essencialmente autobiográficos, que não se constituem como ficção, e que, no entanto, preservam certo teor de ficção. A contradição pode ser mais bem definida, a princípio, se chamarmos a estes textos de "contos autobiográficos" ou "relatos memorialísticos ficcionais", apontando para a condição híbrida de gênero que os caracteriza. Dentre esses textos, destacamos aqui três deles: Lambões de caçarola, "Paulo

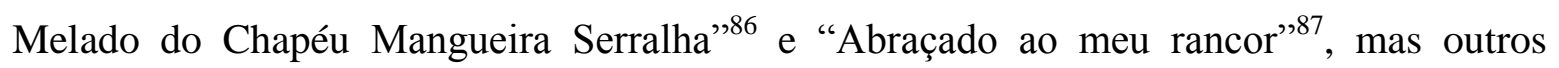
poderiam ser elencados: "Uma força" (em Amr), "No Morro da Geada", "Vibrações, poeiras e pulgueiros" (ambos em Zicartola, 1991) e "Meus tempos de menino" (em Dama do encantado, 1996).

Os três textos aqui analisados são interessantes pois, apesar de ostentarem profundas marcas autobiográficas, não se apresentam evidente ou essencialmente como textos autobiográficos. Em outras palavras, o "pacto autobiográfico", ${ }^{88}$ no caso desses três textos não se estabelece de maneira clara. Ele está ausente ou, como pretendemos mostrar, é perturbado, em diferentes níveis, por certos elementos que permitem hesitar sobre o gênero em que se inserem: autobiografia, crônica, memória, conto?

Seja nos textos de ficção, seja nos relatos autobiográficos, a obra do autor é toda ela atravessada pela relação entre vivência pessoal e tradução literária desta mesma experiência. É importante destacar que, à medida que a carreira do autor foi evoluindo no tempo, o impulso ficcional dos primeiros anos diminuiu, atravessado pela escrita factual e

\footnotetext{
${ }^{84}$ É como o autor se refere aos personagens Malagueta, Perus e Bacanaço em carta de 12 de maio de 1965 a Caio Porfírio Carneiro. ANTôNIO, João. Cartas aos amigos Caio Porfírio Carneiro e Fábio Lucas. Cotia, SP: Ateliê Editorial; São Paulo: Oficina do Livro Rubens Borba de Moraes, 2004, p. 15.

${ }^{85}$ ANTÔNIO, J. Lambões de caçarola (Trabalhadores do Brasil!). Porto Alegre: L\&PM, 1977.

86 "PMCMS". In: Dedo-duro. Rio de Janeiro: Record, 1982.

87 “Amr". In: Amr, pp. 82-83.

${ }^{88}$ A noção de "pacto autobiográfico" de Philippe Lejeune pressupõe a ideia de que a autobiografia é um gênero contratual. Segundo ele, nos textos autobiográficos se estabelece um pacto proposto pelo autor ao leitor: aquele da identidade entre autor-narrador-personagem. As reflexões de Lejeune se assentam sobre a importância do "nome próprio" para a noção de autoria e identidade, ancoradas na centralidade do nome enquanto estatuto civil e autoral, noções que terão grande importância nesta nossa leitura de João Antônio. No caso destes textos de João Antônio, o pacto autobiográfico está ausente ou ambíguo, como veremos, e o nome do narrador e dos protagonistas não são informados, o que faz com que os relatos aqui em questão possam ser classificados na posição $2 b$ (indeterminado), da tabela de Lejeune (p. 28). LEJEUnE, Philippe. Le pacte autobiographique. Nouvelle Édition Augmentée. Éditions du Seuil, 1975, 1996.
} 
jornalística que ocupou o autor profissionalmente nos anos de maturidade, mas também, cada vez mais, pela escrita autobiográfica.

Isto posto, no entanto, é preciso sublinhar que, apesar da inspiração autobiográfica, o que se verifica nos textos de João Antônio não é uma correspondência total entre vida e literatura. Nos contos do começo de carreira, os protagonistas - mesmo aqueles que não têm nome - ganham existência autônoma. Não há nos contos dos primeiros livros nenhum protagonista de nome João Antônio nem há, como haverá em Lambões de caçarola, "Paulo Melado do Chapéu Mangueira Serralha" e "Abraçado a meu rancor", coincidências exatas entre vida do autor e acontecimentos relatados nos textos literários, ainda que em "PMCMS" o narrador trate alguns contos, como "Fujie", como textos autobiográficos. ${ }^{89}$

E se quisermos mais uma vez buscar correspondências entre biografia e criação literária, elas não faltarão, nem nos textos ficcionais, tampouco nas entrevistas ou nas cartas do autor. O exercício, talvez infindável, de encontrar correspondências e diferenças entre vida e obra, pode redundar em simples verificação inócua daquilo que o autor viveu e contou, em forma de ficção ou de relato autobiográfico. A mera constatação de que há e de que não há correspondência entre vida e obra não nos leva, do ponto de vista da crítica literária, a lugar nenhum.

Porém, há certa temática — com desdobramentos formais, como veremos - que nos parece fundamental na constituição dos seus textos autobiográficos, como também o é para a ficção do autor. Essa temática é a do papel, sempre enigmático, da figura paterna nos textos do autor.

A figura paterna é decisiva, desde o primeiro conto do primeiro livro de João Antônio. Em "Busca", primeiro conto do primeiro livro do autor, vale lembrar que é justamente a morte do pai que fará com que o personagem adquira a "mania de andar". Essa morte do pai, tão central e motivadora para o protagonista, não tem nada de

\footnotetext{
${ }^{89} \mathrm{Em}$ "PMCMS", o narrador fará referência ao conto "da japonesa", dizendo que foi o primeiro que escreveu. Na passagem sobre o que se presume ser "Fujie", conto de $M P B$, o narrador confessa ter vivido a situação narrada no texto e relembra a dificuldade de publicar esse conto, pelo conteúdo escandaloso: o adultério, a traição do melhor amigo. Como veremos, porém, o pacto autobiográfico em "PMCMS" está "ausente", na terminologia de Lejeune, o que torna o conto um relato autobiográfico com teor de ficção ou um conto com teor autobiográfico, à escolha do leitor, tornando essa passagem sobre "Fujie" ainda mais ambígua: autobiografia ou ficção, ficção autobiográfica ou autobiografia ficcional?
} 
autobiográfica, pois o pai de João Antônio era vivo quando da escrita e da publicação do primeiro livro do filho. ${ }^{90}$

A constatação não causa estranheza, obviamente, por se tratar de um texto ficcional. Mas a ausência paterna, que marca importantes contos do autor (como "Busca" e "PPT", além de "Meninão do Caixote", em que o pai é uma espécie de presença ausente), marca também os "contos autobiográficos", especialmente um desses textos, “Amr”, não menos importante e central para a obra de João Antônio. E nos "relatos memorialísticos", além da ausência do pai, a presença paterna e o papel central do pai do autor, como não poderia deixar de ser, também são relevantes.

De novo, talvez não seja produtivo simplesmente apontar os textos nos quais a presença paterna é decisiva e aqueles em que a ausência do pai salta aos olhos. Mais relevante é se perguntar pelas razões profundas pelas quais um autor que tantas vezes chamou a atenção para a relação umbilical entre sua biografia e sua obra — um escritor que tantas vezes afirmou a importância do pai em sua vida e em sua opção pela literatura —, mais produtivo é indagar as razões pelas quais em certas ocasiões, tanto na ficção como nos textos autobiográficos, João Antônio Ferreira Filho explorou de maneira tão marcante a falta do pai, quando o pai real, João Antônio Ferreira, não faltava, isto é, não estava, objetivamente, ausente ou morto.

Cumpre começar pelos contos autobiográficos em que o pai está presente na ação narrada.

"Paulo Melado do Chapéu Mangueira Serralha" talvez seja o texto autobiográfico mais conhecido do autor. O conto, incluído no livro Dedo duro (1982), é uma espécie de autobiografia centrada nos tempos de juventude de João Antônio, cuja orientação narrativa conflui, como indica o título do texto, para o momento da estreia literária do autor: Paulo Melado do Chapéu Mangueira Serralha foi o pseudônimo adotado pelo então escritor iniciante (que já havia publicado algumas narrativas em jornais de São Paulo) para mandar originais de seus primeiros contos à editora Civilização Brasileira.

\footnotetext{
90 João Antônio Ferreira, o pai do autor, morreu em 1988, quando o autor estava na Alemanha, durante uma longa temporada, com uma bolsa do DAAD (Serviço Alemão de Intercâmbio Acadêmico) que recebeu para permanecer alguns meses no país. No Apêndice, reproduzimos uma cópia da carta escrita por João Antônio por ocasião da morte do pai, em fevereiro de 1988.
} 
O conto tem como ponto culminante a chegada de um carrão importado ao bairro periférico onde morava o jovem autor. Do carro, saem quatro homens de terno e gravata à procura do "Paulo Melado". João Antônio Ferreira, o pai, teria ficado assustado, pensando que era a polícia atrás do filho mais velho.

Rodrigo Lacerda conta:

Certo dia, entre 57 e 58, um Studebaker cinza, solene, estacionou em frente a uma pequena casa no subúrbio de Vila Anastácio. O primeiro andar da construção abrigava o botequim do pai de João Antônio, morando a família no andar de cima. Aparecer por ali um carro daqueles já intrigou o Sr. Ferreira, atrás de seu balcão. Mas foi quando de dentro do automóvel saíram quatro homens de terno, engravatados, que ele realmente ficou preocupado. Procuravam um tal Paulo Melado do Chapéu Mangueira Serralha. O comerciante, imaginando que só podia ser mais uma das confusões do filho rebelde, abaixou a cabeça, entre envergonhado e temeroso, e perguntou: 'Os senhores são da polícia?'. Não eram. Susto geral quando os engravatados se apresentaram escritores, jornalistas e editores, interessados em conhecer o autor dos contos que haviam recebido recentemente pelo correio, sob aquele estranho pseudônimo. O líder do grupo era Ricardo Ramos, escritor e editor, filho do mesmo Graciliano que vinha a ser o escritor preferido de João Antônio, uma das influências perceptíveis nos primeiros contos que havia escrito. "Paulo Melado", que estava de ressaca, foi então chamado à sala, e foi a vez dos quatro visitantes se assustarem, ao ver que não passava de um jovem de seus vinte anos! ${ }^{91}$

Este episódio, espécie de descoberta literária precoce de João Antônio, é narrado em "PMCMS" e constitui o clímax do conto. Como indica o título do texto, este relato autobiográfico culmina justamente na assunção do garoto boêmio e desregrado a escritor de qualidade, ainda que inédito e conhecido em um círculo muito restrito, formado por alguns intelectuais e os familiares mais próximos. Mas o impacto dessa visita na família e, em especial, na maneira com que o pai via o filho "rebelde" não deve ter sido pequeno. O fato de o título escolhido para o conto ser o pseudônimo adotado por João Antônio indica que a revelação de sua vocação literária e a troca de nome, por assim dizer, constituem o episódio que marcou certa emancipação ou, pelo menos, lhe conferiu nova estatura, no universo

\footnotetext{
${ }^{91}$ LACERDA, R. "O primeiro amor de João Antônio". In: $M P B$, encarte anexado ao livro, em separata. O texto está disponível também em http://www.rodrigolacerda.com.br/o-primeiro-amor-de-joao-antonio-malaguetaperus-e-bacanaco. Último acesso em 30 jun. 2012.
} 
acanhado do núcleo familiar. A figura do pai do autor, como se viu, é central para o acontecimento. Veremos mais adiante como o próprio autor narra o episódio.

Ocorre algo semelhante em Lambões de caçarola (Trabalhadores do Brasil!), ${ }^{92}$ texto em que a figura paterna é presente e forte. Publicado em 1977, Lambões é o primeiro texto autobiográfico do autor, depois de dois livros de ficção, MPB (1963) e $L d c$ (1975), de dois livros de reportagens, Malhação do Judas carioca (1975) e Casa de loucos (1976), e de Lima Barreto, este publicado no mesmo ano de 1977.

O texto de Lambões não é longo, poderia ter sido incluído em algum dos volumes anteriores de não ficção, mas foi publicado independentemente, em formato de livro, em edição da $L \& \mathrm{PM}^{93}$. Trata-se de uma crônica de memória de infância da época em que o autor vivia no Beco da Onça, nas imediações do estádio do Palmeiras (Vila Pompeia, região Oeste de São Paulo). O título do livro é de sentido pouco evidente, mas o subtítulo é mais explícito, pois alude a Getúlio Vargas. “Trabalhadores do Brasil!” era o bordão com que o presidente saudava o povo brasileiros em seus discursos de $1^{\circ}$ de maio..$^{94}$

O relato faz um retrato afetivo da comunidade do Beco da Onça, a partir dos olhos do menino que passou a infância naquela área pobre da cidade, enfatizando a relação entre o dia a dia dos moradores do Beco, a realidade política do país e, especialmente, a figura de Getúlio. O ponto de vista é interno: o texto é narrado em primeira pessoa, por um personagem que não se apresenta claramente, mas é parte daquela comunidade, um antigo morador do Beco da Onça, um menino que morou no local durante a Era Vargas.

Além de se concentrar na figura de Getúlio, cuja voz e imagem são onipresentes na realidade da gente simples, malandra e trabalhadora do Beco da Onça, o narrador irá destacar outro personagem fundamental nesta história: o pai dele próprio. Além de ser conhecido no Beco, por ser dono de uma venda, o pai do narrador será descrito como uma

\footnotetext{
92 ANTÔNIO, João. Lambões. As páginas deste livro não são numeradas, por isso aqui não há indicação de número de páginas nas citações.

93 O texto foi incluído em livro posterior, Meninão do caixote (1983, reeditado em 1984 e 1991), que reúne também "Frio", "Bolo na garganta" e o conto que dá título ao volume.

${ }_{94}$ Apesar de não ter sido um grande orador, Getúlio aproveitou-se da popularização do rádio para conclamar os "humildes", como se dizia, e os trabalhadores. Transmitidos em cadeia nacional pelo rádio, os discursos de Vargas nos feriados do Dia do Trabalho eram aguardados com grande ansiedade pelas camadas mais pobres da população, com expectativa de medidas em favor dos trabalhadores. Ver: FAUSTO, B. Getúlio Vargas: o poder e o sorriso. Coleção Perfis Brasileiros. São Paulo: Companhia das Letras, 2006. pp. 122 a 127 ; e LEVINE, Robert M. Pai dos pobres?: O Brasil e a Era Vargas. São Paulo: Companhia das Letras, 2001, p. 94-95.
} 
figura forte, aos olhos do menino e da comunidade, por ter se recusado a ir, como toda a gente, prestigiar uma visita que Getúlio Vargas fez a São Paulo: o pai do narrador foi o único que não se animou a acompanhar os demais moradores para ver Getúlio discursar no pavilhão da Água Branca.

Duas figuras paternas importantes, portanto, são descritas no livro, uma em confronto com a outra, por este narrador adulto, que relembra seus tempos de menino. Este narrador é João Antônio, pois todos os dados pessoais e familiares do personagem coincidem com a biografia do autor, mas também não é exatamente João Antônio, pois o narrador-personagem não é nomeado ou explicitamente identificado ao escritor - nem quando adulto nem quando criança. O livro não traz, além disso, indicações claras do gênero no qual se enquadra.

O resultado é um texto que é memória de infância — autobiográfico, portanto mas que se abre para uma realidade maior, que é a memória de um menino do Beco da Onça e é memória da vida dessa mesma comunidade, memória de uma infância pobre em São Paulo durante a Era Vargas. Getúlio Vargas, o "pai dos pobres" (ou "pai dos pequenos", como diz o narrador), e o pai do narrador são, além do próprio protagonista, os dois personagens que sobressaem neste texto memorialístico.

O narrador, que relembra um momento preciso da infância, coteja a importância do pai e a do presidente para seu tempo de menino pobre de São Paulo. Como a perspectiva narrativa é distendida no tempo - trata-se de um livro de memórias, de um narrador que é o menino da situação relembrada e já é o adulto que narra - ocorre certa ênfase nas transformações pelas quais passou o lugar onde a ação transcorre. O menino é morador de um pedaço de bairro que aos poucos foi se modificando: passou de "Navio Negreiro" a "Beco da Onça" e daí a área de "apartamento de bacanas", isto é, um pedaço da cidade vulnerável e submetido, ao final, à especulação imobiliária.

A área se chamava Navio Negreiro. E o pai a "crismou", com o novo nome de Beco da Onça. É como se a Era Vargas, naquele microcosmo de uma família pobre, vivendo em um bairro periférico da maior cidade do país, tivesse passado da ordem escravocrata para uma ordem que não é a da democracia de ordem burguesa, mas a de um beco selvagem. De Navio Negreiro a Beco da Onça, da escravidão para a lei da selva, sem passagem civilizatória. 
Em Lambões de caçarola, o sentimento resultante dessas mudanças, aos olhos do narrador, é de nostalgia e perda de algo importante que a urbanização e a "modernização" fizeram desaparecer, uma perda que está vinculada à passagem do tempo e ao esforço de compreensão dos “pais”, Getúlio e o pai biológico, e da relação entre eles — eles que serão os personagens principais deste relato, até o fim.

O mesmo sentimento de pesar acerca das transformações sociais e alterações urbanísticas pelas quais passou a cidade orienta, como veremos, "Amr", texto do livro de mesmo nome, lançado em 1986. Neste texto, porém, o lamento se intensifica, até tomar a forma de rancor, um sentimento que sugere a grande intensidade e a persistência de um descontentamento pelas mudanças. E aqui, as mudanças se multiplicam, ainda que, de certa forma, se conectem: mudaram a cidade e o próprio narrador, além de lugares, hábitos, sociabilidade.

No caso, o narrador é mais uma vez um personagem que lembra em tudo o escritor João Antônio, e mais uma vez, ele não é claramente nomeado. Mas, obviamente, trata-se de um texto autobiográfico, o que se pode identificar desde a primeira página do conto, que dá início a um percurso pelas ruas de São Paulo, percurso que coincide com um trajeto autobiográfico: “Osasco, Lapa, Vila Ipojuca, Água Branca, Perdizes, Barra Funda, centro, Pinheiros, Lapa, na volta. Roteiro é este, com alguma variação para as beiradas das estações de ferro, dos cantos da Luz, dos escondidos de Santa Efigênia. Também um giro lá por aquele U, antigamente famoso, que se fazia entre as Ruas Itaboca e Aimorés, na fervura da zona do Bom Retiro".95

O narrador se pergunta onde andará Germano Matias, sambista paulista renomado mas àquela altura esquecido, para então dar início a um périplo, uma deambulação pela cidade, e a uma série de constatações acerca das mudanças sociais, urbanísticas e econômicas pelas quais passou a cidade, além de relatar observações acerca de si mesmo, entre orgulhosas e amargas, saudosistas e rancorosas. A busca pelo sambista desaparecido aos poucos se torna um périplo pela cidade e pelo passado do próprio narrador-autor.

O conto se passa em São Paulo - e de certa forma São Paulo é o próprio tema do conto, ao lado da história pessoal e sentimental deste jornalista-escritor que é o narrador-

\footnotetext{
${ }^{95}$ Amr, p. 77. Salta aos olhos a semelhança entre este trajeto e o trajeto dos malandros protagonistas de "MPB". Em "PMCMS" (p. 107) também se faz referência ao famoso U da confluência das ruas Itaboca (atual rua Professor Cesare Lombroso) e Aimorés, no bairro do Bom Retiro, em São Paulo.
} 
personagem do texto. Objetivamente, narram-se a história e os bastidores de um trabalho de reportagem, além das reflexões que este trabalho envolve. O narrador é um jornalista do Rio, que volta a sua São Paulo natal para cobrir um evento que promove o turismo na capital paulista. Em terras paulistanas, este jornalista sente-se saudoso do tempo em que ali morou. Percorre então a cidade (de ressaca), relembrando a festa a que compareceu na noite anterior (um evento de trabalho, lançamento da campanha de promoção do turismo em São Paulo), refazendo o trajeto que costumava empreender na juventude. À medida que revisita alguns pontos da cidade, com os quais mantém relação afetiva, constata a artificialidade do discurso turístico-publicitário (que vende São Paulo como um polo econômico, financeiro e gastronômico), contraposto à sua própria experiência da cidade "real", habitada por gente pobre e trabalhadora.

Além dessa oposição irreconciliável entre a São Paulo turístico-financeira e a cidade das pessoas comuns, outras oposições e contrastes vão sendo perfilados pelo narrador. Mas, como não poderia deixar de ser nesta pungente narrativa autobiográfica em primeira pessoa, dois personagens avultam: a cidade e o próprio narrador. Ambos mudaram, e a meditação sobre essas mudanças se torna o motivo do texto.

Narrador e cidade mudaram. Mas mudaram em relação a quê? A referência é, no primeiro caso, a juventude e no segundo, a cidade da juventude, onde ele conheceu e retratou seus personagens de eleição, "uns pobres-diabos sem eira nem beira". Em ambos os casos, além do próprio eu que narra, outro personagem é decisivo nessa marcação que divide passado e presente: o pai.

Se ele, narrador, mudou, ele recorrerá ao pai para, curiosamente, afirmar a si mesmo, e ao leitor, que não foi a influência do pai que causou a mudança - muito pelo contrário:

Carrego um peso, ainda que vago, permanente; e se me ponho nos táxis, é com aborrecimento. Destestável ir a todos esses buracos, desentocaiar vagabundos, localizar salões de sinuca e me mover de carro. Devia tocar de ônibus, que os bondes se sumiram, o asfalto cobriu os trilhos como cobriu os paralelepípedos.

Eu que me mexa pelos trens suburbanos ou pelos ônibus tão lentos desta cidade. Ruins, enormes, cheios, onde se fala pouco. Mas será, pelo menos, decente ou limpo com esta gente, afinal uns pobres-diabos sem eira nem beira, sobrevivendo Deus sabe. Diacho. 
Quando os conheci e gostei deles, quando me estrepei e sofri na mesma canoa furada, a perigo e a medo, eu não tinha esses refinamentos, não. Mudei, sou outra pessoa; terei tirado de onde estas importâncias e lisuras? De teu pai não foi, mano. Também é verdade que agora, visto na moda e não simples. Meto antes as roupas que, só depois, chegarão aqui e ando tostado de sol, areias, mar.

Mas quem de amigo, desafeto, fariseu, estranho, camaradinha, perguntará? Ninguém perguntará o que me dói. ${ }^{96}$

"De teu pai não foi, mano", diz o narrador para si mesmo. ${ }^{97}$ Refinamentos, importâncias e lisuras não foram herança paterna; foram, decerto, conquistas, mas vistas aqui com lamento, contrariedade. Também as mudanças pelas quais passou a cidade são vistas com desconfiança, e também elas são balizadas pela relação entre filho e pai. A cidade que ele tem como sua cidade, como a cidade que ele lamenta ter desaparecido, ou mudado radicalmente, dirá mais uma vez o narrador, é fortemente vinculada à figura paterna:

A cidade que o velho me ensinou a ver não era esta em que me mexo. A dele tinha gentes e ruas, árvores, conduções coletivas, idas ao mercado municipal à beirada do Tamanduateí. A minha, agora, fechada entre quatro paredes. Sempre. Passo do hotel para um carro e daí toco para um coquetel num salão; depois, as paredes de uma secretaria ou redação. Nessas quatro, grupelhos proliferam. Bebericam, conspiram, politicam, fechados em si, armando campanhas, cinismos e mordomias. Golpes, rasteirices.

Minha cidade de meu pai não chegava pelos brilharecos publicitários de um folheto que leio profissionalmente, com nojo. Nunca o pai gabou a Praça da República, falando de uma arte que ela não tem. ${ }^{98}$

Como se viu até aqui, a figura paterna é decisiva nos três principais textos autobiográficos do autor. Em todos eles, o autor recompõe certos episódios de infância e juventude, narrados a partir da experiência do presente. São relatos de memória que se pautam por mostrar como as transformações do próprio autor, da cidade e da sociedade se

\footnotetext{
${ }_{97}^{96}$ Amr, pp. 82-83.

97 Simone Paulino dos Santos vê nessa incidência de uma outra voz uma fragmentação do narradorpersonagem que se relaciona ao seu caráter melancólico e é indicativa de um "princípio de acumulação" de sua subjetividade, uma "tendência a voltar-se contra seu próprio ego". A autora vê nessa voz fragmentada uma "outra dimensão do eu (...) soterrada". SANTOS, S. Nas esquinas do desejo. Um estudo do tema da busca nos contos de João Antônio. Dissertação de mestrado em Letras. FFLCH-USP, 2009, p. 164-165 e 172.

${ }^{98}$ Amr, pp. 117-118.
} 
relacionam entre si. Presença e ausência paterna são decisivas nos três textos. Veremos como, neles, as diferenças de abordagem literária e biográfica impactaram a forma, o estilo e o sentido desses contos autobiográficos.

Importante nesse percurso, do nosso ponto de vista, é atentar para a instabilidade da identidade do próprio narrador-autor, pois o pacto autobiográfico não se coloca de maneira clara em nenhum dos três textos.

Em Lambões de caçarola, livro de 1977, é quase completa a identidade entre autor e narrador-personagem que relembra a infância e a situação social da época. Mas as informações ambíguas sobre o teor do texto, fornecidas pelo próprio livro, e o projeto gráfico arrojado concorrem para desestabilizar o teor autobiográfico do relato.

O pacto se mantém, mas, entretanto, sofre nova perturbação no caso de "PMCMS" (1982), pois o texto está em um livro de contos (ainda que inserido em uma seção de textos memorialísticos deste mesmo livro).

E, no caso de "Amr" (1986), temos, como tentaremos mostrar, um caso de pacto frágil ou ambíguo, indicando que as fronteiras entre ficção e autobiografia, aqui, são mais tênues - e proporcionam, ao nosso ver, ganho literário significativo.

\section{Um lambão entre lambões}

Lambões de caçarola (Trabalhadores do Brasill!) é um pequeno livro de quarenta páginas (não numeradas). O formato, quadrado, é pouco usual, assim como o tratamento gráfico: o volume traz, além de texto, ilustrações e fotografias. As ilustrações do livro são desenhos de Edgar Vasques que representam cenas da narrativa; e em alguns momentos os desenhos se integram ao texto, lembrando a linguagem das histórias em quadrinho. A maioria das fotos são retratos de Getúlio Vargas, um dos "personagens" centrais do livro, como já dissemos.

O tratamento visual incomum e atrativo, que combina fotografias históricas e ilustrações de personagens (ambos os tipos de imagem integradas ao texto, em maior ou menor grau, sugerindo a mistura de realidade e ficção), já seria indicador da ambiguidade que marca o livro e impacta o leitor desde antes do início da leitura propriamente dita. Não bastasse isso e o formato pouco comum (quadrado e de poucas páginas, que lembra os livros infanto-juvenis), o volume não informa claramente de que tipo de texto se trata. A 
capa traz apenas o nome do autor, o título, o subtítulo e o logotipo da editora, além da composição visual intrigante: um desenho assinado por Edgar Vasques que representa alguns homens sentados à mesa de um bar, outros conversando, outros homens de pé, fumando e bebendo; ao fundo, um retrato fotográfico de Getúlio Vargas. Foto e ilustração se integram: o desenho dá a ideia de que o retrato está pendurado na parede desse estabelecimento onde os homens bebem. O fundo da capa é amarelo e, no retrato, Getúlio ostenta uma faixa verde e amarela no peito (a capa e algumas das páginas internas de Lambões estão reproduzidas no Apêndice desta tese).

O leitor que tem o livro em mãos se pergunta: será um livro de história, uma ficção histórica, um livro paradidático, um livro infanto juvenil ou o quê, afinal? A página de rosto do livro e a ficha catalográfica não respondem à pergunta.

Na quarta capa (o verso), há três apreciações sobre o livro, de Wander Piroli, Josué Guimarães e Hélio Silva, que apenas confirmam a dificuldade de definição.

Wander Piroli se questiona: "Literatura? Pois então. Se me perguntarem que negócio é esse, eu poderia dizer que é João Antônio. E estamos conversados. Ele nunca esteve tão inteiro como neste Lambões de caçarola".

O excerto de Josué Guimarães, tirado do prefácio do próprio livro, é um pouco mais assertivo quando ao conteúdo memorialístico do texto, ainda que sublinhe o teor autoral e literário do relato, como indicam as expressões "marca registrada", "linguagem rediviva", "procura recriar", "visão do pé para a cabeça", "perspectiva informe": "Este livro traz a marca registrada de João Antônio. Sua linguagem rediviva agora num tema que procura recriar talvez a época mais importante deste país de pouca memória. Uma visão do pé para a cabeça. A perspectiva informe e confusa dos marginais de um gueto paulista de negros e ratazanas (...) Um livro para a gente órfã de Getúlio Vargas e que no dia a dia da cachaça e da febre corintiana ouvia pela 'Voz do Brasil' a frase famosa: trabalhadores do Brasil. Uma época que João Antônio foi buscar na memória da gente do povo". 99

No terceiro trecho da quarta capa, Hélio Silva diz que para os "personagens" do escritor "só existem o dia a dia brutal, o jogo de futebol, a imagem carismática do pai dos pobres, em quem acreditam e de quem falam mais que do próprio Deus".

\footnotetext{
${ }^{99} \mathrm{O}$ salto indicado com as reticências está no texto da quarta capa, indicando que se trata de um trecho do texto de Josué Guimarães incluído no livro como prefácio.
} 
Capa e quarta capa do livro, portanto, não definem claramente que tipo de texto temos em mãos. Sabemos que é um livro de João Antônio e que traz a sua "marca registrada", como diz Josué Guimarães, aludindo à linguagem do autor. Sabemos que os fundos histórico, coletivo, memorialístico e pessoal estão lá, como indicam a foto de Getúlio, as ilustrações e as observações sobre "a época mais importante deste país de pouca memória" e sobre a perspectiva inusitada, "informe", "do pé para a cabeça".

A orelha do livro, por sua vez, traz um texto assinado por "Os Editores". Vale reproduzi-lo inteiro aqui:

\section{LAMBÕES DE CAÇAROLA}

Neste seu último livro, o Mestre da nova literatura popular brasileira analisa, na sua linguagem característica, o maior fenômeno político brasileiro.

— Trabalhadores do Brasil! Quem não lembra? Quem não ouviu falar? Getúlio Vargas na cabeça do povo. Getúlio no coração do Povo. De dentro do Beco da Onça, João Antônio conta como o povo sentia Getúlio. Getúlio o pai da pátria, Getúlio o trapaceiro, Getúlio a esperança dos becos da onça deste país.

Em LAMBÕES DE CAÇAROLA, João Antônio realiza a síntese do fenômeno. Como Getúlio era sentido pela gente humilde dos subúrbios. A devoção e o desencanto dos pingentes da sociedade. O mito visto de dentro dos becos, das imensas multidões que reverenciaram aquele que bem ou mal - foi o maior líder popular deste país. Um livro para todos os brasileiros de 9 a 90 anos. Fartamente ilustrado. Da criança ao velho. Dos que viram o Gegê aos que só ouviram falar. Para os ginasianos, universitários, doutores, mulheres e homens ricos e lambões de caçarola em geral.

Os Editores

O texto não é esclarecedor do gênero livro, mas a ênfase recai sobre o exame do mito e da figura de Getúlio, o que parece indicar, ao menos a princípio, um livro de não ficção e, mais que isso, de interpretação história, de análise política. Os verbos indicam que o texto se alterna entre o testemunho e a interpretação do vivido: João Antônio "analisa" o fenômeno político e "conta" como o povo sentia Getúlio. Para os editores, o autor "realiza a síntese do fenômeno".

Mas além de ser marcado pelo tom apologético ("mestre da nova literatura popular brasileira"), o texto dos editores de certa forma adere ao estilo de João Antônio no próprio livro, o que contraria o alegado ou suposto teor de análise e de interpretação histórica ou política. O texto da orelha aponta para um conteúdo mais literário, como o livro de fato é, 
ainda que centrado na figura histórica de Getúlio Vargas, apresentado então, desde a orelha do livro, como "mito".

O final do texto indica que a ambição de alcance de público, além disso, era grande, chamando a atenção para a vocação do texto para um público leitor amplo — gente de todas as idade, de todas as classes, de todas as formações.

Voltando ao tema da ambiguidade de gênero textual, a ênfase na inventividade e na excelência literária do livro não esclarece ao leitor qual é o teor exato do que se vai encontrar nas páginas do livro. Conto, crônica, reportagem, análise política, memória? Tudo isso misturado? Literatura e ponto final? Mas que tipo de literatura?

A dedicatória, por sua vez, sugere que é um texto de grande conteúdo afetivo e familiar: "Para João Antônio Ferreira - meu pai - ainda firme na luta". ${ }^{100}$ Mas não afirma explicitamente o conteúdo memorialístico.

O próprio autor também assina um texto, após o prefácio de Josué Guimarães. Parece uma introdução, mas não tem título. Começa com o bordão de Getúlio e tem uma imagem do presidente, descontraído: vestido à gaúcha, de bota e bombacha, cachecol e óculos escuros, ele segura entre os dedos um charuto aceso (ver reprodução no Apêndice).

Trabalhadores do Brasil!

Isto entalado na garganta. E bem. Doía.

Desde o tempo de moleque, a gente no Navio Negreiro. Um dia, meu velho rebatizou aquele pedaço de Beco da Onça. Crismou.

Mais. Creio que aquele povo amargue a dúvida e a castração. Gana de cobrança, de forra. Que de um jeito ou de outro, querendo bem, abominando, desconfiando, tanto faz. Estamos todos empatados. Somos órfãos e viúvos do velhinho.

Até agora.

JOÃO ANTÔNIO

Copacabana, $1^{\circ}$ de maio de 1977

\footnotetext{
${ }^{100}$ Quando o texto de Lambões foi incluído em Meninão do Caixote (Record, 1983), ganhou mais uma epígrafe: “'Pois até quem não tem nada, / Tem ainda a esperança'. Vejo amanhecer (1933), Noel Rosa”. Além de Lambões, Ô Copacabana! é dedicado ao pai. Ambos os volumes trazem também dedicatória a Lima Barreto, como, aliás, quase todos os livros do autor. Uma exceção significativa é Malagueta, Perus e Bacanaço, cuja primeira edição é dedicada apenas a Paulo Rónai e Mário da Silva Brito. A partir do segundo livro, $L d c$, e da reedição de $M P B$, em 1975, o autor passou a dedicar seus livros também ao filho, Daniel Pedro de Andrade Ferreira, nascido em 1967.
} 
Temos afinal a palavra do próprio autor do livro, que, entretanto, agrega novos elementos sobre o conteúdo do texto, sem explicar ao certo de que tipo de relato se trata. Ao contrário, o autor reafirma que é algo que "vem desde o tempo de moleque" e persiste "até agora". O quê exatamente? Algo "entalado na garganta". Ou talvez o sentimento da perda de Getúlio Vargas: "somos órfãos e viúvos do velhinho". O autor fala em nome próprio, mas fala também em nome do povo, "aquele povo", do Beco da Onça, anteriormente chamado Navio Negreiro, rebatizado pelo pai de João Antônio, assim apresentado como uma espécie de fundador daquela comunidade.

O texto está datado de $1^{\circ}$ de maio, feriado de Dia do Trabalho, o que parece ser uma deferência ao ex-presidente trabalhista. Mas o texto dá sinais de que a memória sobre Getúlio é ambivalente: "querendo bem, abominando, desconfiando, tanto faz". Ao fim e ao cabo, os sentimentos parecem se equilibrar, "empatados", talvez graças à morte de Getúlio Vargas, que deixou a todos "órfãos" e "viúvos". Os trabalhadores, o povo do Beco da Onça, o pai do narrador e o próprio narrador, assim, parecem ainda de luto, divididos sobre a interpretação da figura de Getúlio Vargas, "empatados". Aquele povo - e aqui pai e filho estão incluídos — ainda amarga "a dúvida e a castração".

Os sentimentos relacionados ao que se vai contar são fortes e eloquentes. Há dor, pesar, raiva, dúvida, desconfiança, frustração, "castração". Mas a indefinição sobre o conteúdo do texto persiste antes do início da leitura propriamente dita.

Não pretendemos, com isso, questionar ou reivindicar a necessidade de clareza absoluta acerca da definição do teor narrativo, ficcional ou memorialístico do livro, nem chegar a uma definição última do gênero de texto em que Lambões se enquadra. Ao contrário, reconhecemos e destacamos, assim, como o projeto do próprio autor de esgarçar os limites de sua escrita, entre o conto, a crônica e o jornalismo, combinando procedimentos de todos esses gêneros, projeto que João Antônio já vinha exercitando em seu livros imediatamente anteriores, ganha em Lambões de caçarola mais um exemplo bem sucedido de relato, como veremos, em que a forma literária se constrói de acordo com a necessidade da matéria.

A questão crucial que se coloca é: a propalada ideia do próprio autor no empenho em eliminar as fronteiras entre literatura e jornalismo, além de produzir uma forma 
brasileira $^{101}$, aqui aplicada a um livro autobiográfico... que não se restringe aos limites autobiográficos, resulta em que tipo de narrativa e aponta para quais problemas críticos? Deixemos a pergunta em suspenso, por ora.

A combinação de perspectiva individual, linguagem solta e entrecho um tanto à deriva, "ao correr da pena", para lembrar uma fórmula que está na origem do nosso jornalismo e da nossa crônica, permite inclusive inserir a literatura não ficcional de João Antônio na larga tradição brasileira da crônica e das memórias, que remonta a Alencar e Machado de Assis, passa por João do Rio e Lima Barreto, este um dos autores de predileção de João Antônio, e vem culminar na geração de Rubem Braga, Fernando Sabino, Paulo Mendes Campos e outros escritores, autores que Antonio Candido tão bem apontou como os maiores representantes da crônica brasileira, este gênero "menor", que no entanto ganhou estatuto literário de grande gênero brasileiro. João Antônio, autor mais jovem que a referida geração, vem se ligar, portanto, a essa corrente de autores que adotaram a linguagem da crônica para dar conta de uma narrativa que exige, mais do que a trama da ficção, a liberdade da conversa, da associação livre e da reminiscência, recorrendo à memória pessoal, ao devaneio e à notação solta para atingir seus objetivos literários mais amplos. $^{102}$

O leitor informado, tanto visualmente como textualmente, da dificuldade de definição dos propósitos e dos limites do livro, começa então a leitura um pouco inquieto, sem ter certeza do caminho que o relato que tem em mãos tomará. E o texto não o decepciona, combinando desde o princípio temporalidades diversas e elocução ambígua.

\footnotetext{
${ }^{101}$ Ver “Corpo-a-corpo com a vida". In: Malagueta, Perus e Bacanaço incluindo Malhação do Judas carioca. op. cit.

${ }^{102}$ Os textos de João Antônio nos livros de não ficção da década de 1970, como Malhação do Judas carioca e Casa de loucos, entretanto, diferem em muito daqueles textos que retratavam "a vida ao rés-do-chão" tal como o faz, segundo Antonio Candido, a geração de Rubem Braga, Fernando Sabino e Paulo Mendes Campos, ainda que os textos de João Antônio também adotem o "tom menor" e a tendência ao conto e à poesia, numa linguagem que procura aproximar autor e leitor. Esses textos de João Antônio talvez se enquadrem naquilo que Davi Arrigucci Jr. chamou de "poderes" ou modalidades da crônica: o "testemunho de uma vida", no caso dos perfis ou retratos, e o "documento de uma época", no caso dos textos sobre a Lapa, Copacabana, a sinuca, a Cidade de Deus. Na maioria dos casos, porém, entendemos que, nas suas crônicas, João Antônio não consegue "driblar o evento miúdo do cotidiano para escapar do efêmero", que segundo Arrigucci Jr. é o desafio do cronista. Sobre a crônica no Brasil, ver CANDIDO, A. "A vida ao rés-do-chão". In: Recortes. Rio de Janeiro: Ouro sobre Azul, 2004. ARRIGUCCI JR., D. "Fragmentos sobre a crônica". In. A Crônica: uma bibliografia comentada. Boletim Bibliográfico Biblioteca Mário de Andrade. Vol. 46, n. 1/4, p. 43-53, jan./dez. 1985.
} 
Lambões tem início com a frase proferida pelo ex-presidente como um vocativo ao povo brasileiro e segue na descrição das crianças do Beco da Onça e de uma cena específica do lugar, uma cena recorrente, narrada no livro tal como rememorada pelo narrador:

— Trabalhadores do Brasil!

Pé no chão, barriga de fora, nariz moncoso, cabeça despenteada, caras de fome, lombrigada. Aqui no Beco da Onça a molecada negra passa o dia debaixo do sol, na rua de terra. Remexe, apronta e perturba com o carrinho de rolemã, papagaio, bola de vidro, bolão. Cada um ao seu tempo. E tem tempo de tudo. Uma misturação. Não havendo troços de brincar, a atração é com algum gato ou cachorro. Os moleques, então, se espojam na terra fofa da beirada da rua.

Encostou um caminhão das Indústrias Reunidas Francisco Matarazzo para a entrega do açúcar em pacotes de meia arroba. Azuis, de faixa vermelha, sete quilos e meio. Os homens taludos empilhavam uns quatro daqueles nas costas, iam ligeiros, ganhando ritmo, o movimento corridinho. Traquejo. Bíceps enormes, tríceps enormes, cinturas finas, canelas finas de sabiá. Do caminhão à pilha de pacotes do estrado da vendola do velho. Uns quinze metros, se tanto.

Vai que um pacote no ombro do homem sofre um furo, o açúcar escorre do caminhão à pilha, estira um fino, fininho de linha branca pintando um rastro, carreirinha na terra. A molecada esfomeada se agacha, quase se deita. E, rápida, mete a língua naquilo, raspando o chão, nariz ranhento.

Eu não vou esquecer mais. Ele usará a cena como porrada viva e exemplo. Quando eu torcer o nariz, não querendo comer.

— Trabalhadores do Brasil!

O procedimento de iniciar um texto com uma fala não era novo na obra do autor. Lembremos o começo de "Busca", primeiro conto de MPB, que analisaremos no próximo capítulo. Mas aqui o personagem que pronuncia a frase, com marcação de diálogo, não está presente na cena.

O leitor sabe de quem é a frase, de Getúlio Vargas, mas por ora o personagem Getúlio está ausente da cena, isto é, da ação narrada. O bordão retorna, alguns parágrafos adiante, como se viu, e a recorrência será usada pelo narrador para reafirmar a presença constante de Getúlio na narrativa e, por extensão, na comunidade. É como se a voz de Getúlio ecoasse no ambiente retratado. Dirá o narrador que os discursos, ouvidos no rádio, 
e os retratos do presidente, pendurados em todos os estabelecimentos comerciais, eram onipresentes no Beco da Onça.

A posição do narrador-personagem é incomum: ele não se apresenta de maneira direta e retarda a sua aparição na narrativa, por um procedimento que chama a atenção: primeiro define a perspectiva, interna, para depois explicitar o ponto de vista, em primeira pessoa. Em outras palavras, apesar de não demorar a se revelar personagem da história que narra, o narrador já apresenta o relato por meio de uma visão interna, antes mesmo do "eu" aparecer claramente no texto, convidando assim o leitor a partilhar de sua perspectiva: "Aqui no Beco da Onça a molecada negra passa o dia debaixo do sol, na rua de terra". O narrador, com isso, insere a si mesmo no quadro da ação e se diferencia dos demais personagens que primeiro aparecem em cena: o "aqui" define a perspectiva interna e faz com que o leitor, inevitavelmente, se sinta imerso no ambiente, ainda que apartado da "molecada negra".

O ambiente é definido pelo narrador pela "misturação", pela precariedade e pela pobreza, uma caracterização que, apesar de não economizar no retrato da carência, é nuançada pela ênfase na espontaneidade e leveza das crianças, os personagens principais desta primeira cena, que parecem "brincar" com a própria situação, que é de penúria geral: privação material ("pé no chão", "não havendo troços de brincar"), falta de asseio ("nariz moncoso"), fome (a ânsia de lamber o açúcar derramado no chão), doença e insalubridade ("lombrigada"). Além disso, a objetividade com que descreve a cena dos meninos que se "espojam" na terra, sem participar diretamente da cena, indica que o narrador é parte daquele mundo, mas está em melhor situação, pois apenas assiste ao que outros fazem.

A impressão de que o narrador é um menino como aqueles, mas não passa fome nem vive na rua, vem se confirmar na recordação seguinte, que revela o conteúdo moral do ocorrido, algo sublinhado e imposto pelo pai do narrador. Como se viu no trecho, é quando o eu-narrativo finalmente se apresenta, para dizer que não irá esquecer a cena recémdescrita.

A lembrança, além da percepção que o próprio narrador tem do ocorrido, é marcada por mais um fator, externo ao fato narrado. São a interpretação e sobretudo o aconselhamento do pai que farão o narrador guardar a cena como "exemplo". A exemplaridade com que o pai interpreta a cena dos meninos negros, esfomeados, sujos e 
enfermiços indica que a família do narrador vivia muito próxima daquela realidade, dentro mesmo do Beco da Onça, mas em situação privilegiada. O pai do narrador, afinal, é dono de comércio. Ainda assim, a ameaça da pobreza e da fome parece preocupar os mais velhos e acossar os mais novos. ${ }^{103}$

A maneira com que o pai surge na narrativa, sem ser nomeado de maneira clara, também chama a atenção. Os sacos de açúcar chegam no caminhão e são levados à "vendola do velho", onde são empilhados. Aqui, lembre-se que a narrativa se ampara em conhecida passagem autobiográfica. Sabe-se que no começo da década de 1940, quando João Antônio era um menino de 5 a 6 anos, a família se mudou para essa região da cidade, a Vila Pompeia, onde o pai do futuro escritor abriu uma venda. ${ }^{104}$

Fiel ao ponto de vista interno, porém, o texto de Lambões não explicita a correspondência entre o que se conta e a biografia do próprio João Antônio. A maneira com que se narra indica que o narrador trabalha segundo uma via dupla de lembrança. Suas lembranças de acontecimentos factuais se tornam cenas que a memória resgata do passado, atualizando-as e recriando-as por meio do discurso narrativo. ${ }^{105}$ Algumas dessas lembranças vêm ressaltadas pelo compartilhamento entre os moradores do bairro e pelas relações afetivas, sobretudo da família e de alguns personagens que assumem, de quando em quando, o primeiro plano narrativo. As lembranças e a própria narrativa correm sem muita ordenação, mas afinal o narrador se dispõe a caracterizar o Beco da Onça de forma mais definida:

${ }^{103}$ Em sua biografia literária de João Antônio, Rodrigo Lacerda já havia destacado a situação melhor da família, rodeada de famílias mais pobres: "Embora (...) esteja subentendida a melhor situação da família Ferreira em relação aos demais moradores do beco, fica claro que o contato com a pobreza crua do lugar, com sua 'gente que só come carne de galinha aos domingos', foi impressionante". Lacerda também acredita que esta fase marcou profundamente o futuro escritor, enraizando nele uma "ética positiva da pobreza", no convívio com os demais moradores do Beco da Onça. LACERDA, R. João Antônio: uma biografia literária. Tese de doutoramento em Letras. FFLCH-USP, 2006, p. 56.

${ }^{104}$ A marcação histórica do texto irá logo aparecer na narrativa: "Quarenta e dois, quarenta e três ou quarenta e quatro. Muita coisa viva nestes anos. Faço viagens ao Mercado Municipal. Apanhar mercadorias nas beiradas do Tamanduateí. Corre-corre lutado atrás do balcão. Enlitro óleo de cozinha, querosene, ensaco carvão, ajudando os velhos. Há o jogo de trilha à noite com os homens da sacaria. Coríntias, Palmeiras, São Paulo, o goleiro Oberdan, o goleiro Rato". Rodrigo Lacerda registra a mudança da família nessa época, indicando que a vida no Beco da Onça era nova para o menino João Antônio: "Entre 1943 e 1944, o pai de João Antônio decidiu mudar o rumo de sua vida. O bom emprego no frigorífico Armour, como chefe do departamento de custos, permitiu-lhe adquirir um estabelecimento comercial na Vila Pompéia, um armazém de secos e molhados. Este ficava na rua Caiovás, atrás do campo do Palmeiras, num beco que ia dar num riacho por onde hoje passa a avenida Sumaré". LACERDA, R. op. cit., p. 52.

${ }^{105}$ Sobre o trabalho de recriação da memória, ver BOSI, Ecléa. Memória e sociedade. Lembranças de velhos. $3^{\text {a }}$ ed. São Paulo: Companhia das Letras, 1994. 
O Beco da Onça é getulista, negro, negróide, mestiço, emigrante, cafuso, mameluco, migrante, pobre, operário, corintiano roxo, paulista da gema. Faz sua fezinha, jogando no bicho, conforme o palpite ou os sonhos... Gente que só come carne de galinha aos domingos. Que manda botar meia sola nos sapatos. Para quem ir ao cinema é um acontecimento. Paga os aluguéis com dificuldade, teme perder os empregos. Uma vez cada seis meses, quem pode, pode. Toma os rumos de um banho de mar na Praia do Gonzaga, em Santos. Viaja perigoso, demorado nos trens da SantosJundiaí. Mas acompanha o Coríntians em toda viagem que o clube faz. Tudo Getulista.

— Trabalhadores do Brasil!

Além dessa definição mais geral, o narrador recorda os hábitos, como a paixão pelo futebol e o cinema, e alguns acontecimentos marcantes do cotidiano do lugar. Dentre os personagens que são relembrados estão Joaquim Moço, Quim, Dentinho e Boneca, todos moradores do Beco. Outros personagens aparecem ou são lembrados pelo narrador: seu Augusto, viúvo de dona Rosália, a mãe do narrador, um tio, o avô Virgínio. Além desses, o narrador faz alusão a políticos e personagens da época, que são referidos no contexto da Segunda Guerra Mundial, com seus reflexos no Brasil. Assim, Hitler, Mussolini, Churchill e Roosevelt são lembrados para dizer que os moradores do Beco da Onça acompanhavam, pelo rádio, as notícias da Segunda Guerra, e tinham opinião sobre cada um deles. Em 1945, Dutra, o possível sucessor, e o governador Adhemar de Barros, também são mencionados.

Outro trecho do livro dá bem a dimensão errática com que a narrativa se constrói, reconstruindo o panorama político e histórico, ao mesmo tempo que registra o cotidiano do Beco:

Nem se sonhava com transistor, mas todos ouviam rádio. À noite, A Voz do Brasil era obrigação para se ficar sabendo das coisas. Engraçado. Tínhamos as fichas de racionamento, e nas noites de black-out, falavam na possibilidade de passarmos fome.

Dinheiro curto, contado, recontadinho. Bondes cortavam a cidade, onde se atentava para dez tostões no troco. E os discursos de Hitler e Mussolini, gritados, medonhos, apanhados clandestinamente, não sabíamos como. Havia temores e sustos que escorregavam. Pontudos.

Mais que tudo, pé atrás com os italianos, os alemães e os japoneses, a quem chamávamos sonsos. Viviam quietinhos, rabo preso, temendo prisões ou ripadas piores.

Além do rádio, as caricaturas dos jornais abriam conversa nos botequins, nos barbeiros, nas conduções. O povo do Beco da Onça vivia se informando. E falava, quando menos, falava. 
Esses movimentos e esses rumores alertavam meu avô Virgínio que meneava a cabeça, com exemplaridade:

- No meu tempo de menino, nenhum garoto sabia o nome do Presidente da República.

Vai daí, depuseram Getúlio. E, eleições à vista. Era só o de que se falava. Dutra seria bom, Gegê dizia. E a palavra do velhinho era final. Eduardo Gomes e Ademar, dois gostosões, faziam sucesso na ala feminina. Nenhum era líder. Só Gegê tinha a chave:

— Trabalhadores do Brasil!

A fama repetia a vida limpa, sofrida, de vítima, sem bandalheiras. Os outros, pândegos. Mentirosos, não cumpriam promessas, oprimiam, enganavam. Usavam os otários, incautos e iludidos. Ele, não. Isso não era um sentimento confuso.

\section{"Alemão batata}

\section{Como queijo com barata"}

Confusa rejeição aos japoneses, alemães, italianos. Dizíamos o Eixo sem entender o que fosse. Certamente, uma cambada de safardanas mal encarados querendo roer o mundo.

Nosso mundo, pequeno. Nossas ruas, de terra. Quando chove, o Largo da Pompeia se entala e toda beirada do Tamanduateí inunda. Um desastre, atoleiros. Tem gente que fica com a roupa do corpo, prejudicada. Entra ano, sai ano, veste pobre, agüenta fila.

Há uma admiração pelas qualidades modernas dos norte-americanos. Parece uma ordem vinda de cima. Exemplo de capacidade, padrão de amizade. Parceiros, nossos aliados.

Hitler, um verme. Mussolini, uma besta. Churchill, um sabido e Roosevelt, este sim, um grande homem.

Mães, noivas, parentas, chorosas de fazer dó. Mas o Beco da Onça, Navio Negreiro, e outros buracos, muquinfos, enfiados e subúrbios perdoavam, cabeça alta ou baixa, o rádio cantando a Canção do Expedicionário.

"Por mais terra que eu percorra

Não permita Deus que eu morra

Sem que volte para lá."

Lá, a Itália. Nas escolas, a molecadinha cantava. Nas ruas sabíamos a letra de cor e repetíamos, interessados, faladores, bravatando, as historiadas da cobra fumando.

Uma madrugada, saímos de casa e tocamos a pé ao Pacaembu. Ver os que sobraram. Voltando da Itália, eles aprontaram. Ninguém perguntou se tinham enlouquecido. Chegaram exorbitando. Desmandavam, quebravam botequins, pegavam o pé da mulher dos outros. A maioria esbagaçou depressinha a indenização do governo.

Alguns ganharam dezessete contos de réis. Uns compraram carros, casas, fazendas. A gente conheceu um tal Walter, de Osasco, que apanhou a grana, deu juízo, se fez, nunca mais trabalhou na vida. ${ }^{106}$

${ }^{106}$ Os destaques em negrito são do texto do autor. 
Do costume de ouvir rádio e do dia a dia de racionamento de comida, passa-se à situação na Europa, volta-se ao círculo familiar, na frase do avô, para então se falar na deposição de Getúlio, depois voltar às personalidades da Segunda Guerra, e de novo retornar ao Beco, onde se canta a "Canção do Expedicionário" e se espera pelo retorno dos Pracinhas, afinal recebidos no Pacaembu, mas com comportamento surpreendentemente pouco heroico; ao contrário, abusado e inconsequente.

A "confusão" é enunciada pelo narrador, como se viu no trecho acima; isto é, a confusão era a percepção dos próprios moradores do lugar acerca dos acontecimentos históricos, que o narrador registra e incorpora como procedimento narrativo. O narrador relembra os fatos quase sempre aderindo às suas percepções de infância, e não como narrador adulto, como escritor-jornalista que João Antônio então já se tornara. A relativa desorganização do texto se justifica também pelo ponto de vista, interno e infantil, com que o relato se estrutura desde o início - ainda que aos poucos o narrador vá abandonando essa perspectiva.

A construção do texto, daí em diante, segue alternando a ocorrência do bordão “Trabalhadores do Brasil!”, a caracterização do Beco da Onça, as impressões pessoais do narrador sobre o dia a dia do lugar e suas próprias lembranças de infância, que vêm sempre marcadas pela família e pelo núcleo de vizinhança.

O desenvolvimento do texto se abre para a caracterização social do Beco, para algumas histórias marcantes da época, todas essas lembranças retidas na memória do menino que ali passou a infância (e reorganizadas por esse menino que se tornou narrador adulto); se a narrativa é marcada pela "misturação" e pela percepção “confusa" da realidade, o texto a certa altura se encaminha para uma ordenação, com teor de interpretação histórica e pessoal: histórica, porque interessada na figura de Getúlio, e pessoal, porque o ponto de vista do narrador e sua elocução se tornam mais definidos, ainda que, sempre, marcados pelo contraponto da figura paterna e pela memória do presidente.

Neste quadro, ganham destaque Getúlio Vargas e o pai do narrador, como se verifica desde a capa e a cena de abertura, respectivamente. É assim que a narrativa, afinal, vai ganhar certo fio condutor, ao se concentrar na figura de Getúlio e no comportamento do pai do narrador. 
Essa evolução narrativa, de um momento "misturado" e "confuso", o da infância, para outro momento, assertivo e judicioso, acompanha a evolução histórica e alcança o narrador em seu momento adulto. No entanto, é curioso que o texto termine, como veremos, num momento atualizado, mas com o peso da opinião paterna ainda decisivo, recobrindo a perspectiva do narrador. Acompanhar esse desdobramento parece indispensável para uma melhor compreensão do livro.

Num primeiro momento, Getúlio é caracterizado como um líder intocável, recoberto da aura de protetor, destituído de culpa pelas dificuldades. Neste momento inicial, Getúlio parece acima de todas as coisas: "O sorriso do velhinho estava acima dessa historiada. Aguentáramos black-out, desemprego, gasogênio, racionamento e a molecadinha fuçava o chão com a língua para lamber o açúcar caído. Muitos, os culpados pela carestia. Getúlio, não. — Trabalhadores do Brasil!"’.

Nesse período em que a infância do narrador coincide com os anos da Segunda Guerra, Getúlio está acima dessa "historiada": do desemprego, das mazelas, da carestia, da pobreza. Como diz o pequeno trecho do texto de Hélio Silva, na quarta capa do livro, os moradores do Beco acreditam mais em Getúlio que em Deus. Daí por que a atitude do pai do narrador, quando da visita do presidente a São Paulo, pareça tão notável:

Um dia, baixou em São Paulo. A crioulada, a mestiçada do Beco da Onça, foi ver. Lá defronte à refinaria, num pavilhão, na Feira das Nações Unidas. Hoje, ali se planta um supermagazine, limpinho e sem graça, vendendo de um tudo. De alfinete a carro de luxo, de roupas de frio a embelecos de praia ou campo, de nome estrangeirado. Que ninguém sabe para que serve.

A gente se aprontou. Duanas e becas domingueiras nos varais, ao vento, escovadas, tomaram sol. Fomos de banho tomado, aprumados, importantes. De sapatos brilhando, os sapatos de sair. E não os de andar em casa, como nossas mães diziam. Atolado de trabalho na vendinha do começo da Rua Caiovás. Não amarrou a cara, mas disse que não ia. Aquilo nos valeu como um desprendimento esparramado. Então, alguém poderia perder a oportunidade de ver Getúlio? Um cara assim estava bem acima da maioria. Ainda nos encabulou:

— Eu vejo ele na moedinha.

Getúlio nas moedas menores. De dez, vinte e cinquenta centavos. E nas notas verdes de dez cruzeiros.

Alguém dispensar Getúlio, uma renúncia. Troço de homem. Mas ele, firme. Porreta, tinha peito. Boquejaríamos essa vantagem na vida de todo o Beco da Onça. Por uma semana. 
Apesar de assinalar a força e a determinação com que o pai se recusou a ir ver Getúlio Vargas, o narrador, ainda menino, acompanha a visita do presidente e consegue entrevê-lo na multidão, graças à companhia de um tio.

As barraquinhas vendiam algodão-de-açúcar, pé-de-moleque, pirulito, bandeirinhas.

— Trabalhadores do Brasil!

A força nos tocou, assim nunca vista. E, depois, jamais repetida. Muitos anos me encasquetaria a atração, figura, o não-sei-quê do homem que apareceu entre duas bandeiras verdes e amarelas, de pé em carro aberto. Sorrindo e estirava os braços para o alto, os dois a um tempo, na entrada do pavilhão, na Água Branca. Sei lá. Aquilo nos mexia nos pêlos do braço. Eu trepei de cavalinho nos ombros do meu tio, vi Getúlio. Vi Gegê.

Foi papo de uma semana. Daí para frente, fosse o que fosse com ele, era assunto. Qualquer passo de Gegê fazia a gente correr, agitava, virava boato, de comum espetaculoso. Engraçado. A meninada sentia o poder de decisão nas mãos dele.

- A lei. Ora, a lei.

A visita de Getúlio Vargas a São Paulo mobilizou a comunidade do Beco da Onça. Foram todos ver o presidente desfilar em carro aberto. Para o narrador a chance de ver Getúlio foi como que um alumbramento. "Vi Gegê", diz ele, como a enfatizar o teor de expectativa e alegria infantis com que acompanhou o desfile. ${ }^{107} \mathrm{O}$ narrador diz também que a aparição de Getúlio e a atração que este exercia o intrigariam por "muitos anos". Era um "não-sei-quê", uma idolatria sem explicação clara. O sentimento geral, para a "meninada"

${ }^{107}$ O apelido Gegê consagrou-se na composição "Gê-Gê (seu Getúlio)", composta em 1931 por Lamartine Babo e interpretada por Almirante. Boris Fausto cita a música e lembra que as canções populares e o rádio serviram a Getúlio como veículos poderosos de exaltação dele próprio e do regime, por meio do incentivo à cultura popular e da criação de órgãos de comunicação institucional, como o DOP (Departamento Oficial de Propaganda), criado em 1931, o DPDC (Departamento de Propaganda e Difusão Cultural), criado em 1934, que depois virou DNP (Departamento Nacional de Propaganda), e finalmente o DIP (Departamento de Imprensa e Propaganda), este criado já no Estado Novo, em 1939, em substituição aos dois órgão anteriores. FAUSTO, B. op.cit., pp. 115-116. Outra composição, feita por Nássara e Cristovão Alencar para o Carnaval de 1937, assegurava a volta de Getúlio ao poder, antecipando, de certa forma o que ocorreria no mesmo ano, com o golpe do Estado Novo: "O homem quem será?/ Será seu Manduca ou será seu Vavá?/ Entre esses dois meu coração balança porque/ na hora H quem vai ficar é seu Gegê". Manduca era Armando Salles de Oliveira e seu Vavá era José Américo de Almeida (segundo LEVINE) ou Oswaldo Aranha (segundo CARVALHO). Ver LEVINE, R. Pai dos pobres?, op.cit., e CARVALHO, H. "A MPB canta e conta a nossa história", In: Revista Problemas Brasileiros, $\mathrm{n}^{\mathrm{o}} \quad 385, \quad \mathrm{jan} / \mathrm{fev} 2008 . \quad$ Disponível em: http://www.sescsp.org.br/sesc/revistas_sesc/pb/artigo.cfm?Edicao_Id=297\&Artigo_ID=4668\&IDCategoria=5 310\&reftype=1. Último acesso em 22 jun. 2012. 
era de que Getúlio tinha o "poder de decisão". Por isso, o presidente podia relativizar o poder da lei, encarnada, afinal, nele próprio, como indica a expressão “Ora, a lei”. ${ }^{108}$

A perspectiva é a do menino fascinado por Getúlio, e da "meninada", que via em Getúlio uma espécie de figura paterna onipotente, com poder de decisão sem limites. O paralelo com o pai do próprio narrador persiste, apesar de não ser explícito. Assim como durante muitos anos a figura de Getúlio o "encasquetaria", a atitude do pai, a renúncia de ver Getúlio em carne e osso, é para o narrador-menino uma atitude também intrigante e dotada de força, "troço de homem". Sobre o pai, diz o narrador: "Um cara assim estava bem acima da maioria". E o paralelo se estreita na repercussão dos dois acontecimentos: a visita de Getúlio "foi papo de uma semana”, assim como a renúncia do pai em ver Getúlio seria assunto pelo mesmo período de tempo: "Boquejaríamos essa vantagem na vida de todo o Beco da Onça. Por uma semana”. A visita fascinante de Getúlio e a recusa do pai ganham repercussão de mesma duração e impacto semelhante, equiparando-se na vida do Beco e na memória do narrador. ${ }^{109}$

Esse embate entre Getúlio e o pai do narrador persistirá na memória do narrador e na enunciação. Um pouco mais adiante, como se sabe, Getúlio voltaria à presidência, agora eleito pelo povo. A mãe se dispõe a tirar o título de eleitor para votar — presume-se que em Getúlio. Já o pai, “continuava estrangeiro não naturalizado". ${ }^{110}$ E a reação deste é irascível:

\footnotetext{
${ }^{108}$ Sobre o poder de Getúlio, na iminência do Estado Novo, diz Robert Levine: “As eleições presidenciais foram canceladas sem a menor cerimônia, e a Constituição de 1934 foi revogada em favor de um novo documento, escrito pelo jurista ultraconservador Francisco Campos. Essa constituição conferia virtualmente todo o poder ao chefe de Estado. Baseava-se na Carta del Lavoro italiana e na carta fascista polonesa de 1935, na qual se proclamava que 'a única e exclusiva autoridade do Estado se concentra na pessoa do presidente da República'.”. LEVINE, Robert M. Pai dos pobres?. op.cit. p. 82.

${ }^{109}$ Clara Ávila Ornellas também chamou a atenção para a comparação que o texto enseja entre Getúlio Vargas e o pai do narrador. O primeiro seria um "redentor" e o segundo um renunciador, resistente a essa visão idealizada, nostálgica e mitificada de Getúlio como o "pai dos pobres". ORNELLAS, C. O conto na obra de João Antônio: uma poética da exclusão. S. Paulo: FFLCH-USP, 2008, p. 105.

${ }^{110}$ O pai de João Antônio, João Antônio Ferreira, era português de Trás-os-Montes. Passou a infância na França, para onde o pai dele, José Antônio, carpinteiro, partiu em busca de melhores condições de trabalho (depois de uma breve estada em São Paulo, em 1913). João Antônio Ferreira passou a infância em Reims (onde se alfabetizou, em francês) durante a Primeira Guerra Mundial e voltou com a família a Portugal depois da Guerra. Finalmente desembarcou novamente no Brasil, em 1923. A família era composta de José Antônio, Felicidade e cinco filhos. Moraram inicialmente em Higienópolis, onde abriram uma pensão. Felicidade, a avó de João Antônio, tentou convencer o marido a irem morar no Brás. Mas José Antônio Ferreira decidiu ir para Presidente Altino, Osasco, onde havia uma incipiente industrialização e onde parentes portugueses, vindos a São Paulo naquela mesma primeira viagem de 1913, já haviam se instalado. Ver LACERDA, R. João Antônio: uma biografia literária. op.cit., cap. 1.
} 
“- Lenga-lenga. Se estão elegendo o homem de novo, por que o derrubaram? Cambada de zebedeus!".

Desconfiança e reserva, impropério, raiva e, não menos importante, distanciamento em relação a "eles", este "eles" indeterminado, "eles" que estão elegendo o homem de novo. Este "eles", que a fala do pai não revela quem sejam, são os eleitores de Getúlio, mas também são essa "cambada de zebedeus". São, por extensão e proximidade, os moradores do Beco, já que a posição de orgulho e apartamento, sustentada mais uma vez pelo pai do narrador, se dá em oposição aos vizinhos, aqueles mesmos que foram saudar Getúlio na visita do presidente a São Paulo, em desfile de carro aberto, anos antes. Mas também em relação aos eleitores de modo geral, em relação a todos aqueles que apoiaram, cultuaram Getúlio Vargas e votaram nele.

Para o narrador, até aqui, a figura adorada do presidente que se confunde com a lei só encontra resistência e reserva na figura do pai. A perspectiva interna e infantil está marcada por ambos, o presidente e o pai, e mais que isso, marcada pela força deste pai que nega o presidente, que o recusa e o questiona.

Nesta altura do livro, faz-se um corte de tempo. A elipse é grande e indeterminada, e o trecho a seguir vem separado do resto do texto por asteriscos no começo e no final: “Corre. Nada para correr como o tempo. A gente muda, estuda ou não. Casa, não casa. Descasa. Vira funcionário público ou andejo. Pega profissões errantes, malbarata. Um sobe-e-desce dos capetas e, muita vez, a vida não faz graça. Eu andei”.

Com o corte de tempo, as recordações passam a se concentrar cada vez mais em Getúlio e nas mudanças pelas quais passou o Beco.

Ocorre também uma mudança de tom em relação a Getúlio, digna de nota. Pela primeira vez, o narrador chamará Getúlio de "ditador”. Ele relembra um encontro com “um sujeito no Rio", em 1960, que era barbeiro de Getúlio e foi, graças a um decreto do presidente, nomeado fiscal da Fazenda. Diz o ex-barbeiro, agora alto funcionário público, que certo dia Getúlio perguntou se ele não tinha um amigo ou parente em dificuldade. E assim Getúlio nomeou mais um fiscal de Renda, sem nem conhecer a pessoa indicada pelo barbeiro. A passagem faz uma crítica enfática, ainda que indireta, do aspecto "cordial" com 
que Getúlio governava, com nomeações arbitrárias, favorecendo poucos eleitos, de acordo com seu capricho. ${ }^{111}$

A narrativa segue, voltando atrás. Em 1954, com o suicídio de Getúlio, as mudanças políticas e sociais trazem dissabor aos moradores pobres do lugar:

Havia um perereco. A dúvida agulhava. Envolveu num lance Gregório Fortunato, Samuel Wainer, Lacerda, Zenóbio da Costa, Jango, Oswaldo Aranha, Alzira Vargas, Amaral Peixoto. Tudo vertical, rápido em agosto de 54 se atropelando.

Mas aí, o povo do Beco da Onça, do Navio Negreiro, está sumido, jogado. A prefeitura aterrou o córrego Aimberê. Uma construtora demoliu mais da metade dos casarões velhos e encardidos. Prédio de apartamento de bacanas ia surgir ali.

Para o povo miúdo, mais que pesar, uma dor. Mágoa. A morte teve um gosto errado, uma descaída do respeito. Desnorteante, cínico, quase imoral e mais que tragédia. Imaginem. Era como se de repente, no silencioso e gótico de uma igreja velhusca, desfilasse uma mulher pelada: morto, o velhinho.

Uma porrada. Ninguém acredita em suicídio. Nem na carta que ele deixou. Para o povo, conversa dissimulada, manipulada, um engodo. Mais um. Leu-se a carta, ouviu-se a ladainha pelo rádio e se chorou. Uma despedida doeu.

Mas cacete, papagaio, fumo, potoca, bandalha, nhém-nhém-nhém, lambões de caçarola, mondrongos, andravões, bolas, pinóia, lero, quem corre cansa, pé-ré-pé-pé, prosa fiada, vento encanado, deboche, lorota, visagem, quizumba, pombas. Caiporentos.

Tudo bem. E nada presta.

Entrava por um ouvido e saía pelo outro. Desdém. Parecia o mesmo do velhinho diante da lei escrita e promulgada. A carta tencionava uma força de lei.

- A lei? Ora, a lei.

A morte de Getúlio desnorteou o povo, que a sentiu como uma "descaída do respeito". Os pobres, quer dizer o narrador, ficaram órfãos. A reação é, mais uma vez, confusa. Aliás, desde antes do suicídio. O narrador reafirma a percepção desorganizada dos fatos históricos, ao usar as palavras "perereco", “dúvida”, "lance” e arrolar os personagens envolvidos na morte de Getúlio, citados sem hierarquia ou contextualização.

${ }^{111}$ Clara A. Ornellas vê nessa passagem uma carnavalização de Vargas, nos termos de Bakhtin, com a inversão de tom em relação a Getúlio encarnada em seu deslocamento do gabinete de presidente para a cadeira de barbeiro. ORNELlAS, C. O conto na obra de João Antônio: uma poética da exclusão.op.cit., p. 105. 
A imagem a que o narrador recorre para traduzir o sentimento de pesar e dor, de mágoa, de imoralidade, indignação e tragédia é enigmática, ao mesmo tempo sexual e solene: a morte de Getúlio é como uma mulher nua entrando em uma velha igreja gótica. O que pensar desta imagem? Nem mesmo o narrador parece saber. Nem mesmo o narrador parece conseguir articular o pensamento que se segue à morte de Getúlio. O parágrafo seguinte é uma enumeração de palavras estranhas, expressões de sentido obscuro, que teriam interesse por si só, mas ganham ainda mais importância já que entre elas está justamente a expressão que compõe o título do livro: lambões de caçarola. ${ }^{112}$

Os lambões de caçarola são os moradores pobres do Beco da Onça. Eles sentem que a carta-testamento de Getúlio foi endereçada a eles, com força de lei, a mesma lei que era encarnada por Getúlio e da qual ele estava acima, lei exercida com "desdém”, como diz o texto, pois que ele, o ditador, o pai dos pobres, era a própria lei - e podia, assim, relativizá-la, como indicam as frases “A lei. Ora, a lei”, recorrentes ao longo do relato.

A morte do presidente, assim, é vista neste texto aos olhos dos lambões, primeiro com espanto, depois com dor, e finalmente com a percepção de um misto de azar e mau agouro ("prosa fiada, vento encanado, deboche, lorota, visagem, quizumba, pombas"). Os lambões são “caiporentos”, sujeitos de má sorte.

Vale a pena avançar, acompanhando os desdobramentos do texto, agora próximo do final. O trecho anterior tem continuidade assim:

Deu com uma mão, tirou com as duas. Sorrindo muito e gauchamente: um carioca, no fundo. Mordia e assoprava. Molhava a ponta do indicador na boca, entendia. Sabia para onde ia o vento. Manipulou os trabalhadores e namorou o fascismo nos quinze anos de ditador. As cadeias cheias. E os aviões davam sumiços em pessoas, descarregavam prisioneiros políticos atirando em alto mar, lá fora. Um manobrista, não passando disso — vamos deixar como está para ver como é que fica. Encabrestava jeitosamente e trazia os cavalos na corda curta. E, na volta à presidência, sentiu que o mar de lama era ele mesmo, suas intrigas. Tratou de jogar a culpa e a responsabilidade

\footnotetext{
112 O dicionário Houaiss define "lambão" como: (1) guloso, (2) aquele que se lambuza quando come, (3) desajeitado, palerma, (4) fig.: que ou quem faz um serviço mal feito, (5) bruto, grosseiro, estúpido. As duas primeiras acepções remetem ao campo semântico da comida e da pobreza (lembrando o dito popular "quem nunca comeu melado quando come se lambuza"). Clara Ávila Ornellas entende que "lambões de caçarola" são "pessoas que consomem os restos de alimentos deixados nas panelas". A autora associa "lambões" a "trabalhadores", em paralelismo sugerido no título do livro. Para Ornellas, os lambões seriam os trabalhadores marginalizados, que "sustentam a dinâmica social de crescimento econômico", mas a quem são "designados apenas os restos". ORNELlAS, R. O conto na obra de João Antônio: uma poética da exclusão. op.cit. p. 148.
} 
nos outros. Complicou os chegados, filhos, filhas. Virou herói. Marcou o momento de sua morte. A medo e perigo empolou-se num nacionalismo final. Descarte. Pronto: mártir da independência econômica. Nossos exploradores de fora eram auxiliados pelos crápulas da terra. No fim, não podia deixar de ser, useiro e vezeiro, está só. E bem.

Conversa. Nem comovia, nem convencia o Beco da Onça, o Navio Negreiro. Suicídio? Fossem lamber sabão. Ou como naqueles tempos:

\section{"Não faça hora comigo \\ Que eu não sou relógio \\ Da Praça da Sé.”}

O narrador, depois de reconstituir todo um contexto social de época, relembrando seu tempo de menino no Beco da Onça, lembrando de Getúlio em tom de nostalgia e certo desenho mítico, afinal encontra um tom mais assertivo para se referir ao ex-presidente. A passagem da visão dos lambões para o ponto de vista do narrador é abrupta e chama a atenção. A perspectiva agora não é mais de dentro do Beco e já não confunde temporalidades. A perspectiva já é a do distanciamento histórico, num momento em que o mito e a fascinação foram substituídos por boa dose de consciência crítica e opinião.

A morte de Getúlio Vargas precipita essa narrativa memorialística para um momento menos mítico e fascinado, mais desencantado e objetivante. O narrador, pela primeira vez, é assertivo e crítico em relação a Vargas. E depois de endurecer o discurso, o narrador estende essa avaliação mais dura também à comunidade do Beco da Onça: "Nem comovia, nem convencia o Beco da Onça, o Navio Negreiro. Suicídio? Fossem lamber sabão”. A versão do suicídio de Getúlio Vargas não convence os moradores do Beco.

Assim, o texto parece se encaminhar para um julgamento do lugar histórico e da personalidade política de Getúlio Vargas.

Não é, porém, o que acontece logo a seguir. Depois desse trecho bastante contundente acerca do posicionamento ambíguo de Getúlio Vargas, o narrador volta a se perguntar sobre a imagem, a figura de Getúlio, como se o enigma persistisse.

O tempo continua a correr e a narrativa a se atualizar. "Até as beiradas de 70", diz o texto, "seu nome e seu retrato correndo franco". E um pouco adiante: "Onde a chave? A pegada do talento, a matreirice de Getúlio, dos Getúlios? Afinal, nos anos depois da sua 
morte, gaúchos da fronteira ocuparam a presidência. Alquimia? Onde o borogodó, a chama? E a remandiola?".

A chave para entender Getúlio, segundo o narrador, estaria em compreender um dado de personalidade típico do sul: "O povo do Beco da Onça nunca teve dinheiro para ir ao Rio Grande. Tivesse, fosse, atentaria para o ponto. No sul se desenvolve cedo a marcação do tempo, o entrar e o sair, a hora certa de falar. O cabimento, direitinhamente." Trata-se, portanto, de decifrar nem tanto o lugar histórico ou mítico de Getúlio Vargas, mas o dado de personalidade que fazia dele uma figura dotada de tamanha atratividade, tanto carisma ("chama") e até malandragem ("matreirice", "borogodó"). E a "remandiola",113, pergunta-se o narrador, como que se questionando: Como entender esse acidente súbito, inesperado, a mudança de "vento" que significou a morte de Getúlio Vargas?

Para o narrador, afinal, é algo da esfera do comportamento e da personalidade de Getúlio: "Há o chimarrão tomado no galpão. A cuia corre a roda, de boca em boca. A gurizada aprende cedo que há pouco tempo para falar. Muito tempo para ouvir e tempo certo, medido, para cada coisa".

O carisma e a autoridade de Getúlio advêm, segundo a hipótese do narrador, do costume gaúcho da roda de chimarrão, da conversa respeitosa, entremeada dos goles de mate, tomados na cuia que passa de boca em boca. É assim, segundo ele, que "a gurizada aprende cedo que há pouco tempo para falar". É, portanto, um aprendizado de saber a hora certa de falar e a hora certa de ouvir. Para as crianças, mais ouvir do que falar. Essa investigação do fascínio pela personalidade de Getúlio Vargas termina, assim, não na análise do legado político do ex-presidente, mas no exame de sua personalidade, de sua maneira de falar no momento certo.

O texto não acaba aqui, e o desfecho, ainda que de certa forma desconcertante, é coerente com o andamento do relato.

Depois de ressaltar a importância da roda de chimarrão e do respeito pela conversa e pela fala dos mais velhos para o aprendizado da "gurizada", quem retorna ao final da narrativa? O pai do narrador.

113 O dicionário Houaiss define remandiola como "vento fraco e incerto", mas registra também um regionalismo (Pernambuco, Alagoas): acidente súbito, inesperado. 
Uns quarenta anos. Nas rodas, esquinas e botequins, nas fábricas, na andança, na rua, meu pai ouviu discussões sobre Getúlio. Aturou sempre, quieto. Se lhe pediam opinião, cortava ali:

— Gostos e bofetadas são diferentes.

$* * * *$

Até hoje.

Como se vê, a questão passa pela relação entre pai e filho. O fato de o narrador atribuir a Getúlio a capacidade de falar na hora certa, graças ao costume sulista de respeito ao tempo do outro e ao aprendizado de conduta "direitinha", revela que sua interpretação relaciona-se ao comportamento do próprio pai, que também fala pouco e escolhe a hora certa para falar. Apesar de o narrador não indicar o nome deste pai, tampouco o próprio nome, o paralelo com o pai do próprio autor é inevitável. Como indica Rodrigo Lacerda, João Antônio Ferreira, pai, tinha um "espírito proverbial". 114

A oposição entre Getúlio e o pai se mantém, e agora se intensifica no campo da fala, da conversa, do discurso. Por um lado, o presidente, na visão do narrador, fascina e se destaca pela habilidade em se pronunciar na hora certa, pelo discurso ( - Trabalhadores do Brasil!) que ecoa ao longo das páginas e dos anos, pela capacidade de se adaptar aos acontecimentos e às mudanças (sabia para onde ia o vento), pela fala e pelos costumes amalandrados (mordia e assoprava; sorria gauchamente, no fundo era um carioca; tinha a lei a seu bel prazer: “A lei? Ora, a lei”), interpretação que vai culminar na hipótese de que isso se deve à habilidade gaúcha de saber o tempo certo para cada coisa. Ao final, apesar das palavras duras e sentenciosas do narrador acerca de Getúlio, a ênfase recai no seu comportamento ambíguo e maleável: um malandro.

O pai, por outro lado, apesar de também saber a hora de se pronunciar, é visto pelo narrador - sempre em oposição ao presidente - como mais intransigente, ainda que também enigmático. Sua última frase, acerca de Getúlio, é um desafio ao entendimento: “- Gostos e bofetadas são diferentes". O que o pai queria dizer com isso? Que as contradições de Getúlio eram inconciliáveis? Que as opiniões favoráveis e desfavoráveis a respeito de Getúlio eram incompatíveis?

\footnotetext{
${ }^{114}$ LACERDA, R. João Antônio: uma biografia literária, op.cit., p. 63.
} 
Esta última sentença tampouco ilumina a resistência anterior do pai à imagem e ao culto de Getúlio, resistência que, como já vimos, era ferrenha. A severidade do pai, que resiste ao tempo ("quarenta anos") e se mantém em qualquer ambiente ("rodas, esquinas e botequins, nas fábricas, na andança, na rua"), contrasta e se opõe à ambivalência e à "matreirice" do presidente.

Até hoje, diz o narrador, depois da marcação gráfica dos asteriscos. Após o exame de personalidades e capacidade de fala do presidente e do pai, o final do texto aponta para uma questão irresolvida, remetendo para o presente. Este "até hoje" que fecha o relato, seguido de uma grande imagem de Getúlio fumando charuto, indica que o enigma não se desfez: não se compreende o presidente, e não mudou a opinião do pai a respeito do presidente.

Ainda que aponte para certa interpretação — bastante idiossincrática, diga-se — do presidente, o narrador não é conclusivo sobre a totalidade do fenômeno Getúlio Vargas. Não elabora, ao contrário do que diz o texto de orelha assinado pelos editores, uma "síntese do fenômeno", a não ser que se aceite a ideia da retidão sulista e da sabedoria da roda de chimarrão como gênese e sustentáculo da personalidade e do culto à personalidade de Getúlio. A não ser que se entenda a combinação de malandro e mártir de Getúlio como um enigma persistente, e que esse enigma fosse ele mesmo a síntese do fenômeno.

Quanto ao pai, tampouco o narrador conclui algo objetivamente. O que ocorre, no desfecho, é que o leitor termina seguro de que a personalidade paterna contrasta com a de Getúlio, uma iluminando a outra, tanto por afinidade (a fala, o discurso, a autoridade) como por diferença (a matreirice e a volubilidade de um, a severidade e a renúncia de outro). O "até hoje" que conclui o texto direciona a atenção do leitor para o presente e encerra a narrativa abrindo-a para um momento contemporâneo que é o do autor-narradorpersonagem à época da publicação do livro, mas também para um momento presente indeterminado, persistente, que diz respeito ao presidente, ao pai, ao narrador e ao autor.

Lambões se fecha, encerrando em si este enigma indecifrado: quem é esse presidente e quem é esse pai, aos olhos do narrador? Não há como concluir, e, de fato, a articulação entre Getúlio Vargas e o pai deste lambão de caçarola resulta em uma espécie de impasse. Getúlio Vargas, o pai malandro dos pobres, e o pai pobre e severo deste 
menino pobre digladiam-se na memória do narrador e, ao final, "vence" o pai do narrador (por circunstância histórica: a morte de Getúlio).

Literariamente, porém, o final reafirma o lugar do filho retraído em relação ao pai e silmultaneamente o lugar do pai renunciador e sentencioso, que persiste, na memória do filho, como um espírito intransigente, dono de autoridade capaz de ombrear com a figura do presidente. Aquele "estamos todos empatados", enunciado no começo do livro pelo próprio João Antônio, parece se referir, afinal, sobretudo a ele e o pai.

"Até agora", dizia a introdução do autor, e o fim do texto reafirma a persistência do impasse: "Até hoje".

Valeria a pena avançar na análise da relação entre pai e filho, particularizando-a para a relação entre João Antônio Ferreira e João Antônio Ferreira Filho. Lembre-se, a esse respeito, a dedicatória do livro: "Para João Antônio Ferreira - meu pai - ainda firme na luta". E o texto introdutório do próprio autor, que também remete ao pai e se assemelha ao final do relato.

Como nosso objetivo aqui, porém, inclui a leitura de outros dois relatos autobiográficos do autor, convém seguir adiante, mesmo porque os dois textos posteriores ajudam a iluminar este primeiro conto autobiográfico de João Antônio, anteriormente chamado João Antônio Ferreira Filho.

\section{Nome de boêmio - Paulo Melado}

"Paulo Melado do Chapéu Mangueira Serralha" é um conto incluído em Dedo duro (publicado em 1982). Ao contrário de Lambões de caçarola, o livro é mais claro em sua definição de gênero. A ficha catalográfica traz a informação: contos brasileiros. $\mathrm{Na}$ primeira edição do livro, há ilustrações na capa, texto de orelha assinada por Antonio

Candido e, na quarta capa, uma foto do próprio autor, com trecho da "Apresentação" de Jorge Amado que consta do miolo.

Além do texto de orelha de Antonio Candido, antes dos contos propriamente ditos, encontramos a "Apresentação" de Jorge Amado e "Duas palavras", de Paulo Rónai. O começo deste último texto problematiza a classificação dos "escritos" de João Antônio: 
"Pois nem sei se são contos, apesar de o autor batizá-los assim, já que estes escritos, refratários a qualquer classificação, não admitem rótulos (...)". ${ }^{115}$

Ao consultar o sumário, vemos que o volume se constitui de sete textos, ${ }^{116}$ e uma subdivisão, que organiza o livro em duas partes. Na primeira parte do livro, que não tem nome, há quatro contos. Na segunda, denominada "Uma memória imodesta no coração da pouca vergonha", são três textos: "PMCMS", que nos interessa mais de perto, "Dedoduro", que dá nome ao livro e "Bruaca"117. Nesta seção de memórias, o primeiro conto é, como já dissemos, um relato autobiográfico sobre a formação literária do autor. "Bruaca" é um conto sobre um sinuqueiro e vagabundo, apelidado Bruaca, que vive no Beco da Onça, o mesmo beco onde o escritor passou a infância e que retratou em Lambões. O conto do meio, justamente o que dá nome ao livro, parece um pouco deslocado nesta seção memorialística, pois o conteúdo autobiográfico não está claro. Trata-se da história de Carioca ou Zé Peteleco ou simplesmente Peteleco, alcagueta profissional, personagem que em nada lembra o autor; e neste conto tampouco outros personagens, lugares ou ações parecem se referir à vida ou à memória de João Antônio, a não ser que se considere a Boca do Lixo em São Paulo, onde se passa parte da história, como a paisagem por excelência da ficção e da autobigrafia do autor, o que é apenas meia-verdade sobre os lugares de predileção da vida e da ficção de João Antônio. Teria João Antônio se inspirado em suas memórias da Boca do Lixo, em alguém que ali conheceu, para construir o personagem Peteleco? É possível, mas a inserção deste conto na seção memorialística causa certo estranhamento ao leitor que espera um conto de maior proximidade com a vida do próprio autor.

\footnotetext{
${ }^{115}$ RónAI, P. “Duas palavras”. In: AnTôNIO, João. Dedo-duro. Rio de Janeiro: Record, 1982, p. 11.

${ }^{116}$ O sumário da primeira edição parece mal realizado. Nele, inclui-se "Duas palavras", texto introdutório de Paulo Rónai com a mesma hierarquia com que se apresentam os textos do autor. A "Apresentação" de Jorge Amado, por sua vez, não aparece no sumário. $\mathrm{O}$ aspecto mal acabado do sumário reforça a falta de clareza sobre se "Uma memória imodesta no coração da pouca vergonha" se refere apenas a "PMCMS" ou aos três derradeiros textos do livro (este sumário da primeira edição do livro está reproduzido no Apêndice desta tese). A edição mais recente do volume (Cosac e Naify, 2003) apresenta um sumário com bem marcada divisão do livro em dois: os primeiros quatro contos, a divisão "Uma memória imodesta no coração da pouca vergonha" e então os três contos finais, o que indica que estes últimos comporiam mesmo uma seção de textos memorialísticos.

${ }^{117}$ O conto "Bruaca" já havia sido publicado na revista Extra - Realidade Brasileira. Malditos Escritores!, no. 4, ano I, mar. de 1977. Este número trazia uma coletânea de contos de autores como Antônio Torres, Marcos Rey, Wander Piroli, Chico Buarque e Pínio Marcos. O texto de João Antônio se intitulava "Caramba". A mudança do nome do protagonista, de Caramba para Bruaca, é a principal mudança daquela versão original para esta publicada em livro.
} 
Com isso, aventa-se aqui a hipótese de que a rubrica "Uma memória imodesta no coração da pouca vergonha" se refira apenas ao conto "PMCMS" e não seja, na verdade uma subdivisão do livro em "contos", de um lado (na primeira parte), e "contos autobiográficos”, de outro (na segunda parte). A corroborar esta hipótese está o fato de que, entre os contos da primeira parte, consta "Dois Raimundos, um Lourival", texto que é um passeio pelas ruas de Salvador (BA) de um narrador que em tudo lembra João Antônio, guiado por três meninos que lhes mostram os pontos turísticos da capital baiana. ${ }^{118}$ Nas duas partes, portanto, há contos e há contos autobiográficos.

Registrada essa possibilidade, de que o livro na verdade não seja dividido em dois, mas que misture, sem critérios claros, ficção e ficção autobiográfica, avancemos sem resolver a questão - questão, aliás, de resto, insolúvel, como indicam os textos de apresentação do livro.

Paulo Rónai começa seu texto, como vimos, justamente, problematizando a possibilidade de classificação dos textos. Jorge Amado ressalta a relação entre escrita e vida, e chama a atenção para o "parentesco" de João Antônio com Lima Barreto, a quem o livro é dedicado: "Sente-se, nas páginas de um e de outro, ranger de dentes, soluços estrangulados, desencontros, bruscas emoções, e uma vida que jamais é fácil, uma vida destorcida, ganha a socos por homens e mulheres que são os de hoje, desse mundo injusto e desatinado (...)". ${ }^{119}$ Antonio Candido, na orelha do livro, trata os textos como "contos" e fala da arte do autor, de modo geral, como "narrativa". Candido sublinha que o autor “constrói os personagens como se arrancasse de si mesmo os sentimentos e os feitos". Ao se referir ao conto aqui em questão, Candido destaca a "contradança promíscua" que se estabelece entre autor, leitor e personagem: "Embutido pela imaginação e a escrita no seu submundo, que é o mundo, João Antônio não enfeita, porque não se enfeita. E como não posa de distanciado, consegue mostrar que autor, leitor e personagem podem formar uma contradança promíscua mas humana, a exemplo da narrativa 'Paulo Melado'. O resultado é que somos obrigados a despertar, passar a mão pelo fio da alma e duvidar das divisas cujo

\footnotetext{
118 Não iremos comentar aqui os demais contos deste livro. Registremos apenas que os textos "Toni Roy Show", "Milagre Chué" e "Excelentíssimo", todos na primeira parte do livro, são narrativas que podem ser classificadas como contos, se novamente recorrermos à noção de Anatol Rosenfeld de que "o personagem instaura a ficção". Ver RosenfELD, Anatol. "Literatura e personagem". In: Antonio Candido et al. $A$ personagem de ficção. $5^{\text {a }}$ edição. São Paulo: Perspectiva, 1976.

${ }^{119}$ AMADO, J. “Apresentação”, in Dedo-duro, Rio de Janeiro: Record, 1982, p 9.
} 
marco é a convenção. Um banho incrível de humanidade, que inclui mergulhos até o fundo (dentro e fora)". 120

Assim como já ocorrera com Lambões, a leitura do conto "PMCMS" é marcada desde o início pela ambiguidade entre ficção e autobiografia; entre, por um lado, o trabalho refinado de linguagem e de estrutura formal, que tende à ficção, e, por outro, lembranças e reminiscências, reconstituídas por um autor-narrador adulto e maduro, com carreira literária estabelecida e certo reconhecimento literário.

Ao dar início à leitura deste conto, ao aceitar o convite para essa "contradança promíscua", o leitor tem em mente que se trata de um conto autobiográfico, já que o conto vem acompanhado da rubrica "Uma memória imodesta no coração da pouca vergonha" (ou está mesmo dentro desta "seção" de memórias). Entretanto, apesar de ser um texto de memórias, é um relato de autoria de um renomado escritor de ficção.

O começo do texto corrobora essa percepção de ambivalência entre memória e trabalho ficcional. O conto é dividido em seções, separadas umas das outras por subtítulos e, eventualmente, por asteriscos, as seções variando bastante de tamanho. Algumas partes do texto são longas, outras se constituem de poucas frases, não mais de dois ou três parágrafos, e há o caso de trechos feitos apenas de uma única frase (é o caso de "Plantão": "Mas você me sorri, mulher, e a vida vive").

Três epígrafes apontam para hábitos malandros, libertários e boêmios, traduzidos em canções populares, e dão contornos ainda mais "sestrosos" aos títulos do conto ("Paulo Melado do Chapéu Mangueira Serralha”) e da seção ("Uma memória imodesta no coração da pouca vergonha"). Uma das epígrafes é um trecho de "Com que roupa?", de Noel Rosa: "Eu nunca senti falta do trabalho, desde pirralho que eu embrulho o paspalhão, minha boa sorte é o baralho, mas minha desgraça é o garrafão: dinheiro fácil não se poupa, mas agora com que roupa?”. A segunda epígrafe é: “'Solta a rédea a tua juventude, não a poupes.' — das canções que Zorba, o grego, de Nikos Kazantzakis, cantava se acompanhando no santuri". A terceira é um trecho de "samba gravado em disco por Paulinho da Viola, chamado médio na partitura impressa, com letra e música atribuídas a Zé Ketti, mas lembrando, com firmeza, características e ares da majestade dos clássicos de Nélson

\footnotetext{
${ }^{120}$ CANDIDO, A. "Um banho incrível de humanidade", in Dedo-duro, Rio de Janeiro: Record, 1982. Orelha da primeira edição. O texto não foi republicado na edição mais recente do livro. ANTÔNIO, J. Dedo-duro. Cosac e Naify. São Paulo: 2003.
} 
Cavaquinho". O samba, "O meu pecado" (1967), fala dos muitos do eu-lírico da composição: "O meu pecado / Foi em querer / Na minha mocidade / Amar tantas mulheres / O tempo já passou / Eu tenho saudades // O meu pecado / Foi passar noites / Em serestas / E bebendo por aí / Pela cidade.”

As epígrafes, assim, combinam impulsos contraditórios. Por um lado, há desejo e recomendação de liberdade e libertinagem: viver a juventude de "rédeas soltas", sem freios, amar muitas mulheres, passar as noites em serestas, bebendo. Por outro lado, há o sentimento do pecado, do erro e, como diz o samba de Noel, uma noção de que o destino castiga o boêmio e o perdulário: "minha desgraça é o garrafão" e "dinheiro fácil não se poupa". O desejo de liberdade e inconsequência, misturado a uma rígida contenção moral, orienta o texto desde o começo, e será retomado ao final do conto, como veremos, para definir, finalmente, a personalidade deste narrador que conta a sua formação, como homem, boêmio e escritor.

As epígrafes também preparam o início do conto propriamente dito, introduzindo o leitor no universo da boemia. O texto é precedido, assim, de um tom de elogio e incentivo ao comportamento desregrado, ao mesmo tempo que se guarda certa desconfiança moral ("pecado", "desgraça") em relação à vida boêmia.

A primeira parte do conto se intitula "Uma ave noturna", seguida de "Não há volta":

\section{UMA AVE NOTURNA}

Vive-se.

Se se é uma chaga viva, nervo exposto, tontice. Ninguém vê. Meu trabalho tem sido, quando presta, disfarçar isso.

Meu pecado é que as manhã foram feitas para a meditação. As tardes para a contemplação. E, as noites, estas sim, para a concentração e a construção. Nelas, expludo.

\section{NÃO HÁ VOLTA}

Hoje, a marca é nos quarenta anos. E desta não tenho retorno.

Vou firme. Ou penso que. Declaro gozar perfeita saúde. Se me perguntam, até faço frase. Nesta vida, a três coisas dou apreço — todas as manhã ao acordar e abrir os olhos, eu vejo que não tenho automóvel, não uso óculos e ainda estou vivo. Agradeço e prezo.

Ainda uma quarta qualidade me acompanha. Não sou diretor de nada. 
Melhor que isso, só pedindo a Deus uma velhice irresponsável. ${ }^{121}$

O começo do conto, como se vê, apresenta um narrador em primeira pessoa que, aí pelos quarenta anos, define a si mesmo como uma ave noturna. A metáfora refere-se possivelmente ao comportamento boêmio, mas carrega também aspectos de solidão e sofrimento que as expressões "chaga viva" e "nervo exposto" ressaltam. O caráter solitário deste sofrimento é indicado quase como um lamento: apesar da vida intensa, "ninguém vê" esses sentimentos extremos. O narrador, por outro lado, diz que o seu "trabalho" tem sido disfarçar isso, essa condição de sensibilidade extremada. É à noite que "expludo", diz o narrador, indicando que contém seus sentimentos durante o dia, na "meditação" das manhãs e na "contemplação" das tardes. O uso deliberadamente errôneo da flexão do verbo explodir na primeira pessoa do indicativo ${ }^{122}$ denota que o manejo da linguagem é parte desse sofrimento represado, que arrebenta em explosão, meio desajeitado, num verbo equívoco, nas noites de boemia.

A segunda seção do texto abre-se em tom de balanço. Em seus quarenta anos, o narrador diz que vai "firme”. Para em seguida, nuançar a certeza: "Ou penso que”. Sobre a saúde, usa uma construção jocosa, que brinca com o tom protocolar das declarações oficiais: "Declaro gozar perfeita saúde". O tom de ironia prossegue, pois ele se refere ao hábito de responder com graça aos questionamentos sobre esse assunto: "até faço frase". As coisas que preza denotam desprendimento e apontam para uma personalidade, de novo, solitária e folgazã: além de estar vivo, ele preza não ter automóvel, não usar óculos, não ser diretor de nada. A felicidade se afirma pela "falta", pelo orgulho de não possuir, pela ausência ou negação da propriedade (carro), do poder (não ser diretor) e da preocupação com a saúde (não usar óculos). ${ }^{123}$

\footnotetext{
${ }^{121}$ Dedo-duro, pp. 87-88.
}

${ }^{122}$ A forma "expludo" causa ruído, e realmente não é recomendada pela norma culta. Se o verbo explodir fosse verbo regular, o correto seria "explodo". Ocorre que explodir é defectivo, isto é, verbo sem flexão na primeira pessoa do indicativo.

${ }^{123}$ A saúde de João Antônio, ao contrário, não era das melhores, como se sabe. E as preocupações vinham de longe. Em 1966, aos 29 anos, morando no Rio de Janeiro, João Antônio manda carta a Caio Porfírio Carneiro, em que, depois de falar de algumas questões editoriais, revela que está proibido de beber por recomendação médica: "De resto, poucas novidades neste finzinho de inverno carioca. Pouca praia, alguns passeios, uns joguinhos de leve por aí, uma que outra fêmea em disponibilidade. E nenhum álcool. O médico me proibiu definitivamente, pois tenho uma complexa complicação figadal. Como vê, eu não passo de um triste desgraçado". O grifo é do autor. ANTÔNIO, João. Cartas aos amigos Caio Porfírio Carneiro e Fábio Lucas, p. 31. O autor também viria a sofrer de problemas de circulação nas pernas e enfrentaria uma crise nervosa, que 
A frase que fecha a segunda parte do conto mantém o tom bem-humorado de elogio da liberdade e da despreocupação. Pedir a Deus "uma velhice irresponsável” é já um desejo do presente, que se projeta para o futuro. Se o começo do trecho era pautado pelo balanço de começo de meia idade, na faixa dos quarenta anos, o final é uma declaração de desejo que diz mais sobre o presente deste narrador, aos quarenta anos, que do seu futuro.

Até aqui o leitor tende a identificar o narrador-personagem ao escritor João Antônio, mas o texto ainda não deu indícios claros nesse sentido. O narrador, mais uma vez, como já ocorrera em Lambões, não se apresenta - estritamente falando, não há indício, no início do conto, de que o narrador seja equivalente a João Antônio. No entanto, a ênfase sobre o escritor como personagem principal é bem maior que no livro comentado anteriormente. Se em Lambões, os protagonistas eram Getúlio Vargas e o pai do narrador, em "PMCMS" o personagem central será, afinal, o próprio narrador. E, em certa medida, será também o escritor João Antônio, já que se trata, como não era o caso em Lambões, de um texto sobre a escrita e a vocação do próprio autor para a literatura.

Como se infere pela abertura do texto, e como se verá ao longo do conto, este texto autobiográfico já não se volta tanto para o panorama de época ou a comunidade em que cresceu o narrador. "PMCMS" é já um conto sobre alguém estabelecido como escritor, que de alguma forma procura explicação para o próprio talento e as próprias realizações, as "glórias" e os "fiascos", nas palavras do narrador. É um conto também sobre a formação deste narrador-escritor, que nasceu pobre, filho de pai trabalhador e músico, de mãe sem educação formal e ressabiada quanto ao mundo da boemia, e sobre como, finalmente, este narrador na juventude foi capaz de se lançar em uma aventura nova, a da escrita, contrariando as expectativas familiares.

$\mathrm{O}$ começo do texto aponta para um homem maduro, que se orgulha, com ares de modéstia, de seu trabalho e faz graça, irônico, acerca do próprio modo de vida desregrado, ainda que a identidade de boêmio venha contrabalançada por peso moral ("pecado"), castigo do destino (“desgraça"), aura de mistério e algo de lúgubre (qual seria a "ave noturna" que intitula a primeira seção do livro: coruja, corvo, gavião, a "águia dissimulada", que será citada como metáfora da rixa no universo do choro?).

redundou, na década de 1970, na sua internação em um sanatório, onde, aliás, colheria material para a escrita do seu livro sobre Lima Barreto. O cigarro e a bebida também seriam companheiros diários até o fim da vida. 
Nos dois primeiros segmentos do texto, porém, o leitor não é informado a respeito do que faz este narrador, qual é a sua identidade. É um narrador que afirma qualidades e hábitos solitários e boêmios, desprendidos e bem-humorados, ainda que afirme, em sentido oposto, sentir-se "chaga viva", "nervo exposto", sempre prestes a explodir. Sobre o seu "trabalho", diz apenas que tem sido, "quando presta”, disfarçar essa ebulição, dor pessoal, interior, que "ninguém vê".

É apenas a partir da terceira parte, intitulada "Choros e landuás”, que o narrador irá se identificar como escritor. Mais que isso, irá se identificar como escritor de certo sucesso e reputação, que então se põe a contar reminiscências e acontecimentos de sua vida, desde a infância, relacionados a sua vocação para as artes: a música, especialmente, e a escrita.

O leitor desavisado ainda não sabe exatamente aonde o texto vai dar, como sabemos nós, leitores de segunda ou enésima leitura da obra do escritor e da crítica sobre ele. A narrativa vai dar na revelação do título do conto como um pseudônimo de juventude do escritor João Antônio. O leitor, que ainda não sabe onde isso tudo vai levar, graças à habilidade de construção do texto em sonegar o sentido do título até o final, é desde já apresentado a um narrador-personagem que, desfrutando de certa reputação, volta-se para o passado para contar como chegou aonde chegou. Sabe-se apenas, portanto, que o texto restabelece a memória de um caminho formativo, cujo horizonte é o presente: escritor consagrado e desprendido, mas também sofrido, incompleto e incompreendido.

"Choros e landuás", a terceira parte do texto, que dá início à narrativa da formação deste narrador-escritor, é bem maior que as duas primeiras seções do conto. Tem nove páginas na primeira edição do livro. É onde o narrador irá contar sua iniciação na música, especificamente nas artes do choro, levado pela mão do pai. O trecho é longo e de construção pouco usual, pois além do assunto principal, o choro e a maneira com que ele, narrador, desde pequeno tomou gosto por esse gênero musical, surgem outros assuntos, de diferentes tempos e temáticas, ainda que sempre vinculados ao narrador e sua relação com a artes de sua predileção, a música e a escrita.

A forma narrativa, neste trecho mais longo, é mais aparentada àquela de Lambões, em que os temas e os acontecimentos vão sendo narrados de acordo com as reminiscências e lembranças do narrador, um pouco à deriva, mais uma vez ao correr da pena, num formato que lembra a crônica, a anotação, o comentário. O eixo das lembranças e 
rememorações é a relação deste narrador-personagem com a literatura e com a música, mas é curioso notar como essa narrativa evolui misturando recordações da família, especialmente sua relação com o pai e a mãe, num procedimento que lembra mais a misturação de Lambões que a força da ação narrativa dos "Contos Gerais", de "MPB” e "PРT".

A seção "Choros e landuás" começa com um exame de consciência, a que se segue uma declaração de certa humildade e falta, em continuidade com as duas primeiras partes do texto:

Se me pego e esmiúço, e me componho, estou desfalcado. Hoje me cantam as glórias, nenhum escriba me flagra os fiascos. Vejo, no momento, muita coisa correr em meu nome e o mais é floreio, exageração, uma generosidade algo oferecida. E distraída, também.

Meu cabedal é pobre, de livros e descendentes e, elas por elas, filho de um transmontano emigrado e de uma mestiça do Estado do Rio, neta de negros, nasci sem maior lordeza. A família de mestiços, fluminense naquele tempo, andava arada de fome; correu para São Paulo nas beiradas de 29, ano ruço, e tentou se arrumar no que restava de mercado de trabalho nos intestinos industriais de Presidente Altino, Osasco e Jaguaré. Assim, nasci num tempo desmilinguido, inda mais no meio operário. Muito retrato do dr. Getúlio Vargas nas paredes dos estabelecimentos pobres. Sofria-se que não era vida.

A verdade é que ando cansado desse landuá bem-comportado, asséptico e sem peleja, sem refrega, esporro, escorregão, enquanto a vida mesma é escrota, malhada, safada. Algumas coisas me aborrecem em largo e profundo - o que é diferente e bem. O buraco é um bocado mais embaixo. $\mathrm{E}$ o corpo humano tem nove buracos. Estou ainda enfarado do lado estético, que falar do feio com forma bonita é mais farisaísmo. Para que forma feitinha, comportada e empetecada; para que um ismo funcionando como penduricalho para falar de coisas caóticas e desconcertantes? Houvesse, de vez, uma escrita envenenada, escrachada, arreganhada. Nem me venham dizer os sabidos que a vida, aqui fora, fede de outro modo. Parece-me que onde se está abrindo com a frase: "Respeitável público!", talvez coubesse esta, assim: "Detestável público!”. Afinal, deliberadamente ou não, o escriba é um servo da classe média. Então, não comece com floreio de brilhareco, pois estará entrando exatamente no joguinho que essa classe espera dele. ${ }^{124}$

Como se nota pelos três parágrafos iniciais deste trecho do conto, os assuntos e a temporalidade da narrativa, aqui, não se organizam em torno de uma ação narrativa, mas sim de comentários e lembranças que vão acorrendo, um pouco a esmo, à consciência deste

${ }^{124}$ Dedo-duro, p. 88-89. 
narrador. Note-se a retomada da lembrança da família e de Getúlio Vargas, que já aparecera com força em Lambões. Mas aqui, diferentemente do texto anterior, o "eu" se afirma de maneira mais enfática.

Sabemos que a errância é um traço forte da escrita de João Antônio enquanto tema, e nos textos ficcionais contamina também o procedimento narrativo, como veremos em "Busca" e "Aact". Os textos autobiográficos — Lambões, este ora em análise e "Amr" — intensificam o caráter errático da escrita de João Antônio, que passa a obedecer menos à ação dos personagens, e mais à rememoração e ao comentário.

O trecho indica que o autor, de alguma maneira, estava em busca dessa forma mais livre, com intenção de tornar a própria escrita ainda mais contundente e condizente com aquilo que tinha a dizer ou comunicar. É o que se verifica no terceiro parágrafo do trecho citado acima. Nele, o narrador irá fazer a defesa de uma escrita "envenenada, escrachada, arreganhada". Para falar de coisas "caóticas" e "desconcertantes", a forma teria de ser o avesso de "feitinha, comportada e empetecada".

Trata-se de um parágrafo enfático e irritado, que começa com tom de desabafo em relação ao "landuá bem-comportado". Não fica claro do que exatamente o narrador está cansado. O tal landuá (que os dicionários definem como boato, inverdade, mentira, falsidade), conclui-se, é o daqueles escritores que adotam uma forma bonita para falar do que é feio e mal cheiroso, dos que adotam uma forma bem comportada para falar de uma situação caótica e desconcertante. Entretanto, apesar da ênfase e das palavras fortes (a vida, por exemplo, é “escrota, malhada, safada"), o narrador não é objetivo sobre o assunto de que trata (acerca, por exemplo, daquilo que faz a vida escrota, malhada, safada). A ênfase das palavras fortes é acompanhada por certa evasão: "Algumas coisas me aborrecem em largo e profundo - o que é diferente e bem".

O tom assertivo da crítica, que pede mais agressividade nesse estado de coisas "asséptico" (sem disputas ou ataques abertos, sem "peleja", "refrega", "esporro", “escorregão"), é acompanhado de generalização e subentendido ao se recorrer ao dito popular, à frase feita: "O buraco é um bocado mais embaixo". Ou seja, o desabafo é forte, mas vem acompanhado de indeterminação, o que torna o discurso menos objetivo. Em verdade, como não se especifica muito sobre o que se está falando, trata-se de reafirmar aquilo que já sabemos ser característica forte da escrita do próprio João Antônio. Como não 
se agregam elementos claros ou novos, o leitor entende a reclamação, o "cansaço desse landuá", ou como uma simples manifestação de insatisfação, geral e irrestrita, lançada contra os beletristas (quem seriam?; o texto não diz), ou como uma reafirmação dos feitos alcançados até então e dos princípios literários já manifestados. ${ }^{125}$

As glórias são, claro, os livros publicados e a recepção crítica favorável — como sugerido, aliás, pelo início do trecho acima. Apesar do tom autocomplacente sobre o exame de consciência minucioso que resulta em posição desfavorável (ele se julga "desfalcado", incompleto), o narrador afirma que, mesmo assim, lhe "cantam as glórias" e "nenhum escriba" the "flagra os fiascos".

O salto de assunto e de tom, no parágrafo seguinte, é substantivo. Depois de um começo abrangente e metafísico, com reflexões sobre a vida, em geral, e sobre o sentido da sua vida em particular, em tom de ironia e até galhofa, o narrador passa, no parágrafo seguinte, a uma espécie de explanação objetiva de suas origens. De um início tergiversante, passa-se a arrolar uma quantidade razoável de informações concretas: a qualificação e a origem dos pais, a data de mudança da família materna do Rio para São Paulo, a motivação econômica e outras coordenadas geográficas e sociais: a inserção nos bairros industriais, a vida de classe operária, os locais de moradia nos bairros da periferia da capital paulista. $\mathrm{O}$ narrador permanece reivindicando para si mesmo os signos da pobreza e da falta, em tom de humildade. A frase que se inicia com "Meu cabedal é pobre, de livros e descendentes" chama a atenção para a origem desfavorável, intelectualmente falando, por conta dos "livros", mas também de material humano, já que o cabedal de descendentes também é pobre. A pobreza de sua descendência seria alusão ao único filho, Daniel, nascido em 1967? Ou se refere à descendência gerada pelos pais dele próprio, pobres, como se dirá a seguir, e também pobres de descendentes, já que além de João Antônio tiveram apenas mais um filho, Virgínio?

Não é possível dizer. Mas, aqui, já se pode afirmar com mais firmeza que afinal o personagem principal do texto é mesmo o escritor João Antônio. As informações são coincidentes demais com a biografia do autor para que insistamos na hipótese de dissociação entre escritor, narrador e personagem. São eles todos um só, como indica o

\footnotetext{
${ }^{125}$ Sobre o projeto literário defendido pelo autor, ver o texto "Corpo-a-corpo com a vida". In: Malhação do Judas carioca. Rio de Janeiro: Civilização Brasileira, 1975.
} 
segundo parágrafo do trecho acima, em que as informações de filiação apontam claramente para o pai e a mãe do escritor. No entanto, vale ainda ressaltar mais uma vez — sem que isso desfaça, porém, o pacto autobiográfico — que a identificação se dá e ganha contornos nítidos no texto, mas é retardada, mediada, nuançada, misturada e desconversada por procedimentos vários: a inserção do texto num livro de contos; a rubrica "Uma memória imodesta no coração da pouca vergonha", que aponta para "memória", mas com formulação colorida, bem-humorada, amalandrada; as várias epígrafes que antecedem o começo do texto, o tom de balanço reflexivo sobre a vida, com que o texto se inicia, precedendo ao testemunho de memória em si, as alternâncias de temporalidades diversas.

Com isso, o texto constrói uma situação interessante. Ao mesmo tempo que se inicia com o tom de balanço e de autoexame, retorna para recompor a infância deste personagem (que é o autor) num movimento duplo: quem sou hoje e como cheguei até aqui. O exame da situação atual recai sobre a profissão, tratada sempre de maneira larga, abrangente: a escrita. E a formação do escritor é retraçada até a infância, com grande peso conferido, assim, ao ambiente familiar.

Em relação ao texto comentado anteriormente, ocorrem duas grandes mudanças: a opção pela literatura não tinha a relevância que tem aqui, e a infância, se já era o momento por excelência em que se vai recuperar a reminiscência - a recordação significativa —, agora ganhará abordagem ainda mais pessoal, orientada para a descoberta da sensibilidade artística e da inclinação literária, culminando, com a entrada na juventude, em um rompimento: a superação da infância e da dependência do ambiente familiar, a dispensa da "herança" paterna (a vocação para a música), a recusa aos valores sociais burgueses, tais como então instituídos, tudo isso trocado pela boemia e pela escrita. E por uma escrita que se deseja, como se afirma, "envenenada, escrachada, arreganhada".

Depois das reflexões sobre o sentido da vida, sobre suas condições de saúde à altura dos quarenta anos e sobre a escrita, e depois da breve introdução à história familiar, a sequência do texto aprofunda a relação de João Antônio com o choro. O que parecia um início de texto um tanto quanto descosido, caminhará para a confluência das linhas de força do texto - a família, a vocação, as escolhas de vida — em torno desse gênero musical. Será neste ritmo musical que o futuro escritor irá descobrir coisas importantes da 
existência, condutas e relações que ele, agora aos quarenta anos, rememora e tenta, a seu modo, ligar à opção que fez pela literatura.

Neste momento inicial do conto, a passagem dos temas literários para os musicais vai se dar por dois caminhos: a lembrança do contato com o choro em família (por herança paterna, de um lado, e por resistência da mãe, de outro) e a definição do choro como um estilo musical ao mesmo tempo solitário e coletivo, acirrado e solidário, agressivo e malandro, amoroso, "sublime".

Mais importante que entender como o interesse pelo choro e a "afinação da arte de ouvir" choro se refletiram na obra de João Antônio nos parece ser, justamente, o universo de relações que o então menino descobriu em torno desse gênero musical, a começar das diferenças entre o pai e a mãe:

Que me lembre. Frequentei de cedo, rodas de chorões e seresteiros, levado pela mão de meu pai. O velho sequer tinha escola primária completa. Mas tocava por música. Banjo, violão, cavaquinho, bandolim e os instrumentos de corda que conheço. Todos.

Atarracado, mãos quadradas e grossas. Mas de onde haveria arrancado aquela sensibilidade?

A mãe, desafinada. O pai, musical de todo. Ainda assim se entendiam, no cumprimento daqueles anos todos. Aquele homem tinha uma chave escondida com que fazia a seleção das coisas, amorosamente. Onde diabo teria aprendido aquilo? Fino, acima daqueles ambientes $(\ldots)^{126}$

O talento musical e a sensibilidade do pai continuam a impressionar o escritor adulto, como este trecho de memória tão bem registra. Aqui, não é o narrador que rememora como se fosse menino (como se dá também em Lambões), mas o narrador que foi menino e ainda retém a admiração e o espanto pela personalidade do pai. O contraste é sublinhado pelo narrador: o pai era homem de pouco estudo e de constituição física grosseira ("atarracado", "mãos quadradas e grossas"); no entanto, tinha sensibilidade para música, era "fino". Além do choro, da habilidade com os instrumentos de corda, o narrador irá registrar, na sequência do trecho acima, os rudimentos que o pai tinha de latim (sabia pronunciar corretamente o nome da rua Helvetia, com som de $c$ ) e o interesse do pai por orquídeas, que cultivava, promovendo hibridações, e que ia buscar ("caçar parasitas") em viagens à Serra do Mar.

${ }^{126}$ Dedo-duro, p. 91. 
Por outro lado, a mãe era "desafinada", e como saberemos adiante, resistiu o quanto pode em deixar o filho seguir carreira musical, escondendo dele o bandolim. O pai lhe passou o instrumento, e o narrador diz que aos nove anos "pinicava rápido, jeitoso, o Apanhei-te, cavaquinho e a Marcha turca". ${ }^{127}$ Mas a mãe não lhe dava acesso ao instrumento, impedindo assim que o menino João Antônio praticasse o que havia aprendido com o pai. Para ela, dirá o narrador, “o mundo dos chorões e dos cantores era a vida na farra". 128

É por isso que, a certa altura, o narrador vai definir sua vida como um "nó", traduzindo o impasse gerado pelo conflito entre as vontades do pai, que o levava às rodas de choro e serestas, e da mãe, que lutava para impedir a "extravagância antes do tempo": "boêmia, nas bebidas, sapecando-me de mulheres, artes, maturutagens".

Mas, para além do aprendizado sobre as relações familiares, no choro o filho de João Antônio Ferreira reconheceu um modo de vida, um aprendizado que, desde cedo, desde muito menino, abriu sua percepção para as relações interpessoais e sociais. É no choro que o escritor irá encontrar uma atividade e um ambiente em que reinam a amizade e a inimizade, o companheirismo e a rivalidade, a sensibilidade poética e a agressividade:

Tira-se um choro batuta. É do chapéu, vivo, traquejado. Há derrubadas, afrontas e duelos, companheirismos e rixas. Nem tudo é camaradagem. Cada homem de sopro, de percussão ou cordas, carrega sua vaidade acesa e, mais que forte, escondida. Há paradas duras de solo e acompanhamento. Violões. Um querendo comer o outro, inda mais quando se trata de contracanto e improvisação, quando se quer correr por dentro e se entra num recacau lambido, intrincado de sutilezas, recursos arrumados na hora, manhas, picardias.

Vou quieto, sondando. Corremos, eu e papai, as rodas de Presidente Altino, Osasco, Vila Leopoldina, Lapa e nos trens caxinguentos e estropiados da Sorocabana viajamos a Jandira e Itapevi. Ou tocamos para o outro lado da cidade, para a Luz e para Santana. Reviramos os bairros, os dois

127 "Apanhei-te cavaquinho" é composição de Ernesto Nazareth, e a "Marcha turca" é a transcrição para instrumentos de cordas do terceiro movimento (Rondó Alla Turca) da sonata para piano número 11 de Mozart (K 331). A forte ligação do choro com a música clássica é notória. Cláudia Matos distingue o choro (mais refinado, inserido socialmente e ligado à tradição da música erudita) do samba (de raiz pobre e discriminada): "Este é de origem negra e proletária, enquanto o choro vem de matriz branca e das classes mais favorecidas: na origem, era um modo particular de o músico popular executar a música importada que na segunda metade do século XIX animava nossos bailes e salões elegantes. O samba se constrói, sobretudo no início de sua história, sobre uma estrutura rítmica e melódica bastante simples, possibilitando a participação de todos os presentes, pelo menos no bater das palmas. O choro, desde seu aparecimento, exige e exibe alta sofisticação musical na execução". MAtos, C. Acertei no milhar: samba e malandragem no tempo de Getúlio. Rio de Janeiro: Paz e Terra, 1982, pp. 25-26.

${ }^{128}$ Dedo-duro, p. 91. 
nos damos as mãos nas travessias das ruas, andejos. Mas eu não pinico mais nas cordas, a palheta apertada, firme, entre o polegar e o indicador.

Sonsa, tão sonsa. Águia dissimulada. Tensa como as cordas do cavaquinho. Coçando, a rixa não vem a furo. Então, fica no choro um clima que constrange e faz que só resvala. Mas vai fundo e fere. Levanta inimizades que picam e não se declaram. Caminha que caminha, a rixa. Arrasta um fio de anos, dissimulada e roendo, quieta. Beleza de pinimba! Menino, eu não toco. Mas aprendo, na espia, os modos da competição. E passo a torcer por um ou por outro estilo.

Quem ouve o choro ali tocado, não a vê. Mas é um quê engasgando, um lindeza fina e feia, de íntima. Ela vai crescendo nessas disputas, engordando a cada encontro. Toma corpo. Fica no embalo das passagens para as segundas partes, em crescendo. Tarde após tarde, noite após noite, nunca que explode. A birra.

Só música se ouve. Mas já vou sabendo ouvir mais que ela. A briga está lá, enfarruscada e enrugada, no seu escondido, tocaiada, espiando. Como um cuidado zeloso de ciúme recolhido.

Essa diferença entre os homens, é ela. Esse ciúme, é ele. Esse travo, é ele. É ela, é ele e é ele e são eles que fazem a vida, o vício e a continuação das rodas do chorinho. Berçando.

Na derrubada do choro, só o bom fica de pé. Na derrubada do choro, de duas você passa a desconfiar. Quando alguém lhe diz: "deixa isso comigo". Quando alguém lhe diz: "este cachorro não morde". Você aprende. Quem corre, cansa. A derrubada do choro faz com que, só depois dos vinte e cinco, trinta anos um nome de chorão comece a correr as rodas e se imponha considerado, temido, conhecido de longe (...). ${ }^{129}$

A citação é longa, mas oportuna, pois vai dar no tema do nome, que comentaremos a seguir e que voltará, como se sabe, ao final do conto e, antes disso, não no universo da sinuca ou da literatura, mas no ambiente do trabalho, como também veremos adiante.

O primeiro parágrafo do trecho acima descreve a relação entre os chorões: há camaradagem e há rixas entre eles. Sopros, percussão e cordas — um depende do outro para executar bem uma composição. Mas há também solos, vaidade, paradas duras entre os músicos. As expressões lembram aquelas usadas no universo da sinuca. Assim como em “MPB” os parceiros de jogo pensam, a certa altura, em devorar uns aos outros, no choro também a rivalidade é acirrada: "um querendo comer o outro" ou quando se trata de "comer por dentro". No choro, como na sinuca, também é preciso manha, "picardias”. A iniciação no choro, portanto, prepara este narrador para artes e relações futuras, despertando nele o gosto pela amizade e pela parceria, mas também pela disputa e pela rivalidade. Aqui,

${ }^{129}$ Dedo-duro, p. 92-94. 
porém, a iniciação à vida adulta e às relações que vão para além do círculo familiar esbarra nos limites impostos, justamente, pelo pai e pela mãe.

A companhia de pai e filho talvez indique, afinal, que o pai via com naturalidade a presença do filho nas rodas de choro, ao contrário da mãe, que não o queria na companhia dos músicos. O narrador diz que "menino", ele não toca, apenas assiste aos adultos. Nesta época, dirá ele um pouco mais adiante, o pai ganhou dos amigos de choro um amuleto, em referência ao filho que sempre o acompanhava: "uma miniatura de chupeta num laço de fita vermelha que o velho pendura na cravelha do bandolim". A ligação do menino com o pai, por ora, é absoluta: "A chupeta ao bandolim como eu ligado a meu pai". ${ }^{130}$

É curioso que neste momento da infância deste narrador-escritor haja tantas referências que reafirmem sua condição infantil, a começar do próprio nome do ritmo musical, o choro, que remete não apenas às crianças mas, mais que isso, à comunicação dos bebês. O trecho emite outros sinais de que o mundo dos chorões é revivido por este narrador adulto que relembra a infância como um momento de iniciação e infantilidade: as rivalidades são "birras", os recursos são arrumados com "manhas", a vida no choro segue "berçando". A própria natureza artística do choro, gênero musical que, ao contrário do samba, é essencialmente instrumental, isto é, não verbal, também insere toda essa passagem da vida do narrador no terreno da infância, na condição do infante, daquele que não fala.

O choro, como descrito no texto, é uma arte de subentendidos, de insinuações, de dissimulações, em que o não dito, o não verbal, comunica por meio da música. O trecho citado traduz, de maneira bastante poética, todas essas ideias de oposição, rivalidade, subentendidos, contradições ("beleza de pinimba", "lindeza fina e feia") e acomodação ("a continuação das rodas do chorinho"), concentradas em uma construção verbal bastante musical, que procura emular, provavelmente, o andamento do choro: "Essa diferença entre os homens, é ela. Esse ciúme, é ele. Esse travo, é ele. É ela, é ele e é ele e são eles que fazem a vida, o vício e a continuação das rodas do chorinho. Berçando".

E apesar de tudo, apesar do segredos, dos não ditos, das dissimulações, o menino aprende: "Só música se ouve. Mas já vou sabendo ouvir mais que ela". Em companhia do pai, o menino percorre a cidade, e descobre que entre os homens há rixas, disputas, vaidades inconfessas, inimizades que não se declaram, ciúme recolhido. O caráter

${ }^{130}$ Dedo-duro, p. 96. 
inconfesso, não verbalizado, dissimulado e íntimo de como esse menino apreende e compreende a música sublinha a sua condição de infante.

A influência do pai neste momento de descoberta não poderia ser mais incisiva. $\mathrm{O}$ menino ainda é iniciante na capacidade de se expressar verbalmente, isto é, de se comunicar por meio da linguagem verbal, já que ainda é criança, mas também por conta da influência paterna. O pai o leva de um lado para outro - vão os dois, "andejos", como diz o próprio narrador. O menino vira uma espécie de mascote dos chorões, e o pai ganha uma chupeta para adornar o seu instrumento.

É singela e tocante a homenagem dos amigos de choro ao pai do menino. Mas para o pequeno chorão, a chupeta, além de ser um símbolo de carinho e proteção, representando o elo com a figura paterna, é também índice de submissão e dependência ao pai. Uma cena, descrita no curto trecho de uma página intitulado "Afinação da arte de ouvir", ${ }^{131}$ que se segue ao longo trecho "Choros e landuás", indica que o envolvimento do menino com o choro irá culminar não no pleno desenvolvimento de uma vocação musical manifesta, mas na ardilosa e violenta interdição paterna.

Na seção anterior, a criança aprende música e aprende a entender os homens ouvindo choro - e apenas ouvindo. Mas agora o menino descreve, além da "afinação da arte de ouvir", a vontade de tocar. Quando ele se arrisca a pegar num instrumento, esquecido momentaneamente no sofá por um dos chorões, e esboça voltar a tocar as composições que o pai lhe ensinou, é surpreendido pelo próprio pai. A reação do menino é de medo, temeroso de que tenha feito algo errado:

Papai, chegando sem que eu o visse, me pilhou, fala curta:

- Ah, gosta de tocar.

Um frio nos joelhos de fora, que a calça curta não cobria. Pousei o bandolim, num arrepio. Tinha na cravelha, balangando na fita de cetim, vermelha e brilhante, uma miniatura de chupeta, lembrança dos parceiros. Um som que eu tirara, furtivo, ficou na sala. Houve um medo. E, diaba de

\footnotetext{
${ }^{131}$ O título desta seção remete, obviamente, ao conto "Afinação da arte de chutar tampinhas", de Malagueta, Perus e Bacanaço, o que reforça, mais uma vez, a ambiguidade do pacto de leitura deste texto. Ele está entre a autobiografia e a ficção, já que remete a um conto do autor, e esta remissão não vem acompanhada de consequência narrativa. A alusão remete, assim, a outro texto do mesmo autor, mas a um texto de ficção, o que faz o leitor pensar se, apesar de o narrador não se identificar, o conto não seria afinal meramente um texto memorialístico sobre um ficcionista, isto é, essencialmente autobiográfico e, ao mesmo tempo, profundamente relacionado à ficção, tornando o jogo da leitura (a "contradança promíscua", a que se refere Candido), ainda mais intrincado para o leitor.
} 
primeira estrela da tarde que em nada me adiantou. Ele teria percebido que eu não treinara mais a Marcha turca e o Apanhei-te, cavaquinho? Que, por último, eu nem relava no bandolim?

O pai fez uns olhos pretos, miúdos, certeiros.

—É mais difícil ouvir do que tocar. ${ }^{132}$

A última fala do pai retoma aquele espírito sentencioso e proverbial que já vimos aparecer em Lambões. Aqui, é interessante notar a reação ambígua que a súbita aparição do pai exerce no menino. Apesar de serem companheiros inseparáveis de roda de choro, o menino fica com medo ao ser flagrado pelo pai com a mão no instrumento. Num primeiro momento, o leitor tende a imaginar que o pai o proibiria de tocar o bandolim. Mas o temor do menino, ainda que indeterminado ("houve um medo"), parece ser mais o de que, afinal, o pai descubra que ele não tem tocado. Mas o desfecho da cena é ainda mais desconcertante. Do alto de sua autoridade e de sua condição de pai, ele dirá que mais difícil que tocar é ouvir. A frase vem travestida de sabedoria, ensino, aconselhamento. Mas ela é, na verdade, prescritiva, autoritária, e impõe uma fórmula de conduta, um certo receituário de bom comportamento.

O pai, assim, reforça a condição de criança e de passividade do menino. O recado é claro: você ainda precisa ouvir muito antes de tocar. Ou: não adianta tocar se você ainda não sabe ouvir. Qualquer que seja a alternativa escolhida, a situação é de castração da vontade e da vocação do menino. Tiraram o choro da criança ou a criança do choro. $\mathrm{Ou}$ melhor, o pai, sentencioso e proverbial, o impediu de tocar, conservando ainda a ambiguidade sobre o próprio comportamento, apresentando-se a um só tempo como protetor e incentivador do filho, acolhedor e conselheiro, mas assertivo e inibidor.

Esta passagem é importante também na estrutura do texto. A cena fecha uma seção do conto, que daqui em diante irá, de um lado, concentrar-se na descrição da personalidade paterna e no progressivo afastamento do menino das rodas de choro. Assim conta o narrador - sem muitos detalhes, porém - como desvencilhou-se da armadilha em que o choro o prendia: escolheu a escrita. Ou, antes, foi escolhido por ela. "Caí para as escritas" é a formulação que traduz a escolha para a literatura, indicando que a escolha teve algo de involuntário, de inércia, de acidental, de acaso, de algo independente da vontade do próprio escritor.

${ }^{132}$ Dedo-duro, p. 97. 
Sobre a época do choro, que colocou o menino num impasse, e o temperamento temeroso de João Antônio, diz Rodrigo Lacerda:

Essa resignação, essa capacidade precoce de abrir mão de um desejo tão forte, em nome da paz doméstica, ao que tudo indica, nasceu de um temperamento temeroso, bastante sufocado pelas autoridades de pai e mãe. O amor platônico que, passivamente, da platéia das rodas de choro, manteve durante alguns anos com o cavaquinho, mostra seu poder de resistência silenciosa. Assim como o pai, João Antônio, criança, era de poucas falas. "Ninguém dava nada pelo João" - conta o irmão Virgínio, - "ele não falava, só ouvia. João Antônio sentava nos lugares e ficava quieto, sempre foi assim."133

O impasse, ou como dirá o narrador, o "nó" em que a vida dele se encontrava — a indecisão entre desagradar a mãe ou o pai — irá se desfazer aos poucos, à medida que o menino se torna rapaz e encontra na escrita um mundo que permite substituir o choro e desfazer o nó.

Não toco no correr da semana. Nas tardes e noites de folga, sigo papai. Estou numa prensa, entalado e bem. O pai me quer enlaçando o instrumento, a mãe me esconde o bandolim.

Boca presa, boca de mocó. Não entregarei mamãe. Que, se o pai descobre, haverá frege. Ficará fulo, tiririca, um bicho, desandará.

Guardarei com jeito, até onde eu puder, na tranca e no enruste. Esconderei dos dois, não desconfiarei. A ciumada da mãe e o ensino do velho não se trombariam. Mas a minha vida, aos nove anos, assim é um nó. ${ }^{134}$

O nó é a dificuldade de se desenredar de pai e mãe. Agradando a um, desagradava a outro. Aqui, na infância, o narrador não sabe como desfazer o nó. Mas o nó será desfeito: o menino deixará o choro de lado, agradando à mãe, e mantendo em suspenso a relação com o pai. Deixar o choro de lado (deixar de praticar as composições que ele aprendeu) significa, a princípio, evitar a boemia (satisfazendo a mãe) e permanecer um mero ouvinte de choro (agradando também ao pai, e adiando um embate com a autoridade paterna). Ainda assim, posteriormente o fio da vida de João Antônio voltará a enroscar, pois sabemos que a boemia (que a mãe queria evitar) e a opção pela literatura como alternativa ao ensino

\footnotetext{
${ }^{133}$ LACERDA, R. João Antônio: uma biografia literária, op.cit., p. 70-71.

${ }^{134}$ Dedo-duro, p. 92.
} 
e à predileção do pai (que o queria músico ou comerciante) serão as opções de João Antônio, restabelecendo um nó que o autor teria de desembaraçar outras vezes, pois essas escolhas, como veremos, o farão superar e recair no conflito edípico, que envolve a mãe e o pai, isto é, o amor pela mãe e a reverência e o ódio ao pai e o necessário redirecionamento desses sentimentos para deixar a infância.

A escolha será pela literatura. Essa saída do impasse - esse desembaraçar do nó — , ainda que desafiadora, porque imprevista, preserva entretanto certo grau de passividade, como dissemos. "Caí para as escritas" é a construção que indicará a substituição da vocação da música para a literatura, como se a afirmação de uma escolha própria estivesse impedida para este menino fascinado e oprimido pelas figuras parentais. ${ }^{135}$

A "queda" para as escritas revela que aos olhos deste narrador adulto houve um rebaixamento e um desvirtuamento de sua vocação. A escolha pela música (e ainda mais por uma música refinada como o choro) seria a opção elevada e correta. A opção pela literatura vista como uma queda sugere também o caráter pecaminoso desta escolha, uma espécie de expulsão do paraíso, perda da inocência, que marca a passagem da infância para a juventude, da ingenuidade para a boemia, do choro ao samba, da assistência (da época do choro) à ação (a carreira literária e seus feitos, suas "glórias"). Assim, apesar do caráter inferior e pecaminoso da escolha da escrita, trata-se, aos olhos desse narrador, de uma queda bem-vinda e bem sucedida, de uma queda para o alto, já que o rapaz tornou-se homem feito, boêmio e escritor de sucesso.

Nesta altura, entretanto, ainda subsiste certa hesitação entre os dois momentos. A passividade e a introspecção serão atribuídas sobretudo à forte presença do pai, que inclui o

\footnotetext{
${ }^{135}$ Rodrigo Lacerda destaca que o próprio João Antônio acreditava que sua verdadeira vocação fosse a música: "Talvez eu seja uma vocação espúria de escritor. Quem sabe não passe de um músico frustrado, de quem afastaram os instrumentos na primeira infância. (...) Ele [o pai] me colocou um instrumento musical na mão logo aos oito anos de idade: um bandolim. E eu cheguei a tirar de ouvido, sem saber uma nota, alguns trechos de choros difíceis como o Apanhei-te cavaquinho. A minha formação musical é incrível pois, embora seja urbana, eu convivia com grandes músicos, como Garoto e João Pernambuco. Possuo ouvido musical apurado, a ponto de fazer observações profundas em termos de musicalidade. Quem me afastou da música foi o senso protetor de minha mãe que jamais pôde compreender a viabilidade prática da profissão musical. Achava ela que os músicos eram, em geral, dissimuladores e que se valiam do fato musical para acobertar suas farras, porres, boêmias, e, principalmente, pluralidade de mulheres. E, assim, em nome de um valor no qual eu nunca acreditei, ou seja, a monogamia - para ambos os sexos -, acabei desembocando na literatura. Caí na literatura, que parece ter, após um amor que já dura mais de vinte anos, todos os ingredientes do risco e da paixão que tanto me fascinam. Mal sabia minha mãe que se eu me tivesse dedicado à música popular, hoje seria um homem talvez melhor situado, em termo de status, do que é geralmente o escritor no Brasil'." Depoimento de João Antônio em STEEn, Edla Van. Viver e escrever. Porto Alegre: L\&PM, 1981. Apud LACERDA, R. João Antônio: uma biografia literária. op.cit, pp. 71-72.
} 
menino no universo boêmio dos chorões mas ao mesmo tempo o mantém na condição de ouvinte, como se denota pela declaração tachativa e paralisante do pai: "Gosta de tocar? (...) Ouvir é mais difícil". Revestido de pretensa sabedoria, o conselho, na verdade, é inibidor. Ainda mais quando se sabe que o menino, além de querer $e$ estar impedido de imitar o pai (por conta da idade, sublinhada e até diminuída pela chupeta, e por conta da condição de ouvinte, imposta pelo pai e pelos chorões mais velhos), não quer contrariar a mãe, evitando pegar nos instrumentos. Resultado: se ele já evitava "relar" no bandolim, para não desagradar à mãe, aos poucos o envolvimento com o choro — intenso mas marcado pela passividade da escuta - irá arrefecer, em consequência, provavelmente, desta cena em que o pai exerce toda a sua autoridade, de pai e de chorão, para dizer ao menino, por vias tortuosas e em tom impositivo, que a ele é melhor ouvir do que tocar, isto é, melhor permanecer na condição de filho submisso.

O pai, como lembra Rodrigo Lacerda, citando depoimento do próprio João Antônio, também cumpriu papel decisivo na passagem da música para a literatura:

(...) comecei a descobrir o gosto pela leitura porque meu pai, por medo que eu lesse coisas que não prestassem, quando me via lendo alguma coisa, mandava que eu lesse em voz alta; então comecei a perceber que aquilo tinha um ritmo; comecei a perceber que tinha frases que, por melhor que eu lesse, não davam aquela melodia, aquele ritmo. Acho que aprendi literatura muito por ouvido, de tanto ler em voz alta. ${ }^{136}$

A partir da cena em que o pai surpreende o filho tocando o instrumento de cordas e o reprime, o conto praticamente deixará o choro para trás. As seções seguintes, umas curtas, outras longas, concentram-se na personalidade do pai e, progressivamente, na passagem do tempo de menino para o tempo de rapaz.

As páginas dedicadas ao pai caracterizam uma personalidade forte, que exerce fascínio sobre o narrador quando menino:

De comum, seu ensino me batia de modo curto e pontudo:

— As mulheres são criaturas do sexo feminino.

\footnotetext{
136 Depoimento de João Antônio. In: RICCIARDI, Giovanni. Escrever. Libreria Universitaria de Bari, 1988. apud LACERDA, R., op.cit., p. 72.
} 
Vivo, falador, atiçado. Isso, com o bandolim contra o peito. Fora das rodas do chorinho, descaía, amuava para dentro de si. Então, sério como um sapato. ${ }^{137}$

O pai é referência de "ensino", um ensino que inquieta, intriga, cutuca o menino por ser "curto" e "pontudo". Homem "vivo, falador, atiçado" quando no ambiente da música, com seu instrumento junto ao peito. Sem ele, ficava "sério como um sapato". Como dirá o narrador, o pai era "homem de poucas falas", "medidor", calado. Volta a aparecer aqui a característica tão marcada em João Antônio Ferreira, o espírito proverbial e pedagógico do pai, relembrado também pelo irmão do escritor, Virgínio: "Meu pai tinha um relacionamento com a gente em que tudo era ensinamento, tudo o que ele fazia conosco era proposital, para que aprendêssemos alguma coisa. Às vezes deixava de ensinar que era para descobrirmos, deixava inclusive de falar. Falava até a metade, por parábolas". ${ }^{138}$

Para a imagem que o narrador tem do pai, a relação com as mulheres merece atenção. Às mulheres, "não dava trela". Com elas era "silencioso" e "cordato", mas também irritadiço. Ao "falatório" das mulheres, diz o narrador, ele reagia com mais uma de suas tiradas curtas: “- Santa ignorância!”. Ou quando saía do sério e se aborrecia a ponto de não "suportar" mais, o pai apelava para um xingamento, travestido de tratamento pitoresco, que evidencia o desprezo pelas "criaturas do sexo feminino": "—-São todas umas catarinas, pafúncias e hermengardas".

Como se vê, era profunda no menino a impressão de que o pai era um homem rígido e até ríspido, grave, sentencioso e severo. Mas não era apenas com ele próprio, o filho, que o pai se comportava dessa maneira. Era assim também com as mulheres. Uma das seções do conto, intitulada "Imprescindível", descreve o comportamento ressabiado, austero e recolhido do pai quando se formava a roda de homens, que falavam de futebol e de mulheres. Era quando "os machos remoçavam das canseiras da vida e uma alegria nova corria", 139 quando os homens, moços e velhos, reunidos, bebendo cachaça, jogavam prosa fora e se dedicavam a fantasiar "qualidades exuberantes": "Havia pernas, havia rabos e havia peitarias multiplicando atenção". Os homens falavam da zona ("trepar família, aquilo na zona era melhor bem”), falavam mal da sogra (“caricatura azeda, feiosa, desengonço"),

\footnotetext{
${ }^{137}$ Dedo-duro, p. 98.

${ }^{138} \mathrm{O}$ depoimento de Virgínio está em LACERDA, R. João Antônio: uma biografia literária, op.cit., p. 62.

${ }^{139}$ Dedo-duro, p.101
} 
contavam "casos de corneação". O pai, segundo o narrador, sempre quieto. Até que alguém o provocava e ele, mais uma vez, saía com uma de suas tiradas proverbiais: “- O que dói não é dar dinheiro às putas. É elas nos chamarem de meu bem”. Ou, então, com a sentença a que o título desta seção do conto se refere: “- Mulher é imprescindível”.

Com essa reafirmação da personalidade austera, severa e sentenciosa do pai se confirma a noção profunda de ambiguidade com que o menino se relacionava com a figura paterna: mistura de medo e fascínio, respeito e admiração, exemplo e incógnita, incentivo e interdição. Mas apesar da dualidade com que o pai é visto e retratado, a conclusão sobre sua influência, pelo menos na elocução do narrador, é positiva. O narrador voltará a reafirmar a importância do aprendizado que a personalidade e as atitudes do pai lhe forneceram.

Curiosamente, no entanto, o "ensino" do pai é também aquilo que o fez tomar gosto pelo oposto de seu modelo: a brincadeira. Diz o narrador, afinal anunciando a passagem da música para a literatura: "Desses ensinos, outro me ficou, bulindo, cedo —um homem que não sabe brincar vai morto no mundo. E como não brincava no bandolim, dei para outro arremedo. Caí para as escritas. Melhor, pior? Haverei de saber. Sei, é diferente."140 Aqui o ensino do pai concentra as contradições no campo da brincadeira: o pai severo ensina que é preciso brincar. Mas a brincadeira do pai é no bandolim, brincadeira que estava justamente interditada ao menino, tanto pelo pai quanto pela mãe. O pai que ensina e apresenta a brincadeira do choro é o mesmo que reprime e interdita. Assim, a caída para as escritas é acaso, mas também opção "rebaixada", "pecaminosa" e solitária, o que permite ao rapaz uma saída pessoal, desfazer o nó em que sua vida se encontrava.

A passagem da meninice para a juventude será marcada, mais uma vez, pela retomada dos "ensinos" do pai e pela relação entre pai e filho. O texto traz duas indicações de idade. Antes, quando imerso no mundo do choro, menino de nove anos. Depois, quando “cai paras escritas", adolescente de dezesseis. Mas essa passagem não é apenas indicada pelas duas idades. Há também mudança significativa de comportamento, que vai da passividade e da contemplação respeitosa ao pai para a ousadia, o desprendimento e, afinal, o desafio e a superação da figura paterna.

No desenvolvimento do conto, o narrador entra, a partir daqui, em sua fase francamente literária, deixando para trás o mundo do choro. Esta nova fase descreve a

${ }^{140}$ Dedo-duro, p. 103. 
iniciação do narrador na literatura e na vida boêmia, não mais em companhia do pai e como simples ouvinte, mas agora solitário, individualizado e protagonista da própria boemia. Destacaremos algumas passagens do conto em que o narrador associa literatura, boemia e a sua própria emancipação. Para esta análise, voltaremos nossa atenção para a questão do nome e da profissão.

\section{Iniciação literária}

$\mathrm{Na}$ sequência do texto, quando conta dezesseis anos, o narrador relembra os primeiros empregos, de início como estafeta ou office-boy na refinaria de óleo Anderson Clayton, depois como escriturário do frigorífico Armour. ${ }^{141}$ Trabalhava de dia e frequentava a escola noturna. Voltava para casa, agora não mais no Beco da Onça, mas na Vila Anastácio, e parava para beber nos botequins e nas "bibocas" do bairro suburbano. Relembra a primeira relação sexual, a vida na "zona" do Bom Retiro, entre as ruas Itaboca (hoje Professor Cesare Lombroso) e dos Aimorés. Aparecem também as primeiras incursões na sinuca, breve alusão ao tempo em que serviu ao Exército e ao tempo em que estudou teatro no Arena, com Eugenio Kusnet.

Importante também é o tempo em que frequentou a Liberdade e se apaixonou por uma nissei, "mulher do amigo", história que lhe rendeu um conto. A alusão se faz claramente a "Fujie", conto do primeiro livro, que o narrador aqui chama de o conto "da japonesa", o primeiro que escreveu, depois de "Um preso" — este, um texto nunca publicado em livro e pelo qual não mostra apreço ("Digo que defequei aquilo, a que chamei conto").

O despertar para a literatura e os primeiros sucessos, incluindo algumas publicações, ganham no conto um tratamento vago. Já vimos que o narrador diz ter caído para as escritas. Ele usará a expressão uma vez mais, depois de descrever o gosto por rodar a

\footnotetext{
${ }^{141}$ Segundo Rodrigo Lacerda, João Antônio começou a trabalhar aos treze anos, logo depois da falência do pai em um negócio feito com dois sócios: a administração de uma pedreira em Pirituba. João Antônio, pai, teria sido trapaceado pelos sócios. Ainda segundo Lacerda, os credores lhe arrumaram na Vila Anastácio um lugar para instalar um comércio. Foi assim que a família se instalou na casa da rua dos Botocudos e o pai abriu o bar Gambrinus, na rua Conselheiro Ribas. O emprego de João Antônio na Anderson Clayton, segundo depoimento do irmão Virgínio a Rodrigo Lacerda, foi conseguido pela mãe. LACERDA, R. op.cit., pp. 76-80.
} 
cidade de bicicleta, até Moema, onde ficava a sede de um "jornalzinho infanto-juvenil”, $O$ Crisol. ${ }^{142}$ Diz o narrador:

De um lado a outro da cidade pedalando a minha magrela, chispa, trim-trim, firme envergo o lombo do selim para o cano, ganho, são duas horas voadas no selim, a redação do jornalzinho infanto-juvenil, num quartinho de fundos de uma casa em Moema, na Avenida Juriti, onde começo a escrever. Ou antes, a exortar, em patriotadas, a elevação das honras de heróis no fragor de batalhas que nem entendo. Mas imagino.

- Malandrando os seus dias.

Disso caí para as escritas. Destrambelhei-me no gosto pelas palavras e que me lembre, havia uma, lá longe, nos tempos em que lia gibi, minha primeira criação: mononstro.(...)

O teor dessa passagem ainda é francamente jovial. O próprio jornalzinho é "infantojuvenil”, e a corrida de bicicleta ganha sonoridade onomatopaica. A fala, que é da avó Nair, já aparecera anteriormente e retorna para marcar a malandragem despreocupada e destrambelhada dessa fase, em que o gibi era a leitura predileta e a primeira "criação" é uma palavra inexistente, um neologismo ligado ao universo juvenil dos quadrinhos. E, de novo, a expressão confirma algo de casual, de acaso, na escolha pela literatura: "Disso caí para as escritas".

Da época do Crisol, ficaram o gosto pelos quadrinhos, pelos álbuns de figurinhas, por Monteiro Lobato, a descoberta dos primeiros dicionários e, provavelmente, um dos primeiros livros lidos pelo autor, com fábulas de Esopo, que ganhou como recompensa pelas colaborações no jornal. ${ }^{143}$

Vale a pena comentar mais detidamente dois aspectos potencialmente transformadores da travessia da infância para a juventude, envolvendo o filho e o pai, que mobilizam o narrador e levam a narrativa adiante: a capacidade de explodir e de ganhar nome.

\footnotetext{
${ }^{142}$ Trata-se do jornal $O$ Crisol, dirigido por Homero Mazaré Brum, gaúcho de São Sepé, como registra Rodrigo Lacerda (2006, p. 72). Segundo Mylton Severiano (2005, p.82), o autor fez sua estreia literária nas páginas desse jornal em 1950.

${ }^{143}$ O próprio João Antônio diz que Esopo foi fundamental na sua iniciação como leitor: "Esse livro teve uma influência fundamental na minha primeira dentição literária. Eu me apaixonava pelo escravo frígio e tartamudo que tinha duas obsessões: a liberdade e a justiça. Era tão brilhante nessa perseguição, que acabou jogado num abismo. Essa tragicidade da história de Esopo mexeu fundamentalmente comigo e terminei a leitura apaixonado e revoltado". Depoimento de João Antônio. In: STEEn, Edla Van. Viver e escrever, Porto Alegre, LP\&M, 1981. Apud LACERDA, R. op.cit., pp. 74-75.
} 
A contenção do narrador quando criança, tempo em que ainda não pode se afirmar, é expressa por meio da recorrência da negação, utilizando vocábulos de forte conotação negativa ou introspectiva, como "enruste”, “espia”, "íntima”, “escondida", "derrubada”, "desconfiar", "represando".

Além disso, especialmente, o verbo "explodir" vem a ocorrer mais duas vezes nesta altura do conto, retomando o início do texto, em que o narrador diz: à noite "expludo". Depois, voltará a dizer o narrador que, no choro, a "birra" nunca "explode". O verbo reaparecerá também, em negativo, para caracterizar o pai: ao comentar a personalidade desconfiada, introvertida, rígida do pai, o narrador diz que ele parecia "explodir por dentro":

Difícil alguém desentranhar ou pilhar, ao acaso, ainda que de passagem, opinião sua. Quem o buscasse, atirando um lero para colher coisa concreta, sairia de mãos abanando. Tempo e tempo, ouvia quieto, medidor. Uma ruga na testa e ironia desconfiada, parada nos olhos. No canto da boca fechada. Prosa não interessando, se aquietava mais. Aquela conversa fiada o punha abespinhado. Ou calmo? Sei lá. Parecia mais de explodir por dentro. Avançava e não abria a guarda. Aí o freguês vacilava, pejado, tropeçando, perdia a margem de manobra, vacilão. Desencorajado, desguiava. Papai, nenhuma palavra, plantado, teimosamente. Mas em posição de cobrança. ${ }^{144}$

O pai parece explodir "por dentro", assim como no choro, as rivalidades, as rixas, as birras tomam corpo sem explodir. Portanto, aquele "expludo" do começo do texto, que se refere ao tempo do narrador adulto, indica uma diferença forte entre a época do choro, na infância, e entre o narrador adulto e o pai. O narrador, agora adulto, é capaz de explodir, deixando para trás o tempo do choro, de introspecção, introversão, espia, escuta, enruste. Da mesma forma, o "expludo" marca a diferença entre o narrador e o pai, aqui caracterizado como alguém que explode, mas por dentro.

O tempo do choro também ensinou ao menino que leva tempo para um chorão ganhar nome. Já vimos o trecho em que o narrador observa: “A derrubada do choro faz com que, só depois dos vinte e cinco, trinta anos um nome de chorão comece a correr as rodas e se imponha considerado, temido, conhecido de longe".

\footnotetext{
${ }^{144}$ Dedo-duro, p. 98.
} 
Ganhar nome poderia ser apenas sinônimo de fama, mas sabemos que, no caso deste narrador, a questão do nome não é apenas uma simples questão de ser conhecido ou reconhecido. O conto se chama "PMCMS", um nome escolhido pelo narrador, quando jovem, para assinar os contos que mandou para uma editora. Ou seja, houve uma escolha de um novo nome, quando da opção pela literatura.

Antes de vermos como o conto chega ao seu final, vale anotar mais algumas passagens em que o nome ganha destaque no conto.

Ao comentar o trabalho de office-boy ou estafeta na refinaria Anderson Clayton, o narrador observa:

Poucos conhecem este chão, estes cimentados e paralelepípedos das alamedas internas. Eu viro e mexo. Conheço-os melhor que o gerente geral. Sei-lhes o cheiro. Do escritório à funilaria, do tratamento de oxigênio à litografia-transporte, esta fábrica eu ando e ando e ando, quilômetros e magro, capa branca irrepreensível, asseado e cordato, quatro iniciais pretas no bolso externo de funcionário do escritório.

Convivo, me entendo, charlo com tudo quanto é pintor, funileiro, homem da sacaria e do transporte, pedreiro, almoxarife, guarda, apontador, ajudante, operário sem nenhuma qualificação, maioria salário mínimo, fresador, mecânico, motorista, caldeireiro e quando venho lá longe, muito papel dentro da pasta-sanfona, o pessoal se vira e me conhece o nome. Operário não é funcionário do escritório e, logo, me chama pelo prenome. Os do escritório pegaram manias com os gringos mandões. Uma é tratar pelo sobrenome. ${ }^{145}$

As quatro iniciais pretas no bolso são, presumivelmente, JAFF, de João Antônio Ferreira Filho. E a alegria do jovem estafeta é percorrer a fábrica e conviver com todos os operários e outros profissionais de baixo escalão. Ao contrário dos funcionários do escritório, que o tratam pelo sobrenome, como os estrangeiros, os operários o chamam pelo prenome. Se o uniforme do escritório traz as iniciais e os colegas de escritório o chamam pelo sobrenome - Ferreira, presume-se, ou Ferreira Filho —, a amizade com os operários lhe permite ser, apenas e simplesmente, o João, ou João Antônio.

A questão do nome nos devolve, obviamente à relação entre João Antônio e o pai. $\mathrm{O}$ futuro escritor, como se sabe, tinha o mesmo nome do pai. A diferença era apenas o Filho, ao final do João Antônio Ferreira. A preferência de João Antônio pelo tratamento informal,

${ }^{145}$ Dedo-duro, pp. 108-109. 
como aquele que lhe destinam os operários da fábrica, diferencia-o e o afasta do pai. Já a formalidade dos homens do escritório, herdada dos "gringos mandões", o mantém colado ao nome paterno.

A relação com o pai, que fora de tanto companheirismo na infância, ainda que marcada pelo medo, como se viu, ganha aos poucos contornos mais ásperos. À medida que o rapaz cresce, lança-se cada vez mais à "zona" e à bebida. Certo dia, conta o narrador, ficou até tarde no bar do Tico, em Vila Anastácio, jogando sinuca e bebendo. O juizado de menores baixou no lugar. A passagem culmina na reação do pai ao ocorrido e no atrito entre pai e filho:

(...) Pegaram-me com as duas mãos no taco. Os homens bem vestidos, investigadores, ternos brilhantes, asseio, brilhantina nos cabelos, mãos manicuradas, sapatos polidos. Fui dizendo que trabalhava na refinaria de óleo. Mandaram-me andar. E me correram:

- Você que volte aqui e a gente te esfria.

Levei nome de cadelo. Mas na manhã, minha coragem vira boato na boca das turmas. Sou comentado e engrandecido - vou limpo: não me borrei, medroso, à chegada da polícia. Homem. Mas quem pagou foi o dono do bar. Os homens da justa lhe recolheram as bolas, trancaram as mesas, cataram o alvará, meteram-lhe multa de seiscentos cruzeiros.

O diz-que-diz bandeou tudo para o pé das orelhas do velho.

Os dois na mesa. Fechou o punho, crispou a cara quadrada, puxou um suspiro de boca fechada. Devia sofrer, devia estar cansado - e bem. Minhas derrapagens desandavam em repetição. Todo santo dia, pintando má notícia.

- Você tem todos os vícios que eu conheço e até os que eu não conheço.

Falou baixo e era como se urrasse. Pesava um azedume. Havia uma barreira, sei lá, uma diferença me arranhava o peito e me tangia. Por que eu agredia e agredia, sonso ou de cara, aquele homem? Um nada deste mundo e estávamos enfarruscados.

Estamos bem sós, eu percebo. Um estrago. Ele, vindo de mau negócio, rebordosa com uns sócios que o roubavam. Soprava um vento contrário naquela vida.

Sós, na mesa. E atirei:

— Ora, eu não sou tão genial assim.

Não se buliu, não me chapuletou a cara. Recolheu a hostilidade, a testa enrugou-se e os olhos pequenos brilharam, antes de baixarem. Pendeu a cabeça para o prato e comeu até o último. Eu também sofria com aquilo e não podia dizer que me sentisse satisfeito. Mas arrostá-lo me dava força. Aí me deu o golpe e me entravou: 
— Eu já lhe dei categoria de adulto. ${ }^{146}$

O fato de o pai precisar relembrar ou avisar o filho de que já the havia dado categoria de adulto significa que conceder categoria de adulto ao filho é insuficiente. $\mathrm{O}$ sentido da via de crescimento mostra-se, assim, claramente invertido. Não adianta o pai considerar o filho adulto. E o narrador parece saber disso: sabe que será ele quem precisará dar a si mesmo categoria de adulto. E isso só é possível, no que concerne à relação entre pai e filho, por meio do enfrentamento que o filho promove ao pai. O narrador se pergunta por que agredia o pai. Ainda que não saiba por que precisa "agredir" o pai, ele retém o mais importante: "Estamos bem sós, eu percebo". A necessidade de agressão, na relação pai e filho, relaciona-se à necessidade de individuação. Na narrativa do filho, a individualidade ganha acento de solidão, o que dá relevo mais uma vez à vida de ave noturna, mas também se comunica com a atividade literária, sempre em contraponto à música. Escritor escreve sozinho, não precisa de roda de choro.

É preciso enfrentar e derrotar o pai, ultrapassando-o. É preciso matar o pai. Isto é, metaforicamente falando. E apesar de o pai (em sua própria visão, de pai) já o considerar adulto, é isso, matar o pai, que faz o filho, respondendo a ele e o desafiando, como se viu acima, mas também no golpe desferido sorrateiramente, ao adotar o pseudônimo: Paulo Melado do Chapéu Mangueira Serralha. E depois o nome artístico: não João Antônio Ferreira Filho, mas apenas João Antônio, sem mais, sobrenome paterno amputado. ${ }^{147}$

$\mathrm{O}$ enfrentamento da figura paterna precipita o desenrolar narrativo que vai culminar na passagem que narra a revelação do pseudônimo que dá título ao conto. Depois da cena da discussão com o pai, o narrador ainda fará mais considerações sobre o pai e a mãe, chamando a atenção para o momento de dificuldades enfrentado pelo casal: "O pai pelejava e se batia, os nervos estalavam. Mamãe sofria e ia pra luta, se botava ao lado dele, dentro do balcão. Ali, mexendo-se como formiguinhas insistentes, aturando bêbados, gringos e

\footnotetext{
${ }^{146}$ Dedo-duro, pp. 118-119.

${ }^{147}$ Segundo Rodrigo Lacerda, a iniciativa de encurtar o nome, adotando o nome artístico de João Antônio, foi sugerida ao autor por Ricardo Ramos e Mário da Silva Brito: “Até 1958, João Antônio assinava suas publicações com o nome completo, ou seja, João Antônio Ferreira Filho. Mas, já em 1959, ele diria: 'Costumo assinar João Antônio nos meus contos. Foi o Mário da Silva Brito e foi o Ricardo Ramos, quem me puseram na cabeça: meu nome é muito comprido e não haveria cristão que o retesse (sic) guardasse. Bem. Fiquei sendo João Antônio (...)"'. O trecho citado por Rodrigo Lacerda é do próprio João Antônio, em carta de $1^{\circ}$ set. 1959 a Ilka Brunhilde Laurito. Apud. LACERDA, R. op.cit., p.182.
} 
ralados pelos credores, os dois começavam a envelhecer". ${ }^{148}$ A cena do embate com o pai resulta em novo status ao jovem desregrado. Agora, ele sente os pais envelhecerem, um primeiro sinal de que, afinal, ele os ultrapassa, adquirindo, ao mesmo tempo, certa culpa por tê-los desafiado e confrontado.

A nova seção que se inicia, a penúltima do texto, leva o mesmo título do conto: "Paulo Melado do Chapéu Mangueira Serralha”. O conto avança para o tempo do Exército e para as descobertas literárias mais maduras: Graciliano ${ }^{149}$, Gorki, Jack London, Zola, Steinbeck, Hemingway, Eça de Queiroz, entre outros. É aqui também que o narrador irá falar de sua paixão pelos contos, paixão que lhe parecia ter nascido antes do seu próprio nascimento. É nesta seção que ele vai relembrar a dificuldade de publicar "a história da japonesa". Foi com este conto, porém, diz o narrador do texto, que "chamei a atenção dos homens e um deles, Marques Rebelo, fez nascer a expressão clássico velhaco e que hoje anda aí, em meu nome, pelos jornais, pelas revistas e até pela televisão". 150

A publicação de "Fujie", ou melhor, a publicação "da história da japonesa", como diz o narrador, lhe deu nome e, mais que isso, lhe rendeu um epíteto, "clássico velhaco", que segundo ele, depois de cerca de vinte anos, ainda corre em jornais, revistas e até na TV. O início da carreira de escritor, portanto, marcou definitivamente a carreira deste narradorescritor, cujo nome - João Antônio, já sem a ligação filial com o sr. Ferreira - e epíteto correm a grande imprensa, a mídia, fazendo sua fama.

Não se sabe em que ano aconteceu a famosa visita dos editores da Civilização Brasileira à casa da família Ferreira em Vila Anastácio. No conto, o episódio não vem claramente datado: registra-se o dia e o mês, mas não o ano. O fato é que a visita dos homens bem vestidos, ali chegados em um carro importado, ecoa, no conto, um outro grupo de homens bem vestidos, revestidos de autoridade. A visita dos editores liga-se, na narrativa, ao episódio, descrito antes, em que o narrador foi surpreendido pela polícia no botequim e que precipitou a cena de enfrentamento entre pai e filho.

\footnotetext{
${ }^{148}$ Dedo-duro, p.120.

149 De todos esses, Graciliano Ramos é o autor mais importante para o texto em questão. Logo no início do conto, o narrador conta um episódio relacionado à obra do escritor: ele viu uma palestra em que um estudioso falava de Graciliano de maneira pernóstica e vazia, segundo avaliação dele próprio, narrador. A valorização da influência de Graciliano em sua obra, relaciona-se, aqui, ainda que implicitamente, também ao fato de que, um dos homens engravatados que visitaram a casa da família Ferreira atrás de Paulo Melado era Ricardo Ramos, filho de Graciliano, e então editor da Civilização Brasileira.

${ }^{150}$ Dedo-duro, pp. 127-8.
} 
Ressabiado e prevenido pela fama do filho boêmio, o pai supõe que seja novamente a polícia, agora à procura do filho desregrado, mas um filho que curiosamente atende por outro nome, que o pai, entretanto, reconhece. Vejamos como a cena é narrada:

Esbornear, escrever, continuar. Um dia, mandei com pseudônimo maroto e lírico carta ao Rio pedindo publicação de meus contos. E segui, tocando a vida. Que não há nada para ser tocada quanto a vida, e se você está fora dos ambientes como é que vai ver a festa do mundo?

Era um sábado, era um sol, era um dia 28 de setembro. E, claro, eu bebera na sexta-feira da semana inglesa. Ressaca na boca e nas pernas. Os olhos miúdos e inchados, a cara enorme. Provavelmente precisaria de óculos escuros para enfrentar a luz do dia.

Esponjei-me na soleira do quarto. Naquele momento, o carro de quatro portas, americano e cinza do romancista freava na porta do bar. Desciam quatro homens, paletós e gravatas. Eles se chegavam para o balcão. A carta do Rio indicava o endereço do bar. Um deles falou o pseudônimo mais sestroso que já usei até hoje - Paulo Melado do Chapéu Mangueira Serralha.

-É aqui que mora o senhor...?

Meu pai abaixou a cabeça. Atarracado, triste, português envergonhado:

— Sim. Os senhores são da polícia? ${ }^{151}$

Finalmente, o leitor é apresentado a Paulo Melado do Chapéu Mangueira Serralha. O final do conto nos apresenta, como leitores, a uma identidade deste narrador, que até então não havia sido nomeado. No domínio estrito do texto, o narrador agora ganha nome, o que retoma o tema da fama e da autoridade, do status de virilidade e emancipação, que já havia sido anunciado nas páginas sobre o choro.

Como não podemos, ao mesmo tempo, esquecer que se trata, afinal, de um texto autobiográfico, a ligação com o nome de João Antônio também é imediata. O narrador, que já havia anunciado discretamente o próprio nome, ao falar das iniciais no uniforme da fábrica, agora assume outro nome, um "pseudônimo maroto e lírico", com que pretende ganhar a atenção para os seus contos.

${ }^{151}$ Dedo-duro, p. 128. Sobressai aqui o enlevo do narrador, neste momento de glória precoce e de vitória sobre o pai, ao se referir à vida: "E segui, tocando a vida. Que não há nada para ser tocada quanto a vida, e se você está fora dos ambientes como é que vai ver a festa do mundo?". O mundo é uma festa, para este narrador que é um escritor consagrado e relembra seu momento de iniciação na carreira literária. Além disso, "não há nada para ser tocada quanto a vida". O otimismo e a crença na possibilidade de inserção ("fora dos ambientes" se perde a "festa do mundo") exprimem um desejo de inclusão e traem a alegria pela vida que se cumpre, em festa, musical (a vida "tocada"). O verbo empregado também é sugestivo: a ambiguidade de tocar (levar adiante, conduzir, mas também soar um instrumento musical) não deixa de ser irônica com a vocação musical dificultada e, depois, interditada, abortada pelo pai. 
$\mathrm{Na}$ narrativa, é curioso que o narrador descreva o momento em que os homens de paletó e gravata dirijam-se ao seu pai, e anunciem a ele o pseudônimo "maroto", "sestroso". O pai se mostra diminuído e temeroso, "triste, português envergonhado". Interessante é que o pai não titubeia ao responder que sim, é ali que mora o tal Paulo Melado do Chapéu Mangueira Serralha, inferindo que se trata do filho boêmio. O narrador sublinha no pai características que o diminuem e fragilizam: é atarracado e português, estrangeiro, isto é, está apequenado e fora de seus domínios. A caracterização contrasta com o aspecto malandro e agigantado do pseudônimo: Paulo Melado do Chapéu Mangueira Serralha.

O pai pergunta se os homens são da polícia, indicando que pressupõe que as atividades do filho podem levantar suspeita e infringir a lei. Mas a maneira com que este narrador descreve a cena confunde os papéis entre pai e filho. É o narrador que anuncia o pseudônimo. Mas na cena não se pronuncia o nome. Algum dos visitantes dirige uma pergunta que não está completamente formulada: “É aqui que mora o senhor...?”. O complemento à pergunta pode ter vindo antes - é o pseudônimo. A forma com que o narrador encadeia os acontecimento, no entanto, faz com que o complemento à frase fique apenas sugerido, envolvendo o pai diretamente na ação.

A descrição da cena termina aí, em suspenso. E o conto ainda terá uma última seção, curta, que comentaremos a seguir. Aqui, porém, é preciso dizer que, apesar de narrar a passagem de maneira indireta, subentendida, o narrador o faz com propósito certo. Ele narra o momento em que ganhou novo nome e esse novo status foi revelado de maneira consagradora, ao menos no âmbito de sua família nuclear.

O novo nome, que o tornou conhecido no Rio e o fez ser procurado, ali no "subúrbio mesquinho", por aqueles homens de paletó e gravata, por um "romancista" de carro "americano", é um trunfo para este narrador que "caiu" para as escritas. É a prova de que seu talento, que foi desviado da música para a literatura, sobreviveu e ganhou reconhecimento.

A cena, porém, é mais significativa que isso. Esta é a história do próprio João Antônio, em seus passos iniciais como escritor. Este é o episódio que marca, para o escritor, o momento de um primeiro reconhecimento literário e da possibilidade real de assumir um novo nome. 
Trata-se de um golpe, de um golpe violento e vitorioso, contra o pai. Este acontecimento revela que o rapaz desacreditado e desregrado, boêmio e inconsequente, que aos olhos do pai tem "todos os vícios" e é procurado pela polícia, na verdade é um escritor talentoso, capaz de ganhar novo nome e ser procurado não pela polícia, mas por profissionais da melhor casa editorial do país, a Civilização Brasileira.

O filho caiu para as escritas. Esta queda, anterior, agora virou ascensão. A vida boêmia, que pode levantar suspeitas policiais, revela-se não criminosa, mas frutífera e consagradora.

O filho golpeia o pai: sua identidade não é mais a de filho de João Antônio Ferreira. Ele, que se chama João Antônio Ferreira Filho, mostrou que pode muito bem trocar este nome de batismo por um pseudônimo "sestroso", "maroto" e "lírico". Em vez de João Antônio Ferreira Filho, pode ser Paulo Melado do Chapéu Mangueira Serralha.

Para além do impacto que a visita deve ter causado na família, nos parentes e na vizinhança, a construção literária que o narrador engendra no conto, sublinha a vitória do filho sobre o pai. E a vitória definitiva está implícita, ela não é enunciada no conto porque não precisa ser enunciada, já que está pressuposta, eloquente, na capa do livro. Além de Paulo Melado do Chapéu Mangueira Serralha, o jovem aspirante a escritor vai adotar, não um pseudônimo, mas um nome artístico: João Antônio.

Ao final, o leitor é apresentado a Paulo Melado do Chapéu Mangueira Serralha. O pseudônimo. Mas como o leitor permanece ligado ao autor pelo pacto autobiográfico, ele é devolvido à identidade do João Antônio escritor, que assina o conto, ou, antes, assina o livro, com seu nome artístico impresso na capa.

Entretanto, além de, mais uma vez, destacarmos que a revelação do pseudônimo, nas circunstâncias em que se deu, marca uma vitória do filho sobre o pai, é preciso reconhecer que a maneira com que o escritor narra sua mudança de nome - sem chegar a narrar a mudança de nome mais definitiva, a de João Antônio Ferreira Filho para João Antônio - também aponta para um certo temor deste gesto de suplantação do pai, no âmbito da ação narrada. É como se a figura paterna ainda fosse capaz, no entrecho do conto, de limitar, castrar, impor limites. 
Fora dele, no âmbito da biografia de João Antônio, porém, sabemos que o golpe foi certeiro. O primeiro livro seria publicado, com o nome artístico que omite o sobrenome, "Ferreira", e sem o "Filho", que ligam o Ferreira mais novo ao velho Ferreira.

O conto não conta o lançamento e o começo da carreira do escritor João Antônio. O conto, em verdade, não é um conto sobre o escritor João Antônio, apesar de sê-lo. Em essência, ele é um conto sobre o enfrentamento e o distanciamento do filho em relação ao pai.

O desfecho deixa isso mais claro. Da revelação do pseudônimo, passa-se, na última seção, com uma grande elipse, ao momento atual do narrador, aquele mesmo do começo do texto, em que ele já é autor consagrado.

A seção final do conto chama-se: "Nenhuma virtude, nenhuma: Bagdá".

Curta, não mais de uma página, a seção conta como o narrador descobriu uma expressão que traduz o seu tempo de rapaz. Finalmente, diz ele, encontrou-a "na Nairlândia, uma cidade só de marafonas, a maior zona do Brasil, no caminho para Apucarana, norte do Paraná". Ali, ele encontrou a definição de si próprio: "pilhei uma expressão querendo significar e valer assim: estar muito doido, à vontade; botar pra quebrar, deixar cair".

Diz o narrador, fechando o conto: “A expressão era e valia: Pra lá de Bagdá”.

Aquilo que o define, a expressão rematada que delineia a sua personalidade revela que a boemia, a liberdade e a despreocupação — um comportamento libertário, mas descrito em termos ambíguos, que apontam, no limite, para a irresponsabilidade ("botar pra quebrar, deixar cair”) — são as características que este narrador reivindica para si próprio.

Aqui, depois da grande elipse que marca a passagem do tempo de rapaz, da época em que era Paulo Melado, para o momento presente, retomando o início, o texto marca ainda a retomada do tom francamente confessional e autobiográfico. É João Antônio autornarrador-personagem quem retoma o fio narrativo para indicar que sua personalidade é a de um “doido", folgazão, inconsequente, boêmio ("pra lá de Bagdá”, recentemente, tornou-se também expressão que significa “estar bêbado” ou alterado, chapado, drogado). ${ }^{152}$

\footnotetext{
${ }^{152}$ Antônio Hohlfeldt intitula "Pra lá de Bagdá" a sua apresentação dos Melhores de contos de João Antônio. Segundo Hohlfeldt, João Antônio e seus personagens se parecem: "Também ele, à semelhança de suas personagens, está fora do esquema, vê-se obrigado, permanentemente, a uma luta corpo-a-corpo com a vida. Porque também ele, à semelhança de suas personagens, vive à margem, vive pra lá de Bagdá. Ele, como suas
} 
A oposição, aqui, mais uma vez, é com a mãe e o pai. Foi na zona, em uma cidade de "marafonas", que ele descobriu a expressão que o define. Era o que a mãe mais temia: que o filho caísse na vida boêmia, o que significava, é claro, trocá-la por outras mulheres. E João Antônio fez mais que isso. Não apenas conheceu outras mulheres, mas conheceu, como ele diz no texto, uma cidade inteiramente habitada por prostitutas. Em relação à autoridade paterna, a opção pelo pseudônimo sestroso e maroto, o nome artístico que amputa o sobrenome e a posição de "Filho" - essa espécie de castração às avessas —, e o sucesso literário, tão propalado no começo deste texto, tornaram possível a João Antônio enfrentar o pai e, afinal, vencê-lo. ${ }^{153}$ Uma castração para a potência, uma queda para a consagração.

O final de "Paulo Melado do Chapéu Mangueira Serralha" é enfático sobre a recusa de João Antônio em trilhar os passos do pai. O texto conta a história do pseudônimo, mas secretamente conta a história de como João Antônio Ferreira Filho se tornou João Antônio, escritor, boêmio, doido, beberrão, “à vontade”, "pra lá de Bagdá”. O contraste com a carreira de comerciante e com a personalidade severa, moralista, sentenciosa e autoritária do pai não podia ser maior.

\section{Abraçado ao próprio rancor}

É surpreendente ler "Abraçado ao meu rancor" depois da leitura de Lambões e de "PMCMS". Se nos primeiros dois textos, a ênfase era na infância e na juventude deste

personagens, são heróis e vítimas deste capitalismo selvagem que entre nós medra". HoHLFELDT, A. "Pra lá de Bagdá". In: ANTÔNIO. João. Os melhores contos. Sel. Antônio Hohlfeldt. São Paulo: Global, 1997, p. 14.

${ }^{153}$ Rodrigo Lacerda já chamara a atenção para a relação de conflito entre pai e filho, inclusive relacionando os desentendimentos à recusa de João Antônio, em seu tempo de rapaz, em seguir a mesma carreira do pai: "O fato do pai só ter se esforçado para corrigir os defeitos de comportamento de "Joãozinho" até o normal, como nos disse Virgínio, não se deve, aparentemente, a qualquer satisfação com os rumos do filho. Ele ter recebido "categoria de adulto" no início da adolescência significa que era precoce - intelectualmente, em sua mobilidade por toda São Paulo -, mas essa maturidade antecipada não era, aos olhos dos pais, a mais saudável. Continuava presente a frustração com a recusa do filho em trabalhar no comércio e agora ela se somava à impotência diante da vocação do filho para a boêmia. Uma outra hipótese seria um certo desalento em relação a sua própria concepção de mundo, após a falência da pedreira, em grande parte provocada por sua ingenuidade e incapacidade de se impor perante os sócios. Ou ainda a culpa por ter, indiretamente, contribuído para este gosto do filho pela malandragem. Afinal, vale notar que foi através do pai que João Antônio esboçou seus primeiros passos no mundo da música, e que esta lhe serviu, num primeiro momento, como ante-sala da malandragem da sinuca e, num segundo, da literatura. Irene, mãe do escritor, ao lhe tolher o gosto pelas rodas de samba, possivelmente deu um tiro que saiu pela culatra, jogando-o em uma dimensão mais radical da malandragem. (...)". LACERDA, R. op.cit. 2006, p. 93. 
narrador-escritor que se tornou João Antônio, agora a narrativa não é mais uma reconstituição memorialística de um tempo pessoal e comunitário; é um lamento das mudanças que ocorreram e que, justamente, fizeram desaparecer aquele tempo, ou melhor aqueles tempos: o da cidade, o da sociabilidade e o da juventude do narrador. É um retorno do momento da busca, como já assinalou Simone Paulino dos Santos. Segundo a autora, o percurso empreendido pelo narrador seria "tentativa de reconstituir na memória uma geografia íntima para sempre perdida". A busca seria aqui uma necessidade de "reaver" a cidade, necessidade que Simone Paulino liga à noção freudiana de melancolia:

A escolha do mesmo trajeto parece, portanto, determinada pelo anseio por alguma coisa perdida, tal qual ocorre nos estado de melancolia, pois o melancólico carrega consigo a experiência de uma perda afetiva e se sente incapacitado para 'escolher um novo objeto de amor', o que equivale dizer, escolher outro caminho para o seu desejo, rota diversa capaz de substituir o objeto de outrora, de forma a restituir-lhe o prazer de viver.

O objeto em questão não precisa ter morrido concretamente (conforme ocorre na situação de luto), basta apenas que tenha se perdido como objeto de amor para o sujeito - ainda que continue existindo - deixando uma marca de tristeza profunda pelo passado perdido e medo quanto ao futuro incerto. $^{154}$

A interpretação da autora é precisa. Trata-se de buscar algo que já não existe mais, mas diferentemente da inquietação inicial (a busca do conto "Busca", como veremos no capítulo 2). Trata-se agora de uma procura mais determinada, ainda que, de novo, abrangente e pouco clara: a necessidade de substituir os antigos objetos de desejo. Essa busca se mostra frustrada, pois os velhos objetos de desejo — os sambistas, os sinuqueiros, os lugares da boemia - estão perdidos, e tampouco há novos objetos à vista.

Se não há novos objetos de desejo, o narrador irá procurar os antigos. Se a cidade deu em outra, voltemos ao que restou da cidade antiga, a cidade da infância e da juventude. É por isso que, ao final, o narrador retorna a casa, onde residem seus objetos de desejo primordiais. Trata-se, portanto, de um conto sobre a busca, mas também um conto sobre a volta, sobre uma volta pela qual se anseia, mas que se frustra.

“Amr" é, assim como os dois textos anteriores lidos aqui, um texto sobre o passado e sobre a memória. A diferença decisiva, do ponto de vista formal, porém, é que neste conto

\footnotetext{
${ }^{154}$ SANTOS, S. Nas esquinas do desejo. op.cit., p. 158.
} 
a elocução e a ação narrada coincidem, isto é, narrador e narrativa se constituem em situação, e o desenvolvimento narrativo se dá à medida que o leitor avança na leitura, sem que se saiba, ao certo para onde, literalmente, caminha o narrador - e, por extensão, a narrativa. Não há, como havia nos textos anteriores, distanciamento entre narrativa e fato narrado. Esse aspecto faz com que o final do conto coincida com o final da ação narrada, nos moldes do que ocorre, de maneira análoga, ao final de "MPB", como veremos no capítulo 3.

Antes de entrar no cerne formal e na análise do sentido do conto, vale insistir que, mais uma vez, o caráter autobiográfico da narrativa vem carregado de ambiguidade. Tratase de um livro de contos (é o que indica a página de rosto e a ficha catalográfica da primeira edição do livro), em que, entretanto, o texto que dá nome ao volume é uma longa narrativa de teor autobiográfico (ainda que os textos de quarta capa e orelha não apontem para essa combinação ambígua de autobiografia e ficção). ${ }^{155}$ Os demais textos do livro, por outro lado, e confirmando a catalogação do volume, são em geral ficcionais. Alguns deles são protagonizados por Jacarandá, personagem-tipo criado pelo autor. Dos dez textos do livro, ele é o personagem principal de quatro: "Guardador", "Publicitário do ano", "Televisão" e "Sufoco". 156 Além desses contos, podem ser classificados como ficcionais "Maria de Jesus de Souza (Perfume de Gardênia)" e, talvez, "Eguns". Os demais — e ressalte-se que talvez seja o caso também deste último - são textos em que o narrador confunde-se com o próprio João Antônio, sem que isso, como de hábito, seja claramente formulado na elocução do conto.

Dito isso, vale retomar a leitura do conto, que começamos a esboçar no começo deste capítulo.

Já vimos como, em “Amr”, a figura paterna é chave para entender o sentimento de pesar do narrador pelas mudanças urbanas e sociais. A própria apreensão da cidade, na percepção do narrador, está colada à relação com o pai, como indica aquela construção, "minha cidade de meu pai", que já apontamos. E outras figuras familiares fortes, como a

\footnotetext{
${ }^{155}$ Nossa edição de referência é a primeira, da Editora Guanabara, de 1986. Os textos de orelha e quarta capa da edição mais recente (Cosac e Naify, 2001) tampouco fazem referência a essas ambiguidades: na quarta capa, há um trecho de Antonio Candido sobre o autor; na orelha, um texto que combina apresentação do autor e sua obra e cita o prefácio de Alfredo Bosi; na ficha catalográfica, nenhuma referência ao gênero dos textos.

${ }^{156}$ Os vários contos protagonizados por este personagem-tipo foram reunidos em ANTÔNIO, J. Um herói sem paradeiro. Vidão e agitos de Jacarandá, o poeta do momento. São Paulo: Atual, 1993.
} 
mãe, a avó e o avô paterno, serão lembrados no conto. A mãe, especialmente, exercerá função narrativa decisiva, como veremos.

Mas a consequência maior da estrutura formal que faz coincidir elocução e ação é que a galeria de personagens do conto pode ser reduzida a um: o próprio narrador. Sozinho, o narrador caminha, relembra, reflete e narra. Também ao contrário do que ocorrera nos contos autobiográficos anteriores, aqui a proximidade entre fato narrado e narrativa, entre experiência e elaboração do vivido, é reduzida ao mínimo.

Para os temas do conto, isso também traz consequências. Solidão, errância, memória e atuação no presente se desdobram nos campos temáticos abordados pelo narrador, quais sejam: sua individualidade e inserção no espaço urbano, as transformações da cidade e da sociabilidade, a opção profissional pelo jornalismo e o trabalho jornalístico em si mesmo, isto é, a reportagem que ele prepara enquanto caminha pela cidade e que é, afinal, o que motiva, a princípio, a escrita deste conto.

A escolha profissional, que já vinha ganhando corpo no texto autobiográfico anterior, assume em “Amr” o primeiro plano. A própria razão de ser do conto é motivada pela atuação profissional do protagonista, um jornalista incumbido de vir a São Paulo, cidade que detém o "recorde brasileiro de turismo de negócios", para cobrir um evento de promoção do turismo. No momento da escrita, o narrador diz que já está na cidade "faz cinco dias". Na noite anterior, compareceu a mais um dos eventos promocionais da campanha de divulgação turística, e acordou de ressaca. É assim que ele se lança a caminhar pela cidade, a princípio à procura do sambista desaparecido, Germano Matias. ${ }^{157}$ Lembra também, a certa altura do "pedreiro Valdemar", depois de ouvir um louco de rua pronunciar os versos de uma marcha carnavalesca. A busca por Germano Matias e a frase reincidente "- Você conhece o pedreiro Valdemar?" irão percorrer o texto. ${ }^{158}$

\footnotetext{
${ }^{157}$ Nascido em 1934, o sambista Germano Mathias cantou e dançou em 2009 no programa de televisão $S r$. Brasil, apresentado por Rolando Boldrin: www.youtube.com/watch?v=XFDLVAfuYuY. No ano seguinte, participou da Virada Cultural em São Paulo e foi objeto de reportagem da Folha de S. Paulo, que o visitou em sua casa, em um conjunto habitacional na Vila Brasilândia: http://www1.folha.uol.com.br/folha/ilustrada/ult90u694405.shtml. Uma biografia do sambista foi lançada em 2008: Sambexplícito: as vidas desvairadas de Germano Mathias, de Caio Silveira Ramos.

158 A canção que o narrador ouve na rua é a marchinha "Pedreiro Valdemar", de Wilson Batista: "Você conhece o pedreiro Valdemar?/ Não conhece?/ Mas eu vou lhe apresentar./ De madrugada toma o trem da circular,/ faz tanta casa e não tem casa pra morar./ Seu Valdemar é mestre do ofício,/ constrói o edifício/ e depois não pode entrar".
} 
Logo, porém, suas buscas se multiplicam: são os salões de sinuca do centro da cidade que não funcionam mais, os próprios sinuqueiros que não estão mais lá e a boemia como um todo que já não tem lugar, nos lugares em que ele, narrador, a experienciou. A busca se torna uma sucessão de lamentos por aquilo que era do apreço deste narrador e que desapareceu.

O narrador se distancia de sua tarefa imediata, que é escrever uma reportagem sobre São Paulo como polo turístico. Em outras palavras, melhor dizendo, ele está a trabalho e, o conto, ao mesmo tempo, é um retrato negativo deste mesmo trabalho. Trata-se de narrar a dificuldade e, talvez mesmo a impossibilidade deste narrador-escritor-jornalista executar a tarefa que lhe é confiada. Como diz Alfredo Bosi:

Na sinuca, na bola e no samba, negacear é preciso: arte de viver de um povo engodado por séculos mas que se diverte fingindo que vai mas não vai. Malícia sem maldade revela a inteligência da própria condição apurada no homem que sobrevive confiando apenas na destreza do pulo de cada dia.

Nesse corpo a corpo amoroso com os obstáculos do caminho não há, nem por um momento, uma reificação mercantil do tempo vital. Pelo contrário, o tempo continua a fluir subterrâneo, sem pressa, na alma do pobre que joga, que canta ou que dança. Felicidade que parece negada ao pequeno intelectual preso às cadeias do capital: o servo da propaganda, "esta dama loureira e senhoril" na palavra de Machado de Assis, o tarefeiro das empresas, o manipulador de signos por empreitada (vulgo free-lancer), o pesquisador de ocasião. Sobre todos recai a sátira crua do nosso Autor, que não poupa seu desdém nobremente plebeu por toda essa fauna agarrada aos meios de comunicação de massa, vampiros de idéias alheias, onanistas de frases de efeito, demagogos cujo verbo venal é quase uma fatalidade. $\mathrm{O}$ mercado de leitor consumista se entrega baboso a quem grita mais forte, aparece mais vezes e chega mais rápido. ${ }^{159}$

É exatamente com as lides traiçoeiras da comunicação de massa, do jornalismo e da publicidade que vai se deparar o narrador deste conto. Aqui, o contraponto inicial à escrita jornalística é a linguagem publicitária. À medida que caminha pela cidade, o narrador relembra alguns slogans que constam dos folhetos de divulgação da campanha oficial de promoção da cidade. Se o slogan é “Compre em São Paulo o que o mundo tem de melhor”, o narrador lembrará que os moradores de Presidente Altino, de Jaguaré, do Morro da Geada

\footnotetext{
${ }^{159}$ BosI, A. "Um boêmio entre duas cidades". Prefácio a ANTÔNIO, João. Abraçado ao meu rancor, Rio de Janeiro, Guanabara, 1986.
} 
"mal têm para comprar o arroz-e-feijão com que se tapeia". ${ }^{160}$ Há outros exemplos similares, contrastando a linguagem turística à realidade nua e crua que ele, narrador, conhece. Aos exemplos publicitários, ele contrapõe a sua própria visão, uma visão de dentro e não oficial, melancólica e "rancorosa".

Seria de se esperar que o jornalista empreendesse, afinal, uma recapitulação de elementos e fatos ligados à cidade que desmentissem a versão oficial (turística) sobre São Paulo. De certa forma, é o que ele faz, mas não o faz segundo uma orientação objetiva e jornalística, generalizadora, mas sim de acordo com suas experiências singulares e pessoais.

Em suma, o que deveria ter se tornado uma reportagem sobre a campanha de promoção do turismo em São Paulo resultou num conto, e num conto de feições específicas: autobiográfico, melancólico, saudosista, "rancoroso". As aspas em rancoroso ou em "rancor" se devem à indefinição deste sentimento, que merece exame mais detido. Voltaremos ao assunto. Por ora, lembre-se que o título faz referência a um tango, mencionado pelo narrador. Num trecho em que fala de seus "espetos íntimos" e das mudanças, para pior, pelas quais passou a cidade — cidade que é sua "comoção de antigamente" —,${ }^{161}$ ele alude ao tango que remete ao título do conto: "Sei lá, sei lá por quê. Estou me lembrando de uma letra de tangaço. Carregada. E em que o osso, o buraco e o nervo da coisa ficam mais embaixo. Diz, corta, rasga que me quero morrer abraçado ao meu rancor", 162

A letra do tango "Como abrazado a un rencor" fala de um homem moribundo que em seus últimos momento de vida dá ao mundo seu "testamento de palavras amargas". Diz querer morrer sozinho, e lamenta uma traição. Diz o refrão: "Yo quiero morir conmigo,/ sin confesión y sin Dios,/ crucificao en mis penas/ como abrazado a un rencor.// Nada le debo a la vida,/ nada le debo al amor:/ aquélla me dio amargura/ y el amor, una traición". ${ }^{163} \mathrm{Na}$ sequência, diz ele que não quer palavras de consolo nem perdão. Apenas a uma pessoa, à mãe, se fosse viva, ele daria o direito de acender velas, voltar o peito sobre sua "herege agonia", chorar sobre suas mãos e pedir-lhe o coração.

\footnotetext{
${ }^{160}$ Amr, p. 86.

${ }^{161}$ A "comoção de antigamente" evoca, sem que isso esteja enunciado, os versos de Mário de Andrade: "São Paulo!, comoção de minha vida...", do poema que abre Pauliceia desvairada, "Inspiração". 162 idem, p. 95.

163 A letra pode ser consultada e a composição pode ser ouvida no seguinte endereço: http://www.todotango.com/english/las_obras/letra.aspx?idletra=640. Último acesso em 26 jun. 2012.
} 
A letra do "tangaço", como diz o narrador, não é citada no conto. Mas a alusão a uma letra de tango reafirma o tom de lamento do texto. A solidão e o sofrimento vinham enunciados desde o título do conto, mesmo que desconhecêssemos a referência ao tango. O título alude a um abraço pesaroso e solitário. E o isolamento que se anuncia vem se confirmar na sequência do texto. O narrador não irá encontrar o sambista desaparecido e não irá travar contato com nenhum outro personagem - senão com a mãe, ao final do relato. A letra do tango, portanto, ressoa na narrativa para reafirmar a solidão e o balanço da vida de um sujeito sofredor, mas altivo.

Ocorre então que as experiências sobre a cidade se reduzem às experiências individuais do próprio narrador, às suas lembranças, sentimento e ações. É como se a cidade pudesse, afinal, ser reduzida à cidade que ele mesmo experienciou. É a "minha cidade de meu pai”, como ele dirá. E também à cidade que ele encena, percorre, em situação, no desenvolvimento do relato e da ação narrada.

No entanto, como o tom melancólico indica, esta é uma cidade que não se deixa reduzir, nem mesmo à experiência pessoal. O João Antônio narrador parece concluir que, além das transformações pelas quais a cidade passou, desfigurando a si própria e exilando alguns de seus personagens - como Germano Matias, que já não se sabe onde foi parar, e como os sinuqueiros anônimos, que se "esquinizaram" - , parece concluir que a cidade também, e talvez por isso mesmo, já não acolha as experiências dele próprio, nem as passadas, tampouco as atuais.

A cidade deu em outra.

Deu em outra cidade, como certos dias dão em cinzentos, de repente, num lance. As caras mudaram, muito jogador e sinuqueiro sumiu na poeira. Maioria grisalhou, degringolou, esquinizouse para longe, Deus saberá em que buraco fora das bocas-de-inferno em que eu os conheci. Ou a cidade os comeu.

Mas o espírito o mesmo. Dureza, rebordosa, de déu em déu, frio, tropel, sofrência, ô solidão de cimento armado e quanto se enfia represado e se enrosca e se intrinca, cinicamente ou desnorteado e sem solução — transportes, serviços, inda mais para além da Lapa, no pedaço de Presidente Altino, Jaguaré, Anastácio, Morro da Geada, Osasco.(...) ${ }^{164}$

\footnotetext{
${ }^{164}$ Amr, p. 80.
} 
“A cidade deu em outra". A ênfase é na mudança: no desaparecimento da aventura da boemia, na extinção dos sinuqueiros, que foram consumidos, devorados pela cidade. No entanto, como se lê no trecho acima, há algo que permanece: o espírito da cidade. E este espírito é de solidão e confusão: "sofrência", frio, tropel e avanços interrompidos ou solavancos (“de déu em déu”). A cidade mudou, devorou alguns de seus personagens, mas mantém seu espírito impessoal, dificultoso, acelerado e conflituoso ("tropel”), ao mesmo tempo que acidentado, interrompido. Como se trata de "espírito", subentende-se que seja algo persistente, mas também algo do âmbito da experiência urbana que não é exatamente próprio da cidade em si, mas que se reflete em seus moradores, no espírito das pessoas. Mais especificamente no morador que é este narrador que retorna e recorre, de novo, aos seus lugares de estima: Lapa, Presidente Altino, Jaguaré, Vila Anastácio, Osasco, Morro da Geada.

A construção para falar do espírito frio, sofrido e solitário do cimento armado da cidade também desvia a atenção narrativa da cidade para o narrador e de novo para a cidade: a sofrência e a solidão são de cimento armado, mas também de "quanto se enfia represado e se enrosca e se intrinca, cinicamente ou desnorteado e sem solução transportes, serviços (...)”.

Cidade e narrador parecem estar aqui em curto-circuito: um remete ao outro, aparentemente "sem solução", ao menos neste percurso que é o percurso antigo, um percurso antigo que mudou, pois a cidade deu em outra, mas que mantém o mesmo espírito. No narrador, esse curto-circuito se expressa e se formula. Diz ele que "se enrosca e se intrinca". E o curto-circuito manifesta-se numa espécie de represamento, em que se vai “cinicamente ou desnorteado".

A cidade, diz o narrador, mudou, mas continua com o mesmo espírito. Vale dizer que o espírito é, na verdade, o do narrador na cidade, cidade que mudou, mas que ainda pode ser percorrida pelos mesmos circuitos, circuitos que, no entanto, agora estão em curto. Cidade e narrador se relacionam e se embaralham, por conta da experiência passada, da boemia que não existe mais e de um espírito duro que permanece nos "transportes, serviços" que vão dar na Lapa e além: vão dar no percurso de juventude deste narrador, num passado que é de alta estima e, porém, não existe mais. 


\section{O trabalho da escrita}

A ênfase neste lamento pelo que passou, sumiu e não pode mais ser vivido é no desaparecimento da boemia, mas não menos importantes são as passagens em que o narrador comenta o seu avesso, isto é, a faina do trabalho, a sua opção profissional. É aí que entendemos morar o "rancor", e não no universo da boemia e no seu desaparecimento. Emoldurado pelo espírito duro, frio e sofrido da cidade, vai o narrador "cinicamente ou desnorteado e sem solução”. A que se relacionam esses sentimentos de cinismo e falta de norte? Certamente à boemia, que não existe mais, o que o desnorteia, mas também à opção profissional do narrador, narrada aqui em ato, e que é examinada, entre o "rancor", o desnorte e o cinismo.

Não são poucos os trechos da narrativa em que o jornalista-escritor tece considerações sobre sua ocupação. A primeira ocorrência se dá nas páginas iniciais do conto, em que o narrador conta como recebeu a pauta sobre a campanha de divulgação do turismo em São Paulo. Ele descreve a redação em que trabalha como um ambiente velho: "um assoalho batido, ruço, gasto, feito resto estropiado da faina". E compara este tempo de desânimo e esgotamento a outro tempo, em que "a redação fora um lugar de entusiasmo, rumor e movimento". O narrador dirá por que: "Isso sem a ditadura". Agora, porém, “transpirava-se nojo, derrota e, pior, um nhém-nhém-nhém, um chove-não-molha dos capetas". 165

A ocupação de jornalista, no momento atual da narrativa, ganha contornos esmaecidos, derrotados. O narrador lembra a situação política: vive-se o regime militar, a ditadura. Sem ela, ou melhor, antes dela, havia "entusiasmo, rumor e movimento". Mas agora a expressão e a possibilidade de atuação estão dificultadas: impera o "nhém-nhémnhém”, isto é, um discurso que não diz nada, e um infernal "chove-não-molha”, ou seja, ações que não se efetivam.

A contextualização é importante, pois marca o tempo histórico e o pano de fundo político em que se produz o texto - e chama a atenção, pois é pouco frequente na obra de João Antônio. ${ }^{166}$ Mas a referência ao regime militar não ganha desenvolvimento na ação

\footnotetext{
165 Amr, p. 79.

${ }^{166}$ As referências à ditadura são escassas na obra do autor. Não se tem notícias de que João Antônio tenha tido problemas sérios no período. Ao contrário, Flora Süssekind, por exemplo, acredita que a ditadura e a
} 
narrada. A situação política, apesar de claramente desfavorável à atuação dos jornalistas, não irá ganhar, no desenvolvimento narrativo do conto, qualquer consequência. Em “Amr”, as dificuldades para a atuação jornalística e para a expressão verbal vão se dar, isto sim, no âmbito social e econômico, na contenda entre o discurso turístico (oficial e publicitário) e a escrita literária (pessoal e jornalística, a seu modo), entre a pujança econômica (o recorde do turismo de negócios) e a persistência da pobreza e das desigualdades sociais, que se expressam no tecido traiçoeiro e maligno da cidade (a poeira, os buracos, as bocas-doinferno, o "espírito" duro e frio de concreto armado e de "sofrência"). O trabalho, assim, avulta como tema central do conto, em determinado contexto histórico, contraposto a um momento anterior, em que se trabalhava com mais entusiasmo. Assim como a boemia, que perdeu seu viço, desapareceu ou se mudou, também o trabalho já não tem o mesmo apelo e entusiasmo, já não motiva como antes.

Centrais para a constituição e para o desenvolvimento do conto, as considerações sobre o trabalho, portanto, merecem atenção. As passagens em que o autor aborda a prática do jornalismo e da escrita são numerosas e extensas, e não haveria espaço aqui para um exame minucioso dessas reflexões. O sentido geral foi muito bem apontado por Alfredo Bosi: a instrumentalização e a orientação comercial da escrita, que afetam a publicidade e também o jornalismo.

Vale notar, porém, que de início o trabalho aparece referido de maneira geral e abrangente, algo entre o social e o metafísico, relacionado à cidade e à meditação sobre o sentido da vida. Mas logo a reflexão se particulariza e é redirecionada para, mais uma vez, a ocupação do próprio narrador. Essa passagem se dá sem escalas, o que indica uma inclinação inicial de universalidade, que logo recai em particularização, ancorada no depoimento, na experiência pessoal — em suma, na autobiografia.

\footnotetext{
censura favoreceram a recepção da obra de João Antônio. Para a autora, a censura fez "vista grossa" aos textos de denúncia de José Louzeiro e João Antônio, "porque neles, como na maior parte da literatura-verdade do período, percebem colaboradores bastante eficientes. Isto porque servem ao mesmo senhor: ao interesse de representar literariamente um Brasil. E até o negativo da foto interessa à Política Nacional de Cultura. Em positivo ou negativo, o texto-retrato tende a ocultar fraturas e divisões, a construir identidades e reforçar nacionalismos pouco críticos". SÜSSEKIND, F. Literatura e vida literária. Polêmicas, diários e retratos. Rio de Janeiro: Jorge Zahar Editor, 1985, p. 27. Como se disse, nenhum livro do autor foi censurado, mas sofreu censura prévia a edição da revista Extra - Realidade Brasileira. Malditos Escritores!, no. 4, ano I, mar. 1977. Ver Severiano, M. Paixão de João Antônio, op.cit., p. 45.
} 
Viver... Viver é assim, aturdir-se? Aqui se batalha e aqui não se pára. É preciso, hoje mais amanhã, se aturdir pelo trabalho. Assim fazem as pessoas e será provavelmente para se esquecerem de que vivem aqui. E bom não é. Mas viver é isto?

Esta profissão não presta. Com o tempo, você vai empurrando a coisa com a barriga, meio pesadão. Sem qualquer alegria, garra ou crença, cutucado pela necessidade da sobrevivência. Apenas. O pior, se existe um, é que esta ocupação sovina e instável acaba como que atraindo azares, vícios, mortificações e levantando desejos de destruição, pespegando sentimentos culposos. A bebida, alguma esbórnia, outros empurrões que se tenta dar nessa consciência só fazem afundar mais o poço.

Muita vez, tenho achado. Devo estar já no fundo dele. E, assim futricado, só escrevo porque tenho uma consciência culposa. Um homem limpo vai para casa e dorme. Ou vive, ama. E não há fantasmas que o atormentem. Um homem de bem dorme. ${ }^{167}$

O trecho acima resume o tom e o caminho das reflexões. Começa com considerações gerais, de inclinação abrangente e filosófica, sobre a vida e o trabalho, para então particularizar o comentário, ao indicar de qual trabalho ou profissão se trata. Parece ser o jornalismo, afinal, o tema em questão, já que se infere que é da escrita profissional que se fala. O trecho preserva, porém, certa ambiguidade, ao tratar da ocupação de escrever. Seria jornalismo ou literatura o tema da meditação? Ou ambos?

A princípio, é de jornalismo que se fala, pois o narrador trata de uma "profissão", em que se persevera, como que inerte ("pesadão"), pela "necessidade de sobrevivência". É o jornalismo, certamente, o ganha-pão, a atividade que proporciona essa sobrevivência, e não a literatura.

Essa mesma profissão atrai "azares", "vícios”, "mortificações”, “desejos de destruição", “sentimentos culposos". É uma ocupação "sovina” e "instável”, que o faz atingir o fundo do poço. E o fundo do poço continua a afundar ainda mais, por conta da bebida e da esbórnia. Ainda se tem a impressão de que se fala do jornalismo, que causa culpa, talvez neste caso por conta da instrumentalização da escrita, e que leva à boemia desencantada, resumida à "bebida", isto é, à libação sem charme ou prazer, reduzida ao conteúdo líquido, e à "esbórnia”, ou seja, uma festividade desorientada, ou a uma bagunça, uma animação caótica, sem rumo.

${ }^{167}$ Amr, pp. 81-82. 
O jornalismo parece, então, ser o objeto de análise e meditação, o trabalho e a profissão a que o narrador se refere. No último parágrafo do trecho, porém, o narrador parece ter trocado de objeto de análise. Diz que pensa já ter atingido o fundo do poço, mas que continua escrevendo, não mais por necessidade, mas por ter uma "consciência culposa". São os "fantasmas" que o fazem continuar a escrever, e não mais a necessidade de sobrevivência. Trata-se, portanto, de escrever não por uma demanda material, não pela sobrevivência, mas por necessidade espiritual ou psicológica.

Não seria então do jornalismo que se trata, mas de literatura, de uma escrita vital, que se impõe apesar de todas as necessidades materiais de sobrevivência estarem atendidas. Ou trata-se das duas coisas?

A ambiguidade permanece e é esta ambiguidade, em verdade, que talvez instaure a culpa. Uma ambiguidade e uma divisão, digamos, que se manifesta em vários planos e que define o momento maduro de João Antônio, de maneira atormentadora.

Nesse sentido, o título do prefácio de Alfredo Bosi a $A m r$ é muito feliz: "Um boêmio entre duas cidades". Cidade do passado e cidade do presente, cidade paterna e cidade própria, São Paulo e Rio de Janeiro definem, afetiva e geograficamente, a divisão interna do autor, que neste conto ganha expressão tão clara na ação narrada. Lembre-se que o conto narra a história deste jornalista de São Paulo, que mora no Rio e retorna à cidade natal para escrever sobre ela, e já não a reconhece. Ele retorna para escrever uma reportagem sobre a São Paulo turística, mas empreende um percurso por sua cidade de infância e juventude e, não a encontrando, escreve não uma reportagem, mas um conto autobiográfico sobre a cidade que não é mais, ainda sendo. A divisão geográfica é acompanhada também pela divisão sobre a profissão ou ocupação, pela divisão entre jornalismo e literatura, entre escrita jornalística (profissional, vendida, cínica, viciada) e escrita literária (apaixonada e necessária, ao mesmo tempo fantasmagórica e vital).

O drama é também pessoal, e é o drama do próprio João Antônio. O narrador o formula com precisão no que se refere à sua condição social: "Desaprendi a pobreza dos pobres e dos merdunchos. E, já creio, aprendi a pobreza envergonhada da classe média."168 É o próprio autor que é jornalista e escritor, é pobre e não é mais pobre, é merduncho e é de classe média, que sofre a crise de ser e não ser mais.

${ }^{168}$ Amr, p. 102. 
Bosi também aponta para este impasse, ao comentar a volta do narrador à casa materna: "Ele não volta para sempre: parece impossível o retorno a quem já transpôs o limiar da classe". ${ }^{169}$ Com ênfase não na posição social, mas no estado psíquico, Simone Paulino destaca a persistência do rancor e da melancolia, associados à culpa: “O emprego da expressão 'pespegando sentimentos culposos' é exemplar. O verbo 'pespegar' tem o sentido de assentar, comportando, por sua vez, a acepção de 'depositar', sugerindo a existência de um princípio de acumulação na subjetividade da personagem, em consonância com a expressão 'carregado de mim', da epígrafe, e, acentuada pela aliteração do 'p', representação metonímica da sensação de peso". ${ }^{170}$ A autora liga o rancor a um ressentimento, algo que reincide e permanece, mantendo o autor, melancólico, ligado a um sentimento antigo.

O narrador, entretanto, parece se revoltar contra esse estado de coisas. Ele prefere a falta de norte ao cinismo, e a falta de norte se opõe mesmo ao cinismo. Mas gera rancor ou, pelo menos, não é capaz de eliminar o rancor. O "rancor" nasce ou padece desta falta de norte, que se opõe ao cinismo, mas que não encontra destino, não encontra, obviamente, orientação, novos caminhos, aventura, e redunda na "ânsia deambulatória", de que fala Bosi no prefácio ao livro. Abraçado ao próprio "rancor" - esse sentimento vago e violento, que se dirige contra algo que não se sabe bem o que é, mas se intui que seja relacionado à perda (à desaparição da cidade de juventude), uma perda que é social, mas também é pessoal, e ao sofrimento psíquico (o arrefecimento do entusiasmo pelo jornalismo, que hoje já não empolga como antes) - abraçado ao próprio rancor, ele percorre a cidade, a princípio sem rumo, desnorteado.

Até tomar uma atitude: decidir-se, afinal, "ir para casa".

A falta de norte poderia se direcionar para a "perdição", para a boemia ou para uma errância sem fim, para a busca, tão primordial na obra de João Antônio, como sabemos. Mas ela termina, nesta narrativa, por guiar o narrador não para a queda, para o desvio, tampouco para a aventura da busca ou da boemia, mas para o retorno, para um caminho antigo, para um caminho de regresso, e quiçá, regressivo. O narrador está ocupado com

\footnotetext{
${ }^{169}$ Bosi, A. "Um boêmio entre duas cidades." In: Amr.

${ }^{170}$ SANTOS, S. op. cit., p. 165.
} 
"sentimentos culposos" e com uma "consciência culposa". Culpado e "rancoroso", sem saber o que fazer, decide empreender uma volta.

A culpa, do ponto de vista psicanalítico, como se sabe, é fortemente vinculada ao desejo de morte do pai. Freud a analisou em "Dostoievski e o parricídio", ligando-a ao sentimento ambivalente que o menino mantém em relação ao pai. Segundo Freud, ao mesmo tempo que nutre ódio ao pai, e tenta se livrar dele como a um rival, também sente amor e ternura por ele, tendendo a ver o pai como um modelo.

[...] As duas atitudes mentais se combinam para produzir a identificação com o pai; o menino deseja estar no lugar do pai porque o admira e quer ser como ele, e também por desejar colocá-lo fora do caminho. Todo esse desenvolvimento se defronta com um poderoso obstáculo. Em determinado momento, a criança vem a compreender que a tentativa de afastar o pai como rival seria punida por ele com a castração. Assim, pelo temor à castração — isto é, no interesse de preservar sua masculinidade - abandona o desejo de possuir a mãe e livrar-se do pai. Na medida em que esse desejo permanece no inconsciente, constitui a base do sentimento de culpa. $[\ldots]^{171}$

Os sentimentos culposos que ainda o atormentam, este narrador os liga à profissão, isto é, ao jornalismo, mas também à sua atividade de escritor. Ainda que não mencione o pai, nessa passagem, é clara a ligação desses sentimentos com o seu anterior confronto com o pai, que, como vimos em "PMCMS", se deu por conta dos hábitos boêmios e desregrados. Mas o golpe final contra o pai, apesar da ênfase na descrição do comportamento boêmio, foi desferido, no conto anterior, com a revelação do pseudônimo e da visita dos homens da editora, o que significou, como já afirmamos, a consagração do jovem João Antônio Ferreira Filho no âmbito familiar e comunitário.

A escolha pela literatura e depois pelo jornalismo, portanto, tem na raiz um claro sentimento de contraponto ao pai, que, como vimos, o queria comerciante. Daí porque a segunda escolha de João Antônio, o jornalismo depois da literatura, faça com que ele, de alguma forma, recaia na mesma crise de infância e juventude, e no desejo inconsciente de matar o pai. A dúvida, o impasse, a hesitação são componentes hamletianos, de um personagem, como se sabe, consagrado pela inquietação do "ser ou não ser" e pelo

${ }^{171}$ FrEUD, S. "Dostoiévski e o parricídio". In: O futuro de uma ilusão, O mal-estar na civilização e outros trabalhos (1927-1931). Edição Standard Brasileira das Obras Psicológicas Completas de Sigmund Freud, vol. XXI, Rio de Janeiro: Imago, 1996, pp 188-189. 
fantasma do próprio pai. Aqui, é o narrador, mas é também João Antônio — ocupado com seus "fantasmas", também ligados à figura paterna - que deseja ser algo que já não pode ser mais. A ambiguidade e a hesitação parecem insolúveis.

Nesse momento em que o jornalismo se mostra uma profissão "vendida", perigosamente próximo da linguagem publicitária do turismo de negócios, o fantasma é o fantasma do pai comerciante. Os desejos de matar o pai, inconscientes, voltam assim, na forma de culpa em relação à escolha pelo jornalismo, mas também pela literatura. No caso do jornalismo por ele ter se tornado um comerciante de palavras (como o pai) e no caso da literatura por ter se tornado um artista da palavra (contrariando o pai, sentencioso e que o queria comerciante ou, de maneira mais ambígua, músico). Em ambos os casos, contrariando e contemplando as vontades paternas. ${ }^{172}$

O sentimento culposo é vago e indeterminado. Mas o impulso da ação é preciso. É por isso que, a certa altura, o narrador decide retornar e termina, afinal, por encontrar parada: a casa da família. "Porque foi, porque não foi, no meio de um dos goles de chope, resolvo ir para casa". ${ }^{173}$ De súbito, depois da jornada pela cidade, ocupado com a sua divisão interna, ele decide ir para casa, para a antiga casa de infância, em Osasco. E ele vai

${ }^{172} \mathrm{O}$ depoimento da Carta ao pai, de Kafka, é eloquente sobre a tirania e o caráter castrador do pai contra o filho: "É fato que você nunca me bateu de verdade. Mas os gritos, o enrubescimento do seu rosto, o gesto de tirar a cinta e deixá-la pronta nos espaldar da cadeira para mim eram quase piores. É como quando alguém deve ser enforcado (...) Além do mais, das muitas vezes em que, na sua opinião declarada, eu teria merecido uma surra, mas escapara por um triz por causa da sua clemência, se acumulava de novo um grande sentimento de culpa. De todos os lados eu desembocava na sua culpa." (p. 30). A relação de Franz com seu pai guarda semelhanças, mas também diferenças com a de João Antônio Ferreira e João Antônio Ferreira Filho. Os sentimentos positivos do nosso escritor sobre o pai são enfáticos, assim como as diferenças marcantes que os separavam. A carta que João Antônio escreveu por ocasião da morte do pai (reproduzida no Apêndice desta tese) e também algumas de suas cartas posteriores expressam claramente o afeto que sentia por ele e a importância que reconhecia no pai para sua formação e para a sua sensibilidade estética, nas letras e na música. No âmbito das diferenças, o trato severo do pai, em contraste com a simpatia bonachona e inconsequente do filho ("pra lá de Bagdá"), e a escolha pela vida boêmia e pela literatura (como vimos neste capítulo, negando os desejos paternos de que se tornasse comerciante), também lembram a relação dos Kafkas: o pai comerciante, ativo, burguês; e o filho atormentado pela repressão paterna, pela culpa, "preguiçoso" e ocupado com a "afirmação espiritual da existência". O trecho seguinte fala da influência do pai nas relações interpessoais de Franz: "A desconfiança que você procurou me ensinar, na loja e na família, contra a maioria das pessoas (...) - essa desconfiança, que enquanto eu era pequeno não se conformou aos meus próprios olhos em lugar nenhum, uma vez que eu via em toda a parte apenas pessoas inalcançavelmente distintas, transformou-se na minha cabeça em desconfiança de mim mesmo e em medo permanente dos outros." (p. 45) E talvez se possa ver a literatura do nosso autor nos termos em que Franz Kafka refere-se à influência paterna sobre sua obra: "Meus escritos tratavam de você, neles eu expunha as queixas que não podia fazer no seu peito. Eram uma despedida intencionalmente prolongada de você; só que ela, apesar de imposta por você, corria na direção definida por mim" (p. 52). KAKFA, F. Carta ao pai. Trad. Modesto Carone. São Paulo: Companhia das Letras, 2002.

${ }^{173}$ Amr, p. 130. 
refazer esse caminho como uma espécie de expiação da culpa por ter deixado a casa paterna e ter ascendido socialmente. Em vez de pegar um táxi, como vinha fazendo em seus deslocamentos profissionais, ele decide tomar um trem para empreender mais uma vez o percurso de juventude, até Presidente Altino.

Antes de chegar, durante o percurso mesmo, é importante notar que o narrador se inclui entre os trabalhadores que vão com ele no trem. E a maneira com que faz isso, é contrapor a estes os "sabidos dos jornais":

[...] Aqui nos trens vamos mergulhados de cabeça, tronco e corpo numa vida sem retoque ou frivolidade. Mas o lado de dentro da gente ferve. Aí, então, se nos entalam, vem uma depredação, e os sabidos dos jornal nos lacram, somos chamados de nomes. Vândalos. Pior é que o tempo passa e não há melhoria nos trens. Depredação pouco assusta quem tem a polícia a seu favor. E o povinho toca a vida. ${ }^{174}$

Vê-se que a tentativa é se contrapor aos "sabidos dos jornais", àquilo que, justamente, ele se tornou ao deixar a casa paterna ou, em outras palavras, aquilo que virou ao ultrapassar o pai, ao negar seguir o mesmo caminho. Esta nova recusa, aquela que o faz se contrapor aos "sabidos dos jornais", de alguma forma repõe o mesmo desejo: enfrentar o pai, um sabido, um homem de espírito proverbial, e um comerciante, assim como são os jornalistas, "sabidos" comerciantes de palavras. Mas expressa também a culpa de ter se tornado, ele próprio, um "sabido", um intelectual de formação mais ampla e longa que a do pai (e que a dos trabalhadores, entre os quais ele procura agora se incluir).

O termo sabido retoma ainda o trecho de "PMCMS" em que ele defende uma escrita "envenenada, escrachada, arreganhada", em oposição a como os "sabidos" veem a vida aqui fora, isto é, a realidade, em oposição à literatura. Vejamos de novo o trecho:

\footnotetext{
${ }^{174}$ Amr, pp. 138-139. Note-se que o narrador ressalta que as os homens do povo, entre os quais ele se inclui, são chamados de "vândalos", ou seja, de bárbaros, presumivelmente pelos jornalistas, os "sabidos dos jornais". A imprensa os tacha de bárbaros, afirmando o pretenso caráter civilizador das classes altas e dela própria, imprensa. O narrador, aqui, evidencia o processo por meio do qual a sociedade de "bem" diminui e marginaliza. Com isso, esboça a tentativa de relativizar, dado o seu ponto de vista interno, e mesmo inverter os sinais dessa classificação excludente e estigmatizadora. A perspectiva, agora, é desencantada: "o povinho toca a vida", diz o narrador. A passagem contrasta com aquele enlevo do narrador de "PMCMS" que dizia que não há nada como a vida para ser tocada.
} 
Nem me venham dizer os sabidos que a vida, aqui fora, fede de outro modo. Parece-me que onde se está abrindo com a frase: "Respeitável público!", talvez coubesse esta, assim: "Detestável público!". Afinal, deliberadamente ou não, o escriba é um servo da classe média. Então, não comece com floreio de brilhareco, pois estará entrando exatamente no joguinho que essa classe espera dele. $^{175}$

O receio de se tornar um "servo da classe média", que ele temia afetar a sua escrita envenenada se consumou, não na literatura, mas no jornalismo. $\mathrm{O}$ narrador conseguiu salvar a literatura do "floreio de brilhareco" — por meio do rancor. Se o jornalismo não empolga, tal com ele se apresenta neste momento de adversidade econômica e política, resta a literatura, mas uma literatura que não compactue com os valores de classe média. Uma literatura suja, arreganhada e envenenada, isto é, feita contra a classe média. Como fazê-lo? Retornando, voltando à biografia e às origens.

O narrador volta ao lugar de origem: "Fora daqui, por mais que me besuntem de importâncias, fique conhecido ou tenha ares coloridos, um quê me bate e rebate. Foi desta fuligem que saí. E é minha gente". ${ }^{176}$

Finalmente, ao voltar ao bairro de infância e a casa, descobrimos que a volta é uma volta à mãe.

Piso o pedregulho úmido da estação, calado como os outros, cato a passagem de nível, ganho as ruas esburacadas, de terra, onde água poluída se empoça esverdeada no meio-fio.

Não mais prédios, a vista vai se acostumando. Olho as casas baixas, descascadas no sombreado das ruas que a iluminação expõe mal e mal; cães e algum gato vagabundeiam pelos cantos. Sujeitos tristes nas portas, raros nas calçadas. Ou se discute futebol ou se entorna nos botequins. Frio.

A noite caiu. Entro, peço grande e repito, espero arder na garganta. Que lá em cima venta bravo.

E toco a subir o Morro da Geada. Um pensamento me passa, que empurro. Se tivesse de viver de novo aqui, de onde me viria força? Vinte minutos sozinho, vento ou pernilongos enormes, pretos, na picada do mato e da barba-de-bode.

Mamãe fica tímida, depois do beijo. Não querendo contrariar, só pergunta, jeitosa, como estou e se volto. E se é para ficar. Não vou responder, no começo. Eu vou engolir café. Puxar um cigarro, andar para a janela. Como se ouvisse os grilos.

\footnotetext{
${ }^{175}$ Dedo-duro, p. 89.

${ }^{176}$ Amr, p. 139.
} 
Faço tenção de me explicar, que cheguei tarde da noite. Mas ela é minha mãe:

— A sua arte não permite dois amores. ${ }^{177}$

Fim da narrativa.

O narrador retorna ao Morro da Geada, onde, a fim de amainar o frio, para num botequim para tomar um trago, que lhe arde a garganta. Finalmente chega a casa, onde reencontra a mãe. O narrador observa que a reação da mãe é de timidez, de cuidado tateante em relação ao filho.

A alternância dos tempos verbais entre presente e futuro, na passagem final, a do reencontro com a mãe, é o artifício de construção verbal mais importante deste belo e enigmático desfecho.

Os verbos da frase que descreve o comportamento intimidado da mãe, com a presença inesperada do filho, estão no presente: "fica", "pergunta". O uso do presente do indicativo aponta para a continuidade da ação narrada, pois a ação do narrador vinha sendo assim descrita. Mas quando o narrador passa a descrever a sua própria reação de filho ao reencontro com a mãe, ocorre uma mudança de tempo verbal, do presente para o futuro. A passagem é gradual, pois começa com um verbo no presente, indicando futuro, ou melhor, por uma locução verbal, "vou responder", mas na negativa, "não vou responder", seguida de outra locução verbal no presente, indicando futuro: "vou engolir". Depois, duas orações sem sujeito, com verbo no infinitivo: "Puxar um cigarro, andar para a janela".

O final do trecho retoma o presente do indicativo, a fim de levar a ação adiante, e afinal encerrar a ação, ainda que a última palavra seja a da mãe. O narrador faz tenção de se explicar, mas a mãe se antecipa, sintomaticamente glosando a divisão que é a marca deste narrador: "A sua arte não permite dois amores".

A frase nega a divisão da arte do narrador entre "dois amores", e o leitor termina o conto se perguntando que arte é essa e quais seriam esses dois amores.

Mais importante que isso, porém, o leitor fica se perguntando se o encontro com a mãe realmente se deu. Como a construção verbal é ardilosa, entre presente e futuro, é possível ler este desfecho do conto como algo irrealizado ou, talvez, imaginado. Como a ação narrada no encontro com a mãe começa com o verbo no presente, o leitor é levado a

\footnotetext{
${ }^{177}$ idem, pp. 141-142.
} 
situar o encontro no plano da ação. Mas as locuções verbais no presente, indicando futuro, sugerem que ação não se dá, ou melhor, pode se dar apenas na imaginação do narrador.

O final do conto indica que a ação pode ter sido interrompida imediatamente antes. A ação pode ter terminado com o narrador subindo o Morro, pensando se teria forças para voltar a morar ali. Ele chega mesmo a formular a si mesmo esta pergunta crucial: "Se tivesse de viver de novo aqui, de onde me viria a força?". Para esta pergunta, ele não encontra resposta verbal, mas a responde com o corpo, incapaz de continuar. A pergunta o paralisa: "Vinte minutos sozinho, vento ou pernilongos enormes, pretos, na picada do mato e da barba-de-bode".

Dizer que a ação termina antes do desfecho, significa que o encontro com a mãe permanece no plano da imaginação. E que a reação dela é projeção do filho. Significa que o filho gostaria de ser recebido pela mãe da maneira com que o encontro é narrado. E que a mãe, por fim, reconhecesse que a sua "arte" não permite "dois amores". Arte pode ser a literatura e um dos amores, o amor de mãe. A arte pode ser a escrita, e os dois amores podem ser "jornalismo" e "literatura", esta sendo a escolha amorosa de sua preferência. ${ }^{178}$

Mas, a rigor, de qual arte se trata e quais amores seriam esses, o conto não diz.

O leitor, porém, entende que a mãe, resignada, percebe que o filho não voltou para ela, isto é, não voltou em definitivo. A frase final, se imaginada pelo narrador na boca da mãe, significa que ela sabe que o filho tem outro amor, e que a escolha do filho pela arte resultou na fuga do filho rumo a outro amor, que não o dela. O conto não diz que arte é essa e que amores são esses. Mas é possível (e desejável) ler a frase final do conto literalmente: a arte o conduziu a outro amor. Um outro amor nega ou substitui o primeiro, o qual, presume-se, seja o amor da mãe, aquela que enuncia a frase. A aparição da figura da mãe, portanto, evidencia que a volta é a volta ao amor da mãe, ainda que esta mesma saiba que a volta não é definitiva, é apenas uma visita.

A situação é paradoxal. Do ponto de vista profissional ou da vocação — abordagem a que somos impelidos pelo uso da palavra "arte" — não se sabe ao certo quais são os dois amores ou, se estes são a literatura e o jornalismo, qual deles é o amor que o narrador não troca pelo outro.

\footnotetext{
${ }^{178}$ Em carta de 1993 a Mylton Severiano, diz o escritor: "Esta fama que não põe mesa, esse desarvorado amor pela literatura, essa paixão dos capetas, quanto mais eu embranqueço os cabelos, mais apaixonado fico. É sina, é missão e é grande demais”. SEveriano, M. Paixão de João Antônio, op.cit., p.60.
} 
Do ponto de vista pessoal, por sua vez, o reencontro com a mãe repõe o conflito edípico. O narrador volta à mãe, que ainda o deseja só para si, mas ele, na verdade, não quer voltar e não pode voltar. Ele volta para ficar com a mãe, mas não para sempre, em definitivo, pois sabe que isso já não é possível. A mãe também sabe disso, por isso é capaz de formular a frase enigmática, que relaciona arte e amor, referindo-se certamente à vocação, ao talento, à profissão e ao amor, que tanto se relaciona às escolhas profissionais como às opções pessoais, afetivas.

A mãe sabe que a arte do filho, isto é, sua escolha vocacional, seu talento e sua atividade profissional - literatura e jornalismo confundidos — se relacionam com o amor. E que a escolha da arte foi também a escolha de $u m$ amor.

A ambiguidade e a indeterminação são grandes, pois não se sabe se a afirmação traduz uma resignação materna (a mãe que sabe que o filho tem outro amor) ou uma afirmação segura da mãe (que sabe que o filho só ama mesmo a ela) ou ainda se é a imaginação do narrador, antecipando o encontro, e nesse caso imaginando que a mãe, afinal, aceita sua condição de filho desgarrado. Nesta última hipótese, essa volta que não é uma volta é uma forma de o narrador tentar expiar sua culpa de tê-la procurado em outras mulheres, a expressão da culpa por ter, afinal, superado o Édipo, de ter ido muito longe, desgarrado, “pra lá de Bagdá”, até a Nairlândia, a cidade das marafonas.

O que o conto também não diz — mas coloca em cena — é por que o encontro se dá apenas com a mãe. O pai está ausente deste desfecho, apesar de ter sido tão importante ao longo do relato, ao menos no que se refere à relação do narrador com a cidade e, por extensão, com a boemia e também com o trabalho. Ressalte-se que não se trata de uma ausência com correspondência real: o pai do próprio João Antônio ainda era vivo, quando da publicação de $A m r{ }^{179}$

O que esta ausência paterna quer dizer?

A ausência do pai no momento da ação está de acordo com a volta à casa e à mãe. E se relaciona também à impossibilidade da ação. Em outras palavras, a ausência paterna é necessária e condizente com o desfecho da narrativa. O narrador, abraçado ao seu rancor,

179 João Antônio Ferreira, pai, morreu em 1988, quando o filho, João Antônio, estava na Alemanha. A informação está em SEveriano, M. Paixão de João Antônio. op.cit., p. 174. Em nossa pesquisa no Acervo João Antônio, no Cedap da Unesp de Assis, localizamos uma carta do autor que registra a data precisa da morte do pai: 13 fev. 1988. Cópia desta carta está reproduzida no Apêndice desta tese. 
volta a casa, onde não pode encontrar o pai, pois o pai é, ao mesmo tempo, a figura que lhe devolve ao passado, à cidade que não existe mais, e a figura que pede enfrentamento, desafio, para que a ação e a aventura possam se realizar.

É, portanto, a ausência do pai — o fantasma do pai — que mantém o narrador neste estado de rancor e melancolia, de ausência de ação. Ele sente culpa por ter deixado a casa paterna, por ter se "bandeado pelo mundo", por ter deixado de ser pobre e ter ingressado na classe média, por ter se tornado jornalista e não escritor, ainda que as atividades de jornalista e escritor convivam nele.

E, no entanto, de novo, ele sabe que o retorno é impossível.

A ausência do pai se coaduna com o teor geral do conto, que glosa a ausência ou o desaparecimento ou a morte — da boemia, dos salões de sinuca, dos sinuqueiros, dos sambistas —, ausências e buscas que fizeram José Paulo Paes ${ }^{180}$ e depois Simone Paulino postularem a inserção deste conto no topos do Ubi Sunt?.

Como diz Simone Paulino dos Santos:

A evocação do sambista, figura lendária da malandragem paulistana, joga-nos imediatamente no terreno da tópica do Ubi sunt?, revelando por essa pergunta oculta na evocação (Onde estão os que neste mundo viveram antes de nós?) o fato inequívoco de estarmos novamente diante do tema da busca, embora não mais a busca por algo que não se sabe precisar claramente ("Busca" e "Afinação") ou por algo da ordem do concreto como dinheiro, comida, jogo, sexo ("Malagueta, Perus e Bacanaço"). A busca agora é por aquilo que um dia se teve e já não se tem mais, algo também difuso, que parece escapar aos olhos porque encoberto pela poeira do tempo. ${ }^{181}$

Aquilo que se teve e já não se tem mais, além da cidade da juventude, ao final do conto se revela ser o pai e a mãe. Ele é o filho que se perdeu, que se "bandeou pelo mundo", e que retorna à casa paterna. ${ }^{182}$ No entanto, ele volta para reafirmar sua condição

\footnotetext{
${ }^{180}$ PAES, José Paulo. "Ilustração e defesa do rancor". O Estado de S. Paulo, 21 mar. 1987.

${ }^{181}$ SANTOS, S. op.cit., p. 153.

${ }^{182}$ Além da tópica do Ubi Sunt? (Onde estão os que neste mundo viveram antes de nós?), como assinalam J.P. Paes e Simone Paulino, essa busca que se torna uma volta a casa, uma volta irresistível e impossível, é um retorno do conflito edípico e insere o texto também em outra tópica: a tradição dos textos inspirados nas histórias bíblicas da ovelha desgarrada e do filho pródigo. Evangelho segundo Lucas, cap. XV, vs. 1 a 32 . O trecho do conto a seguir é eloquente a respeito: "Penei a infância aqui, nestas filas e trens encardidos, apinhados. Olhem, isto me bole. Daqui me bandeei no mundo. Quando volto ao morro, quantas vezes, é subindo feito cabrito escabriado, meio na culpa, de assim... mas também com alegria, porque o pessoal diz, mal sabendo das coisas e me olhando as roupas, que sou feliz como um desgraçado" (Amr, p. 139).
} 
de filho pródigo. Sabe que a volta à casa paterna é impossível. Intimamente sabe que volta apenas para reafirmar essa mesma condição de ovelha desgarrada e de filho pródigo, reincidente. Ele volta — assim fala o seu desejo imaginado — para ouvir da própria mãe que ela sabe que sua arte "não permite dois amores" e para não encontrar o pai. É uma volta que o faz recair mais uma vez na condição edípica de amante da própria mãe e algoz do próprio pai. A culpa e o rancor traduzem essa ambiguidade: ele anseia por uma volta à origem que, ao mesmo tempo, recusa e que sabe ser impossível. A volta é expiação de culpa e parada para seguir adiante, com rancor.

Como diz José Paulo Paes, o conto estabelece oposições: entre "escritor" e "escriba", entre proletário e pequeno burguês ("desaprendi a pobreza dos pobres e dos merdunchos; aprendi a pobreza envergonhada da classe média", como diz o texto do conto e lembra o crítico em sua resenha). O escritor, diz Paes, é visto como "guardião da linguagem como meio de desvelamento e apropriação da realidade" e o escriba avilta a linguagem "ao fazer dela uma técnica de escamoteamento ou cosmetização do real em proveito dos interesses a cujo serviço voluntária ou involuntariamente se põe”.

O sentimento rancoroso, segundo José Paulo Paes, permite exprimir um mea culpa que é procedimento de resistência - e a prova dessa resistência é "o próprio ato de escrever um texto como o que está escrevendo". Nessa dinâmica, que inclui o próprio escritor, José Paulo Paes vê carga de positividade no rancor:

Tanto a confissão religiosa dos pecados quanto a técnica psicanalítica da anamnese já demonstraram à farta que a única maneira de alguém aliviar-se de um sentimento de culpa é proferindo-o sem atenuantes, proclamando-o alto e bom som. No texto expiatório-confessional de João Antônio, alto e bom som são sinônimos de rancor - e aqui deparamos enfim uma acepção positiva deste sentimento que a moralidade convencional tem por negativo. ${ }^{183}$

Em leitura semelhante, João Luiz Lafetá identifica neste texto uma "estética do rancor". Lafetá observa que na maioria dos contos de Amr "o foco está deslocado" da "pobreza do lúmpem para os personagens de classe média": "Seu centro não é mais o malandro cheio de picardia, mas o escritor ressentido, que vê o capitalismo brasileiro reduzir as artes da malandragem à miséria descorada, esfarrapada e pedinte". Além da

${ }^{183}$ PAES, J. “Ilustração e defesa do rancor". O Estado de S. Paulo, 21 mar. 1987. 
mudança temática significativa do livro em relação aos textos anteriores do autor, não escapou a Lafetá também a dimensão autobiográfica, autorreflexiva e crítica do relato:

Passeio longo, rancoroso. João Antônio perdeu aqui a facilidade feliz de representar os tipos populares, facilidade que lhe deu fama, mas cuja ponta evidente de artifício levava a desconfiar de certa falsificação pitoresca. O resultado é complexo, e não sei dizer se agora melhorou. Sei que o pitoresco quase sumiu, dando lugar a uma matéria muito mais pesada, e o estilo ressente-se, perdendo em graça e flexibilidade. Além disso, o texto carregado de referências autobiográficas, fiel mas pouco transfigurado, corre o risco que José Veríssimo acusou no pioneiro Lima Barreto: a amargura "legítima, sincera, respeitável", atrapalhando a arte.

Mas como poderia Lima Barreto sujeitar-se a uma lei de recato, se nele o essencial eram sentimentos e ressentimentos? — retrucou por sua vez Sérgio Buarque de Holanda. É verdade, também para João Antônio, e o paradoxo está aí. Ele não o resolveu neste livro. No entanto, mesmo o tal impasse de sua narrativa, por desajeitado que pareça do ponto de vista artístico, nos remete para um significado sobre o qual devemos refletir. ${ }^{184}$

Apesar da "desajeitada visão do processo social" e o impasse artístico também "desajeitado" que a indignação intelectual expressa, Lafetá valoriza aqui o rancor como índice de inconformismo e não cooptação.

O sentimento de rancor, assim, se liga a contradições fundamentais da vida e da obra de João Antônio. Relaciona-se a sua condição de classe, a seu trabalho como jornalista e ao seu amor pela literatura e por uma escrita de resistência, preservada das pressões econômicas e políticas. Nesse percurso, o impulso de retorno revela uma necessidade de expiação da culpa, que se relaciona à família, à cidade e à literatura, mas também ao próprio autor e à constituição de seus textos, como sugere Lafetá.

É sintomático, nesse sentido, que o autor tenha inserido neste mesmo livro um texto como "Uma força", escrito tantos anos antes. ${ }^{185}$ Neste texto, autobiográfico e em primeira pessoa, o narrador conta o encontro com um cágado nas ruas da Vila Ipojuca, na Lapa de

184 LAFETÁ, João Luiz. "João Antônio e sua estética do rancor”. In: A dimensão da noite. Organização de Antonio Arnoni Prado. Duas Cidades/Editora 34. São Paulo: 2004. Texto publicado originalmente na Ilustrada, da Folha de S. Paulo, em 6 out. 1986.

${ }^{185} \mathrm{O}$ texto foi escrito em 1963 e remetido por carta a mais de um correspondente do autor, como indicam Ana Maria Domingues e Telma Maciel da Silva, ao comentarem a correspondência de João Antônio com Jácomo Mandatto. OLIVEIRA, Ana Maria Domingues de; SILVA, Telma Maciel da. "Memória e ficção na correspondência do escritor João Antônio", op.cit. Além de ter escrito e remetido o texto para amigos, o que acentua o caráter íntimo do relato, o texto tem outro personagem que remete à biografia do autor: a menina Aldônia, que será também personagem de "Aact", conto de $M P B$. 
São Paulo. Ele o recolhe e o leva para casa, como um bicho de estimação. O bicho "tinha um não sei que de sabedoria e sofrimento" com o que o narrador diz ter se encantado. Em casa, diz o narrador, tiveram medo do bicho e depois quiseram lhe colocar nome de imperador: Maximiliano. O narrador se recusou:

Nada disso. Meu cágado é o cágado. O cágado. Vão nesse nome sofrimento e anonimato o mesmo anuviado andante que nos uniu num instante duro lá numa subida de Vila Ipojuca. Afora o quê, Maximiliano é nome de imperador, e não gosto de imperadores. Avesso a grandezas e importâncias, como o cágado, pendo para as criaturas e viventes que se mexam com humildade e tenham tolerância, humanas e boas. Como o cágado. Que se alimenta da sua persistência. A vida lhe deu longo tempo de existência e dura carapaça. Além de olhos atentos. ${ }^{186}$

O cágado é um duplo do autor, mas também um bicho de estimação que faz as vezes de duplo da namoradinha, Aldônia, também citada no texto. ${ }^{187}$ Como se infere pelo trecho acima, o cágado é, portanto, um símbolo daquilo que o próprio autor se tornou e algo que já era na juventude - maturidade e juventude reconciliadas numa espécie de animal totêmico que o representa em suas características essenciais: vida "semiterrestre", entre a sabedoria e sofrimento, avesso a grandezas e importâncias, apreciador da humildade.

"Uma força", assim como "Amr" também narra um retorno (ao bairro de infância, à namoradinha de infância, à personalidade sofrida, resignada e renunciadora (que lembra a do pai), uma volta narrada por meio do encontro com um duplo, encarnado num bicho de forte simbologia zoomórfica nesta imagem totêmica de um cágado, um cágado essencial e imutável ("Meu cágado é o cágado. O cágado."). O boêmio, malandro, de nome sestroso (um jabuti das lendas), tornou-se um cágado, um bicho ancestral, persistente: um malandro melancólico, mas resistente e atento.

Desamparado, ele quer uma casa, mas a casa é o ser: "Sei que ele próprio carrega a sua casa nele mesmo". ${ }^{188}$

O final de "Amr", assim como "Uma força", aponta para um desejo de reconciliação do protagonista consigo próprio, na volta à cidade paterna, à casa (e à casa materna), uma volta ao pai e à mãe, mas uma reconciliação que o próprio narrador sabe ser impossível, ao

\footnotetext{
${ }^{186}$ Amr, p. 162.

187 Aldônia e o cágado, nesse sentido, são como a Teresa e o porquinho da índia de Manuel de Bandeira.

${ }^{188}$ Amr, p. 162.
} 
menos no plano familiar e social, já que "a minha cidade de meu pai” já não existe, como ele mesmo formula, e ao observar que desaprendeu a pobreza dos merdunchos, trocando-a por uma vida de classe média. Também do ponto de vista profissional o narrador quer voltar, quer deixar de ser o jornalista que se tornou, apartar-se dos "sabidos dos jornais", para viver apenas um amor, o seu amor pela literatura - ou o seu amor pela mãe e por mais ninguém. No plano pessoal, o desejo de volta à casa, o reencontro, real ou imaginado, com a mãe, indica a persistência do desnorteamento de uma crise que não se formula, mas que se encena. $\mathrm{O}$ que não é dito revela também que, inconscientemente, o narrador sabe o que precisa ser feito. Precisa, mais uma vez, reafirmar o amor pela mãe e ultrapassar o pai. E ele de fato "mata" o pai, ao suprimi-lo do final da narrativa. O filho pródigo só volta se for para cometer o parricídio ainda necessário, necessário a este narrador para que possa continuar a viver a boemia e a escrita literária, a aventura e a narração.

O que se constrói em “Amr” é uma investigação das mudanças ocorridas no próprio narrador, isto é, no João Antônio narrador, ou seja, no próprio João Antônio e no narrador João Antônio, indissociáveis, assim como são coincidentes, aqui, a elocução e a ação. Mas é justamente essa coincidência que será examinada e sofrida, ao longo da narrativa: apesar da coincidência entre João Antônio e narrador, há um desacordo que não se deixa apaziguar e reaparece, e reincide como rancor, como um sentimento vago e sem objeto, que se contrapõe ao cinismo, mas que não se mostra consequente, do ponto de vista da aventura, da ação. Trata-se de um narrador, aqui, desconfiado, que reconhece que a ação, no seu caso, trai as origens e o faz aceder a um lugar social, a classe média, que ele não reconhece. Mais: que ele recusa, não quer ser o "animal bufo" da classe média, ainda que não a possa recusar, por fazer parte dela e escrever para um público que é, também ele, de classe média. Daí o rancor, sentimento negativo em que José Paulo Paes vê uma positividade. Um rancor "semiterrestre", como o cágado, positivo e negativo.

A causa desses sentimentos contraditórios é a dificuldade em conciliar a profissão e a vocação; o jornalismo e a escrita vital; a inserção social e a boemia; a ação e a culpa; a ascensão social e a irmandade junto aos humildes, o impulso de rompimento e de libertação, de um lado, e de outro o amor e a gratidão às origens. O rancor parece nascer dessas tensões, dessas incompatibilidades que João Antônio encarnou e viveu, tensões sobre as quais escreveu, contradições que parece não ter conseguido resolver. Ou melhor, 
parece ter resolvido de maneira negativa e inconformada, ainda que melancólica: entre o rancor e o cinismo, o narrador fica com o rancor. Um rancor que é resistência: negatividade positiva.

Apesar da crise biográfica irresolvida, no plano literário, entretanto, a cena final coroa a construção e resume as inquietações deste autor-narrador-personagem. A ação, paradoxalmente, culmina em uma volta, em um impasse. Do ponto de vista literário, assim, “Amr” é a expressão de uma crise: a crise do narrador, que já não é capaz de ação nem de narrativa, senão em termos dilacerados, como este conto formula. De um narrador que viu seu mundo desaparecer e não encontra um novo mundo que acolha seu desejo de liberdade, de aventura, de boemia. Um narrador que se vê impelido a voltar a casa, ao porto que o fez, justamente, se lançar à aventura. Para este narrador, a volta é vivida como um retorno doloroso e castrador, que o desejo e a imaginação insistem em desafiar, criando uma situação dilemática, entre ser e não ser, narrar e não narrar, impasse que o conto encena, transformando em literatura.

O rancor que dá título ao conto vem - além do lamento pelas mudanças da cidade, pelo arrefecimento da boemia e desaparição do sambista — também da impossibilidade de se tornar o que se quer ser (escritor e não jornalista) e voltar a ser o que já não se é mais (um escritor estreitamente ligado ao seu universo literário, "conluiado" aos operários, sinuqueiros, malandros e sambistas). Como já dissemos, esse narrador prefere o desnorte ao cinismo, ainda que, para tanto, precise andar pelo mundo, perdido, feito ovelha desgarrada, abraçado ao próprio rancor.

"Abraçado ao meu rancor" representa um ponto alto da carreira literária de João Antônio, um ápice doloroso, em que o autor coloca a própria identidade em xeque. A crise narrada neste conto, por si só, já seria um legado literário da maior relevância para a obra de João Antônio. Mas, além disso, este texto autobiográfico permite compreender melhor também a ficção de João Antônio, à qual voltaremos, para mostrar como alguns de seus primeiros textos, como os "Contos Gerais", "Malagueta, Perus e Bacanaço" e "Paulinho Perna Torta”, podem ser lidos à luz das contradições aqui entrevistas. 


\section{CAPÍTULO 2}

\section{AFINANDO A MALANDRAGEM}

Dos "Contos Gerais" à sinuca 
A análise dos três principais textos autobiográficos de João Antônio permite, como vimos no capítulo anterior, localizar temas e formulações que pautam a literatura do autor e atentar para modos de constituição de personagens e narradores. Na ficção, podemos constatar motivos e procedimentos similares. Como as obras de juventude são fundadoras de seu universo temático e de soluções formais decisivas, vamos iniciar nossa leitura dos textos de ficção pelos primeiros contos do autor.

"Busca" não foi o primeiro conto escrito por João Antônio, mas é o primeiro conto de seu primeiro livro. A escolha de abrir com ele o volume de estreia, Malagueta, Perus e Bacanaço, faz desse texto uma espécie de marco inaugural da ficção do autor ${ }^{189}$ - e o apreço de João Antônio pelo conto se manteve: "Busca" foi inserido em um dos últimos livros publicados por ele, Sete vezes rua, ${ }^{190}$ em 1996, ano de sua morte. É um conto que permanece entre os favoritos do seu criador, do começo ao fim de sua produção.

Antonio Candido não o comenta explicitamente em seu ensaio sobre o livro de estreia de João Antônio. Diz que em Malagueta, Perus e Bacanaço há "certo ritmo, uma espécie de crescendo, que serve para iniciar progressivamente o leitor nas camadas essenciais de sua visão e da sua escrita, ao longo de três blocos, constituídos por três tipos diferentes de contos, todos eles valiosos e interessantes, mas em graus diferentes de qualidade". ${ }^{191}$ A predileção de Candido, como indica a ideia de crescendo e como o crítico dirá com todas as letras, recai sobre as duas últimas narrativas: "Meninão do Caixote" e "Malagueta, Perus e Bacanaço", esta a história que dá título ao livro. O ritmo de crescendo, diz Candido, prepara o leitor para o percurso das histórias “fáceis” às mais “complexas".

João Alexandre Barbosa, um dos primeiros a resenhar o livro, em 1963, no ano mesmo de seu lançamento, também não se refere ao primeiro conto, a não ser de maneira muito geral, ao destacar "o sopro de criação capaz de fazer viva a imagem percebida pelo

\footnotetext{
${ }^{189}$ A pesquisa de Rodrigo Lacerda aponta a primeira publicação do conto em 1958, na Revista do Globo. Os primeiros textos publicados de João Antônio remontam a 1954, quando o escritor contava 17 anos. É o caso, segundo Lacerda, do conto "Um preso", publicado em $O$ Tempo. Entre os primeiros contos escritos estão também "Índios" (1956), que ganhou menção honrosa em concurso da revista A Cigarra e foi publicado em $O$ Estado de S. Paulo (em 6 fev. 1960), "Meninão do Caixote" (1958) e "Fujie" (publicado em 1958 no Última Hora), provavelmente o primeiro dos contos de $M P B$ a ser escrito. O escritor cogitou intitular seu primeiro livro Fujie e outros contos, depois Meninão do caixote, além de Aluados e cinzentos. Sobre os primeiros momentos de produção literária do escritor ver LACERDA, R. João Antônio: uma biografia literária, op.cit. ${ }^{190}$ ANTÔNIO, J. Sete vezes rua. São Paulo: Scipione, 1996. O livro foi reeditado em 2007.

${ }^{191}$ CANDIDO, A. "Na noite enxovalhada". In: $M P B$, p. 7. O grifo é do autor.
} 
criador por sob a chatice do quotidiano". ${ }^{192}$ A chatice a que se refere João Alexandre talvez tenha relação direta com "Busca", o primeiro conto a ser aqui analisado, como veremos. Mas na resenha o crítico comenta outros contos do livro: "Visita", "Afinação da arte de chutar tampinhas", "Meninão do Caixote" e "MPB", que considera a melhor narrativa do volume.

Apenas recentemente "Busca" passou a merecer leituras mais atentas e iluminadoras, como as de Vima Lia Martin e Simone Paulino. Vima Martin identifica no personagem do conto um comportamento antiburguês, que se volta contra o universo a que ele próprio pertence, prevalecendo a "recusa de Vicente em assumir um lugar socialmente instituído". ${ }^{193}$ A circularidade da história, na visão da autora, atesta a "busca identitária" do protagonista. Ao comentar as constantes entre os dois primeiros contos de $M P B$, "Busca" e "Afinação da arte de chutar tampinhas", Vima Martin identifica os protagonistas de João Antônio ao flâneur. Os personagens do escritor brasileiro seriam recriações dos flâneurs baudelaireanos: "Rejeitando a degradação moral que caracteriza tanto as relações da família patriarcal como as relações de trabalho, sentem-se condenados a uma existência cotidiana sufocante numa grande cidade, engendrando uma busca labiríntica por uma identidade que não conseguem vislumbrar". As marcas desses personagens seriam a "carência" e a "passividade".

Simone Paulino também compara os personagens de "Contos Gerais" ao flâneur e identifica na busca o "princípio de organização da obra"; e Paulino transforma o tema da busca em chave de leitura da obra de João Antônio. Segundo a autora, em João Antônio, “as personagens estão quase sempre deslocadas e desconfortáveis em seus ambientes, por não encontrarem um ponto fixo para se apoiar numa cidade que se metamorfoseia à sua revelia, sendo recorrentemente empurradas para os extremos e colocadas nos limites de seu espaço - físico, emocional e psíquico". ${ }^{194}$ Segundo Simone Paulino, a busca seria, assim,

\footnotetext{
192 BARbosA, J. "Malagueta, Perus e Bacanaço" (1963). In: Opus 60. Ensaios de crítica. São Paulo: Duas Cidades, 1980, p. 138.

${ }^{193}$ MARTIN, Vima Lia. Literatura e marginalidade: um estudo sobre João Antônio e Luandino Vieira. São Paulo: Alameda Editorial, 2008, p. 76.

194 Esse deslocamento dos personagens já havia sido realçado por Flávio Aguiar, como vimos na "Introdução": "O essencial é que nenhum personagem de João Antônio está em sua medida. Um sopro transformador os desengonça a todos (...): eles se fazem símbolos, ao invés de 'retrato fiel' à la naturalismo do século XIX. São símbolos de uma peregrinação universal, daqueles que não têm nas mãos o próprio destino. João Antônio não bate fotos. Pinta quadros apaixonadamente deformados." AGUIAR, F. "A palavra no
} 
um expediente que lhes permite lidar com o sofrimento, "valendo-se do caminhar sem destino como meio de aliviar a angústia de uma condição de isolamento a um só tempo geográfica e psíquica". 195

A permanência de "Busca" não se deve apenas ao gosto do autor e às recentes leituras que o conto vem recebendo. Trata-se de uma história que se mostrará paradigmática e fundante no que se refere à constituição dos personagens e do universo do escritor. "Busca", ao lado de "Afinação da arte de chutar tampinhas", conto que o sucede no primeiro livro, subsiste como uma das mais importantes realizações de João Antônio. Além de alinhavar grande parte dos temas dominantes da obra do escritor, "Busca" já apresenta uma das maiores contradições formais desta literatura: o impulso dos protagonistas à ação revela uma propensão ao romance, à narrativa longa, caracterizada pela confrontação áspera entre indivíduo e realidade, pela tentativa por parte dos heróis de realizar no mundo o âmago de sua interioridade. ${ }^{196}$ E, no entanto, João Antônio escreveu sobretudo contos e notabilizou-se como um dos grandes contistas brasileiros contemporâneos. As narrativas do autor, assim, apesar de anunciar ações romanescas, terminam por se restringir aos limites mais estreitos da forma conto - com raras exceções, como os contos longos, que tendem à forma da novela, como "Malagueta, Perus e Bacanaço" e "Paulinho Perna Torta". Em "Busca" e nos demais textos de "Contos gerais" (a primeira parte do livro Malagueta, Perus e Bacanaço), é possível identificar indícios de por que a literatura do autor, apesar de sua vocação para o romance, terminou por se conformar com os limites menores do gênero curto.

"Busca", especialmente, já apresenta as contradições fundamentais da ficção de João Antônio. O conto opõe família e sociedade, trabalho e ócio, a horizontalidade da busca empreendida pelo protagonista e a verticalidade das interações deste com os demais

purgatório". In: A palavra no purgatório. op.cit., p. 91. O desengonço e o deslocamento também ligam os personagens do autor aos arquétipos do pobre-diabo e do Édipo.

${ }^{195}$ SAntos, Simone Paulino dos. Nas esquinas do desejo. Um estudo do tema da busca nos contos de João Antônio. Dissertação de mestrado em Letras. FFCLH-USP, 2009, pp. 18 e 23.

${ }^{196}$ Sigo aqui as definições de Georg Lukács sobre o romance de formação. A ideia de formação, que tem em Os anos de aprendizado de Wilhelm Meister, de Goethe, sua conformação paradigmática para a literatura, evidentemente não se aplica de maneira direta e sem problemas à literatura de João Antônio. Entretanto, o modelo de aprendizado do indivíduo e de integração do herói ao mundo em que vive ("a reconciliação do indivíduo problemático com a realidade social concreta", nos termos de Lukács) está no horizonte não apenas da literatura de João Antônio, mas na própria concepção de sociedade burguesa (cuja constituição problemática no Brasil de meados do século XX a literatura do autor evidencia) e na relação conflituoso entre o eu e o mundo. Ver LuKÁCS, G. Teoria do romance. São Paulo: Duas Cidades/Editora 34, 2000. 
personagens. As tensões, que neste primeiro conto são colocadas em evidência, não ganham resolução ou desdobramento consequente, o que, do ponto de vista formal resulta em nova tensão, entre o recorte intensivo e a ação vertiginosa, típicos do relato curto, e a distensão de ritmo e a ênfase na constituição e no drama de consciência do protagonista, que são características da narrativa longa.

\section{A angústia da busca}

A história narrada no conto "Busca" é relativamente simples. Vicente, um jovem rapaz solteiro, operário, vive com a mãe num subúrbio de São Paulo. Ele decide sair de casa, num domingo à tarde, para andar. Cogita pegar um trem para o centro da cidade, mas acaba se decidindo por fazer uma visita a Luís, colega de trabalho na oficina onde o protagonista é "chefe da solda". Em suas andanças, evoca a lembrança do pai, que já é falecido, e diz que procura algo que não sabe bem o que é. Depois do encontro com Luís, com quem bebe em um boteco e joga bilhar, Vicente retoma a caminhada e volta a casa, onde, lembra ele, precisa passar uma escova no tanque, sujo de limo.

Além da mãe e do colega, outros personagens aparecem na narrativa, ainda que não participem da ação narrada: Daniel, provavelmente um vizinho, que convida o protagonista para ver futebol na televisão; e Lídia, moça que se dá bem com a mãe de Vicente, com quem faz trabalhos de costura, e que o narrador diz flertar com ele, puxando assunto sobre "festas de casamento". No percurso, o personagem encontra duas crianças, brincando na rua, primeiro um menino, depois uma garotinha, e o encontro com esta, especialmente, o enternece: Vicente imagina que a menina poderia ser sua filha e então cogita, pela primeira vez, casar-se com Lídia. Ao final, o conto retorna ao início, à casa da família. No meio da narrativa, há um trecho, em flashback, em que o protagonista relembra os tempos em que lutava boxe, mas teve de parar depois de ter passado por uma operação, por conta de um problema no fígado, a conselho de Freitas, seu treinador.

Vicente não é mais criança, mas também não é um adulto maduro. Solteiro, ainda vive com a mãe e está incomodado com o assédio de Lídia, que se aproveita da proximidade com a mãe do rapaz para se insinuar, cortejando-o, falando indiretamente de casamento, o que Vicente repudia, de início. No trabalho, ele é bem-sucedido, pois tem 
cargo de chefia; no entanto, irrita-se com a adulação dos demais empregados. Daniel, que vive nas proximidades, gosta da companhia do protagonista, pois o convida para assistir ao futebol na TV, mas como Vicente não se interessa, o amigo expressa sua contrariedade: acha que Vicente "vive no mundo da lua", como relembrará o protagonista-narrador. A mãe, mesmo no domingo, está sempre atarefada com ocupações domésticas, o que também causa contrariedade no personagem-narrador. A irritabilidade e o desnorteamento do protagonista apontam para uma personalidade problemática e imatura.

Vicente quer andar, deixar para trás a casa, o convite de Daniel para o futebol, a paquera de Lídia, a mãe com suas tarefas domésticas, todo o mundo a que está familiarizado. Não se trata de um comportamento extraordinário — ainda que um tanto quanto intempestivo —, mas sim de um hábito recorrente, uma "mania", como o definirá o próprio Vicente. Desde quando, a mania? Desde a morte do pai.

Desde que papai morreu, esta mania. Andar. Quando venho do serviço, num domingo, férias, a vontade aparece. O velho, quando vivo, fazia passeios a Santos, uma porção de coisas. Bom. A gente se divertia, a semana começava menos pesada, menos comprida, não sei. Às vezes penso que poderia recomeçar os passeios.

— Que horas tem trem para São Paulo?

Meia hora não esperaria. Fui caminhando para a Lapa. Mesmo a pé. Os lados da City, tão diferentes, me davam uma tristeza leve. Essa que sinto quando como pouco, não bebo, ouço música. Ou fico analisando as letras dos antigos sambas tristes - dores de cotovelo, promessa, saudade... Essas coisas. ${ }^{197}$

Vicente vincula a mania de andar à morte do pai. A perda da referência paterna, portanto, fez com que o personagem caísse em um estado de luto e de angústia cuja consequência primeira é o "andar" e a "busca" a que o título alude. Andar e busca estão relacionados: "Andando tão devagar. Procurava alguma coisa na tarde”, dirá o protagonista a certa altura. A falta do pai faz com que ele tenha desenvolvido a mania de andar, o que lhe parece ser apropriado para uma procura. A busca, porém, não é clara, não tem objetivo certo, ainda que a saída de casa indique que o objeto da busca não faz parte de seu ambiente familiar. E a "tristeza leve" que o acomete ao se distanciar de casa e percorrer a City Lapa

${ }^{197} M P B$, p. 28. 
(“tão diferente") aponta para uma inibição, uma dificuldade de se afastar. Há ao mesmo tempo desejo e receio no impulso da busca.

Vima Lia Martin já destacara a vinculação entre busca e ausência paterna. Diz a autora:

Relacionada à morte paterna, a mania de Vicente pode ser compreendida como uma busca por preencher o vazio simbólico causado por sua ausência. Em vez de perpetuar as atitudes do pai e, num certo sentido, assumir seu lugar social - casar, ter filhos, tornar-se um chefe de família Vicente parece entregar-se à procura incessante de outra identidade. ${ }^{198}$

O trecho do conto citado acima aponta para uma forte indefinição acerca do protagonista. Ele sabe que quer andar e que o hábito teve início com a morte do pai, mas o luto e a tristeza que advém desse luto se projetam e encontram eco em situações díspares: a música, as restrições de alimentação e de bebida. A tristeza pela morte do pai transfere-se para outras ausências e perdas (as dores de cotovelo dos sambas tristes), para carências de comida e bebida, para atitudes comportadas, retraídas. O sentimento é nostálgico marcado por promessas, saudade, restrições, perdas e pouco definido — "essas coisas", arremata o narrador.

No momento narrativo, Vicente está ocupado com a morte do pai, que o leva a andar. O protagonista vive um luto persistente que o projeta em um estado de melancolia e de indeterminação. No entanto, em sentido contrário, ele busca algo, apresenta-se motivado e inquieto. A angústia e o deslocamento incessantes apontam para um impulso vital, que não pode ser desprezado, em dissonância com o pathos da melancolia, do luto, da perda e da saudade. Este "algo" a ser buscado — que não tem nome, é indeterminado — não está a princípio no âmbito doméstico, como indica o trajeto da casa para a rua empreendido pelo personagem. Assim, apesar de não ser definida pelo protagonista, a busca toma na ação narrada contornos concretos e motivação claramente enunciada: o personagem sente necessidade de andar; e andar, dirá ele, é uma "mania", adquirida desde a morte do pai. É por isso que o personagem decide deixar a casa e sair para a rua, sem direção definida. Morte do pai, mania de andar e busca se aproximam e se mostram relacionadas. Como falta

\footnotetext{
${ }^{198}$ Vima Lia Martin, op.cit., p. 75.
} 
o pai, é preciso andar, buscar algo. Que algo é este e onde ele está? Vicente não sabe dizer e não o encontra no tempo narrado pelo conto.

Vicente sai de casa, pois quer andar. Cogita pegar um trem para São Paulo. Mas acaba se decidindo por uma visita ao amigo Luís. Apesar dos momentos vividos com o colega, persiste a busca por "alguma coisa". Ao final do conto, o personagem não a encontra. Essa busca infrutífera por algo que ele não sabe o que é, mas intui que seja relacionada à falta do pai e possa ser encontrada na companhia do amigo, é aquilo que o protagonista parece querer decifrar - mas não consegue ou, ao menos, não o expressa. Ao fim, Vicente, reconciliado com o mundo em que vive, retorna a casa, volta ao ambiente familiar e à companhia da mãe, rende-se à ideia do casamento com Lídia. A narrativa aponta para a falta de acontecimento, para a manutenção de um estado de coisas e para um protagonista incapaz de ação. Por quê?

\section{Personagem complexo e indefinido}

Vicente, protagonista de "Busca", é o personagem que inaugura o universo ficcional de João Antônio. O protagonista-narrador é um homem jovem e solteiro, de classe baixa, em conflito com seu universo doméstico e social, ocupado com questões de família, vocacionais e existenciais. É um rapaz ainda envolvido em sentimentos infantis, identificado com as crianças que encontra no percurso, indeciso com relação ao seu desejo e, até mesmo, indefinido com relação à própria idade ou estágio de amadurecimento. A idade do protagonista, aliás, não é informada e não pode ser inferida. Apesar dos cabelos brancos, que apontam nas suas costeletas, ele ainda é solteiro, e a recusa a pensar em casamento sugere que é um adulto jovem, que não se julga ainda em idade de casar.

Angustiado e indeciso, em atrito com o seu mundo familiar e profissional, em dúvida sobre seu destino, é um herói problemático, tal como definido por Lukács:

Mundo contingente e indivíduo problemático são realidades mutuamente condicionantes. Quando o indivíduo não é problemático, seus objetivos lhe são dados com evidência imediata, e o mundo, cuja construção os mesmos objetivos realizados levam a cabo, pode lhe reservar somente obstáculos e dificuldades para a realização deles, mas nunca um perigo intrinsecamente sério. O perigo só surge quando o mundo exterior não se liga mais a ideias, quando estas se transformam em 
fatos psicológicos subjetivos, em ideais, no homem. Ao pôr as ideias como inalcançáveis e - em sentido empírico - como irreais, ao transformá-las em ideais, a organicidade imediata e não problemática da individualidade é rompida. Ela se torna um fim em si mesma, pois encontra dentro de si o que lhe é essencial, o que faz de sua vida uma vida verdadeira, não a título de posse ou fundamento de vida, senão como algo a ser buscado. ${ }^{199}$

Vicente é um personagem problemático porque o sentido do vivido lhe escapa e não porque ele não seja capaz de vislumbrar esse sentido, mas porque hesita em aderir ao sentido que o seu meio familiar e social o oferece. Diz Lukács sobre o herói de romance, como vimos acima: seus objetivos não "lhe são dados com existência imediata". A angústia indeterminada do personagem faz com que o leitor acompanhe com interesse suas caminhadas, pois espera por uma resolução, por um encaminhamento, que ao final parece se definir, mas afinal não vem. Vicente termina o conto sem conseguir dar contornos aos seus objetivos e seus desejos, o que reafirma sua condição de personagem indefinido, em processo.

Vicente busca algo, mas não sabe o quê. Indeciso sobre o próprio desejo, ele se inclina à ação, mas se mostra, ao mesmo tempo, incapaz dela. Sua única ação, a rigor, resume-se às caminhadas, à errância que empreende desde sua casa, num subúrbio de São Paulo, até a Lapa, bairro próximo de onde ele reside, para a visita ao amigo, e de volta a casa. Apesar da pobreza da família e do personagem, que é um proletário - trabalha como "chefe da solda" em uma "oficina" —, o que ocupa a atenção do rapaz e move seu impulso para a ação não tem relação direta com a situação profissional em que se encontra ou com ambições materiais. Sua motivação é difusa, a insatisfação que ele sente não se formula com clareza, seu desassossego é indeterminado e a própria estrutura do conto e, mais que isso, a própria elocução apresentam certa desarrumação, errância de estilo e de construção narrativa que fazem do texto uma realização incompleta - mas também intrigante, pois que em consonância com a matéria narrada.

Apesar da dispersão e da tendência à indeterminação vale ressaltar algo de preciso em relação ao primeiro protagonista dos contos de João Antônio. Aliás, duas coisas dignas de nota contrariam a dispersão e a errância, fazendo contraponto à busca, à horizontalidade da ação e ao alargamento do espaço. A primeira, como se disse, é que a ação do conto, ao

${ }^{199}$ LuKács, G. A teoria do romance. São Paulo: Duas Cidades/Editora 34, 2000, p. 79. 
fim e ao cabo, retorna ao início, conferindo circularidade à ação e também forte senso de unidade. A segunda é que o rapaz tem nome e narra a ação, isto é, é um narradorpersonagem. Em outras palavras, há no conto um personagem forte e uma ação que se desenvolve, ainda que de maneira errática, mas com começo, meio e fim, um fim que coincide com o começo, e é desenvolvida sempre do ponto de vista do protagonista.

Chama-se Vicente o personagem central, o que lhe confere singularidade, individualidade e, talvez antes de mais nada, caráter ficcional manifesto, se pensarmos, como Anatol Rosenfeld, que "a personagem realmente constitui a ficção". ${ }^{200}$ Com isso, o personagem-narrador afasta-se, primeiramente, da identificação imediata com o escritor e institui um ponto de vista narrativo próprio, que irá presidir a ação. Vale ressaltar esse aspecto do primeiro conto, que será mantido na maioria dos contos do primeiro livro, quase todos narrados em primeira pessoa. Mas o nome próprio dado ao personagem é exceção e singulariza esta primeira narrativa, pois em outros textos do mesmo volume os protagonistas simplesmente não têm nome ou atendem por seus apelidos, alcunhas ou nomes de guerra. O fato de o estatuto ficcional do conto estar bem sublinhado desde o primeiro texto é importante também para a constituição da obra como um todo de João Antônio, que nesta primeira realização afirma-se claramente como ficção, diferentemente de textos posteriores do autor, que, como vimos, são mais ambíguos quanto a esse caráter, apoiando-se no limiar entre ficção e relato autobiográfico. Mais que isso, o personagem tem aqueles traços fortes que o destacam enquanto criação ficcional, distanciando-o de um indivíduo real.

Segundo a definição de Antonio Candido, o personagem é um "ser fíctício", que se distingue da pessoa de carne e osso por conta de certas constantes de comportamento, que permitem identificar "a lógica da personagem" ou sua "coerência interna"201.

No caso de Vicente, sua lógica é a inquietação, a insatisfação e a falta de algo, que ele não sabe o que é, mas que o faz andar, empreender um caminho de busca, a "mania" de andar. É um protagonista que sabe ocupar o seu posto de destaque na narrativa, acima dos demais personagens, por justamente problematizar o próprio destino e expressar essa

\footnotetext{
${ }^{200}$ RosenfelD, A. "Literatura e personagem”. In: Antonio Candido et al. A personagem de ficção. São Paulo: Perspectiva, 1976. $5^{\text {a }}$ edição, p. 27.

${ }^{201}$ CANDIDO, A. "A personagem do romance". In: A personagem de ficção. São Paulo: Perspectiva, s/d.
} 
inquietação. ${ }^{202}$ Como define Lukács, comparando a epopeia ao romance, a psicologia do herói romanesco se pauta justamente pela busca. ${ }^{203}$

Apesar de ser um narrador-personagem de um conto, o protagonista de "Busca" tem todas as características de um personagem de romance. Como o definiu Lukács, o herói de romance é um indivíduo isolado cuja principal motivação é a procura do sentido do vivido - ele "busca" algo.

Vicente se insere em um quadro arquetípico ${ }^{204}$ de personagens que remete, pelo menos, ao século XIX, mas também à tradição literária secular da "busca”. O personagem e seus sucessores (os protagonistas anônimos de "Aact" e "Fujie") aproximam-se do flâneur, como indicam as leituras citadas. É também um personagem de tons balzaquianos, aparentado a Rastignac e Lucien de Rubempré, e ainda ao Julien Sorel de Stendhal e ao Frédéric Moreau de Flaubert, mesmo que sem a potência arrivista e o trânsito social desses rapazes. Nesse sentido, Vicente é um sucedâneo daquela linhagem de personagens que Lionel Trilling chamou de "young men from the provinces" (jovens rapazes das províncias $)^{205}$, mas cuja trajetória da província à cidade ou da periferia ao centro não se completa. No entanto, para além dessa face moderna, que faz o jovem personagem do autor se aparentar ao herói de romance, sua trajetória também deita raiz em arquétipos mais antigos, que dizem respeito à história recorrente da busca ou procura, cujo parâmetro é a demanda do Graal. Vicente, e como veremos, os outros jovens protagonistas de João Antônio são protagonistas de uma história que se inspira em uma linhagem frutífera deste arquétipo, aquilo que Frye chama de mythos do verão ou estória romanesca. ${ }^{206}$

\footnotetext{
${ }^{202}$ LUKÁCS, G. "A fisionomia intelectual dos personagens artísticos". In: Marxismo e teoria da literatura. $2^{\mathrm{a}}$ edição. São Paulo: Expressão Popular, 2010.

203 "A epopeia dá forma a uma totalidade de vida fechada a partir de si mesma, o romance busca descobrir e construir, pela forma, a totalidade oculta da vida. A estrutura dada do objeto - a busca é apenas a expressão, da perspectiva do sujeito, de que tanto a totalidade objetiva da vida quanto sua relação com os sujeitos nada têm em si de espontaneamente harmonioso - aponta para a intenção da configuração: todos os abismos e fissuras inerentes à situação histórica têm de ser incorporados à configuração e não podem nem devem ser encobertos por meios composicionais. Assim, a intenção fundamental determinante da forma do romance objetiva-se como psicologia dos heróis romanescos: eles buscam algo." LuKÁCs, G. A teoria do romance. op.cit., p. 60.

${ }^{204}$ Sigo aqui a concepção de arquétipo literário de N. Frye em Anatomia da crítica. São Paulo: Cultrix, 1973.

205 TrILling, Lionel. "The Princess Casamassima". In: The liberal imagination. Essays on literature and society. Nova York: The Viking Press, 1950.

${ }^{206}$ FRYE, N. Anatomia da crítica. op.cit. Ver o terceiro ensaio do livro, "Crítica arquetípica: Teoria dos mitos", pp. 131-219. Não se trata de classificar de "história romanesca" este conto (e os demais "Contos Gerais", assim como "MPB", aos quais também se aplica a definição de mythos de verão), mas de apontar como neles predominam o mythos da aventura e da demanda, ainda que os textos tenham elementos de outros mythoi ou "enredos genéricos". Como diz Frye, os diferentes mythoi muitas vezes contrastam, mas também se
} 
A contradição, que colabora com a construção do protagonista, é que Vicente é um personagem que tende ao tipo e ao arquétipo, mas é também um herói problemático, que questiona seu próprio destino e sua condição social e afetiva. No conto, a busca de Vicente preserva elementos dos modelos arquetípicos de herói mítico, romanesco, o que faz dele um personagem plano, ao mesmo tempo em que a psicologia hesitante e angustiada do personagem aponta para um personagem esférico, de personalidade complexa, consciente de si mesma, típica de um personagem de romance, ainda que esta condição permaneça apenas latente e que ao final, o protagonista retorne ao ponto de partida, sem que mudanças significativas tenham ocorrido, tendendo à planificação. ${ }^{207}$ Em outras palavras, o conto "Busca" relaciona-se e deita raízes em tradições literárias antigas e modernas, sem que essa contradição se resolva no âmbito da ação narrada.

Essa combinação inusitada de raiz mítica, inspiração romanesca e de constituição de personagem de romance faz com que a história ganhe forma literária moderna e, ao mesmo tempo, desenvolvimento modesto. Apesar da tendência ao romanesco e ao romance, a ação se conforma em conto. Como veremos, a constituição das narrativas e dos protagonistas em João Antônio vai culminar nas trajetórias mais distendidas de "MPB" e "PPT". Este último conto, em particular, como tentaremos mostrar no capítulo 4, investiga, de maneira mais consequente, as possibilidades narrativas e de constituição do herói na literatura do autor. Em "Busca", porém, a narrativa não se estende e a trajetória de Vicente resulta em uma narrativa breve, que começa e retorna à origem, sem que seu comportamento ou sua consciência sobre si próprio se altere ou sua procura tenham chegado a algum termo. A construção de Vicente como personagem e a própria trama narrativa de "Busca" lembram, em negativo, a formulação de Modesto Carone ao definir o gênero de narrativa curta:

combinam: "Se pensarmos em nossa experiência desses mythoi, perceberemos que formam dois pares opostos. A tragédia e a comédia contrastam em vez de combinar, e assim também o romanesco e o irônico, campeões, respectivamente, do ideal e do real. Por outro lado, a comédia funde-se insensivelmente na sátira, num extremo, e na estória romanesca, no outro; pode a estória romanesca ser cômica ou trágica; a trágica se estende do romanesco elevado ao amargo e irônico realismo" (p. 163). Como veremos no capítulo 4, "Paulinho Perna Torta" enquadra-se na categoria "estória romanesca trágica", combinando o que Frye chama de os mythoi de verão e de outono. Da mesma forma, na teoria dos modos de Frye, os cinco modos (mítico, romanesco, imitativo alto, imitativo baixo e irônico) caminham num círculo em que mito e ironia se tocam. Também é o que acontece em "PPT", que combina características do mito, da tragédia e, ao final, da ironia trágica, na condição de phármakos ou bode expiatório (vítima típica do modo irônico) do protagonista.

${ }^{207}$ A conhecida distinção entre personagens planos e redondos ou esféricos é de Forster, que define os primeiros como tipos, personagens previsíveis, repetitivos, construídos "em torno de uma ideia" ou "qualidade simples", e os outros como capazes de "surpreender de maneira convincente". Ver FORSTER, E.M. Aspectos do romance. Trad. Sérgio Alcides. $4^{\mathrm{a}}$ ed. revista. São Paulo: Globo, 2005, pp. 91-100. 
segundo Carone, o conto é "representação intensiva de um instante da existência no qual o herói passa de um patamar de consciência para outro — superior". ${ }^{208}$ O leitor do conto espera por uma reviravolta, pelo desenlace, pela mudança de consciência do protagonista, mas ao final Vicente retorna à casa, sem que tenha alterado sua percepção do mundo ou de si próprio.

Para acrescentar mais ingredientes contraditórios de elaboração literária, ao estatuto ficcional e arquetípico bem marcados vem se juntar, em sentido contrário, a narração em primeira pessoa, que acentua a aproximação entre: narrador-personagem e mundo narrado, protagonista e demais personagens, universo ficcional e o leitor.

A narrativa que parte e se encerra no eu, no ponto de vista de Vicente, pede a cumplicidade de todas as demais instâncias literárias. O foco narrativo em primeira pessoa faz com que pisemos, todos, o mesmo chão. Estamos, assim, olhando o mundo de Vicente por dentro, internamente ao mundo que se vai descortinando aos poucos, mas sempre enredados na perspectiva do narrador-personagem.

Disso decorrem duas coisas importantes para a recepção e a compreensão do texto. A primeira delas é que o leitor se inclina a aderir ao ponto de vista de Vicente. A segunda, é que tende a se restringir ao universo - já bastante restrito - do personagem.

$\mathrm{O}$ ponto de vista interno e a restrição do universo em que vive Vicente são elementos de construção literária que permitem melhor compreensão das contradições deste conto de João Antônio.

Trata-se de uma narrativa sobre a busca, algo que falta e que o personagem não sabe dizer o que é, justamente porque, assim como o foco narrativo em primeira pessoa restringe o alcance do que se narra, o universo em que o personagem se insere é restrito do ponto de vista social, cultural e psicológico.

Ainda que seja constitutiva da narrativa e concorra para dar verossimilhança à ação e coerência ao personagem principal, a delimitação do foco narrativo e o universo de atuação de Vicente estão a todo momento sendo colocados à prova. A busca desestabiliza a unidade da ação e a coerência do ponto de vista: ao mesmo tempo que é sujeito da busca, o protagonista sucumbe a ela e termina por fracassar. Os momentos críticos do conto, assim,

${ }^{208}$ CARone, M. “Anotações sobre o conto". In: Boa Companhia - Contos. S. Paulo: Companhia das Letras, 2003. 
são aqueles em que o encontro com outros personagens, no momento da ação narrada, promete alterar os termos da busca, conduzindo-a a um desfecho revelador ou significativo, o que a forma conto promete, gerando no leitor expectativa de desenlace, na trama, e mudança de consciência, no protagonista.

Porém, os encontros mantêm a busca e, ao final, terminam por questioná-la e, com a volta do personagem-narrador a casa, até anulá-la, destituindo sua necessidade ou sua razão de ser. Veremos por quê.

\section{Limites de um ponto de vista interno}

Apesar de ser narrado em primeira pessoa, "Busca" tem início não com o discurso do narrador-protagonista, mas com uma fala de um personagem a outro, seguida de uma ação do personagem-narrador em resposta a essa fala.

— Vicente, olha a galinha na rua!

Abri o portão, a galinha pra dentro. Mamãe tinha o avental molhado do tanque. Um balde pesava no braço carnudo.

- Deixa qu'eu levo. ${ }^{209}$

Trata-se de um conto que tem início dentro da ação já em desenvolvimento, como se o leitor fosse inserido diretamente no quadro narrativo. A ação inicial se dá entre dois personagens: Vicente, o protagonista-narrador, e a mãe dele, e se passa no ambiente doméstico. O diálogo define certos contornos desse espaço: é uma casa simples, em que se criam galinhas (ou pelo menos uma galinha, $a$ galinha que escapuliu para a rua), e a mãe é quem cuida dos afazeres de casa, pois tem um avental molhado do trabalho no tanque e carrega um balde pesado no braço, o que aponta para o acúmulo de tarefas (o avental remete não só ao tanque, mas à pia e ao fogão; o tanque, à roupa, lavada à mão; o balde, à limpeza pesada).

A frase que abre o texto é uma fala da mãe do protagonista e narrador, Vicente. No que se refere à ação do conto, como se disse, a frase insere o leitor diretamente no curso da ação narrativa, como se os acontecimentos não tivessem se fixado com distanciamento na

\footnotetext{
${ }^{209} M P B$, p. 27.
} 
elaboração de quem narra. É como se o narrador tivesse sido surpreendido, de supetão, por algo que escapa ao controle dele próprio e, no entanto, tem relação direta com ele, ou melhor, é de responsabilidade dele, como atesta a frase da mãe. A fala avisa que a galinha escapou de casa e pede que ele faça algo. Ela é uma exclamação, mas também uma reclamação velada. A reação do protagonista é de prontidão e anuência: ele abre o portão de casa e põe a galinha para dentro. Acorre também para poupar a mãe do peso do balde.

A situação inicial configura uma relação de grande proximidade e dependência entre mãe e filho, além de indicar certos elementos de condição social. Trata-se de uma casa simples, devassada e até certo ponto vulnerável, como indica o trânsito da galinha entre interior e exterior. Apesar de ser domingo, a mãe - chefe de família, já que falta o pai, como o leitor saberá em seguida - ocupa-se dos afazeres domésticos, como se não fosse dia de descanso ou folga.

A oposição entre casa e rua é marcada desde o princípio do conto, e os dois polos encontram correspondência nos dois personagens centrais: a mãe personifica a casa e a atração para o ambiente interior; o filho quer ganhar a rua, e seus pensamentos e desejos, ainda que difusos, o impelem para fora.

É domingo. A mãe está ocupada em lavar roupa e com a limpeza de casa. Vicente diz que Daniel - um vizinho, provavelmente -, o convidara para assistir futebol na TV. Lembra de Lídia, moça que se dá bem com a mãe, pois costumam costurar juntas, e que "cismou" com ele, "vive de olhadelas, risinho, convite para festa de casamento". Enquanto os pensamentos andam um pouco a esmo, o rapaz avança em seu passeio a pé, desde a casa onde mora, com destino incerto: "Atravessei a ponte. Tinha trocados no bolso, me enfiaria num trem, acabaria na estação Julio Prestes. Daniel com a televisão e Lídia com costuras... Eu queria andar".

A ação do protagonista, assim, é errática. Naquele domingo à tarde, em que não há compromissos profissionais e a mãe toma conta da casa, ele recusa os convites do amigo e da moça que the acena com interesse amoroso. Recusa, para resumir, o universo da casa, da vizinhança e da família, tanto a família que ele tem, como a família prometida pelas insinuações de Lídia e seu "convite para festa de casamento".

Vicente quer andar. Quer outro espaço, ainda que ele não saiba dizer exatamente qual ou por quê. A busca a que o título alude não é formulada com clareza. O objeto da 
procura do protagonista, ele próprio não sabe dizer qual seja: “(...) por dentro estava era triste, oco, ânsia de encontrar alguma coisa (...)"; e, mais adiante, quase no fim do conto: "Andando tão devagar. Procurava alguma coisa na tarde. O vento esfriou. Não sabia bem o quê, era um vazio tremendo. Mas estava procurando". Trata-se portanto de uma inquietação sem nome, algo próximo da angústia.

O estilo da narrativa, isto é, a própria elocução do protagonista se mostra dispersiva, sem norte. A esse respeito veja-se o final do conto, onde a expectativa de um desenlace é frustrada, em função da permanência do devaneio sem rumo do narrador-protagonista:

Domingo chato, mole, balofo, parecia estar gestando alguma coisa. Uma idéia extravagante:

- Preciso cortar à escovinha. Assim escondo os começos de cabelo branco...

Chegaria em casa, beijo na testa da mamãe, cumprimentos para Lídia. Ela repetiria o jogo - indiretas, risinho, interesse, por que não faço isso, por que não gosto de... Mas o vazio não passaria. Comer alguma coisa, botar o paletó. Andar de novo.

$\mathrm{Na}$ rua de pedregulho mal socado o sapato novo subia, descia. Sem pressa, mole. A garotinha do jardim público poderia ser filha minha. Este pensamento agradou-me, jogou-me uma ternura. Cortar à escovinha, que ideia! Lídia maneira, pequenina, talvez desse boa mulher. Pensei com raiva nos sujeitos que me bajulam na oficina. Tontos! A prática que tenho, terão também se quiserem. Mas ficam é com amabilidades falsas, favores bobos — "tenha a bondade", "Vicente, só você pode resolver". Murmurei entre os dentes:

- Ora, fossem plantar batatas...

Julguei muito necessário recomeçar os passeios a Santos, a Campinas... Eu e mamãe. Talvez as semanas começassem melhores, menos compridas. Segunda-feira, não parecendo já o cansaço de quarta...

Agora o sol descendo por completo. Uma lua em potencial, lá em cima, ganhava tons, parecia uma bola de ocre. Enorme, linda. Meus olhos divisavam no fundo de tudo o Jaraguá, mancha grande meio preta, meio azul... Meus olhos não precisavam. Era a hora em que as coisas começavam a procurar cor para a noite.

Lembrei-me de que precisava passar uma escova no tanque. ${ }^{210}$

O foco narrativo em primeira pessoa faz com que a elocução coincida com os pensamentos de Vicente. Frases nominais, recordações, mudanças bruscas de opinião, a percepção da passagem do tempo e, sempre, a caminhada, tudo se passa na interioridade de

${ }^{210} M P B$, p. 32. 
Vicente. Próprias de um pensamento que se deixa deambular, em devaneio, a desarrumação narrativa e a errância com que a elocução se dá conferem ao conto uma conformação pouco definida, aberta e incompleta, em que a organização do espaço está sempre, potencialmente, instável e em constante alargamento e expansão.

Não é fácil localizar neste primeiro conto, por exemplo, as sugestões de unidade de tom e efeito, recomendadas por Edgar Allan Poe ${ }^{211}$, ou aquilo que Julio Cortázar ${ }^{212}$ chama de "acontecimento significativo" - o episódio crucial da ação, para o qual tudo concorre, no qual os significados da narrativas se tornam evidentes e a partir do qual outros sentido se abrem. A errância do personagem, o estilo centrífugo e dispersivo, ao contrário, levam a ação e a própria narrativa a uma conformação solta, condizente com a "busca" indefinida que é, afinal, o tema do conto. Busca indefinida que, por sua vez, proporciona o devaneio, o pensamento sem rumo, a indeterminação dos objetivos e desejos, típicos de um indivíduo problemático.

A busca sem rumo conduz, assim, a uma elaboração errática e no plano da composição a uma elocução desarrumada. O devaneio do protagonista, se por um lado acentua o seu caráter de indivíduo isolado, desejante e fabulador, por outro confere à forma certa inconstância, certa desarrumação e um inacabamento que corrobora a noção de um conto esgarçado, sem "acontecimento significativo".

Começo e final se equivalem, repondo a situação inicial. Vicente sai de casa, passeia, deambula e devaneia, busca algo que não encontra e não descobre o que é. $\mathrm{E}$ retorna a casa sozinho.

No entanto, apesar da solidão do protagonista, que se mantém do início ao fim do relato, três encontros acontecem no momento presente da narrativa: o primeiro, com um menino que joga bola na rua; o segundo, com Luís, na casa deste, que entretanto não parece atender às expectativas de Vicente, mantendo-o em um estado de angústia, de busca sem direção; e o terceiro, com a menina no jardim público, o que reconduz o pensamento de Vicente não ao universo da busca, mas em direção ao mundo que ele já tem: a menina poderia ser sua filha, ele mesmo conclui, e seus pensamentos retornam ao mundo familiar e da família - a paquera de Lídia, a adulação dos colegas de trabalho, o convite do amigo

\footnotetext{
${ }^{211}$ POE, Edgar Allan. "Filosofia da composição'. In: Poemas e ensaios. Trad. Oscar Mendes e Milton Amado. São Paulo: Globo, 1999.

${ }^{212}$ CORTÁZAR, J. “Alguns aspectos do conto”. In: Valise de cronópio. $2^{a}$ edição. São Paulo: Perspectiva, 1993.
} 
Daniel, a mãe e, finalmente, a casa, onde ele lembra que tem a tarefa de passar uma escova no tanque.

Apesar desses três eventos importantes, a ação principal - o acontecimento significativo, que ordena todas as demais ações da trama - parece ter se perdido em algum ponto das elucubrações do personagem-narrador.

Assim, os episódios se sucedem, e acompanham as reflexões, também erráticas, do protagonista: Vicente sai de casa, atravessa a ponte, cogita pegar o trem até a Estação Júlio Prestes mas vai caminhando para a Lapa, onde mora Luís, colega de trabalho na oficina; no caminho, entra por uma rua desconhecida e sua atenção se dispersa pela vizinhança, onde ele nota os jardins floridos, os moradores do bairro ainda de pijama em espreguiçadeiras; depara-se com um menino que joga bola; relembra uma passagem de juventude, quando era pugilista e teve de deixar o boxe por conta de uma operação no fígado; faz uma visita à casa de Luís; continua a andar, para os lados do Piqueri, enquanto relembra o conhaque bebido num boteco e a partida de bilhar com o amigo; senta-se num banco de jardim público, onde enumera lembranças: o tempo de quartel, "maluqueiras", "farras", "porres", boxe; uma "frase qualquer" vem-lhe à cabeça e o faz lembrar dos primeiros cabelos brancos que apontam "incisivos" nas costeletas; uma menina, ainda criança, passa e lhe dá um tapinha no joelho; ele conversa com a menina, e lhe oferece um sorvete de palito, até que a empregada da criança aparece na praça e a leva embora; Vicente volta a andar e falar de sua procura, "alguma coisa"; faz considerações sobre a "gente de subúrbio mesquinho", que se aperta nos ônibus durante a semana e no domingo vai ao cinema, "grande coisa"; continua a andar e os pensamentos se voltam para o universo doméstico mais uma vez, onde encontraria Daniel, Lídia e a mãe.

Como se vê, ressalte-se mais uma vez, os episódios se sucedem e não se organizam claramente, tanto do ponto de vista da ação do conto quando no que se refere às reflexões de Vicente. A sensação é de que nada acontece e que a narrativa é aberta, sem tônus, sem tensão, sem desfecho, contrariando as recomendações de Poe e as expectativas do leitor, o que poderia ser visto como índice de modernidade e experimentalismo, como se a ausência de ênfase e de um final — um pouco à maneira de Tchékhov ${ }^{213}$ —, conformassem o texto.

\footnotetext{
${ }^{213}$ Como observa Boris Schnaiderman a respeito da forma aberta de Tchekhov: "O não-desfecho, ou melhor, um desfecho diferente do consagrado, sugerindo continuidade, afastava o leitor do enclausuramento no determinismo causal do século XIX. Neste sentido, Tchekhov prenuncia a subversão da noção consagrada de
} 
O trajeto empreendido pelo protagonista parece perdido, e ao menos em uma leitura mais ligeira, o conto parece ser daquelas narrativas abertas, em que a falta de consequência da ação contraria as expectativas mais assentadas do leitor, que naturalmente espera que a busca anunciada no título seja cumprida.

No entanto, em sentido oposto, o conto também se volta sobre si mesmo, ostentando algo daquela "esfericidade" ou "forma fechada" a que se refere Cortázar. ${ }^{214}$ A desorganização narrativa, que diz respeito à ação, mas também à elocução do narrador, só não é mais exasperada justamente porque a circularidade espacial do relato e certos traços do protagonista compensam a dispersão, conferindo coesão e certa completude de sentido, na reconciliação que o retorno a casa proporciona. O leitor fica pensando se, talvez, a busca do protagonista, afinal, não esteja dada no universo que ele já conhece.

O caráter circular da ação e a dimensão esférica, fechada, do ponto de vista diz muito sobre o personagem-narrador. Vicente é um rapaz que, apesar da angústia que sente, é incapaz de escapar aos limites em que está encerrado. Tais limites são espaciais, mas sobretudo psicológicos, morais e culturais: não há referência a sua formação escolar; o rapaz trabalha "desde menino"; é refratário ao desejo de Lídia, pouco importado se the dizem que "ela é direitinha", mas afinal se rende à ideia de casar com ela.

O personagem que se contrapõe a Vicente e permite identificar melhor as limitações do protagonistas é Luís, o colega de trabalho. "Sujeito diferente", é como Vicente se refere a ele, antes de encontrá-lo. Diferente porque "meteu-se com estudos à noite, esforça-se". Vicente não consegue articular bem a própria elocução, mas Luís, por sua vez, é desenvolto. Se Vicente está ocupado desde menino em um trabalho alienado, Luís se mantém estudando e se formando para além da ocupação que tem hoje. Vicente é soldador, Luís é desenhista. Se o protagonista gosta das letras de samba, o amigo, por sua vez, tem livros em casa.

O encontro com Luís é indicativo da dificuldade de Vicente de estabelecer novas relações sociais. O rapaz é visto como um colega "ótimo", que não bajula e "só abre a boca

tempo. Em termos de estória curta, na base de episódio na aparência sem maior importância, Tchekhov nos aproxima de uma noção de tempo como a de Proust e como a de Virginia Woolf ". Posfácio a TCHEKHOV, A. A dama do cachorrinho e outros contos. São Paulo: Editora 34, 1999, p. 335. Ver também TCHEKHOV, A. Sem trama e sem final. São Paulo: Martins Fontes, 2007.

${ }^{214}$ CORTÁZAR, Julio. "Do conto breve e seus arredores". In: Valise de cronópio. op.cit., p. 228. 
para coisa aproveitável". No entanto, a visita ${ }^{215}$ que Vicente lhe faz resulta na manutenção do estado de espírito angustiado e dispersivo do protagonista, que se sente diminuído ao tomar contato com o universo íntimo e intelectual de Luís.

A maneira com que Vicente reage ao visitar o amigo acentua a percepção, por parte do leitor, das limitações sociais, intelectuais, psicológicas e de formação do protagonista. No entanto, o rapaz tem certa consciência das limitações que vive. A casa está precisando de manutenção e a mãe vive sobrecarregada de ocupações. No trabalho, apesar do seu cargo de chefia, a alienação das funções ("Vicente, só você pode resolver") e os favorecimentos que se estabelecem (ele se sente "adulado") fazem com que suas relações com os colegas estejam desgastadas. Vicente é respeitado não pelo que ele é, mas por seu status de chefe. É em relação ao "subúrbio mesquinho" onde vive, porém, que o protagonista é mais enfático quanto ao seu descontentamento:

Os ônibus passavam carregando gente que volta do cinema. Para essa gente de subúrbio mesquinho, semana brava suada nas filas, nas conduções cheias, difíceis, cinema à tarde, pelo domingo é grande coisa. Viaja-se encolhido, apertado. Os ônibus se enchem.

— Essas vilas por aí são uma miséria.

Aluado e dado a devaneios, Vicente gostaria de viver outra realidade, mas é parte do subúrbio e das vilas em que circula e onde reconhece os moradores, que são todos da mesma classe que ele. Gente que gosta de samba, de cinema e de passeios, como ele, gente trabalhadora, que passa a "semana brava suada nas filas", mas miserável ("essas vilas por aí são uma miséria", como diz o narrador) e de moralidade estreita (como indica o adjetivo "mesquinhos", de forte conteúdo moral, atribuído aos bairros suburbanos).

Como ressalta Vima Lia Martin, já tendo em vista as outras narrativas de João Antônio, Vicente é um "otário", em oposição aos "malandros", na tipologia de personagens que aparecerão posteriormente na obra do autor. A inserção de Vicente na ordem do trabalho é clara e, de fato, aproxima o personagem do tipo, aos olhos dos malandros que o considerariam um "trouxa". No entanto, Vicente é um otário ou trouxa "aluado", como

\footnotetext{
215 "Visita", narrativa do mesmo livro, inserido na seção "Sinuca", é um conto que se assemelha a "Busca", mas um pouco maior. O protagonista, ao contrário de Vicente, porém, não é nomeado, apesar de o amigo ter nome, Carlinhos. Entretanto, é um personagem mais consciente de seu conflito com o mundo, isto é, com a sociedade em que se insere. E, ainda assim, como Vicente, é protagonista de uma busca infrutífera.
} 
atesta a opinião de Daniel de que Vicente vive no mundo da lua (lembre-se aqui que o livro teve como primeiro título, depois descartado pelo autor, Aluados e cinzentos). ${ }^{216}$ A grande contradição, portanto, é que o rapaz, apesar de saber de suas próprias limitações e de irritarse com isso, está encerrado em seu próprio mundo.

Limitado do ponto de vista de sua formação, pois foi obrigado e a trabalhar "desde menino", insatisfeito com o trabalho que o mantém e no qual é bem-sucedido, descontente com o círculo familiar e social, ele sente o impulso de romper com essa situação, mas seus sentimentos são indeterminados, nostálgicos, e suas estratégias são pouco claras ou... regressivas, pois ele se identifica fortemente com as crianças que encontra ao acaso e, ao final, abre mão da busca, reconciliando-se com o universo doméstico, ao voltar para casa e para a companhia da mãe, cogitando, inclusive a possibilidade de casar com Lídia, a moça de eleição materna - costureira como a mãe do protagonista.

É a própria constituição do personagem, portanto, que está em questão no texto. Ocupado com o luto pela morte do pai e com as atribulações domésticas, Vicente sai de casa à procura de algo que não sabe o que é, mas encontra um confrontamento de si para consigo mesmo. O isolamento do personagem o conduz a um exame de sua própria situação - familiar, social, psicológica. O caminho que se insinua é o da emancipação, da inserção social e do arrivismo, a trajetória da periferia para o centro — da casa para a rua ou do "subúrbio mesquinho" para "São Paulo", nos termos do conto —, mas o que ocorre é a reposição da situação familiar nuclear e a conservação dos valores morais "mesquinhos" e patriarcais, em que o papel de Vicente é o de filho obediente e dedicado; mais que isso, como ele cogita ao final: seu destino é o de substituto do pai.

Ao final do conto, ressalte-se, o protagonista pensa em retomar, na companhia da mãe, os passeios que o pai empreendia quando este, obviamente, ainda era vivo, o que aponta para o passado, para a juventude e a infância do protagonista. Ultrapassar o lugar do pai e romper com a ordem familiar, simbolicamente, seria a saída natural de emancipação do personagem, mas a trajetória de Vicente é literal e conformada: ele sai rumo ao mundo exterior, em busca de aventura e ação, mas ao final retorna ao seio familiar, onde vai ocupar o lugar vago deixado pela figura paterna.

\footnotetext{
${ }^{216}$ Além de Aluados e cinzentos, o autor também cogitou intitular o livro de Meninão do caixote e de Fujie e outros contos, além de ter planejado diferentes versões do livro (e até de não incluir o conto "Malagueta, Perus e Bacanaço" no livro de estreia). Ver LACERDA, R. João Antônio: uma biografia literária. op.cit.
} 
Porém, o percurso da busca, que é ao final retorno, é desestabilizado três vezes, como se disse, em encontros que conferem tensão o desenvolvimento da ação narrada. Vejamos como eles se dão.

\section{Três encontros e um retorno}

Ao sair de casa, Vicente se afasta da família e do que lhe é familiar. Não quer saber da companhia da mãe, absorta com as ocupações domésticas, nem de Daniel, com o futebol na televisão, nem de Lídia, a pretendente que ele evita. Em suas andanças, Vicente terá três encontros, dois deles fortuitos, e apenas um deles premeditado. No percurso da busca, portanto, alguns episódios refreiam o ímpeto horizontal de alargamento do caminho. Os personagens com quem Vicente é confrontado suspendem a busca por alguns instantes, fazendo a narrativa mudar de vetor, ganhando verticalidade.

A primeira pessoa com quem Vicente se depara é um menino que joga bola na rua.

Entrei por uma rua que não conhecia. Olhava para tudo. Jardins, flores, mangueiras esquecidas na grama, gente de pijama estendida nas espreguiçadeiras. A bola de borracha subia e descia no muro. Um menino veio. O que eu adoro nesses meninos são os cabelos despenteados. Chutei-lhe a bola, que ela corria para mim. Transpirava, botou a mão no ar agradecendo.

- Legal!

Ele disparou, vermelho de sol.

Ao andar pela Lapa, o protagonista olhava para tudo, com uma espécie de espanto ou, pelo menos de curiosidade. A descrição que ele faz do bairro, a City Lapa, que lhe dava uma "tristeza leve", como ele já havia dito, é a de um bairro tranquilo e relaxado, com pessoas em espreguiçadeiras, com jardins bem cuidados, flores e crianças brincando na rua. É um bairro residencial mais rico que o subúrbio onde Vicente mora.

O trecho prepara a chegada de Vicente à casa de Luís. Mas o encontro com o menino, ainda que muito rápido e fortuito, é sugestivo, pois pela primeira vez na ação narrada Vicente interage com outro personagem além da mãe. Vicente lhe chuta a bola e faz uma observação interessante sobre os cabelos da criança: “O que eu adoro nesses meninos são os cabelos despenteados". 
Os cabelos despenteados do garoto indicam que o menino tem cabelos compridos, revoltos, desalinhados, e a descrição destaca a desarrumação do personagem. A forte identidade entre ambos é rápida e não tem desenvolvimento. A criança agradece a devolução da bola. Vicente observa que "adora" os cabelos despenteados do menino. A simpatia e o enlevo do protagonista para com o menino marca uma mudança de tom no relato, depois da "tristeza leve" e da irritação do protagonista com Daniel, Lídia e os colegas que o adulam na oficina. $\mathrm{E}$ os cabelos do menino irão ecoar, um pouco à frente, na observação que Vicente fará sobre o próprio penteado. Como o leitor será informado mais adiante — sem que isso seja dito explicitamente, porém — é um tipo de cabelo parecido com o que provavelmente Vicente também usa.

Depois do encontro com o menino, o desenvolvimento da ação no momento presente da narrativa é interrompido. O conto ganha uma marcação gráfica, que separa esta primeira parte do relato do que virá a seguir. ${ }^{217} \mathrm{Na}$ parte que se segue, o tempo do conto muda radicalmente, estruturando-se em flashback. Vicente relembra então o episódio que o fez abandonar o boxe. Voltaremos a esse tema adiante. Por ora, é mais interessante saltarmos esse trecho de evocação, pois quando este se encerra a ação narrativa segue com o segundo encontro do protagonista.

O segundo encontro é com o colega de trabalho. Agora, afinal, Vicente chega à casa de Luís. A descrição da casa acentua o contraste da condição de vida do amigo, em relação à do protagonista:

Luís ficou muito contente. Jamais pensei que tivesse casa tão bem disposta. Capricho nas paredes, tinhorões no jardim. Em seu quarto, mostrou-me livros, entusiasmou-se com uns desenhos sobre a prancheta. Disse-lhe sem sentir, olhando linhas em nanquim preto:

- Você deve continuar. Desenho arquitetônico dá dinheiro, rapaz — lembrei-me de Freitas naquela hora.

O relato, no encontro anterior, com o menino, já preparava o leitor para o contraste entre o subúrbio onde Vicente mora e o bairro ao qual ele chega. A casa de Luís, assim como as casas da City Lapa descritas por Vicente, tem jardim com plantas. Vicente observa

\footnotetext{
${ }^{217}$ As divisões do conto, em edições anteriores, vêm assinaladas com asteriscos. Na edição mais recente, as marcações são de espaços em branco.
} 
que a casa é "bem disposta" e que há capricho nas paredes. Não se sabe se as tais paredes são internas ou externas, mas a descrição faz lembrar, por oposição, a situação inicial de Vicente, ocupado com a sujeira, com "o começo de limo nas paredes", da casa em que mora com a mãe.

Ao adentrar a casa de Luís, e mais internamente ainda, o quarto do colega, o contraste é ainda maior com o universo de Vicente. A elocução ressalta a surpresa de Vicente com a diferença, e a própria construção linguística para falar do universo cultural elevado de Luís se mostra mais refinada, a ponto de tornar-se empolada: a colocação pronominal, o uso da ênclise em "mostrou-me livros", indica que o mundo de Luís faz Vicente tentar se mostrar mais educado, mais polido e sabido do que ele é de fato. O mesmo se dá na tentativa de aconselhamento, depois de ver os desenhos do amigo. Luís mostra os desenhos com entusiasmo, mas Vicente o aconselha, "sem sentir", que siga adiante, pois aquilo pode dar dinheiro. Incapaz de compartilhar o interesse, mais que isso, o entusiasmo de Luís pelos desenhos, Vicente instrumentaliza, pragmático, a arte do amigo e assume um tom conselheiro, paternal. A lembrança de Freitas, seu antigo treinador de pugilismo, aponta para a relação hierarquizada, vertical, que Vicente assume para com o colega e para a sua carreira interrompida — a de boxeador —, que talvez, em sua concepção, pudesse ter lhe "dado dinheiro", como ele infere da ocupação do amigo com desenho arquitetônico.

Se o encontro inesperado com o menino que jogava bola na rua foi insuficiente para alterar a narrativa e o estado de espírito de Vicente, a visita à casa de Luís tinha tudo para conduzir Vicente para uma situação de maior clareza com relação ao seu desejo e à busca. O impulso horizontal que move Vicente, a "mania de andar", fez com que o rapaz fosse à casa do amigo Luís. O protagonista intui, assim, que a busca tem relação com a amizade do colega de trabalho. Mas a chegada à casa de Luís é decepcionante. Vicente parece não se sentir à vontade na casa do colega - e não por falta de acolhida. As diferenças de formação e de classe (apesar de colegas de trabalho, Luís parece estar em melhor situação que Vicente) perturbam o protagonista.

O segundo encontro de Vicente, assim, poderia alterar os rumos da ação ou pelo menos despertar no personagem maior consciência sobre a busca. No entanto, apesar da receptividade com que é recebido na casa de Luís, dos momentos que eles passam juntos e 
do sentimento de diferença de classe, a inquietação de Vicente não passa e sua formulação da busca não muda:

Chateza na tarde. Ia para os lados do Piqueri. Havia bebericado conhaque num boteco, jogado uma partida de bilhar com Luís. Fingira atenção nas tacadas, um capricho que não é meu. Sorrira, pegara no giz, insinuara apostas. Mas por dentro estava era triste, oco, ânsia de encontrar alguma coisa. Não parede verde de tinhorões e trepadeiras, nem bola sete difícil, nem Lídia, nem...

Tempo-será das crianças no jardim público. Sentei-me num banco, cigarros se sucediam. Uma porção de lembranças - tempo de quartel, maluqueiras, farras, porres. Boxe, boxe! Uma frase qualquer me veio na tarde. Ouvida na oficina, na casa de Luís, não a localizava precisa, nem onde. Só sabia que falava dos primeiros cabelos brancos que tenho. Acima da costeleta, apontam incisivos; provavelmente não demorarão em pintar tudo de branco. Uma criança passou-me, deu-me um tapinha no joelho. Achei graça naquilo, sorri, tive vontade de brincar com ela. Ficamos nos namorando com os olhos. Ela se chegou, conversamos. Perguntei essas coisas que se perguntam às crianças. Em que ano do grupo está, quanto anos tem, gosta daquilo, disto... O sorveteiro com o carrinho amarelo. Paguei-lhe um sorvete de palito, e ficamos eu e a menina até os aventais muito brancos da empregada surgirem na praça.

Andando tão devagar. Procurava alguma coisa na tarde. O vento esfriou. Não sabia bem o que, era um vazio tremendo. Mas estava procurando (... $)^{218}$

Depois da visita a Luís, eis o terceiro encontro de Vicente, com a menina no jardim público, o qual mais uma vez, como se percebe na sequência da ação, não altera o impulso deambulatório do personagem e da elocução. Depois de se deparar com um menino que jogava bola e ter-se encontrado com o amigo Luís, Vicente agora tem um encontro significativo e, no entanto, mais uma vez ele volta a andar, sem que a ação principal do conto pareça se alterar substancialmente.

O começo do trecho retoma o estado de espírito da angústia e do tédio, ou do desconhecimento acerca do próprio desejo: "Chateza na tarde". O impulso de horizontalidade, de alargamento do espaço, se manteve depois do encontro com Luís, e agora a horizontalidade se aproxima do ânimo do protagonista, encontrando correspondência no estado de espírito entediado, que o faz estender à tarde a dimensão “chata". A “chateza do quotidiano" mencionada pela resenha de João Alexandre Barbosa se expressa aqui na tarde de um domingo que prometia aventura, uma busca incerta, mas de

\footnotetext{
${ }^{218}$ MPB, pp. 30-31.
} 
possível sentido emancipatório, rumo à libertação do luto e da melancolia. Mas o impulso da busca é refreado pela nostalgia, pelas lembranças da juventude de Vicente, momento da vida mais orientado (no quartel, no boxe) e mais livre (tempo das "maluqueiras", das "farras" e dos "porres").

A presença de outro personagem em cena poderia ter feito Vicente parar e decidir, afinal, dar sentido à busca. Não é o que acontece. A permanência da angústia e do desnorteamento mostra que os dois encontros anteriores conservaram Vicente no mesmo plano - no chato, na horizontal —, sem conseguir alterar seu ponto de vista ou sua compreensão acerca do próprio desejo, o que o mantém em movimento, mesmo depois dos encontros que, a princípio, deveriam conferir certa verticalidade à trajetória do protagonista.

O encontro com a menina é importante. Depois do encontro passageiro com o menino, agora o tempo em que os dois, protagonista e criança, permanecem juntos é mais longo e mais intenso. A interação também é maior que com o menino. Se antes havia a bola como objeto de mediação entre um e outro, agora há contato físico entre os personagens: a menina dá um tapinha no joelho de Vicente. Mais que isso, Vicente usa o verbo namorar para definir a maneira com que ambos se olham, demoradamente. Depois, os dois, Vicente e a menina, conversam, e ele lhe compra um picolé. Vicente parece perder a noção do tempo em companhia da criança, pois diz que ficaram os dois "até os aventais muito brancos da empregada surgirem na praça".

É digno de nota que os dois momentos mais felizes da caminhada de Vicente se deem na companhia de duas crianças. $O$ enlevo que ele sente ao interagir com o menino e a menina contrasta com o estado de angústia e tristeza que o personagem expressa ao longo do conto - e as duas crianças serão os personagens que vão conduzir os pensamentos de Vicente para a mudança de intenções que se observa ao final do relato. Primeiro: ainda achando o domingo "chato", diz que o dia parece estar "gestando alguma coisa"; ao que ele mesmo acrescenta a "ideia extravagante" de "cortar à escovinha" para esconder os "começos de cabelo branco". O possível corte de cabelo revela que Vicente usa um penteado mais relaxado, o que remete aos cabelos despenteados do menino encontrado na rua. Depois: é a lembrança da menina que vai determinar a alteração no pensamento de Vicente: "Na rua de pedregulho mal socado o sapato novo subia, descia. Sem pressa, mole. 
A garotinha do jardim público poderia ser filha minha. Este pensamento agradou-me, jogou-me uma ternura. Cortar à escovinha, que ideia! Lídia maneira, pequenina, talvez desse boa mulher (...)". Assim, Vicente decide manter os cabelos brancos sem corte, conservando um visual desalinhado, ainda que com isso deixe transparecer sinais de envelhecimento. E admite, então, para si próprio, casar-se.

$\mathrm{O}$ encontro com as duas crianças faz Vicente passar em revista seu amadurecimento. Primeiro com o menino, cujo índice de identificação com Vicente são os cabelos. O rapaz diz adorar os cabelos despenteados de menino, para algumas linhas adiantes comentar sobre a ideia extravagante de cortar os seus próprios cabelos "à escovinha", curtos, para esconder os fios brancos que apontam, "incisivos". Talvez com isso renuncie às lembranças boas da época do quartel, quando, como soldado, provavelmente usava o cabelo à escovinha. Mais do que procurar compreender para onde vai o desejo e a orientação do protagonista, é importante notar que as oscilações de tempos e de lembranças conservam Vicente em um estágio indeterminado sobre a própria maturidade e indeciso quanto ao que ele pretende. A identificação com o menino e com outras crianças faz o rapaz reencontrar também a sua experiência de infância, onde se encontram sentimentos menos dolorosos que os do momento presente da ação narrada. O "tempo-será" da infância, que ele vive na companhia das crianças brincando no jardim público, é revivido por ele próprio, indeciso sobre o seu desejo como uma promessa de futuro. Os pensamentos, no entanto, remetem ao passado, a lembranças de juventude e a uma frase ouvida, que ele não sabe localizar quando ou onde.

No outro encontro, com a menina, a identificação é ainda maior. Vicente a namora com os olhos, fica com ela até perder a noção do tempo e, ao final, a construção de texto que revela a chegada da empregada à praça é indicativa de que a perspectiva visual de Vicente se igualou à da menina. A presença da empregada é sentida pela metonímia dos "aventais". É como se, entretidos entre eles, brincando ou "namorando", Vicente e a menina percebessem a chegada da empregada de baixo, no nível dos aventais que ela usa.

Ambos os encontros, com o menino e a menina, portanto, fazem com que Vicente volte a ser criança, ao menos simbolicamente, para depois reencontrar o estágio atual de desenvolvimento afetivo, não sem antes examinar a possibilidade de ele se tornar, rapidamente, um velho: os cabelos brancos, ele sente, em breve tomarão toda a sua cabeça. Simbolicamente, portanto, o devaneio de Vicente acerca de si mesmo, acentua a indefinição 
sobre sua própria idade, ou melhor, sobre sua maturidade. Numa única tarde, Vicente experimenta a sensação psicológica de ser criança e de ser um senhor de cabelos brancos, tudo isso sendo um jovem rapaz solteiro ocupado com questões de trabalho e casamento.

Essa passagem, da infância para a velhice, ou pelo menos, da infância para a maturidade, para uma fase em que os cabelos brancos o distanciam de sua condição de rapaz, se dá a partir do encontro com a menina: o "namoro" que Vicente estabelece com a menina do jardim público substitui, simbolicamente, o namoro que Lídia tenta, sem sucesso, estabelecer com o rapaz. No plano doméstico, Vicente recusa o flerte com Lídia. Ao sair de casa, porém, deixa-se levar pela "investida" da menina na praça. Posteriormente, em lembrança, a Vicente ocorrerá que a menina poderia ser sua filha. Mas no momento da ação é sintomático que o rapaz, em sua busca, estabeleça um "namoro", algo que não admite deixar florescer em seu ambiente familiar.

A garotinha, assim, substitui a moça, assim como os encontros com o menino e com Luís, da mesma forma, podem ser vistos como substituição do encontro recusado por Vicente para o futebol na televisão com o vizinho Daniel.

Neste jogo de identificação e recusa, os dois únicos personagens que o protagonistanarrador não consegue substituir durante a ação do conto são a mãe e o pai.

\section{Romance familiar e questões edípicas}

As estratégias de substituição simbólica de uma personagem pela outra, que a ação do conto põe em cena, indicam que Vicente deixou a casa familiar para repor, no espaço externo, relações análogas às que ele mantém em família. Pai, mãe e "irmãos" (irmãos que o protagonista não tem, mas que ganham sucedâneos em Lídia e Daniel) continuam a ocupar seus pensamentos, mesmo durante a busca.

O pai é figura central nesse momento, ainda que sua presença se dê, paradoxalmente, pela ausência definitiva. Esta centralidade espectral e enigmática da figura paterna, que move o protagonista do conto, merece atenção especial.

As referências de Sigmund Freud à importância do pai para a constituição do sujeito são inúmeras, permeiam sua obra inteira e estão no centro de um dos principais conceitos por ele formulados, o do complexo de Édipo. As menções ao pai remontam à obra 
fundadora da psicanálise, desde o prefácio à segunda edição do livro: “(...) este livro tem para mim, pessoalmente, outra importância subjetiva - uma importância que só apreendi após tê-lo concluído. Ele foi, como verifiquei, parte de minha própria autoanálise, minha reação à morte de meu pai - isto é, ao evento mais importante, à perda mais pungente da vida de um homem". ${ }^{219}$

O papel que a figura paterna desempenha na formação psíquica do indivíduo e a relação conflituosa que os meninos mantêm com o pai ganharão análise de Freud em $A$ interpretação dos sonhos no capítulo dedicado aos sonhos típicos, dentre os quais se destacam os sonhos "sobre a morte de pessoas queridas". Depois de examinar os sentimentos de rivalidade que surgem entre os irmãos, por conta do ciúme do amor dos pais, Freud examina os impulsos destrutivos da criança também em relação ao pai e à mãe.

A forte ligação do menino com a mãe e seus impulsos negativos em relação ao pai, diz Freud, sobrevivem para além da infância e continuam a se manifestar com desejos de morte do pai, lembrando que para as crianças, ressalta o autor, morte e ausência são a mesma coisa. Os sonhos de morte do pai, portanto, seriam realização de desejo, um desejo antigo, que remonta à infância e retorna posteriormente, em sonho ou em outras manifestações inconscientes. Apaixonar-se por um dos pais e odiar o outro, diz Freud, é comum na mente de todas as crianças, e os sentimentos de amor e ódio que elas nutrem pelo casal parental pode ser explicado por meio de um mito da Antiguidade. É quando aparece uma das primeiras menções, na obra de Freud, ao Édipo:

Em minha experiência, que já é extensa, o papel principal na vida mental de todas as crianças que depois se tornam psiconeuróticas é desempenhado por seus pais. Apaixonar-se por um dos pais e odiar o outro figuram entre os componentes essenciais do acervo de impulsos psíquicos que se formam nessa época e que é tão importante na determinação dos sintomas da neurose posterior. Não acredito, todavia, que os psiconeurótícos difiram acentuadamente, nesses aspectos, dos outros seres humanos que permanecem normais - isto é, que eles sejam capazes de criar algo absolutamente novo e peculiar a eles próprios. É muito mais provável - e isto é confirmado por observações ocasionais de crianças normais - que eles se diferenciem apenas por exibirem, numa escala ampliada, sentimentos de amor e ódio pelos pais, os quais ocorrem de maneira menos óbvia e intensa nas mentes da maioria das crianças.

Essa descoberta é confirmada por uma lenda da Antiguidade clássica que chegou até nós: uma lenda cujo poder profundo e universal de comover só pode ser compreendido se a hipótese que propus com

${ }^{219}$ FREUD, S. A interpretação dos sonhos. Rio de Janeiro: Imago, 1999. p. 14. 
respeito à psicologia infantil tiver validade igualmente universal. O que tenho em mente é a lenda do Rei Édipo e a tragédia de Sófocles que traz o seu nome. ${ }^{220}$

Segundo Freud, o destino de Édipo “comove-nos apenas porque poderia ter sido o nosso - porque o oráculo lançou sobre nós, antes de nascermos, a mesma maldição que caiu sobre ele. É destino de todos nós, talvez, dirigir nosso primeiro impulso sexual para nossa mãe, e nosso primeiro ódio e primeiro desejo assassino, para nosso pai. Nossos sonhos nos convencem de que é isso o que acontece. O Rei Édipo, que assassinou Laio, seu pai, e se casou com Jocasta, sua mãe, simplesmente nos mostra a realização de nossos próprios desejos infantis". 221

A noção de complexo de Édipo ganhou centralidade na obra do autor e desdobramentos posteriores, em textos como "Romances familiares", "O Eu e o Id", "Algumas reflexões sobre a psicologia do escolar" e "Totem e tabu", entre outros. No primeiro destes, Freud descreve a passagem que todo indivíduo realiza em relação aos pais - ao sentir que não recebe todo o amor que deseja, por conta da rivalidade com os irmãos ou outras pessoas -, qual seja: de um sentimento de identificação e devoção para o desapontamento e a crítica, ao constatar que os pais em muitas ocasiões o rejeitam ou, ao menos, neglicenciam-no.

Ao crescer, o indivíduo liberta-se da autoridade dos pais, o que constitui um dos mais necessários, ainda que mais dolorosos, resultados do curso do seu desenvolvimento. Tal liberação é primordial e presume-se que todos os que atingiram a normalidade lograram-na pelo menos em parte. $\mathrm{Na}$ verdade, todo o progresso da sociedade repousa sobre a oposição entre as gerações sucessivas. Existe, porém, uma classe de neuróticos cuja condição é determinada visivelmente por terem falhado nessa tarefa.

Os pais constituem para a criança pequena a autoridade única e a fonte de todos os conhecimentos. O desejo mais intenso e mais importante da criança nesses primeiros anos é igualarse aos pais (isto é, ao progenitor do mesmo sexo), e ser grande como seu pai e sua mãe. Contudo, ao desenvolver-se intelectualmente, a criança acaba por descobrir gradualmente a categoria a que seus pais pertencem. Vem a conhecer outros pais e os compara com os seus, adquirindo assim o direito de pôr em dúvida as qualidades extraordinárias e incomparáveis que lhes atribuíra. Os pequenos fatos da vida da criança que a tornam descontente fornecem-lhe um pretexto para começar a criticar os pais;

\footnotetext{
${ }^{220}$ Idem, ibidem, p. 261.

${ }^{221}$ FREUD, S. A interpretação dos sonhos. op.cit., p. 263.
} 
para manter essa atitude crítica, utiliza seu novo conhecimento de que existem outros pais que em certos aspectos são preferíveis aos seus. ${ }^{222}$

Em "Romances familiares", Freud comenta a necessidade psíquica que a criança tem de desenvolver um "romance familiar", isto é, de trocar seus pais por pais substitutos, por conta da desconfiança de que aqueles que ela chama de pai e mãe não sejam, em realidade, seus verdadeiros pais, pois ela ignora sua origem e não tem como se assegurar de que os pais que cuidam dela são realmente seus pais. As fantasias que advêm dessa suposição incluem a desconfiança de que ela pode ter sido encontrada ou de que ela, ou seus irmãos, são na verdade filhos bastardos, e que aqueles que se dizem seus pais são na verdade um padrasto e uma madrasta.

O estágio seguinte é o que Freud chama de "romance familiar do neurótico". A fantasia de substituição dos pais nessa altura do desenvolvimento infantil, assim, "depende da inventividade e do material à disposição da criança":

Essa atividade emerge inicialmente no brincar das crianças e depois, mais ou menos a partir do período anterior à puberdade, passa a ocupar-se das relações familiares. Um exemplo característico dessa atividade imaginativa está nos devaneios que se prolongam até muito depois da puberdade. Se examinarmos com cuidado esses devaneios, descobriremos que constituem uma realização de desejos e uma retificação da vida real. ${ }^{223}$

O romance familiar começa a se desenvolver nas atividades lúdicas, no brincar, e com o tempo passa a povoar a imaginação da criança, tomando a forma de devaneios. No entanto, como a criança, ao tomar conhecimento do conteúdo sexual da relação entre pai e mãe, descobre que o pai é incerto, enquanto a mãe é comprovadamente sua mãe, tende a desenvolver predominantemente fantasias de substituir o pai. Para Freud, porém, não se trata de uma fantasia de eliminar o pai, mas bem ao contrário:

Dessa forma a criança não está se descartando do pai, mas enaltecendo-o. Na verdade, todo esse esforço para substituir o pai verdadeiro por um que lhe é superior nada mais é do que a expressão

\footnotetext{
${ }^{222}$ FREUD, S. "Romances familiares". In: "Gradiva" de Jensen e outros trabalhos (1906-1908). Edição standard brasileira das obras psicológicas completas de Sigmund Freud. Vol. IX. Rio de Janeiro: Imago, 1996, p. 219.

${ }^{223}$ FREUD, Sigmund. "Romances familiares". op.cit., p. 220.
} 
da saudade que a criança tem dos dias felizes do passado, quando o pai lhe parecia o mais nobre e o mais forte dos homens, e a mãe a mais linda e amável das mulheres. Ela dá as costas ao pai, tal como o conhece no presente, para voltar-se para aquele pai em quem confiava nos primeiros anos de sua infância, e sua fantasia é a expressão de um lamento pelos dias felizes que se foram. ${ }^{224}$

O romance familiar, portanto, permite que a criança comece a se libertar de sua dependência psíquica dos pais verdadeiros, devaneando, fantasiando ser filha ou filho de outros pais, ou figuras paternas substitutas. Nesse sentido, o romance familiar é a forma que a imaginação encontra para resolver a crise definida pelo complexo de Édipo: a de amar a mãe e odiar o pai, se ela é um menino, ou ao contrário, amar o pai e detestar a mãe, se ela é menina.

É a partir deste texto de Freud que Marthe Robert desenvolve sua teoria sobre a "fábula biográfica" da criança, que em sua teoria dará origem ao "romance", entendido como devaneio e também como gênero literário. As duas possibilidades acerca da própria origem, que são características do "romance familiar do neurótico", tal como descrito por Freud, levaram Marthe Robert a desenvolver a classificação da narrativa do romance em dois tipos de história recorrente: aquela protagonizada pela "Criança Perdida" e aquela protagonizada pelo "Bastardo". Jogando com o duplo sentido da palavra "romance", Robert diz que assim como a criança precisa fazer seu "romance familiar" para deixar a infância para trás, substituindo os pais que a criaram por pais substitutos, o herói de romance, como o romancista, também é um "fazedor de romance". 225 Assim, o romance das origens de cada indivíduo se torna também a origem do romance, da fabulação, do devaneio e da ação do herói.

Depois do primeiro estágio, em que a criança acredita ter sido adotada pelos pais que conhece, mas que na verdade tem outros pais, mais nobres e mais amorosos que estes que não atendem a todas as expectativas (é uma Criança Perdida), sobrevém a fase em que

\footnotetext{
${ }^{224}$ Idem, ibidem.

${ }^{225}$ Seguindo a definição do dicionário francês Littré, Robert lembra que "fazer romance" é "conquistar o coração de uma pessoa de condição superior, como se vê nos romances" ou "contar as coisas de modo diferente do que aconteceram". Assim, conclui a autora, fazer romance é "agir a exemplo do herói de romance e mentir à maneira do romancista". Com isso, quem faz romance expressa um desejo de mudança: ou conta histórias e muda $o$ que é (isto é, o mundo) ou casa acima de sua condição e muda o que ele é (isto é, a si próprio). ROBERT, M. Romance das origens, origens do romance. São Paulo: Cosac Naify, 2007, pp. 28-29.
} 
a criança, ciente do componente sexual da relação parental, acredita que ela é enjeitada (o Bastardo):

A nova tendência do romance, dessa vez, portanto, sexual, trai seus motivos até nas astúcias que urde para camuflá-los. Ao se declarar ilegítima, com efeito, a criança coloca-se numa situação que, necessariamente pretendida por ela, permite deduzir suas verdadeiras razões e o encaminhamento de seus desejos ocultos. Em primeiro lugar, ela mantém a mãe ao seu lado, e essa proximidade cria uma intimidade ainda mais estreita na medida em que agora ela se impõe na narrativa como único vínculo concreto; depois - mas os dois procedimentos mantêm-se ambos tão próximos que mal se pode dissociá-los —, relega o pai a um reino de fantasia, a um além da família que tem o sentido de homenagem e mais ainda de exílio, pois, para o papel por ela agora desempenhado na ordem corrente da vida, esse pai-rei e desconhecido, esse eterno ausente poderia igualmente com efeito não existir, ser um fantasma, um morto ao qual se pode decerto consagrar um culto, mas também alguém cujo lugar é vazio, sendo tentador substituí-lo. Se pensarmos que, para o maestro inconsciente que administra o arranjo do conto, toda aproximação equivale à aproximação sexual, toda ausência à morte e toda supressão ao assassinato (como o inconsciente ignora a morte, não a concebe senão sob a forma de uma ausência prolongada), vê-se logo que a desigualdade social dos dois pais não responde apenas ao juízo de valor que parece motivá-la, mas claramente antes a uma situação afetiva escabrosa, exatamente a mesma que o romance tem como tarefa dizer e passar sob silêncio, enquanto se esforça para desatá-la. O que se exprime aqui sob a capa de uma desigualdade de condição só pode ser compreendido como alusão à prova mais dolorosa da infância, como evocação desse conflito a que Freud vinculo o nome lendário de Édipo, mostrando que todo homem deve um dia enfrentar seu duplo perigo, em qualquer lugar onde este venha a nascer. ${ }^{226}$

A tendência do romance familiar, portanto, é evoluir para a fase edípica e, dela, "fazer romance", ou seja, superar a fase de fixação no pai e na mãe, situação em que a mãe, nos termos de Robert, é “o único vínculo concreto” e o pai é um "pai-rei” desconhecido, “eterno ausente”. Isso se dá por devaneio, fantasia, imaginação, narrativa.

É justamente, guardando as devidas proporções, o tema do conto em questão e a fase pela qual passa Vicente. Como se voltasse à infância, Vicente é um pequeno Édipo que permanece fixado na mãe e na figura ausente e idealizada do pai. A forte ligação com a mãe e a dificuldade de superar a perda paterna (conservando sua condição infantil de filho "soldado" aos pais) apontam para a dificuldade de Vicente em se desvencilhar do casal

${ }^{226}$ ROBERT, M. op. cit., pp. 40-41. 
parental. A relação edípica irresolvida, que o protagonista, mesmo em idade avançada, ainda carrega, indica que o Édipo é mais um dos modelos arquetípicos a que o protagonista se liga.

O protagonista da busca, afinal, não é bem-sucedido em seu "romance". Por quê?

Porque em Vicente persiste a necessidade de substituir os pais, o que envolve, como sublinhou Freud, sentimentos de decepção e de agressividade, mas também de amor e enaltecimento, em relação ao casal parental.

A história de Vicente dá grandes indicações nesse sentido.

A relação do rapaz com a mãe é de grande proximidade e dependência. É com ela que o protagonista estabelece vínculos concretos. Ao mesmo tempo, o rapaz tem lá as suas críticas a fazer à mãe: acha desnecessário que ela, mesmo no domingo, ocupe-se do trabalho pesado de limpeza; é prestativo, mas não tem paciência com os afazeres domésticos, deixados de lado em favor da andança que ele empreende pela cidade e tratados com certo desprezo, desprezo que se estende a Lídia, ambas "lá com suas costuras e arrumações caseiras”. Lídia é a mulher que pode substituir a mãe, mas permanece colada, ou melhor, "costurada" à mãe do rapaz e "arrumada" com ela nas ocupações caseiras. Vivendo com a mãe, Vicente precisa buscar outra mulher para "fazer romance", mas a única que se apresenta, no espaço do conto, é Lídia, uma espécie de “irmã”, pois que é parte de seu universo social e companheira da mãe.

Com relação ao pai, as referências a ele são poucas, mas as recordações de Vicente lhe são favoráveis: “O velho, quando vivo, fazia passeios a Santos, uma porção de coisas. Bom. A gente se divertia, a semana começava menos pesada, menos comprida, não sei. Às vezes, penso que poderia recomeçar os passeios". É como se a morte do pai tivesse fixado positivamente sua imagem, em uma idealização de boa companhia, que o levava a passeios a Santos e aliviava o peso da semana de trabalho. Vicente identifica o pai, assim, à leveza dos passeios, à diversão, ao fim de semana, à palavra "bom”. Ele cogita recomeçar os passeios, isto é, retomar a mesma atividade que o pai lhe proporcionava. No entanto, em vez dos passeios e da diversão, a morte do pai lhe impôs a "mania de andar" e a "busca". Ou seja, a morte do pai faz com que ele assuma características que não eram paternas, mas 
o mantém sem norte, o que indica que o luto gerado por essa ausência se prolonga, sem que a falta da figura paterna tenha ganhado elaboração ou encaminhamento. ${ }^{227}$

Para além de seu núcleo familiar, as recusas afetivas se sucedem e a únicas identificações do protagonista que permanecem são aqueles que ele estabelece com a mãe e com o pai. Apesar do nome bem marcado, Vicente, que o identifica, e apesar do enraizamento arquetípico como jovem rapaz que empreende o caminho do subúrbio para o centro, em oposição à forte unidade familiar e moral em que está inserido, apesar de tudo isso, a narrativa de "Busca" apresenta um personagem que, ele próprio, tem contornos pouco definidos, em contraponto à constância das caminhadas a esmo mas sempre movidas por um desejo difuso. O romance familiar de Vicente, reatualizado em seus devaneios, faz com que ele sinta a necessidade de se lançar na busca de outro pai. Infere-se que a busca remonte à perda do pai: "Desde que papai morreu esta mania". O hábito de andar, sem rumo, persiste como sintoma do luto, desde a perda do pai. Essa busca então se manifesta como uma andança sem rumo e sem objeto de desejo definido, mas com objeto perdido bem claro.

Vicente revive o seu "romance familiar" tal como definido por Freud, isto é, a inclinação da criança a substituir os pais biológicos por pais substitutos, mas romance este que não chega a se realizar, preservando os contornos de organização familiar tal como ela se dava na infância do protagonista - e a busca pode mesmo ser vista como uma busca pela elaboração de um "romance", isto é, a atualização de uma crise edípica, e a necessidade, malograda, diga-se, de "fazer romance", isto é, um desejo de devaneio, para imaginar uma situação em que o seu desamparo e o seu isolamento encontrem possibilidade de superação.

Os encontros de Vicente com as crianças no caminho também o fazem reviver os tempos infantis, como vimos. Esse retorno do personagem aos seus tempos de menino indicam uma infância que retorna ou, se preferirmos, uma infância que nunca se foi. É provável que o impulso nostálgico de Vicente se relacione a essa permanência de sua condição infantil. Daí a impertinência para com Daniel, Lídia, os colegas de trabalho e até

\footnotetext{
227 Sobre o luto, ver FrEUD, S. Luto e melancolia. Edição standard brasileira das obras psicológicas completas de Sigmund Freud. Vol. XIV. Rio de Janeiro: Imago, 1996.
} 
para com Luís, em quem o protagonista vê um amigo, um parceiro, mas que se revela uma espécie de rival no "romance", isto é, alguém com mais capacidade de busca.

Recapitulando então os sentido da busca de Vicente: para Simone Paulino é um expediente de alívio psíquico para a condição de isolamento; para Vima Lia Martin trata-se de buscar outra identidade, e ocupar o lugar do pai; em nossa concepção trata-se de uma busca por outro pai, um pai substituto que, entretanto, não se apresenta no horizonte do personagem. Para Lukács, a busca é inerente à constituição do herói de romance. Em nosso entendimento, a busca relaciona-se ao romance familiar, isto é, em resumo e em leitura análoga à de Vima Martin e de Simone Paulino, é uma busca por outro pai e pela superação ou alívio de seu sofrimento psíquico.

Mas, apesar das diferentes interpretações sobre o objetivo da busca, é importante restituir a ela os termos em que ela se dá no próprio conto. Assim, a busca de Vicente se mantém indeterminada, irresolvida, não elaborada. Ele busca algo, e este algo, no espaço do conto, não é definido, permanece em suspensão.

\section{Da família à sociedade e de volta à família}

Não é possível localizar com precisão o tempo histórico em que se passa a ação de "Busca", pois o conto não fornece marcações temporais explícitas. O livro, como se sabe, foi publicado em 1963, mas o conto teve sua primeira publicação antes disso, por volta de $1958 .^{228}$ É possível assumir, ao menos, portanto, que a ação do conto transcorra nos anos 1950, década em que foi escrito e publicado pela primeira vez.

Se o sentido da busca e o tempo histórico não estão manifestos no conto, o percurso espacial, por outro lado, é bem definido.

As descrições de lugar e de sociabilidade permitem identificar um espaço urbano que ainda conserva certos traços de localidade rural do interior: a galinha, as ruas de terra que sujam os sapatos de Vicente, a vizinhança que se espreguiça nos jardins de casa, de pijama, na tarde de domingo. Por outro lado, o espaço percorrido já ostenta características

\footnotetext{
${ }^{228}$ Rodrigo Lacerda informa que o conto foi publicado na Revista do Globo, mas que a edição de sua publicação não foi localizada. Em nossa pesquisa no Acervo João Antônio, no Cedap da Unesp de Assis, também não deparamos com reproduções deste conto. Entre os contos desta época, pudemos consultar no Acervo a reprodução em xerox de "Natal na cafua" publicado no Última Hora em 8 jan. 1959. Essa reprodução consta do Apêndice desta tese.
} 
de metrópole: o trem que o protagonista decide não tomar, os ônibus cheios, a televisão que transmite futebol, a própria atividade operária que Vicente exerce. Assim como a maturidade emocional de Vicente, o estágio de crescimento e de organização da cidade é indeterminado e complexo. Nela, assim como no protagonista, convivem tempos diferentes e contraditórios.

O universo retratado diz respeito, provavelmente, à São Paulo dos anos 1950. Nesse momento histórico, a revolução burguesa brasileira, tal como definida por Florestan Fernandes, está em fase avançada - ou em sua segunda fase, circunscrita pelos limites que vão da Crise de 1929 e da Revolução de 30 até o golpe de 1964 —, na qual "o capitalismo industrial reponta como a nova força aglutinadora do crescimento econômico do Brasil", ainda que a situação social do país conserve traços do "complexo econômico colonial", mantendo nossa dependência do capital financeiro internacional. ${ }^{229}$ Assim, segundo Florestan Fernandes, mesmo neste momento histórico avançado, a revolução burguesa continua a se desenvolver de modo "descontínuo, extremamente lento e desigual". O padrão de crescimento econômico "corresponde aos requisitos básicos da civilização vigente, mas opera, tanto quantitativamente quanto qualitativamente, dentro dos limites que essa civilização consegue vigência histórica no Brasil”. ${ }^{230}$

Os aspectos sociais do momento narrado em "Busca" guardam correspondência com os estudos de Florestan Fernandes. O universo familiar e social em que Vicente está inserido constitui o tempo em que, pós-Revolução de 30, uma série de oportunidades se abriram para as camadas mais baixas da sociedade brasileira. Como destaca Antonio Candido, houve a partir dos anos 30 do século passado uma "rotinização" de aspirações que já vinham de antes, como a ampliação ao acesso à cultura e à educação. ${ }^{231}$ Trabalho livre e assalariado, leis trabalhistas e melhora sensível nas oportunidades de educação se tornaram realidade no período, desde a Era Vargas, verdadeiro "divisor de águas da história contemporânea do Brasil", como sublinha Thomas E. Skidmore ${ }^{232}$, referindo-se ao trabalhismo e aos programas de industrialização e bem-estar social de Getúlio Vargas.

\footnotetext{
${ }^{229}$ FERnANDES, F. "Crescimento econômico e instabilidade política no Brasil". In: Sociedade de classes e subdesenvolvimento. São Paulo: Global, 2008, p. 124.

${ }^{230}$ idem, ibidem, pp. 126 e 129.

${ }^{231}$ CANDIDO, A. "A revolução de 30 e a cultura". In: A educação pela noite e outros ensaios, Ática, $2^{\mathrm{a}}$ edição, São Paulo, 1989.

${ }^{232}$ Skidmore, T. Brasil: de Getúlio a Castello (1930-64). São Paulo: Companhia das Letras, 2010, p. 73.
} 
O conto apresenta essa situação, em seus termos, por meio de elementos ficcionais, ao mesmo tempo que indica também como o processo de modernização, de formalização do trabalho e de democratização das oportunidades se deu de maneira desigual. As diferenças entre Vicente e Luís mostram como, mesmo em uma mesma classe social, já que os dois rapazes trabalham juntos, há grandes desníveis culturais e de oportunidade. A situação material de Vicente parece ser mais frágil que a Luís. O protagonista, como indica ele próprio, se viu forçado a trabalhar "desde menino", em uma atividade braçal e insalubre, como a de soldador. Não há referência à formação escolar de Vicente, ainda que ele dê mostras de sensibilidade ao mundo da cultura, pois gosta de música popular e de analisar letras de samba, como ele próprio diz. Luís, por sua vez, parece ter mais educação formal e intimidade com a cultura letrada, pois tem livros em casa, e apesar de trabalhar possivelmente também como operário, prossegue investindo nos estudos de desenho arquitetônico.

A situação profissional do protagonista, que é estável, apesar de pouco valorizada, está também relacionada à sua organização familiar. Se trabalha desde menino é — ainda que a narrativa não indique isso claramente - por necessidade. É provável que Vicente tenha sido obrigado pelo pai a começar a trabalhar desde cedo, pois as lembranças do pai relacionam-se diretamente ao trabalho, ainda que Vicente o expresse de maneira enviesada: os passeios que o pai promovia em família faziam as semanas começarem "menos pesadas", não tão cansativas. O pai, quando vivo, portanto, deve ter sido responsável pelo início profissional precoce de Vicente, ao mesmo tempo que exercia papel de contrapeso ao mundo do trabalho, proporcionando alívio nos fins de semana, com os "passeios a Santos", à atividade pesada que o personagem, soldador desde menino, exercia.

Situação familiar e profissional, portanto, vinculam-se mutuamente, e apontam para a imbricação e a complexidade da busca do protagonista, num momento histórico de grandes transformações, em que a revolução burguesa brasileira já se deu e ao mesmo tempo permanece incompleta e desigual, conservando traços antigos da sociabilidade nacional.

O lugar vazio deixado pelo pai faz com que o luto de Vicente persista e impeça que o rapaz renove o seu romance familiar, aproximando-se de algo mais próximo de uma nostalgia pela figura paterna. $\mathrm{O}$ pai não é nomeado e o narrador não se refere à vida e à 
personalidade dele em detalhes. Como indicado, as referências ao pai no relato de Vicente são parcas. As lembranças são permeadas de bons sentimentos, ligados ao tempo livre, à viagem (os passeios a Santos e a Campinas) e a um universo mais largo (uma "porção de coisas"). A perda, portanto, fez com que a lembrança do pai se cristalizasse como algo bom e contrário ao universo do trabalho e da inserção social burguesa — ou, pelo menos, como uma figura protetora e "aliviadora" do peso das exigências de inserção social. Vicente observa que a mania de andar, que sabemos ter relação com a morte do pai, aparece em momentos de descanso: "quando venho do serviço, num domingo, férias (...)".

Como já observou Simone Paulino, "a vontade de andar só lhe assalta ao voltar do trabalho, aos domingos ou nas férias, estando condicionada, portanto, aos raros momentos de ócio, nos quais o sujeito se vê liberto da alienação do trabalho e pode dar vazão ao que está para além das necessidades básicas cotidianas". ${ }^{233}$ A saudade do pai, portanto, é ligada a um tempo que se relaciona ao universo do trabalho e, no entanto, aparece desvinculado do trabalho, ou melhor, vinculado ao "tempo morto" do descanso, o "domingo chato" em que se passa a ação narrada no conto.

Essa nostalgia do pai morto pode ser lida de acordo com outro texto bastante conhecido de Freud, "Totem e tabu", em que o autor delineia o mito da passagem do estado primitivo da organização coletiva, a "horda primeva", para uma ordem social organizada. Em linhas gerais, de acordo com esse mito tal como descrito por Freud, no princípio um pai tirânico controlava a tribo de acordo com a lei do mais forte e exercia sozinho o domínio sobre todas as mulheres. A certa altura, os irmãos resolvem matar o pai e devorá-lo coletivamente, na chamada a "refeição totêmica". A partir do estudo do totemismo, Freud faz uma analogia entre pais e filhos, associando o totem a um pai substituto:

A psicanálise revelou que o animal totêmico é, na verdade, um substituto do pai e isto entre em acordo com o fato contraditório de que, embora a morte do animal seja em regra proibida, sua matança, no entanto, é uma ocasião festiva - com o fato de que ele é morto e, entretanto, pranteado. A atitude emocional ambivalente, que até hoje caracteriza o complexo-pai em nossos filhos e com tanta frequência persiste na vida adulta, parece estender-se ao animal totêmico em sua capacidade de substituto do pai. $^{234}$

\footnotetext{
${ }^{233}$ SANTOS, Simone Paulino dos. Nas esquinas do desejo. op.cit. p. 35.

${ }^{234}$ FREUD, S. "Totem e tabu”. In: Totem e tabu e outros trabalhos (1913-1914). Edição standard brasileira das obras psicológicas completas de Sigmund Freud. Vol. XIII. Rio de Janeiro: Imago, 1996, p. 144-45.
} 
Para Freud o assassinato primordial e a substituição do pai morto por um totem dá origem à organização social, às restrições morais e à religião. $\mathrm{O}$ assassinato do pai tornou-o ainda mais forte, pois ele é lembrado, "pranteado", gerando a culpa a que os filhos estão submetidos. Simbolicamente, portanto, a morte do pai e a eleição de um totem que o substitui lembra aos filhos que há certos limites que não podem ser desrespeitados. Os filhos "criaram, assim, do sentimento de culpa filial, os dois tabus fundamentais do totemismo, que, por essa própria razão, correspondem inevitavelmente aos dois desejos reprimidos do complexo de Édipo" ${ }^{235}$. A matança original institui dois tabus: a adoração do animal totêmico, que substitui o pai morto, e a exogamia, isto é, a proibição de possuir as mulheres do próprio clã.

O mito da horda primitiva e do assassinato do pai tirânico, assim, é elaborado por Freud para explicar a passagem mítica da humanidade em estado selvagem para um estado civilizado, social, cultural e religioso. O assassinato do pai pelos filhos instaura a "função paterna", o pacto firmado entre os irmãos que institui o tabu do incesto e cria o indivíduo enquanto sujeito do desejo inconsciente. Tomados simbolicamente, a morte do pai primordial e sua substituição pela Lei (a moral, a cultura, a linguagem), a renúncia à posse da mãe e das irmãs (o tabu do incesto) e o sentimento de culpa pelo crime (que gera angústia e desejo) marcam, portanto, a passagem de um estado de "selvageria" - em que vigora a lei do mais forte, aquele poder absoluto do pai tirânico - a um estado de “civilização" em que os limites são dados por funções paternas abstratas.

Ou, como anota Paulo Vidal:

Ao repartir o corpo do pai, os irmãos tinham criado, portanto, os germes de um direito igualitário, deixando sem sucessor a glutonaria do pai. Porém, como o decorrer do tempo, a nostalgia do pai sentida pelos filhos fará com que este perca a forma totêmica e reassuma a forma humana como um deus muito acima do comum dos mortais, encarnação do ilimitado poder do pai originário. Na igualitária sociedade clânica, sociedade sem pai onde a filiação é matrilinear, tal emergência de deuses paternos logo ocasionará a reorganização do social em bases patriarcais. A família é de certo modo uma reestruturação da horda primeva, pois restabelece o poder do pai, mas sem que as conquistas do clã fraterno sejam abandonadas. Entre o pai de família submetido a obrigações e o Urvater absoluto há, portanto, uma enorme distância, grande o bastante para fazer durar, nutrir o

${ }^{235}$ Idem, ibidem, p. 147. 
anseio religioso dos filhos, sua insaciável nostalgia do pai. Do ponto de vista político, paralelamente à família aparecerão então sobre a terra reis divinos dispostos a governar patriarcalmente o Estado. ${ }^{236}$

Não temos notícia se os temas freudianos do totem e do tabu eram de conhecimento de João Antônio, mas eram, ainda na época modernista, não apenas de conhecimento de Mário e Oswald como se tornaram tema e inspiração para suas obras literárias. No "Manifesto antropófago", como se sabe, Oswald lanças as bases daquilo que veio a se tornar um princípio estético e cultural da maior relevância: a Antropofagia. ${ }^{237}$ A inspiração em Freud é evidente (“A transformação permanente do Tabu em totem”), e não apenas do manifesto do que o autor chama de a Revolução Caraíba, mas também nas formulações que se seguiram, nas quais Oswald postula a volta a um matriarcado em substituição ao regime patriarcal da herança e da ordem burguesa. ${ }^{238}$

Mário de Andrade, por sua vez, interessava-se sobremaneira pelas teorias freudianas, a ponto de ter debatido teoricamente com a psicanálise, por exemplo, em "Do cabotinismo" e de ter investigado a "psicologia" (termo que ele preferencialmente empregava) dos romances brasileiros contemporâneos. Mas também na ficção de Mário se pode entrever o forte conteúdo emocional, psíquico, com que os personagens são construídos - algo que, aliás, Mário advogava como ganho do momento modernista em relação aos escritores realistas, com as exceções de Machado de Assis e, em menor grau, Lima Barreto. ${ }^{239}$ Alguns de seus contos apresentam forte carga de investigação psicológica, e já tivemos oportunidade de comparar os contrastes da ficção de Mário com a de Alcântara Machado, ${ }^{240}$ este conhecido pela secura emocional de sua prosa e até pela ausência de ternura para com seus personagens, como definiu o próprio Mário de Andrade. Nos contos maduros de Mário, é possível identificar, assim como em João Antônio, uma elaboração

\footnotetext{
${ }^{236}$ VIDAL, Paulo. Freud e a nostalgia do pai. In: BERnARDES, Angela C. (org.). $10 x$ Freud. Rio de Janeiro: Azougue Editorial, 2005, p. 16-17.

${ }^{237}$ ANDRADE, O. "Manifesto antropófago". In: . A utopia antropofágica. $4^{\mathrm{a}}$ ed. São Paulo: Globo, 2011.

${ }^{238}$ Segundo Oswald, a antropologia provou que "o matriarcado precedeu o patriarcado em toda a terra". Seriam expressões patriarcais o casamento e a monogamia. Na formulação oswaldiana: "Antes da instituição do casamento, que regime poderia existir, senão o matriarcal?". Andrade, O. "Variações sobre o matriarcado". In: _. A utopia antropofágica, op.cit., pp. 299-303.

239 Ver "A psicologia em ação" e "A psicologia em análise", in: Andrade, Mário. O empalhador de passarinho. $3^{\text {a }}$ edição. São Paulo: Livraria Martins Editora; Brasília: INL/MEC, 1972.

${ }^{240}$ ZENI, B. Fachada, sinuca e afasia. Alcântara Machado, João Antônio e Fernando Bonassi. São Paulo, ficção no século XX. Dissertação de mestrado em Letras. Orientação de Joaquim Alves de Aguiar. FFLCH-USP, 2004.
} 
psicológica de personagens e situações que permitem ser analisadas de acordo com as sugestões freudianas. Lembrem-se de contos como "O peru de Natal", em que a memória do pai morto é substituída por um totem ${ }^{241}$ — justamente, o peru de Natal do título —, e "Frederico Paciência", em que o narrador-protagonista, Juca, desenvolve verdadeira adoração pelo amigo, em termos que lembram muito as relações entre os jovens protagonistas de João Antônio e seus amigos (o par Frederico Paciência-Juca remete aos pares Luís-Vicente, Toshi-narrador-protagonista de “Aact”, Carlinhos-narradorprotagonista de "Visita").

Mas é talvez "A terceira margem do rio", de Guimarães Rosa, o paradigma do tema da perda do pai na ficção brasileira. No conto, narrado pelo filho mais novo, o pai decide mandar fazer uma canoa e, a certa altura, embarca nela e some no rio, com destino a uma terceira margem que pode ser vista como uma viagem definitiva - a morte ou o além ou a própria figuração do tempo - no símbolo poderoso do rio que corre sem cessar. Mas o conto é sobre o filho e não o pai. É o narrador-personagem, filho mais novo, que não consegue - ao contrário da irmã, que casa e se muda, e do primogênito, que vai para a cidade —, deslindar-se da memória do pai, que o imobiliza e o submete, deixando-o preso, fixado na figura paterna. A certa altura, o pai se transforma, na imaginação do filho em um animal selvagem, espécie de totem: “Às vezes, algum conhecido nosso achava que eu ia ficando mais parecido com nosso pai. Mas eu sabia que ele agora virara cabeludo, barbudo, de unhas grandes, mal e magro, ficado preto de sol e dos pêlos, com o aspecto de bicho, conforme quase nu, mesmo dispondo das peças de roupas que a gente de tempos em tempos fornecia". ${ }^{242}$ Mas ao final é a imagem de um fantasma do pai que termina por se impor e que assombra este filho que, já velho, não consegue destituir-se da sua condição infantil, de indivíduo não desenvolvido. Não é capaz de suplantar a figura do pai ausente. Ao contrário, decide tomar o lugar o pai, assim como acontece com Vicente, o protagonista de "Busca".

Também em Freud, a passagem mítica da "selvageria" para a "civilização", se a entendermos não mais no nível amplo e imemorial da instituição dos laços sociais humanos, mas na evolução de cada ser, essa passagem também é reatualizada na chamada ontogênese, na existência pessoal do indivíduo em seu processo de crescimento e

\footnotetext{
${ }^{241}$ Nesse sentido, podemos dizer que, antropofágico, “O peru de Natal” é um conto oswaldiano de Mário.

${ }^{242}$ RosA, G. "A terceira margem do rio”. Ficção completa. vol. 2. Rio de Janeiro: Nova Aguilar, 1994, p. 411.
} 
maturidade. É por isso que o parricídio recorrente é visto por Freud como algo necessário ao indivíduo em seu processo de amadurecimento, sempre que "o fruto acalentado do crime - a apropriação dos atributos paternos — ameaçava desaparecer". ${ }^{243}$

No mito das origens freudiano, escreve Maria Rita Kehl,

[...] um cadáver real se produziu como resultado de um ato fundador da civilização. Quando aplicamos este mito filogenético à ontogênese, para explicar a constituição do sujeito operada pela introdução da função paterna, não é mais de um crime que se trata, mas de uma operação simbólica - embora, do ponto de vista da moeda com que o neurótico negocia sua culpa, isto não faça a menor diferença.

Se o ato dos irmãos, no mito das origens, instituiu a função paterna, é a partir da cultura, da linguagem, que esta função continua operando. O pai real, e as diversas autoridades que podem substituí-lo, não fazem mais do que transmitir a Lei - à qual também estão como sujeitos... assujeitados. Separar o pai (real) do pai simbólico equivale, na ontogênese, ao assassinato primordial; refazer na vida pessoal o percurso da horda primitiva à coletividade civilizada é tarefa que não se realiza sem a participação do semelhante. ${ }^{244}$

Na ontogênese, isto é, no desenvolvimento da vida individual, a passagem mítica descrita por Freud ganha atualização. A passagem da infância para a idade adulta, com a adolescência no meio, atualiza o mito totêmico e exige, como diz Maria Rita Kehl, a partir da cultura e da linguagem, a substituição do pai real por pais simbólicos- ou totens, como queria Oswald. O caminho e a busca, aqui, são aqueles da emancipação do ambiente familiar e ingresso no mundo social. A lembrança recorrente do pai morto, no caso de Vicente, reatualiza o romance familiar do rapaz e o relembra constantemente que o seu pai real já não existe, mas sugere também que certa autoridade paterna persiste no nível da cultura e das relações sociais, isto é, existe a Lei que institui uma série de restrições morais e que limita a realização imediata do desejo. O romance familiar, que nasce da percepção de abandono dos pais ou de rivalidade entre os irmãos pelo amor dos pais, evolui então para a necessidade de encontrar outro pai e um irmão que seja não um rival, mas um "igual", um semelhante que instaure o que Kehl chama de "semelhança da diferença".

\footnotetext{
${ }^{243}$ FREUD, S. Totem e tabu. op.cit., p. 148.

${ }^{244}$ KEHL, M. “Existe uma função fraterna?”. In: Função fraterna, R. de Janeiro: Relume Dumará, 2000 , p. 35.
} 


\section{Impulsos desorientados, promessas não cumpridas}

Vicente não faz a passagem da família nuclear para a sociabilidade. Mostra-se relutante em "fazer romance" com Lídia, reticente em retribuir a boa vizinhança de Daniel e incapaz de estabelecer uma relação fraterna, de parceria, com o amigo Luís. Em vez disso, substitui Lídia pela menina do jardim público, e Daniel e Luís pelo menino com quem depara jogando bola. O pai e a mãe, porém, que deveriam estar no centro de seu "romance familiar", a fim de serem substituídos, são as únicas figuras de quem o protagonista não consegue se distanciar.

Vicente está fixado no pai e na mãe. Para usar uma metáfora condizente com sua ocupação profissional como chefe de solda, Vicente está de certa forma "soldado" às suas figuras parentais, o que o mantém em um estado regressivo de dificuldade de relacionamento e de incapacidade de decisão sobre o seu próprio desejo.

Se a busca pelo pai perdido não é possível, é preciso algo que substitua o pai, como o romance familiar exige. Mas a busca, como explicita o conto, se revela infrutífera, o que indica que, simplesmente, o pai substituto não foi encontrado. A busca, na verdade, se volta para o amigo Luís, um "irmão", um "semelhante", cuja companhia poderia ajudar a compartilhar a dor e a culpa sentida pela ausência do pai. Em Luís, Vicente poderia ter encontrado um "irmão substituto" que o fizesse distanciar-se de si próprio, de maneira a reavaliar valores, perspectivas, desejo - que o fizesse, enfim, reorientar a busca para algo mais consequente e emancipatório. No entanto, o encontro com o amigo não modifica substancialmente o comportamento de Vicente, e o final do conto o encaminha de volta à casa, à mãe e ao lugar vazio deixado pelo pai "real". Não há totem à vista, no percurso de Vicente.

No momento em que Vicente narra, não há mais o caminho do boxe, em que Freitas, o treinador, personificava a referência paterna forte. Também na oficina onde trabalha, Vicente não encontra referências acima de si próprio, pois os colegas parecem têlo colocado acima de todos, adulando-o. A parceria com Luís, ao contrário, em vez de

colocar Vicente em patamar de igualdade "fraterna" (horizontal, como a de um irmão e parceiro de aventura social), faz com que ele se sinta diminuído. A relação de verticalidade que se estabelece com Luís, porém, não supre a ausência da figura paterna. O rapaz é um 
colega, e Vicente adota em relação a ele uma falsa posição paterna, reagindo, desconfortável, ao sentimento de inferioridade social, aconselhando-o "sem sentir", como se reagisse, de maneira postiça e empostada, ao acanhamento que sente na casa "bem disposta" do colega.

O trecho em flashback, que remete aos tempos do boxe, não é gratuito e corrobora a permanência da condição infantil do protagonista. As reminiscências de Vicente a esse respeito fazem-no reviver um momento anterior de promessa de emancipação. Freitas, o treinador, cumpria então o papel de figura paterna, que apadrinha, dirige, aconselha. De certa forma, Freitas era então o pai substituto que Vicente encontrou para se livrar da relação ambígua com o pai real. O problema é que Freitas terminou por assumir uma posição vertical de autoridade e de interdição, de pai substituto controlador e impositivo: convenceu Vicente a ser operado. Assim, Vicente recaiu em uma relação de submissão ao "pai", incapaz de cometer o parricídio contra o pai substituto que, vitorioso e onipotente, o castrou: obrigou-o a abandonar os ringues.

O episódio é ilustrativo do impulso de Vicente para a ação (o "boxe" aqui como metáfora de atuação viril e agressiva para o inconformismo e a luta), assim como, em sentido oposto, sua predisposição para a inação, a desorientação, a conformação à autoridade paterna. As metáforas do boxe são sugestivas: o protagonista escolhe lutar, mas encontra a queda (o nocaute para o adversário), o padecimento e, depois, a castração (ao passar pela cirurgia do fígado, que o deixou incapacitado para o combate). Em vez de desafiar o treinador e as recomendações médicas, Vicente aceita a cirurgia e deixa o palco da luta. ${ }^{245}$

É como se Vicente soubesse que precisa de algo, intui que esse algo está relacionado ao pai e, no entanto, não consegue fantasiar uma realidade para si próprio em que a figura paterna seja desafiada e superada, permitindo-o desligar-se do universo familiar. Vicente é um herói que não consegue "fazer romance". Vicente não realiza o romance que o permite ultrapassar o próprio universo da casa e do "subúrbio mesquinho" em que vive, ainda que seu desejo aponte e o conduza, na mania de andar, para isso. A

\footnotetext{
245 A inação de Vicente já fora bem sublinhada por Vima Lia Martin, chamando a atenção para outra metáfora, a do limo nas paredes de sua casa, que traduziria "a necessidade de tirar o limo de sua própria vida". Vima Lia Martin. op.cit., p. 77.
} 
busca que ele empreende não se afirma e a elocução não formula claramente a contradição fundamental do personagem: a vontade de se emancipar e a incapacidade de fazê-lo.

Ao relembrar, no presente, o episódio de sua desistência da luta — na metáfora da promessa interrompida, a carreira no pugilismo - Vicente aponta para um conflito que permanece: contrariar as recomendações paternas de que desista ou seguir na luta? Como falta o pai verdadeiro, e sua lembrança está carregada de bons sentimentos, tornando a figura paterna uma referência nostálgica e adorada, Vicente sente a premência da busca, mas não consegue formular seu objetivo. A ausência de um pai substituto explica a angústia irresolvida e a movimentação incessante do protagonista. A busca infrutífera do rapaz mostra ainda que, na ordem social em que ele está inserido, a passagem de um estado de "barbárie" para um estágio de "civilização", pelo menos para alguém como ele, também permanece impedida ou, pelo menos, incompleta.

Essa liberdade da andança sem rumo poderia redundar em um alargamento de horizonte caso Vicente conseguisse, no plano social ou da cultura, encontrar alguma referência acima de suas possibilidades. No entanto, o impulso da busca do protagonista é horizontal, e as restrições (sociais, morais, econômicas) do mundo em que o rapaz se insere impedem que essa busca se dê de maneira consequente.

$\mathrm{O}$ "romance familiar" de Vicente, assim, guarda relação com a condição social do protagonista e com seus limites existenciais. As tensões familiares que envolvem o personagem-narrador não se restringem a ele e aos seus pais, nem dizem respeito apenas à organização da família nuclear (apesar da ênfase com que, ao final, o rapaz decide retornar a casa e à companhia da mãe, cogitando, inclusive ocupar o lugar vazio do pai). Como aponta a própria noção de "romance familiar", o impulso do protagonista se projeta para o exterior.

O desejo de Vicente se move da família (a mãe, a casa) e da vizinhança (Daniel, Lídia) para fora desses limites. A horizontalidade do deslocamento espacial que move o personagem indica que ele sente a necessidade de alargar sua esfera de desejo e de ação, estendendo o "romance" a outros personagens e paisagens. A própria movimentação da casa para a rua aponta para o alcance social do romance familiar.

É da família para a convívio social que Vicente se sente impelido, mas ao mesmo tempo ele se mostra incapaz de estabelecer um novo romance. Já vimos como a 
caracterização da casa, do ambiente familiar de Vicente, é modesta e restritiva. A própria trajetória do personagem, que anda a pé e cogita pegar um trem para São Paulo, aponta também para parcos recursos financeiros e uma liberdade reduzida de movimentação apesar do forte impulso deambulatório, ele desiste de esperar meia-hora pelo trem que o levaria à cidade.

Também profissionalmente Vicente tem uma ocupação modesta. Apesar de experiente e de ter cargo de chefia, é operário: chefe da solda em uma oficina. Diz que está nesta ocupação "desde menino", o que sugere a necessidade de ter começado a trabalhar muito cedo. Não há referências à escola ou a estudos formais; o boxe, a luta, era uma atividade mantida também "desde menino" e que "era tudo".

O ambiente em que Vicente cresceu dá mostras de ser bastante duro com a criança. O trabalho braçal praticado desde cedo, a ausência de referências à educação formal e a escolha de uma luta violenta como o boxe como atividade esportiva provavelmente fizeram do menino uma criança com pouco tempo para ser criança. E as limitações de Vicente persistem depois da infância. A estreiteza com que ele lida tem relação não apenas com sua inserção familiar e social, mas com ele próprio, nos termos em que ele vive e convive com os seus semelhantes. Sua inserção no âmbito da cultura e das letras, talvez em decorrência da educação falha, também se mostra acanhada. A única referência à esfera artística, por exemplo, é às "letras dos antigos sambas tristes”.

Apesar de ter consciência de que a organização familiar o limita, Vicente é incapaz, no tempo da ação narrativa, de "fazer romance" ou de estabelecer relações "fraternas", de semelhança na diferença, como diz Kehl, a não ser com o menino que joga bola na rua e com a menina do jardim público. O "namoro" que o rapaz estabelece com a garotinha e o prazer do encontro com o menino indicam que o protagonista vive um estado emocional de retorno à infância, do qual quer se libertar mas não consegue.

Seu único vislumbre de alteração da situação angustiante em que vive é ocupar o lugar do pai morto. Em vez de romper com o suor da "semana brava", com as filas, com as conduções cheias, onde se viaja apertado, mesmo no domingo, ele deseja compensá-la, retomando os passeios que o pai fazia a Santos, Campinas. Em vez das viagens "difíceis" nas conduções apertadas de seu ambiente social, Vicente deseja os "passeios" aprazíveis que o pai promovia em família, a evasão para outros lugares - cujos nomes se ligam aos 
universos da religião (Santos) e do campo (Campinas) - fugindo do urbano, da cidade, do mundo social em que vive.

O pai-substituto não está disponível no universo em que vive Vicente, não aparece dentro dos limites do conto que o próprio personagem conta. Vicente, o que vive, é incapaz de "fazer romance". Vicente, para viver, faz um conto.

Os limites impedem Vicente, mais uma vez, de realizar o seu romance familiar e, assim, suplantar a perda do pai. Em parte, isso se deve ao mundo em que Vicente nasceu e onde continua a circular: o "subúrbio mesquinho", como ele mesmo se refere ao bairro em que vive, a moral rígida da família e o universo do trabalho alienado na oficina. Este, aliás, tudo indica, é herança da vontade onipotente do pai do protagonista. Isto é, o trabalho de solda, em que Vicente está "desde menino" e no qual permanece, é a continuidade da vontade paterna quanto à sua vocação e o seu destino. Assim, explica-se por que a vontade de andar apareça apenas nos momentos em que ele não está no trabalho: na volta do trabalho, nas férias, num domingo como este em que ocorre a ação do conto. Vicente sai em busca de outro pai, de um pai substituto que lhe permitam ultrapassar os limites de si mesmo e de seu próprio mundo. Assim, permanece num estágio infantil de nostalgia do pai real e adoração do pai morto, preso à situação familiar e social que o limita.

Vicente não é vagabundo nem malandro. É um otário, um trouxa, mas um trouxa e um otário aluado. Trabalha desde menino, e desde menino, provavelmente, tinha o sonho de ser pugilista. Fracassado o sonho de ser lutador de boxe, restou-lhe o trabalho na oficina, onde se tornou chefe, graças, ao que parece, muito empenho, dedicação e competência. Mas ali ele se sente adulado. A relação de puxa-saquismo, de forte conteúdo cordial, repõe no trabalho elementos de origem familiar.

Seu impulso divide-se entre a permanência da condição infantil e uma angústia difusa, desejo de mudança e emancipação que não consegue elaborar. Deseja ao mesmo tempo a manutenção dos valores familiares mas também a ascensão social, o arrivismo e a emancipação - para os quais, porém, ele não encontra o caminho. As limitações de seu ambiente familiar e social o angustiam, pois ele sabe que para ultrapassar os limites do "subúrbio mesquinho" precisa romper com ele — o que significa romper com a família, com a vizinhança e consigo próprio, para mudar, caminhar e chegar em algum lugar, libertando-se da mania de andar. 
A figura paterna ausente, que poderia tê-lo liberado para o percurso de reinvenção do próprio destino, no entanto, fez dele um saudoso do pai, que, morto, permanece como uma figura a um só tempo protetora e castradora. Insatisfeito com o subúrbio mesquinho, com as costuras da mãe e de Lídia, com o futebol na TV a convite de Daniel e com os aduladores, Vicente não consegue imaginar para si outro caminho. Sua busca, deambulatória e dispersiva, é motivada e dominada pela figura paterna: começa e retorna para o pai, sem que este possa ser trocado por um totem ou figura paterna substituta.

Vicente está em um momento de crise pessoal, em que sua própria maturidade é colocada em questão. Ao mesmo tempo que olha para o futuro, pensando em casamento e na recomposição da ordem original de seu núcleo familiar, o rapaz volta-se para lembranças que continuam a afetar sua predisposição à ação, tolhendo seu impulso de alargar os limites de seu próprio mundo.

O reencontro com a condição infantil expresso nas cenas em que o protagonista depara com as duas crianças na rua o faz reviver seu romance familiar, que no entanto não pode, nos limites do conto, ganhar consequência e transformar-se em ação. Os devaneios de Vicente, assim, direcionam-se para uma condição regressiva: a volta a casa, à mãe e ao lugar vago deixado pelo pai, cogitando inclusive render-se ao casamento com Lídia, a vizinha que é uma espécie de "irmã" (adotada pela mãe do rapaz) ou simplesmente uma espécie de "mãe substituta". Em vez da expansão do próprio universo de atuação ou dos limites do próprio mundo, Vicente vive uma busca que se volta para si mesma, para a imagem paterna ausente e cultuada, para a mãe, ou para a mãe-irmã-vizinha que é Lídia, e para as limitações de uma realidade social estreita.

Como primeiro conto do primeiro livro de João Antônio, "Busca" faz jus à sua posição inaugural na ficção do autor. O protagonista inaugura um projeto de ficção que tem entre suas bases as possibilidades de atuação de um jovem rapaz brasileiro pobre dos anos 1950 e 60. "Busca" aponta para os desejos e as limitações desse herói, insatisfeito com a estreiteza moral e material do mundo em que vive, mas ao mesmo tempo incapaz de tomar uma atitude consequente e contrária a essa configuração social e familiar.

\section{Da "vagabundagem" à sinuca}


Os dois outros "Contos Gerais" do livro revisitam semelhante constituição dos personagens e temas análogos ao de "Busca". Uma diferença substancial, porém, marca a composição de "Aact" e "Fujie": apesar de narrados em primeira pessoa, como o primeiro texto, nestes dois contos os protagonistas-narradores não têm nome, o que causa certo estranhamento e provoca no leitor uma espécie de inércia receptiva, como se a primeira narrativa tivesse continuidade nas duas seguintes. Não diríamos que a ambiguidade aqui é da mesma ordem ou intensidade daquela dualidade que marca os contos autobiográficos (analisados no capítulo anterior), erigidos entre autobiografia e ficção. Apesar de o narrador não vir identificado por nome próprio nos dois contos, não é possível confundir autor e personagem, afinal trata-se claramente de um livro de ficção, cujo pacto com o leitor é claro. Mas o que o leitor dos "Contos Gerais" se pergunta, inicialmente, é se o protagonista de "Aact" e "Fujie" não seria o mesmo Vicente de "Busca". Não é a nossa hipótese, mas a composição dos contos permite essa leitura; mais que isso, a ausência de nome próprio dos dois outros protagonistas e a semelhança deles com Vicente faz com que a leitura dos três contos, afinal reunidos sob uma mesma rubrica, contamine uns aos outros.

"Aact" é o mais longo dos três contos e aquele que desenha com mais clareza as contradições futuras da ficção do autor, ainda que "Fujie", como veremos, aponte para certa resolução do impasse que marca os três "Contos Gerais", aquele mesmo impasse que já fora anunciado em "Busca": a dificuldade dos protagonistas em formular seus romances familiares e, afinal, solucioná-los, ultrapassando os limites da família nuclear, deixando a infância para trás e integrando-se socialmente.

De "Busca", "Aact" mantém como tema central a indefinição de seu protagonista, agora acentuada pela anonimia do personagem. A própria designação com que foram agrupados, sob a rubrica "Contos gerais", já apontava para traços de indeterminação, de generalidade que dizem respeito ao tema mais fluido das narrativas, em oposição ao tema forte da "Sinuca", mas também às características pouco específicas, "gerais", dos personagens e até mesmo das próprias situações narradas. Ao contrário dos contos mais conhecidos e mais apreciados do autor, que são intitulados com os nomes dos protagonistas — "Meninão do Caixote", "Malagueta, Perus e Bacanaço", "Paulinho Perna Torta" —, nesses primeiros contos os títulos não remetem a personagens, mas a ações: "Busca" e "Afinação da arte de chutar tampinhas". A exceção, entre esses primeiros textos, é "Fujie", 
o terceiro dos "Contos Gerais", que também é intitulado a partir do nome de uma personagem - mas, note-se, não com o nome do protagonista, e sim com o nome da personagem, Fujie, pela qual o protagonista-narrador se apaixona.

Em "Aact", no entanto, apesar da ênfase na ação de chutar tampinhas, o conto tematiza e problematiza, isso sim, a própria capacidade de ação do protagonista, como já ocorrera em "Busca", mas agora de maneira ainda mais acentuada, a começar, como dissemos, da própria constituição indefinida e indeterminada do personagem-narrador — aliás, como também no primeiro conto.

Vejamos como se desenrola o segundo conto de $M P B$.

Trata-se de um conto relativamente longo, com cerca de 10 páginas (com variações, obviamente, dependendo da edição), dividido em 4 partes. Conta com três planos temporais distintos: o presente da ação narrativa, a infância do personagem e o tempo de quartel (rememorado a certa altura do texto). O número de personagens também é grande: o protagonista-narrador, o pai, o irmão, Biluca, Noel, a mocinha Aldônia, o comandante e seus dois filhos, as senhoras mães de família, a mãe do protagonista, a professorinha e, claro, as tampinhas. Apesar dos três tempos distintos em que a narrativa se estrutura e dessa profusão de personagens, ou talvez por isso mesmo, é difícil dizer com precisão qual é a ação decisiva do conto.

O narrador não enuncia seu nome. Mas sua idade é menos oscilante que a de Vicente, que como vimos é, a um só tempo, adulto, criança e adolescente.

O conto se inicia com a frase "Hoje meio barrigudo", o que indica que estamos num estágio da vida do protagonista em que a passagem do tempo já se faz notar na própria constituição física do personagem. No entanto, não se trata de um velho, mas alguém num estágio intermediário, no meio do caminho da existência, o que o advérbio "meio" evidencia. Nem muito nem pouco barrigudo, mas "meio". A barriga, que indica sedentarismo, e a ausência de verbo nesta primeira frase, nominal, apontam também, desde já, para um personagem marcado pela inação.

A frase inicial marca um tempo presente: hoje. Mas logo a partir da segunda oração, a narrativa volta a um tempo passado: "Mas já fui muito bom centro médio". O tema do futebol aparece para marcar o tempo da infância. "Centro médio" é uma posição de jogador de futebol, meio-campista, como se diria hoje. De novo, a frase marca a posição 
intermediária do personagem, agora no universo futebolístico, no qual, porém, ele diz ter sido "bom", qualificação que, por sua vez, confere conotação positiva a essa posição intermediária e ao passado de jogador de futebol. No conto, o tema do futebol será retomado adiante, na longa descrição do hábito ("mania", "tarefa", "trabalho", nos termos do conto) de chutar tampinhas na rua.

A partir daí o narrador relembrará a infância, quando costumava jogar bola com amigos e quando começou a se interessar por samba, em especial pelas composições de Noel Rosa. É também quando ele relembrará o pai: "Na Mooca, agora, eu via os moleques do Caióvas F.C. Papai vivia me apertando na escola. Era o único jeito, porque não estudaria de outro. Eu via os moleques e não podia jogar". ${ }^{246}$

A família vivia em Presidente Altino, pressupõe-se pela menção à U.M.P.A - União dos Moços de Presidente Altino, e vai morar na Mooca. Assim, depois da mudança, o pai passa a cobrar do menino bom desempenho escolar, o que o narrador liga a um impedimento de praticar o futebol. Agora ele apenas “via”, não podia jogar. Autoridade paterna e disciplina escolar ligam-se, nesta enunciação memorialística do narrador, à interdição do prazer lúdico do futebol.

O narrador não fará mais nenhuma menção à escola, mas irá rememorar acontecimentos que promoveram seu alargamento de horizonte e certo aprendizado. Porém, não é o universo da educação formal que irá provê-lo de conhecimento, aprendizado e compreensão do mundo, e sim o samba e o futebol: "Aos domingos a gente trepava num caminhão e ia jogar noutras vilas. Havia batucada na ida e na volta. Ou melhor, às vezes voltávamos de cabeça baixa, maldizendo juiz, campo que a gente não conhecia, tudo para justificar a derrota". 247

O deslocamento espacial, depois da mudança da família, neste momento da infância é proporcionado pelo futebol. Os meninos da Mooca vão "jogar em outras vilas”. E no trajeto, "havia batucada". O narrador a esta altura já tinha rememorado o costume de se juntar com os amigos, à noite, na sede da U.M.P.A para batucar: "Os mais velhos iam ajeitando as coisas, Biluca no seu cavaquinho, eu repicava na frigideira. Havia um surdo que um sujeito da Força Pública tocava (ele também era bom no pandeiro). As vozes se

\footnotetext{
246 “Aact”, in: $M P B$, p. 37.

${ }^{247}$ Idem, ibidem, p. 39.
} 
chegavam, se uniam e a gente batucava com vontade". ${ }^{248}$ É na época do futebol e do samba improvisado em Presidente Altino que o jovem narrador é despertado para a sensibilidade estética, justamente pelas letras dos sambas:

Naquelas noites me surgia uma tristeza leve, uma ternura, um não sei quê, como talvez dissesse Noel... Eu estava ali, em grupo, mas por dentro estava era sozinho, me isolava de tudo. Era um sentimento novo que me pegava, me embalava. Eu nunca disse a ninguém, que não me parecia coisa máscula, dura, de homem. Não os costumes que a turma queria. Mas eu moleque gostava, era como se uma pessoa muito boa estivesse comigo, me acarinhando. As letras dos grandes sambas falavam de dores que eu apenas imaginava, mas deixava me embalar, sentia.

Aos pés da santa cruz

Você se ajoelhou,

E em nome de Jesus

Um grande amor você jurou... ${ }^{249}$

O samba e o futebol, assim, promovem a individuação do narrador, que pela primeira vez se sente destacado da turma, consciente de dores imaginadas, de uma "tristeza leve", de um sentimento novo. A letra de "Aos pés da santa cruz", de Marino Pinto e Zé da Zilda, arremata essa rememoração de uma espécie de educação sentimental do narradorprotagonista, que é enunciada de maneira um pouco misturada, em estado de confusão, mas atravessada pela experiência do samba - "um não sei quê, como diria Noel”, assinala o narrador. As dores imaginadas pelo narrador se relacionam a algo que ele não sabe dizer o que é. Mais que isso, o narrador-personagem sublinha que não conta a ninguém esses sentimentos novos por não lhe parecerem viris, coisa de homem. Mas que ele gostava, como se alguém o acarinhasse. As experiências do futebol e do samba se dão em grupo, mas contribuem para a individuação do personagem. Mais que isso, para a sua solidão ("por dentro estava era sozinho, me isolava de tudo"). Samba e sensibilidade o tornam diferente da "turma".

\footnotetext{
${ }^{248} M P B$, p. $37-38$.

${ }^{249}$ Idem, p. 38.
} 
As letras de samba, que acompanhavam o convívio com outros moleques e que faziam parte da prática amadora do futebol, assim, iniciaram o personagem no universo da cultura, da arte, das letras e dos sentimentos contraditórios, inconfessáveis. Ele receia contar o que sente. Daí que o isolamento, a individuação, resulte também em um encabulamento, uma dificuldade de falar dos próprios sentimentos ou, mais que isso, uma dificuldade de falar, que é também marca desse personagem-narrador.

A diferenciação do protagonista, portanto, é problemática. Ele é da turma — gosta de futebol e batucada. Mas é diferente — sensível às "dores" das "letras" dos "grandes sambas", que falam de amor e traição. A solidão do personagem-narrador irá ganhar descrição acabada na seção do conto em que ele descreve o costume de chutar tampinhas. Mas ela é definida aqui em função de sentimentos e de percepção do mundo, afetos e aprendizado. A letras de "Aos pés da santa cruz" fala de um amor, de uma traição, de mentira e de pecado. Fala de dores, diz o narrador, que ele apenas imagina, mas que o embalam e que ele sente. Há nos verbos acarinhar e embalar, empregados pelo narrador uma forte conotação feminina e maternal, que contrasta com o ambiente masculino do futebol. Estética, criação individual, música, dor, amor são elementos que o narrador descobre no samba. Mas ele teme que isso não seja coisa "máscula, dura, de homem".

Já vimos que a figura paterna, aqui, ao contrário do que ocorre com Vicente, é presente e exigente. O pai o apertava na escola, diz o narrador. E o personagem do pai irá reaparecer adiante, ainda nesta primeira fase do conto, quando o narrador relembra um episódio de infância em que foi castigado. A namoradinha Aldônia ("uma espécie desajeitada de namoro que eu andava engendrando") o pegou fumando escondido. A menina o delata à família dele e presume-se, pela maneira com que ele narra o episódio, que isso causou o rompimento do namoro. O menino apanhou duas vezes: a primeira por ter fumado escondido, a segunda por ter escrito um bilhete xingando Aldônia:

Tolice enorme. Surra dobrada em casa. Papai me esperando com o bilhete na mão. A diaba contava tudo porque sabia que eu apanhava mesmo. Aquilo já era me fazer de palhaço.

— Não fala mais comigo.

Engraçado - Aldônia até hoje não presta. ${ }^{250}$

${ }^{250}$ Idem, ibidem, p. 40. 
A "surra dobrada" foi dada, claro, pelo pai, a quem a menina presumivelmente entregou o bilhete com os xingamentos. A letra de "Aos pés da santa cruz" ecoa aqui, pois Aldônia é uma “diaba”, capaz de traí-lo, denunciando-o ao pai, com intenção de torturá-lo ("porque sabia que eu apanhava mesmo"). O final do trecho acima aponta para a contrariedade persistente com que o narrador vê a antiga namoradinha. Mas antes disso, vem uma fala, com marcação de diálogo, que o leitor fica sem saber exatamente quem a profere: “- Não fala mais comigo”. Quem a enuncia? O protagonista ou Aldônia? Difícil dizer. Mas a letra do samba, à qual este episódio se vincula, acarinha o narrador, embalando-o e aliviando sua dor.

O samba, porém, não resolve as agruras sentimentais e a crueza dos elementos afetivos persiste. Pai violento, disciplinador e castrador. Namoradinha pouco confiável.

Por ora são as duas figuras, uma masculina e outra feminina, que polarizam as relações de afeto e autoridade mais intensas no relato. Mas a mãe será mencionada adiante, já na última seção do conto, justamente a propósito de uma nova possibilidade de romance que se apresenta ao protagonista:

Mamãe costuma dizer que eu não sou dos mais feios. Bem — veio morar cá no bairro uma professorinha solteira, muito chata. Rapazes lhe dão em cima por causa de um dote, ou de coisa parecida. Não sei. A vida dos outros nunca me interessou. Nem a dela, embora viva me provocando. Quer casamento, com certeza. Olho para a mulher, para os modos, para o anel... Quer casamento, eu não.

Dia desses no lotação. A tal estava ao meu lado querendo prosa. Tentava, uma olhadela, nos cantos os olhos se mexendo. Um enorme anel de grau no dedo. Ostentação boba, é moça como qualquer outra. Igualzinha às outras, sem diferença. E eu me casar com um troço daqueles?... Parece-me que procurava conversa, por causa de um Huxley que viu repousando nos meus joelhos. Eu, Huxley e tampinhas somos coincidências. Que se encontraram e que se dão bem. Perguntou o que eu fazia na vida. A pergunta veio com jeito, boas palavras, delicada, talvez não querendo ofender o silêncio em que eu me fechava. Quase respondi...

- Olhe: sou um cara que trabalha muito mal. Assobia sambas de Noel com alguma bossa. Agora, minha especialidade, meu gosto, meu jeito mesmo, é chutar tampinhas da rua. Não conheço chutador mais fino. ${ }^{251}$

${ }^{251}$ Idem, ibidem, p. 47-48. 
A ação narrada é a de um encontro romântico. E como é esse encontro? Um fracasso completo. Por quê? Esta é a pergunta-chave para se entender a narrativa e a atitude do protagonista. O flerte não avança porque o personagem-narrador não dá bola para a professorinha. Em que termos ele coloca a situação?

Primeiro, ele manifesta desprezo pela moça, chamando-a de "a tal" e de "troço", quando antes já a tratara por "professorinha". Além dos termos pejorativos e do diminutivo com que ele se refere a ela, ele expressa também seu desdém também pelo "enorme anel de grau” que ela traz em uma das mãos, dizendo que aquilo é “ostentação boba”. O desprezo é pelo "dote", disputado pelo rapazes do bairro, pela superioridade intelectual, simbolizada no anel de grau, que indica curso superior, e pela profissão de professora, ligada à escola, à carreira do ensino, a um aprendizado formal, que para um amante de sambas e fino chutador de tampinhas parece ostentação. ${ }^{252}$ Depois, ele recusa a conversa, evitando o flerte. À pergunta sobre o que ele faz da vida, ele reage de maneira intempestiva e afirma a sua especialidade vagabunda: chutar tampinhas da rua.

O trecho é aquele que define a ação mais importante do conto, que encaminha a narrativa para o final e que deveria concentrar o momento significativo, aquele que revela, afinal, o sentido do narrado. A rigor, porém, talvez nem se possa dizer que a ação de fato ocorra. Por parte do narrador, pelo menos, ela definitivamente não ocorre. O que diz o narrador? Que ela, a professorinha, lhe colocou a questão: o que você faz na vida? Ao que

\footnotetext{
${ }^{252}$ A desconfiança com relação à escola e ao aprendizado formal, que a recusa à "professorinha" resume, lembra a ressalva à palavra escrita como expressa na literatura de Graciliano Ramos. Lembrem-se as atribulações de Fabiano com as contas nos papéis do patrão, a dificuldade de escrita que perpassa toda a obra de Graciliano (como ressalta Lafetá acerca de João Valério, Paulo Honório, Luís da Silva e o narrador das Memórias do cárcere) e a dor com que o narrador de Infância repassa o aprendizado da leitura (o que também remete ao aperto na escola e às surras que o protagonista de "Aact" recebia do pai). Sobre essa violência traumática do protagonista de Infância, João Luiz Lafetá observa que "o processo de aprendizagem é, simbolicamente um processo de castração" e liga o personagem-narrador de Graciliano ao arquétipo do bode expiatório: "O pharmakós, herói por excelência do modo irônico, é o ser desamparado. O menino de Infância - desdobrado depois nos heróis de Graciliano - sofre de desamparo. (...) o centro de Infância é constituído pela narrativa do aprendizado de leitura. Como todos os outros aprendizados, este se dá através de uma sucessão de choques penosos, de traumas violentos que marcam a criança (...). Levanto a hipótese de que a contenção irônica do estilo está relacionada com esta gênese traumática. Aí está o miolo do trabalho. A ironia, técnica literária, é iluminada - e ajuda a iluminá-las — pelas condições sociais de vida e pelas reações pessoais às determinantes da experiência. Literatura, sociedade e psicanálise juntam-se nesse ponto: o menino explica o homem Graciliano (como disse Otávio de Faria), mas não apenas - as condições de vida do menino ajudam a entender o homem e a constituição de sua escrita." Neste artigo, Lafetá lê os romances de Graciliano de acordo com três suportes teóricos: psicanalítico (Marthe Robert), sociológico (Lukács) e literário (Frye). LAFETÁ, J. "Três teorias do romance: alcances, limitações, complementaridade". In: A dimensão da noite. Organização de Antonio Arnoni Prado. Duas Cidades/Editora 34. São Paulo: 2004.
} 
ele diz: “Quase falei”. Ou seja, o diálogo não se estabelece, e o narrador, na situação narrada, não diz nada, permanece fechado em seu silêncio. O que se narra, então, é um encontro malogrado. $\mathrm{O}$ que se anuncia como um flerte, um encontro romântico, como o clímax do conto, revela-se ao final como uma espécie de não acontecimento, um incidente sem consequência.

O texto ainda continua, com mais um último parágrafo, que, em vez de levar a narrativa adiante, irá retomar os temas lá de trás, da infância do personagem e um tom de desalento, de tristeza leve, que em algum momento havia sido deixado para trás e agora reaparece, no epílogo, fechando a narrativa:

Mas não sei. A voz mulata no disco me fala de coisas sutis e corriqueiras. De vez em quando um amor que morre sem recado, sem bilhete. Ciúme, queixa. Sutis e corriqueiras. Ou a cadência dos versos que exaltam um céu cinzento, uma luva, um carro de praça... Se ouço um samba de Noel... Muito difícil dizer, por exemplo, o que é mais bonito - o "Feitio de oração" ou as minhas tampinhas.

Em vez de o protagonista ficar com a professorinha, ele "quase" lhe diz o que realmente gosta. E, depois, afirma uma dúvida: "Mas não sei”.

Em vez de ficar com a mocinha, o mocinho fica com a "voz mulata do disco", "os sambas de Noel"253 e "as tampinhas", como o narrador mesmo diz no último parágrafo. E com o leitor, a quem o conto se destina, a quem o texto apela, clama por atenção.

O que pensar desse movimento narrativo que prepara um clímax conservador - um motivo romântico forte, o flerte amoroso, e a possibilidade de um casamento —, mas que não se realiza?

Como já ocorrera com Vicente, temos novamente um narrador que apresenta resistência à ideia do casamento. Assim como Vicente, o narrador de "Aact" hesita entre a ordem familiar e o mundo mais largo das relações sociais. Na família ele é o filho torto.

\footnotetext{
253 "Feitio de oração", de Noel Rosa, a composição que o narrador cita como uma de suas preferidas, reafirma a descrença na educação formal, em favor de um conhecimento espontâneo. Diz a letra: "Batuque é um privilégio/ Não se aprende samba no colégio." O narrador prefere o ensino de Noel Rosa à conversa com a professorinha, adota o samba e não a oração ou — para evidenciar a ambiguidade de sua exclusão-inserção em seu contexto social e familiar - adota um samba "em feitio de oração". O começo da composição diz "Quem acha vive se perdendo", o que evidencia uma inversão promovida pelo sambista: achar-se é perder-se. Invertendo-se a formulação: perder-se é achar-se, o que resulta numa defesa da perdição, do pecado, da subversão, em consonância com o comportamento "aluado" do protagonista.
} 
Tem um irmão que é a camisa, enquanto ele é o avesso. Ele tem fama de aluado e farrista, "uma porção de coisas que sou e que não sou".

Da infância solta e festeira - mesmo que introspectiva, também coletiva no convívio com a turma de boleiros e batuqueiro - à vida de rapaz adulto e solitário que "trabalha mal", "aluado", "farrista". Passa-se da infância, em que o samba e o futebol apontavam para a modos de convivência e de aprendizado mais livres e prazerosos, para a vida adulta, pautada pelas obrigações assumidas por pressão familiar e social.

No meio de tudo isso, quartel e as tampinhas. Há uma seção no conto para cada um desses temas.

Sobre o quartel, o rapaz diz que nele "nem me deixaram pensar em jogo de bola". Ali, ele irá praticar jiu-jitsu e terá de aturar os filhos do comandante, de quem se torna instrutor de luta. Diz, porém, que para ele o comandante era bom: "Favores, dispensas, o homem me dava um fio de liberdade. Porém, um defeito sem remédio. Eu nunca rasguei o verbo. Senão, cafua". ${ }^{254}$

Para este personagem marcado pela solidão e pela hesitação, pelo caminho do meio, o quartel é o único ambiente em que o protagonista se mostra um pouco mais enfático, decidido. Ali, os lugares estão definidos. Senão, "cafua”, prisão. E, no entanto, é no quartel que o personagem irá encontrar ambiente propício para burlar as regras, por meio de uma trapaça, como veremos: o desvio de algumas garrafas de cerveja preta.

A autoridade do comandante no quartel é marcada no curto trecho sobre a época de serviço militar. A hierarquia a que o personagem se submete no ambiente fechado e de regras claras do quartel, porém, não é uma exceção. De certa forma, o protagonista já conhecia esse regime de relacionamento: as relações interpessoais vividas pelo protagonista são pautadas pela autoridade, sobretudo com outros homens, mas também com as "senhoras mães de família". Biluca, por exemplo, mandava no time, porque era dono das camisas. O pai lhe apertava na escola e the surrava quando sua conduta não era correta. No quartel, o comandante podia castigar ou prender, ainda que lhe desse um fio de liberdade. $\mathrm{O}$ irmão o considerava um "largado". No bairro, a fama dele era péssima.

É na companhia das tampinhas, então, que ele se encontra, "homem se atilando naquilo que faz". A chutação de tampinhas é "mania", "arte", "tarefa", "trabalho", palavras

\footnotetext{
${ }^{254}$ MPB, pp. 40-41.
} 
que o narrador emprega para definir sua atividade, aquilo que afinal o define, como ele dirá à professorinha ao final do conto. Nesta nova ocupação, não é mais apenas um fio de liberdade, concedido por uma figura de autoridade, mas uma nova realidade que se apresenta. "Fica outra a minha cidade!", diz o narrador. Essa cidade que é a mesma cidade, mas que vira - "fica outra" durante as madrugadas, aos sábados e domingos em que "se despovoa" - , é o espaço em que ele pode, afinal, dar vazão às suas fantasias, ser ele mesmo, descobrir a sua arte, sua vocação e afinar seus sentimentos. E essa educação sentimental se dá com as tampinhas:

Só um sujeito como eu, homem se atilando naquilo que faz, pode avaliar um chute digno para determinadas tampinhas. Porque como as coisas, as tampinhas são desiguais. Para algumas que vêm nas garrafas de água mineral, reservo carinho. Cuidado particular, jeito. É doce chutá-las bem baixo, para subirem e demorarem no ar. Ou de lado, quase com o peito do pé, atingindo de chapa. Sobem. Não demoram muito, que ainda não sou um grande chutador. Mas capricho, porque elas merecem.

Minhas tampinhas... Umas belezas. ${ }^{255}$

É gritante o contraste entre o tratamento dispensado a elas, tampinhas, e o tratamento que o protagonista reserva à professorinha. Não apenas a passagem acima, mas todo o trecho em que ele faz uma tipologia da sua atividade de chutador é permeado de afeto e de excitação, enlevo e discernimento sobre as tampinhas. Como vimos, ao final, ao contrário, com a professorinha ele será ríspido e desconfiado, tenso e quieto. E afinal melancólico de novo, depois do encontro.

O trecho final do conto concentra os temas da educação sentimental do personagem - trabalho, literatura, relações afetivas - e retoma os motivos anteriores, das tampinhas e do quartel. Os trechos das tampinhas e do quartel, por sinal, se comunicam em duas passagens, uma na seção das tampinhas e outra no trecho final do conto, modulando, rumo à malandragem, o comportamento "vagabundo" e criativo do protagonista, capaz de instaurar uma nova ordem, mais livre e afeita a ele mesmo, que nega a "ordem", o mundo “direito". Durante a descrição de suas perambulagens noturnas, ele relembra uma passagem dos tempos de quartel, sugestionado pelas tampinhas de cerveja preta: "Também me dedico

${ }^{255} M P B$, p. 42. 
com simpatia às de cerveja preta. Provavelmente porque me lembram serões, almoços improvisados, trechos duros da vida". Esses trechos duros são os tempos de serviço militar? Provavelmente. Mas trechos duros que são compensados com pequenos confortos, como cerveja preta, conseguidas, como o narrador irá contar, nos tais "serões".

$\mathrm{Na}$ geladeira do aprovisionamento do quartel, havia sempre cerveja preta, reservada aos sargentos. "Difícil cavar cerveja preta", diz o narrador. Diz também que não era "nem tão trouxa nem tão caxias". Uma fala rememorada recomenda que ele se vire: “ — Você não é praça? Se vira”. E é o que ele faz: tomando conta do aprovisionamento, confere os relatórios de produtos que chegam e se aproveita da malandragem do sargento:

Havia no quartel uma caixa delas. Reservadas para sargentos do dia. Cada um tinha direito a uma. Na geladeira do aprovisionamento sempre havia. Difícil cavar cerveja preta. O comandante me encarregou de tomar conta do aprovisionamento, ajudando o sargento Cunha. Pagar o mantimento ao pessoal do rancho. Boa vida. Meu lugar bem que era outro, lá na secretaria. Datilografando, esquentando a cabeça com números e preços na máquina de calcular. Mas eu ensinava jiu-jitsu aos filhos do comandante, era peixe... As cervejas pretas eram inacessíveis. Todos queriam. Os homens viviam de olho naquilo.

- Se sumir, desconta-se na folha de pagamento.

Na minha folha de pagamento, é claro. Ordem de não sei quem.

Eu me defendia de acordo. Pois um dia, o sargento Cunha esqueceu-se de uma caixa no relatório. Ficavam cópias do relatório dentro do armário. Espiá-las. Era a primeira coisa que eu fazia no começo de cada mês. Às vezes sobrava alguma coisa que faltava no relatório... Eu me ria.

— O sargento não é santo.

E quem é santo?

Disputa brava, então. Porque o homem percebia as minhas olhadelas no relatório. Um tapeando o outro, se escondendo.

Faca de dois gumes. ${ }^{256}$

É assim, sendo mais malandro que o sargento malandro, que o praça consegue desviar as cervejas pretas que não estavam contabilizadas no relatório. Um tapeando o outro, ambos cientes da malandragem, faca de dois gumes, mas impossibilitados de denunciarem um ao outro, o que seria, também, denunciar a si próprio.

${ }^{256} M P B$, p. $44-45$. 
É na ordem fechada e instituída do quartel, então que o rapaz irá aprender a ser malandro. E no quartel ele também irá aprender um ofício e descobrir as vantagens de um bom relacionamento. Ele trabalha "datilografando", na contabilidade. E é "peixe" do comandante. É a dedicação e a competência com os números que o levam para o aprovisionamento, onde ele irá "tomar conta" das provisões. A indicação é do comandante, de quem o rapaz é "peixe", isto é, é amigo, protegido, apadrinhado. O trabalho e a relação de hierarquia, portanto, são o lado direito que o praça vira em avesso: tapeação e favorecimento. É malandragem em estado nascente, dentro do ambiente rígido, em aparência, do regimento militar.

O desvio da caixa de cerveja é esperteza do narrador, que é possível graças à sua inteligência, mas também graças ao funcionamento da malandragem já instalado no coração da ordem militar. É, assim, conduta individual que só pode prosperar porque o ambiente é propício. A malandragem do narrador do conto, assim, pode ser bem-sucedida porque se reproduz sobre uma outra malandragem. Malandragem sobre malandragem. Malandragem ao quadrado, em pleno quartel.

O protagonista não "era trouxa nem tão caxias", como ele próprio diz. Era, desde cedo, um praça que se vira, que sabe $\operatorname{cavar}^{257}$ aquilo que não tem. Nem trouxa, nem caxias: malandro.

A malandragem incipiente do personagem lhe será de grande serventia, depois do quartel: a ligação entre as tampinhas, os serões e a malandragem retorna no trecho derradeiro do conto, ganhando condensação e agudização, rumo ao desenlace, ligando-se ao trabalho e, depois, ao romance.

O trabalho que o protagonista arruma, à noite, é de "escritas", contabilidade. Saindo do escritório de contabilidade, onde faz serão, ele retoma a chutação das tampinhas:

Faço serão, fico até tarde. Números, carimbos, coisas chatas. Dez, onze horas. De quando em vez levo cerveja preta e levo Huxley. (Li duas vezes o Contraponto e leio sempre). Não parei na várzea da U.M.P.A, nas lições de distribuição de passes e centros que Biluca me dava.

Deixando o escritório. A madrugada costuma enegrecer tudo. Casas e homens. Só as minhas tampinhas reluzem na calçada. Contraponto debaixo de um braço. Garrafa de cerveja preta no outro. Assobiando, mãos nos bolsos. ${ }^{258}$

\footnotetext{
${ }^{257}$ O verbo "cavar" é utilizado também pelo narrador de Os ratos, de Dyonélio Machado, para descrever as tentativas de o protagonista do romance, Naziazeno, conseguir algum dinheiro.
} 
O trecho condensa, nas noites depois do serão no escritório de contabilidade, os temas da constituição do protagonista e sua ação. É um personagem isolado, que conseguiu um emprego "chato", com números, em contabilidade. O que ele quer mesmo, não é a chatice, mas o "contraponto"; não são os números, mas a escrita, e não a escrita de contabilidade, mas a escrita literária, ${ }^{259}$ aqui representada pelo livro de Aldous Huxley, que ele leu duas vezes e relê sempre.

Ele quer aprendizado, mas não quer a professorinha. A desconfiança, que nasceu com o namoro frustrado com Aldônia e que o samba ecoa, é que ela o traia, delatando suas malandragens: lá atrás o cigarro, fumado escondido; agora, talvez as tampinhas, a cerveja preta, o samba, a boemia, a... malandragem.

Com a atividade solitária e noturna da chutar tampinhas, o protagonista consegue realizar algo que os relacionamentos e as instituições não the permitem: a liberdade, o alargamento de horizonte, a criação, o devaneio, a arte, o afeto, tudo concentrado nas tampinhas. ${ }^{260}$ Nessa tentativa de encontrar a si mesmo e suas vocações, o personagem promove uma série de substituições, algumas muito claras, outras apenas insinuadas no conto. Algumas das mais evidentes: o personagem troca o dia pela noite, a ordem social direita pelo seu avesso, o trabalho pela vagabundagem, o quartel pelas ruas, as mulheres pelas tampinhas. Outras menos evidentes, apenas sugeridas: o protagonista troca a escrita contábil pela escrita literária (como leitor de Huxley), troca Aldônia por Aldous (mas não pela professorinha), as lições de passes e centros (do futebol de Biluca) pela leitura do Contraponto de Huxley (troca de "lições" por uma "leitura", livre, artística, que, de novo, nega a professorinha, ainda que atraia a atenção dela), troca a batucada coletiva pelo samba, a religião pelo samba de Noel (samba em "Feitio de oração" é o seu samba preferido; e, afinal, como ele próprio, narrador, se pergunta: “E quem é santo?”).

\footnotetext{
${ }^{258} M P B$, p. 46.

${ }^{259}$ Uma espécie similar de adaptação da vocação ocorre com o personagem Belmiro Braga, de Cyro dos Anjos. Como a mãe do protagonista sonha para ele uma carreira literária e o pai o queria agrônomo, Belmiro vai para as "letras agrícolas", tirando "carta de agrônomo". Aqui, em João Antônio, o rapaz arruma ocupação com escrita contábil, o que indica uma análoga conjunção das letras com uma carreira mais instituída socialmente. Dos Anjos, Cyro. O amanuense Belmiro. Belo Horizonte: Livraria Garnier: 2001.

260 Ana Maria Domingues e Telma Maciel da Silva, além disso, associam as "tampinhas" a "palavras". Oliveira, Ana Maria Domingues de; Silva, Telma Maciel da. "Memória e ficção na correspondência do escritor João Antônio”. Teresa. Revista de literatura brasileira [8] [9]; São Paulo, p. 356-371, 2008.
} 
Há, no protagonista de "Aact", portanto, uma forte desejo de individualização e libertação. Mas o personagem não consegue levar a termo esse processo. $\mathrm{O}$ crescimento e o desenvolvimento do personagem permanecem num momento intermediário... de afinação. Ele poderia ter trocado Aldônia pela professorinha, mas não o faz. Ele gostaria de trocar os números pelas letras (de samba e de literatura), mas o faz apenas nas madrugadas e na solidão. Em vez de Aldônia, agora ele tem Aldous, mas parece ter se fixado, acanhado e obsessivo: lê e relê o livro de Huxley, assobia sambas de Noel, chuta tampinhas, não fala com a moça que flerta com ele, pois a moça representa o que lhe atemoriza: o ensino formal, a moralidade convencional do matrimônio, o trabalho "bom".

Ele recusa os valores instituídos, preservando essa invenção excepcional: chutar tampinhas na rua, o que faz dele um contestador da ordem, um malandro em estado latente. A tarefa de chutar tampinhas é um rito moderno, totalmente criado e aperfeiçoado na imaginação em ato deste protagonista que se recusa a aderir aos valores consagrados como corretos. Nos termos de Maria Rita Kehl, chutar tampinhas na rua é uma atividade "disruptiva", que permite uma experimentação de linguagem e de ação que se aproxima de uma dimensão utópica ao questionar a ordem instituída, abrir sentidos imprevistos na realidade e criar novas práticas. No caso, uma prática gratuita, lúdica e improdutiva. Em certo sentido, a afinação da arte de chutar tampinhas — em afinidade com o samba e a literatura - antecipa a malandragem da sinuca (sem o caráter eventualmente exploratório do jogo) e cristaliza essa "vagabundagem" como uma ação "bárbara" e renovadora, imprevista, sem lugar social, e por isso mesmo altamente contestadora e alternativa.

O que o protagonista deseja é se atilar, ${ }^{261}$ ser ele mesmo, aprimorando-se naquilo que ele "faz da vida": trabalha mal, mas assobia sambas de Noel com bossa e chuta tampinhas na rua. A singeleza da resposta do personagem sobre suas vocações aponta para um desejo e uma recusa contraditórios: ele quer ser ele mesmo, afirmar seus gostos e idiossincrasias, mas não quer ingressar na ordem social tal como ela se apresenta, pois os valores sociais instituídos ou respeitáveis, “de bem”, não reconhecem sua personalidade: ele é "aluado", "farrista", "vagabundo".

\footnotetext{
${ }^{261}$ O uso do verbo "atilar", que ocorre no conto duas vezes, é recorrente em João Antônio e traduz bem a ambiguidade dessa espécie de aprendizado na malandragem: os jovens aspirantes a malandros como este protagonista de "Aact" (e depois os malandros de "MPB") se aprimoram, atilando-se, isto é, tornando-se Átilas. Ou seja, civilizam-se barbarizando-se. No primeiro capítulo, vimos como o narrador subverte a lógica de chamar "vândalos" aos pobres. Aqui, na ficção, a ambiguidade é mais sutil — e mais forte.
} 
Embora proceda a uma série de substituições que fazem com que ele consiga, ao menos para si mesmo, constituir-se enquanto indivíduo, o processo ainda está em fase de aprimoramento, afinação, e a dimensão utópica da chutação de tampinhas não encontra correspondência coletiva, pois a marca de solidão e isolamento do protagonista, que já ocorria em "Busca", acentua-se. Há substituições que não foram feitas, há personagens que ele não abandona e há encontros que não são consequentes — ele é um personagem do contraponto, como indica o título do livro de Huxley que ele carrega, lê e relê. ${ }^{262}$

Os personagens que ele não troca, ao menos explicitamente, são os pais. De novo, como em "Busca", repõe-se a dificuldade do romance/romance. A ação é abreviada, pois o protagonista não consegue ir além de seus próprios domínios. Ainda que as tampinhas proporcionem deslocamento, não são tarefa capaz de afastar o personagem de sua origens e de sua constituição infantil. A corroborar a condição de infante, lembre-se o final do conto, em que o protagonista nem mesmo conversa com a professorinha ("Quase falei”) e a dependência do círculo familiar (o emprego que ele arrumou serve para "defender uns cobres extras", o que sugere que ele ainda depende do que a família proporciona).

Fora do esquema que ele armou para si, permanecem, portanto, a família, o sustento e o relacionamento amoroso. Conquistar novas dimensões familiares, de trabalho e de amor são elementos da vida adulta que o personagem narrador permanece incapaz de conquistar nos limites deste conto e nos termos que ele projeta para si mesmo. Ele quer se emancipar e viver como indivíduo, mas hesita substituir os elementos que o mantêm dependentes de sua origem. ${ }^{263} \mathrm{O}$ dilema permanece: a história que ele conta não é um romance, isto é, não gera desdobramentos de tema e forma. Não é relacionamento amoroso, vida adulta e desenvoltura, romance; mas solidão, infância, acanhamento, conto.

${ }^{262}$ Como afirma Vima Lia Martin, “o mal-estar sentido pelo narrador do conto de João Antônio e o modo como ele enfoca a questão dos relacionamentos amorosos encontram eco no romance inglês. Afinal, sua aversão ao casamento deve-se a um profundo questionamento dos valores que sustentam as relações socialmente instituídas e, nesse sentido, está em sintonia com a falência das relações amorosas apontada por Huxley. Também a forma do romance, que busca aproximar a literatura da música, já que ele é escrito com base na analogia do contraponto musical, encontra ressonância na forma do conto brasileiro que acaba por reproduzir a cadência melancólica e comovente dos sambas mais sensíveis de Noel Rosa." MARTIN, V. Literatura e marginalidade: um estudo sobre João Antônio e Luandino Vieira. op.cit., p. 87.

263 Nesse sentido, Vima Lia Martin afirma que Vicente e o protagonista deste conto "se deslocam para a margem de uma estrutura social pautada em valores essencialmente burgueses. Sem infringir as normas que regulam nossa sociedade, os dois homens manifestam um profundo mal-estar pelo fato de suas condutas, de certa forma, compactuarem com elas". Idem, ibidem. 
Apesar do título, que chama a atenção para o tema do futebol vadio, o tema permanece sendo o mesmo do primeiro conto: a hesitação do protagonista em aceitar o caminho direito do trabalho, do bom comportamento e, sobretudo, do casamento, ou em outras palavras, a resistência do personagem em "fazer romance". Esta história ganha no conto uma estrutura narrativa desarrumada, cuja principal evidência é a discrepância entre o título e a ação significativa do relato. A força do conto reside, justamente, na ênfase temática na atividade de chutar tampinhas e, com isso, no deslocamento da ação principal do conto, que é o encontro do protagonista com a personagem da professorinha que o corteja, o (anti)clímax do conto. O encontro amoroso - frustrado, na ação, enquanto elemento romanesco, mas decisivo na estrutura do relato - é o momento significativo de “Aact", mas está de certa forma escanteado, dados a relevância e o espaço que a atividade de chutar tampinhas ocupa na narrativa.

Em outras palavras, chutar tampinhas é a atividade que mobiliza e ocupa o narrador, é uma daquelas coisas que ele diz, ao final do relato, "fazer da vida", mas para a economia estrutural do texto, não é central, ainda que seja decisiva. No conto, a ação propriamente dita, a ação que se encena e que marca o presente da enunciação, só ocorre realmente ao final, quando o narrador-protagonista encontra a professorinha no lotação. Ou nem isso, dado que o encontro não ganha desdobramento.

Em outras palavras, e então repondo a centralidade (deslocada) das tampinhas, a recusa à professorinha é uma afirmação da boemia, da "vagabundagem", da capacidade de criar um rito, uma ação e uma arte que não se enquadra no esquema conservador que envolve o protagonista.

Os elementos que caracterizam o personagem, segundo ele próprio, são coincidências (“Eu, Huxley e tampinhas somos coincidências. Que se encontraram e que se dão bem.”), o que confere caráter aleatório à constituição do personagem e da situação narrada. Mas, ainda que gratuitas, as coincidências dos elementos são coerentes, pois se as oportunidades e gostos se apresentam como casuais, o narrador procura ordená-las, como o faz com as tampinhas, por meio do afeto e de seu desejo de diferença. Esse impulso de diferenciação, porém, é castrado pelo pai (que o surrava), pelo irmão (que é o "direito", enquanto ele é o “avesso"), pelas senhoras mães de família (que lhe imputam a fama de “farrista"). O protagonista quer vagabundagem, samba e literatura. Mas o contexto familiar 
e social exige trabalho, escola, hierarquia militar e casamento. A arte de chutar tampinhas, porém, não é conformista ou purgadora, mas o princípio que ele próprio desenvolveu e que lhe permite a recusa e do desafio à ordem vigente. E, ao final, ao desprezar o assédio da professora, ele inverte os sinais que o senso comum e a moralidade convencional estabeleceram: ele não quer casamento, e recusa o flerte com a professora, mulher de nível social acima do dele e de maior formação educacional. "Aact" é uma recusa ao romance. “Aact" é um conto e um rito noturno da solidão, da individualização, da criação artística.

Em "Aact", diferentemente do que ocorre em "Busca", o protagonista não volta a casa, e não há reencontro com o pai, tampouco com a mãe, apesar de mãe e pai não estarem ausentes da ação narrada. Não há o retorno do filho pródigo, que vimos ser encenado nos contos autobiográficos, também consorciado com ausência paterna.

Estamos, porém, num estágio um pouco mais avançado que o de "Busca". E ainda podemos levantar a hipótese de que o progressivo desaparecimento do pai do protagonista ao longo do conto (o que ocorrerá também em "Fujie") sugira um parricídio simbólico que o tenha liberado para as artes da chutação de tampinhas, para o samba e para a literatura, artes que o afastam e o libertam do casal parental, da família, dos valores burgueses, devolvendo centralidade à chutação de tampinhas e fazendo afinal do conto uma narrativa de forte conteúdo contestador da ordem.

Isso é possível porque, apesar de não substituir o pai no momento presente da narrativa, ele já o substituiu anteriormente, transformando-o em totem. Vejamos uma possível leitura antropofágica para essa afinação de chutar tampinhas.

A figura do sargento substitui o pai biológico: no ambiente deslocado do exército, o protagonista irá encontrar no oficial uma figura paterna substituta. E o que ele faz com esse pai substituto? Consegue lográ-lo, utilizando o mesmo artifício malandro de que o sargento lançava mão, e então desvia algumas garrafas de cerveja preta para consumo próprio. Assim, transforma as garrafas de cerveja preta em trunfo totêmico de sua malandragem: a de ter enganado o sargento, figura paterna que é, assim, como o pai biológico, também ultrapassada.

O protagonista transformou a autoridade paterna em libação de cerveja preta. Antropófago, ele transmuta o tabu da autoridade paterna tirânica em totem de adoração e celebração. As tampinhas de cerveja preta vão ganhar destaque em sua arte de chutar: 
"Muito injusto esquecer-me de que as de cerveja preta são interessantes. Igualmente. Não posso desprezá-las. Elas com seus símbolos no meio. Uma cabeça de bovino ou muar". 264 As tampinhas que tem uma figura de boi ou de muar acentuam o caráter totêmico das garrafas de cerveja preta. É por isso que, ao deixar o trabalho, à noite, o rapaz leva debaixo do braço um livro de Huxley (a literatura, a escrita artística que o livra da castração do ensino formal) e uma garrafa de cerveja preta, dois amuletos totêmicos que ele carrega como que para garantir para si próprio sua devoração antropofágica da autoridade paterna, a lembrança do festim totêmico (regado a literatura e cerveja preta) que o permitiu "matar" o pai e seguir seu caminho. Assim, a chutação de tampinhas é libertadora e se contrapõe aos valores conservadores: trabalho alienado, moralidade convencional, casamento, ensino formal e ostentação.

Mais uma vez, entretanto, apesar do parricídio simbólico que o protagonista promove (primeiro o pai, ao ir para o exército, e depois o sargento, logrado em suas própria artimanha), trata-se de um personagem que é incapaz de fazer romance. Isola-se e recusa a ordem social, especialmente os valores sociais que se lhe apresentam: o aprendizado formal (a escola, o anel de grau que sugere o título acadêmico), o trabalho ("trabalho mal", "arrumei umas escritas") e as mulheres (Aldônia, a professorinha, as senhoras mães de família), todas elas traidoras e castradoras, pois que o denunciam, expõem suas transgressões e o recriminam (causam as surras, impõem comportamento "adequado" de bom moço, "educado" e trabalhador).

No entanto, o conto termina irresolvido, no meio do caminho, num tempo suspenso, das madrugadas, da vagabundagem, da afinação. Da afinação... da malandragem, já que a escolha do protagonista se dá, mas é encenada em estado de hesitação, de processo e de inconclusão, meio cá, meio lá. Porém, como o personagem escolhe as tampinhas, o samba e a leitura, mais lá (no lado avesso, boêmio, noturno e artístico) do que cá (o lado direito, burguês, diurno e convencional).

Há desejo: de liberdade (a individualidade, a vagabundagem), de escrita (a literatura de Huxley, as "escritas" noturnas), de afeto e posse (as tampinhas), de beleza estética, de dança e jogo (os sambas, a arte de chutar tampinhas). Como o próprio título indica, o conto marca ainda um momento de "afinação", de processo, preparo de uma trajetória, de uma

\footnotetext{
${ }^{264} M P B$, p. 44.
} 
situação que nos contos seguintes irá evoluir para a boemia, a sinuca, a malandragem e o crime. Mas essa passagem ainda não parece ser possível na sociedade instituída, ou, mais precisamente, nos limites do conto, no horizonte deste narrador-personagem.

Se passarmos então à leitura de "Fujie", veremos que os "Contos Gerais", afinal, terminam com certa resolução, do ponto de vista da atuação do protagonista, e preparam os desdobramentos não apenas dos demais contos de $M P B$, mas também da fícção de João Antônio como um todo. Entretanto, a resolução de "Fujie" indica, também, o impasse que irá perdurar: a atuação do protagonista ganha consequência, mas esbarra nos limites dessa mesma atuação, no contexto dado, já que, por conta mesmo das limitações dos protagonistas, de suas origens e do universo em que estão inseridos, eles não conseguem se desvencilhar do âmbito da família e das imposições estreitas de seu meio social. Não conseguem "fazer romance". E, posteriormente, se mostrarão reféns de uma malandragem, destrutiva e autofágica, como veremos em "MPB" e "PPT".

Assim como "Busca" e "Aact", "Fujie" é a história de um romance. De novo dilemático. Entretanto, desta vez, realizado. Mas que, ainda assim, conduz ao impasse dos limites familiares e sociais.

Se nos dois primeiros contos, os personagens hesitam em se entregar ao caso amoroso, o protagonista de "Fujie" não consegue... fugir. ${ }^{265}$ Não consegue evitar o que deseja, mas que sabe ser proibido.

A história de "Fujie" é a história de um triângulo amoroso e uma história de traição. A história do "conto da japonesa", como já vimos no capítulo 1, é aludida pelo narrador de "PMCMS". Foi um dos primeiros contos escritos por João Antônio e, assim, como os demais contos de $M P B$ tem correspondências fortes com a biografia de João Antônio. A inspiração autobiográfica não é o que nos interessa aqui, mas sim a mudança significativa da ação, em relação aos dois primeiros contos, e ao mesmo tempo a persistência do impasse no que se refere à atuação do protagonista. Trocando em miúdos: em "Fujie", afinal, temos um protagonista que se relaciona amorosamente com uma personagem feminina que não faz parte de seu círculo familiar ou comunitário. No entanto, esta personagem é "proibida",

\footnotetext{
${ }^{265}$ Simone Paulino dos Santos levanta a hipótese de a pronúncia de "Fujie" ser "fugi", com a tônica recaindo na última sílaba (fazendo rima e eco com Toshi e coincidindo com a primeira pessoa do verbo fugir flexionado no pretérito perfeito: eu fugi). A hipótese é boa, mas, por outro lado, a pronúncia paroxítona, com a tônica na primeira sílaba, confirma a associação do nome da protagonista com o monte Fujie, símbolo do Japão, o que acentua o caráter civilizador (acesso à cultura japonesa) da conquista amorosa do protagonista.
} 
é a mulher do amigo, a mulher do melhor amigo, quase como que um irmão do protagonista, ou seja, ela é uma espécie de irmã, ou cunhada. Assim, além do escândalo da trama que encena um triângulo amoroso, além do escândalo do tema do adultério, temos aqui também a história de um romance de teor incestuoso e, não bastasse isso, a história apresenta forte conteúdo homoerótico.

A história é simples, ainda que narrada com grande artifício e beleza.

O jovem protagonista relembra como se tornou amigo de Toshitaro, um colega de judô que conheceu numa academia de luta no bairro da Liberdade, e como se afeiçoou tremendamente ao amigo. A relação intensa entre os dois será ameaçada, do ponto de vista do narrador-protagonista, pelo casamento de Toshi com Fujie. O narrador teme que a mulher do amigo os afaste, interfira na convivência e estrague a amizade entre eles. A amizade, porém, ao contrário do que supunha o protagonista, não esmorece, pois apesar de casado o amigo ainda mantém o afeto e a proximidade que marcavam a amizade antes de "entrar mulher na história"266, como diz o narrador. O que de fato acontece e que pode de fato ameaçar a amizade é que o protagonista se apaixona por Fujie. E esta alimenta o amor proibido, insinuando-se para ele. $\mathrm{O}$ evento significativo, para o qual conflui a narração, é a cena final, em que o protagonista cede aos acenos sensuais de Fujie e vai ao encontro dela — pois sabe que Toshi está ausente - e faz amor com a mulher do amigo.

O tom do relato, desde o início, mas acentuado ao final, é uma combinação de desnorteamento, sensualidade, atração, tristeza e culpa. A frustração se explica: apesar do alargamento do horizonte que a cultura japonesa proporcionou - e é o que move o protagonista, afetiva e profissionalmente - o final, ponto de onde se rememora e se narra, repõe o impasse da dificuldade de extrapolar os limites familiares e sociais.

Vejamos como isso se dá no conto.

O protagonista não tem nome. Mas o pai dele tem: Antônio. É o pai quem o leva para a academia de judô. E é a luta que faz com que o moleque da Penha percorra a cidade, em "provas": competições no Pacaembu, Lapa e, finalmente, Liberdade. Entre os judocas, ele vai encontrar camaradagem: "Muito bom o convívio com japoneses cá de São Paulo.

\footnotetext{
${ }^{266} M P B$, p. 56.
} 
Sujeitos dóceis, cordatos, bem educados a ponto de parecerem moças. E quem os vê não avalia o que podem na briga...". ${ }^{267}$

A observação sobre os japoneses marca uma posição de forte alteridade. São eles, os japoneses, que são educados, dóceis, cordatos, enquanto ele, narrador-protagonista, é um "touro", "cabeludo que nem urso". E nas lutas ele sua como "boi ladrão". 268 As imagens com que o narrador se define são, assim, marcadas por uma animalidade selvagem, que contrasta com o universo da educação e da cultura japonesa. O convívio com os japoneses fará o narrador conhecer uma cultura diferente, que ele não imaginava existir. A maneira com que ele conta essas descobertas ressalta a sensação de ingresso em um mundo novo. E essa entrada no universo da cultura, em oposição à situação de selvageria anterior, vem associada ao encontro com o amigo Toshitaro.

Academia, disputa, camaradagem, mais coisas. Lá na Liberdade achei o ótimo Toshitaro. Nunca vi ninguém como. Costumo dizer que o sujeito que não se der com Toshitaro não presta. Ou não conhece Toshi.

Eu nunca havia sentido nada pelas coisas do Japão. Levou-me a beber saquê nos restaurantes da Liberdade, mostrou-me cinema. Depois gravuras, depois pinturas, tatuagens. Fui atingindo a dimensão mística de todas aquelas belezas. Percebi, por exemplo, que naquelas mulheres passivas e tímidas e afáveis, mexendo-se dentro de quimonos enormes, quase aos pulinhos, e que o cinema me trazia entre neve e casas do Japão, morava um mundo diferente de sensualidade. Poesia naquelas coisas.

Gostei. Como quem descobre uma maravilha, gostei. Não me arredava daqueles ambientes. Gostei demais. Judô, folclore japonês, depois teatro, fotografia.

Aquilo, sim, meu Deus, era um mundo!

À mesa, papai se admirava com meus entusiasmos. Gostava — rapazola, eu já era faixa vermelha.

Toshitaro, com cinco anos à minha frente, me levava pela mão direita ao judô. Esquecia a condição de faixa preta e o terceiro dan, me dava o lado direito na luta. Dava tudo. Sujeito espetacular, enorme no tatame e fora dele. Aprendi mais com Toshi do que com os três professores que já tive. Só me abro mesmo é com meu pai. ${ }^{269}$

\footnotetext{
${ }^{267} M P B$, p. 53.

${ }^{268}$ Idem, ibidem, p. 53

${ }^{269} M P B$, p. 54.
} 
São muitos os índices de costume, cultura e arte, ligados ao Japão, que a amizade com Toshitaro proporciona: saquê, folclore, tatuagens, teatro, fotografia, cinema, gravuras, pinturas. A introdução ao mundo cultural é, por assim dizer, completo, globalizante, a ponto de o narrador associar os novos conhecimento aos conceitos amplos e totalizantes da "beleza" e do "mundo". A descoberta de uma sensibilidade estética, própria de uma vida social complexa, no entanto, vem carregada de mistério, além de afeto e de sensualidade: para o narrador é a "dimensão mística de todas aquelas belezas", é a descoberta de uma "maravilha", da sensualidade e da poesia, de algo muito maior do que ele próprio. Tudo sempre, graças ao "ótimo Toshitaro", “sujeito espetacular”, “enorme”, cuja ascendência sobre o narrador é de maturidade (cinco anos mais velho) e de horizonte de conhecimento. A fotografia, em especial, irá selar a ligação entre eles, por laços não apenas afetivos e estéticos, mas também profissionais: o protagonista consegue emprego no laboratório de fotos de seu Teikan, pai de Toshi.

Além da admiração que o narrador sente pelo amigo e da forte relação entre a figura de Toshi e a descoberta do mundo novo da cultura japonesa ("aquilo sim, meu Deus, era um mundo!"), sublinhem-se neste trecho duas outras coisas: o aprendizado que o narrador diz ter adquirido com Toshi, e não com os professores, e certa confusão entre as figuras de Toshitaro e do pai do narrador. As lembranças do narrador se sucedem. Sobressai a importância que o pai e Toshi assumem para a rememoração: Toshitaro é quem o conduz, paternal e protetor (“pela mão direita”) no universo do judô. Além disso, as duas última frases do trecho citado apresentam um Toshi professor e um pai conselheiro e confidente, o que indica que, pelo menos na memória e na recriação narrativa do protagonista, os papéis de ambos de fato se aproximavam.

Este aspecto, o da correspondência entre as figuras do pai e de Toshi, é importante. Vima Martin vê na relação entre o protagonista e Toshi uma relação de verticalidade, como se Toshi representasse para o narrador uma espécie de pai substituto. ${ }^{270}$ A percepção de Vima ampara-se ainda em outra passagem, também bastante relevante do conto, em que o narrador assinala as etapas de vida pela qual ele e o amigo vêm passando:

\footnotetext{
${ }^{270}$ MARTIN, Vima Lia. Literatura e marginalidade: um estudo sobre João Antônio e Luandino Vieira. São Paulo: Alameda Editorial, 2008, p. 88.
} 
Quatro datas quase coincidentes: a primeira barba, dezoito anos, casamento de Toshi, minha faixa marrom.

Fizeram lua-de-mel numa estação de águas.

Toshitaro casado. Papai engordando. Minha barba crescendo, pedindo segunda raspagem. Três semanas sem ver Toshi e eu fiquei vazio. [...]

Nossa percepção, a qual já havíamos desenvolvido em trabalho anterior, é a de que a relação entre os dois é horizontal, fraterna, de amigo para amigo. O par narrador/Toshi reedita o par Vicente/Luís, de "Busca", e ganhará nova versão no par narrador/Carlinhos, de "Visita". São parceiros que os narradores procuram para, juntos, empreenderem alguma aventura e, assim, esgarçarem os limites comunitários, sociais e, até, de linguagem, potência disruptiva que Maria Rita Kehl valoriza no que ela chama de "função fraterna".

Entretanto, de fato a mistura entre o pai e Toshitaro salta aos olhos nos trechos citados, conservando, porém, a relação de amizade que une os dois personagens. Talvez, assim, possamos ver, na relação a um só tempo vertical e horizontal, paterna e fraterna que se estabelece entre os amigos uma versão embrionária da contradição que iremos encontrar expressa e desenvolvida em contos posteriores do autor: uma contradição própria das interações de autoridade (portanto, verticais) entre iguais (por isso, horizontais). Os iguais são parceiros, amigos, "irmãos", manos, que vão, na busca pelo parceiro, encontrar semelhantes, que por sua vez tendem a tentar se impor, ou figuras mais experientes, mais velhas, mais malandras, que são leais, parceiras, mas também autoritárias. Essas contradições e desníveis entre parceiros que deveriam ser iguais, mas que interagem por meio de uma hierarquia desequilibrada e pautada pela violência, estruturam as relações da malandragem e da criminalidade, onde elas são relações a um só tempo verticais e horizontais, com consequências dramáticas, como mostram os contos de João Antônio.

Já aqui, em "Fujie", é possível entrever os elementos e dilemas próprios dessa mistura de autoridade e parceria, de ensino e camaradagem, de orientação e cumplicidade que marcará também as relações entre malandros mais velhos e malandrecos, entre patrões de malandragem e malandros iniciantes.

Mas os contos também apresentam elementos que podem aproximá-los dos romances de formação, já que todos os grandes personagens de seus contos estão em maior ou menor medida ocupados com o aprendizado. Como já observamos, não se trata de 
aplicar à literatura de João Antônio o modelo do romance de formação, ${ }^{271}$ mas atentar para o fato de que os jovens personagens do autor estão, em geral, ocupados com diversas formas de aprendizagem, não apenas com o aprendizado formal, escolar, mas sobretudo com um aprendizado informal, adquirido nas ruas, fundamental para a sobrevivência em condições marginais, aprendizado que em ambos os casos, formal ou malandro, relacionase com os impulsos ambivalentes de aptidão e sobrevivência, inserção social e resistência aos valores instituídos.

Jesus Antonio Durigan vinculou os temas da busca e do caminhar à "necessidade de aprendizagem que invariavelmente acompanha toda a ficção de João Antônio":

Como acontece esse aprendizado? Na própria busca de sobrevivência que o malandro realiza, perambulando pela cidade grande, sofrendo e aprendendo com os mais velhos, malandros experientes. Por isso, na sua ficção, os atores andam o tempo todo, procurando por todos os lados, vagueiam por diferentes lugares. Frequentemente, são os textos mesmos que se estruturam a partir da movimentação dos atores, como ocorre, apenas para exemplificar, em "Busca", "Frio" e "Malagueta, Perus e Bacanaço", verdadeira ciranda da malandragem em que os três atores — representando as três idades da existência humana — realizam uma trajetória circular que inicia e termina no bairro da Lapa. ${ }^{272}$

\footnotetext{
${ }^{271}$ Se no modelo clássico do romance de formação, o protagonista recusa os valores burgueses a que está destinado em favor de uma educação humanista, artística e multifacetada (nega o comércio em favor do teatro), na obra de João Antônio o quadro é semelhante, ainda que não seja, por óbvio, equivalente. O modelo do Wilhelm Meister, no entanto, faz-se sentir na biografia do escritor, como vimos, pois o escritor se recusou a seguir a carreia do pai no comércio, preferindo lançar-se na boemia, na vida artística, na literatura. João Antônio, aliás, chegou a se aventurar pelo teatro, em aulas com o grupo do Teatro Arena: Eugenio Kusnet, Gianfrancesco Guarinieri, Vianinha. O aprendizado também é uma necessidade nos protagonistas da ficção do autor, mas trata-se, em João Antônio, de uma atualização degradada do modelo do Bildungsroman — a começar pelo fato de que o autor não escreveu romances. Além disso, a "formação" por assim dizer "formal" dos protagonistas é frustrada, não se completa, ainda que esteja sempre no horizonte pessoal de seus protagonistas, os quais a recusam em favor de outras práticas. A afinação de chutar tampinhas, a literatura e o samba (no caso de "Aact") e o cinema, as artes, a fotografia e a cultura japonesa (em "Fujie") são exemplos de práticas e estudos que compõem a formação dos personagens do autor. Vima Lia Martin vê nos contos de $M P B$ uma homologia com outra tipologia do herói romanesco definida por Lukács, aquela do "romantismo da desilusão", isto é, personagens com "a tendência de esquivar-se de lutas e conflitos externos, e não acolhê-los, a tendência de liquidar na alma tudo quanto se reporta à própria alma". (MARTIN, op.cit., p. 71) E, de fato, no caso dos textos do autor (repita-se: contos e não romances), não se pode falar em percurso formativo ou desenvolvimento humanista das potencialidades, ainda que a aquisição da picardia, como veremos em "PPT", possa ser vista como um estágio formativo decisivo da vida malandra. Sobre o romance de formação ver MAZZARI, M. "Apresentação" a Os anos de aprendizado de Wilhelm Meister, de J.W. Goethe. Trad. Nicolino Simone Neto. São Paulo: Editora 34, 2006; e . Romance de formação em perspectiva histórica. São Paulo: Ateliê Editorial, 1999.

${ }^{272}$ Jesus Antonio Durigan, “João Antônio e a ciranda da malandragem”, in: SCHWARZ, R. (org.), Os pobres na literatura brasileira, São Paulo, Brasiliense, 1983, pp. 216-217.
} 
Em "Fujie", o tema do aprendizado, do alargamento de horizonte do protagonista, do desenvolvimento de suas potencialidades e, em consequência, da possibilidade de alargamento da forma (do relato breve de uma situação que define o conto, à narrativa longa que põe em cena uma trajetória de vida, o romance), parece anunciar finalmente certa resolução e algum desenvolvimento. Neste conto, afinal, temos uma estrutura narrativa que aponta para a necessidade, mais que isso, para o desejo ardoroso e culpado, de um protagonista que quer "fazer romance" e que, no entanto, recai, novamente, no dilema dos limites impostos por sua formação estreita e pelas possibilidades exíguas de ampliação de seus horizontes, tanto culturais como de trabalho, de convívio social e, resumindo tudo, de emancipação e realização pessoal.

Neste conto, afinal, o protagonista avança em relação aos protagonistas anteriores. Realiza o seu desejo, um desejo proibido, o de possuir a mulher do amigo, amigo que é também uma espécie de pai. Realiza o seu destino edípico e, assim, "criminoso", é tomado pela culpa, por uma culpa indefinida, análoga à da busca indeterminada de Vicente. Com "Fujie", encerra-se a seção "Contos Gerais" e tem início "Caserna", seguida de "Sinuca".

Depois do crime afinal cometido, é sintomático que o livro enfeixe dois contos sobre a experiência do cárcere, para então adentrar o terreno da sinuca, da boemia e da malandragem. Não nos deteremos aqui sobre os contos de "Caserna". E da seção "Sinuca" empreenderemos a análise apenas de "Malagueta, Perus e Bacanaço", no próximo capítulo, com breves comentários sobre "Meninão do Caixote", a seguir. Registre-se, porém, que nos contos de "Sinuca", a última seção do livro, a constituição dos protagonistas se mantém muito semelhante à dos "Contos Gerais". Especialmente nos dois textos narrados em primeira pessoa, "Meninão do Caixote" e "Visita", os temas e dilemas dos protagonistas são os mesmos dos personagens dos "Contos Gerais". 273

Em "Visita", temos um narrador cujo nome não sabemos, mas com inquietação e trajetória muito semelhantes às de Vicente. Ele também está insatisfeito com a situação familiar e com o trabalho. Vive com a mãe, que o demanda com ocupações caseiras (“probleminhas domésticos"), e a irmã, que o irrita pela futilidade e extravagância (a irmã é

\footnotetext{
${ }^{273}$ Narrada em terceira pessoa, a história de "Frio", conto que não iremos comentar no espaço deste trabalho, por sua vez, guarda parentesco com a trajetória do protagonista de "Paulinho Perna Torta", ambas histórias de meninos de origem desconhecida, desde cedo imersos no universo da malandragem, situação que, como veremos no capítulo 4, também guarda relação com as interações entre indivíduo, família e sociedade.
} 
"uma tonta", que "sabe é ouvir novela, ler romancinhos para moças, discutir babados"), exageradas pelo narrador-protagonista.

O rapaz relembra o tempo em que curtiu desemprego e, trocando o dia pela noite, se lançava aos salões de sinuca. Decide fazer uma visita ao “ótimo Carlinhos”, ex-colega de trabalho na refinaria, por ocasião das festas de fim de ano, para retribuir um cartão de Natal recebido. "Carlos deveria ter uma irmã linda, cheia de modos e não cabeça oca. Nunca estivera em sua casa. Sabia o endereço, que ele jamais esquece essas coisas. Eu não. Tanto faz

A visita do protagonista é a Carlinhos, mas o desejo é o de que o colega tenha uma irmã linda e não cabeça oca (ou seja, que não seja "tonta", como a irmã dele próprio). A busca, em Visita, portanto, ganha direção mais nítida. O rapaz busca uma mulher. E ao chegar à casa do amigo, num "cortiço", "moradia de ferroviários”, encontra uma mocinha namorando um rapaz no portão. Era, de fato, a irmã de Carlinhos, mas o amigo não estava. O rapaz entrega o cartão a ela e vai embora.

Depois da visita, o personagem lamenta não ter encontrado o "excelente Carlinhos". E formula o desejo: "Por que não arranjo uma namorada?". Mas em seguida, ele recua deste desejo, ao mesmo tempo degradando-o e idealizando-o: "Que nada... arranjaria uma dessas franguinhas bobas, que se ajustam a meninos bonitos. Ao pé do letreiro, um modelo de dentes muito brancos, teria pernas bonitas como as da irmão do ótimo Carlinhos. Meu dentes são amarelos, manchas de fumo. Ambas teriam coxas mornas, brancas”. Em vez de uma namorada, ele arrumaria uma franguinha ou sonharia com uma modelo de publicidade. Em vez de uma namorada, uma mulher qualquer, "franguinha”, ou uma mulher inatingível, idealizada, "modelo".

O conto é repleto de passagens sugestivas, revisitando os temas que já apareceram nos demais textos comentados. Aqui, por ora, basta ter em mente que o narrador está ocupado com imprecações contra a escola, o trabalho, a própria "vila mesquinha" e "rodeada de fábricas" onde ele mora, contra o quartel "indecente" pelo qual ele passa, os "sujeitos bestas" do bar onde ele entre para beber e jogar sinuca e contra o próprio "jogo triste" de sinuca.

Apesar da diferença de tamanho entre "Busca" e "Visita" e de, neste, o personagem conseguir elaborar um pouco mais os elementos da realidade em que vive, a situação se 
mantém. A irritabilidade do personagem é maior, mas as contrariedades (com escola, trabalho, círculo familiar, vizinhança) são semelhantes às dos protagonistas dos "Contos Gerais”. A sinuca, apesar de acenar com possibilidades de aventura, ganhos e realização, é também motivo de temor e ameaça de queda, como indica o sonho que abre o conto, em que o personagem sonha com as grandes paradas, em companhia de Carlinhos, mas é surpreendido com a queda da bola branca na caçapa. ${ }^{274} \mathrm{O}$ jogo, em "Visita", é "o mundo de dimensões do pano verde de uma mesa de sinuca". ${ }^{275}$ Aqui, a sinuca é meio de vida, é prazer, é promessa, é habilidade e caminho, mas também é ameaça, chateação, azar, acaso, descaminho, perdição.

"Meninão do caixote", por sua vez, volta a apresentar um protagonista em tudo semelhante àqueles dos Contos Gerais, mas o conto já antecipa os movimentos posteriores da ficção do autor, ensaiando motivos que reaparecerão, por exemplo, em "Paulinho Perna Torta”. Ambos os contos, note-se, são narrados em primeira pessoa e intitulados com os nomes de seus protagonistas.

Penúltimo conto do primeiro livro de João Antônio, "Meninão do caixote" antecede o conto que dá nome ao volume. Se o último conto apresenta personagens completamente imersos no circuito da sinuca e os contos anteriores encenam a hesitação dos protagonistas entre aderir ou não ao mundo da boemia, a história de Meninão narra a entrada do protagonista no universo do jogo, mantendo entretanto o presente narrativo ancorado no círculo familiar, o que acentua a comunicação entre as duas esferas, a da família e a da boemia. O conto narra os acontecimentos que levaram o menino a se tornar jogador de sinuca, à revelia dos pais, a ganhar nome entre os jogadores e a ultrapassar o malandro mais velho, Vitorino, aquele que é seu "patrão" no jogo de sinuca. A frase que abre o texto aponta para a vitória do menino sobre o velho sinuqueiro: "Fui o fim de Vitorino".

Os elementos do entrecho vêm confirmar as linhas de força que já organizavam as narrativas anteriores. O protagonista, que narra a história, não informa o próprio nome. Vive com a mãe e o pai. Ela é costureira, ele é caminhoneiro. A família mora na Vila Mariana, onde o menino e o primo Duda brincam juntos, tomam banho na lagoa e apanham

\footnotetext{
${ }^{274}$ A branca é a bola que o jogador atinge com o taco, de maneira que ela se movimente e colida com as demais bolas. O objetivo do jogo é encaçapar as bolas coloridas por meio de tacadas na branca. Se inadvertidamente a bola branca cai na caçapa, o jogador é penalizado com a perda de sete pontos (o valor da maior bola, a preta) e cede a vez ao oponente.

${ }^{275} M P B$, p. 122.
} 
quando chegam em casa de cabelos molhados, mal disfarçando a brincadeira que as mães reprovavam ("nossas mães não eram sopa e com mãe havia sempre uma complicação"276). A certa altura, a família se muda para a Lapa.

No novo bairro, tudo piora: a rua onde moram é sem graça, o menino passa a sentir saudade do primo, o pai está sempre viajando, em longas estadas distantes (“demorava dois-três meses"), a mãe passa os dias a costurar ("na casa vazia só os pés de mamãe pedalavam na máquina de costura até a noite chegar"), e a professora do grupo escolar era exigente ("mandava a gente à pedra"277).

A professora é, além de exigente, disciplinadora. Manda bilhetes para a mãe do aluno: "Coisas horríveis no bilhete, surra em casa". Já vimos algo semelhante ocorrer em “Aact". Um bilhete de uma personagem feminina denuncia aos pais o mau comportamento do protagonista. Antes, era Aldônia, a namoradinha. Agora a professora. Nos dois casos, os protagonistas saem do episódio castigados.

Aqui, o menino relembra a vida na Lapa em tons desmaiados: a ausência do pai, a escola como um lugar exigente e repressor, a falta do primo, a mãe sempre trabalhando ou batendo nele ("quando papai não estava, os nervos de mamãe ferviam",278). Até que ele descobre um mundo novo: o da sinuca.

Por ironia, é a mãe quem, involuntariamente, o conduz ao salão de jogo. Ela pede que ele vá buscar leite. Estava em falta no estabelecimento habitual. O menino então vai comprá-lo no Bar Paulistinha, onde nunca havia entrado. No caminho, é apanhado pela chuva, corre para o bar para se proteger e fica preso ali, por um tempo, esperando o tempo melhorar. Descobre que no fundo do bar, depois do balcão, das mesas e de uma cortina, há um salão de sinuca. O menino pergunta a um homem magro, de braços finos, chapéu e olhos sombreados, "lá no fundo da cara”, se pode dar uma espiada no salão.

— Mas é claro, garotão!

Fiquei sem graça. Para mim, moleque afeito às surras, aos xingamentos leves e pesados que um moleque recebe, aquela amabilidade me pareceu muita. ${ }^{279}$

\footnotetext{
${ }^{276}$ MPB, p. 125.

${ }^{277}$ Idem, p. 126 e 127.

${ }^{278}$ Idem, 128

${ }^{279}$ MPB, p. 130
} 
A fala receptiva é de Vitorino, malandro velho, enfermiço, que conquista o menino com sua combinação de amabilidade, habilidade de fala e decadência física. $\mathrm{O}$ aspecto desleixado e o modo de falar amalandrado fazem "picam" o menino:

- Larga a brasa, rapaz!

Aquela fala diferente mandava como nunca vi. Picou-me aquela fala. Um interesse pontudo pelo homem dos olhos sombreados. Pontudo, definitivo. O que fariam os dedos tão finos e feios? ${ }^{280}$

A fala pica, ou seja, incomoda, mas também inquieta, desperta um "interesse pontudo". O campo semântico do verbo picar e do adjetivo pontudo relacionam-se à animalidade da sinuca, agressiva, mas também à sexualidade, pois o menino fica excitado com o novo ambiente. É uma realidade desconhecida que se apresenta: "Para mim, Vitorino abria uma dimensão nova".

Vitorino será o padrinho de sinuca, depois "patrão" no jogo. De início, o menino irá apenas espiar o jogo de sinuca. Mas começa a frequentar o salão e aos poucos fica conhecido como "Meninão". Até que um dia ele começa a jogar: "Um dia peguei no taco. Joguei, joguei muito, levado pela mão de Vitorino, joguei demais". De novo, sinuca e sexualidade se aproximam e confundem: o menino pega no taco; com isso, mostra-se ativo, habilidoso, contundente. Ele é iniciado por Vitorino, que o leva pela mão, paternal. O malandro mais velho, pai substituto, é quem lhe apresenta essa "nova dimensão", em que o menino vira Meninão, jogador de sinuca e, logo, como "atirador”, “bárbaro”.

Como o menino era baixinho, para conseguir alcançar a mesa, passou a subir em um "caixote de leite condensado que Vitorino arrumou". ${ }^{281}$ Assim, virou "Meninão do

\footnotetext{
${ }^{280}$ Idem, 130-131.

${ }^{281}$ As duas referência ao leite são cruciais no conto. O menino se inicia no mundo da sinuca ao ser enviado pela mãe à venda para comprar leite; depois, é um caixote de leite que irá possibilitar a ele alcançar a mesa de sinuca e, afinal, praticar o jogo e sua habilidade. A simbologia do leite liga-se à maternidade, à pureza e à alimentação infantil, o que intensifica a ligação do menino com a mãe e com a infância. Por outro lado, a ação do conto o distancia do universo da casa e da infância e o elemento que o afasta é, justamente, a busca do leite e o caixote de leite. Assim, em "Meninão do Caixote", os elementos maternais e de sobrevivência, de nutrição e de pureza ligam-se ao mundo "sujo", desviante e promíscuo da sinuca, o que evidencia a proximidade entre os mundos da ordem e da desordem, entre os polos "positivos" e "negativos", entre família e boemia, fome de sobrevivência e fome de jogo. A centralidade de um elemento como o leite faz lembrar também o romance $O s$ ratos, de Dyonélio Machado, em que o protagonista precisa saldar sua dívida com o leiteiro para evitar a interrupção do fornecimento de leite e salvar, assim, a família (ele, a mulher e o filho pequeno). Há grande semelhança também de Os ratos com o conto "Malagueta, Perus e Bacanaço": a ação de ambos os textos transcorre em um único dia e a busca dos protagonistas por dinheiro é marcada por uma espécie de contagem
} 
Caixote". Ainda que o malandro mais velho não o tenha batizado de Meninão do Caixote, como irá acontecer com Paulinho Perna Torta, rebatizado por Laércio Arrudão, é o padrinho que arruma o caixote que lhe dará o novo nome. E sua fama começa a correr: "Meninão do Caixote... Este nome corre as sinucas da baixa malandragem, corre Lapa, Vila Ipojuca, corre Vila Leopoldina, chega a Pinheiros, vai ao Tucuruvi, chegou até Osasco”. Veremos, no capítulo 4, sobre "Paulinho Perna Torta", como a aquisição de um novo nome e a fama que corre, levando o nome do malandro para lugares onde nem mesmo ele chegou, constrói uma situação contraditória de admiração e respeito, mas também rivalidade e ameaça ao malandro. Em "Meninão do Caixote", a habilidade na sinuca e a fama fazem com que ele ganhe relativa independência em relação à família e à escola. Para ele, "moleque afeito às surras, aos xingamentos" e às reprimendas da professora, é mais que um alívio, é crescimento e libertação: "Minha vida ferveu"282.

Enquanto o pai estava ausente, viajando pelo país, ele fugia de casa e se lançava à sinuca. Ao voltar, levava bronca da mãe, "baixava a crista", mas "a malandragem continuava". ${ }^{283} \mathrm{O}$ menino permanecia na escola, mas não conseguia se concentrar, considerava os colegas uma "cambada de trouxas".

A boemia e a malandragem da sinuca o levam à iniciação sexual e à aquisição do dinheiro. Mas a sinuca não é feita apenas de ganhos e prazeres. Meninão do Caixote descobre que "sinuca é ambiente da maior exploração". Ele se torna, também ele, malandro obrigado a compartilhar os lucros de sua malandragem: "Estava era sustentando uma cambada, sustentando Vitorino, seus camaradas, suas minas, seus..."284 . É a partilha do dinheiro, que ele é obrigado a dividir com Vitorino, que vai fazer com que Meninão do Caixote manifeste seu desagrado com a parceria.

A relação com as figuras paternas, o pai e Vitorino, indica que a sinuca proporciona a aventura e a promessa de ascensão social e de autonomia que o protagonista não reconhece no caminho instituído da escola, da família e do trabalho. Ele irá se dividir, até o fim da narrativa, entre o mundo da ordem - a escola e sobretudo a família - e o mundo do avesso, a sinuca. Ao final, no dia do seu último jogo, a revanche que Meninão concede

regressiva, marcada pelo transcurso inclemente do tempo cronológico. MACHADO, D. Os ratos. $10^{\mathrm{a}}$ edição. São Paulo: Ática, 1986.

${ }^{282}$ MPB, p. 134.

${ }^{283}$ idem, p. 135.

${ }^{284}$ MPB, p. 137. 
por insistência de Vitoriano a Tiririca, um dos maiores tacos da cidade, o protagonista volta para casa, em companhia da mãe, que o vai buscar no salão. Ela leva um prato de comida, uma marmita para o filho, que prometera voltar a tempo do almoço de domingo. Meninão não consegue segurar o choro. A mãe já deixava o salão, também chorosa. Ele consegue alcançá-la: "Nossas mãos se acharam. Nós nos olhamos, não dissemos nada. E fomos subindo a rua". ${ }^{285}$

O final do conto, no reencontro com a mãe e a volta para a casa, acentua a ausência paterna e a escolha do mundo da ordem. O pai, aos poucos, vai sendo deixado de lado, em benefício, para o desenvolvimento da ação narrada, da figura de Vitorino. Meninão deixa o pai de lado e adere à vontade de Vitorino, aceitando a partida final contra Tiririca, revanche da qual Meninão sai vitorioso mais uma vez. Sai vitorioso, para ao final, abandonar a sinuca e voltar de mãos dadas com a mãe para casa.

Teria sido mesmo o último jogo de Meninão? Talvez não. Seu comportamento oscilante, que no fim do conto acena com uma volta a casa e o abandono da sinuca, permite ao leitor supor. Ainda mais que sabemos, nós leitores, como teve início essa narrativa. Aliás, fim e início se confundem, nesta narrativa.

O fim do conto está no final do texto, mas o final da ação narrada está, na verdade, em seu início: "Fui o fim de Vitorino". É do momento em que Vitorino é um malandro decadente e decrépito que o protagonista narra sua história.

Se o final do conto tem algo de singelo, de ingênuo, de romântico e de regressivo, o retorno ao seu começo, que é na verdade o final da ação, o ponto de fuga da história deste narrador-personagem, revela que a narrativa é ácida e desencantada:

Fui o fim de Vitorino. Sem Meninão do Caixote, Vitorino não se aguentava.

Taco velho, quando piora, se entreva duma vez. Tropicava nas tacadas, deu-lhe uma onda de azar, deu para jogar em cavalos. Não deu sorte, só perdeu, decaiu, se estrepou. Deu também para a maconha, mas a erva deu cadeia. Pegava xadrez, saía, voltava...

E assim, o corpo magro de Vitorino foi rodando São Paulo inteirinho, foi sumindo. Terminou como tantos outros, curtindo fome quietamente nos bancos dos salões e nos botecos. ${ }^{286}$

\footnotetext{
285 idem, p. 146.

${ }^{286} M P B$, p. 125.
} 
É portanto de um momento futuro - posterior ao desenlace do conto, ao evento significativo, a partida final - que narra este narrador, que optou pela sinuca, sem deixar a família; que ficou com a família, mas fez nome na sinuca. Um aventureiro que, por ter voltado a casa, é capaz de narrar. Um narrador, sedentário, que contempla, vitorioso, o drama de um perdedor. Vitorino carrega em seu nome a ironia da malandragem: o sufixo "ino", diminutivo que qualifica Vitório, aponta para um malandro capaz de vitórias no diminutivo. Que termina apagado, "sumindo".

Meninão do Caixote, por sua vez, é atirador, bárbaro, cobra, um taco, mas ainda é um Meninão, taco novo, constatando a queda do taco velho. O protagonista é Meninão do Caixote, como indica a perspectiva privilegiada de onde ele narra (o apelido é sua identidade, é o nome que lhe deu fama e é o título de sua história), contemplando a decadência do velho malandro, numa mistura de regozijo e mea culpa: "Fui o fim de Vitorino".

Veremos que a história do malandro novo, cujo nome corre e que ganha fama, mas que cogita abandonar a boemia, ganha desdobramento em Paulinho Perna Torta, conta que guarda correspondências significativas com "Meninão do Caixote".

Até aqui, os temas da hesitação entre a ordem burguesa e a boemia, entre a escola oficial e a escola das ruas, entre o trabalho, de um lado, e a vagabundagem, a malandragem e o crime, de outro, são temas que os contos iniciais de João Antônio visitam e revisitam, sem que ganhem desdobramentos consequentes na ação ficcional, já que todos os personagens destes contos iniciais, mesmo os da seção "Sinuca", como vimos, apesar de flertar com a malandragem, permanecem ligados à família e à ordem do trabalho, da moralidade instituída e da legalidade. São personagens em processo, que não se formaram, ainda não se decidiram entre a permanência na ordem familiar e o ingresso na esfera social, pois não reconhecem na ordem e nos valores burgueses campos de atuação em que possam desenvolver suas potencialidades. Nesse percurso formativo, como veremos nos próximos capítulos, a sinuca e a malandragem vão se apresentar como universos em que os protagonistas vislumbram aventuras e narrativas capazes de os constituir.

Como vimos no capítulo anterior, são questões que dizem respeito ao próprio João Antônio. De certa forma, suas primeiras obras, os contos de $M P B$, eram já uma tentativa de elaboração de dúvidas e inquietações que o jovem rapaz com aspirações literárias 
transformou em matéria de ficção. Mas o autor não se restringiu a uma reinvenção ficcional de suas dilacerações pessoais — o que já seria algo extraordinário, diga-se. Nos contos mais longos, João Antônio fez mais que isso. Levou adiante, na ficção, a investigação das histórias de rapazes de origem humilde que, inquietos e insatisfeitos, encontram na boemia, na malandragem e no crime horizontes de existência mais ricos, tanto do ponto de vista existencial, no nível do tema e da experiência biográfica, quanto no que se refere à forma artística, pois que as atividades boêmias — o samba, a sinuca e as façanhas malandras e criminosas - proporcionam aventura, experimentação de linguagem e esgarçamento dos limites morais, legais e estéticos.

Veremos no desenvolvimento deste trabalho que as questões centrais da obra de João Antônio, aqui colocadas em estado latente, ganham desenvolvimento em seus contos e livros posteriores. Com maior e muitas vezes menor dimensão literária, com soluções formais mais arrojadas, mas também mais acanhadas, o autor irá explorar temas como a problemática inserção social dos protagonistas, as limitações morais e econômicas dos personagens em quadro, a passagem da hesitação e da reflexão sobre o próprio destino para uma espécie de formação malandra, que é constituída de picardia e fantasia, habilidades e disfarces, identidade e nome de guerra. E em "MPB" e "РPT", o reconhecimento trágico do caráter destrutivo e autofágico da formação malandra e da própria malandragem.

A análise do desenvolvimento desigual da obra de João Antônio mostra que a permanência das figuras paternas como referências fortes para os protagonistas repõe o conflito entre ação e conformismo, entre a ordem social instituída e a malandragem, entre os limites do mundo e os limites do indivíduo.

Depois da indeterminação da busca e da hesitação que marca os personagens dos "Contos Gerais" - e que marca mesmo um protagonista como "Meninão do caixote", imerso no ambiente e no universo da sinuca (a prática do jogo) e da "Sinuca" (última parte do livro de estreia de João Antônio) —, os protagonistas dos contos maiores de João Antônio (maiores em extensão e realização artística), "Malagueta Perus e Bacanaço" e "Paulinho Perna Torta", elevam o dilema dos rapazes pobres a um novo patamar: o drama da malandragem, como veremos a seguir. 


\section{CAPÍTULO 3}

\section{DESTINO DE MALANDRO É VIRAR LENDA}

Sobre "Malagueta, Perus e Bacanaço" 
"Malagueta, Perus e Bacanaço" é, como se sabe, o conto mais conhecido de João Antônio. Em relação aos textos do autor vistos aqui anteriormente — os chamados "Contos Gerais" (primeira parte do livro Malagueta, Perus e Bacanaço) e "Paulinho Perna Torta" —, o texto agora em análise apresenta duas grandes diferenças: (1) é narrado em terceira pessoa por um narrador onisciente, que não participa da história, ao contrário das narrativas iniciais, em que os protagonistas eram os narradores de suas próprias histórias, e (2) não tem apenas um protagonista, mas três personagens principais, como indica o título do texto, que nomeia os três "malandros" que se unem para jogar sinuca e tentar tirar dinheiro dos "trouxas", por meio da trapaça no jogo.

As aspas em "malandros" e "trouxas" vão aqui com propósito de, desde já, chamar a atenção para a identidade instável dos personagens assim identificados. Não só malandros e trouxas trocam de lado, ${ }^{287}$ alternando-se nesses papéis de acordo com a situação em que se encontram e com quem estão se relacionando (basta lembrar o final do conto, em que os "malandros" caem por não identificar no "trouxa" Ricardinho um grande "malandro"), como a própria condição de malandro é instável, provisória, ou melhor, é circunstancial. Quanto a este último ponto, é como se Malagueta, Perus e Bacanaço fossem malandros apenas no espaço do conto. Em outras palavras, seus papéis de malandros não são apenas identidades estáveis, mas identidades em situação. Eles são malandros (ou trouxas) na situação narrada.

O conto narra a noite de três personagens que lançam mão da malandragem (tornando-se "malandros" ou "trouxas") para tentar mudar a própria condição, aproveitando os ventos da fortuna, aquilo que eles próprios - personagens e narrador — chamam de marés de sorte e azar. A princípio sem dinheiro, eles decidem empenhar um relógio, para levantar algum capital, e então sair em conluio para dar um ou mais golpes e conseguir, por meio da sinuca - jogo em que ganha o mais habilidoso, mas também o mais sortudo ou o mais malandro —, multiplicar o dinheiro. Ao final, como se sabe, terminam da mesma maneira como começaram: sem dinheiro, com fome e estropiados.

\footnotetext{
${ }^{287}$ Antonio Hohlfeldt e Jesus Antônio Durigan chamaram a atenção para as inversões de papéis de malandros e trouxas no conto na obra de João Antônio. HoHLfELDT, A. "Para lá de Bagdá", prefácio a Os melhores contos. João Antônio. 2a edição. São Paulo: Global, 1997. DuRIGAN, J. "João Antônio e a ciranda da malandragem", In: Roberto Schwarz (org.), Os pobres na literatura brasileira. op.cit., pp. 214-218.
} 
Do ponto de vista da estrutura narrativa, a grande mudança em relação aos textos já vistos, como se disse, é que "Malagueta, Perus e Bacanaço" é narrado em terceira pessoa. Assim, há no conto um narrador que não participa da ação. No entanto, sua empatia com os personagens o aproxima dos protagonistas e do universo narrado, a ponto de, em alguns momentos não sabermos ao certo quem narra e quem fala pelas palavras do narrador — se este mesmo ou se a personagem em foco. Sobressai aqui, como talvez em nenhum outro conto do autor, o uso do discurso indireto livre, que aproxima e confunde voz narrativa e pensamentos dos personagens. Antonio Candido, como já dissemos, sublinhou a capacidade do autor em irmanar sua voz à de seus personagens. ${ }^{288}$

A carga de oralidade e narratividade que informa o conto também é digna de nota. Malagueta, Perus e Bacanaço estão o tempo todo fantasiando grandes façanhas, relembrando jogadores e malandros famosos (ou nem tão famosos assim, pois que conhecidos apenas naquele círculo de malandragem). Os personagens centrais estão sempre rememorando outras histórias, ao mesmo tempo em que vivem sua própria aventura. Bacanaço recorda a história de Sorocabana e Bacalau. Perus sonha com os jogos de Vila Alpina. Mesmo alguns dos personagens menores se põem a contar histórias do universo da malandragem. Não são poucos os personagens coadjuvantes: Bacalau, Sorocabana, Durão, Lima, Calói, Teleco, Carne Frita, Silveirinha, Maria, Marli, Robertinho, entre outros. Alguns desses participam diretamente da ação narrada no conto. Outros, entretanto, são apenas aludidos, aparecem em histórias contadas por outros personagens, em casos rememorados sobretudo pelos protagonistas, mas também pelos personagens secundários.

O universo da malandragem, portanto, é um universo carregado de narratividade, o que faz com que as trajetórias dos personagens estejam o tempo todo orbitando o terreno da oralidade, da história contada de um indivíduo a outro - o domínio do conto, mas também o domínio do mito, da lenda e da legenda ("formas simples", como as define André Jolles $^{289}$ : formas artísticas não consolidadas, informadas pela oralidade e pela cultura popular), característica que a circularidade da história reforça.

\footnotetext{
288 CANDIDO, Antonio. "Na noite enxovalhada". In: MPB. Como indica a nota bibliográfica do livro de Candido onde o ensaio foi recentemente republicado, este texto foi escrito em 1995, a pedido de João Antônio, para servir de prefácio a uma edição ilustrada de $M P B$, que afinal não foi editada. CANDIDO, A. $O$ albatroz e o chinês. Rio de Janeiro: Ouro sobre azul, 2004, p. 154.

289 JoLles, André. Formas simples. São Paulo: Cultrix, 1976, p. 20.
} 
No entanto, apesar da tendência à lenda, à fábula e à estrutura mítica, o resultado disso é um conto, escrito por um escritor e narrado por um narrador. Este, especificamente, é personagem que está de fora daquele universo e, simultaneamente, muito rente à ação narrada. Clara Ávila Ornellas recentemente chegou a formular a hipótese de que o narrador também seja um personagem, dada a intimidade que ele demonstra com o ambiente da sinuca, num jogo “especular” entre narrador e personagens. ${ }^{290}$

Segundo nossa leitura, as alternâncias de proximidade e distanciamento do narrador em relação aos protagonistas e ao universo da malandragem são chave de interpretação privilegiada para o conto. Nesse sentido, no que se refere à posição do narrador e à mistura de elementos arcaicos e modernos na estrutura da obra, o conto de João Antônio propicia também paralelos com Graciliano Ramos e Guimarães Rosa.

Como veremos, uma característica que é comum tanto ao narrador quanto aos personagens é que, todos, precisam de alguma forma usar do subterfúgio do disfarce, da supressão de sua própria identidade e do conluio com outros malandros, o que confere à narrativa uma dinâmica de instabilidade que é reflexo do universo social narrado e também artifício de sobrevivência, forma de vida malandra que é necessária para sobreviver em um contexto marcado pela violência e pela lógica da espoliação e da lei da selva — selvageria social a que os malandros estão submetidos e na qual são também atores.

Para melhor compreender o sentido deste conto de João Antônio é importante entender, assim, a maneira com que os três malandros se relacionam entre si e com os demais personagens que encontram ao longo da narrativa. Mais importante ainda, talvez, seja entender a posição do narrador no conto.

O que distingue um protagonista do outro e um personagem dos demais é a relação de hierarquia que se estabelece entre eles: no caso dos três malandros, Bacanaço os chefia, é o patrão do menino Perus e do velho Malagueta. Os personagens que surgem ao longo da história podem ser trouxas ou malandros, nunca muito bem identificados, e essa indeterminação é fundamental para a dinâmica da história e do sucesso ou do fracasso do conluio malandro que os protagonistas estabelecem entre si. O narrador não está fora desta dinâmica: é também parceiro dos três, pois narra a história colado ao ponto de vista dos personagens. Porém, em certas passagens se mostra superior e distanciado, para mostrar a

${ }^{290}$ Ornellas, C. O conto na obra de João Antônio. op.cit. p. 105. 
face cruel e iludida de seus "malandros", mas também a vulnerabilidade da posição social deles, pois os malandros podem virar trouxas a qualquer momento ou sofrer a condição inferior e frágil de malandro, nas mãos da polícia ou na dinâmica instável da "fortuna". Veremos como essas relações se dão na situação narrada.

O universo da família, tão importante nos "Contos gerais" foi deslocado do centro da ação narrada para uma área de menor destaque (a volta ao ambiente doméstico e a reconciliação familiar vividas pelos protagonistas dos primeiros contos não estão no horizonte dos personagens de "MPB”). Mas apesar de o universo da família ser apenas aludido em "MPB", as relações verticais de autoridade se mantêm. Pode-se, assim, averiguar como a malandragem e o alargamento social que marca este conto é, na verdade, uma consequência e um desdobramento do esquema familiar que se anunciava nos contos iniciais do autor. Família e malandragem, assim, mantêm uma relação de correspondência, compondo também o jogo de disfarce e dissimulação necessários para sobreviver na situação que o conto narra.

A malandragem é apresentada, em "MPB", como um estilo de vida e uma estratégia de sobrevivência que tende à selvageria (como atestam as inúmeras designações zoomórficas com que os personagens são identificados ${ }^{291}$ ), mas ela se mostra também uma organização social com forte correspondência com a organização familiar, privada e afetiva, com consequências e expressão literárias interessantes.

O conto formula com muita habilidade as contradições entre oralidade e escrita, ordem burguesa e malandragem, mito e representação realista, pois que essas ambiguidades não saltam aos olhos — antes, são disfarçadas, em estratégia malandra que está em conformidade formal e temática com a estrutura e o sentido do texto.

\section{Três malandros e... um narrador-personagem?}

Diferentemente dos contos antes analisados, "MPB" é um conto sem protagonista definido, ou melhor, com três protagonistas em vez de apenas um. Trata-se de um

\footnotetext{
${ }^{291}$ No conto, a designação dos personagens por nomes de bichos constitui um verdadeiro bestiário: piranhas, cobras, baratas, coiós, mocorongos, cavalos-de-teta, crocodilo, papagaio, periquito, frangalhos. Além disso, um dos personagens chama-se Perus. Apesar de o apelido se referir a um bairro de São Paulo, onde o rapaz mora com uma tia, é mais um animal que compõe a galeria.
} 
alargamento do universo de personagens: os protagonistas que dão título ao conto têm como companhia um sem-número de personagens secundários, alguns que participam da ação, outros que são referidos e mais um tanto a que outros personagens aludem.

A narrativa se constitui em função dessa partição do herói em três, que na verdade continua sendo um (os malandros conluiados), ${ }^{292}$ e na tensão constante entre forças opostas: a união e a dispersão dos malandros, os papéis de "malandros" e de "trouxas", a "fome" que sentem e o "fogo" do jogo, o tempo cronológico, que corre contra eles, e a necessidade urgente, de um lado, de arrumar "parceiros" de jogo para conseguir dinheiro e, de outro, a atemporalidade das grandes histórias da malandragem, que permanecem na memória, nas lendas de malandros famosos e nos "contos" que os boêmios contam uns para os outros.

Como bem observa Simone Paulino, diferentemente dos contos iniciais, em "MPB" “as personagens passam a ser mobilizadas e se deslocam pelo espaço fíccional da cidade, não mais por um mal-estar difuso que não sabem nomear, mas por necessidades concretas e prementes como a fome e a falta de dinheiro". ${ }^{293}$

A condição de penúria social e marginalidade, associada à circularidade da história, já foi apontada, com muita precisão, por Vima Lia Martin, que destaca o caráter paradigmático da narrativa para o universo da malandragem que descreve:

A história apresenta claramente um caráter cíclico: começa e termina no mesmo lugar — a Lapa - e, ao seu final, os três malandros se encontram na mesma situação de carência e desamparo com que iniciaram sua peregrinação pela cidade. Desse modo, as aventuras desditosas vividas pelos protagonistas adquirem uma dimensão paradigmática, podendo ser estendidas a outros malandros como eles, que têm em comum a origem pobre e a condição marginal caracterizada sobretudo pela recusa ao trabalho formal. ${ }^{294}$

O conto narra uma história protagonizada por três personagens, como indica o título do texto. São três homens, de idades diferentes, distintas fases da vida: um rapaz, Perus, um velho, Malagueta, e um homem adulto, Bacanaço. Todos eles, como se nota, são tratados

\footnotetext{
${ }^{292}$ Simone Paulino dos Santos formulou muito bem essa alternância de foco dos três malandros vistos em conjunto para os personagens vistos individualmente: "do três ao um, do um ao três", "um por todos", "todos por um", "ninguém por nenhum". SANTOS, S. Nas esquinas do desejo. Um estudo do tema da busca nos contos de João Antônio. Dissertação de mestrado em Letras. FFLCH-USP, 2009.

${ }^{293}$ SANTOS, S. op.cit., p. 24.

${ }^{294}$ MARTIN, V. Literatura e marginalidade: um estudo sobre João Antônio e Luandino Vieira. São Paulo: Alameda Editorial, 2008, pp. 132-133.
} 
não por seus nomes mas pelos apelidos. ${ }^{295}$ Eles se encontram num boteco da Lapa e, em conluio, saem, juntos, pela noite de São Paulo para jogar sinuca. Fazem o seguinte circuito: Lapa, Água Branca, Barra Funda, Cidade, Pinheiros, Lapa. À medida que avançam pelas ruas da cidade, deslocando-se por esses bairros da zona Oeste e pelo centro de São Paulo (a Cidade), os três protagonistas encontram outros personagens, que compõem um universo de boemia, prostituição e crimes. A sinuca é a atividade que sobressai nesse panorama, pois é uma maneira ardilosa — e não criminosa — de arranjar dinheiro fácil.

Penúria social e caráter cíclico, fechado, da narrativa fazem com que o universo noturno do conto ganhe autonomia, como se estivesse apartado do polo diurno e "positivo" da sociedade, isto é, o mundo do trabalho, das "famílias" e da moralidade convencional — e até de nós, leitores, que não fazemos parte do mundo narrado.

Os movimentos do narrador, de apresentação e descrição de personagens e ação narrada, porém, obedecem a um interessante jogo de aproximação e distanciamento, em relação aos protagonistas, e de alternância entre euforia e melancolia no que diz respeito aos estados de espírito destes e ao ritmo das ações. Este movimento do narrador inclui, por assim dizer, o leitor nessa dinâmica, pois joga com os sentimentos de empatia e repulsa que estabelecemos com os personagens. É como se o narrador incorporasse, também ele, um comportamento próprio da malandragem, que exige posições móveis e ambíguas, e estivesse também ele submetido à fortuna, isto é, às marés de sorte e azar, alternando momentos de otimismo e de confiança com períodos de tédio e desalento.

Vejamos como isso se dá, primeiro na tarefa de apresentação dos protagonistas.

Os dois primeiros personagens a surgir em cena são Bacanaço e Perus. O conto tem início com a ação em desenvolvimento. Num salão de sinuca da Lapa, Bacanaço tem os sapatos polidos por um engraxate, e logo encontra o jovem Perus.

O engraxate batucou na caixa mostrando que era o fim.

Bacanaço se levantou, estirou uma nota ao menino. Os olhos dançaram no brilho dos sapatos, foram para as cortinas verdes.

\footnotetext{
${ }^{295}$ A ausência dos nomes de registro e a adoção de apelidos ou nomes de guerra retoma os temas da fama, do "nome que corre", do tamanho e da identidade, que já apareceram nos contos autobiográficos e que veremos retornar, com mais força, em "PPT". Sobre a nomeação dos três malandros por seus apelidos, Clara Ávila Ornellas observa que isso reforça a inserção dos personagens na "zona de exclusão social". ORNELLAS, C. $O$ conto na obra de João Antônio, op.cit. p. 122. A autora também chama a atenção para a falta de moradia dos personagens, tema do qual também trataremos no próximo capítulo.
} 
Vestido de branco, com macio rebolado, Bacanaço se chegou:

— Olá, meu parceirinho! Está a jogo ou está a passeio? ${ }^{296}$

Nas linhas iniciais do conto é o malandro adulto quem ganha a primeira descrição, como a indicar a proeminência deste personagem, apontando assim para um certo protagonismo de Bacanaço. Desde as primeiras linhas do conto, como se vê no trecho acima, as descrições de Bacanaço fazem dele um personagem privilegiado e dotado de autoridade e elegância. Ele tem dinheiro para cuidar de seus sapatos. Veste branco, o traje típico do malandro. Seus olhos "dançam" ao aprovar o brilho que os sapatos ostentam depois do serviço do engraxate. $\mathrm{O}$ "macio rebolado" indica que ele anda com desenvoltura e jogo de cintura, o que se confirma com a abordagem que em seguida ele fará a Perus, interpelando o outro personagem. Diz o narrador que Bacanaço "se chegou" ao malandro mais novo, o que sugere uma proximidade física que, desde já, anuncia a intimidade e o conteúdo afetivo, quase erótico, que pauta a relação entre os dois malandros.

A apresentação de Bacanaço, assim, desde o começo o instala em um lugar de destaque e proeminência. É o primeiro personagem a aparecer, e é descrito de maneira a reforçar sua vaidade e confiança: a maneira cuidadosa de vestir, a arte de se movimentar com rebolado macio de malandro, os olhos que dançam e ecoam o brilho dos sapatos, a desenvoltura e a superioridade com que ele trata os outros dois personagens, o engraxate e Perus.

O narrador desde as primeiras linhas o contrapõe a duas figuras frágeis, menores e mais jovens que ele. Primeiro, ao engraxate, um "menino", a quem Bacanaço estende uma nota como pagamento pelo brilho proporcionado aos sapatos. E depois, a Perus, também um "menino", que o malandro adulto vai abordar assim que o serviço do outro menino, o engraxate, terminou. O contraste com Perus, como logo o leitor verá na sequência da narrativa, acentua a posição de autoridade e protagonismo de Bacanaço, apelando à empatia do leitor, convidado a ver em Bacanaço um exemplo bem-sucedido e folgazão de malandro maduro.

O próprio nome do personagem, aliás, de certa forma já indicava a constituição de um malandro com conotações, a princípio, positivas. Este personagem, indica seu apelido, é

\footnotetext{
${ }^{296}$ ANTÔNIO, João. Malagueta, Perus e Bacanaço. $4^{\text {a }}$ edição. São Paulo: Cosac Naify, 2004, p. 149. Esta é a edição que serve de base para este trabalho, aqui citada como $M P B$.
} 
bacana, isto é, bom, amistoso e, como diríamos hoje, "descolado". O sufixo "aço", 297 aumentativo que reforça as características citadas e ainda acrescenta a resistência do metal, sugerindo uma constituição maciça e dura, faz do personagem, neste momento inicial, o protagonista dotado de força e poder, aquele que conduz a ação e concentra as atenções e expectativas do leitor.

Quando Perus entra em cena, o contraste que se anunciava entre Bacanaço e o outro personagem, o engraxate, é reafirmado. Bacanaço chama o interlocutor de parceirinho, no diminutivo, e pergunta “Está a jogo ou está a passeio?”. Perus é apresentado, então, sem responder ao outro, mas, ao contrário, retraindo-se:

O menino Perus encolheu-se no blusão de couro. Os dedos de Bacanaço indo, vindo, atiçando. Desafiavam.

— Está a jogo ou a passeio?

Calado. O anelão luzia no dedo do outro e o apequenava, largava-o de olhos baixos, desenxabido. O menino Perus chutou para longe uma ponta de cigarro, arreou no banco lateral. Três dedos enfiaram-se nos cabelos.

— Que nada! Tou quebrado, meu — os dedos voltaram a descansar nos joelhos. ${ }^{298}$

Perus é interpelado por Bacanaço e se encolhe, recusando o desafio que o malandro mais velho lhe propõe. Ao final do trecho, ele dirá que está “quebrado", sem dinheiro. Mas o recuo do menino não se deve apenas à realidade concreta, de falta de capital para o jogo. Logo aparecem o sentimento de inferioridade e a falta de desenvoltura de Perus, em oposição ao comportamento de Bacanaço. A caracterização de Perus, assim, se dá em contraste com o outro malandro, mas também indica um comportamento menos impetuoso, mais retraído, e isso se dá não apenas em relação à atitude desafiadora e incisiva de Bacanaço. Perus, como se verá no desenvolvimento, é um rapaz imaturo, um malandro que ainda não se formou. Apesar de ser um bom taco, não adquiriu outra capacidade essencial: a desenvoltura verbal, a "charla", a arte de falar e de narrar.

\footnotetext{
${ }^{297}$ Simone Paulino dos Santos já chamou a atenção para a composição do sufixo "aço" no nome do malandro. Santos, S. Nas esquinas do desejo. Um estudo do tema da busca nos contos de João Antônio. op.cit.

${ }^{298}$ MPB, p. 149.
} 
Neste primeiro momento, porém, é interessante notar como a relação entre os dois é, simultaneamente, de identificação e de contraste. Bacanaço e Perus são parceiros que já se conhecem, companheiros de jogo com certa experiência conjunta.

Avistavam-se todas as tardes, acordados há pouco ou apenas mal dormidos. Dois tacos conhecidos e um amigo do outro não pretendem desacato sério. Os desafios goram, desembocam num bom entendimento. Perus e Bacanaço, de ordinário, acabavam sócios e partiam. Então, conluiados, nem queriam saber se estavam certos ou errados. Funcionavam como parelha fortíssima, como bárbaros, como relógios. Piranhas. Lapa, Pompeia, Pinheiros, Água Branca... Ou em qualquer muquinfo por aí, porque todo muquinfo é muquinfo quando se joga o joguinho e se está com a fome. Negaça, marmelo, trapaça, quando iam os dois. Um, o martelo; o outro era o cabo. ${ }^{299}$

O narrador passa a apresentar Bacanaço e Perus como uma dupla, como "amigos" e "sócios". Conluiados, isto é, combinados, em sociedade, formando uma parceria, os dois personagens tinham o hábito de percorrer os "muquinfos" onde "se joga o joguinho". Se individualmente os dois poderiam se assemelhar aos "vagabundos", aos "viradores", aos "erradios" (palavras do narrador) que frequentavam o salão - o mesmo salão onde eles se encontram - , quando se unem os dois malandros passam a se comportar como "parelha fortíssima". Juntos, eles podem ser afinal, trapaceadores, fazer "marmelo", "negaça".

Juntos, "martelo e cabo", então, eles se tornam malandros, o que não eram capazes de se tornar sozinhos. Mesmo Bacanaço, tão típico em seu traje de malandro - o branco, o sapato brilhante, o anelão no dedo — , sem dinheiro não é capaz de se lançar ao jogo e, assim, não passa, por ora, de um sofredor, um trouxa. Em resumo, sozinho e sem dinheiro ele está impedido de ascender à condição de malandro na sinuca. Voltaremos a isso ao final deste capítulo, no item "Malandragem: tipicidade e situação narrada".

Assim, como estão sem dinheiro, eles não veem perspectiva de mudança daquela situação. Sem capital, estão impedidos de se lançar no jogo. "Sem dinheiro", dirá o narrador, "o maior malandro cai do cavalo e sofredor algum sai do buraco". A frase, com seu teor de dito popular, de sentença e sabedoria colhida na vida malandra, é sem dúvida eco do universo da malandragem.

${ }^{299} M P B$, p. $149-150$. 
Insinua-se, portanto, talvez pela primeira vez no conto, o uso do discurso indireto livre. O narrador, até então, restringia-se a descrever e apresentar os personagens e suas ações. Mas agora ele parece de fato colado ao mundo narrado, ao estado de espírito e aos pensamentos de seus personagens. A frase seguinte mantém o mesmo teor de ditado e de sabedoria popular: "Esperar maré de sorte? A sorte não gosta de ver ninguém bem."

O narrador do conto vai aos poucos apresentando e desvelando as identidades dos personagens da história, ao mesmo tempo em que essas mesmas identidades vão ganhando complexidade à medida que o conto se desenvolve. $\mathrm{O}$ discurso indireto livre aparece nos momentos de individualização de cada um dos protagonistas e serve ao narrador como processo pelo qual ele particulariza os comportamentos e ocupações dos personagens. Também à medida que a narrativa caminha o narrador apresenta aspectos da intimidade $\mathrm{e}$ da vida pessoal de cada um dos personagens, o que permite descortinar a existência desses malandros para além dos limites temporais e espaciais da ação narrada.

Bacanaço, nestes primeiros momentos do conto, ainda na primeira parte, é o personagem que recebe mais atenção do narrador, desde as primeiras linhas, como vimos.

Ainda quando os dois estão sem a companhia de Malagueta, o qual logo aparecerá no salão, Bacanaço e Perus se põem a "brincar", "com a boca e com as pernas, indo e vindo e requebrando", num jogo de simulação de briga que lembra a capoeira e o duelo (Bacanaço chega a puxar a navalha, com a intenção de "podar" o menino). Além dessa brincadeira de malandros, para fazer o tempo passar enquanto o jogo de sinuca não "ferve" no salão, os dois juntos se põem a "contar façanha", lembrando aventuras de outros parceiros.

Como estão impedidos de agir, de se lançar à aventura, eles se põem a contar. Bacanaço lembra uma façanha de outros malandros e trouxas. O narrador passar a contar esta aventura que está fora de cena, do presente da ação narrada. Agora evocada, ela pertence ao universo de histórias da malandragem.

Depois de relembrar a história do "coió-sem-sorte" Sorocabana e do "malandro" Bacalau, faz-se ocasião de retomar a descrição de Bacanaço, que afinal era quem contava a história, a façanha protagonizada pela dupla rememorada. Agora, a descrição do malandro adulto ganha finalmente contornos mais definidos, ainda tendo a comparação com Perus como parâmetro: "Bacanaço era taco melhor, jogador maduro, ladino perigoso da caixeta, 
do baralho e da sinuca, moreno vistoso e mandão, malandro de mulheres. Camisa de Bacanaço era uma para cada dia. Vida arrumada. De mais a mais, Bacanaço tinha negócio com os mascates, aqueles que vendiam quinquilharias e penduricalhos nas beiradas da Lapa-de-baixo, e era um considerado dos homens do mercado (...)”.

A descrição de Bacanaço é feita de maneira objetiva pelo narrador, ainda que o vocabulário e a pormenorização das atividades do malandro indiquem, mais uma vez, grande intimidade com o assunto e o personagem. A descrição segue, destacando a força e a valentia de Bacanaço, para depois contrabalancear essas características, ao dizer que o malandro também era capaz de grande amizade e afeição: "Agora, se gostasse, gostava. Era igual, amigão. Ninguém botasse a mão em amigo seu. Porque seria como mexer com sua cara ou bulir com amiga sua. Assim era Bacanaço com o menino Perus. E por isso o menino o admirava."

O foco permanece em Bacanaço, mas o ponto de vista desloca-se agora para o menino, indicando que a afeição e a admiração que o malandro jovem sente é expressa por um narrador que também é capaz de se aproximar de Perus. É como se o narrador deslizasse de perspectiva em perspectiva, em movimentos sutis, que o permitissem passar do discurso indireto livre, colado ao ponto de vista de Bacanaço, para uma descrição objetiva deste e, em seguida, mudar o foco mais uma vez, passando a expressar o ponto de vista de Perus.

Quando ainda estão no primeiro salão de sinuca, onde a ação narrada tem início, Bacanaço vai até a porta do estabelecimento e passa a observar o movimento das pessoas nas ruas da Lapa. É ali que ele surpreende "gente", "gente mais gente", gente que "se apertava", "gente que vem ou que vai", "para a cidade ou para as vilas", os "homens de gravata" e os "homens das fábricas". A oposição se faz entre o ambiente da sinuca e o ambiente da cidade, entre Bacanaço e os trabalhadores, invertendo a ordem dos valores. São os trabalhadores, e não ele, o malandro, que "se apertam”, que vão e vem, da cidade para as vilas, parecendo não saber aonde ir. É mesmo o momento do "lusco-fusco", como assinala o narrador.

Outros personagens do bairro movimentado, nesse momento de saída do trabalho, surgem na descrição do narrador em terceira pessoa, que a tudo registra, colado ao ponto de vista de Bacanaço: uma cega que pede esmolas aos gritos, uma criança que chora porque 
quer um sorvete, o barulho dos comerciantes, "mascates", que dispõem mercadorias na rua e entoam seus pregões, um casal de namorados encabulados e desajeitados, vistos ao lado de um anúncio de venda de terrenos.

Este trecho em que Bacanaço contempla a cidade lá fora é pontuado pela recorrência da frase "Bacanaço sorri". A posição apartada do malandro parece lhe conferir certo orgulho e soberba, contemplando a afobação dos trabalhadores, postura que o sorriso cínico e inabalável acentua. Essa impressão se confirma quando o narrador afinal recorre ao discurso indireto livre.

Trouxas. Não era inteligência se apertar naquela afobação da rua. Mais um pouco, acendendo-se a fachada do cinema, viria mais gente dos subúrbios distantes. A Lapa ferveria. Trouxas. Do Moinho Velho, do Piqueri, de Cruz das Almas, de Vila Anastácio, de... do diabo. Autos berrariam mais, misturação cresceria, gente feia, otários. Corriam e se afobavam e se fanavam como coiós atrás de dinheiro. Trouxas. Por isso tropicavam nas ruas, peitavam-se como baratas tontas.

Há espaços em que o grito da cega esmoleira domina. Aquela, no entanto, se defende com inteligência, como fazem os meninos jornaleiros, os engraxates e os mascates. Com inteligência. Não andam como coiós apertando-se nas ruas por causa de dinheiro. ${ }^{300}$

Se a proximidade do narrador com Bacanaço já se insinuara anteriormente - em sua descrição de "malandro fino" e no uso do dito popular quanto à sorte, mantendo a assertiva num estado de saber compartilhado, de conhecimento geral - o trecho acima indica que o narrador também é capaz de ir além e abrir espaço para o ponto de vista do malandro adulto, identificando-se totalmente com ele.

Alternam-se, assim, descrições mais objetivas (como a que descreve o grito da cega, destacado da algaravia das ruas) e frases que traduzem o ponto de vista do malandro. Bacanaço enuncia um juízo de valor pessoal acerca dos trabalhadores: são trouxas, otários, gente feia, baratas tontas. Aqui, o narrador acolhe a visão de Bacanaço de que os trabalhadores são trouxas que vivem se afobam e se fanam como coiós, "apertando-se nas ruas por causa de dinheiro". O malandro destaca-se dessa multidão anônima, para se colocar à parte, sentindo-se um pouco mais próximo de quem, como ele, se defende "com inteligência", como a velha cega esmoleira, os meninos jornaleiros, os engraxates e os

\footnotetext{
${ }^{300} M P B$, p. 156.
} 
mascates. Bacanaço dá a entender que considera o trabalho correto algo alienante e pouco satisfatório. As metáforas são sugestivas: trabalhadores formais, aqueles que cumprem horário e se apertam nas ruas e conduções, vivem como animais desprezíveis (como baratas), como tolos (coiós) ou como indivíduos não desenvolvidos, que podem ser enrolados (trouxas).

Voltaremos à distinção entre malandros e trabalhadores. Por ora, é interessante evidenciar como o narrador se porta nesse jogo de definições e identificações de seus personagens. O narrador é o elemento narrativo que dá destaque objetivo à realidade exterior, que está para além do espaço dos personagens, e ao mesmo tempo transmite as impressões e os valores dos protagonistas na ação. Assim, Bacanaço vê a movimentação geral do fim da tarde, a hora do rush, quando a jornada de trabalho se finda, e emite juízos de valor a respeito dos personagens que a protagonizam - e paradoxalmente estão fora da ação do conto, o que aponta para a estratégia ardilosa, malandra, do narrador.

Com Perus se passa algo parecido. A apresentação do personagem, como vimos, se dá em situação, na relação que ele estabelece com Bacanaço, e destaca a sua retração, um certo desânimo que tem a ver com a falta de dinheiro, mas também com a inferioridade que o menino sente em relação a Bacanaço. Aos poucos, os contornos do personagem vão se definindo melhor. O discurso do narrador, como apontamos, já deslizara discretamente para o seu ponto de vista, no final da descrição de Bacanaço como malandro valentão e afetuoso, protetor dos amigos. O narrador segue aproximando-se cada vez mais do malandro jovem quando Bacanaço e ele se impacientam com a falta de jogo bom (jogado a dinheiro) — algo que era comum naquele salão da Lapa, segundo registra o narrador.

Como estão acostumados a enfrentar oponentes na sinuca, valendo dinheiro, Bacanaço passa a provocar os estudantes que estavam ali jogando apenas por jogar, por divertimento, sem apostar para valer. O narrador, ecoando Bacanaço, os chama de "frangalhos", e o malandro diz que ali só tem "pixote". Perus, por seu turno, é menos agressivo, mas o narrador dará lugar à sua frustração:

Perus encabulado. Onde andariam os trouxas, os coiós sem sorte, que o salão não tinha jogo? Por que era assim, assim, sempre? Uma oportunidade não vinha, demorava, chateava, aborrecia. Os castigos vinham depressinha, não demoravam não, arrasavam, vinham montados a cavalo. E os trouxas? Noivando ou namorando, por aí, nas esquinas, nos cinemas. Ou dando dinheiro 
a mulher, que é o que sabem fazer. Os tontos. E quando apareciam, gordos de dinheiro, otários oferecidos, era fora de hora e era sempre outro malandro quem os abocanhava. Ele? Nem almoço nem janta. Sinuca, grande estrepe... Pôs-se a tamborilar, lento, contando as batidas. Pensou nos joguinhos de Vila Alpina. ${ }^{301}$

Este trecho em que o ponto de vista de Perus e do narrador se unem tem início com o estado de espírito de novo retraído do menino. E a maneira com que ele liga aquela pasmaceira a um estado recorrente - "por que era assim, sempre?" - mostra que o humor deprimido do jovem malandro não é circunstancial, mas persistente. Perus é mais sofrido e mais retraído que Bacanaço, como o narrador já indicara desde o início do conto. Neste trecho, o discurso indireto livre reafirma essa caracterização do personagem.

O procedimento do narrador é assemelhado ao que ele já recorrera para mostrar como Bacanaço percebe os trabalhadores se afobando e se fanando na rua. De novo, o trecho começa com uma frase curta, cujo sujeito é o personagem. Lá, o verbo indicava uma ação, com discreto cinismo, que aponta para um personagem ativo e senhor de si: "Bacanaço sorri”. Mas aqui, a frase é nominal, "Perus encabulado", e a timidez, a retração, a encabulação são sublinhadas pela forma verbal flexionada, "encabulado", funcionando como adjetivo, apontando para uma evidente passividade do jovem malandro. Como se a timidez de Perus tivesse sido imposta por alguém, como se ele sofresse a ação de ser encabulado, isto é, tivesse sido encabulado.

Outras características desse trecho apontam para a mesma caracterização de Perus: a incidência de perguntas, expressando dúvidas e indefinições, o uso do diminutivo (“depressinha" e "joguinhos"), as frases nominais ou fragmentadas ("Noivando ou namorando por aí"; "Os tontos"); e as expressões de negação, impasse e falta ("nem almoço nem janta", "sinuca", "estrepe"). São todas noções que partem do personagem, de quem o narrador traduz os pensamentos, desde as duas interrogações que seguem à primeira frase, passando por assertivas menos indeterminadas, mas ainda bastante subjetivas ("Ou dando dinheiro a mulher, que é o que sabem fazer"), até chegar às duas últimas frases, que retomam a descrição mais objetiva, para depois fechar o intervalo ("Pôs-se a tamborilar, lento, contando as batidas"), indicando os pensamentos de Perus ("Pensou nos joguinhos de Vila Alpina").

${ }^{301} M P B$, p. 158. 
Em seguida é a vez de Malagueta aparecer na história, como veremos a seguir. Mas o narrador, ainda nesta primeira parte do conto, "Lapa", voltará à caracterização de Perus, como já o fizera com Bacanaço, para complementar o retrato do menino. Dirá que tem 19 anos e mora com uma tia em Perus, bairro da zona noroeste, periferia de São Paulo, de onde lhe vem o apelido. Apesar de não sabermos o nome do jovem, ficamos sabendo, assim, que ele tem uma tia - e nenhuma notícia dos pais. A tia vive com um "amásio", com quem o menino mantém relação tumultuada: “(...) isto entorta tudo, porque o homem e ele se atracam muitas vezes. Grudam-se, se socam, rebolam como bichos, que a coisa por bem não vai".

Repete-se aqui, com Perus, o que já acontecia com os jovens protagonistas dos primeiros contos no que se refere às figuras paternas. O pai está ausente - não se sabe se morreu ou não - e novas figuras paternas vêm substituir o pai biológico. $\mathrm{O}$ amásio da tia (esta também uma substituta da mãe) não é reconhecido como pai nem como padrasto, pois entre os dois "a coisa por bem não vai". Diz o narrador em seguida que isso acontece "por causa dos muitos porres do amásio da tia e da vida errada do menino".

Não se diz o que é a vida errada de Perus, mas o leitor infere que diga respeito à boemia e à sua atividade de sinuqueiro. Perus vive com uma "tia", que também não faz as vezes de mãe ou madrasta, pois não acolhe o personagem como as mães dos protagonistas anteriores. Ao contrário, deixa-o à mercê do "amásio", um pai substituto que o menino não reconhece como pai nem como tio nem, tampouco, como companheiro da tia, como sublinha a palavra depreciativa "amásio", que aponta para a relação conjugal informal, não formalizada, não oficial.

Sem lugar em casa, portanto, Perus vai encontrar na rua as figuras paternas que the orientam, acolhem e o estimulam (ainda que estes pais substitutos sejam guiados menos pelo afeto que pelo interesse). É o caso de Bacanaço, a quem o menino admira, como já se viu, e dos "patrões" da sinuca:

O menino Perus que tem seu lugar de taco, confiança de alguns patrões de jogo caro, devido à habilidade que na sinuca logrou desenvolver nas difíceis bolas finas, colocadas em diagonal na mesa. O menino Perus mal e mal se aguenta - fugido do quartel, foge agora de duas polícias. A Polícia do Exército e a polícia dos vadios. 
Uma semana, muitas vezes, na Lapa. Nas bocas do inferno se defende, se arranja pelas ruas, trabalha nas conduções cheias, surrupia carteiras. Deixa-se ficar e fica uma semana. A mesma camisa, o mesmo sono, a fome de dias. A fome raiada.

Mas pensa nos joguinhos famosos de Vila Alpina.

— Quando eu der uma sorte e a vida tomar jeito.

Vestiria panos bons, iria àquele fogo. Então, iria, dissimulado, aos jogos caros de Vila Alpina, onde corria a grana e as melhores virações da sinuca funcionavam. Vila Alpina era falada na boca de todos os malandros. E lá Perus não era conhecido.

Malagueta propunha-lhes o conluio fantasiando grandezas. Claro que se arrumariam, eram firmes nas tacadas e davam muito juízo. Se Bacanaço os chefiasse... ${ }^{302}$

A irrupção de Malagueta em cena como que interrompe o devaneio de Perus. Antes de o velho malandro propor sociedade aos dois outros parceiros, o narrador vinha conduzindo a divagação do menino por meio do discurso indireto livre. Perus sonha com os jogos famosos de Vila Alpina, mas sua fantasia é interrompida por Malagueta.

O movimento, não nos deixemos iludir, é presidido pelo narrador, claro. O jovem Perus é retratado como um bom jogador de sinuca, especializado nas tacadas finas, e bem considerado pelos patrões de jogo caro. No entanto, o narrador, após chamar a atenção para a habilidade do menino e para dizer que ele tem seu "lugar de taco", na frase seguinte reafirma a condição de precariedade e insegurança material em que vive o personagem: "mal e mal se aguenta", passa fome, furta carteiras nas conduções, veste a mesma camisa durante uma semana inteira.

Perus fugiu do quartel, e continua em fuga. Agora, foge de "duas polícias", a do Exército e a dos vadios. A ambiguidade da atuação da polícia, que ganhará desdobramento quando os malandros, mais adiante na ação narrada, encontram o policial Silveirinha, já se esboça aqui. A polícia do Exército tem seus motivos para buscar Perus, pois trata-se de um desertor, que acaba de fugir do serviço militar (lembre-se que Perus tem 19 anos). A "polícia dos vadios" (civil ou militar?), isto é, a polícia comum, digamos, também tem seus motivos para vê-lo como suspeito, pois o menino é batedor de carteiras e jogador de sinuca, um malandro de "vida errada". Mas o narrador diz que Perus foge é da "polícia dos vadios", o que sugere que os vadios têm a sua própria polícia. Voltaremos a essa discussão

\footnotetext{
${ }^{302} M P B$, p. 160.
} 
sobre o caráter policial da malandragem, aqui insinuado pelo narrador, e sobre o embaralhamento das identidades de malandro e polícia.

O trecho acima revela ainda outra contradição inerente à condição de malandro jogador de sinuca. Apesar de Perus ser bom no jogo e ter seu lugar de taco, não pode ostentar sua habilidade. Ao contrário, para se dar bem nos jogos de Vila Alpina, que são o seu sonho, ele precisa dissimular sua capacidade como jogador. Seu sucesso nos jogos caros de Vila Alpina depende, justamente, de entrar no jogo incógnito — "lá Perus não era conhecido".

Perus é bom jogador e considerado dos patrões do jogo. Ao mesmo tempo, precisa dissimular seu talento e procurar jogo onde ele passe anônimo e incógnito, de forma que possa, por meio da surpresa e do segredo - ao esconder suas capacidades, para no momento certo dar o bote, mostrar os dentes de "piranha", partindo para cima do adversário —, vencer a partida, dentro das regras ou por meio do "marmelo". O jogo de identidade e dissimulação, mérito e trapaça, traduz o modo de vida malandra e seus limites.

O trabalho do narrador, assim, vai constituindo os personagens paulatinamente, à medida que a ação transcorre. Alternando descrições objetivas e o mergulho na consciência dos protagonistas, ele aos poucos revela o que cada um faz e pensa. À medida que o retrato dos malandros ganha corpo, o narrador também procura apontar para as contradições inerentes às práticas e à condição da malandragem, ainda que dissimuladamente — à malandra - , de dentro desse mesmo universo.

Essa proximidade entre narrador, mundo narrado e personagens é a característica que, ao lado da estilização da oralidade, Antonio Candido destaca na obra de João Antônio. A escrita do autor engendraria, segundo o crítico, um mundo próprio, "uma segunda natureza no reino da transfiguração criadora":

Prolongando a tradição estilística que remonta a Émile Zola, João Antônio inventou uma espécie de uniformização da escrita, de tal maneira que tanto o narrador quanto os personagens, ou seja, tanto os momentos de estilo indireto quanto os de estilo direto, parecem brotar da mesma fonte. Aqui não há, com efeito, um narrador culto que reserva para si o privilégio da linguagem de outra esfera através da imitação de sua linguagem irregular, que serve para manter a distância. Longe disso, narrador e personagem se fundem, nos seus contos, pela unificação do estilo, que forma um lençol homogêneo e com isso define o mundo próprio a que aludi. Não se trata, portanto, de mais um autor que usa como pitoresco, como coisa exterior a si próprio, a fala peculiar dos incultos. Trata-se 
de um narrador culto que usa a sua cultura para diminuir as distâncias, irmanando a sua voz à dos marginais que povoam a noite cheia de angústia e transgressão, numa cidade documentariamente real, e que no entanto ganha uma segunda natureza no reino da transfiguração criadora. ${ }^{303}$

Narrador e personagens de fato se irmanam em uma linguagem comum, a ponto de muitas vezes não sabermos ao certo quem fala pela voz do narrador, se ele próprio, se o personagem em foco. Interessante é que essa uniformização da linguagem move a ação narrada e aos poucos delineia os personagens. A descrição das personalidades dos personagens e a própria constituição destes se dá em processo e em situação, o que permite ao narrador ir dando a eles feições mais elaboradas e definidas, mas também apontar para os limites e as contradições da vida malandra.

Assim como já fizera com Bacanaço e Perus, o narrador fará algo semelhante com Malagueta: vai apresentar o malandro velho em situação — sua aparição se dá integrada à ação narrada — , para aos poucos ir lhe definindo melhor os contornos da personalidade, seu comportamento e sua condição.

É assim que o terceiro malandro surge na história:

Capiongo e meio nu, como sempre meio bêbado, Malagueta apareceu. No pescoço imundo trazia amarrado um lenço de cores, descorado; da manga estropiada do paletó balançavamse algumas tiras escuras de pano.

Bacanaço lhe buliu:

- Quer jogo, parceiro velho?

O velho se escapuliu, foi procurar o último banco do salão, o seu lugar, e sentou. Era um velho acordado e gostava de explicações. Dali tudo via, pernas cruzadas, na dissimulada, como quem não visse nada. E ali embiocado não o enxergavam bem.

Bacanaço e Perus lhe voltaram.

- Está a jogo ou a recreio, meu?

Malagueta os olhava. Bacanaço boquejando, largando desafios e bazófias. Perus no acompanhamento, feito um dois de paus. "É”, pensou, "quando vocês iam no moinho buscar fubá, eu, cá no meu quieto, já estava de volta com o bagulho empacotado". E soltou para si o risinho canalha com que os malandros entendem, reconhecem. Risinho meio parado, metade na boca, metade nos olhos. Pela charla que diziam e pela manha com que vinham... Ali não havia dinheiro.

\footnotetext{
${ }^{303}$ CANDIDO, Antonio. "Na noite enxovalhada", in $M P B$, pp. 10-11.
} 
Então o velho se levantou, gingou nos seus sapatos furados e piscou o olho raiado de sangue.

— A gente se junta, meus. Faz marmelo e pega os trouxas. ${ }^{304}$

A descrição do malandro mais velho é a de um malandro doentio, desfazendo-se, como a roupa que ele veste. Malagueta aparece "capiongo", manquitolando, meio bêbado. A figura desengonçada e descomposta parece que pode tombar ou se despedaçar a qualquer momento. Usa um lenço gasto, de cores que já se apagaram e deixaram apenas um vestígio do que foram um dia - talvez como o próprio malandro, hoje velho, seja o que restou de um malandro de outros tempos. A roupa, que é pouca, pois ele está sempre "meio nu”, está se desmilinguindo: a manga do paletó é estropiada, e a camisa, que ele veste por debaixo, é um apanhado de tiras de pano escuras, dando ideia de uso e sujeira. Sapatos furados e o olho raiado de sangue completam a descrição de um malandro maltrapilho e alquebrado, enfermiço.

No entanto, Malagueta sobrevive no mundo da malandragem por deter certa sabedoria adquirida naquele mesmo universo, por conhecer o comportamento típico dos malandros. Diz o narrador: "Era um velho acordado e gostava de explicações", destacando uma esperteza e uma inteligência que resistem ao tempo e à decadência física do personagem, permitindo que ele continue a frequentar os salões de sinuca. Além da esperteza de malandro "acordado", Malagueta parece ter incorporado o modo de vida da malandragem, pois adota a dissimulação como conduta. Acossado pelos dois outros malandros, ele consegue escapulir e procura o último banco do salão para se acomodar, um ponto privilegiado, de onde pode ver tudo e ao mesmo tempo se preservar, "na dissimulada", como quem não visse, e "embiocado", não fosse visto.

A malandragem de Malagueta permite, assim, transformar em trunfo, em vantagem, a decadência física que o tornou um malandro maltrapilho e alquebrado. Malagueta é um malandro que se esvai, magro e decrépito, mas "acordado" e sorrateiro, capaz de ver sem ser visto, como se fosse um espectro de malandro. Mas, se preciso, é também capaz de se mostrar "acordado", apelando à identificação de seus iguais. Sua sabedoria virou modo de vida, marcando o corpo: capiongo, manco, ele cruza as pernas para sumir e sorri como

\footnotetext{
${ }^{304} M P B$, pp. 158-159.
} 
malandro: pela metade, um "risinho canalha com que os malandros entendem, reconhecem". É um riso ambíguo, "meio parado, metade na boca, metade nos olhos".

Sinal de sua esperteza de malandro "acordado" é o fato de que parte justamente de Malagueta a ideia do conluio entre os três jogadores. É dele também a sugestão de que Bacanaço chefie a empreitada, o "marmelo" para pegar os "trouxas", sugestão que o narrador apresenta por meio da frase incompleta que já tivemos oportunidade de ver, no final de uma descrição de Perus: "Malagueta propunha-lhes o conluio fantasiando grandezas. Claro que se arrumariam, eram firmes nas tacadas e davam muito juízo. Se Bacanaço os chefiasse...".

Malagueta deposita esperanças no conluio, pois assim como os outros está sem dinheiro. Vive como um indigente, aliás, pois o narrador voltará a descrever a conduta recente do velho, que se faz passar por mendigo. Para comer alguma coisa, roubara uma maçã no mercado, e quase foi pego pelos guardas. Depois, esmolou, estendendo "a mão que roubou a maçã", "com a aquela cara de sofredor, de Jesus Cristo". A identificação com Jesus Cristo e com a vida de sofredor aponta mais uma vez para certa empatia do narrador e para a inscrição do conto, pelo menos do personagem, em um pano de fundo social que guarda também ligação forte com a religião e com a moralidade convencional. ${ }^{305}$

Reunidos os três malandros e surgida a ideia de conluio com que eles podem, finalmente se lançar ao jogo, permanece o impasse: sem dinheiro, não podem fazer nada. $\mathrm{O}$ dinheiro é necessário para entrar na ciranda da malandragem, na roda da fortuna, a fim de mudar a "maré de azar danado". $\mathrm{Na}$ falta do dinheiro, eles se entretêm fantasiando, imaginando e contando façanhas.

O narrador, agora, se põe a descrever a ação dos três, em conjunto:

Estavam os três quebrados, quebradinhos. Mas imaginavam marotagens, conluios, façanhas, brigas, fugas, prisões — retratos no jornal e todo o resto — , safadezas e tramoias; arregos bem arrumados com os caguetes, trampolinagens, armações de jogo que lhe dariam um tufo de dinheiro; patrões caros aos quais fariam marmelo, traição; imaginavam jogos longínquos, lá pelos longes dos subúrbios, naquelas bocas do inferno nem sabidas pela polícia; principalmente imaginavam jogos caros, parceirinhos fáceis, que deixariam falidos, de pernas para o ar. $\mathrm{E}$ em pensamento

\footnotetext{
${ }^{305}$ Além disso, Frye associa Cristo ao arquétipo do "incongruentemente irônico", a vítima inocente de todo, excluída da sociedade humana, a quem se tenta transferir uma culpa que, assim, lhe confere "algo da dignidade da inocência”. FRYE, N. Anatomia da crítica. op.cit., p. 48.
} 
funcionavam. E os três comendo as bolas, fintando, ganhando, beliscando, quebrando, entortando, mordendo, estraçalhando... ${ }^{306}$

A aventura que os chama, aos malandros, é de natureza vária. São "marotagens, conluios, façanhas, brigas, fugas, prisões, safadezas, tramoias, arregos, trampolinagens, armações de jogo, marmelo, traição, jogos longínquos". A diversidade de ações e situações aponta para uma variação excepcional na vida da malandragem, que promete, a princípio, liberdade, imprevisibilidade, risco e, de novo, aventura. Entende-se por que a malandragem fascina o narrador: a conduta malandra é sinônimo de ação. Outra imagem chama a atenção: essa variabilidade de procedimentos malandros está a serviço de uma esperança e, até, de uma ilusão: arrumar um tufo de dinheiro. A miragem do dinheiro fácil, que pode ser obtido sem esforço, por meio da esperteza e da habilidade para o jogo, move os malandros para uma aventura que tem por essência a indeterminação e a dúvida, que pode conduzir à "fortuna", ao dinheiro fácil e grande, por conta da "fortuna", o acaso, as marés de sorte ou azar - bem diferente da rotina do trabalho e da danação do crime. A malandragem, porém, assemelha-se ao crime em sua dimensão demoníaca. Como diz o narrador, expressando a imaginação dos três protagonistas, os malandros pensavam em jogo em bocas do inferno nem conhecidas pela polícia. O inferno da malandragem, portanto, pode ser um inferno isolado, longínquo, desconhecido até da polícia, ao mesmo tempo que se imiscui com a polícia. Em outras palavras, a malandragem é algo maior que a polícia, que malandros e trouxas, ela é um funcionamento que envolve e pressupõe a ação de todos, mas que se expressa, muitas vezes, sem que todos os elementos estejam em situação.

A "traição" aos "patrões caros", então, é apenas uma consequência dessa pequena mas significativa amostra do que a malandragem é capaz, tanto do ponto de vista da façanha quanto da própria essência do seu funcionamento: a ilusão e o disfarce, que ensejam o golpe, com definições variadas (como marotagens, conluios, façanhas, safadezas, tramoias; arregos, trampolinagens, armações, marmelo, traição, jogos). A malandragem, de certa forma, depende de uma carnavalização permanente, em que os papéis sociais se invertam reincidente e continuamente. ${ }^{307}$

\footnotetext{
${ }^{306} M P B$, pp. 161-162.

${ }^{307}$ Nesse sentido a malandragem em João Antônio ganha na sinuca um retrato ritualizado das relações e dos conflitos sociais, no contexto histórico dado. Em certos momentos, ela parece abrir portas para que as
} 
Tudo isso é façanha e gera notícia, é motivo para "retratos no jornal e todo o resto". A malandragem, como golpe e inversão de papéis, com desdobramentos imprevistos, é acontecimento, aventura, e é fama, história e imagem. Ela pressupõe a façanha e a narrativa, as ações e as histórias dessas ações. Não apenas na dinâmica da ação, isto é, no golpe, mas também na dinâmica da narrativa a malandragem envolve a todos os atores em jogo, sem que precisem, de novo, estar em cena.

A necessidade de deslocamento incessante, que os jogos longínquos reafirmam, indica que a malandragem é a ocupação dos erradios, dos viradores, dos aventureiros, dos pingentes sem eira nem beira - marginais à margem, mas dependendo do centro, vagabundos que dependem de trabalhadores, "pingentes" dependurados nos vagões do progresso.

Mas a narrativa, aqui, se constrói de uma perspectiva bem localizada. Em "MPB”, o narrador escolhe o ângulo dos malandros. Ele se aproxima dos três personagens, em conjunto, conluiados, prestes a ganhar a noite de São Paulo para se lançar na aventura da sinuca. "Em pensamento funcionavam" é a frase que chama a atenção para o aspecto imaginativo e competente da atividade de malandros. Pois se ainda estão "quebrados, quebradinhos", é apenas a fantasia que lhes proporciona algum consolo, projetando-os juntos a um estágio de sucesso potencial. Aqui, o narrador está colado ao ponto de vista dos malandros, retratando-os como um corpo único, e se expressa de maneira confiante, simpático às fantasias dos personagens.

Mais à frente, à medida que a narrativa avança, mesmo os vendo em conjunto, o narrador habilmente dará espaço para a individualidade de cada um. O recurso preserva a identidade de cada protagonista, destacando as características recorrentes dos personagens, aquilo que faz deles tipos, ${ }^{308}$ mas também personagens mais complexos. Ao mesmo tempo,

inversões se tornem libertadoras, no sentido de produzir protagonistas que se elevem, ganhem autonomia e se entronizem como grandes jogadores, malandros que possam ser aceitos, inseridos, ainda que mantenham sua conduta "bárbara", erradia e ressabia em relação aos valores burgueses. No entanto, João Antônio também encena os limites da carnavalização da malandragem, como atesta o final de "MPB" e como veremos também em "PPT". Sobre a carnavalização e os ritos de inversão social ver BAKHTIN, M. A cultura popular na Idade Média e no Renascimento. São Paulo: Hucitec, 1987; e DAMATTA, R. Carnavais, malandros e heróis. Rio de Janeiro: Rocco, 1997.

${ }^{308}$ Sobre a definição de personagem e a distinção entre tipo e personagem complexo, ver CANDIDO, Antonio

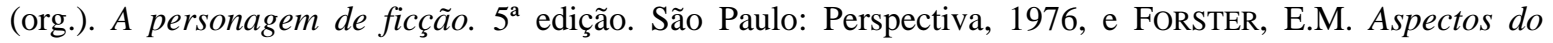
romance. Trad. de Sérgio Alcides. 4ª edição revista. São Paulo: Globo, 2005. 
o discurso indireto livre que ilumina a interioridade de cada um expressa as diferenças entre os três personagens e também os desacordos e descompassos entre eles.

Haviam andado na noite quente! Bilhar após bilhar, namoraram mesas, mediram, estudaram jogos lentamente. Não falavam não. Picava-lhes em silêncio, quieto mas roendo, um sentimento preso, e crispados, um já media o outro. Iam juntos, mas de conduta mudada e bem dizendo, já não marchavam em conluio. 309

Iam juntos, mas separados. Assim, o narrador prepara aos poucos a situação final da narrativa: o conluio entre os três personagens encontra um limite e entra em colapso.

Os exemplos de discurso indireto livre se sucedem e não seria producente apontar todos aqui. $\mathrm{O}$ interessante é que, por meio desse recurso, o narrador aprofunda a representação de seus personagens e confere tintas fortes ao drama individual de cada um. Em sintonia com a estratégia e o modo de vida malandros, mas também com distanciamento eventual, o narrador vai revelando as faces mais sombrias dos personagens, e em alguns pontos da narrativa se coloca entre os malandros, mas também acima deles e, simultaneamente, apartado de seus personagens.

De início aliado ao ponto de vista dos protagonistas, o ponto de vista do narrador vai se dissociando, a princípio de maneira sutil, dos personagens. Como vimos acima, na passagem por Perdizes, o narrador os flagra em desacordo com o espaço e desconfortáveis consigo próprios. A passagem marca um primeiro distanciamento do narrador, ainda que este se mantenha por ora muito afinado ao estado de espírito dos malandros, talvez até solidário com eles, pois o narrador ecoa uma percepção de desacordo e desconforto que vem dos próprios personagens.

À medida que a narrativa avança, porém, o distanciamento do narrador vai se agudizar para tornar o retrato dos malandros ainda mais nítido. É por meio do discurso indireto livre que o narrador mostrará a face cruel de Bacanaço e a crise psicológica profunda de Perus, como veremos a seguir.

Em Pinheiros, depois de terem deparado com o policial Silveirinha e de terem escapado ilesos do achaque do policial, depois de terem ficado animados por escapar de uma ronda policial em um salão onde, eles estão de novo desanimados, e a madrugada é

\footnotetext{
${ }^{309}$ MPB, pp. 161-162.
} 
alta, resta pouco para a noite terminar e eles precisam ainda de mais um salão aberto, com trouxas disponíveis, mais jogo, mais um golpe.

Andando pelo bairro, Perus recorda um episódio de quando era engraxate e foi incriminado por um roubo que não praticara. O ladrão em fuga deixou o dinheiro aos pés do menino. Perus teve de se explicar à polícia:

[...] A rua estava azoada e a polícia chegou não querendo prosas fiadas. Houvesse explicações e imediatamente. Ô atrapalhação ingrata que foi justificar aquele dinheiro... Assim sempre, pensava Perus, trabalhando para os outros, curtindo as atrapalhadas dos outros. Papagaio come quieto, periquito leva a fama. Como um pé-de-chinelo, como um dois de paus. Para que esperar um dia de maré de sorte? Para que pretender os joguinhos caros e bons de Vila Alpina? O menino Perus achava que seria sempre um coió-semsorte, sofredor amansando a vida deste e daquele. E lhe chegava a ideia velha, solução pretendida, única saída dos momentos de fome.

- Um dia eu me apago. ${ }^{310}$

O sofrimento psíquico de Perus ganha aqui um retrato extremo. O jovem malandro pensa em se matar. E não é de hoje. A ideia é "velha". E ela vem em resposta aos momentos de fome. É uma solução que se relaciona à condição socioeconômica, mas está também profundamente ligada aos desejos do menino. Para que esperar pela sorte? Para que "pretender", isto é, acalentar o desejo dos “joguinhos caros e bons de Vila Alpina"? Além da fome, necessidade imediata e premente, Perus se pergunta também sobre suas ambições de ascensão social. A própria fome, neste conto, é ambígua: é fome de alimento e de dinheiro. Ele sonha com a Vila Alpina - o nome do bairro também aponta para a ascensão (os Alpes da malandragem paulistana) — , sonha ascender por meio de um atalho malandro aos jogos caros e bons, que lhe renderiam um bom dinheiro, certamente dinheiro de sobra, para além da fome e da subsistência.

O padecer do menino, assim, tem um fundo de escassez material, mas liga-se também à ilusão do dinheiro fácil e da ascensão fulminante, de uma emancipação que neste momento lhe parece difícil, pois ele tem a sensação que será para sempre um sofredor amansando a vida deste e daquele, sempre a serviço dos outros. Com isso, o narrador completa o desenho do personagem, que além do suicídio, irá cogitar também uma saída

${ }^{310}$ MPB, p. 203-204. 
não menos angustiante: voltar para a vidinha besta em Perus e trabalhar na fábrica. Voltaremos a essa caracterização de Perus.

Com relação a Bacanaço, o narrador vai aos poucos expondo a crueldade do malandro. A face sombria do malandro fino e lustroso, elegante e boa gente, aparece com força na mesma passagem do conto em que Perus está ocupado com seu impulso destrutivo e "regressivo" (suicida, trouxa e trabalhador). Bacanaço relembra suas ocupações que estão além da sinuca, especialmente a atividade de cafetão:

Bacanaço andava agora com uma mina nova, vinte anos. Morena ou ruiva não se sabia, que ficava loira de cabelos oxigenados, porque o mulato preferia loiras. Fazia a vida num puteiro da rua das Palmeiras, tinha seu nome de guerra - Marli. A mina lhe dava uma diária exigida de mil, mil e quinhentos cruzeiros, que o malandro esbagaçava todos os dias nas vaidades do vestir e do calçar, no jogo e em outras virações. Quando the trazia menos dinheiro, Bacanaço a surrava, naturalmente, como fazem os rufiões. Tapas, pontapés, coisas leves. Apenas no natural de um cacete bem dado para que houvesse respeito, para não andar com bobice na cabeça e para que não se esquecesse preguiçando na rua, ou bebericando nos botecos, ou indo a cinemas, em vez de trabalhar. Obrigação sua era ganhar - para não acostumá-la mal, Bacanaço batia-lhe. Nas surras habituais, o porteiro da pensão da Lapa surgia, assustado. Bacanaço o encarava.

- Olhe, camarada: entre marido e mulher, ninguém bote a colher.

E se o homem perguntava, solícito:

- O seu negócio deve ser cuidar de sua vida - e abria os braços — ou é cuidar da minha? O tipo se ia, cabisbaixo, desenxabido, para o mesmo lugar donde viera.

Se a desobediência se repetia, o cacete se dobrava. Bacanaço se atilava em crueldades mais duras. Para começo a trancafiava no quarto e partia para a rua, onde se demorava horas. Ia à sinuca, ia andar a fim de pensar bem pensado; a mulher que lá ficasse aguentando fome e vontades. Voltava tarde, bebido e abespinhado, usava o cabo de aço e agia como se Marli fosse um homem. Proibia-a de gritar. Malhava aquele corpo contra as paredes, dava-lhe nos rins, nos nós e nas pontas dos dedos. Encostava-lhe o cigarro aceso nos seios. As vezes, Marli urinava. $^{311}$

O distanciamento do narrador, perto do fim do conto, se desenha de maneira bastante evidente. É, a bem dizer, uma tomada de distância significativa, em um panorama

${ }^{311}$ MPB, pp. 204-205. Note-se mais uma vez a ocorrência do verbo atilar, que como observamos no capítulo 2 concentra a ambiguidade dos malandros, que se aprimoram (eles se atilam) tornando-se "bárbaros" (o verbo atilar como sinônimo de se comportar como Átila). 
geral de grande proximidade e afinidade. Sempre muito próximo aos personagens e colado ao ponto de vista dos protagonistas, o narrador também é capaz de destacar-se do universo narrado para apontar a crueldade do malandro "bacana". Bacanaço é um rufião que explora economicamente a prostituta Marli: bate nela e a tortura com o cabo de aço ("aço" inscrito no nome de guerra do malandro) e com o cigarro aceso nos seios da mulher.

Assim como já fizera com Perus, visto à distância, para mostrar como o menino pensa em suicídio, pensa em abrir mão da malandragem, voltar a trabalhar, mas que também se mantém incapaz de sair da condição de malandro, o narrador agora, em relação ao malandro adulto, é ainda mais prevenido e distante, ainda que mantenha o recurso do discurso indireto livre, muito próximo da linguagem do personagem: "Bacanaço a surrava, naturalmente, como fazem os rufiões”, diz o narrador, à distância, para em seguida aderir ao ponto de vista do malandro: "Apenas no natural de um cacete bem dado para que houvesse respeito, para não andar com bobice na cabeça e para que não se esquecesse preguiçando na rua, ou bebericando nos botecos, ou indo a cinemas, em vez de trabalhar”. A alternância de adesão e distanciamento se mantém: "Se a desobediência se repetia, o cacete se dobrava" (posição do narrador entre a proximidade e a isenção); "Bacanaço se atilava em crueldades mais duras" (narrador afastado do personagem, para acusar de cruel seu comportamento).

O papel do narrador no conto ainda não foi bem sublinhado, talvez porque, justamente, sua constituição tenha por objetivo suprimir-se para conduzir a ação como se ela se desenrolasse por si mesma, sempre em frente. A ênfase está mais no movimento, na ação narrada e, menos, nos personagens. A própria caracterização dos protagonistas é retardada pelo narrador, o qual está fora da ação, mas rente a ela.

Trata-se de um narrador maleável, cujo movimento é de aproximação e distanciamento dos personagens. Neste sentido, ele se assemelha ao narrador de Vidas secas. Veja-se este trecho do romance de Graciliano Ramos, uma das primeiras ocorrências do discurso indireto livre no livro, que vem logo depois que Baleia caça um preá:

[...] Aquilo era caça bem mesquinha, mas adiaria a morte do grupo. E Fabiano queria viver. Olhou o céu com resolução. A nuvem tinha crescido, agora cobria o morro inteiro. Fabiano pisou com segurança, esquecendo as rachaduras que lhe estragavam os dedos e os calcanhares. 
Sinhá Vitória remexeu na baú, os meninos foram quebrar uma haste de alecrim para fazer um espeto. Baleia, o ouvido atento, o traseiro em repouso e as pernas da frente erguidas, vigiava, aguardando a parte que lhe iria tocar, provavelmente os ossos do bicho e talvez o couro.

Fabiano tomou a cuia, desceu a ladeira, encaminhou-se ao rio seco, achou no bebedouro dos animais um pouco de lama. Cavou a areia com as unhas, esperou que a água marejasse e, debruçando-se no chão, bebeu muito. Saciado, caiu de papo para cima. olhando as estrelas, que vinham nascendo. Uma, duas, três, quatro, havia muitas estrelas, havia mais de cinco estrelas no céu. $\mathrm{O}$ poente cobria-se de cirros - e uma alegria doida enchia o coração de Fabiano.

Pensou na família, sentiu fome. Caminhando, movia-se como uma coisa, para bem dizer não se diferençava muito da bolandeira de seu Tomás. Agora, deitado, apertava a barriga e batia os dentes. Que fim teria levado a bolandeira de seu Tomás?

Olhou o céu de novo. Os cirros acumulavam-se, a lua surgiu, grande e branca. Certamente ia chover.

Seu Tomás fugira também, com a seca, a bolandeira estava parada. E ele, Fabiano, era como a bolandeira. Não sabia por quê, mas era. Uma, duas, três, havia mais de cinco estrelas no céu. A lua estava cercada de um halo cor de leite. Ia chover. Bem. A catinga ressuscitaria, a semente do gado voltaria ao curral, ele, Fabiano, seria o vaqueiro daquela fazenda morta. Chocalhos de badalos de ossos animariam a solidão. Os meninos, gordos, vermelhos, brincariam no chiqueiro das cabras, sinhá Vitória vestiria saias de ramagens vistosas. As vacas povoariam o curral. E a catinga ficaria toda verde. ${ }^{312}$

A pergunta “Que fim teria levado a bolandeira de seu Tomás?” introduz na narrativa uma voz que é a do narrador, mas é também a de Fabiano, personagem cujo ponto de vista vinha sendo traduzido pela posição onisciente e distanciada do narrador. Duas frases, um pouco mais à frente, embaralham a perspectiva de narrador e personagem: "E ele, Fabiano, era como a bolandeira. Não sabia por quê, mas era". A primeira frase, sendo do narrador, traz inscrita a perspectiva de Fabiano sobre ele próprio, pois retoma questão semelhante àquela formulada na pergunta que ensejou o discurso indireto livre. A segunda frase é do narrador, mas este passa a aderir ao "espírito atribulado do sertanejo". 313

\footnotetext{
${ }^{312}$ RAmOS, Graciliano. Vidas secas. Rio de Janeiro: Record, 2000, pp. 14-15.

${ }^{313}$ Idem, ibidem, p. 10.
} 
Se aqui, no começo do romance, o narrador está ao mesmo tempo distanciado e colado ao ponto de vista de Fabiano, mais à frente, quase ao final de Vidas secas, o narrador alterna a objetividade da descrição às perspectivas de Fabiano e Sinhá Vitória:

[...] E talvez esse lugar para onde iam fosse melhor que os outros onde tinham estado. Fabiano estirou o beiço, duvidando. Sinhá Vitória combateu a dúvida. Por que não haveriam de ser gente, possuir uma cama igual à de seu Tomás da bolandeira? Fabiano franziu a testa: lá vinham os despropósitos. Sinhá Vitória insistiu e dominou-o. Por que haveriam de ser sempre desgraçados, fugindo no mato como bichos? Com certeza existiam no mundo coisas extraordinárias. Podiam viver escondidos, como bichos? Fabiano respondeu que não podiam.

— O mundo é grande

Realmente para eles era bem pequeno, mas afirmavam que era grande - e marchavam, meio confiados, meio inquietos. Olharam os meninos, que olhavam os montes distantes, onde havia seres misteriosos. Em que estariam pensando?, zumbiu sinhá Vitória. Fabiano estranhou a pergunta e rosnou uma objeção. Menino é bicho miúdo, não pensa. Mas sinhá Vitória renovou a pergunta - e a certeza do marido abalou-se. Ela devia ter razão. Tinha sempre razão. Agora desejava saber que iriam fazer os filhos quando crescessem.

— Vaquejar, opinou Fabiano.

Sinhá Vitória, com uma careta enjoada, balançou a cabeça negativamente, arriscando-se a derrubar o baú de folha. Nossa Senhora os livrasse de semelhante desgraça. Vaquejar, que ideia! Chegariam a uma terra distante, esqueceriam a catinga onde havia montes baixos, cascalhos, rios secos, espinho, urubus, bichos morrendo, gente morrendo. Não voltariam nunca mais, resistiriam à saudade que ataca os sertanejos na mata. Então eles eram bois para morrer tristes por falta de espinhos? Fixar-se-iam muito longe, adotariam costumes diferentes. $^{314}$

Como se percebe, o narrador de Graciliano, está ao mesmo tempo colado e distanciado de seus personagens. A frase inicial do trecho está formulada como discurso do narrador, mas ela é fala de Sinhá Vitória, como se infere pela reação de Fabiano, que duvida do que se exprimiu, estirando o beiço. As perguntas que se sucedem são inquietações de Sinhá Vitória, mas mescladas ao discurso do narrador, que afirma "Com certeza existiam no mundo coisas extraordinárias", a um só tempo contrapondo-se às dúvidas da personagem, mas também formulando uma certeza que pode vir do pensamento desta.

${ }^{314}$ RAMOS, Graciliano, op. cit., pp. 121-122. 
Segue-se mais uma vez a reação de Fabiano, e o narrador chega a lhe registrar a fala, enunciada por meio do travessão. Mais à frente, os pensamentos de Fabiano assumem o primeiro plano, mas pelas palavras do narrador: "Ela devia ter razão. Tinha sempre razão". O narrador também dá voz aos pensamentos e falas de Sinhá Vitória: "Vaquejar, que ideia!" é certamente uma objeção que parte dela. E o uso da forma verbal do futuro do pretérito envolve a todos em uma perspectiva vindoura, desejada, mas incerta. $\mathrm{O}$ arremate do trecho, com esta forma verbal construída por meio de uma mesóclise, "Fixar-se-iam muito longe, adotariam costumes diferentes", indica que o narrador retomou o ponto de vista para si, de forma a adotar uma visada mais distanciada, prevenida, em relação aos sonhos acalentados e formulados pelos personagens.

O procedimento do narrador de João Antônio é análogo. No conto, ele é orientado e determinado pela necessidade de estabelecer uma relação de proximidade com o universo narrado, envolvendo narrador, personagens e também o leitor no mundo da malandragem, mas também por uma necessidade tão importante quanto à anterior, uma necessidade de distanciamento, para não perder a medida de brutalidade e violência deste mesmo mundo — desconfiança e prevenção que fazem dele um narrador realista onisciente, com visada crítica relevante.

O movimento do narrador também está em sintonia com o andamento da própria matéria narrada: as ondas de maré de sorte e azar a que estão submetidos os personagens, marés do acaso a que eles se referem várias vezes ao longo do texto, e a alternância de euforia e melancolia que os acomete. Esse movimento oscilante da narrativa já foi sublinhado muito bem por Vima Lia Martin: “(...) há uma oscilação entre momentos em que os malandros renovam a certeza de que estão 'por baixo' e momentos em que eles se permitem sonhar com uma situação menos dura, fantasiando dias mais venturosos. É esse movimento que impulsiona os três homens na sua perambulação pelas sinucas da cidade. Pessimismo e otimismo se alternam, assim, ritmando também o andamento da narrativa".315

A altura e o distanciamento de onde o narrador se coloca para, em alguns momentos, retratar os personagens evidencia a fragilidade e a dimensão "real" dos malandros, para além de suas condutas corretas, erradas ou malandras.

\footnotetext{
${ }^{315}$ MARTIN, Vima Lia, op. cit., p. 137.
} 
O olhar do narrador, desencantado, conduz o leitor a um olhar também desencantado, restituindo aos personagens uma estatura e uma potência reduzidas, típicas da forma conto, e de um realismo complexo, que é ao mesmo tempo solidário e crítico a esses personagens marginalizados e alquebrados que, entretanto, teimam em fantasiar grandezas e façanhas.

Dois exemplos talvez bastem para evidenciar, uma vez mais, esse movimento compreensivo, simpático, mas também patético e reflexivo do narrador. A primeira passagem em que se percebe mais claramente o modo desencantado do narrador ocorre na Barra Funda, quando ele descreve Malagueta e o aproxima de um cachorro vira-lata.

Pararam naquele boteco à beira dos trilhos do trem.

Veio o vira-lata pela rua de terra. Diante do velho parou, empinou o focinho, os olhos tranqüilos esperavam algum movimento de Malagueta. $\mathrm{O}$ velho olhava para o chão. $\mathrm{O}$ cachorro o olhava. O velho não sacou as mãos dos bolsos, e então, o cachorro se foi a cheirar coisas do caminho. Virou-se acolá, procurou o velho com os olhos. Nada. Prosseguiu sua busca, na rua, a fuça nas coisas que esperava ser alimento e que a luz tão parca abrangia mal. De tanto em tanto, voltava-se, esperava, uma ilusão na cabecinha suja, de novo enviava os olhos suplicantes. $\mathrm{O}$ velho olhando o cachorro. Engraçado - também ele era um virador. Um sofredor, um pé-dechinelo, como o cachorro. Iguaizinhos. Seu dia de viração e de procura. Nenhuma facilidade, ninguém que lhe desse a menor colher de chá. Tentou golpe, tentou furto, esmola tentou, que mendigar era a última das virações em que o velho se defendia. ${ }^{316}$

É nesta passagem melancólica pela Barra Funda, quando Malagueta se põe a refletir sobre sua vida para além da sinuca e da boemia, quando recorda a relação que mantém com a preta Maria, vendedora de pipoca de porta de cinema, que Malagueta se revela, ou melhor, é revelado pelo narrador, em sua dimensão de fraqueza e fragilidade, em sua condição não malandra, que também constitui sua malandragem:

\footnotetext{
${ }^{316} M P B$, p. 179. Comentando esta passagem, Vima Lia Martin liga o vira-lata à personagem Baleia, a cachorra da família de retirantes de Vidas secas: "A interação entre o velho e o cachorro e a humanização do animal, capaz de criar 'uma ilusão na cabecinha suja' evocam passagens do romance Vidas secas, de Graciliano Ramos, que opera a personificação de uma cadela - Baleia - e a brutalização das personagens centrais - Fabiano, Sinhá Vitória e os dois filhos do casal. Na narrativa do escritor alagoano, tal recurso tem a mesma função que encontramos no conto de João Antônio: promover a denúncia social através do apagamento das fronteiras que separam a condição de vida das pessoas marginalizadas e a condição de vida dos bichos. Também o determinismo social, que já verificamos, assemelha-se à perspectiva expressa pelo narrador de Vidas secas". MARTIN, op.cit., p. 144.
} 
Assim, parado, se vendo pelo avesso e fantasiando coisas, Malagueta, piranha rápida, professor de encabulação e desacato, velho de muito traquejo, que debaixo do seu quieto muita muamba aprontava, era apenas um velho encolhido. ${ }^{317}$

E o desalento derradeiro vem justamente ao final do conto, quando os três malandros retornam à Lapa, de onde haviam partido:

A curriola formada no velho Celestino contava casos que lembravam nomes de parceirinhos.

Falou-se que naquela manhã por ali passaram três malandros, murchos, sonados, pedindo três cafés fiados. 318

O narrador, ao final, descola-se dos três personagens. Volta-se para a curriola, que continua em sua tarefa de narrar, contar “casos com nomes de parceirinhos". É a curriola quem tem a última palavra. Na ação narrada, é a malandragem anônima que conta a história de Malagueta, Perus e Bacanaço.

\section{A arte de contar}

Definir, detalhar e compreender o movimento do narrador, como fizemos até aqui, nos leva a um segundo olhar para a característica mais forte do conto e que entra em atrito com a ideia de distanciamento e desencanto do narrador: a profunda oralidade que permeia a história, do começo ao fim, envolvendo narrador, protagonistas e personagens menores e anônimos em um mesmo universo de histórias, contadas e recontadas de boca em boca. Estamos no terreno da narratividade, do mito e da lenda - ou, neste último caso, para usar o termo de André Jolles, da legenda.

No caso de "Malagueta, Perus e Bacanaço" alguns aspectos permitem identificar o conto a essas narrativas de fundo arcaico, inclusive à própria forma conto, em suas características que também fazem desse gênero exemplo de "forma simples": a oralidade, a

\footnotetext{
${ }^{317}$ MPB, p. 181.

318 idem, p. 222.
} 
circularidade, a zoomorfização e o tema em questão, a malandragem, que se liga à tradição da literatura popular, mas também erudita.

Trata-se de um conto sobre uma única noite, sobre uma jornada em que os malandros saem da Lapa, percorrem outros bairros, incluindo o centro da cidade, e retornam à Lapa, cumprindo um percurso circular que, assim como já ocorrera com o conto "Busca", confere a esta narrativa um caráter avizinhado à poesia, ao mito e à lenda. Esta "ciranda da malandragem", como bem define a expressão de Jesus Antonio Durigan, ${ }^{319}$ aponta para o teor repetitivo, recorrente e inescapável das trajetórias dos personagens. É como se a história de Malagueta, Perus e Bacanaço não tivesse começo nem fim, e eles fossem prisioneiros do próprio destino de malandros.

A estrutura espacial é circular. E o tempo é bem marcado: uma noite. O transcurso do tempo e o desenvolvimento da ação narrada, porém, oscilam no ritmo das marés de sorte e azar que acometem os personagens, com influência no tom e no andamento, e expõem uma contradição que estrutura o conto: a ação dos personagens se dá "na noite", na boemia, no universo da malandragem, ordem que parece destacada da sociedade, à margem da vida "normal", do mundo burguês regido pelo trabalho, pela convenção moral e pela família; por outro lado, a ação é acossada o tempo inteiro por uma espécie de contagem regressiva, que tem horizonte temporal marcado, o fim da noite, e o que imprime essa aceleração, a ansiedade pela passagem do tempo, é o dinheiro, valor maior do mundo burguês que os malandros tanto desdenham. ${ }^{320}$

O primeiro ponto de virada da narrativa, aquela primeira centelha de ação que move os personagens, se dá com a ideia de Bacanaço de empenhar o seu relógio. Com isso, eles amealham "uma quina", isto é, quinhentos cruzeiros, a título de capital inicial da jornada de sinuca noturna. O gesto de trocar o relógio por dinheiro é bastante sugestivo. Assim, os malandros "abdicam" da linearidade temporal (simbolizada pelo relógio) em favor de uma aventura que não é regida pelo tempo cronológico, mas por um tempo em "suspensão" (o universo da boemia, da "noite", que só se extingue realmente ao nascer do sol, como o

\footnotetext{
${ }^{319}$ DURIGAN, J. “João Antônio e a ciranda da malandragem”. In: Os pobres na literatura brasileira. op. cit. .

${ }^{320}$ Contagem regressiva similar, também por dinheiro, ocorre na busca de Naziazeno, de Dyonélio Machado, em Os ratos.
} 
conto tão bem irá mostrar) e também pela quina, isto é, simbolicamente por um golpe de sorte, um dinheiro que se arruma por "fortuna", acaso, contingência. ${ }^{321}$

Esta narrativa, portanto, em sua combinação de modernidade (a corrida contra o relógio, a falta que move, a miragem do dinheiro fácil) e circularidade (a "suspensão" temporal na noite, tendendo ao mito e ao universal), parece dizer que a malandragem é uma prática a um só tempo atual e atemporal. Essa dualidade da temática - contemporânea e antiga, nova e imemorial - também define a contradição que estrutura o conto enquanto narrativa moderna e, ao mesmo tempo, de forte teor arcaico.

A noção que une as pontas dessa complexa arquitetura literária é a arte de narrar e a caracterização dos personagens, também eles, como narradores. O mundo em que vivem os personagens de João Antônio é povoado de narradores, que vêm se juntar ao narrador em terceira pessoa, instância narrativa a princípio apartada da ação narrada, pois que, justamente, instaura essa ação. No entanto, as identidades de narrador e personagem, como vimos, tendem a se embaralhar, e a própria tarefa de narrar em alguns momentos é compartilhada entre personagens e narrador.

$\mathrm{O}$ conto de João Antônio, à primeira vista não se relaciona com o universo mítico tal como estamos acostumados a entender as narrativas tradicionais e o mito: relatos que se contam e se recontam, de geração em geração, com o intuito de explicar a origem das coisas, os fenômenos naturais, a ordem do mundo, tendendo ao universal e ao atemporal. Ao contrário, o cenário, a realidade a que ele se reporta e a partir da qual se origina, como se sabe, é bastante específico e localizado: a São Paulo da década de 1950. O universo é o da malandragem dos anos 50 e começo dos anos 60. O texto não traz datas ou marcação histórica evidentes, mas alguns elementos permitem localizá-lo nesse período. Não há, por exemplo, referência a armas de fogo. Bacanaço provoca Perus munido de uma "navalha". Lima, o velho tira aposentado, conta a história de um malandro, Calói, que acabou os dias no Juqueri, depois que a maconha lhe apodreceu o cérebro - nenhuma referência ainda à cocaína. Os malandros assobiam um tango, "Garufa", como código para avisar um ao outro de que há "otário nas proximidades", "trapaças funcionando" e "lucro em perspectiva".

\footnotetext{
321 Inspirada em conceituação de Milton Santos, Clara Ávila Ornellas vê no conto uma alternância entre "tempo rápido" (hegemônico: a pressa, a curta duração da noite, as partidas de sinuca, o dinheiro) e "tempo lento" (o dos hegemonizados: a cidade e seus personagens marginais). ORnELlAs, C. O conto na obra de João Antônio. op.cit., p. 118.
} 
Quando eles passam por Perdizes, a descrição aponta para pessoas que tomam a fresca nas calçadas, hábito que desapareceu do bairro. Acrescente-se a isso as declarações do próprio João Antônio de que o conto se inspirou em suas próprias experiências de juventude, do final dos anos 1950.

Trata-se, assim, como se sabe, de um conto realista, que se relaciona com a situação social brasileira e paulistana de meados do século passado. No entanto, a literatura do autor, como já tivemos oportunidade de observar em outros contos (como "Busca" e, como veremos, "Paulinho Perna Torta"), mantém ligações profundas com tradições narrativas e literárias universais e antigas, que remetem, por exemplo, ao mito de Édipo.

Assim como na história da literatura a narrativa da lenda de Édipo vem se repetindo, atualizando e ganhando novas leituras, na obra de João Antônio este mito retorna. O mito é, aliás, segundo Vernant, aquele relato que se conta e se reconta, por gerações, sem esgotar sua força narrativa e de explicação. No entanto, o mito, em sua forma pura, se narra e se atualiza sem que essa história seja contada por um autor, como se dá nos textos literários. Para Vernant, memória, oralidade e tradição "são as condições de existência e sobrevivência do mito" ${ }^{322}$ Mito, segundo A. Jolles, "é a forma capaz de criar objetos a partir de uma pergunta e de uma resposta" ${ }^{\text {"23. }}$ : perguntas e respostas sobre o mundo.

No caso, as perguntas latentes no conto em análise são: O que é a malandragem? O que é ser malandro? Quem, nesta história, é de fato o malandro? Vale a pena ser malandro? Há mesmo diferença entre ser malandro e ser trouxa? São perguntas enigmáticas, que pedem decifração e permanecem sem resposta, no âmbito da narrativa, ainda que se possa concluir, como o faz Vima Lia Martin, que João Antônio afirma uma perspectiva profundamente melancólica sobre a realidade nacional, ela também fundada em impasses. Para a autora, "a ênfase negativa que o escritor imprime às consequências da transgressão - desidealizando-a e potencializando o seu prejuízo para os malandros que dela dependem para sobreviver -, presentifica o trauma constitutivo da história brasileira". ${ }^{324}$

Há, no entanto, para além da dimensão material do drama e do trauma brasileiros presentificados pelos malandros, uma dimensão narrativa arcaica e de fundo lendário, ligada à cultura popular desde a Antiguidade, que se traduz em uma pergunta enigmática,

\footnotetext{
${ }^{322}$ Vernant, Jean-Pierre. O universo, os deuses, o homem. São Paulo: Companhia das Letras, 2000, p. 11.

${ }^{323}$ JOLLES, op. cit., p. 98.

${ }^{324}$ MARTIN, Vima Lia, op. cit., p. 163.
} 
ligada a um mito antigo. Essa questão ganha, de fato, formulação difusa, mas resposta desenvolvida neste conto de João Antônio: a história dos três malandros, um jovem, um adulto e um velho responde - atualizando-a — a pergunta da esfinge, que Édipo decifrou. Trata-se de um conto sobre as três idades do homem: Perus, o menino; Bacanaço, o adulto; Malagueta, o velho. ${ }^{325}$

Além dessa moldura mítica que contorna o texto e o insere em uma tradição literária e cultura antiga e ainda atuante - o mito, a fábula, a legenda - o enquadramento social de seus protagonistas - as camadas mais pobres e despossuídas, os "coiós sem sorte", "sem eira nem beira", "pingentes" -, também permite identificar os personagens à tradição cristã dos despossuídos e desterrados. Como bem define Flávio Aguiar, o universo literário de João Antônio está inserido dentro de um quadro cristão:

O essencial a compreender na obra de João Antônio é que ela vive a partir de um universo cristão. É claro que não de um cristianismo burocratizado, distante dos homens, perdido em formalidades e fricotes incompreensíveis. Mas daquele cristianismo primevo, que fez o Messias nascer e crescer entre os deserdados da terra, amigo dos pescadores e da gente simples, e que depois transformou seus seguidores em mártires muito além do que prometia a força humana, pelo menos a dos balofos imperadores romanos. Sem dúvida, a Bíblia foi um dos primeiros livros a fixar os humildes na Terra como personagens dignos de debater e encarnar os grandes destinos da humanidade, coisa antes reservada para nobres e próximos. Seres "pequenos" - pescadores, doentes, camponeses, prostitutas — se agigantam e batem às portas do universo da história do Cristo. $^{326}$

O enquadramento dos personagens como seres errantes, peregrinos, que perambulam sem encontrar parada, despossuídos, sem eira nem beira, permite identificá-los aos humildes, aos "sofredores" que se comportam e se inserem socialmente como sucedâneos de Cristo. Talvez nem fosse necessário ligar os personagens diretamente à figura mítica de Jesus, mas o narrador o faz, pelo menos no caso de Malagueta, ainda na primeira parte da narrativa, logo depois de apresentar o personagem e definir suas

\footnotetext{
${ }^{325}$ Vima Lia Martin sugere que os personagens "simbolizam a ascensão, o apogeu e a queda típicos da trajetória de um malandro". MARTIN, V. Literatura e marginalidade, op.cit., p. 133. Jesus Antônio Durigan também já havia chamado a atenção para as três idades do homem representadas em cada personagem. DURIGAN, J. "João Antônio e a ciranda da malandragem". In: Os pobres na literatura brasileira. op. cit.

${ }^{326}$ AgUIAR, Flávio. A palavra no purgatório. São Paulo: Boitempo Editorial, 1997, p. 90.
} 
artimanhas de virador. A relação com o universo cristão, que é dos trouxas, mas também é deles, malandros, aparece então não como sentimento religioso ou profissão de fé, mas em função da estratégia de sobrevivência:

Malagueta esfriou, perdeu num átimo o alegre rebolado. Andava tudo ruim. E ele com a fome. Maré de azar danado, nem quisessem saber. Comer? Surrupiando uma maçã duma prateleira lá do mercado, quase o pilharam com a mão na coisa. Caíra no chão, botara aquela cara de sofrimento, estendera a mão que roubou a maçã, esmolara. Com aquela cara de sofredor, de Jesus Cristo, talvez algum trouxa lhe pingasse uma grana. Mas a onda de crepe era raiada - de olho vivo, andavam guardas lá no mercado, finos como tiras. ${ }^{327}$

Os personagens de João Antônio são "sofredores" e pingentes que fantasiam e narram. A experiência intercambiável, a capacidade de transmitir aquilo que se viveu e se aprendeu, é a matéria-prima dos narradores, como registrou Walter Benjamin: “A experiência que se passa de pessoa a pessoa é a fonte a que recorreram todos os narradores. $\mathrm{E}$, entre as narrativas escritas, as melhores são as que menos se distinguem das histórias orais contadas pelos inúmeros narradores anônimos". ${ }^{328}$ Benjamin distingue dois grandes grupos de narradores, dois "tipos fundamentais" que têm a capacidade de narrar: o camponês sedentário e o marinheiro comerciante. São tipos que se complementam: “A extensão real do reino narrativo, em todo o seu alcance histórico, só pode ser compreendida se levarmos em conta a interpenetração desses dois tipos arcaicos". ${ }^{329}$ No entanto, como também ressalta Benjamin, após a Primeira Guerra Mundial a própria noção de experiência entrou em crise. É conhecida a afirmação do autor de que os soldados voltaram mudos do campo de batalha. ${ }^{330}$

A própria noção de experiência estaria em vias de desaparecer, com reflexos na arte de narrar, como sustenta Adorno. ${ }^{331}$ Esta ideia ganha contraponto, no conto em quadro, pois o texto de João Antônio elenca uma série de personagens que têm por hábito contar

\footnotetext{
${ }^{327} M P B$, p. 161.

${ }^{328}$ BENJAMIN, W. "O narrador. Considerações sobre a obra de Nikolai Leskov". In Obras escolhidas. Magia e técnica, arte e política. vol. 1. $4^{\mathrm{a}}$ edição. São Paulo: Brasiliense, 1985, p. 198.

${ }^{329}$ Idem, ibidem, p. 199.

${ }^{330}$ Benjamin, W. "Experiência e pobreza". In: Documentos de cultura, documentos de barbárie. Sel. de Willi Bolle. São Paulo: Cultrix/Edusp, 1986.

331 ADORNO, Theodor W. "Posição do narrador no romance contemporâneo". In Notas de literatura I. Trad. de Jorge de Almeida. São Paulo: Duas Cidades, Editora 34, 2003.
} 
histórias de malandragem. Entretanto, a confirmar a hipótese de Benjamin, a ideia de narrador experiente, que tem algo a transmitir por conta de sua vivência, é também ela colocada em questão no universo da malandragem em que se passa a história narrada.

No que se refere à importância da arte narrativa, o conto se desenvolve segundo a tensão entre as histórias que se contam e a ação narrada, que empurra os personagens sempre adiante. O momento de narrar é o momento do sedentarismo, mas as histórias também precisam ser vividas, no momento da aventura.

Vale lembrar aqui que o ensaio de Antonio Candido sobre o livro de João Antônio chama a atenção para a capacidade do escritor "de criar linguagem a partir do que se fala no dia a dia". ${ }^{332}$ É a propósito da oralidade e da elaboração estilística que o autor empreendeu em “MPB” que Candido irá relembrar o começo de São Bernardo, de Graciliano Ramos, quando Paulo Honório conta que contratou um jornalista para escrever sua história e que o profissional da imprensa "acanalhou o troço", no dizer do personagem. Paulo Honório decide, então, redigir ele mesmo o seu livro, escrevendo "como se fala".

O momento vivido por Paulo Honório é o tempo do sedentarismo, em que ele se estabeleceu como proprietário da fazenda São Bernardo. É também o momento de Riobaldo, "Narrador nostálgico do sertão que já não há, e pelo aburguesamento do exjagunço aposentado e barranqueiro do São Francisco em que se transforma, dono, além do mais, de suas possossas fazendas herdadas do padrinho (na verdade, pai) Selorico Mendes". 333

Ambos os personagens, Paulo Honório, de São Bernardo, e Riobaldo, de Grande sertão: veredas, se tornaram narradores depois de uma vida de aventuras, como capataz e jagunço. Neste momento em que ascenderam socialmente e se tornaram proprietários sedentários, portanto, podem se dedicar a contar e construir a própria história. Como mostrou José Antônio Pasta Jr., no caso de Riobaldo, a constituição problemática do eu faz com que Riobaldo viva entre dois mundos: moderno e arcaico, indivíduo isolado e membro de fratria ou clã, livre e dependente, homem de lei e de mando, de contrato e de pacto,

\footnotetext{
${ }^{332}$ CANDIDO, Antonio. "Na noite enxovalhada". In: MPB, op.cit., p. 7.

333 ARriguCCI JR., D. “O mundo misturado. Romance e experiência em Guimarães Rosa”, Novos Estudos Cebrap, n ${ }^{\circ} 40$, nov. 1994, p. 16.
} 
letrado e iletrado. Segundo o crítico, Riobaldo se forma "passando no seu outro" (de um polo a outro, de um bando a outro, de uma convicção a outra, de um sexo a outro). ${ }^{334}$

A contradição de ser $e$ não ser — entre o "mesmo" e o "outro" nos termos de Pasta Jr. - que acomete o jagunço aposentado de Guimarães Rosa, tem correspondência no universo da malandragem de João Antônio. No caso deste conto, os narradores não são aventureiros estabelecidos, mas, ao contrário, aventureiros em pleno momento da ação, mas ameaçados pelas marés de azar que, a todo momento, podem transformá-los no avesso, em trouxas sedentários.

A vida de malandro certamente se aproxima mais daquela de um marinheiro comerciante, sempre a navegar pela noite, pela boemia, intercambiando experiências e "bens", por meio do jogo, dos pequenos golpes, dos furtos, da cafetinagem. No caso de Malagueta, Perus e Bacanaço, a movimentação noturna, sem parada, indica que os três malandros se enquadram nesta categoria de narradores.

A própria valorização da capacidade de narrar, entre os malandros, é evidenciada pelo narrador, já na primeira ocorrência de uma história narrada dentro da ação, por um dos personagens.

O elenco de personagens que contam histórias começa pelos próprios protagonistas. Bacanaço é o primeiro dos personagens que, a certa altura do relato, se põe a contar façanhas, proezas, histórias de outros personagens, que não participam diretamente da ação narrada, mas são evocados para demonstrar alguma ideia, para relembrar características da malandragem ou simplesmente para entreter narrador e ouvintes com suas histórias, lendas, façanhas.

A primeira vez que isso ocorre é, ainda na primeira parte do conto, quando Bacanaço e Perus estão à toa no Celestino, salão de sinuca da Lapa, e se põem a lembrar de um episódio ocorrido ali mesmo, "não fazia uma semana”. A princípio, é o narrador quem conta a história de Sorocabana, um "trouxa", "coió-sem-sorte", que colocou na roda um salário-prêmio e foi derrotado por Bacalau, malandro que terminou por lhe "morder os últimos". Ao final deste episódio rememorado, porém, diz o narrador:

\footnotetext{
${ }^{334}$ PASTA JR., José Antônio. O romance de Rosa. Temas do Grande sertão e do Brasil. Novos Estudos Cebrap $n^{\circ}$ 55, 1999, pp. 61-70. Nessa lógica, diz Pasta Jr., está a formação supressiva de Riobaldo: "passando no seu outro, ele vem a ser no e pelo movimento mesmo em que deixa de ser: ele se forma suprimindo-se" (p. 64).
} 
Contava Bacanaço que sabia muito bem das coisinhas da façanha. O menino Perus também sabia. Mas era um menino diante de Bacanaço e por isso ouvia quieto, só meneando a cabeça e de acordo com tudo. Para final - Bacanaço era taco melhor, jogador maduro, ladino perigoso da caixeta, do baralho e da sinuca, moreno vistoso e mandão, malandro de mulheres (...) ${ }^{335}$

Já vimos para onde caminha o trecho acima, para uma melhor definição de Bacanaço, artifício narrativo e descritivo que irá culminar na exposição da crueldade deste personagem. É interessante retomar a passagem aqui para tornar mais claro porque Bacanaço ganha maior visibilidade neste momento da trama: é porque o malandro maduro assumiu o centro da cena por sua capacidade de contar. Como aponta o narrador do conto, Perus também sabia da façanha, "mas era um menino diante de Bacanaço". A experiência de vida, aqui, confere também maior capacidade de narrar.

Aquele momento específico vivido pelos dois personagens na ação narrada é propício à narrativa de feitos da malandragem. Os dois estão "quebrados", impossibilitados pela circunstância de se lançar à aventura. A fortuna impôs a eles um tempo de sedentarismo, ainda que breve, o que lhes abre oportunidade, então, para rememorar histórias e narrar.

Algo parecido se dá na segunda passagem do conto em que ocorre outra narrativa de façanha de malandro, agora narrada por Lima, um policial aposentado que frequenta o salão de sinuca da Água Branca, na segunda parte do texto. É a história de Calói, um "artista" da sinuca, que acabou fraquejando por causa de mulher e de maconha. A história é contada por Lima com intenção moralizante, para alertar que destino de malandro é o Juqueri ou a Casa de Detenção.

Apesar de caracterizar o tira aposentado com traços desfavoráveis ("era um velho gordo e estranho"), o narrador também vai dizer que Lima era "conselheiro dos mais moços", e pelas palavras "desusadas" desse personagem vai, mais uma vez reafirmar o lusco-fusco moral em que se assenta a malandragem. Diz o personagem, aos demais jogadores do salão:

${ }^{335} M P B$, p. 154. 
— Tudo aqui é passageiro - arrotava. — Não é expediente de gente que se preze. Gente moça namora, noiva e casa. É o caminho certo. Aqui, não; aqui é o fim. ${ }^{336}$

E conclui Lima: " - A maior malandragem, meus filhos, é a honesta".

Mas não são apenas os protagonistas, como Bacanaço, e os personagens menores, como Lima, que são narradores e, no momento da ação narrada, colocam-se a narrar outras história de malandragem. Também os malandros anônimos que apenas passam pela história, aparecem também em franca atividade narrativa.

É o que se depreende do início da quarta parte do conto, “Cidade”. Depois de terem jogado na Água Branca, de terem percorrido as ruas de Perdizes e de passarem pela Barra Funda, os três parceiros agora chegam à Cidade, isto é, o centro de São Paulo. Ali, depois da melancolia e do marasmo que encontraram na Barra Funda - lembre-se que a seção anterior termina com a descrição de Malagueta como um velho encolhido —, os malandros parecem ter chegado a um lugar totalmente diferente, e para melhor, como se depois da ressaca da parte anterior do conto, eles vivessem nova maré de sorte. $\mathrm{O}$ tom do começo desta parte é de animação, quase de euforia:

Uma, duas, três, mil luzes na avenida São João!

A curriola formada à esquina era de sete mais uma mulher, que era amiga de um deles. Fala de bordel, falavam de casos passados, antigamente febris para a baixa malandragem. Fulano fez, fez, acabou lá na cadeia; beltrano deu sorte, levantou duzentos contos nos cavalos, arrumou-se na vida hoje é dono disto e daquilo; mas um outro, seu parceiro, maconhava com exagero e endoideceu anda aí pelas ruas falando sozinho; sicrana navalhou a cara da outra, que era sua costureira, mas andava com seu homem. Fosse chibar no diabo! (...) ${ }^{337}$

Se a capacidade de narrar é, talvez, o grau máximo de habilidade com que um malandro pode se exercitar na arte da linguagem verbal, antes disso, a fala desenvolta, a "charla", é também uma capacidade com que se reconhece o malandro e sua inserção e estatura no universo da malandragem. Em um nível semelhante, mas talvez acima da charla, está o uso apropriado da sabedoria adquirida com a experiência de vida, nas ruas, que se traduz no largo uso dos ditos populares, das frases feitas, das fórmulas assertivas

\footnotetext{
${ }^{336}$ MPB, 168.

${ }^{337}$ Idem, p. 182.
} 
sobre a malandragem e, de modo geral, sobre a vida, seja a dos malandros, seja a dos trouxas. O aprendizado, a charla, a habilidade no jogo e a picardia - a formação malandra —, possibilita ação e aventura, subsistência e sobrevivência, fama e respeito, mas requer uma ambiguidade própria da fantasia, do disfarce e de uma identidade instável e impermanente que a troca do nome de batismo pelo nome de guerra consubstancia.

Salta aos olhos a profusão de assertivas proverbiais (frases feitas e ditos populares, glosados), com que depara o leitor ao longo do conto, proferidas pelos personagens, mas também pelo narrador. Alguns exemplos: "A sorte não gosta de ver ninguém bem"; "Joguinho ladrão, ganha aqui quem der mais sorte", "Quando vocês iam no moinho buscar fubá, eu, cá no meu quieto, já estava de volta com o bagulho empacotado"; "Sem dinheiro o maior malandro cai do cavalo e sofredor algum sai do buraco"; "Jogo acabado, quem comeu regalou-se, quem não comeu estrepou-se"; "Não havendo capital, sofredor algum tira o pé do buraco".

Essa capacidade de manejar a fala e o uso das frases feitas, aliás, também compõe a estratégia de disfarce de que esses personagens lançam mão, para ao mesmo tempo se colocar em evidência, mas se proteger, se escudar atrás de um código verbal compartilhado. É como se os malandros estivessem a todo momento se medindo. "Eu sou mais malandro que você, mas veja bem, somos semelhantes, parceiros, iguais", poderia ser a fórmula das relações interpessoais no mundo fechado da malandragem. ${ }^{338}$

O tom conselheiro que os malandros maduros assumem também permite classificálos como grandes narradores. Recorrendo de novo a Benjamin, vale lembrar que a experiência e a sabedoria são as marcas da narrativa tradicional, que traduz a vivência aventurosa e o sedentarismo sábio do narrador, e essa miríade de ditos populares que aparecem no conto de João Antônio poderiam ser vistos como um tesouro vivo e coletivo de conselhos, recomendações, fórmulas de conduta, uma ética do vivido que se transmite e se perpetua, em função da sabedoria e da cultura. Mas em "MPB", a experiência e a narratividade, a charla e a capacidade verbal (e proverbial) não apenas se mostram muitas vezes vazias de sentido, como via de regra se apresentam como facas de dois gumes estão a serviço da ambiguidade malandra. É já, portanto, uma sabedoria esvaziada,

\footnotetext{
${ }^{338}$ Berthold Zilly também chamou a atenção para a importância da linguagem como disfarce no conto. ZILLY, B. "João Antônio e a desconstrução da malandragem". In: Brasil, país do passado?, organização de Ligia Chiappini, Antonio Dimas e Berthold Zilly. São Paulo: Edusp/Boitempo, 2000.
} 
experiência degradada, que pode ser aproveitada em benefício próprio ou usada contra trouxas, malandros oponentes e inimigos. Uma pobreza de experiência que é expressão de barbárie, mas uma barbárie, como diz Benjamin, positiva. ${ }^{339}$

Vale lembrar ainda qual é o contraponto definido por Benjamin em relação à narrativa tradicional e à sabedoria do narrador. A grande ameaça ao narrador estaria em uma "nova forma de comunicação" que, "ameaçadora", paulatinamente vinha substituir a arte de contar: a informação. A contradição, encarnada em João Antônio, um autor que se dividiu entre as atividades de jornalista e escritor de ficção, também está evidenciada em suas maiores obras. Em outro dos grandes contos de João Antônio, "Paulinho Perna Torta", escrito pouco depois da publicação de $M P B$, como veremos no próximo capítulo, o narrador-personagem dirá que os jornais andam "encurtando" o seu nome. A imprensa aparece como uma adversária, um ator social que tem a capacidade de fazer a fama e depois descartar seus personagens, assim que outros acontecimentos tomem maior corpo. Aqui, em “MPB”, a menção à imprensa é sutil e aparece mais positivada. No entanto, já é possível identificar a oposição entre universo da malandragem, mítico e oral, e mundo instituído dos meios de comunicação, letrado e formal. Quando os três malandros encontram o já lendário sinuqueiro Carne Frita, há menção a suas aparições na TV e no jornal:

À esquina da Santa Efigênia toparam Carne Frita, valente muito sério, professor de habilidades. Havia na cidade e ainda noutras cidades bons entendedores e tacos atilados com capacidade para fechar partidas, liquidando as bolas. Havia nomes e famas que corriam. Muitos, muitos. Praça, Paraná, Detefom, Estilingue, Lincoln, Mãozinha... Eram artistas do pano verde. Mas Frita... quem entendia de sinuca era ele. Em cima dele foram e gramaram muitos e muito esperto perdeu o rebolado, e muito cobra ficou falando sozinho, esfacelado em volta da mesa, como coruja cega. E muito patrão de jogo caro se perdeu em apostas contrárias, em lances para mais de vinte contos. O homem ganhara tamanho, celebridade; uma curiosidade que se exibiu ensinando até na televisão. Seu nome e fotografia em pose de jogo foram para o jornal numa reportagem que assim dizia: "sinuca de carne frita é falta de adversário!". Era Carne Frita. Botassem respeito, sentido e distância com silêncio e consideração.

Moço, baixinho, com uns olhos de menino, esguio como os malandros do joguinho, que andam quilômetros ao redor das mesas, ninguém daria nada àquele, parado, à esquina da Santa Ifigênia, dando um gesto de mão a Malagueta, Perus e Bacanaço. Fossem ver... Perguntassem em

${ }^{339}$ BenJamin, W. "Experiência e pobreza”. In: Documentos de cultura, documentos de barbárie. p. 196. 
Goiás, em Curitiba, em Porto Alegre, no Rio, em Fortaleza... Sua história abobalhava, seu jogo desnorteou todos os mestres.

Quem de sinuca entendia era Frita. ${ }^{340}$

O malandro que encontram na rua é famoso, uma "celebridade". Segundo o narrador, ele ganhara tamanho, como se sua imagem tivesse se tornado maior que ele mesmo, ali reencontrado por acaso na rua pelos malandros. Frita é um malandro que já virou lenda. Uma lenda viva, como se costuma dizer. Sua fama está acima da de outros grandes nomes da sinuca, como os demais citados (Praça, Paraná, Detefom, Estilingue, Lincoln, Mãozinha), e seus feitos são maiores que os de todos eles. Como uma espécie de mago da sinuca, ele faz outros malandros perderem o rebolado, muito adversário ("cobra") ficar falando sozinho, e desnorteia os oponentes, deixando-os esfacelados, como "coruja cega". Seu apelido, Carne Frita, aponta para uma ambiguidade enigmática, uma agressividade destrutiva e ao mesmo tempo nutritiva: é um sinuqueiro, ele mesmo, encarnado e fritado, mas que é capaz de fritar a carne dos adversários.

Além disso, Carne Frita é descrito com certa aura de santo: "Botassem respeito, sentido e distância com silêncio e consideração". Para acentuar a aura religiosa com que os personagens veem Carne Frita, que surge como uma aparição na narrativa, o encontro se dá na rua Santa Ifigênia. Como se sabe, esta rua do centro de São Paulo, não tem nada de santa: é atualmente a rua de comércio especializado em artigos eletrônicos e de informática. Mas à época fazia parte do circuito boêmio, e o narrador mesmo irá chamar a atenção para o local em que se dá o encontro dos personagens com o lendário Carne Frita: "Despediramse do maior taco do Brasil, ligeiros e firmes entraram pela Santa Ifigênia, rua de virações como outras, àquela hora dormidas. Alcançaram o largo Santa Ifigênia, a igreja de um lado, a sinuca do outro".

A Santa Ifigênia é uma rua de "virações", como outras, um local simples, sem suntuosidade, apesar da aura de santidade que o nome indica. Além disso, há uma igreja nas proximidades, e um salão de sinuca. A oposição entre igreja e sinuca, uma de cada lado do largo, a proximidade aponta para uma convivência pacífica, para uma existência compartilhada, o que retoma a noção dos malandros como vadios "sofredores", como seres

${ }^{340}$ MPB, p. 188-189. Note-se que neste trecho a expressão tacos atilados generaliza a condição de "bárbaros" (Átilas) para os bons jogadores de sinuca. 
errantes, sem eira nem beira, sucedâneos de Cristo, como a narrativa já os havia caracterizado.

A narrativa da vida de um santo também é considerada por André Jolles uma "forma simples". Na tradição da hagiografia, a legenda ou lenda é a forma que narra a vida de alguém considerado um modelo de virtude a ser seguido: "O santo é o indivíduo em quem a virtude se consubstancia e objetiva, o personagem que permite aos que o cercam mais ou menos de perto imitá-lo". ${ }^{341}$ A vida do santo, "êmulo de Cristo", é uma espécie de sucedâneo do modelo inaugural, e a peregrinação dos seguidores uma atualização da via crucis. Se aproximarmos as figuras lendárias dos malandros como modelos de imitação para os malandros-seguidores, é possível ver os malandros como peregrinos que se movem em função dos malandros-modelos, que aparecem nas histórias contadas sobre os grandes malandros - "heróis" lendários como Carne Frita, ou anti-heróis também lendários como Calói ou Bacalau. Jolles opõe à legenda (a narrativa da vida de santo), uma espécie de antilegenda, que seria a narrativa da vida de um antípoda do santo: o malfeitor ou criminoso. $^{342}$

Os três malandros, assim, são personagens que habitam um mundo em que as lendas sobre as façanhas, algo próximo do "milagre", são contadas e recontadas, transformando os personagens em figuras lendárias - por suas virtudes ou por suas maldades. Santos ou malfeitores, os boêmios, os sinuqueiros e os malandros estão sempre à beira de se tornarem protagonistas de histórias extraordinárias, lendas que serão contadas e recontadas, fazendo a fama de qualquer um que se lançar às aventuras várias do mundo da malandragem.

A contradição inerente à arte de narrar, que exige aventura e sedentarismo, é exposta no conto ao contrapor, de um lado, a experiência, isto é, o aprendizado e a capacidade de sobreviver no universo da malandragem, e de outro o acaso, as marés de sorte e azar a que estão sujeitos os personagens - a fortuna, na qual, sintomaticamente, eles depositam grandes esperanças, como a indicar a insuficiência da "experiência" e da "picardia" de malandros. O aprendizado e a sobrevivência permitem aos malandros narrar suas experiências, suas aventuras passadas. Mas como eles não se estabeleceram - nem

\footnotetext{
${ }^{341}$ JOLLES, p. 40.

342 A figura emblemática da antilegenda seria o Anticristo, mas o autor cita também personagens literárias como Fausto e Don Juan, dentre outros. Entre as atualizações da legenda, Jolles cita as histórias de vida dos grandes esportistas, cujos "milagres" seriam os feitos de que são capazes, os recordes que estabelecem.
} 
como trabalhadores (caso do policial aposentado Lima) nem como grandes criminosos eles permanecem na condição ambígua e instável de malandros, sujeitos às marés da sorte, e, portanto, sempre na iminência de nova aventura.

Lembremos de novo o breve e excepcionalmente conciso encerramento do conto, que se chama "Lapa", assim como a primeira parte da narrativa: "A curriola formada no velho Celestino contava casos que lembravam nomes de parceirinhos. Falou-se que naquela manhã por ali passaram três malandros, murchos, sonados, pedindo três cafés fiados".

$\mathrm{O}$ mundo da malandragem subsiste, à revelia dos três parceiros, que naquela manhã voltaram ao lugar de onde partiram, mais uma vez quebrados, massacrados. No mesmo Celestino de onde eles partiram, reúne-se de novo a curriola, para dar sequência ao ato de contar, à narração de casos que lembram "parceirinhos". O narrador descreve uma situação em que, mais uma vez, narradores anônimos se põem a contar histórias de malandros, inclusive a história de Malagueta, Perus e Bacanaço. Terminado o conto, tem início a lenda, o mito, a narração.

Não se quer dizer, com isso, que o texto de João Antônio seja um relato mítico. Trata-se obviamente de uma obra literária, um conto moderno, assinado por um autor e realista a seu modo. Mas a estrutura circular, a suspensão temporal, noturna, no desenvolvimento da ação, por um lado, e por outro a orientação dos personagens pelas marés de sorte e azar, pela fortuna, fazem de "MPB" um conto que se apoia na oralidade e na arte de contar, num universo, a malandragem, em que a lenda e o mito ainda têm lugar. E, no entanto, apesar de a experiência malandra se tornar experiência e narrativa, a fama, o nome "que corre", o estatuto de celebridade (a legenda) dos malandros também é ameaçadora e os torna vulneráveis, visados pela polícia ou por rivais. De malandros acesos, acordados, eles passam a malandros apagados ou trouxas, a qualquer momento.

\section{Malandragem: tipicidade e situação narrada}

Nem santos nem criminosos: malandros. Já vimos como Malagueta, Perus e Bacanaço são personagens que vão, aos poucos, sendo delineados pelo narrador, que lhes atribui comportamentos não apenas de malandros, mas também de trouxas, de pobresdiabos, de criminosos. No entanto, é a identidade de malandro que prevalece, como indica o 
final do conto, quando os personagens são, mais uma vez, chamados de malandros. Agora, porém, "murchos", "sonados" e de novo sem dinheiro. Ao final, os personagens se afiguram como malandros decaídos, o que lhes devolve à condição de sofredores, erradios, sem eira nem beira. De novo, a ciranda se fecha: são malandros e são otários.

O importante a esse respeito é que o conto narra a noite de Malagueta, Perus e Bacanaço enquanto malandros. Os personagens, como já dissemos, são malandros em situação. A identidade dos três é instável, mas é a ação que os define como malandros, e não como trouxas, coiós, vagabundos e criminosos - o que eles também são. Em outras palavras, "MPB" é um conto sobre a malandragem em ação.

Já vimos também que a estratégia de dissimulação é a essência do negócio da malandragem. A própria condição de malandro pressupõe uma espécie de indefinição constitutiva, que é expressa inúmeras vezes ao longo do relato. Bacanaço, por exemplo, é um tipo: veste-se à malandra, de branco, camisa sempre bem passada, sapatos brilhantes, anel no dedo. No entanto, é um rufião cruel, criminoso rematado, que tortura a prostituta Marli, queimando-a com cigarros e a supliciando com cabo de aço. Perus é um menino, caracterizado também como tipo, naquela concepção de personagem, tal como definida por Antonio Candido, regido por uma lógica ${ }^{343}$ : suas características recorrentes são a mudez, o hábito de enumerar coisas, o sonho com os jogos caros de Vila Alpina e a inação. Malagueta é capiongo, um velho encolhido. Os apelidos os identificam menos como sujeitos complexos, e mais como peças. Os demais personagens da história também são caracterizados como tipos, mas tipos instáveis. Na Cidade, os três protagonistas vão encontrar personagens da noite que são "malandros": jogador que parece senador, cafetões que parecem deputados, "invertidos", mulheres lindíssimas que "berram erotismo", "mulheres profissionais", camelôs, malandros pés-de-chinelo e malandros de turfe. As identidades da boemia são mutáveis e ambíguas.

A malandragem por excelência, neste conto, porém, se dá obviamente em torno da sinuca. A esse respeito, Antonio Candido diz que no conto, em torno da sinuca, "se desenham uma técnica, um ética e até uma estética, formando um modo de existir que é sobretudo um modo de subsistir". ${ }^{344} \mathrm{O}$ jogo, de fato, é o meio pelo qual os três parceiros

\footnotetext{
${ }^{343}$ CANDIDO, A. “A personagem do romance". In: A personagem de ficção. $5^{\text {a }}$ ed. S. Paulo: Perspectiva, 1976. 344 _. "Na noite enxovalhada". In: MPB, p. 10.
} 
decidem se lançar, na noite em questão, a fim de tentar multiplicar o capital arranjando depois de terem empenhado o relógio.

É por meio das regras da sinuca e de certo comportamento compartilhado em torno desse jogo que os malandros podem atuar, mas, justamente, trapaceando sempre que possível as regras e o comportamento esperado pelos demais envolvidos na roda. Assim, a "malandragem" extrapola o mundo do "pano verde" para se tornar um estilo de vida, ligado à sinuca, mas com consequências que vão muito além desse universo. $\mathrm{O}$ conto sugere a correspondência entre o jogo e a vida, logo na primeira (e única, diga-se) passagem em que o narrador descreve o jogo e os personagens em ação jogando sinuca.

É a primeira vez que os parceiros atuam como malandros. A primeira parada dos três, depois de deixarem a Lapa, é no bairro da Água Branca. Ali, a ação se passa no salão de sinuca Joana D'Arc, onde alguns homens jogam o "jogo de vida”. É a primeira vez que os protagonistas são confrontados por outros personagens - e não apenas de acordo com as regras do jogo.

A sinuca e a vida são aproximadas, e desenvolve-se uma espécie de descrição de um modo de comportamento que tem algo de prescrição de conduta, manual de boas maneiras no universo da sinuca e da boemia. Talvez se possa ver aqui, a estética e a ética de que Candido fala. Mas é, justamente, a dissimulação e o disfarce, a aceitação cínica das regras, para subvertê-las, que permite ao conluio dos malandros funcionar. É preciso manter a aparência de normalidade, para que a malandragem possa operar.

Os personagens precisam jogar como se fossem "trouxas", mas ao mesmo tempo desempenhar o papel a que estão destinados por hierarquia na malandragem. Bacanaço chefia, Perus "se atira às bolas" e Malagueta defende o menino no jogo de vida. As funções estão bem definidas e concorrem para delinear com nitidez os personagens em situação.

Fervia no Joana d'Arc o jogo triste de vida. Um bolo de vida vai a muito porque cresce. Seis, sete ou oito homens dão bolos de bom tamanho. Quatro, cinco, até seis mil, começando por baixo, baixo - cem cruzeiros por cabeça. O joguinho vai correndo como coisinha encrencada, pequenina e demorada. Gente sai e entra gente. O bolo crescendo, o jogo ficando safado. Fica porco, fica sujo como pau de galinheiro. Um homem quebra o outro comendo-o pela perna, correndo por dentro dele.

Um bolo de vida fica grande para só um homem comer. 
Então, o jogo exige porque diferente o jogo fica. Paciência, picardia, malandragem. Quem não tem, tivesse... Uma sujeira do diabo, que costuma enviar o dinheiro do parceiro para a casa onde o diabo mora. Um taco é um taco quando é amarrador, no jogo de vida. Se o parceirinho se encabula, tropica. Perde vida, se perde, vai lá e tropica mais e cai do cavalo. Fica quebrado, quebradinho, igualzinho à coruja — sozinho, feio e no escuro.

Corria no Joana d'Arc o triste jogo de vida. ${ }^{345}$

No salão Joana d'Arc eles encontram o terreno propício para a malandragem. Podem fazer o conluio que armaram. A ambiguidade do jogo de sinuca é de conhecimento de todos, e por isso o jogo permite que a roda comece pequena e "encrencada", para depois o "bolo" crescer e o jogo ficar "safado". O relevo aqui é para a conjunção que se dá entre jogo, dinheiro e caráter demoníaco da ação em cena, que vai ganhando contornos infernais (o jogo é diferente, sujo, safado, e a situação é de perdição, queda e quebra). O jogo, tal como ele é jogado pelos parceiros que apostam dinheiro, exige "picardia", isto é, uma habilidade que é tanto do conhecimento das regras e da competência técnica como de uma capacidade de dissimular o próprio comportamento, a fim de estudar o comportamento alheio e enganar, para não ser enganado.

Sobre o trecho acima, em que o narrador explica o funcionamento do jogo, Clara Ávila Ornellas aponta muito bem para a constituição ambígua do narrador. Aqui, a autora surpreende a presença do narrador como personagem do conto: "Não é um personagemjogador que apresenta essa explicação, mas o próprio narrador, que, por alguns momentos, deixa de lado a narração das aventuras dos personagens para atestar sua imergência no mundo sobre o qual fala. Ao mesmo tempo em que essas explicações reforçam a contextualização do ambiente representado, elas deixam a seguinte impressão: aquele que narra é um jogador também, ou se faz passar por um deles.",346

Narração, sinuca e malandragem, portanto, são atividades que se aparentam: para se jogar sinuca é preciso malandragem, e para um malandro a sinuca é terreno propício, e as histórias e as regras da sinuca precisam ser enunciadas, contadas, narradas.

Essa modalidade jogada no salão da Água Branca, o “jogo de vida” serve à perfeição para o narrador introduzir o leitor na malandragem, pois a regra, também no jogo,

\footnotetext{
${ }^{345} \mathrm{MPB}, \mathrm{pp} .164-165$.

${ }^{346}$ ORnellas, C. O conto na obra de João Antônio: uma poética da exclusão. op.cit., 2008, p. 105.
} 
é a da dissimulação: cada jogador tem a sua bola e precisa defendê-la, procurando encaçapar as demais, que são dos adversários. Pouco importa de quem é determinada bola, basta defender a própria. A sinuca é um jogo em que se joga de acordo com as regras e que premia o mais competente, não necessariamente o mais malandro. Mas é o mais malandro que transformará um simples jogo em rito e depois em mito, em ação e em narrativa.

O subterfúgio malandro, então, é Malagueta defender a própria bola, mas também a de Perus, isto é, sem procurar roubar a "vida" do rapaz. Assim, Malagueta amarra o jogo, permanecendo na mesa e evitando também a saída de Perus. Este, por sua vez, atua como um franco-atirador, justamente "atirando-se às bolas", como diz o narrador.

O jogo só é jogado desta maneira, à malandra, porque nele há também os parceiros "fáceis", aqueles que jogam a sério e jogam pouco, que colocam o seu dinheiro no "bolo" e depois, ao perder a rodada, saem da mesa. Ficam aqueles que sabem jogar o jogo "safado", que vai ficando "sujo" como "pau de galinheiro", pois ao final haverá apenas um vencedor.

Quem visse aquela roda e não soubesse, diria que era aquele o natural do jogo. Para quem está do lado de fora, como para os otários de jogo, as muitas coincidências do joguinho são predestinações. Como se não houvesse tabelas, efeitos, puxadas, trucagens e outros recursos que em sinuca se chamam picardia. Assim falam os trouxas e os coiós e os papagaios enfeitados e os mocorongos e os cavalos-de-teta:

- Joguinho ladrão, ganha aqui quem der mais sorte. ${ }^{347}$

Vê-se, portanto, que malandragem e sinuca foram feitas uma para a outra, pois a dissimulação e embaralhamento das identidades estão pressupostos em ambas, sinuca e malandragem, no jogo e na vida. A frase "Joguinho ladrão, ganha aqui quem der mais sorte" - proferida não se sabe por quê ou por quem, apenas que é uma convicção de um "trouxa" - é mais uma vez uma espécie de "sabedoria de salão" que traduz essa ambiguidade da malandragem: a sinuca é um jogo de azar, pois ganha quem tem mais sorte, mas também é um jogo que exige competência; e, no entanto, é uma atividade que possibilita trapaças, marmelos, malandragem. Picardia é habilidade, mas também "trucagens".

${ }^{347} M P B$, p. 170. 
Na passagem citada do conto, o narrador estende essa ambiguidade à vida, por meio dessa metáfora fácil, o "jogo de vida", mas bastante apropriada no que se refere à verossimilhança da ação narrada, pois trata-se de fato da denominação do jogo, como os sinuqueiros mesmo chamam essa modalidade. O narrador, porém, vai além, ao mostrar que nesse "jogo de vida" é preciso não apenas sorte ou competência, mas também picardia, isto é, capacidade, competência, "efeitos" e "outros recursos".

Tem lugar mais uma vez o jogo de dissimulação. Perus joga como realmente é: um atirador. Malagueta finge jogar a sério, mas está "amarrando" o jogo. O disfarce de Bacanaço, por sua vez, está justamente em se manter fora da roda de sinuca, na assistência, como se fosse um "otário". Mas o narrador está sempre atento aos movimentos internos de Bacanaço. O discurso indireto livre não deixa o leitor esquecer as intenções malandras do protagonista:

Bacanaço sorria. Negócio dos bons era ser patrão dos dois. Aqueles não tropicavam, tinham fome, iam, firmes, e sofredor desempregado dá tudo o que sabe no quente do jogo. Firma a tacada, se mexe como piranha atenta, quer morder. E belisca porque vai com juízo. Talento já traz escondido na massa do sangue e juízo a fome lhe dá. Bacanaço examinava o anelão como se não quisesse nada. Chegava-se à mesa, estendia o maço de cigarros para Malagueta:

— Fuma, meu camarada? ${ }^{348}$

Bacanaço fica de fora, e Malagueta não pode deixar que percebam que ele está "amarrando" o jogo. Apenas Perus pode se manter fiel ao que de fato é: um rapaz imaturo e hesitante, que apenas na sinuca sabe encontrar a linha reta.

No entanto, o disfarce de retos jogadores de sinuca é desmascarado por um novo personagem da trama: Lima, o policial aposentado que frequenta o salão e "é considerado" pelos demais frequentadores da roda, os "homens da curriola", por conta da autoridade de sua palavra. As palavras que ele usa e as histórias que conta fazem dele um "conselheiro dos mais moços, naquelas bocas de inferno".

O personagem de Lima faz par, às avessas, com o personagem de Malagueta. São dois velhos que habitam o mundo da boemia. Mas Lima é um "tira" aposentado "desses tipo encabuladores que ficam entre os malandros e são o quê? Viradores, curiosos?". Ele

${ }^{348}$ MPB, p. 170. 
diz qual é o caminho certo: "gente moça namora, noiva e casa. É o caminho certo. Aqui, não; aqui é o fim". Usa palavras antigas, tem sua fala respeitada e também é bom de contar histórias, como já vimos, ao rememorar a história do sinuqueiro Calói, que terminou os dias no hospício do Juqueri, depois que o cérebro "apodreceu” de tanto ele fumar maconha.

É Lima quem vai, a certa altura do jogo, desconfiar que Malagueta está trapaceando, pois o velho malandro deixou de encaçapar uma bola fácil.

Ali tinha coisa. A bola era fácil, fácil, Malagueta não liquidara. Por que raios o velho Malagueta só amarrava o jogo, defendendo e defendendo aquela bola quatro? Lima não era um velho coió. A quem pertencia a bola? Havia coisa.

Lima balançou o indicador no ar e mudou o tom daquela roda.

Botem fé no que digo, qu'eu não sou trouxa não e nessa canoa não viajo. Tá muito amarrado o seu jogo, seu velho cara-de-pau. Botem fé. Eu pego marmelo neste jogo, arrumo uma cadeia para os dois safados.

Bacanaço se alertou, a mão jogou o cigarro, o rosto se frisou. Diabo. Malagueta facilitara, deixara entrever a proteção. Também não havia outra saída; derrubasse a bola quatro, teria quebrado Perus num só lance, estariam os dois no buraco. Diabo. Aquele jogo poderia render mais. ${ }^{349}$

O narrador aqui aproxima-se de Lima, para surpreender seus pensamentos e o momento em que este descobre o marmelo de Malagueta e Perus. É então que Bacanaço, de fora da mesa, intercede com a imparcialidade de quem supostamente não tem interesse no jogo. O jogo de disfarces e de identidades atinge aqui um ponto crítico. Lima faz valer sua autoridade de policial, ainda que aposentado, ao dizer que arrumaria cadeia para os "safados".

Vê-se que não se trata de crime, é malandragem, e passível de punição pelo mando, pelo poder que o velho tira conserva, com suas ligações com a polícia. Mas o velho Lima, que o narrador volta a dizer "não era um velho coió", também impõe sua identidade, não sou trouxa não, e reafirma seu poder de policial decaído, mas residual, com poderes e influências que podem voltar, se a situação exigir. Não se explicita, mas se trata certamente de sua ligação com colegas policiais ainda na ativa.

Mas a maneira com que o narrador descreve a mudança de comportamento de Lima e a forma com que este expressa sua alteração de humor, de percepção e de atitude têm algo

${ }^{349}$ MPB, 176. 
de mágico: "Lima balançou o indicador no ar e mudou o tom daquela roda". É como se o velho tira, num passe de mágica, pudesse alterar os rumos daquela situação.

Além do poder mágico, Lima também apela aos sentimento religioso: "Botem fé". A conotação religiosa é reafirmada pelo narrador, que ecoa os pensamentos dos malandros, que invocam o "diabo" para maldizer aquele mau passo.

Assim, Lima percebe que algo está fora das regras, que "havia coisa", que pega o "marmelo". Assim, pressentindo o conluio, Lima ameaça os malandros com sua autoridade de policial, renovada, e recua do perigo, da aventura, ao dizer "nessa canoa não viajo". Isto é, o velho policial sabe que naquela aventura malandra é melhor não embarcar. Mas está preso às regras e ao desenvolvimento da partida. Sem saber, embarcou em uma canoa furada.

É curioso que esta é a única passagem do conto em que os malandros são retratados jogando sinuca em ação. Em outras passagens, posteriores, o narrador fará referência a outros jogos naquela noite, mas sem descrever os lances e os oponentes, as circunstâncias e os subterfúgios usados pelos malandros. Assim vai a narrativa até a disputa final, quando os três parceiros são confrontados por Robertinho, o malandro que os deixa mais uma vez quebrados.

Com isso, o leitor acompanha as andanças dos três malandros sem que o jogo de sinuca esteja no centro da ação. A malandragem então evolui e é apresentada pelo narrador de outras maneiras.

Os parceiro continuam a rodar os salões de sinuca, mas nem sempre encontram boas oportunidades. No centro da cidade, passam pelo Americano, um dos pontos mais movimentados da malandragem.

Muita conversa. Sono, fome e vagabundos nos bancos laterais. Muitas falas daquela gente parda e pálida no Americano, famoso ponto de aponto. Um reduto em que batedores de carteira, rufiões e jogadores e o geral da malandragem se promiscuíam com tiras e negociantes de virações graúdas e miúdas. Quando se pretendia um encontro, era o Americano para todas as espécies de múltiplas arrumações. Mil e um conchavos. Ali funcionavam tipos de muitos naipes, desde a malandragem das beiradas das estações até os comerciantes da rua 25 de Março. Tiras decaídos, tiras 
atuantes, gente da Força Pública compareciam contemporizados à malandragem. Engraxate, manicure, barbeiro ao fundo. ${ }^{350}$

Como se nota pelo trecho acima, nem só de sinuca se faz a malandragem e tampouco ela se faz apenas de malandros. O narrador registra que no Americano se misturam os personagens que constituem a boemia, o trabalho e a malandragem. Policiais e agentes da Força Pública "contemporizavam” com a malandragem. São jogadores, mas também são vagabundos, batedores de carteiras, rufiões, que se "promiscuíam" com negociantes e tiras, isto é, comerciantes e policiais, da ativa ou não, que fazem "mil e um conchavos". A inversão é digna de nota, pois, a princípio quem deveria se promiscuir seriam os policiais e negociantes, em tese do lado "correto" da sociedade, mas o narrador enxerga a realidade do ponto de vista dos “errados", e então diz que são os criminosos e vagabundo que são os promíscuos, ao se misturar aos agentes da lei e da ordem.

É uma gente "parda e pálida" 351 que frequenta o salão, na rua Amador Bueno, uma rua "triste", como já era "triste" o jogo da vida dos malandros. Mais uma vez o narrador embaralha as noções entre vida e jogo, malandros e policiais, negociantes e trapaceiros, comerciantes e viradores, vagabundos e trabalhadores como manicure, engraxate e barbeiro. Ali, têm lugar "virações graúdas e miúdas", "múltiplas arrumações".

A malandragem, portanto, é vista pelo narrador como um modo de viver que permeia tudo. O funcionamento social em que vivem os personagens do conto é permissivo, permeável a todo o tipo de conchavo e arrumação, com prejuízo dos mais marginalizados e mais iludidos, aqueles que frequentam os salões de sinuca, tanto malandros quanto otários, sempre à mercê dos que, neste universo de profunda violência, mantém o poder de explorar, extorquir, prender - como diz o tira aposentado Lima, "habitante daqui é futuro residente da Casa de Detenção".

${ }^{350} M P B$, p. 187.

${ }^{351}$ O primeiro título do livro, cogitado por João Antônio, era Aluados e cinzentos. Com outro título ainda, "Cinzentos vagabundo por aí", João Antônio chegou a publicar um trecho do conto, que inclui a passagem aqui citada, quando os protagonistas ainda se chamavam Caculé, Lustroso e Chafrinha. O texto foi editado em adendo, em separata, de Malagueta, Perus e Bacanaço, $4^{\mathrm{a}}$ edição, Cosac e Naify, 2005. Um ano antes da edição de $M P B$, o autor publicou outra parte do conto (aquela da partida no Joana D'Arc), com o título de "Conluio na Água Branca", em O Estado de S. Paulo, 14 jul. 1962. Curiosamente, no mesmo ano, mas depois, em novembro, outro conto do autor traz os mesmos protagonistas com outros nomes: Malagueta se chama Pirolito, Bacanaço é Lascado e Perus se chama Luisinho. "Um velho e um cachorro". In: OESP, 17 nov. 1962. Este último conto corresponde à seção "Barra Funda" de "MPB". As páginas do jornal com os dois textos estão reproduzidas no Apêndice desta tese. 
Outra passagem do conto fornece a imagem rematada da promiscuidade entre policial e malandro. Bacanaço e o tira Silveirinha aparecem confundidos, coincidentes, e fazem um acordo. $\mathrm{O}$ encontro se dá de maneira imprevista. Os três parceiros estão na Cidade, tentando encontrar um salão com jogo bom. Encontraram Carne Frita, o que thes parece indicar que estão no caminho certo (a aura de santidade lendária do sinuqueiro parece ser o sinal da salvação). Chegam ao Paratodos, junto à igreja de Santa Ifigênia. Ali, vão encontrar uma figura que contrasta com a do Santo Carne Frita.

O encontro se dá com a figura demoníaca do policial Silveirinha, que achaca Perus, ameaçando o menino. O policial é direto. Quer dinheiro. O jovem malandro fica sem ação, e os dois parceiros relutam em interceder pelo menino. A cena toda é bastante tensa e arrastada, como se o narrador se demorasse para acentuar o calvário do jovem malandro, que, como de hábito no caso de Perus, não consegue se expressar, argumentar com o policial que o ameaça.

Bacanaço, finalmente, depois da insistência do velho Malagueta, resolve negociar com Silveirinha. O policial imediatamente libera Perus. O policial e o malandro adulto, então, sentam-se lado a lado. Silveirinha é o dono da situação:

Pediu bebida com desplante, indicou o tamborete, sentaram-se como iguais. Como colegas. O malandro e o tira eram bem semelhantes - dois bem ajambrados, ambos os sapatos brilhavam, mesmo rebolado macio na fala e quem visse e não soubesse, saber não saberia quem ali era polícia, quem ali era malandro. Neles tudo sintonizava. ${ }^{352}$

Se o encontro com Silveirinha, depois da aparição de Carne Frita, prometia o inferno da extorsão e da prisão, o procedimento de Bacanaço apela para a semelhança entre ambos. A malandragem, assim, fala a língua da polícia, que por sua vez é também dona de uma fala e de procedimentos típicos da malandragem. Se a malandragem lhes acenava com a estatura de santidade de Carne Frita, a conduta malandra também lhes serve para enfrentar a ameaça demoníaca da polícia. A "charla” entre Bacanaço e Silverinha acomoda as tensões e as diferenças, diluídas pelo dinheiro que o policial extorque do malandro.

Assim, o conto parece indicar que a exploração e a malandragem tomaram conta de tudo. Policiais são malandros, sinuqueiros são malandros, malandros são trouxas, trouxas

\footnotetext{
${ }^{352}$ MPB, p. 196.
} 
são trouxas mas podem vir a ser malandros $o u$ viradores $o u$ pés-de-chinelo, sem eira nem beira. A "ciranda da malandrangem", como bem definiu Jesus Antonio Durigan, tira todos para dançar.

Não há mais distinção clara entre os polos da ordem e da desordem, ${ }^{353}$ ou melhor, estes polos são instáveis, movediços, dissimulados e, inesperadamente, podem revelar ser o avesso do que aparentam. A tipologia do malandro definida por Candido, como se sabe, tem como inspiração as Memórias de um sargento de milícias, de Manuel Antonio de Almeida, e o modo de funcionamento social do Brasil imperial, em meados do século XIX. Um século depois, a sociedade brasileira parece conservar certos aspectos daquela oscilação entre ordem e desordem, mas com aprofundamento da violência e dos mecanismos de marginalização, opressão e dissimulação. Depois de o malandro ter sido cantado pelo samba nos tempos de Getúlio Vargas e ter permanecido forte no imaginário coletivo brasileiro, o retrato que faz dele João Antônio ainda é romântico e conserva certa potência latente de subversão da ordem burguesa estabelecida, mas ganha contorno de marginalidade social mais exasperada.

Ainda é possível oscilar entre o polo da ordem e da desordem (como fazia o personagem do século XIX e o malandro do começo do século XX), e recusar o mundo burguês do trabalho, ainda que dependendo deste. Mas no caso dos malandros de João Antônio, recorrer à malandragem é a única saída que resta depois de que todas as outras possibilidades de subsistência parecem naufragar. Como bem define Vima Lia Martin, há uma diferença decisiva entre Leonardo e os três parceiros de sinuca:

[...] se as personagens malandras de Malagueta, Perus e Bacanaço podem ser inseridas na tradição que se inaugura com Leonardo Filho, a primeira personagem malandra da novelística brasileira, é importante lembrar uma importante diferença que as afastam. Leonardo vive de maneira um tanto gratuita, praticando a astúcia pela astúcia e manifestando um apreço pelo "jogo em si”, enquanto que os malandros presentes na obra de João Antônio estão afastados da dimensão lúdica do jogo, já que sua prática está ligada fundamentalmente à subsistência. ${ }^{354}$

353 CANDIDO, Antonio. "Dialética da malandragem”. In: O discurso e a cidade. 2a edição. São Paulo: Ed. Duas Cidades, 1998.

${ }^{354}$ MARTIN, op. cit., p. 157-158. 
A dimensão lúdica da sinuca não está elidida de todo na história. Lembre-se que os malandros chamam uns aos outros para "brincar". Mas a gratuidade da brincadeira vem acompanhada de insinuações, dissimulações, de um cinismo que de fato corrompe o caráter lúdico do jogo. Note-se que o verbo "brincar", com que Bacanaço convida os parceiros ao final do conto, antes da aparição de Robertinho, retoma o começo do conto, e relembra o forte conteúdo erótico da briga encenada entre os dois malandros. ${ }^{355}$ No conto, como já tivemos oportunidade de verificar, nas palavras do narrador e dos personagens, o universo da sinuca e da boemia é "promíscuo", e o jogo é "sujo" e "ladrão".

A ação do conto se passa, provavelmente, em meados dos anos 50, durante os anos JK, e apesar de não dar indicações explícitas de localização temporal, exprime contradições do desenvolvimentismo brasileiro, da constituição problemática de uma sociedade burguesa que não é capaz de absorver toda a população. Segundo Ricardo Miyake, "num momento histórico preciso, de cruciais transformações no tecido social e econômico brasileiro, as personagens de 'Malagueta, Perus e Bacanaço' efetivamente representam os impasses da política desenvolvimentista que, grosso modo, já se havia iniciado desde os primórdios da década de 1930 ". 356

Malagueta, Perus e Bacanaço vivem, como bem diz Vima Lia Martin, uma espécie de "malandragem de subsistência", mecanismo de defesa em uma sociedade que oferece poucas oportunidades além do trabalho alienado, do crime, da exclusão, da mendicância e das artes da trapaça e dos golpes. São também "pingentes”, prisioneiros de uma lógica que os exclui, ao mesmo tempo que os mantém de certa forma "pendurados" na mesma lógica de exclusão social.

Os contos anteriores de João Antônio, como vimos, mostram como os personagens passam de operários a vagabundos a malandros. Já neste primeiro livro do autor, é possível ver os protagonistas como que transformados de "pingentes" em "merdunchos", como diz Ligia Chiappini, lembrando algumas das metáforas usadas por João Antônio para falar dos excluídos: "Pingente, de enfeite a merduncho, o percurso é o mesmo que vai do menino que

\footnotetext{
${ }^{355} \mathrm{O}$ verbo brincar também ecoa o erotismo malandro de Macunaíma, personagem que, como se sabe, usava o termo como sinônimo de prática sexual.

${ }^{356}$ Miyake, R. Cidade, malandros e Capital: uma leitura dos contos de Malagueta, Perus e Bacanaço. Dissertação de mestrado. São Paulo, Universidade Presbiteriana Mackenzie, 2004, p. 71.
} 
se pendura na porta do ônibus como diversão ao trabalhador que arrisca a vida para não perder a hora". 357

Para Chiappini, a figura do pingente se liga à figura do jogo: "Na brincadeira do menino, há já um rito de iniciação para a inglória trajetória do adulto, um treino para enfrentar a luta cotidiana contra a morte em que precisa se adestrar desde cedo, com muito jogo de corpo e astúcia (...)". A autora vê a sinuca como metonímia do Brasil, os pingentes como os brasileiros marginalizados e o jogo como metáfora da luta:

O jogo foi visto, originalmente, como símbolo de luta contra a morte (jogos funerários), contra os elementos (jogos agrários), contra as forças hostis (jogos guerreiros), contra si mesmo (contra seu medo, sua fragilidade, suas dúvidas). Para usar as categorias de Roger Caillois (Os jogos e os homens), ele permite associar o combate, a sorte, o simulacro e a vertigem. João Antônio, em certos momentos nos fala no jogo da vida, expressão que virou título do filme inspirado no conto "Malagueta, Perus e Bacanaço". Em outros momentos nos mostra que para seus merdunchos a vida é uma batalha cotidiana. Esse jogo é preparação para a luta e luta mesma desde a infância do pingente-menino que pensa que apenas brinca. O jogo é sério, tão sério quanto aquele dos jogadores noturnos que, na mesa de sinuca, disputam o pão nosso de cada dia. O jogo é um mundo de chances e riscos, cujo resultado vai decidir, como para os jogadores de futebol, feito Garrincha, quem vai ser vencedor para fazer parte do Brasil dourado e quem vai cair nos trens da Central do Brasil. Por isso desde cedo carece aprender as regras do jogo para lidar com a sinuca de ter nascido pobre num país que não sabe sair do "atoleiro em que se meteu". 358

Interessante, porém, é tentar compreender por que, dentre as opções que se apresentam - grosso modo, o trabalho, o crime e a malandragem — neste conto os três parceiros ainda optem pela terceira opção, mas sem abrir mão das demais. Vale insistir que Malagueta, Perus e Bacanaço são malandros na situação narrada, mas são também criminosos (batedor de carteira, rufião) e dependem do mundo do trabalho, dos trouxas com dinheiro, para poder operar suas artes da malandragem. Como ressalta Berthold Zilly, em

\footnotetext{
${ }^{357}$ Chiappini toma a metáfora do "pingente" das crônicas do próprio João Antonio. Em Malhação do Judas carioca, livro do autor, há uma reportagem intitulada "Pingentes", sobre os trabalhadores que viajam pendurados nos trens da Central do Brasil. João Antônio, neste texto, refere-se explicitamente a Lima Barreto, ao lembrar a frase de Lima de que o "subúrbio é o refúgio dos infelizes". A precedência da metáfora do pingente, porém, pode ser localizada não em Lima Barreto, mas em Graciliano Ramos. Ver "Os passageiros pingentes". In Linhas tortas. Graciliano Ramos. 21 a edição. Rio de Janeiro: Record, 2005.

358 ChiAprini, L. "O Brasil de João Antônio e a sinuca dos pingentes". In Brasil, país do passado?. Organização de Ligia Chiappini, Antonio Dimas e Berthold Zilly. São Paulo: Edusp/Boitempo, 2000, p. 166.
} 
João Antônio o malandro opera uma volta à criminalidade, sem deixar de ser malandro, o que configura uma postura desmistificadora por parte do escritor:

Ele quis empreender a desmitificação do malandro, opondo-se à sua visão pitoresca e folclorizada que conhecia muito bem, como músico amador. Quis mostrar que a modernização da sociedade brasileira e as reformas urbanísticas de Getúlio Vargas até a ditadura militar obrigaram o malandro, que tinha descido do morro nos anos 20, a voltar para lá, confinado no seu espaço de origem, obrigando-o mais do que nunca à criminalidade ou à miséria. ${ }^{359}$

João Antônio, de fato, escreve num momento em que a malandragem, digamos, se marginalizou (se que é nesse processo cabe acentuação, se o malandro é também lumpem, pingente, otário). Mas o conto em análise mostra que, ao mesmo tempo, malandros e otário, malandros e policiais, malandros e senadores estão "sintonizados", "confundidos", o que aponta para a permanência e a centralidade da malandragem. É verdade que João Antônio desmistifica a malandragem, mas conservando elementos de seu caráter mítico e típico. Em outras palavras, a malandragem se expressa em "MPB" no tipo malandro e no funcionamento amalandrado, em permanência e em ação.

Essa inquietação sobre a escolha da malandragem como tema parece encontrar melhor formulação, para os nossos fins, se colocarmos a questão de outra maneira: por que narrar um conto sobre a malandragem e não sobre o crime ou sobre o trabalho?

A escolha da matéria narrada e da forma narrativa nos parece ser motivada pela permanência, na cultura e na sociedade brasileira, de uma tradição popular de oralidade e de informalidade, favorável à literatura que se ocupa das camadas mais pobres da população. Como tentamos mostrar aqui, a obra de João Antônio, além de refletir a situação social brasileira e paulistana de meados do século passado, também deita raízes em uma linhagem narrativa de origens ancestrais, que se relaciona com o mito e com a arte secular de contar histórias.

A malandragem, assim, é uma prática que combina aventura e sedentarismo, organizadas no relato guardado na memória do Narrador: o narrador do conto e os narradores-personagens. De um lado, o deslocamento, a viagem (a errância, neste caso), a

\footnotetext{
${ }^{359}$ ZILly, B. "João Antônio e a desconstrução da malandragem”. In: Brasil, país do passado?, op. cit., pp.
} $182-183$ 
ilusão de um golpe de sorte e as ocasiões da "fortuna", entendida como as marés de sorte e azar, mas também como a possibilidade de angariar um dinheiro fácil, tomado como um "tufo", tomado a um otário, colhido na selva da grande cidade; de outro, os momentos de calmaria, pasmaceira e sedentarismo (uma "aposentadoria” que é retirar-se da febre do jogo e não regenerar-se), em que os malandros se põem a contar "façanhas", "fantasiando grandezas", aconselhando os demais, especialmente os mais jovens, que no entanto são também malandros e aspiram, da mesma forma às façanhas (a gesta, os milagres) e às fantasias de grandeza (a ascensão social), compondo a roda-viva da malandragem, que é também a roda da fortuna, a ciranda da qual todos são reféns.

Nesse quadro, o escritor soube tirar proveito do universo da boemia de São Paulo nos anos 1950-60, para mostrar como, em tempos de desenvolvimento, a sociedade brasileira que se moderniza, urbanizando-se e se industrializando, mantém características antigas, que também se "modernizam" e permanecem atuando e dificultando a emancipação dos sujeitos, especialmente os mais pobres, sempre presos a ocupações massacrantes (a condição de trouxas, o trabalho alienado e espoliador) ou ao mundo da transgressão, em diferentes graus (golpe, trapaça, marmelo, malandragem, crime). Mais que isso, que boa parte da sociedade brasileira nos anos 1950 e 60 permanece sem opção: escolha o trabalho ou a transgressão, o indivíduo corre o risco de ser espoliado, massacrado, achacado, violentado. Desde os "Contos Gerais", os protagonistas parecem desconfiar, hesitantes, das promessas do polo social "positivo". Em "MPB", vemos que os personagens já não veem o trabalho e a norma social como opção, senão como avesso de uma conduta que eles adotam, explorando e sendo explorados pelo lado "direito".

Do ponto de vista da narrativa, a malandragem permite, sobretudo, delinear personagens que são tipos, mas também são complexos: tendo como modelo as figuras lendárias da sinuca, eles se lançam à aventura da própria malandragem, sonhando façanhas, mas se mantêm ocupados com outras histórias, com os conselhos ouvidos de outros malandros ou proferidos por eles próprios, sempre a partir de uma coleção de ditos e sentenças populares tomadas da tradição brasileira, sedimentadas num saber compartilhado que é também estratégia de sobrevivência em uma sociedade permeada da oralidade, em que a Lei e a palavra escrita conservam seu poder e sua superioridade, mas não estão 
acessíveis aos pingentes, excluídos, sem eira nem beira. A desconfiança da norma é também desconfiança da palavra escrita, do aprendizado formal e da lei. ${ }^{360}$

O narrador do conto, como vimos, é o elemento literário que é o veículo e a ligação desses mundos que se encontram: a oralidade (as narrativas da malandragem, contadas pelos próprios malandros) e a escrita (a norma e a literatura, o conto contado pelo narrador), a malandragem e a ordem, a simpatia aos malandros, vistos com proximidade, de dentro do universo narrado, mas também de fora e à distância, para lhes desenhar como cruéis, patéticos, imaturos. Neste conto, que se tornou o mais conhecido do autor, e apresenta seus personagens mais conhecidos, sobressai assim a complexidade desse “mundo misturado", como em Guimarães Rosa. ${ }^{361}$

João Antônio, neste texto e em contos posteriores, como veremos, desenvolveu uma escrita que é realista e crítica, mas também é devedora de elementos antigos, próprios da cultura oral e da tradição popular. Sua visão desse universo, da malandragem, é a um só tempo romântica e ácida, desencantada e encantada, oscilando, pois, entre os polos da fascinação e do desalento, da euforia e da melancolia, acompanhando as marés de sorte e azar, de fantasia e ressaca de seus personagens.

Na situação narrada, portanto, Malagueta, Perus e Bacanaço são personagens que permanecem, até o final, em conluio, ao mesmo tempo "funcionando" como malandros, como parceiros, e impedidos de romper com a ordem da malandragem, que os torna prisioneiros dessa ciranda de exploração, espoliação e, a seu modo, também alienação, assim como no mundo do trabalho, pois que a ação e a reflexão também são prisioneiras dessa mesma lógica: é a aventura do golpe, que pode voltar contra eles próprios, e é reflexão baseada nas lendas de outros malandros, nos ditos populares, em uma sabedoria de experiência malandra (picardia) e de frases feitas que está a serviço do disfarce, da proteção de suas próprias existências (restritas material e intelectualmente ao mundo em que vivem) e também do golpe, fechando o circuito da ciranda.

\footnotetext{
${ }^{360}$ Como vimos no capítulo anterior, a desconfiança com relação ao ensino formal, liga-se à violência do processo de aprendizado, como ocorre também em Infância, de Graciliano Ramos. Sobre isso ver LAFETÁ, J. "Três teorias do romance: alcances, limitações, complementaridade". In: A dimensão da noite. Organização de Antonio Arnoni Prado. Duas Cidades/Editora 34. São Paulo: 2004.

${ }^{361}$ Para uma análise da combinação entre narrativa, mito, oralidade e romance de formação no Grande sertão: veredas, ver o ensaio de Davi Arrigucci Jr., "O mundo misturado. Romance e experiência em Guimarães Rosa", Novos Estudos Cebrap, n. 40, nov. 1994, pp. 7-29.
} 


\section{Ponto de fuga: Perus, um infante entre velhos malandros}

Haveria assim possibilidade de emancipação desse universo em que a malandragem permeia tudo, isto é, deste mundo em que ser malandro é não apenas necessário como inescapável? Qual a possível saída daquele mundo corrompido? Uma saída aventada pelos malandros é a vingança, a rixa. Diante de um desaforo ouvido contra um outro malandro, em um dos salões por que passam, o proverbial Malagueta se exaspera: “- A gente fica até coisa, meus. Aquilo nem é cinismo, é cinidez". ${ }^{362}$ À possibilidade de intervir naquele evento específico, o malandro adulto generaliza a vontade de vingança:

— A gente ainda vai à forra, velhão. Bacanaço deu um tapa no paletó imundo de Malagueta.

— Deix'estar. Tenteia, velho.

Só Perus não falou, inteiro no seu quieto. ${ }^{363}$

A vingança, porém, está na lógica da malandragem, que abarca também o crime e a rede de corrupção, achincalhe, acertos de contas - "mil arrumações", como diz o narrador, apresentando o mundo corrompido da malandragem e da sociedade de modo geral com tintas nuançadas, pois o faz de dentro, já que também ele se sente parte do mundo narrado. $^{364}$

Apesar, portanto, de serem malandros conluiados — três personagens vistos como apenas um —, a situação narrada caminha para o desmembramento do enlace e mais que isso para detonar o arranjo que mantém os três unidos. A tensão entre os três protagonistas vai apartá-los, ainda que isso, mais uma vez, não redunde em individuação com sentido emancipatório.

Ao final, o conto evolui para um desenlace que desestabiliza essa igualdade selvagem que se estabelece entre os malandros, para sugerir uma disputa de todos contra todos, que está latente nesse mundo selvagem da malandragem, mas que não se afirma, pois do ponto de vista narrativo seria como que passar da malandragem para a criminalidade. $\mathrm{O}$

\footnotetext{
${ }^{362}$ MPB, p. 198.

${ }^{363}$ Idem, ibidem.

${ }^{364}$ Para uma visão das relações entre vingança e malandragem, ver o ensaio de Edu Teruki Otsuka, "Espírito rixoso: para uma reinterpretação das Memórias de um sargento de milícias", Revista do IEB, n. 44, fev. 2007, pp. 105-124.
} 
conto insinua essa passagem, e não a cumpre: pouco antes de serem desafiados pelo oponente final, Robertinho, os três protagonistas pensam em partir para cima uns dos outros: "Malagueta, Perus e Bacanaço preparavam-se para se devorar", diz o narrador, como já vimos.

Neste momento crítico, em que os três parecem abandonar definitivamente o conluio, a união de três em um, para voltarem a ser um contra os demais, a narrativa vê surgir outro personagem em cena, Robertinho, que os malandros pensam ser um trouxa, mas na verdade é um dos maiores tacos da cidade. Mantém-se, assim, o quadro da malandragem. Surge uma oportunidade de os "cobras" tentarem um último bote, tomar um "tufo" de dinheiro do "cavalo-de-teta" que se oferece, indefeso. A estratégia do disfarce e da dissimulação se repõe. E os "malandros" Malagueta, Perus e Bacanaço decidem enfrentar o "trouxa” Robertinho. Ao final, invertem-se os papéis: malandros são trouxas, o trouxa revela-se um malandro.

O conto, então, afirma a manutenção dos personagens na ciranda da malandragem. Mais que isso, o conto figura a permanência da malandragem e sua engrenagem de produzir malandros e trouxas, alternando esses papéis de acordo com a situação.

Além da possibilidade da rixa, que apesar de se manter dentro da lógica da malandragem poderia elevar a condição dos personagens de malandros para criminosos, o conto apresenta outro ponto de fuga menos evidente, ainda que mais frágil: Perus.

Este personagem parece estar ainda mais deslocado que todos os demais na pele de malandro. Perus é o único dos três protagonistas que não adquiriu a capacidade de contar, não tem a "charla", não é narrador como os demais. O personagem é construído em torno dessa constante (a lógica do personagem): a dificuldade de falar.

A condição de infante, o que não fala, se relaciona certamente com sua juventude. Mas a posição de Perus na hierarquia do conluio também revela algo interessante a respeito da malandragem. A relação do jovem malandro com Bacanaço é, como vimos no início, de admiração e de inferioridade. Na primeira parte do texto, o narrador chega a dizer que Bacanaço, em tom de brincadeira, pensa em "podar” o menino. Além disso, Perus sofreu na própria pele a violência com que o malandro maduro costuma tratar aqueles que estão a seu serviço. Lembre-se a passagem em que Perus relembra o esculacho que levou, certa feita, 
de Bacanaço: “- Vai levar muita porrada se quiser ser um virador, seu coió de mola!”. 365 O narrador, ecoando pensamentos do jovem malandro, registra que Perus não gostou do tratamento, mas não reagiu.

Perus mantém uma relação de inferioridade em relação a Bacanaço. Diz o narrador que o menino admirava Bacanaço, estabelecendo assim uma relação filial, que o mantém entre esse sentimento positivo e a ameaça constante da violência e da castração. A grande contradição da malandragem está aí: parceria horizontal, "fraternidade” e respeito, mas também hierarquia vertical, de autoridade e dominação. Por que Perus não consegue se livrar dessa condição, apesar de dar sinais de que não quer seguir na malandragem e a certa altura aventar a possibilidade de suicídio?

Um motivo prosaico é justamente aquele do qual viemos nos ocupando até aqui. A malandragem proporciona a aventura e as promessas de liberdade, a errância e a distância da família, uma "vida errada" que a sociedade burguesa e a moral familiar não aceitam como caminho reto. Assim como os demais malandros, portanto, Perus vê na sinuca a possibilidade de persistir na boemia, sonhar com os jogos caros e talvez assim não ter de continuar fugindo da polícia.

Mas é possível que haja ainda uma razão mais profunda para a impossibilidade de Perus romper com essa configuração circular e demoníaca da malandragem: a configuração psíquica do jovem malandro contribui para o seu mutismo e a sua inação; e além de estar abaixo de Bacanaço na hierarquia da malandragem, e portanto manter uma relação "filial”" com o malandro mais velho, Perus é também um "igual", um parceiro do malandro adulto, um "irmão" de malandragem.

A "igualdade" entre os parceiros é um dos valores mais arraigados na ética da malandragem. Como dizem os próprios malandros, no conto, "Bacalau quis ser mais malandro que a malandragem" e "isso o perdeu". Essa igualdade, portanto, não é de fundo fraterno ou solidário, mas de fundo opressivo, pois ela não é fruto de afeto, mérito, sentimento religioso ou da ordem dos direitos perante a lei. Trata-se de uma igualdade “selvagem", que pune aqueles que ousam se destacar ou se desgarrar da horda.

Essa condição de selvageria não é exclusiva de Perus; ao contrário, é comum a todos os malandros. Os malandros permanecem em um estado intermediário entre a

\footnotetext{
${ }^{365}$ MPB, p. 183.
} 
passagem da "selvageria" à "civilização". São na definição do narrador "bárbaros, piranhas" que atuam como "relógios" e se lançam à aventura da malandragem sem saber se estão "certos ou errados". As aspas, aqui, marcam a relatividade de conceitos que como vimos João Antônio trata de questionar e mostrar como são instáveis e permutáveis, ao encená-los em ação.

Perus, entretanto, é o único dos três que ostenta um sofrimento psíquico e uma subjetividade diferenciada em relação aos demais malandros todos — como vimos, Perus diz já ter pensado em se matar.

A metáfora usada por Perus para formular seu impulso de se suicidar é "se apagar", o que indica que guarda relação estreita e antitética com o "fogo" do jogo. A metáfora do fogo, ressalte-se, espalha-se pela narrativa. Os malandros sentem a "febre" da ganância, vão ao "fogo" do jogo, enfrentam outros sinuqueiros no Joana D’Arc, onde o jogo "fervia", como que justificando o nome do salão, batizado com o nome da heroína queimada na fogueira da inquisição.

O fogo e o calor também remetem à dimensão demoníaca do jogo, que em certos momentos é personificada na menção ao Diabo, ainda que este não seja personagem e não tenha a ubiquidade de que desfruta, por exemplo, no sertão de Guimarães Rosa. No universo da malandragem e na obra de João Antônio, o diabo e as metáforas demoníacas do fogo vêm associadas não a um mistério transcendente, mas a questões materiais bem claras: a ganância, o jogo e, em suma, o dinheiro. Lembre-se aqui a passagem de "Paulinho Perna Torta” em que o protagonista elenca uma série de designações para o dinheiro, mesmo procedimento que se encontra em Grande sertão: veredas no que se refere aos nomes do demônio. ${ }^{366}$ Retomaremos essa questão no próximo capítulo.

O mistério sobre a existência ou não do diabo, que perpassa o relato de Riobaldo, não ocupa os personagens de "Malagueta, Perus e Bacanaço". Não há referências expressas ao diabo enquanto entidade ou personagem, como se disse. Não há pacto com o diabo. O pacto do conto aqui em análise, tácito, é o pacto da malandragem, que envolve a todos e

\footnotetext{
${ }^{366}$ Em João Antônio, a associação entre o demônio e o dinheiro aponta para uma mudança significativa com relação às obras de Rosa e Graciliano. A ascensão social, cujo momento do sedentarismo permite aos personagens tornarem-se narradores, deixou de manter relação direta com a propriedade da terra e passou a se relacionar à posse do dinheiro, o que aponta para o momento social posterior, de financeirização da propriedade e das relações socioeconômicas, de onde nascem as histórias do escritor.
} 
"contemporiza" malandros e trouxas, policiais e criminosos, num mundo misturado e sem transcendência.

O mistério da existência ou não do diabo, o mistério do Mal, no conto aqui em análise, porém, subsiste. Mas está introjetado. Saiu do mundo e migrou para dentro dos personagens, e especialmente para um dos personagens, Perus, aquele que tem a psicologia mais frágil e mais complexa entre os três protagonistas.

Ao final do conto, o menino expressa um sentimento de grande desamparo, ecoando suas impressões e sensações na visão que ele tem do nascer do sol, que "feriu, nascendo". Ele não tem coragem de contar esse sentimento: "Não podia explicar aquele sentir aos companheiros. Seria zombado, Malagueta faria caretas, Bacanaço talvez lacrasse: - Mas deixe de frescura, rapaz!". Perus, dirá o narrador, achava "que aquele sentimento não era coisa máscula, de homem". A emoção arrebatadora que sente, o menino não consegue formular verbalmente. Ele sabe que o nascimento do dia tem outros nomes, e gosta de "aurora". O nome, feminino e mítico - Aurora, deusa da manhã —, para o nascer do sol resume a condição combinada da fragilidade do menino: Perus é um malandro infante, enlevado pela aurora, por um nascimento que é ao mesmo tempo promessa de um novo dia e desejo angustiado, impulso não verbal, pictórico.

O tom do céu, ao nascer do sol, concomitante ao cair da lua

era de um rosado impreciso, embaçado, inquieto, que entre duas cores se enlaçava e dolorosamente se mexia, se misturava entre o cinza e o branco do céu, buscava um tom definido, revolvia aqueles lados, pesadamente. Parecia um movimento doloroso, coisa querendo rebentar, livre, forte, gritando de cor naquele céu. ${ }^{367}$

O temperamento contemplativo do jovem malandro traduz, no âmbito da ação narrada, um anseio e uma incapacidade. Perus é o único dos três malandros que não tem capacidade de narrar ou desenvoltura com a charla ou com a sabedoria popular. Mais que isso, o personagem de Perus é todo ele construído em função de sua incapacidade verbal e, ao final - depois desse momento contemplativo, plástico, artístico em sua descrição pictórica — de sua impossibilidade de falar.

\footnotetext{
${ }^{367} M P B$, p. 210 .
} 
Em Perus, assim, preserva-se um manancial de desejo e de angústia, difusos, em estado latente, de sentimentos não resolvidos, que se relacionam às noções vagas de nascimento, feminilidade e arte (não verbal), características que ele vive com um pathos singular, um sentimento que precede o cinismo de Bacanaço e de Malagueta, fazendo dele um malandro imaturo e inquieto, angustiado, como os protagonistas dos "Contos Gerais". A emoção com que ele contempla a aurora indica que o espírito de Perus está em desacordo com o mundo da malandragem e com a própria existência.

Perus poderia ainda, em seu estado latente de infante, desafiar as regras da malandragem. Ainda que esteja o tempo todo sonhando com os joguinhos de Vila Alpina, ele parece, em muitos momentos, inadaptado a esse mundo, e cogita, até mesmo, voltar a morar em Perus e se tornar de novo um trouxa.

Além do caminho do trabalho "honesto", alienado, porém, Perus também pensa em "se apagar". Ele é o ponto de fuga que a narrativa rascunha, mas não chega a delinear, a saída da ciranda, o desafio ao "mundo fechado" de que fala Antonio Candido, constituído da boemia, da sinuca, da malandragem, o avesso patético da ordem burguesa à brasileira, em que se combinam trabalho alienado e moral familiar restritiva e conservadora.

Perus poderia ter evitado a disputa final, em que os parceiros são derrotados por Robertinho e ficam, mais uma vez, completamente sem dinheiro. Mas está impedido, pelas regras tácitas da malandragem, de "denunciar" Robertinho, revelar que ele é um cobra, um malandro, e não um trouxa, coió sem sorte, como pensam os "malandros" Malagueta e Bacanaço.

É uma última individuação que a ação narrada promove, a de Perus, contraposto a Bacanaço e Malagueta. Mas o menino aceita sua inserção no universo da malandragem, segue as regras, e evita falar - o que também está em consonância como sua caracterização como personagem. Assim, o menino permanece em sua condição de infante, de jovem imaturo, de parceiro menor, de malandro e, finalmente, de trouxa que vai terminar a noite sem dinheiro, pedindo café fiado.

Ao contrário de Paulinho Perna Torta, o personagem do conto de mesmo nome, Perus permanece na condição imatura de malandreco, incapaz de desafiar as autoridades que lhe surgem pelo caminho: o amásio da tia, com quem ele se atraca, mas com quem não rompe; Bacanaço, parceiro mais velho, espécie de pai substituto e irmão de malandragem, 
já que parceiro de sinuca e conluio; o policial Silveirinha; o malandro Robertinho. Perus não é, como Perna Torta, um parricida. Com isso, está preso à condição infantil e sofrida de malandro imaturo.

Perus é aquele que poderia romper com a ordem da malandragem. Mas ele está impedido de fazê-lo. Poderia enfrentar o amásio da tia, mas este é um "tio", do qual ele prefere fugir (ao aderir à malandragem) ou aceitar (quando pensa em virar trabalhador, trouxa). Poderia enfrentar Bacanaço, mas este é, além de chefe (um pai substituto), também um parceiro, um irmão de malandragem, em quem o menino deposita suas esperanças, nunca realmente apagadas, de se tornar um grande malandro e de dar um golpe, arrumar um parceirinho fácil:

Mas o joguinho virava, sorria, chamava, dava-lhe um parceirinho fácil em duas partidas de duzentos e cinquenta cruzeiros. Os pensamentos bons iam embora, arranjava um patrão, caía na sinuca. Ganhava um tanto, se arrumava por uns dias. Na continuação, de novo se estrepava, o joguinho castigava. Perus combatia, entretanto. Doía-lhe na pele ver o capitalzinho juntado irse minguando, pingado fora de seu bolso, feito coisa do alheio. Desnorteava-se nas tacadas, com pouco estava sem nenhum, arruinado, sem dinheiro e sem patrão. Dias depois, se mortificava com lamentações novas. ${ }^{368}$

Ao não cometer o parricídio necessário à sua emancipação, Perus reafirma sua inserção na ciranda, incapaz de romper com o conluio, ao menos no espaço da ação narrada. Ele também é refém do caráter demoníaco da malandragem, sempre em círculos, sempre na roda da fortuna, indeciso entre a vida reta de trouxa e a vida atirada de cobra da sinuca, mas permanentemente seduzido pela malandragem, pela lógica das marés de sorte e azar, que faz o dinheiro vir e ir, "feito coisa do alheio", coisa feita, feito coisa do demo.

Além do suicídio, Perus cogita outra saída: abandonar a malandragem e voltar a ser trabalhador, sem se decidir por uma ou por outra decisão, indicando que o demônio não é a malandragem nem o dinheiro, nem está na boemia, tampouco no crime, mas na indecisão. Como diz Davi Arrigucci a respeito do Mal no Grande sertão, Riobaldo ostenta um "demonismo íntimo", "uma interioridade partida entre as contradições fundas da existência". ${ }^{369}$ Perus, da mesma forma, tem um demônio dentro de si — a angústia e o

\footnotetext{
${ }^{368}$ MPB, p. 204.

369 ARRIGUCCI JR., D. “O mundo misturado”, op. cit., p. 9.
} 
desejo - que o faz perseguir o demônio exterior, o dinheiro, sem que sua fome, de existir e de ganhar, seja saciada, ainda que ele cogite, há muito tempo, apagar o fogo da própria vida.

A contradição que permanece é a da constituição dos personagens malandros, que são um, mas precisam ser três. Sozinhos e sem dinheiro, eles estão impedidos de ascender à condição de malandro e, portanto, lhes restam estratégias, digamos, menos dignas, ao menos para a concepção de mundo malandra e para a estratégia narrativa do narrador do conto, quais sejam: o trabalho, a família, a moral, o mundo burguês tal como ele se afigurava na São Paulo dos anos 1950 ou o crime.

A malandragem pressupõe uma estratégia de conluio, a relação entre um e outro malandro, um mais malandro que os demais, a oposição entre um "chefe" e um “subalterno", uma relação de hierarquia que é ao mesmo tempo vertical e horizontal, já que os malandros são parceiros, isto é iguais, que conservam a ideia de que há malandros mais malandros que eles e que há sempre alguém no comando, um líder, um chefe que se destaca. Essa relação ao mesmo tempo vertical e horizontal, paterna e fraterna a um só tempo, os prende na lógica da dissimulação, que exige ser e não ser ao mesmo tempo.

Destino de malandro é virar lenda; é viver como um indivíduo excluído, um pingente, que entretanto é parte da mesma conformação social que inclui aqueles que eles desprezam, os trouxas; é ser $e$ não ser. ${ }^{370}$

Esse destino contraditório e ambíguo da malandragem ganha neste conto de João Antônio um retrato complexo, "misturado", que combina elementos da literatura oral, das formas simples, ao mesmo tempo que uma formalização contemporânea e realista, que explora os aspectos antigos e modernos do gênero conto e da própria arte de narrar.

Talvez a constituição singular deste narrador de João Antônio seja uma resposta ao impasse formulado por Adorno, de que "não se pode mais narrar". ${ }^{371} \mathrm{E}$, no entanto, o conto, assim como o romance, exige a forma narrativa, a ação que se desenrola no tempo. A questão para Adorno é que o realismo da forma romance e sua objetividade épica não tem

\footnotetext{
${ }^{370}$ Nesse sentido, os personagens se aproximam também da "formação supressiva" de que fala José Antônio Pasta Jr., e a autofagia dos personagens se liga ao que o crítico chama de "luta de morte". PASTA JR., J. "O romance de Rosa. Temas do Grande sertão e do Brasil". op.cit.

${ }^{371}$ ADORNO, T. "Posição do narrador no romance contemporâneo". In Notas de literatura I. op.cit., p. 55.
} 
mais lugar num mundo em que "se desintegrou a identidade da experiência, a vida articulada e em si mesma contínua, que só a postura do narrador permite". ${ }^{372}$

João Antônio parece ter em mente essa questão - a experiência como fonte da narração - ao criar um narrador ao mesmo tempo fascinado pela matéria narrada, cujo ponto de vista se insinua entre os malandros, e apartado desse mesmo universo. $\mathrm{O}$ narrador registra a fala e os pensamentos dos personagens, colado a eles, e narra, avança e recua, distanciado, sugerindo a um só tempo a necessidade e a dificuldade da aventura e da elaboração da experiência sobre ela - a narrativa.

A elaboração da experiência passa pela narração, pela capacidade de contar histórias e pela constituição dos personagens. A façanha e a narração, no entanto, são ambíguas, pois elas acarretam fama: fazem o nome do malandro e redundam em ameaça ao personagem.

A constituição dos personagens é central para sua sobrevivência e para a sua atuação. A fama faz o malandro ganhar nome e muitas vezes ganhar nome de guerra, tornando-o famoso. Já vimos como isso aconteceu com Meninão do Caixote. Aqui, ocorre o inverso com Perus: ele precisa buscar jogo em bairros distantes, onde não é conhecido por outros malandros e pela polícia. No universo da "desordem", no polo "negativo" da sociedade, ter nome resulta, de novo, em sinuca: ganha-se fama e com isso passa-se a ser respeitado, mas também temido e sobretudo visado (pela polícia e por outros malandros). Veremos como essas contradições ganham representação mais elaborada em "Paulinho Perna Torta", no próximo capítulo.

Assim como se aproxima dos personagens, a ponto de se confundir e se misturar a eles, o narrador também se mantém à parte e, algumas vezes, acima de seus personagens. A posição de superioridade do narrador com relação aos personagens se evidencia em alguns momentos do conto em que aquele se refere a estes de maneira ambígua. Os malandros, para o narrador, são vagabundos, sofredores: "Eram três vagabundos, sofredores, sem eira nem beira", como registra o conto quando os malandros passam pelo bairro das Perdizes.

O narrador não usa a expressão pobres-diabos, mas os descreve como se fossem.

José Paulo Paes tem uma interessante distinção acerca dos personagens populares na ficção brasileira. Para o autor, os personagens pobres são representados ora como proletários, ora como lumpem. Mas o pobre-diabo é o ator literário mais interessante:

\footnotetext{
${ }^{372}$ Idem, ibidem, p. 56.
} 
Como acontece com alguma frequência nas frases feitas, o sal da expressão "pobre-diabo" está em seu caráter paradoxal. Nessa expressão, um núcleo de negatividade se abranda numa aura de positividade. O foco da negatividade é evidentemente a palavra "diabo", que nomeia o espírito do mal, o decaído de Deus exilado para sempre no mundo inferior das trevas, de onde costuma se escapulir para vir praticar maldades em nosso mundo terrestre e desviar-nos do caminho da salvação, que é o do mundo celeste. E como a perdição constitui o máximo de feiúra moral, "diabo" designa também fígurativamente o "homem de mau gênio" o "indivíduo feio". Todo esse feixe de acepções negativas de que o nosso espírito virtuosamente se retrai é abrandado, porém, por um adjetivo que não só as neutraliza como chega até a lhes inverter o sinal. "Pobre" se diz de quem se acha falto ou privado do necessário; de quem foi mal dotado ou pouco favorecido; por extensão, de quem seja infeliz, desprotegido, digno por isso de lástima e compaixão. Compadecer-se é, etimologicamente, padecer junto, mas — atenção - em posição de superioridade. Magnanimamente abdicamos, por um momento, do nosso conforto de não sofredores para, sem risco pessoal, partilhar o sofrimento de alguém menos afortunado e por conseguinte inferior a nós. De alguém a quem possamos entre depreciativa e compassivamente chamar de "pobre-diabo". 373

No caso da tipologia de José Paulo Paes, a figura por excelência do pobre-diabo na literatura brasileira é o pequeno funcionário público, de boa proveniência, cuja família já teve dias melhores, mas que decaiu para uma condição de classe rebaixada e vulnerável ou que conseguiu ascender ao funcionalismo ou a outra profissão liberal, como o jornalismo. Os exemplos mais eloquentes do ensaio de Paes são o Luís da Silva, de Graciliano Ramos, em Angústia, e o Isaías Caminha de Lima Barreto. ${ }^{374}$

Em João Antônio, os merdunchos, pingentes, sem-eira-nem-beira são pobres-diabos ainda mais pobres, personagens de um lumpesinato que, por meio da malandragem, aspira a melhorar de condição, mas que sabe que a ascensão social e a inserção no polo social positivo são improváveis. Os merdunchos são excluídos e, no entanto, são parte dessa mesma sociedade de bem que os exclui, isto é, são marginais, ligados à "ordem" pela condição de "desordem" que lhes é destinada... pela "ordem". A imagem do pingente, consagrada pelo autor, traduz bem essa condição simultânea de exclusão e dependência do polo social "positivo", ordem da qual os personagens sabem que são reféns, pois não pertencem a ela, mas da qual, como estão estão inseridos-excluídos, eles intuem que a

\footnotetext{
${ }^{373}$ PAES, José Paulo. “O pobre-diabo no romance brasileiro". In: Armazém literário. São Paulo: Companhia das Letras, 2008.

${ }^{374}$ Além de Angústia, de Graciliano, e Recordações do escrivão Isaías Caminha, de Lima Barreto, José Paulo Paes analisa em seu ensaio O Coruja, de Aluízio Azevedo, e Os ratos, de Dyonélio Machado.
} 
malandragem pode oferecer alguma saída — um golpe, provisório e improvável, mas ainda assim, sedutor, pois promete aventura, façanha, história, fama, narração.

O narrador do conto não é um pobre-diabo. Ele trata os personagens ao mesmo tempo de maneira igual e superior, como se eles fossem pobre-diabos com quem ele se identifica, mas de quem está à distância e acima. Mas apesar de, como vimos, o narrador se colocar ao lado de seus personagens e à parte deles, seu ponto de vista distanciado não se constitui, salvo engano, de maneira soberba ou moralmente superior, apelando ao pitoresco.

A narração tem capacidade de torná-los figuras dignas de serem cantadas e relembradas. Assim, vagabundos se tornam malandros e viradores viram heróis. No mundo desencantado e sem perspectivas da cidade grande brasileira nos anos 1950, a sinuca, o jogo, o crime e os pequenos golpes a que se dedicam os personagens são ocasião para não apenas proporcionar sobrevivência, permitir certa sobrevida, mas também galgá-los a um status simbólico mais elevado de existência. É o jogo que confere sentido às existências e permite que suas vidas ganhem relevo e estatuto literário. Como o mundo da pobreza, da marginalidade e da sinuca é, digamos, desprovido de história oficial e cultura letrada, é na oralidade das conversas, dos causos e das narrativas sobre malandros lendários que se constrói a vida e a representação da malandragem.

Como já ocorrera em "Busca", temos novamente um conto de estrutura circular, em que a ação, do ponto de vista espacial, retorna ao ponto inicial. E o tempo do conto é regido pela contradição entre a atemporalidade da noite e a cronologia do tempo do relógio, que corre contra eles, mas que eles tentam ignorar, ou melhor, lograr, empenhar em troca de dinheiro, como o gesto de Bacanaço indica.

Não é apenas o trajeto circular dos personagens que confere teor de mito e lenda ao universo narrado. Além do desenho da ação, que começa, desenvolve-se e retorna ao mesmo lugar, também o elenco e as falas (proverbiais e narrativas) dos personagens corroboram a inscrição da boemia e da malandragem no universo do mito e da lenda. Além da ação narrada - a história que descreve as andanças e golpes de Malagueta, Perus e Bacanaço -, o conto apresenta outras histórias de malandros e otários, narradas por personagens que, na situação narrada, são... narradores.

Talvez possamos, recorrendo à distinção de Octavio Paz dizer que o conto de João Antônio, acompanhando a oscilação das marés de sorte e azar dos protagonistas, também 
oscila entre a prosa e a poesia, o conto moderno e a narrativa antiga, entre o realismo da literatura contemporânea e as histórias fabulares características da lenda e do mito:

Enquanto o poema se apresenta como uma ordem fechada, a prosa tende a manifestar-se como uma construção aberta e linear. Valéry comparou a prosa com a marcha e a poesia com a dança. Relato ou discurso, história ou demonstração, a prosa é um desfile, uma verdadeira teoria de ideias ou fatos. A figura geométrica que simboliza a prosa é a linha: reta, sinuosa, espiralada, ziguezagueante, mas sempre para diante e com uma meta precisa. Daí que os arquétipos da prosa sejam o discurso e o relato, a especulação e a história. O poema, pelo contrário, apresenta-se como um círculo ou uma esfera: algo que se fecha sobre si mesmo, universo autossuficiente e no qual o fim é também um princípio que volta, se repete e se recria. E esta constante repetição e recriação não é senão o ritmo, maré que vai e que vem, que cai e se levanta. 375

Destino de malandro é virar lenda. E este destino, como todo destino, precisa ser cumprido. A história dos personagens mais conhecidos de João Antônio é uma narrativa sobre narrativas da malandragem, sobre a própria arte de contar e suas limitações. Malandros viram lenda por seus feitos, mas também por suas malfeitorias, e o momento da constituição da lenda é o da glória, o reconhecimento do milagre, ou da danação, da queda, da cadeia ou do hospício.

Por fim, o conto é também um conto sobre a investigação das três idades do homem, a resposta ao enigma da esfinge, tal como formulada pela malandragem paulistana de meados do século xx. O velho Malagueta, conselheiro e capiongo, é o retrato do malandro sábio, mas estropiado, espoliado pela vida malandra. Bacanaço é o chefe dos malandros, que é admirado, fino, mas também cruel e pouco reflexivo. Perus, como dissemos, é um ponto de fuga que não se delineia com clareza, mantendo o desenho mítico dessa narrativa que também é um crônica realista da malandragem. Sua juventude e sua inquietação mostram que, nele, se esboça uma tangente da roda da fortuna, um ponto de saída da ciranda, mas que a narrativa, fiel à sua mistura de mito e realismo, não formula na ação narrada. O ponto de fuga está lá, justamente, em estado latente.

Apesar da ideia de que a narração não é mais possível, expressa por Adorno a respeito do romance contemporâneo, a oralidade profunda que se apresenta no texto aqui

\footnotetext{
375 PAZ, Octavio. "Verso e prosa". In: Signos em rotação. $3^{\text {a }}$ edição. Organização de Celso Lafer e Haroldo de Campos. São Paulo: Perspectiva, 2003, pp. 12-13.
} 
em análise, mostra que o universo da malandragem subsiste como um terreno de resistência "ao mundo administrado, à estandardização e à mesmice", ${ }^{376}$ mas também como um mundo dependente da ordem burguesa e do capital, contradição que o conto não resolve. Antes, reafirma nas marés de sorte e azar, nas alternâncias de euforia e melancolia, na dissimulação e no disfarce, nos golpes dados e sofridos pelos malandros, na metáfora do fogo e do jogo, do diabo e da fortuna.

A permanência da lenda, do mito e da aura santa e nobre que se ergue em torno dos malandros traz consequências literárias interessantes que dizem respeito à tragédia e à realidade latente da sociedade brasileira, com desdobramentos na ficção, na biografia e na autobiografia de João Antônio.

A continuação das leituras dos contos de João Antônio, especialmente de textos como "PPT", tema do próximo capítulo, permite compreender de que maneira o escritor condensou, na ficção, as promessas e limites da malandragem, que também dizem respeito à biografia do autor, em conexão com sua literatura.

${ }^{376}$ ADORNO, T. "Posição do narrador no romance contemporâneo". op.cit., p. 56. 


\section{CAPÍTULO 4}

\section{ASCENSÃO E QUEDA DO}

MALANDRO

Sobre "Paulinho Perna Torta" 
"Paulinho Perna Torta" é um dos textos mais conhecidos de João Antônio, mas não dos mais comentados: a fortuna crítica do autor registra poucas leituras aprofundadas deste conto. Como se sabe, é uma das principais realizações ficcionais do escritor, que Antonio Candido definiu como obra-prima: "João Antônio publicou em 1963 a vigorosa coletânea Malagueta, Perus e Bacanaço; mas a sua obra-prima (e obra-prima em nossa ficção) é o conto longo 'Paulinho Perna Torta', de 1965. Nele parece realizar-se de maneira privilegiada a aspiração a uma prosa aderente a todos os níveis da realidade, graças ao fluxo do monólogo, à gíria, à abolição das diferenças entre o falado e o escrito, ao ritmo galopante da escrita, que acerta o passo com o pensamento para mostrar de maneira brutal a vida do crime e da prostituição". ${ }^{377} \mathrm{O}$ elogio de Candido foi feito em um ensaio, "A nova narrativa", em que o crítico procurava apresentar, no final da década de 1970, a prosa de ficção brasileira contemporânea. Dentre outros autores, destaca Rubem Fonseca e João Antônio, que diz terem inaugurado uma nova tendência da nossa literatura, um "realismo feroz". No entanto, Candido não faz uma leitura interpretativa de "Paulinho Perna Torta". Sua apreciação do conto se dá dentro de um contexto amplo, que ele avalia como de grande dinâmica, experimentalismo e renovação na literatura nacional. No que se refere à prosa realista, Candido valoriza os relatos em primeira pessoa, pois neles "a brutalidade da situação é transmitida pela brutalidade do seu agente (personagem), ao qual se identifica a voz narrativa, que assim descarta qualquer interrupção ou contraste crítico entre narrador e matéria narrada". ${ }^{378}$ A primeira pessoa, relato em que o narrador é também o protagonista de sua própria história, é o foco narrativo de "Paulinho Perna Torta", com implicações formais e críticas decisivas, como veremos.

Jesus Antonio Durigan também destaca em "Paulinho Perna Torta" a narrativa em primeira pessoa, para valorizar a linguagem empregada, que o crítico chega a definir como um "saber narrar malandro", que se manifesta, segundo ele, por um processo de colagem: "A competência que garante a sobrevivência do narrador está intimamente ligada à sua capacidade de valer-se de textos (ditos populares, biografias, gírias, estereótipos etc.) e de características textuais (ritmo, pontuação, sonoridade) alheias. Sua sobrevivência como

\footnotetext{
${ }^{377}$ CANDIDO, Antonio. “A nova narrativa”. In: A educação pela noite \& outros ensaios. op.cit., pp. $210-211$.

${ }^{378}$ Idem, ibidem, pp. 212-213.
} 
narrador depende, em outras palavras, não do que cria, mas do que agarra do mundo dos outros e maneja com a maestria gerada pela necessidade de sobrevivência". 379

Tania Macêdo, em texto publicado na edição mais recente do livro, retoma a importância do olhar narrativo interno, que orienta as três principais narrativas de Leão-deChácara (além de "Paulinho Perna Torta", "Leão-de-chácara" e "Joãozinho da Babilônia" são narrados em primeira pessoa, e apenas um dos relatos é narrado em terceira: "Três cunhadas - Natal 1960"). A autora chama a atenção para a grandeza trágica do personagem, que reflete sobre sua própria história. Para Macêdo, ao adquirir consciência sobre seu destino, Paulinho Perna Torta "defronta-se com a solidão e, nesse movimento de mirar-se sem piedade, impregna-se de uma tragicidade que o engrandece sobremaneira". ${ }^{380} \mathrm{~A}$ conjunção de ponto de vista interno e caráter trágico traduz bem o espírito do conto e informam sua estrutura formal, como veremos.

Apesar de ter saído em volume de autoria de João Antônio apenas em 1975, quando do lançamento de Leão-de-chácara, segundo livro do autor, "Paulinho Perna Torta" foi publicado pela primeira vez dez anos antes, em 1965, na coletânea Os dez mandamentos. A participação de João Antônio no livro, organizado por Ênio Silveira, se deu a convite deste, então editor da Civilização Brasileira. ${ }^{381} \mathrm{O}$ volume trazia contos de escritores brasileiros, como Jorge Amado, Carlos Heitor Cony, Marques Rebelo e Campos de Carvalho, entre outros, inspirados nos preceitos bíblicos. O conto de João Antônio, o último da relação, correspondia ao décimo mandamento: "Não cobiçar as coisas alheias".

É, assim, um texto contemporâneo das primeiras realizações do autor, apesar de ter sido incluído em seu segundo livro. Além da boa, ainda que escassa, recepção crítica, ${ }^{382} \mathrm{o}$ apreço do próprio autor com relação ao texto se manifestou em diversas ocasiões e se manteve ao longo de sua trajetória. ${ }^{383}$

\footnotetext{
379 DURIGAN, Jesus Antônio. "João Antônio: o leão e a estrela". In: ANTÔNIO, João. Leão-de-chácara. $7^{\text {a }}$ edição. São Paulo: Estação Liberdade, 1989, p. 16.

${ }_{380}$ MACÊDO, Tania. "Malandros e merdunchos". In: ANTÔNIO, João. Leão-de-chácara. São Paulo: Cosac e Naify, 2002, p. 12.

${ }^{381}$ Sobre isso, ver o capítulo 2 do trabalho de Rodrigo Lacerda sobre João Antônio. LACERDA, Rodrigo. João Antônio: uma biografia literária, tese de doutoramento, DTLLC, FFLCH-USP, 2006.

${ }^{382}$ Ver trabalho de Jane Cristina Pereira sobre a recepção crítica da obra de João Antônio: "Estudo crítico da bibliografia de João Antônio (1963-1976)”. Dissertação de mestrado, Unesp, Assis, 2001.

${ }^{383} \mathrm{Em} 1993$, o conto ganhou edição voltada ao público infanto juvenil, pela editora Mercado Aberto, de Porto Alegre. Em 1996, foi incluído na coletânea do autor Patuléia. Gentes da rua, pela Ática de São Paulo.
} 
No ano de lançamento de Leão-de-chácara, 1975, já morando no Rio de Janeiro, João Antônio comenta, em entrevista, a inspiração pessoal que o motivou a escrever o conto: "Eu sou paulista, nasci na Maternidade de São Paulo, dia 27 de janeiro de 37. Fui criado em São Paulo uma boa parte de minha infância. Morei em muitos lugares de São Paulo, principalmente lugares pobres, porque meus pais eram e são pobres. Morei nos lugares mais diversos, Vila Pompéia, Osasco, Presidente Altino, moramos nas Perdizes, meu pai mudava muito, questões de vida e tal. De forma que São Paulo é uma cidade que conheci muito profundamente. A história de 'Paulinho Perna Torta', evidentemente, não é autobiográfica, mas muita coisa daquilo foi vivenciada, foi vista, fui acompanhando, como a história 'Malagueta, Perus e Bacanaço'. A aventura ou desventura da noite dos três jogadores, em cima da qual eu faço a novela ou conto, foi vivida por mim muitas vezes. Meu conhecimento de São Paulo chegou a ser quase milimétrico em certas áreas. E posso dizer até o seguinte: que com esses mesmos nomes existiram jogadores de sinuca, Malagueta, Perus e Bacanaço". ${ }^{384}$ Nos últimos anos de vida, o autor voltaria a declarar sua preferência pelos contos de juventude, como já vimos nos capítulos 1 e 2, com especial predileção por "Paulinho Perna Torta": "Gosto de todos os meus contos. (...) Gosto, creio que seja natural, um pouco mais dos filhos da minha juventude, no caso os contos extraídos do livro Malagueta, Perus e Bacanaço. Mas gosto também do 'Paulinho Perna Torta'", 385

Apesar da semelhança e da contemporaneidade de "Paulinho Perna Torta" com relação aos contos de $M P B$, o conto dá um passo além das narrativas iniciais do escritor, mantendo entretanto semelhanças importantes com os textos do primeiro livro. A mudança formal mais significativa de "Paulinho Perna Torta" em relação a, por exemplo, "Malagueta, Perus e Bacanaço" é que este, como vimos, é narrado em terceira pessoa, enquanto aquele retoma o ponto de vista interno que marcava os "Contos Gerais" e outros contos do livro de estreia.

"Paulinho Perna Torta" é um conto narrado pelo protagonista ele mesmo: assim como Vicente e Meninão do Caixote, Paulinho Perna Torta é o narrador de sua própria

384 "O [sub]mundo de João Antônio". Entrevista publicada em setembro de 1975, na revista Crítica. In: ANTÔNIO, João. Leão-de-chácara, São Paulo, Cosac e Naify: 2002, p. 173.

385 “João Antônio: 'Escrevo de dentro para fora”". Entrevista com João Antônio. In: da rua. São Paulo: Ática, 1996, p. 3. Patuléia: Gentes 
história. $\mathrm{O}$ arco de tempo em que a narrativa se desenrola, porém, é expressivamente maior que em todos os relatos anteriores em primeira pessoa. Ademais, em consequência disso, o conto se estende e ganha corpo, densidade narrativa, marcação histórica e maior número de páginas. Dentre as narrativas ficcionais de João Antônio, "PPT" é, ao lado de "MPB", seu texto mais longo e aquele que desenvolve com mais segurança a trajetória de ação e ascensão do protagonista, além de se relacionar, intimamente, com a história social da cidade de São Paulo - este conto sobre um malandro que se torna rei do crime guarda relação com a história real de Hiroito de Moraes Joanides, ainda que não se inspire diretamente nela. ${ }^{386}$

O conto narra a trajetória distendida do herói individualizado, que conta sua própria história. O foco narrativo em primeira pessoa, além de obviamente proporcionar um olhar interno ao próprio relato, cumpre no conto uma outra função, que ganha ênfase na enunciação: reparar as inverdades que se contam sobre o personagem-narrador. Paulinho Perna Torta se empenha em negar certas calúnias que, diz ele mesmo, são contadas a seu respeito, por conta mesmo da fama que corre em seu nome. Nesse embate, estão o protagonista, de um lado, e de outro os oponentes que espalham falsidades a seu respeito, encurtam-lhe o nome e o perseguem: a imprensa, a polícia e outros malandros e criminosos.

Essas informações inverídicas, pretensamente falsas a respeito dele próprio, o narrador as enuncia para negá-las: uma delas é a de que ele teria matado o próprio pai para ficar com uma herança; outra, a de que ele começou na "zona”, isto é, sua iniciação na malandragem e no crime teria se dado na região da antiga área do meretrício, no Bom Retiro. Na verdade, diz ele, começou sua vida de virações muito antes, como engraxate e menino de rua. A questão inicial e principal, entretanto, não é uma mentira que corre em seu nome, mas, mais grave que isso, a ameaça ao seu nome de guerra.

As ambiguidades entre identidade, fama e ameaça ao nome (que é em verdade uma ameaça ao próprio personagem) concentram no tema do nome a principal chave de

\footnotetext{
${ }^{386}$ Originalmente publicado em 1977, o livro de Hiroito de Moraes Joanides que conta a sua própria trajetória e a história da Boca foi republicado há cerca de dez anos: Boca do Lixo. São Paulo: Labortexto Editorial, 2003. Em entrevista incluída em Patuléia (1996), coletânea de seus contos voltada ao público jovem, João Antônio comenta a inspiração em uma história real e a relação entre Perna Torta e Hiroito: "Existiu um malandro com esse apelido e até com a figura física do Paulinho Perna Torta. Já a sua história foi criada por mim. Tempos depois, apareceu alguém e disse que eu havia escrito a história de um marginal famoso em São Paulo, uma lenda viva, Hiroito Joanides. 'Paulinho Perna Torta' chegou a ser bastante namorado pelo cinema nacional, acabou tudo paralisado, nem me lembro por quê". "João Antônio: 'Escrevo de dento pra fora"'. In: Patuléia. Gentes da rua, op. cit., p. 14.
} 
interpretação do texto. O conto é intitulado com a alcunha do personagem, e a constituição deste apelido e a progressiva amputação a que está sendo submetido são o cerne do entrecho. Mais do que a história de formação de um bandido - o que o texto também é —, "Paulinho Perna Torta" é um conto sobre o nome deste jovem criminoso que começou como engraxate e moleque de rua e virou "rei" do crime. O conto combina a história pessoal deste personagem, narrada por ele mesmo, a uma reconstituição de fundo histórico, pois ela se dá em um contexto mais amplo: o da constituição da Boca do Lixo paulistana e do avanço da criminalidade em São Paulo nas décadas de 1940, 50 e 60.

O foco narrativo em primeira pessoa acarreta também mais uma dualidade que contribui para tornar este conto uma realização rica em sentidos contraditórios. Além da ambivalência encarnada no nome do protagonista - a de lhe dar fama e respeito e ao mesmo tempo lhe tornar vulnerável e alvo da polícia, da imprensa e da "curriola" —, outra ambiguidade marca o relato: uma combinação de ferocidade e lirismo, de violência e candura que marcam a personalidade e as ações do protagonista. Paulinho Perna Torta é um bandido bonitão: tem olhos verdes, pinta de galã de cinema italiano e é chamado de "meu modelo" por Ivete, sua primeira mulher, a quem a certa altura ele passa a agenciar como prostituta. De início hesitante, malandreco de hábitos desinteressados e inocentes (como os passeios de bicicleta), ele se torna criminoso violento e voraz.

Além das ambiguidades do próprio personagem, sobressaem no texto as contradições entre indivíduo e sociedade, trajetória singular e forma literária, experiência e ficção. O conto narra a formação de um malandro, desde o começo de sua vida de virações, como engraxate nas estações da Luz e Julio Prestes, até o seu auge como criminoso, ao mesmo tempo que acompanha um momento histórico de transição: o fechamento da "zona" (no Bom Retiro) e a constituição da Boca do Lixo. É ali que Perna Torta vira "rei": empresário de jogo, cafetão e traficante. No entanto, apesar das descrições sobre suas atividades malandras e criminosas, não se trata de um conto sobre a malandragem ou o crime. Trata-se de um conto, como indica o título, sobre um indivíduo, sobre a constituição deste personagem, sobre sua crise e a autoconsciência - difusa, mas concreta, pois remete ao seu nome e ao seu corpo - que ele adquire desta crise e da possibilidade de aniquilamento a que ele próprio está sujeito. 
O momento presente da ação é o de um Paulinho Perna Torta conhecido na cidade inteira, perseguido pela polícia, falado pelos jornais e difamado pela malandragem. A ação irá culminar na tomada de consciência do protagonista a respeito da própria trajetória na criminalidade. É o ponto de tensão máxima do relato, o momento privilegiado que organiza toda a narrativa, e com isso faz com que esse texto longo, que tende à novela, de fato ganhe um teor de conto. Pode-se ler o relato de Paulinho Perna Torta segundo as noções de Edgar Allan Poe e Julio Cortázar sobre o conto moderno, que já discutimos na leitura dos "Contos Gerais". ${ }^{387}$ No entanto, como veremos, "Paulinho Perna Torta" é um relato que narra a trajetória do embate entre indivíduo isolado e o mundo, nos termos de Lukács. Indivíduo isolado que tende a "fazer romance", como diz Marthe Robert, ${ }^{388}$ e que ao final, entretanto, descobre que vive um destino trágico.

O final do relato faz convergir toda a inquietação e todo o desejo do protagonista em um instante de hesitação e autoconsciência, retomando o pathos dos primeiros textos do autor, mas com uma diferença fundamental: Paulinho Perna Torta, diferentemente de Vicente e dos protagonistas de "Aact" e "Fujie", que eram jovens pobres indecisos entre a norma e seu avesso, é um malandro imerso na criminalidade; é um malandro arrependido, mas que não vê saída do crime; um criminoso que não pode retroceder; um personagem que não pode retornar, pois não tem para onde retornar. Nesse sentido, ele anuncia também o drama do próprio João Antônio, que como vimos, em "Amr", empreende um retorno a casa, arrependido, "rancoroso" e ao mesmo tempo impedido de, de fato, voltar.

A cobiça que move o personagem o impele a uma trajetória progressiva e também ascendente. Nesse caminho, Paulinho Perna Torta será apadrinhado por Laércio Arrudão, malandro mais experiente, figura paterna que será seu guia na malandragem e no mundo do crime. Aos poucos, porém, o padrinho será ultrapassado. A superação do pai postiço, o padrinho de malandragem, indica que teve lugar um parricídio simbólico, permitindo ao protagonista subir na carreira de malandro e criminoso.

Os temas principais do conto - a cobiça, o desejo, o dinheiro, o parricídio e o destino de malandro e criminoso - percorrem todo o texto e em alguns trechos ganham

\footnotetext{
${ }^{387}$ As ideias de Poe, retomadas por Cortázar, como vimos no capítulo 2 deste trabalho, constituem uma reflexão sobre o conto que compreende as ideias de unidade de ação, tom e efeito, brevidade, intensidade e "acontecimento significativo".

${ }^{388}$ ROBERT, Marthe. Romance das origens, origens do romance. Trad. de André Telles. São Paulo: Cosac Naify, 2007, p. 28.
} 
condensação, a mostrar que estão interligados, como nesta passagem, quando Paulinho Perna Torta assume "tamanho" de malandro:

Crio nome de piranha. Como os trouxas pela perna, cobiço. Torno a tomar a verba do alheio. Corro por dentro dos pacatos. Há tipos basbaques, pivetes ainda, aprendizes principiantes na roda da malandragem, que vêm de longe para me espiar jogando carteado. Porque atiço os dedos e vou ao jogo alto, não querendo nem saber se ando certo ou errado. Vou lá. Sou um relógio. Mamo a grana. Meu nome corre.

O diz-que-diz me exagera, começa a me pintar de negro. Anda por aí que, por uma herança, matei meu pai a tiros... Trouxas!

O diz-que-diz não está me dizendo nada. Fama não me ilude e não me estorvando... Interessa é a grana. $^{389}$

"Paulinho Perna Torta" é um conto sobre o nome e o desaparecimento do nome, sobre o desejo e o dinheiro, a cobiça e a castração, o parricídio e a impossibilidade de cometê-lo (um parricídio ainda que necessário e de certa forma cometido, ao menos simbolicamente). Narrativa seminal no conjunto da obra de João Antônio, concentra os principais temas e problemas críticos relativos à sua literatura e também, ainda que não explicitamente, à sua biografia e à sua carreira literária. É um conto sobre um personagem complexo - ser "fictício", com "lógica" própria, ${ }^{390}$ como Antonio Candido define o personagem de romance —, sobre "a capacidade do personagem atingir a autoconsciência" e sobre "a tomada de consciência do próprio destino", como definiria Lukács. ${ }^{391}$ Mas, como veremos, uma tomada de consciência que, apesar do caráter complexo desse conto e da própria constituição problemática do protagonista como personagem de romance, aquele que "busca algo",392 que persegue "a possibilidade de uma atuação da personalidade", 393

389 AnTÔNIO, João. Leão-de-chácara, São Paulo, Cosac e Naify, 2002, p. 133. Todos os trechos do conto citados tomam por base esta edição, a partir daqui referida como $L d c$.

${ }^{390}$ CANDIDO, Antonio. "A personagem do romance". In: (org.). A personagem de ficção. $10^{\mathrm{a}}$ edição. São Paulo: Perspectiva, 2000.

391 Sobre o destaque que o protagonista assume em relação aos demais personagens, diz Lukács: “(...) o protagonista se eleva acima do personagem secundário precisamente porque a sua mais profunda característica pessoal é a de não viver espontaneamente o próprio destino, tal como este se apresenta em sua casualidade e imediatismo, bem como de não reagir a ele com espontaneidade sentimental. O núcleo de sua personalidade, ao contrário, consiste na aspiração — vivida com toda a alma — a sair do imediatismo, do dado acidental, a fim de viver o próprio destino individual em sua generalidade, em sua relação com o universal. LUKÁCS, G. "A fisionomia intelectual dos personagens artísticos". In: Marxismo e teoria da literatura. Sel., apres. e trad. de Carlos Nelson Coutinho. São Paulo: Expressão Popular, 2010, p.194.

${ }^{392}$ LuKÁCS, G. A teoria do romance. São Paulo: Duas Cidades/Ed. 34, 2000, p. 60. 
assemelha-se mais ao reconhecimento trágico de um personagem preso a um destino que é maior que ele.

\section{O nome (e a imagem) do malandro}

A primeira seção do conto tem início sem marcação de subtítulo (ou intertítulo) ao contrário das demais, intituladas "Moleque de rua", "Zona" e "De 53 para cá". É uma espécie de intróito que marca o momento presente da ação narrativa. Apresenta Paulinho Perna Torta e anuncia sua inquietação inicial, ainda que a motivação do personagem não fique clara, o que talvez antecipe também o teor indefinido, até certo ponto aberto, do final da narrativa. ${ }^{394}$ Ela marca, entretanto, uma posição do narrador-protagonista em relação aos seus oponentes e a contrariedade sobre o encurtamento do seu nome de guerra.

Que essa cambada das curriolas, que esses ratos da polícia e esses caras dos jornais, gente esperta demais com seus fricotes, máquina e pé-ré-pé-pés, espalha que espalha mais brasa do que deve.

Sei que deram para gostar ultimamente de encurtar o nome de Paulinho duma Perna Torta.

Paulinho duma Perna Torta. Paulinho da Perna Torta. Apenas.

Nos jornais, nas revistas. Também na televisão já vi essas liberdades. Leio e ouço por aí. E assim, São Paulo inteiro acabará me chamando de Perna Torta.

Não gosto. 395

O texto tem início com uma construção verbal inusitada. A oração começa com um pronome relativo "que" a indicar algo que poderia ter vindo antes: estou tão enraivecido (que essa cambada)... o pior é (que essa cambada)... sei (que essa cambada)... leio e ouço por aí (que essa cambada)... etc. A frase iniciada no meio indica um estado de espírito turbulento, como se o discurso tivesse sido iniciado de súbito, num rompante. A revolta,

393 idem, ibidem, p. 144.

${ }^{394}$ Em entrevista de 1975, João Antônio comenta o caráter “desdobrável” do protagonista: “(...) o Paulinho Perna Torta é um personagem muito desdobrável. Na batida em que ele vai, eu parei a novela onde eu quis. $\mathrm{Na}$ batida em que ele vai, pode se transformar até em um líder. Ele pode ser, por exemplo, um cartola, um dono do jogo-do-bicho, ele pode ser um contraventor de qualquer uma dessas espécies que andam por aí. Não quero dizer que os cartolas sejam contraventores. Pode ser um dos donos do poder, seja o poder legal ou o poder marginal. (...)". "O [sub]mundo de João Antônio”, entrevista citada. In: Ldc, pp. 174-175.

395 Ldc, p. 99. 
irritação ou contrariedade do personagem-narrador é enunciada ao final do trecho, curta e direta: "Não gosto".

Antes disso, o narrador trata de apontar seus oponentes, aqueles que "espalham brasa". 396 São a "cambada das curriolas", 397 os "ratos da polícia" e "esses caras dos jornais". A definição dos oponentes é importante, pois, além de marcar, por contraste, a individualidade deste narrador que não demora a anunciar o próprio nome, insere-o em um contexto social marcado pelas oposições entre polícia, imprensa e a "curriola" (outros malandros e criminosos). Se havia nos contos anteriores a marca forte da busca e do conluio, este conto, desde o início, apresenta um forte componente de individualidade e isolamento do protagonista.

Do ponto de vista literário, o texto, por conta de sua extensão distendida e da própria constituição de um personagem-narrador individualizado, faz com que a narrativa tenda ao romance, como já era o caso, em menor grau, dos “Contos Gerais”. Vimos como a ação e a constituição mesma dos personagens naqueles contos impediam desdobramentos narrativos de maior fôlego. Em "Paulinho Perna Torta", por outro lado, a ação é mais longa e mais consistente. Da mesma forma, porém, o texto não é um romance, mas um conto, talvez uma novela - e a mesma questão do acanhamento do alcance narrativo se impõe. Mais uma vez, aliás, a narrativa vai tratar, justamente, desses limites, agora consubstanciados na alcunha do personagem.

A inquietação inicial do narrador-protagonista, como se vê pelo trecho acima, é justamente a do encurtamento do seu nome. Ele anuncia o nome de guerra, Paulinho duma Perna Torta, para dizer que os seus oponentes ou inimigos o estão encurtando para Paulinho

\footnotetext{
${ }^{396}$ O dicionário Houaiss registra o verbete "espalha-brasas" e assim o define: "que ou aquele que é ruidoso, espalhafatoso, bagunceiro". Já vimos que a metáfora do fogo é central para o conto "Malagueta, Perus e Bacanaço". No relato de Paulinho Perna Torta, mais adiante, o narrador irá usar o termo "braseiros" para se referir aos prostíbulos. A zona era um "braseiro isolado", que com a ação da polícia em 1953 se espalhou para a região da Boca do Lixo. A ideia de espalhar a brasa, então, se liga também à dispersão e ampliação do meretrício e da criminalidade.

${ }^{397}$ No Houaiss, não consta o verbete curriola, mas uma das acepções para "corriola" é: "grupo de pessoas que agem desonestamente ou de forma inescrupulosa; quadrilha". O Aulete on line registra as duas grafias e um das definições é: "Grupo de pessoas desonestas, mancomunadas, acumpliciadas; quadrilha". O termo "corriola" aparece também em "Desafio ao malandro", composição de Chico Buarque, feita para o filme Ópera do malandro (1985), de Ruy Guerra (pode ser ouvida em: http://www.youtube.com/watch?v=FuN853WAJu0). A letra da composição está em: BUARQUE, Chico. Tantas palavras. Todas as letras e reportagem biográfica de Humberto Werneck. São Paulo: Companhia das Letras, 2006.
} 
da Perna Torta. E o protagonista indica que este é um processo em andamento. Logo, diz ele, começarão a chamá-lo apenas de Perna Torta.

A questão não se restringe ao nome, claro, pois o nome do personagem, como indica o início do texto, é mais do que a maneira com que o próprio se identifica. É uma alcunha, um nome pelo qual ele ficou famoso, um nome de guerra que ganhou projeção graças aos seus feitos, tornando-o conhecido entre policiais e outros malandros. Mas também um nome que ganhou as páginas dos jornais e até os programas de televisão, o que indica que Paulinho Perna Torta se tornou objeto de narrativas jornalísticas, de versões de seus feitos criminosos, que ele é malandro famoso, conhecido pela sociedade instituída, dita de bem, aqui representada pela imprensa (e em outra passagem pelas "famílias"). Ele se contrapõe algumas vezes a essa fama adquirida para diminuí-la, desclassificá-la e, até mesmo, negála, como no caso do suposto parricídio.

A condição de afamado e difamado de Paulinho Perna Torta lembra a situação do jagunço Damázio, do conto de Guimarães Rosa, intrigado com o epíteto de "famigerado" que o "moço do governo" lhe imputou. A esse respeito, José Miguel Wisnik lembra que a inquietação do personagem rosiano tem a ver com os valores e tabus patriarcais, com a regra de valentia que vige no sertão (onde a lei não vigora), com uma dúvida quanto à origem do personagem e com a própria ambiguidade da palavra que lhe designa, entre "fama" e "infâmia". Como indica Wisnik, a palavra "famigerado", assim como "bárbaro", pode designar a coisa e seu contrário, simbolizando uma condição dúbia que pede significação, mas cujo sentido é sempre oscilante. A ambiguidade a que o famigerado jagunço está submetido se repõe na situação do conto, pois ele está "pronto a negar que é matador matando".398

398 Como diz Wisnik, famigerado é uma "palavra-fármacon": "São palavras em que o excesso que elas designam, no limite indizível, revira no seu contrário, como bárbaro e formidável, palavras-fármacon, ao mesmo tempo veneno e remédio, a exemplo de "merda", que, no seu uso como amuleto teatral (trocado entre os atores antes do início do espetáculo), incorpora a menção-tabu ao fracasso - materializado no dejeto caótico-malcheiroso -, tomando-a como irradiadora de força, imantação e voto de sucesso. Palavras assim, semanticamente oscilantes, deixariam entrever o quanto toda significação é virtualmente equívoca, flutuando e deslizando num eixo de polaridades cujo sinal pode se inverter, a depender do acento que nela se imprima e do recado que a atravesse. Assim também certos palavrões emblemáticos, que servem para expressar estados opostos: "filho-da-mãe", "filho-da-puta" e "puta-que-o-pariu" podem implicar aviltamento e estigmatização, ao mesmo tempo que euforia e entusiasmo intenso. As palavras-fármacon são palavras que pendulam sobre o paradoxo e o excesso, transformando em totem aquelas zonas-tabu em que as dualidades opositivas vacilam: o nó inexorável entre morte e vida, potencializado no veneno-remédio; o nó inextrincável 
Paulinho Perna Torta, da mesma forma, é afamado, um famigerado a seu modo também ambíguo, pois é conhecido como jogador habilidoso, modelo bem apessoado, malandro do partido alto, bandido perigoso, matador. Sua a fama tem a ver com suas "habilidades", digamos, e seus feitos e malfeitos, mas a fama corre com o nome.

A fama tem a ver com o nome e o nome tem a ver com a fama, são duas faces de um mesmo processo. Acompanhar os momentos em que o nome do protagonista assume primeiro plano nos conduz ao núcleo temático da ação, como sugere o começo do relato que já vimos e que veremos retornar, glosado, no desfecho da narrativa.

Depois da introdução, o conto entra em uma longa seção chamada "Moleque de rua". O narrador-protagonista recua no tempo para relembrar os tempos de menino, quando começou na "viração", como engraxate. O tempo presente da narrativa não é abandonado. Ao contrário, é ele quem ordena e orienta o curso dos acontecimentos e da motivação do narrador. Ao lembrar da infância, o narrador dirá: "Aguentei muito xingo, fui escorraçado, batido e dormi de pelo no chão. Levei nome de vagabundo desde cedo. Lá na rua do Triunfo, na Pensão do Triunfo, seu Hilário e dona Catarina". ${ }^{399}$ O narrador recua no tempo para contar seus tempos de "moleque de rua", quando morava em uma pensão e trabalhava de engraxate nas estações Julio Prestes e Luz. Ele não relata nada a respeito de seus pais ou de seu nome de batismo ou de registro. Desde cedo, como ele diz, ganhou "nome de vagabundo" e morava na pensão dirigida pelo casal Hilário e Catarina, dois personagens que assumem ares de pais postiços, já que não há referência aos pais biológicos. Ainda criança, o menino já convive com viradores e prostitutas: “Aquilo, àquele tempo, já era o casarão descorado dos dias de hoje, já pensão de mulheres. Mas abrigava também, à noite, magros, encardidos, esmoleiros, engraxates, sebosos, aleijados, viradores, cambistas, camelôs, gente de crime miúdo, mas corrida da polícia; safados da barra pesada, que mal e mal amanhecia, seu Hilário mandava andar. Cada um para a sua viração", ${ }^{400}$

A origem do personagem, portanto, não se conhece. Talvez nem ele mesmo a conheça. ${ }^{401} \mathrm{O}$ narrador recua, porém, para contar esse momento inicial de sua formação na

de que a mãe, interditada, fez sexo.” WISNIK, José Miguel. “O famigerado”. In: Sem receita. Ensaios e canções. São Paulo: Publifolha, 2004, pp. 131-132.

${ }^{399} L d c$, p. 100.

${ }^{400}$ idem, ibidem.

401 A questão da filiação e da origem do personagem está na origem do gênero romance e na própria constituição do enredo das obras romanescas, como aponta Marthe Robert. A autora chega a distinguir duas (e 
malandragem, na "viração". Em seguida, ele retoma a questão inicial, sobre os boatos e a fama que correm em seu nome:

Ainda escrevem aí que matei meu pai a tiros por causa de uma herança... Esses tontos dos jornais me botam cabreiro.

Outra coisa errada que em meu nome corre é que comecei na zona. Que zona, que nada... Zona foi vida boa. Foi depois de Laércio Arrudão me apadrinhar e me ensinar o riscado do balcão, pra cima e pra baixo, servindo cachaça, fazendo sanduíche e tapeação nos trocos; misturando água nas bebidas quando, noite alta, as portas do bar desciam e Laércio ia fazer a féria e eu as marotagens nas garrafas. Sim. Mas antes dessa coisa de zona, me rebentei por aí.

Os inícios desse narrador-personagem são nebulosos. A fama que corre em seu nome é que ele começou na zona e que matou o próprio pai, por causa de uma herança. A fama que lhe atribuem, assim, é a de um filho bastardo (que se iniciou na zona do meretrício), mas que apesar disso, devia saber quem era o pai, a ponto de tê-lo assassinado para ficar com a sua "herança". Esta palavra indica, obviamente, dinheiro. Mas, talvez, não só. A herança a que o narrador alude é uma herança, o que sugere que poderia se tratar de dinheiro ou não - talvez uma herança de outra natureza. Mas o artigo indefinido também indica que a tal herança era, talvez, espúria: uma herança, adquirida pelo pai sabe-se lá como e então tomada pelo protagonista ao assassiná-lo. Uma herança tomada de um pai que talvez o protagonista nem saiba quem é. ${ }^{402}$

Não sabemos quem eram seu pai e sua mãe, onde nasceu, qual o seu verdadeiro nome. Antes da zona, ele foi engraxate, e morava na pensão do Triunfo. E antes disso? Não se sabe. Sua origem, repita-se, é desconhecida ou, ao menos, não é narrada.

O teor de indefinição, como se vê, interessa ao narrador-protagonista, que conduz o relato de maneira a negar a fama que corre em seu nome, mas fazendo-o de maneira pouco

apenas duas) linhagens de romance, uma que conta a história de personagens de origem incerta e outra que narra a vida de personagens enjeitados. Essas duas vertentes corresponderiam às fábulas da Criança Perdida e do Bastardo (fases edípicas e pós-edípicas). A leitura de Robert parte da noção psicanalítica de "romance familiar" para classificar os romances nessas duas linhagens, que corresponderiam, assim, respectivamente aos romances fantásticos ou fantasiosos (de autores como Cervantes, Defoe, Hoffmann, Melville, Kafka) e realistas (de Dickens, Balzac, Flaubert, Dostoiévski, Tolstói). Ver: RoBERT, Marthe, op.cit., p. 58.

402 Como lembra Marthe Robert, a concepção freudiana de "romance familiar" assenta-se sobre a ideia de que a mãe é certa, mas o pai é sempre incerto. A noção está no texto de Freud, que alude à frase latina pater semper incertus est. FREUD, Sigmund. "Romances familiares". In: Gradiva de Jensen e outros trabalhos (1906-1908). Edição Standard Brasileira das Obras Psicológicas Completas de Sigmund Freud. Vol. IX. Rio de Janeiro: Imago, 1996. 
clara, de forma a construir a própria história mantendo certo grau de indeterminação e mistério que concorrem para dar relevo a essa mesma fama. O narrador não narra a própria origem, acalentando a indeterminação e a dúvida, fazendo de si próprio fiador único e seletivo do que narra e da verdade a seu próprio respeito.

O que de fato ele narra, isto sim, é a sua iniciação na malandragem: "Comecei por baixo, baixo, como todo sofredor começa. Servindo para um, mais malandro, ganhar. Como todo infeliz começa. Já cedinho batucava. - Vai um brilho, moço?”. ${ }^{403}$ O início da viração se dá como engraxate, atividade marcada pela posição de inferioridade e sofrimento. Mais que isso, pela submissão a um outro, "mais malandro". Sabemos, porém, que a situação presente deste personagem é de destaque, de fama, de boatos e de inverdades que correm em seu nome, um nome que está, ao mesmo tempo, em risco.

Já vimos, na leitura dos contos anteriores, como ganhar nome no mundo da malandragem (assim como no universo do choro, no caso dos textos autobiográficos) é algo decisivo e elementar - é como passar a existir socialmente ou, pelo menos, existir no universo da boemia e da malandragem (como é o caso de "Meninão do Caixote"). O nome de guerra indica um estatuto de respeito medo, fama e admiração, uma forma de reconhecimento e muitas vezes de demonstração de poder e de força. Quem ganha nome passa a ser não apenas conhecido e identificado, mas temido e visado. A narrativa de Paulinho Perna Torta encaminha-se para a história de como esse menino que começou como engraxate se tornou, justamente, um malandro de nome, famoso, mas que por isso mesmo passou a ser não apenas admirado mas também mirado pela cambada das curriolas, estampado nas páginas dos jornais e perseguido pela polícia.

Sabe-se, assim, desde o começo da narrativa que esta é uma trajetória ascendente. Paulinho Perna Torta, este malandro famoso, que tem seu nome falado nos jornais, nas revistas e até na televisão, começou por baixo, como todo "sofredor". A trajetória, ao cabo, é de sucesso, e os tempos de sofrimento ficaram para trás. Logo de início, como se viu no trecho acima, anuncia-se a "vida boa", a superação de um momento inicial de grande inferioridade. E o que marca o começo da vida boa na zona é um apadrinhamento. Foi a proteção e o ensino do malandro Laércio Arrudão que lhe introduziram na "zona" e nas "marotagens" de trapacear no troco e misturar água nas bebidas. Entretanto, o

\footnotetext{
${ }^{403} L d c$, p. 99.
} 
apadrinhamento de Laércio Arrudão marca a passagem da fase de sofrimento para a "vida boa", mas repõe a situação de inferioridade e submissão, em que ele trabalha para alguém "mais malandro".

O impasse, como já vimos em “MPB”, é constitutivo da malandragem, e aqui ganha um retrato mais acabado, com ênfase na aquisição do nome, na iniciação no crime, na ascensão do protagonista e, afinal, na ameaça ao nome e à própria identidade do personagem. Os avanços e recuos que marcam a vida da malandragem encontram campos de sentido privilegiados nos temas do nome e nas relações horizontais e verticais de autoridade, que se dão entre os malandros e os malandros mais velhos, irmãos e padrinhos de malandragem.

Antes mesmo de ganhar o seu nome de guerra, o nome e a fama já eram preocupações do personagem-narrador, como indica a passagem, ainda no início do texto, que narra o primeiro gesto de maior ousadia malandra do protagonista. As passagens da viração como engraxate vão culminar, na narrativa, no primeiro ato criminoso do protagonista: ele decide furtar um "tufo" de dinheiro do seu "chefe", o dono da banca de jornais da estação Júlio Prestes. Apanhado em flagrante, o personagem-narrador finta, rebola, requebra, ginga e consegue escapulir. Porém, sabe que a fuga não termina ali:

Mas logo-logo percebi que caíra de dois pés num buraco só. Estava espetado, espetadinho, engolobado. Como um martelo sem cabo.

Meu nome, na boca dos caras, ia correr as estações. E o Juizado atrás. Estava complicado; eu que me cobrisse. Andasse dali. ${ }^{404}$

A imagem do "martelo sem cabo" ecoa a passagem de "MPB" em que o narrador diz que Perus e Bacanaço são um o martelo e o outro, o cabo. Aqui, PPT está sozinho, sem cabo, parceiro para as suas malandragens e virações. Mas o processo da fama já está em andamento, à revelia do personagem. Seu nome ia correr.

Mais uma vez o nome, este "nome que corre", é algo ambivalente. O nome do protagonista vai correr as estações, na "boca dos caras", e chegará também ao conhecimento do Juizado de menores. Assim, o feito de ter furtado o jornaleiro que o explorava e ter escapado, graças à capacidade de gingar, requebrar e driblar aquele que o

${ }^{404}$ Ldc, p. 107. 
oprimia, é a um só tempo uma façanha, aos olhos dos “caras”, isto é, dos demais malandros e trabalhadores, e um crime, aos olhos do Juizado. A contrastar com a velocidade com que a fama se espalha - com que o nome corre — , o protagonista é levado a procurar uma cobertura ("eu que me cobrisse") e a fugir (“andasse dali”).

A ginga é, portanto, um dos atributos de sobrevivência do jovem malandro. É ela que permite que ele drible seu oponente e consiga fugir, evitando o enfrentamento direto, ainda que ele tenha afrontado o "patrão" que o explorava. Ao comentar esta passagem do conto, Benjamin Abdala Júnior vê a ginga como uma "atualização de uma estrutura articulatória", "apropriação simétrica aos esquemas de conduta do futebol brasileiro". ${ }^{405}$ Segundo o crítico, há comunicação entre a ginga e a dinâmica do encurtamento do nome do protagonista. E a ginga é também estratégia de sobrevivência e inserção do personagem:

Figurativamente, a ginga da personagem narradora do conto de João Antônio é, de um lado, “Paulinho" e, do outro, "Perna Torta". Na ascensão, seus passos são registrados pelos jornais como os de um "Paulinho de uma perna torta". Quando cai reduz-se apenas ao apelido "Perna Torta". Na determinação desse caminhar social, ele oscila entre seus pares e a polícia que se alimenta deles. Precisa gingar para que seu triunfo se efetive dentro das brechas do sistema. ${ }^{406}$

Na juventude de Paulinho Perna Torta, a ginga é uma atitude que combina o confronto e o deslizamento, configurando um funcionamento amalandrado de lidar com as situações difíceis, de conflito e ameaça. Ela permite transitar entre "ordem e desordem", para retomar a conhecida formulação de Candido. ${ }^{407}$ A ginga, porém, será também elemento que irá escapar ao controle do protagonista, que ao final de sua trajetória não tem como usar da ginga para escapar, justamente, à ameaça a seu nome. A "ginga macumbeira" de Zião da Gameleira será, ao final do relato, mais um elemento da crise de consciência do protagonista, que o conduz ao reconhecimento de seu próprio destino e a atitudes autodestrutivas que confirmam este destino.

Portanto, a ginga é estratégia ambígua, pois serve ao malandro e também ao seus oponentes, aos detratores de Paulinho Perna Torta. Como observa Abdala Júnior, ela está

\footnotetext{
405 ABDALA JÚNIOR, Benjamin. Literatura, história e política: Literaturas de língua portuguesa no século XX. Cotia: Ateliê Editorial, 2007, p. 87.

406 idem, p. 93.

${ }^{407}$ CANDIDO, A. "Dialética da malandragem". In: $O$ discurso e a cidade. Op.cit.
} 
figurada no nome e no encurtamento latente do apelido. E no final da narrativa a ginga estará também ligada à confusão, à "encabulação" que o personagem sente como uma crise de consciência e uma mudança de comportamento, antes malandro e voraz, depois evasivo e autodestrutivo.

A ginga, no momento inicial de sua trajetória, permite afronta e deslizamento. A trajetória do personagem, a partir deste primeiro momento de confronto e de fuga de uma personagem paterna — de seu patrão explorador — será de perambulação. Ele vai percorrer a cidade inteira, trabalhando com diversas atividades, todas elas informais, fazendo bicos, esmolando, correndo da polícia, morando em favela, passando fome. O menino - moleque de rua e engraxate — recomeça o seu ciclo de perambulações: “(...) dei para bater perna de novo, catando virações pelos cantos e longes da cidade”. Então, elenca uma série de aventuras que viveu em sua existência de malandro: lavou carro, esmolou nos subúrbios, trabalhou em ferro-velho, ajudou pipoqueiros no Pacaembu e no hipódromo de Cidade Jardim, trabalhou na feira, morou em favela no Piqueri, vendeu jornal nos trens da Sorocabana. "Andando por aí como um bicho", diz ter apanhado da polícia, aprontado tudo isso e mais um pouco e que o pessoal da imprensa, interessado só na sua "grandeza", nunca escreveu. Diz a narrativa: "Mas nas minhas perambulagens aprendi a ver as coisas. Cada rua, cada esquina tem sua cara. E cada uma é cada uma. Não se repete mais. Aprendi." ${ }^{408}$

O aprendizado que Paulinho Perna Torta adquire da cidade, porém, não faz com que ele se forme. Aprendizado, houve. Mas Paulinho ainda é garoto. É virador, malandro, mas malandro não formado. Apesar de todas as suas andanças, apesar de ter percorrido a cidade toda, sente que ainda lhe falta algo: picardia.

Muitos anos de janela, muito estrepe, muita subida e muita piora me permitem dar fé de que tudo tem seu senão. Eu ainda era um trouxinha. Cadê picardia?

Uma criança que não conhecia o resto do balangolé — cadeia, maconha, furto, jogo, mulher.

Pois. Assim, até os quinze anos, quando Laércio Arrudão e eu nos topamos. ${ }^{409}$

\footnotetext{
${ }^{408}$ Ldc, p. 109.

${ }^{409}$ idem, p. 108.
} 
O termo picardia, de forte conotação sexual, indica que, como o malandreco ainda não a adquiriu, a passagem de menino a homem ainda não se deu. Ele se pergunta "cadê picardia?", pois não sabe onde encontrar a virilidade necessária para continuar sua vida de malandro. Essa virilidade amalandrada, a picardia, ele não a localiza em si mesmo, mas a entrevê na possibilidade de acesso ao mundo adulto, masculino e malandro, que o apadrinhamento de Laércio Arrudão proporciona.

A combinação de peripécias que se sucedem e o aprendizado extensivo, mas insuficiente, indicam que a trajetória de Paulinho Perna Torta situa-se num terreno intermediário entre a picaresca e o romance. Sua história, que será pautada até o final por esta oscilação entre experiência e incompletude — inserção instável, ascensão sem acomodação, num processo movido pela ganância — indica que o personagem está entre o pícaro e o herói de romance. Nos termos de Candido, ele vive a dialética da malandragem, entre ordem e desordem. Mas ao contrário dos personagens malandros dos contos anteriores, sobretudo Bacanaço, Perus e Malagueta, a inserção no mundo da malandragem, sempre instável, vai se dar pautada pela mesma dinâmica entre a aprendizado e não formação, conquista e ganância, ascensão e sedentarismo, dinâmica que o protagonista acredita que irá se resolver por meio do apadrinhamento do malandro mais velho, encontrando um equilíbrio dinâmico, que permitiria equacionar impulsos contraditórios. ${ }^{410}$

A segunda seção do conto, que se chama "Moleque de rua", vai culminar, justamente no encontro entre o protagonista e o malandro Laércio Arrudão. Tem início, depois disso, a seção "Zona".

Não percamos, apesar das peripécias, o fio: o nome do protagonista. É na zona, graças a Laércio Arrudão, que o personagem ganhará seu nome de guerra. A descrição da cena da briga em que ele machuca uma das pernas e passa a mancar é longa e não há espaço para comentá-la. Registre-se que foi uma briga passional entre um "invertido", Jane,

\footnotetext{
${ }^{410}$ Em "Dialética da malandragem", como se sabe, Antonio Candido discute a inserção do romance Memórias de um sargento de milícias na tradição da novela picaresca, que tem em Lazarilho de Tormes seu representante mais conhecido. O conceito de "dialética da malandragem", formulado por Candido, procura definir um modo de funcionamento social brasileiro, especialmente no que se refere aos homens livres (nossa incipiente classe média do século XIX), ainda durante a vigência da escravidão. Nos termos de Candido, Paulinho Perna Torta é uma espécie de combinação de pícaro e malandro, cuja trajetória irá avançar para a criminalidade, conferindo a ele novo estatuto, nem pícaro, nem malandro, mas bandido, empresário e rei do crime, sem deixar de ser pícaro, malandro e (anti)herói de romance, em uma formação e inserção às avessas, negativa, que tem motivações psicológicas e sociais que estão intrincadas e expressam, como veremos, conteúdos arcaicos da sociedade brasileira contemporânea.
} 
e a prostituta Ivete, que já era então mulher do protagonista. Mas quem golpeou o protagonista na perna, com uma cadeira, foi um cliente que saía do quarto de Ivete e entrou na briga ao chamar o personagem de "cafetãozinho".

Golpeado na perna, o protagonista consegue escapulir por uma janela. Mas a sequela do golpe faz com que ele passe a mancar.

Tornei à Boca do Arrudão, encabulado, murcho como um balão furado. Horas depois, capengando, capiongo e rasgado. Pegara um rabo-de-foguete. A façanha voou e Laércio já era sabedor. Ria.

Ele quem me chamou primeiro de Paulinho duma Perna Torta.

Depois, só depois, os vadios da turma. Para adular Arrudão, os vagabundos fizeram o acompanhamento estúpido. (Será que a mãe deles, na hora de pô-los para fora da barriga, também não ficou com a perna torta?)

— Paulinho duma Perna Torta!

Paulinho duma Perna Torta. Fiquei.

Como outros malandros grandes e pequenos de São Paulo, eu ganhava um nome de guerra. Que ia se exagerar e virar lenda na boca das curriolas, nas ocorrências da polícia e na mentirada dos jornais. Como Saracura, como Bola Preta, Ivinho Americano, Diabo Loiro, Marrom e como tantos outros. ${ }^{411}$

O trecho narra o batismo do afilhado pelo padrinho, graças à façanha de ter escapado da briga, da qual porém saiu com a sequela que lhe dá nome. A assunção do nome de guerra marca nova fase em sua trajetória de malandragem. $\mathrm{O}$ apelido o torna selvagem e voraz: "Crio nome de piranha". 412

A partir daí, Paulinho Perna Torta encosta a bicicleta, a "magrela", deixa de namorar as "franguinhas direitinhas" das lojas da José Paulinho e, com as trapaças no balcão e a habilidade no carteado, seu “capital sobe na Caixa Econômica da Praça da Sé”.

A subida não é apenas do capital. Ele próprio ascende na sua trajetória de malandro e se equipara aos demais nomes da malandragem, como indica a enumeração de malandros no trecho acima. Suas atividades ganham corpo e se diversificam, às raias do crime. Além

\footnotetext{
${ }^{411} L d c$, p. 132.

412 idem, p.133.
} 
de Ivete, passa a explorar também Valquíria, ex-doméstica que ele tira do emprego, "deflora" e ensina a "lidar com homem na cama".

Ivete sabe, está claro. Mas não abre o bico — meu nome de perverso anda falado. Boquejam por aí que se me tiram do sério eu apago um. Que matei meu pai a tiros. Durmo com as duas. Cresço a galope. Aos vinte anos, a crônica policial já me adula. "Perigoso meliante." Trouxas... Volta e meia, dão o meu retrato e minúcias. Um desses tontos dos jornais me comparou, dia desses, a um galã do cinema italiano...

Paulinho duma Perna Torta é respeitado, quase de igual para igual, pelos três maiores cobras da malandragem baixa de São Paulo - Bola Preta, Diabo Loiro e Marrom.

Sou um nome. Laércio Arrudão me aprova a conduta. E atiça. Minha concentração é na zona, mas reviro os quatro cantos da cidade.

Faço um conluio com a curriola de assaltos de Bola Preta. Mão armada, máquina na mão. Assalto, surrupio carteira, Colt 45, vou gatunando por aí. Cinco passagens na Delegacia de Furtos. A Captura já farejou atrás de mim. Carrego cinco processos no lombo, de que o Doutor Aniz Issara cuida a bom preço. Trato Aniz de você, me impondo - e ele é o maior especialista do crime em São Paulo.

Mas estou fichado apenas como ladrão e assaltante. Rufianismo, vadiagem e jogo, não.

Faço h. Sirvo a Laércio Arrudão somente para confundir os ratos da polícia. É um h. O empreguinho é uma dissimulada que eu e Arrudão aplicamos e que me garante a carteira profissional em dia. ${ }^{413}$

"Sou um nome." Assim, o apelido não apenas passou a identificar o malandro, como o nome de guerra ganhou autonomia. Paulinho Perna Torta está se tornando um malandro famoso e temido. Já ombreia com os principais malandros da cidade, "quase" de igual para igual. Para além isso, ele está virando criminoso. Mais que um simples malandro, ele é fichado não por vadiagem, jogo e cafetinagem, mas por roubo e assalto. Ao mesmo tempo em que sobe na carreira do crime, procura garantir-se na legalidade: mantém o dinheiro na Caixa Econômica e tem como advogado o melhor criminalista de São Paulo.

A relação com Laércio Arrudão também se modificou. Aos poucos ele se distancia também do antigo padrinho. Como indica o trecho acima, ele faz um " $\mathrm{h}$ ", mantendo-se como empregado dele apenas para despistar a polícia. Paulinho Perna Torta começa a servilo apenas para se escudar da polícia.

${ }^{413} L d c$, p. 135. 
O padrinho foi ultrapassado. Nada parece deter o protagonista. No entanto, como a sua história é também a história de toda a malandragem — ainda em estágio comunitário, reunida na zona do meretrício -, um revés vem se interpor à sua ascensão meteórica. $\mathrm{O}$ governo decide "fechar a zona". A polícia, com apoio das "famílias da cidade" e dos jornais, abre guerra contra a malandragem da área. A Boca do Arrudão é fechada, e o padrinho de Paulinho Perna Torta foge para Santos ou Londrina ("ninguém viu"). Muitos malandros vão para a Casa de Detenção, outros fogem, "se esquinizando pelas favelas e pelos buracos".

O trio de malandros, Paulinho Perna Torta, Diabo Loiro e Bola Preta, faz acordo, corrompe a polícia: "Os ratos aceitam dinheiro". Mas a campanha da imprensa contra a zona é intensa e a polícia, "em massa", não demora a agir.

As páginas do conto que descrevem o massacre de malandros e prostitutas são fortes e sufocantes. Ao entrever, pela veneziana do quarto de Ivete, que aproximam-se entre $150 \mathrm{e}$ 200 policiais, Paulinho Perna Torta escapa alojando-se na caixa d'água do bordel. À iminente invasão da polícia, o bandido abandona Ivete dormindo e se esconde ali. De seu esconderijo, ele verá a invasão e o massacre, inclusive a morte da prostituta, queimada pela polícia: "Minha boca fechada há muito, os lábios se mordendo. Ivete cai de vez". ${ }^{414}$

Com a invasão da zona pela polícia, a prisão dos malandros e o massacre das prostitutas, encerra-se uma seção do conto, para começar a última parte da narrativa, "De 53 para cá". Assim como os demais malandros haviam sido capturados no dia da invasão da zona pela polícia, também Paulinho Perna Torta não demora a ser preso. Passa três anos na Casa de Detenção, o Presídio do Carandiru.

$\mathrm{O}$ que poderia ter se configurado como um revés ou uma "queda" ${ }^{415}$ como o próprio narrador descreve o fechamento da zona, torna-se em verdade um novo começo para a criminalidade de São Paulo, a começar do próprio Paulinho Perna Torta. Na prisão, "corre maconha, tóxico, cachaça e carteado". Ali, diz ele, "afino o meu joguinho (...) cobiço e tomo tudo dos outros e penso mais demorado no jeito de roubar". A prisão se revela uma escola de malandragem: "E vou ficando malandro dos malandros". 416

\footnotetext{
${ }^{414} L d c$, p. 141.

415 idem, p. 142.

${ }^{416}$ idem, p. 143.
} 
De moleque de rua e engraxate a malandro dos malandros. O sentido da trajetória será de ascensão até o fim, apesar da ameaça anunciada ao seu nome. Ao sair da cadeia, Paulinho Perna Torta só faz crescer e subir no universo da malandragem. Quanto mais cresce no âmbito da criminalidade, contraditoriamente, mais se afirma também no mundo da legalidade e da ordem, simbolizados pela polícia e pela imprensa, indicando como os dois universos, o do crime e o da lei, se imiscuem.

Passo para o partido alto. Manicuro as unhas, me ajambro com panos ingleses, fumo charuto holandês, e a crônica policial comenta com destaque porque declarei, dia desses, que a minha marca é só Duc George. Holandês. E caftinar é o negócio.

(...)

Nas madrugadas altas, entro no Parreirinha, ali na Conselheiro Nébias. Frequento, uma boneca a tiracolo sempre, dessas putinhas de teatro de revista.

Sou tratado de doutor, jornalistas me adulam. E nessas umas e outras me estendem convites. Com as equipes esportivas dos jornais e dos rádios, conheço a Argentina, o Uruguai e o Peru. É Paulinho duma Perna Torta quem nessas delegações melhor ajambra a elegância de sua picada. ${ }^{417}$

A ascensão social de Paulinho Perna Torta é tida como conquistada e definitiva pelo próprio narrador-protagonista: "Passo para o partido alto". E, ainda, o tratamento de doutor e a maneira com que ele transita pela boemia, o teatro de revista, e por certas rodas jornalísticas demonstram que o personagem de fato chegou lá. Entretanto, a inserção é instável, já que as atividades com que conseguiu acumular o capital são criminosas. E sua elegância extravagante, à antiga moda malandra, denuncia sua proveniência suspeita. É por isso que, apesar de circular pelas altas rodas e manter relações íntimas e provavelmente corruptas com certos jornalistas, a imprensa não o perdoa quando ele assassina o cafetão Mandureba, concorrente na rua dos Gusmões, Boca do Lixo: "Os jornais aprontam um escarcéu preto com o nome de Paulinho Perna Torta e me espianto para Campo Grande, Mato Grosso, enquanto Aniz Issara me cuida no fórum". ${ }^{418}$

O malandro ainda mantém, por conta do seu poder econômico, certo controle do judiciário, por meio de seu advogado, que deve "cuidar" de seus processos certamente por meio da influência, do favorecimento e da corrupção. Mas essa curta passagem já anuncia

\footnotetext{
${ }^{417}$ Ldc, pp. 146-147.

${ }^{418}$ idem, p. 147.
} 
certa mudança de tom na maneira com que o narrador-protagonista fala de si próprio e de sua onipotência, antecipando o final da narrativa, em que o protagonista, melancólico, irá questionar sua situação e, mais que isso, sua trajetória.

“Os jornais aprontam um escarcéu preto com o nome de Paulinho Perna Torta": pela primeira vez, ele sucumbe à designação amputada de seu próprio nome, ainda que atribuindo o tratamento de Paulinho Perna Torta, sem o "duma”, aos jornais. E a maneira com que ele se refere à atuação de seu advogado aponta para uma situação de vulnerabilidade: “Aniz Issara me cuida no fórum”. O verbo empregado sugere que o malandro inspira cuidados, e talvez não apenas jurídicos, como logo saberemos, pois, em seguida, a narrativa irá encaminhar-se para o desfecho.

O final do conto retoma a situação inicial e marca uma crise e uma tomada de consciência do protagonista e que, como se disse, já se anunciava desde o começo do relato. A marcação da mudança, de um estado de cobiça, ascensão e euforia que vinha marcando até então a narrativa, para um estado de desnorte, desconfiança e melancolia, porém, não é muito clara.

O narrador continuará a afirmar sua ganância e seus desejos onipotentes de conquista ("Cobiço toda a Boca do Lixo, já me entendo como futuro dono único" "419), continuará a tratar a si próprio de Paulinho duma Perna Torta e a imprensa continuará a difamá-lo (“Os jornalecos me fervem outra vez"420), mas as dúvidas e as inseguranças começam a assumir o primeiro plano ("Nessa coisarada de façanhas, já não sei a quantas ando" $\left.{ }^{421}\right)$.

Após uma fuga para Curitiba, depois de Paulinho Perna Torta cometer mais um assassinato $^{422}$ — à morte de Mandureba segue a de outro malandro, Valdão ou

\footnotetext{
${ }^{419}$ Ldc, p. 147.

${ }^{420}$ idem, p. 148.

421 idem, ibidem.

422 Como mostra Edu Teruki Otsuka, a “dimensão sombria da malandragem” compreende uma rede de vinganças entre os mais pobres. Este "espírito rixoso" que permeia a relação dos despossuídos — que vivem na dialética entre a ordem e a desordem, o lícito e o ilícito, a norma e a infração da lei — é expressão da própria lógica de uma sociedade estruturada na desigualdade profunda. Nesse sentido, a criminalidade avançada do conto em análise atualiza o funcionamento da malandragem nos termos analisados por Antonio Candido em Memórias de um sargento de milícia e aprofundados por Otsuka, situando o universo de Paulinho Perna Torta nessa tradição "sombria" da malandragem, que não afronta a ordem vigente ou a posição de superioridade de proprietários e poderosos, reafirmando as desigualdades sociais. Como diz o autor, a respeito da situação do Brasil escravista, mas em observação válida para os dias de Perna Torta, "a percepção da divergência de interesses existe, mas ela não contribui para insuflar nos pobres a vontade de modificar as
} 
Valdãozinho, que caguetou Paulinho Perna Torta para a polícia —, a narrativa ganha uma interrupção, marcada no texto por um espaço, do tamanho de um linha, para a continuação da narrativa. $\mathrm{O}$ espaço indica uma elipse de tempo, que entretanto não é grande. Marca, mais que isso, a mudança definitiva do tom do relato. Passa-se agora a narrar a crise de consciência do malandro. Mas, como se vê, ela não se formula claramente: "Não é mulher bonita, nem gostar o que está me perdendo. Laércio Arrudão, os anos de janela e de Detenção não me ensinaram tudo". ${ }^{423}$

Para reafirmar a indeterminação do que o incomoda, a partir daí, o narrador irá usar a palavra "encabulação", ligada à macumba de um malandro: “A encabulação maior me nasce de umas coisas bestas, cuja descoberta e matutação a ginga macumbeira de Zião da Gameleira começou a me despertar. Uma virada do destino, na vida andeja deste aqui". 424

Ao final do conto, o protagonista diz que, ao fazer trinta anos, se deu conta de que talvez tenha se iludido esse tempo todo de malandragem: "Tenho a impressão de que me preguei uma mentirada enorme nestes anos todos". O presente da ação narrativa, anunciado desde o início, coincide no final com o momento de tomada de consciência de Paulinho Perna Torta, evento mais uma vez relacionado ao seu nome.

E é uma porcaria. Meu nome é ninguém. Paulinho duma Perna Torta, de quem andam encurtando o nome por aí, é uma mentira. Como foram Saracura, Marrom, Diabo Loiro, Bola Preta... e como são esses de hoje em dia, donos disso e daquilo, da putaria, do jogo, das virações... A gente não é ninguém, a gente nunca foi. A gente some, apagado, qualquer hora dessas, em que a polícia ou outro mais malandro nos acerte.

- O que é que eu tenho feito?

A gente pensa que está subindo muito nos pontos de uma carreira, mas apenas está se chegando para mais perto do fim. E como percebo, de repente, quanto estou sozinho!

Uma parada sem jeito, ô encabulação! Agora a briga não é com ninguém, não. O pior de tudo, o espeto é que eu mesmo estou me desacatando e me dando um esporro. E é o maior enrosco!

relações vigentes. Como a própria revolta assume feição pessoal e não de classe, as diferenças sociais acabam estimulando antes o desejo de obter vantagens no interior das relações de desigualdade (ao invés de transformá-las).". OTsuKA, Edu Teruki. "Era no tempo do rei. A dimensão sombria da malandragem e a atualidade das Memórias de um sargento de milícias. Tese de doutorado, DTLLC, FFLCH-USP, 2005 , p. 128. ${ }^{423} L d c$, p. 149.

${ }^{424} L d c, 149-150$. 
Eu acho que ando muito cansado. ${ }^{425}$

Depois de relembrar seus anos de formação na malandragem, sua passagem pela cadeia e sua vitória no mundo da bandidagem, o malandro se dá conta de que talvez toda essa trajetória tenha sido uma grande "mentirada". A história pessoal do personagem é vazia de sentido, já que depois "que a polícia ou outro mais malandro" o acertarem restará o nada. Paulinho Perna Torta vai se tornar um "ninguém", destino de todos os bandidos de origem pobre - a dimensão coletiva da catástrofe anunciada é expressa na narração do personagem, que fala em nome da malandragem-bandidagem, como denota o sujeito "a gente" das orações em que Paulinho Perna Torta antevê seu destino de malandro-bandido. Apesar de ter se tornado um criminoso temido, apesar de ter passado para o partido alto, apesar de sua ascensão econômica, Paulinho Perna Torta percebe que não pode mais voltar a ser reles malandro e que seu nome, assim como ele próprio, logo será apagado, tornandose uma "mentirada", um "ninguém".

A trajetória de Paulinho Perna Torta culmina, na consciência do próprio personagem, na crise de identidade que se expressa na ameaça a seu nome. A crise emocional é profunda, mas difusa, pois o personagem não sabe dizer por que, afinal, sentese culpado e solitário, já que conseguiu tudo o que cobiçou: dinheiro, fama e uma namorada, de nome sugestivo, Maria Princesa, ${ }^{426}$ que lhe dá status.

O estado depressivo e autodestrutivo é uma "encabulação", como ele próprio o define, encabulação relacionada à macumba de Zião da Gameleira. O isolamento e o desamparo do personagem ganham condensação na ameaça ao nome, que é ameaça a ele próprio. Paulinho Perna Torta percebe a ambiguidade insolúvel relacionada ao seu nome de

\footnotetext{
${ }^{425}$ idem, p. 150. Esta edição, que é a mais recente do livro e referência para as nossas citações neste trabalho, traz um erro na passagem citada. O livro registra: "E como percebo, de repente, quando estou sozinho!" (grifo meu). O correto é quanto, como indicam todas as demais edições do livro consultadas: Melhores contos de João Antônio. $3^{\mathrm{a}}$ edição. São Paulo: Global, 2001; Leão-de-chácara. $7^{\mathrm{a}}$ edição. São Paulo: Estação Liberdade, 1989; Patuléia. Gentes da rua. São Paulo: Ática, 1996, Paulinho Perna Torta. 12a edição. Porto Alegre: Mercado Aberto, 1993. No Arquivo João Antônio, na Unesp de Assis, tivemos oportunidade de consultar o manuscrito do conto. A letra miúda, mas clara, do autor registra "quanto". A reprodução do manuscrito com este trecho do conto está no Apêndice desta tese.

${ }^{426}$ É assim que o protagonista se refere a ela: "E Maria Princesa, minha última de umas e outras fixas, é uma boneca e novinha cheirando a broto do interior — tratada, vestida, desfila como rainha....". (p. 149). Veremos adiante como os fumos de nobreza são ambição, fantasia e estratégia de sobrevivência do malandro.
} 
guerra: é o apelido que lhe deu fama e "tamanho", e é o nome que será perseguido, amputado e apagado.

O nome que corre é o nome que encurrala.

E como o nome é a identidade e está inscrito no corpo do protagonista, é um nome do qual o personagem não pode se desfazer.

Ao longo deste capítulo, voltaremos a examinar as ambiguidades relacionadas ao nome do protagonista, que percorrem todo o texto. Além dessa questão, vale a pena comentar dois outros aspectos do conto, um deles ligado a esse tema e outro que, apesar de não assumir o primeiro plano narrativo, estrutura todo o relato. Trata-se, respectivamente, do parricídio e do dinheiro, que se ligam à questão do nome e também à ascensão e à queda do malandro - temas com os quais encerraremos este trabalho.

\section{O desejo e o dinheiro}

Para Paulinho Perna Torta, como ensina Laércio Arrudão, "só o dinheiro interessa", "só ele é positivo". Além da ameaça a seu nome e do fantasma do parricídio, o protagonista se vê, desde o começo do relato, até o fim, às voltas com a falta do dinheiro e o imperativo de consegui-lo, das mais diversas formas. A necessidade e a ubiquidade do dinheiro já podiam ser localizadas, sempre latentes, em "Malagueta Perus e Bacanaço", ainda que a sinuca e a representação dos personagens assumisse o primeiro plano da ação e, de certa forma, empurrasse para a sombra os motores do relato: a ganância e a miragem da grana.

Neste conto, porém, a cobiça é o tema central. Como já se disse, o texto foi escrito sob encomenda para uma antologia de contos inspirados nos mandamentos bíblicos. "Paulinho Perna Torta" inspirava-se no mandamento "Não cobiçar as coisas alheias". O conto, porém, não tem nada de bíblico ou de religioso, apesar de, como sempre em João Antônio, relacionar-se em negativo com o universo cristão.

Não se trata, obviamente, de um conto que chancele o mandamento que o inspira. Ao contrário, ele evidencia como o preceito cristão que condena a ganância não tem lugar no contexto histórico e social em que a trama se desenvolve, senão enquanto instrumento de dominação. No universo do conto, justo ao contrário, a cobiça é o que move o 
protagonista. Em suas perambulações iniciais e, depois, como malandro e criminoso, a sede do dinheiro é o que irá nortear seu caminho.

Em sentido afinado ao preceito bíblico, entretanto, cedo aparecem as forças contrárias ao seu desejo de posse e enriquecimento. No conto, porém, o impedimento à cobiça ganha tons não religiosos, mas sociais e psicológicos. São aqueles que estão acima do protagonista, na escala social e no amadurecimento pessoal, que irão, sempre implicitamente, impôr-lhe o mandamento bíblico, nunca enunciado no relato, mas evocado pelo narrador em certos momentos, para marcar sua motivação e, depois, seu arrependimento.

Antes de encontrar Laércio Arrudão, o menino se virava engraxando nas estações de trem da cidade. Na Luz, tomavam-lhe o dinheiro. Então, ele decide procurar outro lugar para a viração. Vai para a vizinha estação Júlio Prestes, onde passa a ser explorado pelo dono da banca de jornais. Nesta fase de virações, o narrador dirá que era um "trouxinha", "moleque escorraçado". E o primeiro ato de desafio à situação opressora em que vive se dá em função do dinheiro: ele quer se apoderar do "tufo" de dinheiro daquele que o explora:

O dinheiro do cara era gordo, era um tufo. Com aquilo eu faria gato e sapato, mil e uma presepadas, me arrumaria a vida. Ferveria.

Eu era um trouxinha que não sabia mandar o dinheiro do alheio. ${ }^{427}$

A cobiça do protagonista aparece, desde cedo, como um desejo, como um desejo reprimido pela violência de alguém mais forte: “(...) os safanões que levei no meio das ventas, quando me atrevia a vontades, me ensinaram que o meu negócio era ver e desejar. Parasse aí." 428 Ele quer ter os sapatos dos clientes, mas os safanões o colocam no seu devido lugar: ele é apenas um engraxate, moleque, trouxa. Seu desejo e sua cobiça, portanto, são reprimidos e sua aventura está impedida. A ação do personagem está fadada à rotina de trouxa: violência e frustração, exploração de sua força de trabalho e sofrimento.

A estrutura da narrativa, no entanto, que parte de um momento presente para voltar às origens do protagonista na malandragem, apresenta ao leitor, simultaneamente, a ambivalência constitutiva do personagem, também em relação ao dinheiro: ele é o Paulinho

\footnotetext{
${ }^{427} L d c$, p. 106.

${ }^{428}$ idem, p. 100.
} 
Perna Torta que se tornou criminoso bem-sucedido e é o menino escorraçado, trouxinha, sem dinheiro. É o narrador, já adulto, criminoso falado, que relembra seus tempos de menino.

Eu bem podia me virar na Estação da Luz. Também rendia lá. Fazia muito freguês de subúrbio e até de outras cidades. Franco da Rocha, Perus, Jundiaí... Descidos dos trens, marmiteiros ou trabalhadores do comércio, das lojas, gente do escritório da estrada de ferro, todo esse povo de gravata que ganha mal. Mas me largava o carvão, o mocó, a gordura, o maldito, o tutu, o pororó, o mango, o vento, a granuncha. A seda, a gaita, a grana, a gaitolina, o capim, o concreto, o abre-caminho, o cobre, a nota, a manteiga, o agrião, o pinhão. O positivo, o algum, o dinheiro. Aquele um de que eu precisava para me aguentar nas pernas sujas, almoçando banana, pastéis, sanduíches. E com que pagava para dormir a um canto com os vagabundos lá nos escuros da Pensão do Triunfo. Onde muita vez eu curti dor de dente sozinho, quieto no meu canto, abafando o som da boca, para não perturbar os outros. ${ }^{429}$

Neste momento em que relembra seus primeiros tempos na Pensão do Triunfo note-se a ironia do nome da pensão, habitada por toda a sorte de perdedores que sonham com o triunfo - , Paulinho Perna Torta relembra a fome e as dores de dente que enfrentou, sozinho, sem companhia, sem ter a quem recorrer: amigos, parentes ou instituições.

É sintomático que o narrador, neste momento que é o da juventude do malandro mas já é também o do tempo presente da ação narrativa, isto é, que, neste tempo rememorativo, ele, que irá se tornar o rei da Boca, relembre o tempo em que sofria de fome e de dor de dente. A conquista futura do malandro que virou criminoso e se tornou soberano da Boca ganha, assim, contornos ainda mais extraordinários, ligadas aos campos semânticos da boca, da comida, da fome e da dor. Neste momento em que ainda não é criminoso, ele já pratica as artes da viração, mas vive isolado, sem o amparo dos irmãos e do padrinho de malandragem, e pode contar apenas com o dinheiro incerto, conseguido graças à viração.

A rememoração liga presente e passado. O personagem que narra relembrando fatos que já ocorreram atualiza a experiência passada para atar sua história pregressa à situação do momento presente, que ordena o desenvolvimento da narrativa. O elemento forte que faz essa ponte entre o Paulinho Perna Torta de hoje, bandido poderoso, temido e ameaçado, e o Paulinho Perna Torta menino de rua é o dinheiro.

${ }^{429}$ idem, pp. 101-102. 
O personagem arrola uma série de termos para nomear o dinheiro: "o carvão, o mocó, a gordura, o maldito, o tutu, o pororó, o mango, o vento, a granuncha, a seda, a gaita, a grana, a gaitolina, o capim, o concreto, o abre-caminho, o cobre, a nota, a manteiga, o agrião, o pinhão, o positivo, o algum, o dinheiro". ${ }^{430} \mathrm{O}$ tempo desta cena é aquele em que o protagonista ainda é engraxate, ganha uns trocos para subsistência (para comer, para dormir em pensão, para se “aguentar nas pernas sujas”). Mas é já o personagem-narrador maduro que narra aquele tempo desde o momento presente da narrativa, em que ele já é "malandro dos malandros", depois de ter encontrado Laércio Arrudão e de ter se tornado rei do crime. A série de nomes identificados ao dinheiro será retomada adiante na narrativa, como já vimos, quando o protagonista dirá que aprendeu com o padrinho. É Laércio Arrudão que o ensinará que apenas o dinheiro importa, que "só ele é positivo". 431

A passagem enumera uma série de nomes para o dinheiro, como se a matéria fosse fugidia, como se qualquer designação fosse insuficiente para estabelecer a permanência e a definição deste. $\mathrm{O}$ caráter demoníaco do dinheiro fica ainda mais evidente se lembrarmos a passagem de Grande sertão: veredas em que o protagonista fala do demo. A certa altura de seu relato, Riobaldo elenca as seguintes palavras para se referir ao diabo: “o Tal, o Arrenegado, o Cão, o Cramulhão, o Indivíduo, o Galhardo, o Pé-de-Pato, o Sujo, o Homem, o Tisnado, o Coxo, o Temba, o Azarape, o Coisa-Ruim, o Mafarro, o Pé-Preto, o Canho, o Duba-Dubá, o Rapaz, o Tristonho, o Não-sei-que-diga, O-que-nunca-se-ri, Osem-gracejos". 432

A passagem de "Paulinho Perna Torta" indica a dimensão ao mesmo tempo santa (“o positivo") e demoníaca (“o maldito”) que o dinheiro assumiu. Uma das designações que o narrador usa para defini-lo é "o abre-caminhos", o que indica, além da força econômica, a potência espacial e a conotação mágica que o dinheiro apresenta para este narrador.

Além de comunicar o passado ao presente do protagonista, o dinheiro se liga aos caminhos e ao desejo. É o dinheiro que poderá lançá-lo à aventura e à conquista. Sem ele, o protagonista estava fadado apenas a "ver e desejar". Paradoxalmente, porém, a força do

\footnotetext{
${ }^{430} L d c$, p. 102.

${ }^{431}$ idem, p. 121. A mesma passagem em que Laércio Arrudão ensina a importância do dinheiro a Paulinho Perna Torta é uma das epígrafes ao conto: “... quem gosta da gente é a gente. Só. E apenas o dinheiro interessa. Só ele é positivo. O resto são frescuras do coração." A outra epígrafe é um trecho de "Século do progresso", composição de Noel Rosa: "Um valente muito sério, / professor de desacatos / que ensinava aos pacatos /o rumo do cemitério".

${ }_{432}$ RosA, João Guimarães. Grande sertão: veredas. Rio de Janeiro: Nova Fronteira, 1986, pp. 29-30.
} 
dinheiro tem o poder de submeter tudo à sua lógica: desejo, aventura, memória, conquista e perdição.

Segundo essa dinâmica, impulsos, afetos e ações direcionam-se à tomada do dinheiro e à acumulação financeira, num jogo em que vale tudo e os mesmos valores e procedimentos são positivos e negativos, violência e sedução se confundem, conduta certa e errada não se distinguem: o desejo que Paulinho Perna Torta sente por Ivete logo se torna violência e exploração; a mulher vira uma "mina", de onde o personagem irá "mamar" o dinheiro; o trabalho, mesmo os trabalhos informais a que o protagonista se submeteu quando menino, desaparece para dar lugar à exploração (a cafetinagem e a féria que um malandro cobra do outro), ao jogo e ao tráfico; as instituições também se corrompem: polícia, imprensa e Justiça estão submetidas ao poder financeiro e funcionam de acordo com esse interesse.

Em um contexto social em que o dinheiro se tornou ubíquo e corroeu as instituições, a malandragem é a normalidade. Para os que nasceram pobres é, além da regra de funcionamento geral, um modo de existir, quando não inevitável, muito sedutor, pois permite vislumbrar, além da pobreza e da penúria, promessas de ascensão e inserção. E, entretanto, a malandragem assegura apenas a ambiguidade frágil e fugidia dessa promessa, pois, como indica a narrativa de Paulinho Perna Torta, sua vida, assim como seu nome, está ameaçada, até que "um mais malandro o acerte".

Nesse sentido, Paulinho Perna Torta é um personagem social típico do autor, tal como os define Jesus Antonio Durigan:

As personagens de João Antônio, em toda sua obra, constituem uma galeria de tipos residuais, trapos humanos, marginalizados pela sociedade cruel que aparentemente abriga e "protege" os otários, aqueles que são integrados. Aos malandros, personagens prediletas de sua ficção - jogadores, gigolôs, prostitutas, viradores, praças, dedo-duros, artistas decadentes, marginais — não lhes resta tão-somente a exclusão do sistema, mas lhes são negados até o direito e o sonho de conseguir os mesmos objetivos da 'gente bem', restando-lhes apenas a sobrevivência difícil, só alcançada quando o malandro quer sobreviver e sabe como fazê-lo. Daí a necessidade de seus personagens buscarem um aprendizado diário no submundo, na sarjeta, no prostíbulo, nos grupos marginais. 433

${ }^{433}$ DURIGAN, J. A. “João Antônio: o leão e a estrela”, in Leão-de-chácara, op. cit., p. 14. 
Nesse contexto em que o dinheiro compra tudo e subsume tudo, aos mais pobres resta sobreviver e conformar-se com a falta e a penúria ou sonhar com uma promessa de ascensão, desde sempre latente e sedutora, mas incerta e tortuosa (se pela via da malandragem) e promissora e acelerada (se trilhada pelos caminhos do crime). A ascensão, para os merdunchos é vislumbrada, pois eles também são parte da sociedade, apesar de excluídos da sociedade de "bem" — o que o polo "bem" não reconhece é que a malandragem é parte mesmo dessa “ordem” social. De todo modo, para a malandragem e para o crime, a trajetória ascendente está sempre sujeita à difamação, à fuga, ao estrepe e antes da queda, perdição, morte —, à cadeia. Mas a prisão, porém, é uma queda, mas uma queda para o alto, pois a cadeia, no universo da malandragem e do crime, é escola, o que repõe o moto contínuo de alternância entre legalidade e ilegalidade, ordem e desordem.

Excetuando as opções da malandragem e do crime, para sobreviver os mais pobres precisam vender o pouco que têm: os corpos e a força de trabalho. A remuneração da força de trabalho, porém, nem sempre é garantida, como indicam as variadas opções de trabalho informal que Paulinho Perna Torta exerce antes de entrar para a malandragem. E para alguém sem origem definida, como Paulinho Perna Torta, sem casa e sem família, escola ou emprego, sem instituições e sem Estado, sobrevivência confunde-se com malandragem, que depois se torna crime, já que nele a cobiça e o vislumbre de ascensão encontram terreno aberto e seguro, pois que ele é parte constitutiva dessa organização social.

A segurança e a liberdade, a amizade e o desafio, Paulinho Perna Torta vai encontrar no dinheiro... e no padrinho. Quando Paulinho Perna Torta decide fugir, diz que precisa de uma cobertura (“eu que me cobrisse”). Quando encontra Laércio Arrudão e é apadrinhado por ele, diz que pela primeira vez tinha uma "casa".

A casa, porém, é a boca de Arrudão, lugar que é refúgio, mas também é alvo da polícia e de outros malandros.

A casa de Paulinho Perna Torta é uma "boca": lugar que alimenta e que devora, onde ele entrou moleque de rua e se tornou malandro, onde é malandro, mas também criminoso, onde trabalha, mas também onde faz trapaças e inicia a vida de cafetão, a trajetória de empresário e depois de "rei" do jogo e do tráfico. No entanto, nem mesmo na boca ele encontra uma casa estável. A ciranda da fortuna e da malandragem fará com que 
ele não tenha parada nem na boca nem mesmo em outra "casa" onde ele "encontra" refúgio: a Casa de Detenção.

Não surpreende, então, que nesse contexto em que o dinheiro se tornou ubíquo adorado e demoníaco, o positivo e o maldito - o último refúgio dos mais pobres, talvez o único refúgio daqueles de origem pobre seja o corpo. ${ }^{434}$

Às mulheres, resta vender o próprio corpo: a prostituição. Tornam-se "minas" dos malandros. Aos malandros, cumpre explorar: as prostitutas, os otários e os outros malandros; e, no limite, matar.

A imprensa, a polícia e logo a cidade inteira vão deixar de chamar o protagonista de Paulinho duma Perna Torta. Em breve, vão amputá-lo, o nome, para Perna Torta. Depois de ter o nome amputado, também ele, o corpo, voltará a ser amputado, Paulinho Perna Torta vai ser "apagado".

É porque o corpo se tornou a casa - porque o corpo é a identidade de Paulinho Perna Torta, que tem no seu nome de guerra a alusão a um desvio do seu corpo —, é porque corpo e casa coincidem que a ameaça ao seu nome é também ameaça à sua morada, à sua cobertura, ao seu corpo. É ameaça à própria existência de Paulinho Perna Torta, que, ele mesmo percebe, será apagado, ele e o nome, sem restar sequer o nome "para contar história", como se diz.

Como o corpo e o nome se tornaram a última morada do malandro, Paulinho Perna Torta, assim como já o fizera Laércio Arrudão, passa a cuidar da fama, mas também da aparência, como um bom malandro de antigamente. Para passar para o partido alto, não basta o dinheiro. Para ser do partido alto, é preciso parecer do partido alto. Para alguém de origem pobre, é preciso passar a se vestir bem, cuidar das unhas, fumar charutos finos. É preciso se fantasiar de alguém da alta classe: "Manicuro as unhas, me ajambro com panos ingleses, fumo charuto holandês (...)”. Para esconder a origem plebeia, é preciso se

\footnotetext{
${ }^{434}$ A conhecida fórmula de Lima Barreto "O subúrbio é o refúgio dos infelizes" encontra então um novo patamar histórico, em que os infelizes, apesar de não necessariamente estarem nos subúrbios, não encontram, tampouco, refúgio onde quer que estejam, pois o último refúgio é o corpo e o nome, ameaçados ambos por conta mesmo da informalidade e da vulnerabilidade impostas a eles. A malandragem em seu momento de constituição, por meio do samba, tornava a favela nos morros cariocas uma alternativa ao subúrbio infeliz e subvertia a noção de territorialidade, tornando o corpo um refúgio malandro, por meio da dança e do rebolado. Mas a malandragem do jogo, da sinuca e do carteado, da prostituição, da ubiquidade do dinheiro e da criminalidade em escala industrial transformou o corpo de refúgio em alvo.
} 
fantasiar de nobre: Laércio Arrudão, "bem ajambrado e já senhor, no terno claro de brilhante inglês", tinha "imponência" e "batida de lorde num macio rebolado".

É o padrinho, Laércio Arrudão, quem ensina a importância do dinheiro, o positivo e o maldito. É o padrinho o exemplo a ser seguido, como indica a fantasia de malandro, estratégia de inserção amalandrada: não tendo lugar "instituído" na sociedade burguesa, o malandro se traveste de nobre. Lorde, como Laércio, que se veste com alinho e não trabalha, "faz a féria", apenas explora seus, digamos, súditos, os pequenos malandros que lhe servem. Como já dizia Chico Buarque, "o malandro é o barão da ralé", 435

Paulinho Perna Torta irá emular o padrinho, ao passar para o partido alto e começar a se comportar e se trajar como malandro das antigas: mãos manicuradas, roupa boa, charuto fino, relações promíscuas com a polícia, a imprensa e a Justiça. Mas, como já se disse, Paulinho Perna Torta não vai parar por aí. Sua cobiça e seu desejo de conquista o fazem ultrapassar o padrinho, ainda que conservando a lealdade que lhe deve, seu afeto e sua gratidão.

Seguir e emular o padrinho ou ultrapassá-lo, eis a questão do malandro.

\section{Matar ou não matar o pai?}

O encontro de Paulinho Perna Torta com o malando mais velho, Laércio Arrudão, que o adota na zona, marca a passagem do protagonista de engraxate a virador, de menino a malandro. A descrição do encontro com o padrinho é transbordante de afeto e admiração:

Engraxando lá uns tempos nas caixas da entrada da barbearia, que eu conheci, bem ajambrado e já senhor, no terno claro de brilhante inglês, que fazia a gente olhar, mão luzindo um chuveiro e dentes brancos muito direitinhos, um mulato muito falado nas rodas da malandragem, professor de picardias, dono de suas posses e ô simpatia, ô imponência, ô batida de lorde num macio rebolado! Laércio Arrudão.

435 A canção “A volta do malandro" (1985), de Chico Buarque, feita para o filme A ópera do malandro, diz: "Eis o malandro na praça outra vez / Caminhando na ponta dos pés / Como quem pisa nos corações/ Que rolaram dos cabarés // Entre deusas e bofetões/ Entre dados e coronéis/ Entre parangolés e patrões/ O malandro anda assim de viés // Deixa balançar a maré/ E a poeira assentar no chão/ Deixa a praça virar um salão/ Que o malandro é o barão da ralé". Sobre a composição da música, ver HoMEM, Wagner. Histórias de canções: Chico Buarque. São Paulo: Leya, 2009. 
Que foi pelos meus olhos acesos e verdes ou pela minha cara de esperto muito acordado; que foi pela mão de Deus ou por uma trampolinagem do capeta. Mas foi a minha maior colher de chá, o meu bem-bom, a minha virada nesta vida andeja.

Laércio Arrudão me topou e me deu uma luz, me carregando para empregado lá na zona, no boteco da Alameda Nothmann. Ali, no Bom Retiro. Pegado aos trilhos do bonde, na esquina da rua Itaboca, defronte à rua dos Italianos; ali, naquele muquifo escuro, onde minha vida virou, é que os vadios das curriolas, os trouxas das ruas, os tiras das rondas, as minas, as caftinas, os invertidos, as empregadas da zona e os malandros encostavam o umbigo no balcão pedindo coisas, balangando seus corpos e queimando o pé nas bebidas. E cujo nome, de muito peso e força, era repetido de boca cheia na fala da malandragem. Boca do Arrudão.

Pela primeira vez eu morava em algum lugar. ${ }^{436}$

Além de encontrar em Arrudão um padrinho que lhe dá "cobertura" e lhe oferece um local de trabalho e malandragem, é ali que Paulinho Perna Torta vai encontrar, pela primeira vez, uma casa, como indica a última frase do trecho acima. Os termos com que o malandro mais velho é descrito são carregados de uma afetividade a um só tempo infantil e erótica ("minha colher de chá", "meu bem-bom"), revelando a relação umbilical ("os malandros encostavam o umbigo no balcão pedindo coisas") que Paulinho Perna Torta e os demais malandros mantêm com a Boca do Arrudão.

Laércio Arrudão é "professor de picardias", "lorde" de "macio rebolado", "bemajambrado" e já "senhor", mas "imponente". Na figura do malandro mais velho, assim, Paulinho Perna Torta encontra um modelo, padrinho, pai substituto, professor, provedor e protetor. Arrudão é casa, sustento, ensino e malandro que apresenta ao malandreco a picardia.

A relação de Paulinho Perna Torta com Laércio Arrudão é descrita, a princípio, com enlevo e forte conteúdo afetivo e erótico. No entanto, mais adiante, a crueldade e a violência da malandragem de Laércio Arrudão vão se tornar explícitas na enunciação. É quando o narrador credita ao aconselhamento de Laércio Arrudão a sua mudança de atitude com relação à prostituta Ivete, a fim de "deixar de ser um pivete frouxo". Cansado de se submeter às vontades dela, seguindo os conselhos do malandro mais velho, ele recorre à força para se impor como cafetão desta prostituta.

${ }^{436} L d c$, p. 111. 
O brilho de simpatia nos olhos de Laércio Arrudão começou por me ensinar que quem bate é o homem. E manda surra a toda hora e fala pouco. Quem chega tarde é o homem. Quem tem cinco-dez mulheres é o homem - a mulher só tem um homem. Quem vive bem é ele - para tanto, a mulher trabalha, se vira e arruma a grana. Quem impõe vontades, nove-horas, cocorecos, bicos-depato e lero-leros é o macho. Homem grita, manda e desmanda, exige, dispõe, põe cara feia e pede pressa. A mulher ouve e não diz um a, nem sim, nem não, rabo entre as pernas. Mulher só serve para dar dinheiro ao seu malandro. Todo o dinheiro. Por isso, entre os malandros da baixa e da alta, as mulheres se chamam minas.

Laércio Arrudão me ensinou.

- Mulher lava os pés do seu homem e enxuga com os cabelos.

Laércio Arrudão me ensinou.

- Outra coisa: duas ondas bestas podem perder um homem. Gostar e mulher bonita. Malandro que é malandro se espianta e evita tudo isso.

Pousando as duas mãos nos meus ombros, falando baixo e sério um português bem clarinho, Laércio começava a me escolar que quem gosta da gente é a gente. Só. E apenas o dinheiro interessa. Só ele é positivo. O resto são frescuras do coração.

Eu precisava tomar uns pontos na ignorância.

À noite, à toa, à toa, meti-lhe um sopapo na caixa do pensamento. Ela caiu e quis pôr a boca no mundo. Chapoletei-lhe mais um muquete e se aquietou.

- Fale baixo comigo.

Agora, ganha porrada toda a mão que tenta uma liberdade. Às vezes, à frente das outras mulheres do Salão Azul. Então, meu nome se espalha e começa a ganhar tamanho na zona. Boquejam à boca pequena:

Um valente ponta firme.

Ivete se sente mulher de malandro e me agrada mais. Vem se aninhar como uma cachorra. Sou temido e presenteado. ${ }^{437}$

A passagem acima indica que graças aos conselhos de Laércio Arrudão, os quais o protagonista leva à risca, finalmente ele ganhou fama de "valente". Ao atender às recomendações de bater em Ivete, prostituta de quem é cafetão, o protagonista não apenas se torna malandro temido e respeitado por ela, mas também por outras pessoas que vivem na zona. É ali que o seu nome "se espalha e começa a ganhar tamanho".

A violência e a crueldade da cena em que o malandro passa a bater na prostituta dispensam comentário. Vale destacar, porém, que as surras e outras violações que Paulinho

${ }^{437} L d c$, pp. 120-121. 
Perna Torta impõe a Ivete (e depois também a Valquíria) vêm emolduradas por contornos de simpatia e lirismo. Seguindo a ambivalência com que ele próprio conta a sua história, o narrador começa por dizer que foi o "brilho de simpatia" do olhar do malandro mais velho que the ensinou a bater em mulher. Além dessa introdução que pinta de tons positivos ("brilho", "simpatia") os conselhos do malandro experiente, a linguagem do trecho também combina um vocabulário limpo e direto a certo linguajar colorido e dissimulado, para falar dos gestos e atitudes violentos ("nove-horas", "cocorecos", "bicos-de-pato" e "lero-leros").

Para completar a moldura lírica da crueldade de Paulinho Perna Torta, a passagem vem toda ela rememorada durante um longo trecho em que o narrador empreende um passeio de bicicleta pelas ruas da cidade: "E zanzo demais por aí, em cima da minha magrela. Gosto do pedal. Nele é bom curtir essa onda de andar. Sei lá por que gosto. Sei que gosto. Atravesso essas ruas de peito aberto, rasgando bairros inteirinhos, numa chispa, que vou largando tudo para trás — homens, casas, ruas. Esse vento na cara...". ${ }^{438}$

Após a cena da violência contra a prostituta o narrador retoma, na elocução, o passeio de bicicleta, que irá culminar nos arredores do estádio do Pacaembu, onde o protagonista fica "namorando com os olhos" uma "dona novinha", "filha de bacana", uma "princesa", uma "boneca", uma "gata", em quem, ele reconhece, não pode "pular em cima”, pois ela, nas palavras dele próprio, "é do partido alto e minha charla ali não dá pé".

O contraste com a maneira com que ele trata a prostituta e a menina da alta sociedade é sintomático. Ele descreve como passou a tratar de Ivete como propriedade sua; ao passo que a moça do partido alto, que vai aos arredores do estádio fazer aulas de direção de automóvel, ele não tem como conquistar, nem pela força ("pulando em cima" da "gata"), nem pela fala (a "charla") - a única possibilidade, talvez, fosse passar por alguém do partido alto, algo que o narrador ainda não entrevê. A dualidade de ternura e violência culmina na frase final sobre a menina rica: “(...) se pego essa criança costuro toda de carinho". 439

O flerte com a moça do partido alto aponta para um impulso de Paulinho Perna Torta que o afasta da zona e que o distancia dos conselhos de Laércio Arrudão ("apenas o dinheiro interessa, o resto são frescuras do coração"), ainda que a ascensão que o possível

\footnotetext{
${ }^{438}$ Ldc, p. 113.

${ }^{439}$ Ldc, p. 122.
} 
relacionamento com a moça pudesse proporcionar seja coerente com o ensino de que só o dinheiro interessa. Os desejos de ascensão social, de passar para o partido alto, ganham nesta passagem um momento que resume a contradição do relacionamento de Paulinho Perna Torta e seu padrinho. O malandro mais velho é a um só tempo um igual, um irmão de malandragem, a quem Paulinho Perna Torta deve lealdade e fidelidade, mas também um pai substituto, que apesar de ter o respeito e a admiração de Paulinho Perna Torta, tende a ser ultrapassado por ele. A moça que não faz parte do universo da zona, em contraste com Ivete e Valquíria, o namoro no bairro "bom”, o Pacaembu, e não no bairro "degradado", a zona do Bom Retiro, indicam que o malandro mais novo permanece em conflito com a figura paterna de Laércio Arrudão: sabe que só o dinheiro interessa, mas quer passar para o partido alto, adquirindo não apenas capital, mas também status; explora a prostituta Ivete, mas sonha com a moça da alta classe.

O conflito não enunciado com o padrinho de malandragem aponta para uma contradição que é anunciada, afrontada e desfeita, mas que permanece operando na trajetória de Paulinho Perna Torta. O malandro mais novo quer ultrapassar o padrinho, mas lhe deve fidelidade. Trata-se de um relação de ambiguidade difícil de resolver.

Ao comentar os sentimentos conflituosos, a relação de amor e ódio em relação ao pai, Freud observa, em "Totem e tabu”:

(...) a ambivalência implícita no complexo-pai persiste geralmente no totemismo e nas religiões. A religião totêmica não apenas compreendia expressões de remorso e tentativas de expiação, mas também servia como recordação de triunfo sobre o pai. A satisfação por esse triunfo levou à instituição do festival rememorativo da refeição totêmica, no qual as restrições da obediência adiada não mais se mantêm. Assim, tornou-se um dever repetir o crime de parricídio muitas vezes, através do sacrifício do animal totêmico, sempre que, em consequiência das condições mutantes da vida, o fruto acalentado do crime - a apropriação dos atributos paternos - ameaçava desaparecer. Não nos surpreenderá descobrir que o elemento da rebeldia filial também surge nos produtos posteriores da religião, freqüentemente sob os mais estranhos disfarces e transformações. 440

\footnotetext{
${ }^{440}$ FREUD, S. "Totem e tabu". In: Edição standard brasileira das obras psicológicas completas de Sigmund Freud. Vol. XIII. Rio de Janeiro: Imago, 1996, pp. 174-175.
} 
Os impulsos agressivos dos filhos em relação ao pai, como sugere Freud, têm papel central nas organizações sociais, nas quais substitui-se o pai por figuras paternas ou totens, na passagem da "horda primitiva" para a "civilização" ou "cultura". Estariam aí as origens dos sentimentos religiosos, que transformam o pai real em pai simbólico, ou Deus. E nos produtos posteriores da religião, isto é, nas organizações sociais complexas, estaria na simbolização da figura paterna a origem da disposição coletiva em obedecer a um conceito abstrato de limite ou de lei, que faz as vezes de pai quando pai não há, isto é, quando se vive em uma sociedade livre, laica, democrática, sem figura de autoridade tirânica, tornando todos os indivíduos iguais perante certas normas e códigos definidos. Assim, os sentimentos psíquicos que se estabelecem entre pais e filhos e entre filhos e filhos evoluem para sentimentos que exigem transcender os laços pessoais e religiosos, avançando para uma organização social baseada na abstração da lei perante à qual, em tese, todos são iguais. Não vigem mais os impulsos selvagens nem os mandamentos religiosos, mas sim as leis e normas sociais.

As reflexões freudianas sobre as relações conflituosas entre pai e filho, com reflexo na dinâmica social, retomam suas leituras da tragédia de Édipo. Como já vimos, essas reflexões vêm desde $A$ interpretação dos sonhos, onde o autor assinala os sentimentos contraditórios que a figura paterna desperta no filho, especialmente no filho homem, quando este descobre nele um rival pelo amor da mãe.

Marthe Robert, como já observamos no capítulo 2, parte de um texto freudiano, "Romances familiares", para mostrar como os romances encenam sempre dois tipos de histórias sobre a origem de seus protagonistas: as fábulas da Criança Perdida e do Bastardo, que correspondem, na teoria psicanalítica freudiana, às fases edípica e pós-edípica do desenvolvimento do indivíduo. A fábula do Enjeitado ou do Bastardo corresponde ao momento em que a criança descobre a sexualidade e, por consequência, as diferenças entre os gêneros. Passa então a acreditar que a mãe é certa e que o pai que ela acredita ser pai pode não o ser. Assim, a criança rebaixa a mãe a uma situação degradada e alça o pai — o pai que ela não conhece - a uma condição admirável, elevada e nobre. ${ }^{441}$

Com isso, tende a ocorrer a dissolução do Complexo de Édipo, permitindo que a criança, afinal, afaste seus impulsos eróticos em relação à mãe e agressivos em relação ao

\footnotetext{
${ }^{441}$ Ver FREUD, S. "Romances familiares", op. cit., e ROBERT, Marthe, op.cit, pp. 40-44.
} 
pai, ou melhor, reprima esses desejos e os transforme em conteúdos latentes, inconscientes, conferindo caráter simbólico à interdição do incesto (tornado tabu) e ao parricídio (associando a figura do pai ao totem e à lei). Isso acontece, segundo Freud, no caso dos garotos, por conta da "ameaça da castração", que surge na psicologia da criança em decorrência da descoberta da sexualidade e da diferença entre os gêneros. ${ }^{442}$

A construção do protagonista Paulinho Perna Torta concentra, em um único personagem, as duas fábulas de explicação da origem, tanto a da Criança Perdida como a do Bastardo. Ao contrário de Vicente, protagonista de "Busca" - que encarna a fábula do Bastardo, pois perdeu o pai e ainda tem na mãe um elo familiar concreto e seguro, que coincide, nos termos daquele conto, com a sua própria casa —, Paulinho Perna Torta não faz referência a seus pais biológicos, senão para negar a fama de parricida. A origem nebulosa do personagem encena a fábula da Criança Perdida, a história de alguém que nasceu sem saber quem são seus pais e que sonha em reencontrá-los, idealizando-os como pais superiores, protetores e nobres. A certa altura, Paulinho Perna Torta de fato encontra em Laércio Arrudão este segundo pai, um padrinho, pai postiço e substituto que o adota, protege-o e o orienta.

Como diz o discípulo, palavra de Arrudão tem "peso de lei”.

A gente nunca diz apenas Laércio. É Laércio Arrudão.

Que só aparece à noite alta, vistoso e mandão, barbeado e luzindo. Dono da bola, sua palavra tem peso de lei. Canta de galo aqui e não trabalha. Fiscaliza. Faz a féria, pede o livro. Dar ordens é com ele. Os malandros ficam à sua roda ouvindo, aprendendo e adulando. Os irmãos guardam distâncias. Seu andar é de doutor, de chefe, parece um deputado. Meu padrinho. Joga-me um agrado.

- Ô batuta!

Tem o ouro e nunca ninguém soube com certeza sobre o quanto que lhe pertence. Sabe-se que é ligado ao Jóquei Clube, fala-se que tem lá um cavalo no Haras Guarani; à boca pequena boqueja-se que é dono de dois rendez-vous da rua Guaianazes; diz que tem negócio com jogo e

\footnotetext{
${ }^{442}$ FREUD, S. "A dissolução do Complexo de Édipo". In: Obras completas, volume 16. O Eu e o Id, Autobiografia e outros textos (1923-1925). Trad. de Paulo César de Souza. São Paulo: Companhia das Letras, 2011. O sentimento da ameaça de castração, segundo Freud, ocorre, em geral, por meio da repressão ao hábito da masturbação, mas tem sucedâneos: o desligamento do seio materno, a excreção e a descoberta pelo menino do genital feminino, isto é, de que há outro ser humano, tão parecido com ele, mas sem pênis.
} 
contrabando em Santos... A certeza ninguém tem. A gente jamais fica conhecendo Laércio Arrudão. E se está sempre por baixo dele. É homem que não abre o seu jogo. Nem com reza brava. ${ }^{443}$

A caracterização que Paulinho Perna Torta faz do padrinho Laércio Arrudão é a de um pai onipotente, com ares de nobreza e aura misteriosa. Só aparece à noite alta, sempre alinhado, "vistoso". Manda e desmanda ("canta de galo") e ninguém sabe quanto dinheiro tem. Não trabalha, como bom malandro, mas também como fidalgo, como o "lorde" de rebolado macio de que já falara o protagonista. É um pai, na visão do personagem, elevado e dotado de capacidades extraordinárias, que escapam ao entendimento. Paulinho Perna Torta associa-o a figuras paternas simbólicas que são a um só tempo malandras, burguesas, fidalgas, poderosas, inseridas e criminosas: lorde, professor, jogador, contrabandista, doutor, chefe, deputado.

Como o protagonista não tem pai, e não se sabe se ele de fato matou o pai, a adoção dele por Laércio Arrudão o torna afilhado, protegido do velho malandro. Isso confere ao malandro mais novo não mais a condição de Criança Perdida, mas o estatuto de Bastardo, um estatuto, como diz Marthe Robert, "vergonhoso" $e$ "glorioso", pois que o permite, apesar da origem vexatória, engendrar, ele próprio, a mesma história de expansão e conquista, com as capacidades paternas - tomadas do pai, ao transformá-lo em totem (nas organizações tribais) ou em lei (nas sociedades democráticas) - capacidade de convívio (ritual ou social), potência e procriação, em suma, uma capacidade essencial: a de participar "ativamente da fabricação secreta da vida". 444

O Bastardo nunca terminou de matar seu pai para substituí-lo, copiá-lo ou ir mais longe que ele, decidindo "tomar seu caminho". Criminoso em si, não por acidente, mas totalmente, inclusive em virtude de sua inspiração, ele arrasta o romance em sua esteira no ciclo da transgressão em que gira infinitamente em torno de sua consciência pesada e de sua revolta, escandalizado pelas limitações de seu ser, culpado, envergonhado, assombrado pela expiação e o castigo. $^{445}$

\footnotetext{
${ }^{443}$ Ldc, pp. 126-127.

${ }^{444}$ ROBERT, M. op. cit., p. 46.

${ }^{445}$ idem, ibidem.
} 
Paulinho Perna Torta é Criança Perdida $e$ Bastardo. No relato que ele mesmo empreende, como personagem-narrador, não há referência a casa ou à primeira infância. Não se conhece a família, não há menções à educação formal, não há irmãos ou amigos que compartilhem com o personagem a desventura. Isolado, solitário, o protagonista conta que desde cedo teve de inventar o seu próprio caminho. Mas esta empresa, a de fazer a própria história, é contada do ponto de vista de quem deixou de ser um perdido, ou simplesmente um malandro, para se tornar um criminoso. Ele sabe que a sua história, a história que ele próprio decide contar, como narrador de si mesmo, é uma história de ascensão, que ora está ameaçada. Onde, quando e como ela terminará, não se sabe, assim como as origens também são desconhecidas. Mas o início da ação é localizado pelo narrador, como já vimos: "Comecei por baixo, baixo, como todo sofredor começa. Servindo para um, mais malandro, ganhar. Como todo infeliz começa. Já cedinho batucava. — Vai um brilho, moço?”. ${ }^{446}$

Não se sabe de família na vida de Perna Torta. Ou melhor, sabemos apenas do pai, dos boatos que contam de que ele matou o próprio pai: "Ainda escrevem aí que matei meu pai a tiros por causa de uma herança... Esses tontos dos jornais me botam cabreiro". A fama que lhe colocaram é de parricida, o que ele nega, sem porém conseguir se desvencilhar dela. Antes mesmo de encontrar um pai substituto - uma figura paterna protetora, na pessoa do malandro Laércio Arrudão -, o personagem já encontrara outra figura paterna, mas opressora, no jornaleiro que o explorava na estação Julio Prestes. Para escapar dele, como já dissemos, o protagonista recorre à ginga e ao deslizamento, relacionando-se antecipadamente e em negativo com destino de "perna torta". Ainda antes de enfrentar esse patrão explorador e de encontrar o padrinho, ele já observara que havia começado por baixo, servindo malandros maiores. A maneira com que ele apresenta a própria história é como se estivesse predestinado a ser explorado: "como todo sofredor começa". Além disso, a corroborar a predestinação, as primeiras virações confirmam o que lhe foi destinado: o protagonista se achava em posição de inferioridade em relação aos malandros que the tomavam o dinheiro na Estação da Luz. Para escapar destes, diz que teve de "mancar", "deslizando" dos malandros que o achacam:

${ }^{446} L d c$, p. 99. 
Bem. Na Estação da Luz me tomavam o dinheiro. Com o tempo me apavorei, achei que não estava no tom aquela malandragem correndo para cima de mim e me manquei. Entendi. Parei de estalo. Desguiei, me espiantei, me esquinizei e, deslizando dos malandros, bati perna, acabei me escorando lá na Estação Júlio Prestes. ${ }^{447}$

Assim como na história de Édipo, tal como contada na lenda e na tragédia grega, Paulinho Perna Torta também ignora quem são seus pais verdadeiros. O paralelo com o mito edípico é inevitável, ainda mais quando sabemos que, na lenda grega, o rei de Tebas também era um "perna torta". Como ensina Jean-Pierre Vernant, Édipo descende de uma linhagem de "gerações mancas": era neto de Lábdaco, "o manco", e filho de Laio, "o desajeitado". Ao nascer, Édipo é confiado por Laio e Jocasta, seus pais, a um pastor, que terá como missão dar fim à criança, pois os pais temem seu destino. Como previu o oráculo, o menino está predestinado a matar o pai e dormir com a mãe. O pastor fere o pé de Édipo para acorrentá-lo, mas termina por não o sacrificar e o entrega a outro pastor, que por sua vez o entregará ao casal de reis de Corinto, onde Édipo será criado.

Mesmo se não manca no sentido literal da palavra, Édipo guarda em seu pé a marca desse afastamento que lhe impuseram, da distância que está em relação ao lugar onde deveria estar, e que constitui suas verdadeiras origens. Portanto, também se acha em um estado de desequilíbrio. ${ }^{448}$

De nascimento nebuloso, incerto, Paulinho Perna Torta está em desequilíbrio, vulnerável e livre, solto no mundo, afastado de suas origens, que são desconhecidas. Sozinho, de início, ele é capaz de deslizar, para enfrentar e fugir das figuras paternas que encontra pela frente, negando o conflito direto. Quando conhece Laércio Arrudão, ele tende a conservar o mesmo comportamento, mas irá ultrapassar o padrinho, evitando o confronto com ele e, ao mesmo tempo, o vencendo. Irá sobrepujá-lo, ainda que se mantenha leal a ele e inclinado a emulá-lo. Inconscientemente, terá de matar o pai postiço, confirmando a fama de parricida, sem tê-lo feito, sem ter cometido o assassinato do padrinho.

\footnotetext{
${ }^{447} L d c$, p. $104-105$.

448 Vernant, Jean-Pierre. O universo, os deuses, os homens. Trad. de Rosa Freire d'Aguiar. São Paulo: Companhia das Letras, 2000, p. 166.
} 
Assim como Édipo, Paulinho Perna Torta está predestinado a matar o pai. Assim como na lenda grega, Paulinho Perna Torta também carrega este fardo, sem que, na narrativa, o parricídio tenha lugar, ao menos objetivamente, na ação narrada, ainda que na enunciação o narrador insista em negar a fama que atribuem a ele. Note-se que o protagonista relata outros crimes de natureza semelhante, como a morte de um malandro rival. É a narrativa do próprio protagonista que declara que Paulinho Perna Torta apagou Valdãozinho, um malandro que o denunciou à polícia e deu informações à imprensa, isto é, Paulinho Perna Torta é impelido a matar aquele que ameaça seu posto de único dono da Boca.

Por que, então, esse criminoso confesso nega ter matado o próprio pai?

A insistência com que ele evoca a fama de parricida indica que o personagem, apesar de presumivelmente não ter assassinado o pai, carrega a fama e a culpa por tê-lo feito, sem poder livrar-se delas. Simbolicamente, portanto, a persistência e a reincidência da culpa indicam que o malandro sente o desejo latente de fazê-lo, revive inconscientemente o impulso de matar o pai.

O gesto mais radical, porém, Paulinho Perna Torta termina por não cometer: a morte do padrinho, o Arrudão. E talvez por isso o final do conto seja tão melancólico, de uma tristeza profunda do personagem por perceber que a cobiça de ter tudo, de ter acumulado riqueza, não o levou a lugar nenhum, e permanece a ameaça de que um "mais malandro" o apague.

\section{Do eu ao mundo}

Ao final do conto, melancólico e arrependido, Perna Torta evidencia o seu próprio drama. Seu medo é ser apagado por alguém mais malandro que ele. O sentimento difuso de melancolia e a instabilidade do mundo em que Paulinho Perna Torta vive indicam que o seu feito de ultrapassar o "pai”, seu padrinho Laércio Arrudão, não faz com que ele tenha, de fato, deixado para trás a infância e adentrado o mundo adulto. No plano social, indica que a passagem da "barbárie" para a "cultura" não se deu, não se completou. 
Figura-se um impedimento da passagem de uma horda de malandragem — dos "bárbaros" que atuam como "relógios", como João Antônio se refere aos malandros em ação -, para uma possível civilização burguesa, em que o dinheiro é valor positivo, mas com instituições que funcionem sem obedecer à sua lógica.

A questão é tanto psíquica quanto social e estrutura-se no conto, como já sublinhamos, em torno da trajetória de um menino pobre, que se forma malandro, que vira criminoso e quer passar para o partido alto, num dado contexto. A marcação de tempo histórico, neste conto, entretanto, não é clara, mas é possível presumir que, orbitando em torno da década de 1950, a narrativa avance até o começo da década seguinte. O tempo da narrativa, portanto, é anterior ao golpe militar e à ditadura. Apesar disso, o conto foi publicado em livro em 1975, o que o insere num contexto de publicação e recepção em que viviam-se tempos duros do regime militar.

Como vimos, o pano de fundo de "Abraçado ao meu rancor" e a própria constituição do personagem neste conto da fase madura avançaram em relação a "Paulinho Perna Torta”. Em “Abraçado ao meu rancor”, a referência à ditadura e à censura é explícita - ainda que não assuma o primeiro plano da narrativa - e concorre para conferir motivação mais concreta ao estado melancólico do protagonista.

No livro de ficção que se segue a Leão-de-chácara, Dedo-duro, publicado em 1982, os contos curiosamente não trazem referência alguma ao panorama político - e mesmo o tema do conto que dá título ao volume, a alcaguetagem, que poderia ganhar feições políticas, em época de recentes perseguições, militância e luta armada, permanece num nível apolítico, em que se enfrentam policiais e malandros, criminosos comuns.

Em resumo, no que se refere à representação da realidade política, apesar de ter sido publicada durante o regime militar, a literatura de João Antônio parece não se ocupar da ditadura no que se refere à construção formal e à ação narrativa. No entanto, se lembrarmos da definição de Antonio Candido, em "A nova narrativa" ao referir-se ao ambiente político carregado, podemos identificar na literatura do autor o espírito combativo, "do contra", comum à literatura do período:

[...] vê-se que estamos ante uma literatura do contra. Contra a escrita elegante, antigo ideal castiço do país; contra a convenção realista, baseada na verossimilhança e o seu pressuposto de uma escolha dirigida pela convenção cultural; contra a lógica narrativa, isto é, a concatenação graduada 
das partes pela técnica da dosagem dos efeitos; finalmente, contra a ordem social, sem que com isso os textos manifestem uma posição política determinada (embora o autor possa tê-la). Talvez esteja aí mais um traço dessa literatura recente: a negação implícita sem afirmação explícita da ideologia.

Estas tendências podem ser ligadas às condições do momento histórico e ao efeito das vanguardas artísticas, que por motivos diferentes favoreceram um movimento duplo de negação e superação. A ditadura militar - com a violência repressiva, a censura, a caça aos inconformados - certamente aguçou por contragolpe, nos intelectuais e artistas, o sentimento de oposição, sem com isso permitir a sua manifestação clara. Por outro lado, o pressuposto das vanguardas era também de negação, como foi entre outros o caso do tropicalismo dos anos 60 , que desencadeou uma recusa trepidante e final dos valores tradicionais que regiam a arte e a literatura, como bomgosto, equilíbrio, senso das proporções.

É possível enquadrar nesta ordem de idéias o que denominei "realismo feroz", se lembrarmos que além disso ele corresponde à era de violência urbana em todos os níveis do comportamento. Guerrilha, criminalidade solta, superpopulação, migração para as cidades, quebra do ritmo estabelecido de vida, marginalidade econômica e social - tudo abala a consciência do escritor e cria novas necessidades no leitor, em ritmo acelerado. Um teste interessante é a evolução da censura, que em vinte anos foi obrigada a se abrir cada vez mais à descrição crua da vida sexual, ao palavrão, à crueldade, à obscenidade — no cinema, no teatro, no livro, no jornal — , apesar do arrocho do regime militar. ${ }^{449}$

Não se tem notícia de problemas que a literatura de João Antônio tenha tido com a censura e com o regime militar. Flora Süssekind, em visada oposta, inclusive, acredita que a ideologia nacionalista e ufanista da ditadura contribuíram para a popularização e o sucesso da obra de João Antônio à época. ${ }^{450}$

É evidente, porém, que sua literatura pretende representar o avesso e a negatividade da sociedade instituída, mostrando o quanto a ordem, a dinâmica econômica, a vigência da lei e a própria presença efetiva do Estado favoreciam apenas certas parcelas da população.

${ }^{449}$ CANDIDO, A. "A nova narrativa”. op.cit., p. 212.

${ }^{450}$ Flora Süssekind entende que a literatura do autor foi favorecida pelo que ela chama de "os delegados Fleury das letras", que, em vez de censurar e se opor, incentivam certas obras, sobretudo as que retratam o país. No que ela chama de "literatura-verdade" de autores como José Louzeiro e João Antônio a ditadura militar teria encontrado "colaboradores bastante eficientes" (p. 27). A autora insere João Antônio no rol de autores que seguiram a trilha de um "neonaturalismo". Inspirada pela leitura de Davi Arrigucci em "Jornal, realismo, alegoria", ela entende que havia, então, uma "ficção de mãos dadas com o jornalismo", em que o romance-reportagem estabelece uma literatura parajornalística "que se crê retrato", que pretende informar e - tomando de empréstimo leitura de Silviano Santiago - procura "nomear o assunto proibido" e "despojarse dos recursos propriamente ficcionais na ficção." (pp. 58-59). SÜSSEKIND, Flora. Literatura e vida literária: Polêmicas, diários \& retratos. Rio de Janeiro: Jorge Zahar Editor, 1985. 
Nesse sentido, as contradições individuais de Paulinho Perna Torta expressam também fraturas de ordem social. Matar ou não matar o pai, desafiar e ultrapassar ou não o malandro mais velho, ascender socialmente e passar para o partido alto ou não, virar "empresário" ou "rei" do crime são questões que unem história individual e pano de fundo sócio-histórico, representam um drama pessoal que se apresenta em uma organização social dada e em desenvolvimento, cuja dinâmica tende a excluir os mais pobres e favorecer os mais ricos, submetendo malandros, criminosos e otários à lógica do dinheiro, da corrupção e da violência, com consequências desiguais. Para os sem-eira-nem-beira, dramáticas.

O que fizeram João Antônio e Rubem Fonseca, esses dois autores do realismo feroz, foi mostrar como a violência urbana - que o senso comum associa aos estratos mais baixos da sociedade, impondo aos marginalizados e mais pobres os estereótipos de bandidos e de marginais —, está disseminada também nas classes mais altas, quando não é, ela mesma, gerada no interior da elite, assim como a corrupção. Rubem Fonseca fez isso à sua maneira, ao mostrar como a violência permeia as camadas sociais de alto a baixo, em contos como "Feliz Ano Novo", "O cobrador" e "Passeio noturno", entre outros. Nesses contos, a leitura aguda de Boris Schnaiderman ouve "vozes de barbárie" e "vozes de cultura". Na ficção do autor, "as vozes de barbárie são contaminadas por algo que não se coaduna com a palavra 'bárbaro'. E a crueldade máxima, o ápice da violência, está muitas vezes matizada por algo que lhe é claramente oposto". ${ }^{451}$ Em Rubem Fonseca, segundo Schnaiderman, "a barbárie está muitas vezes presente nas atividades que, por definição, pertencem à esfera da cultura”. Nele, brutalidade e lirismo se alternam, muitas vezes num mesmo personagem, como é o caso do protagonista de "O cobrador", numa caracterização que lembra também a ambiguidade com que João Antônio pinta Paulinho Perna Torta.

A estratégia de Rubem Fonseca, porém, difere da de João Antônio. A orientação teleológica das histórias de suas narrativas, aliada à recorrência com que narradores e personagens expressam e citam elementos da cultura erudita, aponta para um autor e para narradores que, via de regra, pertencem ao território das classes privilegiadas, habitam esse espaço ou o acessam. Os contos do autor na década de 1970 contam histórias em que a violência extrema encontra o caminho da perversão, da escatologia, do cinismo e da...

\footnotetext{
${ }^{451}$ SCHNAIDERMAN, B. "Vozes de barbárie, vozes de cultura. Uma leitura dos contos de Rubem Fonseca”. In: FonseCA, R. Contos reunidos. São Paulo: Companhia das Letras, 1994.
} 
violência extrema, sem perspectiva de acomodação ou resolução nos termos da ação narrada. Não há tragicidade, como em João Antônio. Como o ponto de vista do autor é marcadamente exterior ao seu universo ficcional, o ponto de fuga da ficção realista de Rubem Fonseca paradoxalmente escapa ao realismo e tende à alegoria (“O cobrador”, “O quarto selo"), à autorreferência irônica ("Intestino grosso"), à literatura que se dobra sobre si mesma ("Lúcia McCartney", "Pierrô da Caverna"). A contradição do ponto de vista interno, "onde o narrador na primeira pessoa não tem qualquer afastamento temporal, mas parece estar na própria duração do acontecimento", como anotou Antonio Candido sobre os contos de Rubem Fonseca, redunda neste autor em cinismo, mas em cinismo que mantém dissociados autor e narrador, o que faz do cinismo, em certas narrativas, como "Passeio noturno" e "Feliz ano novo", instrumento de crítica contundente.

Em João Antônio, por sua vez, a representação realista é levada, no que se refere à ação, aos seus limites e impasses formais, que são investigados e esgarçados por meio de uma figura de narrador que se aproxima do universo narrado, que "dá voz aos excluídos", fazendo com que estes "existam acima de sua triste realidade". ${ }^{452}$ Em "Paulinho Perna Torta” especialmente é a própria constituição do personagem que está em jogo. O ponto de vista interno que preside a ficção de João Antônio permite que narrador e personagens, aproximados, quando não confundidos, expressem seus desejos, violências e limitações.

O drama que a ficção de João Antônio encena é o de um mundo do avesso, que é o da malandragem, ou melhor, que é o mundo do crime e o mundo da polícia, conluiados, e que é também a sociedade — esta sociedade cinzenta, ${ }^{453}$ em que não se distingue quem é malandro, quem é criminoso, quem é otário. Neste mundo direito e avesso, positivo e maldito, a condição de selvageria, anterior à da ordem civilizatória, está sempre latente e mesmo os malandros estabelecidos não se sentem seguros da ordem que impuseram, por meio das leis da malandragem, pois as "leis" que vigoram são, na verdade, as leis da selva, que na verdade não são leis, mas os instintos de satisfação e predação desgovernados, que impõem uma barbárie latente. ${ }^{454}$ Como o ponto de vista do autor e do narrador são internos,

${ }^{452}$ CANDido, Antonio. "Na noite enxovalhada". In: ANTÔNIO, João. Malagueta, Perus e Bacanaço. São Paulo: Cosac e Naify, 2004, p. 11.

${ }^{453}$ Como se sabe, Cinzentos e aluados foi o primeiro título cogitado para o livro de estreia do autor, depois mudado para Malagueta, Perus e Bacanaço.

454 "Bárbaros", lembre-se mais uma vez, é como o narrador de "Malagueta, Perus e Bacanaço" se refere, a certa altura, aos três malandros. O conto os toma por "bárbaros" agindo como "relógios". 
a possibilidade de uma saída extrema se mostra limitada e os personagens se revelam intricados nos próprios enredos.

\section{Refinamento sem inserção}

Paulinho Perna Torta não pode parar e não tem como voltar. Ele sabe que o retorno a um estado selvagem não é possível, pois tem noção da importância de matar o pai, apesar de negar tê-lo feito. Talvez por isso, a solidão que decorre da impossibilidade de matar Laércio Arrudão — seu padrinho, mas seu igual — faz com que ele caia em melancolia. $\mathrm{O}$ trecho a seguir está nas páginas finais do conto:

A rua está ruim.

Os jornais me desrespeitando, me encurtando o nome; as ratarias apertam, meu nome está se apagando. Acabará. Estão limpando as ruas, arrancando os malandros das tocas mais escondidas.

Eu me refinei, eu me refinei, não devia tanto. ${ }^{455}$

É ao refinamento, isto é, ao enriquecimento e à passagem para um estágio mais “civilizado", à perda da brutalidade, à “encabulação", que ele atribui a sua queda. O estado depressivo em que Perna Torta cai aponta para seu maior medo: o de ter perdido a virilidade, a potência, a picardia. E, como vimos, refinamento é também o termo usado pelo narrador-autor de "Abraçado ao meu rancor" para entender a sua própria melancolia. A confusão aqui, porém, é maior: há melancolia e culpa, mas ele não pode localizar ao certo as causas desse sentimento - a ponto de creditar sua crise psicológica à macumba. Paulinho Perna Torta é incapaz de "matar" o padrinho, que é pai, mas também irmão de malandragem; a ascensão (o "refinamento", visto como aprendizado, enriquecimento e acúmulo de bens materiais) se coaduna com a castração (o mesmo "refinamento", visto como fraqueza e tormento psíquico, melancolia, “encabulação”).

Qual é o lamento inicial de Perna Torta? É que a imprensa está lhe encurtando o nome: deixaram de chamá-lo de Paulinho duma Perna Torta, eliminando o "duma". Passaram a lhe tratar apenas de Paulinho Perna Torta, e não demora vão começar a chamá-

${ }^{455} L d c$, pp. $154-155$. 
lo apenas de Perna Torta. Quando ele começa a ser retratado como o rei da Boca do Lixo, diz que não gosta de uma fotografia que saiu nos jornais porque está só "de camisa esporte, sem charuto na boca". E, ao final, volta a lamúria pelo nome encurtado e pela perda da brutalidade, que ele associa a "refinamento". O medo do malandro é o da impotência, da castração. A imagem do malandro, em camisa esporte, sem charuto, despe-o da fantasia de malandro dotado de picardia (à esportiva, sem o terno e o charuto que fazem dele um "profissional", ele é um malandro amador e desarmado - castrado, como a ausência do charuto na boca evidencia).

A posição de inferioridade é vista com insatisfação, mas também com temor, repondo o medo de que uma ascensão possa vir a ser punida com a repressão e a perda da potência. Algo que estava sugerido desde o início e que será confirmado, como sabemos, pela amputação a que o nome do personagem está sujeito.

$\mathrm{O}$ que distingue este texto dos textos anteriores do autor, é que aqui o horizonte de inserção do personagem já é, de saída, improvável. Trata-se de um malandro desde criancinha, pois Perna Torta começa seu relato pelos anos que viveu como "moleque de rua", trabalhando como engraxate, dormindo em pensão na rua do Triunfo (na Boca do Lixo paulistana). Desde cedo na "viração". A primeira vez que ele é levado a cometer o assassínio de um pai substituto ocorre ao furtar o homem que o explora na Estação Júlio Prestes, isto é, ao tentar tomar à força a herança a este pai-substituto escolhido na selva da cidade grande; ao fazê-lo, ele o enfrenta, mas não lhe toma o lugar. Paulinho Perna Torta escapa por meio da ginga, do deslizamento, num gesto e jogo de corpo que são mais do malandro que do criminoso parricida.

A jornada deste personagem, nas condições dadas, só pode ganhar desdobramento, assim, contra a figura que o oprime e impede de trilhar o próprio caminho. Esta figura é, primeiro, a do jornaleiro, de quem o personagem toma o "tufo" de dinheiro e de quem escapa por meio da ginga, e depois a de Laércio Arrudão, que o protagonista também está impedido de matar, por ser, além de padrinho, um igual, um irmão de malandragem.

Como Freud observa em "Dostoiévski e o parricídio" sobre a autoria do assassinato paterno em Os irmãos Karamázov, "é indiferente saber quem realmente cometeu o crime; a 
psicologia se interessa apenas em saber quem o desejou emocionalmente e quem o recebeu com alegria quando foi cometido". 456

Saber se Paulinho Perna Torta matou de fato ou não o pai não é decisivo. Aliás, é impossível, dado que nada, na enunciação, indica que o crime de fato ocorreu, e a narrativa em primeira pessoa pressupõe que se confie no que narra o personagem. O crucial é que o protagonista repete, por duas vezes, a acusação que lhe dirigem e sublinha sua contrariedade para com essa fama, como quem confessa não o crime, mas a culpa por ter, possivelmente, cometido este ato - o parricídio, que, aliás, ele tende a cometer de novo, de maneira simbólica, ao longo do relato em sua trajetória ascendente, na qual encontra outros malandros acima e, depois, abaixo de si.

É o que acontece depois de sua saída da cadeia, onde reencontra Laércio Arrudão. Paulinho Perna Torta permanece dois anos e meio no presídio do Carandiru. Certo dia, recebe uma visita do antigo padrinho:

Uns dois anos e meio aqui e me apareceu Laércio Arrudão. Duas semanas depois, a grana correndo por mim lá fora, ganhei um alvará de soltura.

Paulinho duma Perna Torta pisa o meio-fio da Avenida Tiradentes e é fotografado. Mas não liga aos tontos da crônica policial que estão à sua roda. Espera um táxi. Está com a grana, saiu de casa com a cobiça raiada.

São Paulo ia ser meu. ${ }^{457}$

Laércio Arrudão aparece depois de mais de dois anos em que seu pupilo estava preso. E o texto sugere que foi por influência dele que o protagonista foi solto. A relação ainda é de colaboração, de conluio, uma relação de fraternidade malandra. Mas ao sair, o protagonista anuncia: "São Paulo ia ser meu”. A decisão indica que o jovem bandido não

\footnotetext{
${ }^{456}$ FREUD, S. "Dostoiévski e o parricídio". In: O futuro de uma ilusão, O mal-estar na civilização e outros trabalhos. Edição standard brasileira das obras psicológicas completas de Sigmund Freud. Vol. XXI (19271931). Rio de Janeiro: Imago, 1996, p. 194. Neste texto, Freud investiga os impulsos parricidas do próprio Dostoiévski e os relaciona a um bissexualismo latente na personalidade do autor russo, ligando esses impulsos também à epilepsia e à obsessão pelo jogo, frutos do masoquismo e do sentimento de culpa pelos desejos parricidas reprimidos. Freud vê nisso a explicação para a simpatia com que Dostoiévski via os criminosos: "A simpatia de Dostoiévski pelo criminoso é, de fato, ilimitada; vai muito além da piedade a que o infeliz tem direito e nos faz lembrar do 'temor sagrado' com que os epilépticos e os lunáticos eram encarados no passado. Um criminoso, para ele, é quase um Redentor, que tomou sobre si a culpa que, em outro caso, deveria ter sido carregada pelos outros. Não há mais necessidade que alguém mate, visto que ele já matou, e há que ser-lhe grato; não fosse ele, ver-nos-íamos obrigados a matar. [...]".

${ }^{457} L d c$, p. 145.
} 
pretende respeitar nem mesmo a figura do velho malandro, anunciando a disposição para o parricídio do padrinho — ou pelo menos um impulso parricida que indica seu descompromisso com o velho malandro.

O protagonista havia topado com Laércio Arrudão como um filho que encontra um novo pai. O malandro mais velho se torna seu "padrinho" no mundo do crime, pai substituto que fará as vezes de guia e autoridade a ser seguida. A relação evoluiu à medida que Paulinho Perna Torta subiu no crime, tornando-se uma relação de equilíbrio, horizontal, como se fossem iguais, irmãos de malandragem.

A ambiguidade da figura do malandro mais velho, assim, é a de ser a um só tempo um igual e um superior, um "mais malandro", alguém que está um nível acima na hierarquia do crime e dos afetos. É o que acontece com Perna Torta e Arrudão. O primeiro, o malandreco, precisará suplantar o padrinho para se estabelecer, ele mesmo, como malandro, também ele como uma figura, a um só tempo, fraterna e paterna que, por sua vez, precisará impor autoridade em relação aos demais malandros. No entanto, precisa manter a lealdade ao seu irmão de malandragem.

Talvez por isso Paulinho Perna Torta tenda a cometer o parricídio mas... não o cometa. $\mathrm{Ou}$, ao menos, não o narre.

A trajetória de ascensão contínua do personagem, entretanto, indica que os obstáculos de figuras maiores, em posição mais elevada que a do protagonista, foram vencidos. E que, portanto, o parricídio, simbolicamente, teve lugar.

É por isso que o sentimento de ter ido longe demais faz com que o protagonista se questione sobre a própria conduta. A culpa que acomete o personagem, ao final do relato, revive a dor e o arrependimento relacionados ao parricídio:

A rua está ruim.

Os jornais me desrespeitando, me encurtando o nome; as ratarias apertam, meu nome está se apagando. Acabará. Estão limpando as ruas, arrancando os malandros das tocas mais escondidas.

Eu me refinei, eu me refinei, não devia tanto. Fiz muito fricote, me escarrapachei mais do que a conta, me empapucei. Ou foi essa vida que me ensinou a cobiçar tudo o que é 
dos outros, iludindo, avançando, tomando, estraçalhando. Também por isso tenho uma situação, carro, apartamento, telefone, viagens, bordel. Não nasci com isso não. ${ }^{458}$

A situação presente da ação narrada retoma o conflito com a origem e com a relação com o pai, de quem Paulinho Perna Torta teria tomado uma herança, por meio do parricídio. O refinamento - a percepção de que a cobiça fez dele algo que o afasta de sua origem ("não nasci com isso") — é motivo de culpa e arrependimento. Este parricídio simbólico, o de ter tomado a herança de um pai que falta, um pai ausente, faz com que o narrador carregue a culpa e o arrependimento pelo sentimento de cobiça, pelo refinamento, que o afasta da origem pobre.

Mas o arrependimento não interrompe a narrativa. O protagonista não empreende um recuo nem um retorno, ainda que o entreveja e o cogite: "Estou com tóxico no caco e uma idéia besta me passa - talvez eu devesse ter ficado com a magrela e as namoradinhas do comércio das lojas do Bom Retiro. Ou tirado Ivete da vida". ${ }^{459}$ E, no auge de sua trajetória no crime, aos trinta anos, ainda jovem, mas com extensa ficha corrida, ele pressente que, ele próprio, se tornou alvo dos mais jovens: "Dia mais, dia menos. Essa rataria agora é moça. A molecada vai acabar me catando". 460

Os elementos em jogo são sua origem desconhecida, a fama de parricida, a ascensão vertiginosa no mundo do crime, a amputação de seu nome e a ameaça a ele próprio. Essa combinação faz com que ele não possa parar e retornar. Faz também com que Paulinho Perna Torta não tenha lugar nessa organização social burguesa corrompida. É por isso que ele sabe que será apagado - e quando isso acontecer ele terá, afinal, o título de “rei”.

\section{Um destino trágico, antes da catástrofe}

A importância do nome próprio individual e singular para a constituição da identidade pessoal está na origem do gênero romance. A maneira com que os escritores modernos definem os personagens por meio de seus nomes, tal como eles são usados na vida real, concorre para tornar o personagem de ficção um ser particularizado e mais

\footnotetext{
${ }^{458} L d c$, pp. $154-155$.

459 idem, p. 155.

${ }^{460}$ idem, p. 152.
} 
próximo da experiência comum. Como afirma Ian Watt ao analisar o tratamento que os primeiros romancistas empregaram para nomear seus personagens, os nomes próprios

(...) são a expressão verbal da identidade particular de cada indivíduo. Na literatura, contudo, foi o romance que estabeleceu esta função.

Nas formas literárias anteriores evidentemente as personagens em geral tinham nome próprio, mas o tipo de nome utilizado mostrava que o autor não estava tentando criá-las como entidades inteiramente individualizadas. Os preceitos da crítica clássica e renascentista concordavam com a prática literária, preferindo nomes ou de figuras históricas ou de tipos. De qualquer modo os nomes situavam as personagens no contexto de um amplo conjunto de expectativas formadas basicamente a partir da literatura passada, e não do contexto da vida contemporânea. Mesmo na comédia, onde em geral as personagens não eram históricas, mas sim inventadas, os nomes deviam ser "característicos", como nos diz Aristóteles, e tenderam a permanecer como tal muito depois do surgimento do romance. ${ }^{461}$

De fato, a constituição do nome dos personagens passa, no romance, a ser um elemento de construção realista e singular, em sintonia com a própria caracterização do indivíduo. Se antes os personagens tinham nomes emblemáticos e inspirados na história e na tradição literária, na modernidade passarão a ser conhecidos por nome e sobrenome, de maneira particularizada e individual, única. Além da eleição individualizada dos nomes, nos primórdios do romance a identidade dos personagens se dá, também, por meio de sua localização precisa no tempo e no espaço. ${ }^{462}$

Nas narrativas de João Antônio, sabemos como a escolha dos nomes dos protagonistas se liga a características de personalidade e de determinadas situações vividas, em momentos particulares da existência, que, por serem significativos, emprestaram nova identidade aos seus atores. Não ocorrem, como nos romances, personagens com nome e sobrenome, por conta mesmo do contexto social em que estes estão imersos - ao contrário das classes altas, em que o sobrenome indica linhagem familiar, tradição e poder, nas classes mais baixas, mas sobretudo no universo da malandragem, preponderam os apelidos e os sobrenomes comuns, sem história e muitas vezes sem procedência conhecida.

\footnotetext{
${ }^{461}$ WATT, I. Ascensão do romance. Trad. Hildegard Feist. S. Paulo: Companhia das Letras, 1990, pp. 19-20.

${ }^{462}$ D. Quixote e Robinson Crusoé, dois dos primeiros romances, têm início com a localização dos protagonistas no tempo e no espaço e com a explicação da origem de seus nomes (e não, exatamente, da origem dos próprios personagens). A importância do nome, aliás, está marcada no próprio título destas obras de Cervantes e Daniel Defoe.
} 
Na maioria dos casos, nos contos do autor, o leitor desconhece o nome de batismo dos personagens, referidos por seus apelidos ou alcunhas de guerra. A própria instabilidade ou fragilidade dos nomes dos protagonistas indica que a existência desses personagens depende menos de suas origens, filiação e identidade formal, e mais de sua atuação e daquilo que eles são capazes de empreender, mas também do acaso e da maneira com que a proveniência ou os feitos desses personagens são recebidos e transmitidos, isto é, compartilhados coletivamente pelos parceiros. O amplo uso dos nomes de guerra indica que, na ficção de João Antônio, individualidade e coletividade concorrem para redefinir as identidades dos personagens, que dependem de uma reinvenção de si próprios, ou melhor, de um distanciamento de suas origens (muitas vezes desconhecidas ou nebulosas, mas sempre humildes, inferiores) para que possam atuar, inserir-se socialmente, lançar-se à aventura e, no limite, existir.

No caso de "Paulinho Perna Torta", a importância da adoção e da consolidação de um nome próprio atinge ponto máximo de tensão no que se refere à obra de João Antônio. Sua origem é desconhecida. Não se sabe qual é seu nome de batismo. Mas sabemos que ele começou "por baixo", como "sofredor". Depois de algumas aventuras, ele entra para a malandragem e ganha um nome de guerra, à sua revelia, mas nome de guerra que adota como se fosse sua própria identidade, a ponto de transformar a ameaça ao seu apelido em crise pessoal e prenúncio de queda e aniquilamento.

A tomada de consciência de Paulinho Perna Torta, então, contraria a sua constituição de herói moderno, de personagem individualizado, que se caracteriza por ser único, singular e livre. Nos termos de Marthe Robert, a princípio Paulinho Perna Torta é um "fazedor de romance". ${ }^{463}$ Entretanto, apesar desse impulso inicial de "fazer romance", ao final Paulinho Perna Torta é um protagonista que se percebe incapaz de controlar sua própria atuação, acuado e impotente em relação à trajetória que ele imaginava bemsucedida. A expansão de seus negócios e sua ascensão vertiginosa, percebe ele, não passam de uma grande "mentirada", o que antecipa a percepção de sua queda. Ele descobre que seu

\footnotetext{
463 "Nos antípodas do herói trágico ou épico, que sofre pela ordem de que é testemunha, o 'fazedor de romance' é em seu próprio projeto um fomentador de distúrbio, um difamador das qualidades e das classes, até mesmo em seus esforços para conquistar as mais elevadas. Um arrivista, portanto, que funda suas esperanças na intriga e na mitomania, mas também um espírito apaixonado pela liberdade, determinado a não mais se inclinar diante do irreversível, rebelde às idéias tradicionais bem como às situações preestabelecidas, e subversivo malgrado o conformismo ao qual acaba por obedecer.” RoBERT, M. op.cit, p. 29.
} 
nome é "ninguém" e que será, a qualquer hora, apagado pela polícia ou outro malandro. Seu nome, que correu e ganhou fama, que se tornou lendário, revela-se ser nada, "ninguém”. E nesse dia, e talvez apenas nesse dia, Paulinho Perna Torta se torne "rei".

A princípio, PPT poderia, como o fez Ulisses na Odisseia, disfarçar-se de Ninguém, mas sua fama tornou-o famigerado, isto é, afamado e difamado, seu nome correu e sua imagem, como indicam as fotografias que a imprensa registrou, está indelevelmente associada a seu nome. O disfarce que ele ostenta, de malandro e de integrante do partido alto, além de não esconder sua origem desconhecida, origem incerta deste que é um ninguém - e poderíamos dizer um zé-ninguém, para usar uma expressão popular consagrada - o disfarce também não encobre o corpo do malandro: a perna torta que é seu nome e sua imagem. Em verdade, PPT é um ninguém, mas já não pode ser Ninguém, não pode refugiar-se no anonimato, pois o corpo, casa do malandro, já não é refúgio. Ou melhor, o corpo do malandro é refúgio, mas também é alvo.

Nesse sentido, Perna Torta é um malandro que virou bandido, isto é, virou um renunciador, nos termos de Roberto Damatta, ${ }^{464}$ mas que não tem como assumir novo nome. Sua conversão de malandro em vingador (justiceiro) ou santo está impedida por sua condição de origem (desconhecida) e pela marca do seu corpo, que é também a marca de seu nome. Ele está fadado a ser Paulinho Perna Torta ou ninguém, como a progressiva amputação do nome indica (logo será apagado, como diz o próprio personagem). O nome Paulinho Perna Torta, portanto, é o nome de um malandro que virou bandido - e que não pode voltar (ser malandro) e não pode ir além (renunciar ao crime e se converter), pois não tem para onde fugir e não tem como se livrar do nome, que está inscrito em seu corpo.

Paulinho Perna Torta não pode mudar de nome. Não tem a opção, por exemplo, de Nhô Augusto: a opção de se tornar Matraga. A noção de que PPT é "ninguém”, aliás, lembra o sentido do nome do personagem do conto de Guimarães Rosa: Matraga "não é nada". A passagem de Augusto Esteves a Nhô Augusto e daí a Augusto Matraga, como sugere Roberto DaMatta, é a passagem do nome jurídico, para o nome social (um nome de força, de posição de poder) e daí para o nome de santo, daquele que se converte e se coloca fora da ordem social. ${ }^{465}$

\footnotetext{
${ }^{464}$ DAMATTA. R. Carnavais, malandros e heróis, op.cit.

465 idem, ibidem. Ver cap. VI, “Augusto Matraga e a hora da renúncia”.
} 
PPT é um malandro que, apesar de ter passado para o partido alto, não pode aceder ao partido alto, pois é bandido matador e faz parte de uma rede de vinganças, da qual fazem parte a polícia e outros bandidos. Assim, ele sente que sua única chance é a renúncia, mas sabe também que a renúncia, na sociedade em que ele está inserido e de acordo com a sua trajetória e sua condição não está a seu alcance. A hora e a vez de Paulinho Perna Torta não virão, pois que ele carrega uma cicatriz, o estigma da perna torta, que não lhe permite ser outro alguém. Ele só pode ser ninguém.

Renato Janine Ribeiro reflete sobre a importância social dos pronomes, em especial de ninguém, ao comentar o canto IX da Odisseia, em que Ulisses derrota o ciclope Polifemo ao se disfarçar de Ninguém. Inspirado nessa passagem de Homero, Janine Ribeiro sustenta que a importância do pronome é a possibilidade de trocar de posição na sociabilidade, ser outro e estar na posição de outro, algo que, justamente, PPT está impedido de fazer. Por isso, a descoberta de que é "ninguém" e não pode ser "Ninguém" é também a constatação do caráter irremediável de sua condenação, de sua queda.

Janine Ribeiro valoriza em Ulisses, no episódio em que o herói consegue lograr o ciclope, a astúcia do mais fraco que vence o mais forte, que o filósofo liga à teoria do Estado de Thomas Hobbes, segunda a qual o Estado garante a força dos fracos, pois possibilita o uso da força por meio de astúcia ou coletividade. ${ }^{466}$ Porém, como em "PPT" o Estado ou, nos termos do conto, o governo é o inimigo - já que o governo persegue os malandros, fazendo valer não apenas a lei, mas, antes dela, a força da polícia —, PPT não é capaz de trocar de lugar, de ser outro, de deixar o crime, de retroceder ou de se refugiar no anonimato. Sua perna torta faz dele o que ele é - nomeado, renomado, malandro famoso e bandido famigerado -, e também o que ele não é, isto é, seu inverso, ninguém, um zéninguém, alvo que, cedo ou tarde, será atingido pela polícia ou pela malandragem.

Talvez por isso ele recorra à ginga macumbeira de Zião da Gameleira. Se não pode ser santo, Perna Torta terá de recorrer ao sobrenatural, à uma religiosidade laica e sincrética, invocar uma divindade que dê jeito nessa sinuca de malandro-criminoso em que se meteu e foi metido.

\footnotetext{
${ }^{466}$ Sobre a importância social dos pronomes, em especial de ninguém, ver o texto de Renato Janine Ribeiro sobre esse episódio de Homero: Ribeiro, R. "Meu nome é ninguém (sobre o canto IX da Odisseia), disponível em: http://www.renatojanine.pro.br/Cultura/cultura.html.
} 
Paulinho Perna Torta se imaginava personagem de romance, mas se descobre herói trágico. O conto, porém, como é narrado pelo próprio protagonista, não coloca em cena a catástrofe, a morte desse malandro que é aclamado rei do crime. Como o protagonista ele mesmo afirma ao final de seu relato:

Outra vez o governo está vencendo Paulinho Perna Torta.

Mas não vou parar. Atucho-me de tóxico e me aguento. Para final, tenho ainda a grana e Maria Princesa é uma boneca.

Eu só posso continuar. Até que um dia desses, na crocodilagem, a polícia me dê mancada, me embosque como fez a tantos outros. E me apague.

E, nesse dia, os jornais digam que o crime perdeu um rei. ${ }^{467}$

A narrativa interrompe a trajetória de Paulinho Perna Torta antes de seu final. Como é narrado pelo próprio protagonista, o conto não encena a catástrofe. O que se narra é o crescimento do personagem, sua expansão e ascensão, e o processo de amputação do seu nome, a castração que faz com que o personagem caia num estado melancólico e destrutivo. O reconhecimento de sua trajetória trágica se dá apenas na sua própria consciência, indicando que o contexto social em que ele se insere é indiferente ao seu drama íntimo, mas está esperando pela queda de sua pessoa pública, de seu nome e de sua imagem.

Mais que isso, o "governo" e a "sociedade" (as "famílias", a imprensa) torcem e conspiram contra ele. A polícia é o braço do Estado que atua em favor dos estratos sociais privilegiados, expondo o temor e o privilégio de classe com que "as famílias" condenam as classes marginalizadas, revelando também o teor de hipocrisia que pauta a família nuclear brasileira, já que mantém relação estreita com o mundo da prostituição e da malandragem, como bem apontou Antonio Candido ao estudar a composição da família patriarcal brasileira. ${ }^{468}$ Lembre-se que o machucado na perna do protagonista, que lhe rendeu o nome de guerra, foi provocado por um cliente de Ivete, um "otário" que frequentava a zona, um

\footnotetext{
${ }^{467} L d c$, p. 156.

${ }^{468} \mathrm{Em}$ "The Brazilian family", Antonio Candido apresenta a estrutura da família patriarcal brasileira, seu "núcleo legal" em contato estreito com os estratos marginalizados pela sociedade, como os agregados e as prostitutas. A mesma comunicação entre a o mundo da ordem e o mundo da informalidade estrutura "Dialética da malandragem", o ensaio do autor sobre as Memórias de um sargento de milícias. CANDIDO, Antonio. "The Brazilian family". In: Smith, T. L. e MARChant, A. (orgs.), Brazil, portrait of a half continent. New York: The Dryden Press, 1951, e CANDIDO, Antonio. "Dialética da malandragem". In: $O$ discurso e a cidade, São Paulo: Duas Cidades, $2^{a}$ edição, 1998.
} 
membro das famílias, integrante do polo "positivo" da ordem social instituída, tanto do ponto de vista econômico como no que se refere à moralidade.

Completando o quadro de atores conservadores que se opõem a Paulinho Perna Torta, a imprensa, esta espécie moderna de coro de tragédia, encurta seu nome e anuncia sua queda. E o próprio Paulinho Perna Torta sabe que a imprensa falará dele depois de seu apagamento, cantando a morte deste "rei" do crime.

De personagem de romance, que é capaz de fazer seu próprio caminho, a personagem trágico: a narrativa de Paulinho Perna Torta, é um conto sobre a dualidade de um indivíduo pobre e de origem misteriosa, que se torna rei da Boca Lixo, mas que descobre, a certa altura, que é um "ninguém", mesmo que ainda esteja no auge. Contra o famigerado Governo, encarnado na polícia, ele sai perdendo. Será, cedo ou tarde, apagado, pois não pode ser vingador nem santo nem voltar a ser malandro, quanto mais otário, menino de rua.

O destino da malandragem, tal como narrado por um de seus malandros, um "malandro dos malandros", é trágico. Mas esta malandragem descrita e vivida em "Paulinho Perna Torta" está, de certa forma, em um momento posterior ao de "Malagueta, Perus e Bacanaço", em que a malandragem se circunscrevia a determinados lugares e às práticas mais antigas da criminalidade, como o jogo, a prostituição e os pequenos golpes.

"Paulinho Perna Torta" narra um momento de ampliação do alcance da malandragem e da criminalidade. O impulso de expansão e ascensão do protagonista se dá na horizontal e na vertical. De um lado, com a dispersão da criminalidade para além do antigo espaço da zona, o personagem pretende conquistar a cidade inteira. De outro, quer atingir o topo da escala econômica, como de fato consegue, a certa altura, o que, aliás, vai lhe causar o sentimento de vazio e de culpa que é também o ápice do conto.

Sua estratégia para conquistar a cidade é a da expansão do crime. Esse impulso de horizontalidade faz com que novas formas de atuação precisem ser desenvolvidas. A dissolução das fronteiras do crime se dá de maneira bastante marcada na narrativa: o protagonista atribui essa disseminação à ação do governo e da polícia. A repressão ao crime, à zona, à prostituição e à malandragem, acompanhada da lógica de corrupção com que essa repressão se dá, faz com que o crime não apenas não desapareça, mas cresça e se espalhe: "A Delegacia de Costumes voltou a recolher arreglo das minas e vem nascendo a 
Boca do Lixo. O formigueiro que era a zona está se espalhando por toda São Paulo. O governo começa a perder". 469

Estamos, portanto, em um momento e em uma escala de atividades malandras e criminosas posterior àquela de Perus, Bacanaço e Malagueta, personagens que tinham lá seu impulso horizontal, o circuito dos salões de sinuca do centro e dos bairros da zona Oeste da cidade. Mas na cidade e na criminalidade de Perna Torta, o impulso horizontal não tem limites, pois a escala e a escalada do crime se ampliaram e se disseminaram. Não se trata apenas de pequenos golpes, sinuca, cafetinagem em nível individual (de gigolô para prostituta) ou em pequena escala. Todas essas atividades se mantêm, mas ganharam disseminação. E outras atividades criminosas vêm se juntar a elas, com destaque para o tráfico de drogas, ainda que não haja, por ora, menção à cocaína. ${ }^{470}$

O impulso horizontal ganha força graças à atuação do protagonista como empresário do crime, mas é precipitado pela intervenção da polícia (o poder público, o governo), chancelada pela imprensa, ao fechar a zona e espalhar a criminalidade por toda São Paulo. Com isso, os negócios de PPT logo se estendem não apenas à cidade inteira, mas também ao interior do Estado, a outros Estados brasileiros e ao exterior (Uruguai e Argentina). É menos, portanto, a atuação do próprio protagonista que o faz ampliar seus negócios e mais o próprio ambiente social propício ao crime. Em outras palavras, é porque o crime já está disseminado na sociedade (levando de roldão a polícia, a política, o Judiciário e, no limite, a própria vigência da lei) que Paulinho Perna Torta pode expandir seus domínios e galgar os degraus da fama e da criminalidade.

Ao alargamento de sua atuação criminosa corresponde a ascensão vertical do protagonista, que de moleque de rua e engraxate passou a malandreco, malandro, malandro dos malandros e empresário do crime. Esta ascensão, porém, não vem acompanhada de inserção. Ao final, como diz o próprio protagonista, "a gente pensa que está subindo muito nos pontos de uma carreira, mas apenas está se chegando para mais perto do fim”.

A ascensão de Perna Torta é a ascensão na carreira do crime, que entretanto ele percebe ser o rumo do cemitério, como já anunciava a epígrafe de Noel Rosa. Como a

\footnotetext{
${ }^{469} L d c$, p. 145.

470 “Lido com tóxicos. Desço à zona de Sorocaba e ao Retiro de Jundiaí. Compro o Pervitin a cem mangos e passo por oitocentos. Passadores de fumo vêm comigo. Só se trabalha com a melhor maconha, a pura. Cabeça-de-nego, vinda de Alagoas." Ldc, p. 147.
} 
própria constituição social é marcada pela promiscuidade e pela prostituição, a carreira "positiva" que poderia se desenvolver redunda em trajetória "criminosa", duas pistas que se confundem nesta sociedade burguesa que ainda carrega um funcionamento arcaico, herdado dos tempos coloniais escravistas e patriarcais. ${ }^{471}$

De moleque de rua a empresário e rei do crime. De malandro burguês a fidalgo do crime. Daí a "ninguém", quando ele descobre que será apagado e que "nunca foi".

O reconhecimento que o conto opera, é o de um destino da malandragem: Paulinho Perna Torta descobre que é "ninguém". Este reconhecimento (a anagnorisis aristotélica) de Paulinho Perna Torta é um autorreconhecimento e um reconhecimento negativo que também faz com que a catástrofe seja anunciada, mas não ocorra no espaço da ação narrada (no mythos).

Para Paulinho Perna Torta, ascensão e queda são uma coisa só. O destino de Paulinho Perna Torta é trágico não apenas porque seu fim será a morte, será sumir, "apagado, qualquer hora dessas, em que a polícia ou outro mais malandro nos acerte". O destino de Paulinho Perna Torta é trágico porque sua ascensão leva a um destino que the escapa, ao destino de todo malandro criminoso de origem pobre e desconhecida, revelado ao final do conto como algo inevitável, apesar da ação deste personagem que se fez por si só, como um personagem de romance, mas incapaz de suplantar o destino de criminoso: ser morto por outro malandro ou pela polícia, sumir, apagar-se, aniquilar-se.

\section{O lugar do escritor}

A operação literária empreendida por João Antônio neste conto de fato é notável. Os primeiros contos, e mesmo "Malagueta, Perus e Bacanaço", apesar da maior extensão deste último, tinham como escopo narrativo o relato de algo pontual. "Paulinho Perna Torta", porém, combina as duas coisas: ação narrativa e constituição do personagem evoluem simultaneamente.

\footnotetext{
${ }^{471}$ Como lembra Florestan Fernandes, no Brasil "a revolução burguesa surge dentro do contexto e como episódio da expansão econômica do mundo rural" e "assume um tempo e um ritmo que atestam a dificuldade do país em realizá-la". Segundo o autor, desde o último quartel do século XIX até nossos dias (isto é, os anos 1960, quando o artigo foi escrito), esse processo tem sido "lento, descontínuo e convulsivo". FERNANDES, Florestan. "A dinâmica da mudança sociocultural no Brasil". In: Sociedade de classes e subdesenvolvimento. São Paulo: Global, 2008, p. 107.
} 
Se nos "Contos gerais" a delimitação da ação narrativa era mais restrita, como vimos, aqui o arco de tempo é maior, e a própria extensão do conto indica que o teor do que é narrado se alterou. Não se trata mais do momento em que os protagonistas precisam decidir e hesitam. Agora, a formação do protagonista já se deu, ele já optou — há muito tempo, aliás - pela malandragem e o momento é de, talvez, sair dela.

Contrariando o preceito clássico de que os homens piores e mais baixos, na escala social, deveriam ser tratados pela comédia, e os mais elevados pela tragédia, ${ }^{472} \mathrm{o}$ autor criou uma obra de ficção que revela o destino trágico de um personagem que começou por baixo e virou "rei". A origem desconhecida, a trajetória ascendente e o embate com as figuras paternas indicam que Paulinho Perna Torta é um fazedor de romance, um arrivista, um bastardo, um Édipo moderno, personagem que, a princípio, faria um caminho pessoal, singular e inovador, rumo ao topo social e à conquista do dinheiro e de uma mulher de classe mais alta. No entanto, o seu auge coincide com a percepção de que ele é "ninguém" e que o título de nobreza que o consagrará como soberano do crime virá, mas apenas com a sua própria morte, ansiada pelos jornais e acalentada pela polícia, tornando-o lenda, lenda por sua vez também ameaçada, já que o nome, além dele próprio, também está em risco.

A jornada de Paulinho Perna Torta indica que, no contexto dado, para aqueles de origem humilde, "sofredores", o caminho mais rápido e aventuroso de ascensão social não é o trabalho, sempre incerto e informal, destituído de valorização e de recompensa, mas a malandragem e o crime, desde cedo convidativos e sedutores. Como indica a obra de João Antônio, e este conto em particular, as possibilidades de inserção social se mostram incertas, improváveis, ainda que a promessa de enriquecimento e de ascensão permaneça latente, em uma sociedade em que o processo de financeirização transformou o dinheiro em único valor "positivo". Para além da trajetória individual deste protagonista pobre, que flerta com a malandragem e termina imerso na criminalidade, o conto coloca em questão a

\footnotetext{
${ }^{472}$ A formulação de Aristóteles é bastante conhecida: "a Tragédia é a imitação de homens melhores do que nós". (Poética, 1454b). Um crítico contemporâneo como Frye vê na literatura do século XX um retorno às origens da literatura ocidental e classifica de "tragédia imitativa baixa" as obras que encenam tragédias de personagens comuns (no mesmo nível dos demais homens da sociedade em que vivem). Nos termos de Frye, a trajetória de Paulinho Perna Torta seria provavelmente um caso de uma ironia trágica, que trata do "isolamento trágico em si", sem correspondência com o caráter do herói. Apesar de ser criminoso, o erro de Perna Torta (a hamartía) não é claro, o que talvez o aproxime da figura do bode expiatório (pharmakós) de que fala Frye. Ver o capítulo "Modos da ficção trágica" em FrYE, N. Anatomia da crítica. op.cit., pp. 39-72.
} 
própria constituição desta sociedade em termos democráticos e burgueses, constituição que é colocada em xeque - incompleta e já pervertida.

Para Paulinho Perna Torta, este personagem de origem pobre e nebulosa, a escalada social se dá através da malandragem, mas sobretudo pelo crime. Trata-se de um malandro que ultrapassou a malandragem e se estabeleceu como empresário do crime, graças não à ausência de instituições mas à promiscuidade do crime com instituições corruptas: a própria malandragem, a imprensa, a polícia, a Justiça. Nesta trajetória de ascensão em um contexto de revolução burguesa incompleta, é uma ascensão negativa, já ela que se dá pelo crime, mas também positiva, já que crime e legalidade não se distinguem, movidos pela força do dinheiro - o "positivo" e o "maldito".

Apesar da ênfase na trajetória individual e de classe, singularizada mas coletiva (a princípio de romance, mas ao final trágica) é a própria existência corrompida desta sociedade que impede a conversão de Paulinho Perna Torta ao polo "positivo" da ordem social, o "partido alto". No fundo, o que o conto explicita é que não se pode nem mesmo falar em termos de positivo e negativo, de exclusão e inserção, já que no contexto social dado os polos se embaralham. E, aos de origem pobre, o polo positivo não se oferece, senão como miragem, fantasia.

É por isso que, apesar de sentir que "a rua está ruim", Paulinho Perna Torta sabe que não pode parar, ainda que cogite um retorno. A volta, ele sabe, é impossível, pois ele é um criminoso perseguido e as feições da própria criminalidade mudaram, espalhando-se e adquirindo nova escala. $\mathrm{O}$ criminoso não pode parar porque não tem como deixar o crime. Não há saída para um personagem de origem pobre, sem filiação, que tem apenas o próprio corpo, um nome que vem sendo amputado e a fantasia de malandro e de nobreza. Nem com ginga, nem com macumba, nem com muito dinheiro, pois não se trata apenas de comprar a imprensa, a polícia e a Justiça, pois num contexto em que só o dinheiro é positivo, essas instituições que deveriam atender a valores como a verdade, a preservação da vida e a igualdade, operam de acordo com interesses e pressões, de todo o tipo, mas sobretudo, de novo, do dinheiro.

Nessa situação, a força do indivíduo de origem pobre, mesmo que depois de uma trajetória que lhe proporcionou status e capital, não pode ser comparada à força das instituições, que estão a serviço do dinheiro, e das classes altas, das "famílias". Nem à força 
de muito dinheiro, pois há algo que o dinheiro não compra: a possibilidade de este personagem escapar ao destino trágico de criminoso de origem incerta ou de origem pobre e bastarda, ilegítima. Num caso ou noutro, melancolia e culpa abreviam uma trajetória que, de início, apontava para promessas de aventura e conquista.

A solidão e o isolamento dominam Paulinho Perna Torta, acometido também por um sentimento que ele não sabe qual é, a ponto de creditar a sua queda ao sobrenatural, à macumba de Tião da Gameleira. Ao final, a ginga - agora a "ginga macumbeira" também é ameaça à sua capacidade de preservar o próprio nome e evitar o seu apagamento.

O enfrentamento do padrinho e a vitória sobre a figura paterna redundam em uma arrancada acelerada para cima, para o alto da escala social e para a fama, que é também uma ascensão para a queda - e o próprio Paulinho Perna Torta irá se tornar uma figura a ser enfrentada, não apenas pelos outros malandros, mas também pela polícia, especialmente pelos policiais mais jovens.

Num mundo em que só o dinheiro é positivo, este personagem-narrador de origem nebulosa não é capaz de refazer a própria história. Paulinho Perna Torta é incapaz de reinventar o próprio nome, que está sendo, paulatinamente, amputado, até que ele se torne "ninguém".

Isso nos devolve ao núcleo temático da ação de "PPT" e, então, ao ponto de vista do autor.

O texto tem início com uma construção verbal inusitada, como dissemos, que insere o leitor diretamente no curso dos acontecimentos. Ao final, vamos descobrir que a ação que está em curso é a da consciência do protagonista sobre o próprio destino. Paulinho Perna Torta descobriu que está enredado num destino que é o destino de um rapaz pobre, malandro, criminoso, que sonhou com o "partido alto", fez parte dele e pensou tê-lo conquistado, mas que percebe que a ascensão social, na sociedade em que vive, é vivida pelos mais pobres por vias tortuosas - malandragem e crime - que não garantem inserção. O destino do criminoso rico e poderoso é se tornar rei, mas um rei sem trono, soberano sem reino, pois que se vive uma ordem burguesa, ainda por cima incompleta e corrompida. E um "rei" que só receberá este título de nobreza depois da queda.

Em "Paulinho Perna Torta", João Antônio reuniu as contradições de todos os seus personagens. O protagonista deste conto é um menino pobre de origem desconhecida; é 
também um bastardo fazedor de romance; um malandro que se torna criminoso; um personagem trágico enredado no destino comum a toda uma coletividade da qual ele tenta se distanciar, sem conseguir; um "rei" sem reino e sem majestade, prestes a cair, que não tem como evitar a catástrofe, pois só se tornará rei quando a catástrofe vier.

O título do conto, neste sentido, concentra as contradições desta narrativa e implica, nesta dinâmica, o ponto de vista do autor. O conto não se chama "Paulinho duma Perna Torta", como o próprio personagem gostava de ser chamado, nem "Perna Torta", como o personagem intui que acabará sendo chamado, mas "Paulinho Perna Torta". Essa nomeação intermediária é do autor do texto, obviamente, que assim se inclui no processo de constituição e desaparecimento de seu personagem. O fato de João Antônio ter intitulado o conto como o fez indica que ele, como escritor, está implicado nesta lógica, a meio caminho entre o fascínio e a ressalva à trajetória do protagonista, a simpatia e a recusa ao malandro.

O ponto de vista interno, a capacidade de João Antônio de dar voz e vida a um personagem marginal e marginalizado, a construção narrativa que se constrói à medida que o protagonista se constitui, ascende e decai, que avança com o protagonista e definha com ele, essa combinação define um ponto de vista complexo e crítico. O ponto de vista de João Antônio o situa como um escritor de pé atrás com o processo que galgou Paulinho Perna Torta a rei do crime. $\mathrm{O}$ autor e a perspectiva de sua ficção se estabelecem em algum ponto que não coincide com o do malandro, o da imprensa, o da polícia e tampouco o da sociedade instituída.

O lugar do escritor, aqui, também está em questão.

A narrativa é de João Antônio, mas a história é contada pelo personagem. O foco narrativo em primeira pessoa, assim, cumpre mais uma função neste conto: a de contar uma história de um ponto de vista interno, em que o protagonista se expressa, por meio de sua linguagem e de sua perspectiva, mas uma narrativa que preserva a autonomia do ponto de vista do autor.

Por que Paulinho Perna Torta conta a sua história? Porque sabe que, mais dia, menos dia, irá desaparecer, seu nome irá se apagar, e assim também sua história. Sua história talvez vire lenda - destino de todo malandro - , mas talvez não vire nada. Talvez ele seja "ninguém" e, depois de morto, permaneça sendo "ninguém", cuja história vai se 
perder nas matérias passageiras, simplistas e suspeitas dos jornais. Contar a própria história é também passar para o partido alto da narrativa, inscrever seu nome na literatura, não nas páginas degradadas da imprensa.

Por que João Antônio conta essa mesma história? Para mostrar, por dentro, o drama e o destino de um menino pobre, que é malandro e criminoso violento, e continua sendo menino pobre, de origem incerta; para contar a história deste personagem, que é também a história de uma sociedade incompleta, malandra e oscilante, mas também moralista, corrupta e excludente, vista por um de seus excluídos, que é malandro e criminoso sem nunca ter deixado de ser moleque de rua. 
Conclusão 
"Paulinho Perna Torta" é o mais longo e ambicioso texto de ficção de João Antônio, ao lado de "Malagueta, Perus e Bacanaço". Escrito quando o autor ainda era muito jovem, antes de seus trinta anos, permaneceu, por toda a carreira literária do autor como sua realização ficcional mais complexa. Depois de Malagueta, Perus e Bacanaço e de Leão-dechácara, onde "PPT" foi incluído, o escritor viria a publicar cerca de quinze outros livros. Poucos deles, porém, podem ser elencados entre suas obras principais. E a própria produção ficcional foi aos poucos perdendo espaço na carreira de João Antônio, dando lugar ao jornalismo, ao chamado conto-reportagem e aos textos autobiográficos.

O universo temático da obra de João Antônio, comparado aos primeiros livros, também não se alterou muito ao longo dos anos. Certo que ganhará desdobramentos e ampliação, com especial proveito nos textos autobiográficos e nas narrativas sobre o universo dos marginalizados, dos "pingentes". No entanto, o círculo familiar e seus sucedâneos (a prostituta, o malandro, o criminoso) permanecem sendo seu núcleo dramático de predileção, e o tema favorito será, até o fim de sua carreira, o das possibilidades de atuação e inserção social dos personagens de origem pobre.

Entre os livros de destaque da fase madura do autor, posteriores a $M P B$ e $L d c$, estão Dedo-duro (1982) e Amr (1986). Este último, como já comentamos, reúne alguns contos em que o personagem principal é Jacarandá, o tipo criado pelo autor que ganharia um volume apenas com textos por ele protagonizados. ${ }^{473}$ A predileção pelos volumes jornalísticos e pela crônica (Malhação do Judas Carioca, Casa de Loucos, Ô, Copacabana!, A dama do encantado), a ficção protagonizada pelo personagem-tipo (Um herói sem paradeiro), e os livros dirigidos ao público infanto-juvenil que se avolumam nas décadas de 1980 e 90 (praticamente sem textos inéditos, porém), indicam uma perda de interesse pelos grandes projetos de ficção. A produção ficcional do autor tem em "PPT", portanto, um ápice prematuro.

Alguns textos de ficção, apesar do alcance e das pretensões mais modestas, merecem registro, por se relacionarem aos temas aqui comentados.

Em Dedo-duro, o volume de contos de 1982 que traz o autobiográfico "PMCMS", dois textos de ficção merecem breve comentário.

\footnotetext{
${ }^{473}$ Um herói sem paradeiro: Vidão e agitos de Jacarandá, poeta do momento. $2^{\text {a }}$ ed. São Paulo: Atual, 1993.
} 
"Dedo-duro" e "Bruaca" narram, como já havia acontecido anteriormente na obra do autor - em "PРT", por exemplo —, a trajetória extensiva de dois malandros. O primeiro deles, Zé Peteleco, alcunhado Carioca, torna-se informante da polícia e passa a delatar aqueles que deveriam ser seus companheiros de vida bandida; o segundo, é um velho trabalhador que se estabeleceu, malandramente, na vizinhança do Beco da Onça, na Vila Pompeia, em São Paulo, vivendo de pequenos golpes e da mendicância.

O protagonista de "Dedo-duro", Zé Peteleco, ou Zé Vesgo, como ele também é conhecido, por conta do estrabismo, é um malandro fracassado, sem "picardia", que pretende arrumar um emprego na polícia, começando como informante, alcagueta, dedoduro, atividade que ele considera um "degrau de uma carreira”. Diz ele que a alcaguetagem é a alma da polícia. Ele pensa em fazer jogo duplo, mas desiste, pois sabe que na malandragem a delação é condenada com pena de morte. Zé Peteleco sabe que malandro não tem futuro, então aspira a um emprego. E qual é o emprego que ele cobiça? Quer ser investigador de polícia.

O narrador-personagem expõe as razões pelas quais não se estabeleceu na malandragem:

Sendo um zé-mané qualquer, um pé-inchado, sem escola e sem padrinho, sem goma ou endereço fixo, nunca tive jeito de mandar à frente qualquer plano. De repente, um cana me vem, faz que se engraça, descubro que ser dedo-duro é caminho. Palmilhado direitinho, atenção e juízo, pode desembocar num emprego bom. ${ }^{474}$

Mais uma vez aparecem, neste momento tardio da obra de João Antônio, temas que já haviam sido centrais para o autor, em sua ficção inicial, e certos elementos recorrentes, como a busca por um caminho e a importância dos pés para os protagonistas. De novo, o personagem principal alude ao problema da falta da formação e da ausência do pai.

Ele não teve escola e não tem padrinho. E parece, de novo, encarnar o Édipo lendário, pois tem os pés inchados. A certa altura do conto, quando já está estabelecido como dedo-duro, atividade que ele descobre ser o "caminho", como diz o trecho acima, ele observa:

${ }^{474}$ Dedo-duro, p. 144. 
Sirvo a um só tira, o falado Sebastião Pé de Chumbo, que traz anelão de chuveiro na mão manicurada e troca camisa de preço todos os dias. Seu Sebastião diz que camisa é como mulher. Não se pode ter só uma. Isso não tenho, ainda não. Apanho da mão dele o meu jabaculê, a minha cara, magra, cada fim de mês. Grande coisa não. Mas tenho mulher na vida, que me dá algum na mão e tenteio. ${ }^{475}$

O pequeno malandro infiltrado na polícia é um Édipo desmilinguido, que afinal encontra um pai substituto, que, por sua vez, como ele, é também um Édipo a sua maneira, pois tem o apelido de Pé de Chumbo, indicando que se estabeleceu, com o peso do chumbo, na condição de Édipo, sem pai a quem enfrentar. A estes Édipos malandros parece interessar, justamente, que permaneça a condição de horda coletiva, anterior à ordem "civilizada". Nessa condição de "barbárie", em que a lei não serve a todos igualmente, mas que, ao contrário, vigora a lei da selva da malandragem, em que malandro e polícia são uma coisa só (não se distinguem e podem ser delatados de lado a lado), neste mundo cinzento (como já o era nas obras iniciais), os malandros podem, por exemplo, ter muitas mulheres, uma por dia, como quem troca de camisa (como indica o trecho acima), submetendo-as também à "selvageria".

Zé Peteleco sobe na hierarquia da polícia, mas sua atividade exige que ele continue "de campana", isto é, mantenha o disfarce de malandro, confundindo-se com eles, para poder conhecer seus planos e denunciá-los à polícia. É assim que ele adota o nome de Carioca, para poder se infiltrar em uma quadrilha de contrabando. O final do conto, porém, mantém a armação, sem que haja um desarranjo na ordem da malandragem policial a que pertence Peteleco: ele precisa localizar o seu "rato", o Pé de Chumbo, a quem serve, para que possam dar o flagrante na quadrilha de Carniça, contrabandista que será vítima da caguetagem.

"Dedo-duro" é, portanto, um conto sobre um malandro que recusa o mundo do trabalho instituído, para arrumar um emprego na polícia corrupta, a qual se confunde com a malandragem. O protagonista caminha para a ilegalidade por vontade própria e por fraqueza, por conta de uma inaptidão para a vida "direita".

${ }^{475}$ Dedo-duro, p. 149. 
O conto sugere, por meio da narrativa do próprio Peteleco, um retrato da impotência que domina esse Édipo que não pode virar "rei", como Perna Torta. Apesar de subir na hierarquia da polícia e da malandragem, ele permanece "servo", lacaio do Pé de Chumbo.

Assim como em Paulinho Perna Torta, em "Dedo-duro" a constituição do personagem está vinculada às sua dificuldade de inserção e seu começo marcado por inferioridade e impotência, por falta de malandragem e picardia. Ao contrário de Perna Torta, porém, Zé Peteleco vende-se para a polícia, associando-se de maneira corrupta com a força da ordem, também corrupta e corruptora.

O texto retoma o tema da constituição de um personagem que começa por baixo, que não tem a malandragem necessária para subir na vida e que só obtém a picardia graças a uma atuação corrupta e traiçoeira. Para poder atuar e sobreviver, Zé Peteleco troca de nome, assumindo a identidade de Carioca, disfarce de malandro que permite manter sua identidade de policial infiltrado na malandragem. A atividade de delator, alcagueta, dedoduro é vista como traição imperdoável e alimenta a ciranda de rixas e vinganças, que só fazem girar o motor da violência, da corrupção e da exclusão. Ao contrário da fantasia de malandro de Perna Torta, que é abrigo e única identidade, o codinome de Carioca serve ao policial Zé Peteleco como disfarce traiçoeiro, dentro da polícia corrompida, isto é, dentro do avesso da malandragem, que é também malandragem a seu modo.

Os temas da investigação da identidade e das possibilidades de atuação malandras, criminosas ou corretas —, ganham em "Bruaca"476 (incluído no mesmo livro, Dedo-duro) um relato de grande riqueza formal, um conto que se situa entre a memória e a ficção, entre o cômico e o trágico.

O conto, em terceira pessoa, narra as artimanhas de um velho malandro, que trabalhou num frigorífico da Lapa, de onde foi dispensado por conta de uma friagem que pegou nas pernas. Além da doença adquirida no trabalho, por conta mesmo das condições insalubres a que foi submetido, o narrador credita a demissão ao fato de Bruaca ser preto.

Era um grande jogador de sinuca, fez fama no Beco da Onça e depois saiu pelo mundo, mas começou a beber e se perdeu. No Beco da Onça, acreditavam que era praga de otário. Quando voltou à vizinhança que o havia acolhido, "parecia um pardal molhado,

\footnotetext{
${ }^{476} \mathrm{O}$ conto, como já indicado no capítulo 1, teve uma versão anterior publicada na revista Extra-Realidade Brasileira. Malditos Escritores!, n . 4, ano I, março de 1977.
} 
enxovalhado e lambido, puxando de uma perna". Passou a dormir com os ratos na carvoaria de seu Augusto, "foi ficando e assim ficou" no Beco da Onça. Quando o tempo melhorava, suas pernas se firmavam e ele virava um "picardo" e "aprontava bem". As artes da malandragem têm o poder de rejuvenescer o velho, já de carapinha branca: "Não the faltando as pernas, Bruaca era um menino", diz o narrador. Trocava de nome por necessidade. É assim que ele adota outros nomes de guerra, como Boca Murcha ou Florzinha do Guarda-Chuva. Dividia-se entre a sinuca, em que era mestre, e a mendicância. Diz o narrador que "naquela manha de pechinchar é um relógio". Também se envolvia com outras “trampolinagens", como furtos e jogo do bicho. Quando em quando, pegava cadeia.

Certo dia, Bruaca aparece morto na calçada. E ali fica, esperando o rabecão da polícia, o que indica que não tinha parentes e o povo do Beco da Onça, onde era considerado, não se mobilizou para enterrar o velho malandro.

Diz o narrador que a morte saiu no jornal:

A gente ficou sabendo que era Orlando porque veio no jornal. Gaiato, morreu folgado, num trono de caixotes de salão, com a coroa. O chapéu ensebado lá no alto da cabeça. Veio no jornal com foto tirada em seu ponto ali no começo da rua Caiovás, quase Turiaçu, atrás do campo do Palmeiras. (...)

A gente não vê, ela mais esconde que mostra. Olhem aí: não se percebe na fotografia, que lhe faltava um dedo, o médio, na mão direita. Olhem aí: não se vê, no meio dos pelos, a cicatriz da barriga, acima do umbigo, parecendo uma boceta.

Nos pés inchados que a barra da calça pega-ladrão não alcança, os tamancos encardidos, saltos e bicos comidos, largados, tomam vento. Cambados.

São as pernas cruzadas, os braços estendidos que lhe dão a panca de rei. ${ }^{477}$

O malandro velho, que adota alcunhas femininas (Caramba, em versão anterior do conto, Bruaca, Boca Murcha, Florzinha), aparece morto. Só assim, revela-se seu nome verdadeiro, sua identidade real. É a foto no jornal que lhe confere certa majestade, como diz o narrador. O que a foto esconde, porém, são as falhas que ele carrega: falta-lhe um dedo, o dedo médio, e ele tem uma cicatriz no tronco que parece uma "boceta". Quem diz é o narrador, que faz parte desta história, ainda que sua enunciação tenda a generalizar o relato, por meio do uso da expressão "a gente", que pode tanto significar "nós" quanto "as

${ }^{477}$ Dedo-duro, pp. 179-180. 
pessoas". Ele, narrador e a gente, as pessoas do Beco da Onça, não conheciam o nome verdadeiro de Bruaca, mas sabiam que ele era um malandro impotente, sem o dedo médio e dono de uma boceta no meio do corpo, elementos deste velho Édipo, de "pés inchados", carapinha branca, que é rei dos pobres apenas na hora da morte dele próprio. Um Édipo mendigo, como Édipo em Colono, negro e excluído, efeminado e aleijado. Este Édipo castrado, como o Édipo cego da velhice, depois da queda, entretanto, ainda mantinha, para si mesmo, e aos olhos da comunidade em torno dele — a gente do Beco da Onça —, certa arte malandra, cuja majestade é revelada, porém, apenas na hora de sua morte, assim como ocorrera com Paulinho Perna Torta.

Ao contrário de Perna Torta, porém, Bruaca tinha a capacidade de trocar de nome, de arrumar um disfarce qualquer - disfarce que é morada de malandro e que pode, a qualquer hora, assumir nova configuração, se o malandro souber arrumar outra fantasia. Perna Torta, ao contrário, por conta da fama, do nome que corre e da inscrição no próprio corpo de seu nome de guerra não tem como trocar de identidade ou, com o perdão do paradoxo redundante, disfarçar sua fantasia.

Além desses contos, "Dedo-duro" e "Bruaca", que retomam os temas dos contos de juventude, "Abraçado ao meu rancor" (incluído no livro seguinte do autor, publicado em 1986) revisita o tema de "Paulinho Perna Torta", mas em chave autobiográfica.

Publicado vinte anos depois de "PPT", "Amr"478 também apresenta um protagonista que empreendeu uma trajetória de ascensão e que sente o momento presente como um tempo de crise de identidade e de autoconsciência. À diferença de Paulinho Perna Torta, o protagonista de "Amr" pode empreender um retorno à sua origem, à casa da família e da infância. O retorno, porém, como vimos no primeiro capítulo, é um retorno problemático, que questiona a ascensão, a distância da origem e a própria volta à casa familiar.

A volta a casa é um retorno impossível à mãe e ao pai, mesmo que o pai esteja ausente, como se dá no final de "Abraçado ao meu rancor". Não há volta possível para o

${ }^{478}$ É possível que o autor tenha começado a escrever "Amr" muito antes da publicação em livro, em 1986. Em carta de 26 jan. de 1976 a Caio Porfírio Carneiro, João Antônio diz ter escrito um conto que, pela descrição, se assemelha a "Amr": "Hoje estou como um limão espremido. Acabo de fazer um conto que me vinha na cabeça há tempos e tempos, coisas espichadas, aí por volta de 34 laudas. Uma pauleira que me esgotou; dei o batismo: 'Cor de cinza'. E meti uma espécie de subtítulo: 'Visita à Cidade Natal'. Total: boto a língua pela boca de exaustão. Que aventura terrível é a literatura, Caio!”. ANTÔNIO, J. Cartas aos amigos Caio Porfírio Carneiro e Fábio Lucas. op.cit., p. 67. 
narrador maduro criado por João Antônio - que se confunde com o autor, ainda que, como tentamos mostrar no capítulo 1 , seja problemática a equivalência com o próprio João Antônio ele mesmo. A ascensão social e a opção pelo jornalismo e pela literatura o afastam da origem, ainda que a casa mantenha sua importância, representada em especial na figura da mãe, como o porto seguro e inicial que possibilita a busca, a aventura e a própria existência autônoma e madura - distanciada da origem, mas vinculada a ela.

A relação com a mãe, aliás, também avulta, além da relação com o pai, na fase madura, tanto nas narrativas autobiográficas, como vimos, quanto na ficção tardia. Em textos como "Mariazinha Tiro a Esmo" e "Maria de Jesus de Souza (Perfume de Gardênia)" — dois contos que não tivemos oportunidade de comentar neste trabalho —, as prostitutas estão no centro do relato. E é curioso notar que mesmo textos de combinação jornalísticoficcional como "Cais" (de Malhação do Judas carioca) e $\hat{O}$, Copacabana! $!^{479}$ e de corte autobiográfico como "Amsterdam, ai" (de Amr) tenham prostitutas como protagonistas. Mais que isso, sejam textos sobre a relação, expressa pelo narrador-protagonista, de fascínio e dependência para com essas personagens.

A mãe é importante também nos textos da ficção inicial do autor, com destaque para "Busca" e "Meninão do caixote", como vimos. E em "Paulinho Perna Torta", a relação conflituosa com as figuras paternas, que o suposto parricídio de Paulinho Perna Torta simboliza, vem acompanhada de uma relação maternal com as prostitutas. É sintomático disso como narrador se refere à maneira de explorar as prostitutas: "Vou mamando". Além do pai substituto, encontrado em Laércio Arrudão, Perna Torta encontra em Ivete e em outras prostitutas as mães substitutas, "minas" em quem ele vai "mamando".

"Paulinho Perna Torta", assim, pode ser visto como a narrativa de ficção que é a síntese da obra do autor, onde João Antônio procurou investigar as possibilidades de atuação individual e de investigação social, a partir da trajetória de um personagem pobre, de origem nebulosa, mas que se afirma e se constitui por meio de uma existência marginal,

\footnotetext{
${ }^{479}$ Apesar de ser uma narrativa sobre um dia na área do porto de Santos, "Cais" se torna, na pena do autor um texto sobre os bordéis e as prostitutas da zona portuária da cidade, com destaque para Rita Pavuna e Odete Cadilaque. Em Ô, Copacabana!, é o próprio bairro que será comparado a uma prostituta, logo no início do relato: "Meu amor. Hoje, acordei encapetado. E me ganiu, profunda, alta, uma vontade de brigar contigo, te chutar a barriga, sua marafona engalicada!". E também ao final, que retoma o começo: "Copa injuriada, mal lambida, prejudicada, velha antes do tempo, mijada e cagada pelos cachorros, marafona fanada, os letreiros das fachadas de tuas lojas ficando passados, marafona muquirana, muquira, lambona, estuprada, matas cachorro a grito e jacaré a beliscão, haja-te Deus, pasto de energúmenos, caxinguenta outrora linda, atopetada de carros e viventes até onde não agüenta e diz chega. És a que nos resta".
} 
malandra e afinal criminosa, que é reflexo e reflexão sobre a sociedade, sobre o indivíduo e a interação entre eles. O conto encontra contraponto e desdobramento, vinte anos depois, em "Abraçado ao meu rancor", em que o protagonista também se questiona sobre a própria existência, seus limites e possibilidades. Neste último conto, o contexto em que essa narrativa foi escrita, e que emoldura a crise pessoal e profissional do narrador-protagonista, não é mais a da malandragem antiga e do crime em pequena escala; são os tempos de ditadura, de um processo econômico excludente - de escalada e dispersão do crime - que o autor, fiel a seus impulsos de criação e de pesquisa literária mais pessoais, irá retratar mais uma vez por meio de um personagem individualizado, que é acossado e ameaçado pela dinâmica da sociedade em que está inserido: um jornalista, narrador e, mais que tudo, um escritor que se afirmou como criador, crítico e intérprete da realidade, cujo lugar social e a própria atuação estão em risco. "Amr" é um ponto alto na carreira de João Antônio ao combinar ficção e autobiografia, aventura e retorno, lamento e rancor como resistência à lógica excludente e destrutiva das mudanças pelas quais São Paulo passou em pouco mais de duas décadas.

As oposições e confluências entre vida e literatura, entre ficção e não ficção acompanharam João Antônio até o fim de seus dias. Ao leitor que se dispõe ao esforço de ler a totalidade da obra de João Antônio, chama a atenção a disparidade de formas narrativas e modos de construção textual, ainda que, como se sabe, o autor tenha se mantido fiel a poucos gêneros literários: o conto, a crônica, a reportagem; não escreveu poesia nem romance, apesar de ter arriscado alguns versos e de ter mantido planos de realizar uma narrativa longa. A sensação de dispersão formal de sua obra cresce à medida que o leitor avança cronologicamente na lista de livros publicados pelo autor, culminando na produção da década de 1990. Com exceção de Dama do encantado (editora Estação Liberdade, 1996), que reúne perfis inéditos em livro, os demais títulos do autor na última década retomam e reagrupam textos anteriormente publicados em outros volumes, com escassos textos inéditos. ${ }^{480}$

\footnotetext{
${ }^{480}$ É o caso dos livros Patuléia. Gentes da rua. São Paulo: Ática, 1996; Sete vezes rua. São Paulo: Scipione: 1996; Paulinho Perna Torta. Porto Alegre: Mercado Aberto, 1993; Um herói sem paradeiro. Vidão e agitos de Jacarandá, poeta do momento. São Paulo: Atual Editora, 1993. Guardador. Rio de Janeiro: Civilização Brasileira, 1992; Meninão do caixote. São Paulo: Atual, 1991; Zicartola. São Paulo: Scipione, 1991.
} 
Por outro lado, a leitura e a releitura de sua ficção revelam, em sentido contrário, temas e características narrativas que se repetem, que se mantêm e que assumem variações, desde o começo de sua carreia de escritor e o acompanham até as últimas realizações. Sobressai um forte sentido de coerência no universo ficcional do autor. A unidade marcada da obra de João Antônio se deve à sua poderosa capacidade de criar personagens marcantes e sua ligação duradoura com o universo temático e humano de suas primeiras e mais conhecidas obras - a ponto de, ao final da carreira, continuar republicando os contos de juventude.

Certa diluição das fronteiras de gênero e a combinação de literatura e reportagem na obra do autor podem ser vistas como condizentes com o momento em que foram produzidas. Como indicam Antonio Candido e Davi Arrigucci Jr, a "confusão de gêneros" 481 e a tendência à "literatura mimética", com "lastro de documento"482, deu a tônica da ficção brasileira na década 1960 e 1970. E Alfredo Bosi também chama a atenção para a "surpreendente variedade", o "caráter plástico" e a condição "proteiforme"483 do conto brasileiro contemporâneo à época.

No entanto, entendemos que todas essas características, aparentemente contraditórias, podem ser vistas e analisadas, segundo nossa leitura, de acordo com as relações entre os narradores, os protagonistas e demais personagens dos textos de ficção de João Antônio. Mais especificamente, essas características confluem na ficção e nos contos autobiográficos para tensões expressas entre os personagens masculinos e as figuras paternas a que eles estão submetidos e também às figuras paternas substitutas, às quais se submetem por exigência social, por acaso e até por vontade própria. Nesse sentido, na relação entre protagonistas e seus pais, entre os protagonistas e as figuras paternas substitutas, entendemos que a literatura do autor, mais uma vez, carrega elementos contemporâneos, que podem ser identificados como índices de modernidade literária e de forte conteúdo psicanalítico, mas também de teor arcaico, informados pelo mito, pela oralidade e por uma situação social que expressa as contradição de uma modernização que não eliminou traços patriarcais, de herança colonial e escravista.

\footnotetext{
${ }^{481}$ CANDIDO, A. "A nova narrativa". In: A educação pela noite \& outros ensaios. op.cit.

482 ARRIGUCCI JR., D. "Jornal, realismo, alegoria: O romance brasileiro recente". In: Outros achados $e$ perdidos. São Paulo: Companhia das Letras, 1999.

${ }^{483}$ BOSI, A. "Situações e formas do conto brasileiro contemporâneo". In: O conto brasileiro contemporâneo. $4^{a}$ edição. São Paulo: Cultrix, 1981.
} 
João Antônio trilhou o caminho de um "realismo feroz", como diz Antonio Candido, mas um realismo que procura constituir-se de dentro do universo que retrata, para mostrar as possibilidades de atuação dos despossuídos e marginais num contexto social que lhes é desfavorável, mas no qual eles insistem em trilhar um caminho de aventura e, talvez, inserção, desde cedo promissora, mas improvável. Como bem apontou Candido, a possibilidade de dar voz aos despossuídos, especialmente nos relatos em primeira pessoa, faz do trabalho ficcional de João Antônio uma obra irmanada aos pobres, marginais, malandros e criminosos, mas segundo nossa leitura também crítica e investigativa das possibilidades e limites dessa representação.

Nesse percurso, João Antônio deixou cada vez mais a ficção, em favor da reportagem literária, dos textos de corte mais ensaístico, dos perfis jornalísticos (reunidos em Dama do encantado) e da escrita autobiográfica (as cartas e os contos autobiográficos). Esta, sobretudo, percorre sua obra do início ao fim, desde a ficção de inspiração pessoal aos contos autobiográficos da maturidade, passando pela intensa correspondência mantida pelo autor ao longo da vida toda.

Não se trata de dizer que João Antônio virou personagem de si mesmo, ${ }^{484}$ o que talvez não seja de todo equivocado, mas de ressaltar como a produção fíccional de juventude estava desde então marcada pela experiência do autor, o que viria a se confirmar nos contos autobiográficos de vinte anos depois. A natureza dessa experiência pessoal, que o autor usou como matéria-prima para sua obra literária, porém, não era apenas factual ou como aquela que o senso comum costuma relacionar como correspondência entre vida e literatura e que o próprio escritor, de certa forma, alimentou como um projeto literário. ${ }^{485}$

\footnotetext{
${ }^{484}$ É o que registra Mylton Severiano, expressando opinião de Marília, ex-mulher do autor: "João Antônio era um personagem que ele mesmo criou, acha Marília, 'dentro da literatura dele', que tinha que viver até as últimas consequências, ainda que às raias da demência". (p. 150). No mesmo livro, diz Marília sobre a relação entre eles e sobre os últimos anos do autor: "Um ano antes de morrer, me ligou, totalmente bêbado: 'Amor da minha vida, procurei você nos braços de todas as mulheres'. E eu com o meu marido do lado. 'João Antônio, você está bem?' 'Estarei bem quando você voltar para mim.' 'Mas você sabe que já casei de novo.' 'Se você ficar viúva, pode voltar para mim que eu te perdôo.' Achei que estava muito solitário. Comecei a ligar mais, para ver se estava bem. Nunca esqueci o João Antônio, porque foi o primeiro homem da minha vida. Não só sexualmente, mas também emocionalmente. Foi pai do meu primeiro filho. E foi traumático, porque não me aceitava como mulher. Cheguei a esta conclusão depois de fazer terapia. Eu não fazia parte daquele roteiro que ele fez para ele. Não era mulata! De acordo com o que ele pensava, era pequenoburguesa. Esquerda festiva. Não era puta!” (pp. 145-146). Severiano, M. Paixão de João Antônio. São Paulo: Casa Amarela, 2005.

${ }^{485}$ Sobre isso, ver os textos "Corpo-a-corpo com a vida". In: Malhação do Judas carioca. Rio de Janeiro: Civilização Brasileira, 1975; "De Malagueta, Perus e Bacanaço". In: MPB; e as entrevistas: "João Antônio:
} 
João Antônio escreveu sobre o que viveu e sobre um universo que é fundado em sua própria experiência, inspirado na observação da realidade mas também na elaboração formal e, portanto, profundamente ficcional. Seus protagonistas, na ficção e nos contos autobiográficos, nascem da vivência e da imaginação do escritor, mas se distanciam dele próprio para ganhar o mundo, com existência e nomes próprios, enfrentando os percalços que a "realidade" impõe, no espaço ficcional. Dentre os obstáculos para o desenvolvimento dos personagens de sua ficção, avulta o contraponto com as figuras paternas, que são ambivalentes: provedoras, protetoras e orientadoras, mas também violentas e castradoras.

Os pais, em João Antônio, são instâncias que precisam ser enfrentadas e superadas para que, no nível pessoal, os protagonistas possam crescer, e no âmbito social empreendam um caminho de conquista e inserção, sempre incertas, mas desejadas e problemáticas: narradores e personagens fabulam trajetórias de ascensão e aventura, mas permanecem fiéis à própria origem, irmanados aos marginais e inconformados, arredios aos valores "positivos" da sociedade em que vivem.

Ficção e autobiografia expressam, em João Antônio, questões pessoais - que se relacionam ao homem que foi João Antônio - , mas também problemas críticos que dizem respeito à interpretação literária e à historiografia da literatura brasileira. De Malagueta, Perus e Bacanaço aos contos autobiográficos da maturidade, passando por "Paulinho Perna Torta", o autor investigou as possibilidades e as fronteiras da narrativa de ficção, afirmando-se como escritor e jornalista, narrador e narrador de si mesmo, moldando na literatura seus desejos e seus limites. Na obra do autor, a constituição de narradores, de personagens e da própria ação está em processo, tematizada, debatida e investigada. E João Antônio, ele mesmo, não escapou a essas contradições, tomando a ficção e a autobiografia como campo de formação, atuação e identidade — problemático até o fim.

Como já indicou Rodrigo Lacerda:

João Antônio viu-se um homem traído pelos dois mundos que tinha, o seu de origem, do qual seu auto-didatismo, entre outros elementos de sua personalidade, e seu novo status o distanciavam; e o mundo literário, que o tirou da vida proletária mas não lhe deu a tão sonhada

"Escrevo de dentro para fora”". In: Patuléia. Gentes da rua. São Paulo: Ática, 1996; "O leitor como parceiro", in $L d c$, pp. 159-162, e "O leitor é um parceiro que eu vou procurar". In: Malagueta, Perus e Bacanaço. São Paulo: Ática, 1987. 
chance de viver exclusivamente de sua literatura, e, a partir de um certo momento, cassou o trânsito fácil e prestigiado de seus textos, e ainda lhe roubou a força literária. Despontar para a fama como escritor durante os anos 60 e 70, época de intensa modernização não apenas dos valores na sociedade, mas também da indústria cultural, campo específico de sua atuação, deulhe a impressão de que a sociedade iria permitir a "muralha positiva", ou seja, a obtenção de uma vida ganha exclusivamente como escritor, a dedicação completa a sua arte, àquele amor que, como sua mãe mesmo disse, não admitia concorrentes. Daí sua defesa tão contundente da profissionalização do escritor, sua guerra santa em nome do pagamento dos direitos do autor no Brasil, cujo respeito, estranho que seja, não era a norma no mercado editorial da época (até hoje, mais raramente). Daí as brigas que teve com quase todos os seus editores. Daí, em parte, o gradual desaparecimento de seus livros das prateleiras das livrarias. Daí suas desilusões com a televisão, ele que sonhava em ver os escritores ocupando lugar de destaque na tele-dramaturgia e na programação como um todo. Daí suas desilusões com o jornalismo, que, após um espasmo renovador, retrocedeu e abandonou as experimentações e a convivência com a literatura. Nunca João Antônio se libertou da necessidade de ganhar dinheiro para sobreviver. Ele se livrou das obrigações familiares, dos vínculos sentimentais, obstáculos para sua vida integralmente literária, mas nenhum sacrifício foi suficiente. ${ }^{486}$

Como vimos ao longo deste trabalho, essas contradições ganharam representação literária, tanto ficcionais como autobiográficas, em João Antônio. Entender o percurso que vai da casa para a rua e do ambiente familiar para o convívio social, que na obra do autor é também a passagem da juventude para a idade adulta, permite compreender que essa movimentação horizontal, a "ânsia deambulatória"487 dos protagonistas do autor, traz consigo também um impulso vertical de subidas e descidas que faz com que os personagens se lancem não apenas à deambulação sem rumo, mas também à ação, com consequências dramáticas. Em certos casos, trágicas.

Esse impulso vertical se expressa na hierarquia que se estabelece entre os protagonistas e na própria ideia de ascensão e queda — real ou imaginada — que marca a trajetória dos personagens. É, portanto, um movimento de mão dupla. Vive-se a expectativa e o desejo de ascensão ao mesmo tempo que se teme e se antevê a queda.

É preciso cometer o crime de parricídio, para passar da infância à idade adulta; é preciso substituir o pai por pais substitutos, como o professor, o chefe, o patrão - e também “assassiná-los”, isto é, suplantá-los, a fim de se livrar do seu jugo. Nos contos do

\footnotetext{
${ }^{486}$ LACERDA, R. João Antônio, uma biografia literária, op.cit., pp. 449-450.

${ }^{487}$ BosI, A. "Um boêmio entre duas cidades". In: AMR.
} 
autor, porém, essa passagem não se dá. Pois os personagens estão, de certa forma, presos à roda-viva da malandragem: malandros viram otários, que desejam ser malandros, mas na verdade não passam de vagabundos mirrados, trouxas, que podem vir a ser malandros, mas acabarão cedo ou tarde como trouxas, como indica "MPB". Eles vivem a "ciranda da malandragem", como bem definiu Jesus Antonio Durigan. Com isso, as narrativas ficcionais de João Antônio encenam situações de circularidade e de incompletude.

Para a ascensão é necessário ultrapassar o pai. No entanto, por uma certa constante de comportamento, os protagonistas estão impedidos de cometer o parricídio. Isso se dá por conta das regras da malandragem, no caso dos contos mais desenvolvidos, e também por certa dificuldade psicológica relacionada à relação entre os protagonistas e as figuras paternas, no caso dos contos iniciais, que apresentam personagens em processo. Assim, de certa forma, os personagens do autor não podem (ou são incapazes ou estão impedidos) de executar o crime que os permitiria "fazer romance" ou que consubstanciaria a narrativa trágica. E isso se torna um problema, impasse, sinuca, pois transforma os textos, que têm impulso de romance e inclinação trágica, em contos e em tragédia anunciada e não realizada. Daí a conexão entre o tom melancólico e a forma inacabada (em processo) de alguns de seus textos. O impulso dramático para o conflito e a preferência pela desdita e não pelo sucesso ou arrivismo tendem a conferir caráter trágico aos seus melhores contos.

A posição do narrador nos contos é uma boa porta de entrada e também de saída interpretativa para a análise crítica da obra ficcional de João Antônio.

Os protagonistas são, em geral, como se disse, jovens pobres inseridos em uma sociedade desigual, que além de não lhes permitir uma inserção estável, ainda faz com que eles temam ser ainda mais rebaixados na escala social. São conhecidos os termos pelos quais João Antônio os denominava: pingentes, sem-eira-nem-beira, pobres-diabos e, no universo da malandragem, trouxas, coiós sem sorte, otários, que até podem virar malandros... sem deixar de ser trouxas.

É notória também a capacidade de João Antônio ter se aproximado desses personagens, conduzindo de maneira empática a fala de seu narrador para com a dos despossuídos. No entanto, é preciso destacar também a distância que separa o narrador de João Antônio desses personagens. Trata-se, assim, de um movimento duplo e recorrente, de 
aproximação e distanciamento, que faz do narrador de João Antônio um figura literária de interesse.

No terreno da ficção, o realismo praticado pelo escritor, apesar de, sem dúvida, ser contemporâneo e atento às circunstâncias históricas em que se originou, apesar do sopro renovador com que foi saudado, carrega desde as primeiras realizações um forte sentimento de nostalgia. A escrita do autor é atravessada por um lirismo que a mantém vinculada ao passado, não apenas histórico, mas também pessoal, tanto no que se refere a aspectos biográficos, isto é, elementos da vida do próprio escritor, como no que se refere aos personagens, sempre ocupados com a infância e com um sentimento dolorido de passagem do tempo. Os reflexos dessa tendência de volta ao passado e de circularidade temporal se dão no nível da forma: a prosa do autor mostra-se tributária de características narrativas antigas, de grande oralidade, de um estilo tortuoso, que desacelera o ritmo do que se conta, e de um forte pathos que aproxima sua escrita da melancolia, da culpa, do impasse, de uma sinuca que em alguns momentos singulares de sua obra ganham perspectiva de resolução. Personagens como Perus e Paulinho Perna Torta, como vimos, encarnam as ambiguidades dessas trajetórias ascendentes e centrífugas, que tendem a escapar da ciranda, da lógica perversa da marginalidade brasileira, mas que, também eles, se veem reféns das contradições da malandragem e do crime.

Seus personagens são complexos e as escolhas de foco narrativo são ambíguas. São muitos os textos em primeira pessoa, em que o próprio protagonista se põe a relatar a história, em que a narração e ação coincidem. No entanto, como se disse, mesmo com a adoção de um ponto de vista colado ao do narrador-protagonista que narra e vive a ação, as voltas ao passado e o apelo à memória são uma constante nos contos do autor. Quando a escolha recai sobre o foco narrativo em terceira pessoa, a posição do narrador dos textos do autor, também se mostra tradicional, distanciada, objetiva e, simultaneamente, moderna, aproximando-se dos personagens, incorporando a fala e a oralidade típicas da cultura brasileira ao seu modo narrativo, por meio do discurso indireto livre, o que por sua vez arrasta o modelo narrativo para o terreno da cultura oral, da história popular, do causo e da lenda.

A imagem mais apropriada para caracterizar os contos do autor talvez tenha sido fornecida pelos próprios contos e pelo funcionamento formal e temático das narrativas. $\mathrm{O}$ 
andamento das ações nos contos do autor obedece ao ritmo das marés de sorte e azar, de fortuna e desdita, de euforia e melancolia que atingem os personagens. A um só tempo distanciado da trama e rente a ela, o narrador de João Antônio recorre a um jogo de disfarce e de supressão - assim como seus personagens e personagens-narradores - que acompanha o movimento da fortuna e da desdita, as marés de sorte e azar a que estão submetidos seus personagens, fazendo dele, narrador, também um personagem do universo narrado e relativizando, assim, o realismo onisciente da posição tradicional do narrador. ${ }^{488}$

Acrescente-se a isso a grande mobilidade vertical a que os personagens estão sujeitos e chega-se a uma concepção trágica da existência — ou, mais especificamente, da existência desses personagens, jovens brasileiros de origem pobre, em meados do século XX, uma trajetória em que a ascensão é improvável, mas desejada, e a queda está sempre à espreita.

Apesar de estar entre os fundadores do conto contemporâneo brasileiro, o parâmetro narrativo dos textos de ficção de João Antônio, entretanto, são anteriores. A trajetória de seus protagonistas aponta para modelos consagrados pelo romance do século XIX. As histórias recorrentes de João Antônio atualizam um grande tema do romance: a história do herói isolado que, apartado da sociedade, procura se inserir socialmente por meio de uma trajetória individual e nova.

Mas, mais que isso, a questão principal que se coloca em relação à ficção de João Antônio, e que se espraia para seus textos de não ficção (especialmente os autobiográficos) é da própria constituição dos personagens e da narrativa em si mesma.

O narrador em João Antônio também está implicado na dinâmica de mobilidade e ascensão, sujeito ao impulso vertical latente que confere caráter trágico aos contos - e não apenas os narradores-personagens, mas também o narrador em terceira pessoa, como vimos em "MPB", já que está a um só tempo irmanado aos personagens mas também distanciado e acima deles. Nesse quadro, destacam-se "Amr" e "PPT", contos em que a ascensão se dá, um parricídio simbólico tem lugar e, entretanto, a sinuca se repõe: a nostalgia e a fidelidade à origem mantêm os protagonistas presos à culpa e ao rancor.

Por conta, porém, desse impulso vertical que atua sobre os personagens, os protagonistas que são em geral despossuídos - merdunchos, trouxas - estão sujeitos a

${ }^{488}$ ADORNO, Theodor W. "Posição do narrador no romance contemporâneo". In: Notas de literatura I. op.cit. 
ganharem status e se tornarem maiores e mais poderosos do que são. Em outras palavras, os jovens protagonistas sonham com grandes "paradas" ("Visita"), fantasiam grandezas ("MPB"), aspiram à aventura e ao partido alto ("PPT"), sempre um pouco à deriva, sujeitos às marés de sorte e azar que guiam a malandragem e a vida de otário. Trouxas e malandros trocam de lugar, de acordo com a circunstância: otários podem se revelar grandes malandros, grandes malandros podem cair para a condição de trouxas, assim como os malandrecos podem se tornar grandes ases do jogo se tiverem picardia e se a fortuna os favorecer.

O impulso ascendente, porém, nunca deixa de atrair os personagens e nos textos mais complexos prevalece. Nesse sentido, os protagonistas de João Antônio, incluindo ele próprio, são heróis trágicos. Vivem o drama da malandragem e, quando conseguem ultrapassá-lo, escapando da sinuca, e adentrando o mundo do crime, como em "PPT", voltam a se deparar com um destino que lhes escapa, encontram a iminência da tragédia e percebem que estão condenados a desaparecer. E ninguém vai contar sua história, a não ser eles mesmos, malandros e criminosos. Daí porque João Antônio tenha assumido a tarefa de narrar. Para contar a história dos merdunchos e dos malandros e para narrar a sua própria história.

Assim, João Antônio experimentou as possibilidades de retrato e invenção do merduncho, do malandro, do boêmio, do criminoso e do narrador, e o fez como narrador, narrador-protagonista, jornalista, cronista e biógrafo de si mesmo, inovando e deixando marca pessoal em todas essas modalidades de criação. Nesse percurso foi fiel e infiel a si mesmo, ultrapassando a própria biografia. Sua concepção de escritor - de sua própria atuação como escritor - não se resumiu a parâmetros estabelecidos, porque the interessava, justamente, examinar as possibilidades de criação e liberdade, tanto pessoais como literárias.

Para além das questões sociais e históricas que sua ficção aborda, mas incluindo e fundando-se nelas, a obra de João Antônio expressa as possibilidades e os limites da arte narrativa produzida por um escritor de origem pobre, que conseguiu, por méritos próprios, afirmar-se como escritor e retratista complexo de seu próprio mundo, profundamente interessado na investigação de suas origens, de sua trajetória e de suas possibilidades de realização. 
Por conta do forte conteúdo autobiográfico de sua obra, essas contradições dizem muito sobre o próprio João Antônio, mas não apenas sobre ele. As características mais complexas de sua obra também iluminam problemas críticos e de composição relacionados ao realismo, à linguagem e à cultura urbanas no Brasil do século $\mathrm{XX}$, que ainda pedem desenvolvimento e continuam a desafiar críticos e influenciar escritores contemporâneos.

Nesse sentido, João Antônio persiste sendo um autor que tem muito a dizer ainda hoje para a ficção e a crítica literária. Ancorada no mito, na oralidade, na modernidade literária, na investigação da realidade e da psicologia de seus personagens e de si próprio, a escrita de João Antônio é matéria e inspiração estimulantes para leitores e escritores contemporâneos, para a crítica e a historiografia brasileiras. A combinação de realismo inovador - enraizado na tradição não apenas brasileira mas universal - com retrato íntimo, psicológico e social faz dessa literatura uma obra singular, um "realismo feroz", mas reflexivo, que continua a interessar e desafiar o leitor crítico.

O percurso analítico empreendido aqui, desde os primeiros contos de ficção, passando pelos relatos de memória, como Lambões de caçarola e "PMCMS", vão culminar cronologicamente em "Amr", conto autobiográfico que alia, de maneira poderosa - em ação —, a ficção e a autobiografia. Se em Lambões, primeiro texto autobiográfico de maior relevância, a atenção para o mundo objetivo, para a comunidade, para a história e para as figuras paternas se mostra estruturante da narrativa, nos dois últimos outros contos autobiográficos, "PMCMS" e "Amr", a identidade do próprio narrador-escritor é que passa a ser examinada em primeiro plano.

Em todos os contos, e nos autobiográficos em particular, o embate com as figuras paternas é determinante para a identidade do narrador. Em Lambões, o pai biológico e o presidente se equiparam na relação que o narrador mantém com as figuras modelares, de autoridade e identificação. Como vimos, aos poucos o narrador se distancia do presidente, mantendo-o, entretanto, muito próximo do pai biológico, sem que consiga, ainda, formular um contraponto consequente entre as duas figuras paternas e o próprio narrador. Em "PMCMS", o escritor adquire maior centralidade, e o narrador examina a maneira com que, a partir do enfrentamento da figura paterna, conseguiu afirmar-se e, mais que isso, afirmar um modo de ser, em contraponto e oposição à figura paterna. 
“Amr” representa um momento de maturidade, momento visto, entretanto, como problemático. A identidade do escritor é colocada em xeque, pois ele não se reconhece mais na cidade que o gerou (a cidade como um modo de ser) nem, tampouco, como o narrador que se tornou ao narrar esta mesma cidade que desapareceu. Neste conto, cidade, lugares e personagens são reduzidos ao próprio escritor, à sua percepção, ao lamento pessoal de um narrador que não quer mais narrar, que recusa a aventura num mundo que não reconhece, que não quer conquistar, onde não quer se afirmar nos termos que lhe restam. Ele empreende uma volta a casa, uma casa, porém, que ele também recusa, por saber que não pode voltar.

Pode-se dizer da obra de João Antônio o que Antonio Candido disse a respeito da confluência entre ficção e confissão em Graciliano Ramos:

[...] O escritor vê o mundo através dos seus problemas pessoais; sente necessidade de lhe dar contorno e projeta nos personagens a sua substância, deformada pela arte. [...]

A tendência para manifestar-se leva porém a uma encruzilhada: o romance, todas as suas exigências formais, vai parecendo molde apertado e incompleto [...] Sente-se constrangido na ficção e abandona-a para sempre no apogeu das capacidades, com apenas quatro livros publicados. O desejo de sinceridade vai doravante levá-lo a retratar-se no mundo real em que se articulam as suas ações; já instalado na primeira pessoa do singular como artifício literário, deslizará para a experiência real dentro da mesma perspectiva de narração, mas sem qualquer subterfúgio. ${ }^{489}$

Assim como Graciliano, João Antônio abandonou a ficção em favor da autobiografia. No entanto, como tentamos mostrar, mesmo os textos autobiográficos do autor, vêm carregados de ambiguidades que permitem enquadrá-los em uma categoria fronteiriça, entre a ficção e a biografia. Desde o formato e a definição dos livros (a maneira com que os paratextos apresentam as obras ao leitor), nota-se uma combinação entre os dois aspectos, o biográfico e o ficcional, que fazem desses relatos memorialísticos "contos autobiográficos".

Do ponto de vista crítico, o problema que se apresenta é, portanto, entender em que medida autor e narrador não coincidem e por que não coincidem. Como vimos, para o escritor João Antônio, a dissociação se deu por conta de um impasse, de uma crise que é

${ }^{489}$ Candido, Ficção e confissão, op.cit., pp. 64-65. 
pessoal, social, política, econômica, mas também e sobretudo literária: a dificuldade ou, talvez mesmo, a impossibilidade de narrar - a certa altura da vida e do processo social uma história que é localizada no tempo, mas também é atemporal, pois se relaciona com a memória, com o mito, com a lenda, com o mistério da existência e de como narrar a existência. Distanciado da origem e de seu universo de criação e fabulação, o escritor deixa de frequentar a arena literária para manter-se fiel às origens e seu mundo literário de formação: os personagens merdunchos, malandros e boêmios. Mas, paradoxalmente, não pode mais deixar de ser o que é, de origem pobre $e$ de classe média, boêmio $e$ trabalhador intelectual, escritor $e$ jornalista, para voltar a ser merduncho, boêmio e escritor. Essa hesitação entre ser e não ser, que é também a de seus personagens, ganha no próprio João Antônio expressão complexa, como vimos nos contos autobiográficos.

O conto "Amr" marca um momento da carreira de João Antônio em que ele ainda é o escritor João Antônio, mas talvez já não consiga mais ser narrador. Daí porque sua identidade, nos contos autobiográficos, paulatinamente deixe de ser a do escritor-narradorpersonagem que define os relatos autobiográficos. Assim como o narrador, também o personagem João Antônio, de certa forma, encontra aqui sua última representação, pois “Amr" é um conto sobre um narrador que perdeu o mundo em que nasceu, onde se criou, que sonhou e no qual viveu, sobre um narrador que não tem mais o que narrar, pois o passado desapareceu, e que não encontra mais motivos para se lançar à aventura, neste mundo conspurcado pela violência política e econômica, que a ele parece ter se fechado às possibilidades de ação. Um mundo em que a escrita literária também está em risco, acossada pelo jornalismo, pela publicidade, pela televisão e pelo próprio funcionamento do sistema literário brasileiro, que não permite viver de literatura.

Depois do livro Abraçado ao meu rancor, publicado em 1986, o autor publicaria escassos textos ficcionais. Sintomaticamente, no mesmo ano deste livro, sai o volume de Melhores contos do autor. ${ }^{490}$ E depois da publicação desses dois títulos, o escritor não voltou a publicar um volume relevante de ficção, indicando um momento de chegada, uma parada na criatividade e na carreira, que vão se revelar, aliás, definitivos.

"PMCMS" marca o momento da vida em que o jovem escritor se lançou como autor. Como vimos, o rapaz boêmio e desregrado é capaz de ganhar nova identidade, a de

${ }^{490}$ ANTÔNIO, J. Os melhores contos. Prefácio de Antônio Hohlfeldt. $2^{a}$ edição. São Paulo: Global, 1997. 
um escritor lírico e sestroso, Paulo Melado do Chapéu Mangueira Serralha, nome depois abandonado em favor da assinatura literária: João Antônio.

"Amr", por sua vez, assinala o tempo da maturidade de escritor. Um autor de uma arte que "não permite dois amores", como se formula no texto, indicando que houve uma escolha pela literatura, pela ficção e não pelo jornalismo, pela escrita factual, pela nãoficção. Em “Amr”, a identidade do personagem é a de um escritor que ama a literatura, mas sente-se inseguro quanto à capacidade de sustentar esse amor, de um jornalista que não quer ser jornalista, mas que também não pode ser apenas escritor, ainda que seu amor seja o amor pela escrita, pela escrita literária.

Essa contradição conduz a obra do autor ao tempo de uma maturidade problemática e melancólica, em que os textos de ficção foram rareando e mesmo os textos inéditos escassearam. Nos últimos anos de vida, João Antônio não voltou a desfrutar do sucesso e do prestígio que alcançou nos anos 70. Depois do auge da carreira literária em termos de vendagem e reconhecimento popular, quando chegou a ter um livro no topo das listas de mais vendidos, ${ }^{491}$ o autor terminou seus dias editando velhos textos em formato infanto juvenil, por várias editoras, e, como vimos, saudoso dos tempos passados e ligado aos textos de juventude.

E, no entanto, apesar do final melancólico, a leitura das últimas cartas do autor, se corroboram a ideia de um fim de vida sem glória literária, atestam também a permanência do apreço de João Antônio pela literatura, pela arte e pelo caráter irrequieto de sua personalidade, por um inconformismo que se manteve afiado e rancoroso, mas também bem-humorado, até os momentos derradeiros.

As cartas, aliás, tornaram-se local privilegiado para a experiência literária de João Antônio. Na troca de correspondências, o autor encontrou possibilidade de seguir escrevendo criativamente e, ao mesmo tempo, ser fiel a si mesmo. Encontrou também leitores fiéis a ele, algo que de certa maneira atendeu a seus desejos de interlocução e suas necessidades de atenção e afeto, de acolhimento a seus impulsos de criação e experimentação literárias.

\footnotetext{
${ }^{491}$ Carta do autor a Caio Porfírio Carneiro, datada de 30 nov. 1975: “... e Leão-de-chácara está sendo o livro mais vendido do País (revista Veja). Como se vê, o danado de Leão ruge grosso". Cartas aos amigos Caio Porfírio Carneiro e Fábio Lucas. op.cit., p. 63.
} 
Em nossa pesquisa no Acervo João Antônio, localizamos uma carta de fevereiro de 1988 em que o escritor, então na Alemanha, comenta a morte do pai.

Berlim, nevando, 23 de fevereiro de 1988.

Faz hoje seis meses que estou na Alemanha. (...)

A 13 de fevereiro, sábado de Carnaval, morreu meu pai em São Paulo. Eu soube com dez horas de diferença. Foi uma porrada seca, rente, grossa e redonda como poucas levei em vida. Tive que parar o que estava fazendo e chorar. Passei, a partir dali, a viver dois dramas. A perda de um pai inesquecível, basta ler os meus livros para sentir o tamanho de meu pai; a impossibilidade de viajar imediatamente ao Brasil. Eu estava em Berlim e era Carnaval. (...)

(...)

Claro que não sou tão incauto a ponto de cometer a ingenuidade, o que me custaria alto em termos de decepção humana, de contar aos alemães a morte de meu pai.

De uns dias para cá, amigos me têm telefonado de São Paulo e Rio. Amigos valiosíssimos me trazendo solidariedade, um recado de amor. Reconforta.

Estou vivendo uma fase dura. E, claro, certas dores não se podem confiar a qualquer um. Só àqueles que as merecem.

São como alguns textos. Não basta ao sujeito saber escrever aquele texto. É preciso merecer escrevê-lo. Essa conversa é de profundidade.

E, também, é tudo como Deus quer.

(assinatura)

JOÃO ANTÔNIO

Mas também tenho conhecido aqui alemães que, com grandeza humana, têm me dado conforto e muita solidariedade. Claro, há o vazio da perda de um pai inesquecível, uma das personalidades mais ricas, humanas e talentosas que já conheci. Mas há um aprendizado de vida e humildade em todo esse sofrimento.

Virgínio, meu irmão, que conheceu meu pai milimetricamente e o amou no dia-a-dia duro de Presidente Altino, me fez uma carta que é um momento único de amor filial. Minha mãe, dona Irene, se comporta como uma rainha. Rainha da compreensão. Amigos meus têm me telefonado do Brasil para exaltar a dignidade e a coragem daquela mulher.

Deus abençoe a todas essas boas almas que me confortaram. ${ }^{492}$

\footnotetext{
${ }^{492}$ No Apêndice desta tese, há reprodução fac-similar da cópia desta carta mantida no Acervo João Antônio. Parte da carta já havia sido divulgada no trabalho de Telma Maciel da Silva, Posta restante: um estudo sobre
} 
A morte do pai vai alcançar João Antônio em país estrangeiro, no inverno alemão. Logo ele, que odiava o frio. Distâncias de tempo e espaço parecem acentuar a dor da perda que o atinge. Ele diz ter recebido a notícia com "dez horas de diferença", talvez por conta do fuso horário ou pela dificuldade da família em contactá-lo. Mas ele não diz por quê, o que acentua o sentimento de impotência, o golpe que o atinge fortemente: "porrada seca, rente, grossa e redonda". E o texto se abre chamando a atenção para o tempo longo em que está distante do Brasil, para onde está impossibilitado de viajar imediatamente.

Além da dor da perda que a carta comunica, vale observar que a morte do pai, neste momento ainda de luto, remete não apenas à pessoa perdida e aos sentimentos dele, João Antônio, mas aos livros. É o que João Antônio anota, para sublinhar a notável importância do pai para ele: "basta ler os meus livros para sentir o tamanho de meu pai”. A perda efetiva do pai remete aos livros, à literatura publicada pelo autor, onde, como vimos e como o escritor então sublinha, "o tamanho", isto é, a presença e a ausência do pai já vinham sendo investigadas.

O próprio teor de balanço desta carta que começa contando o tempo longe do Brasil $^{493}$ — neste momento em que neva na Alemanha e no Brasil é Carnaval, e ele está longe e de luto - aponta para o teor literário deste texto. A carta não tem destinatário e, apesar de começar da maneira usual com que o escritor escrevia aos amigos, assume um caráter de diário. Não há destinatário explícito nem menção a um interlocutor como em outras cartas do escritor, sugerindo ainda que a carta pode ter sido enviada a mais de uma pessoa.

A princípio, trata-se de carta dirigida a alguém dando notícia da morte do pai e de seus sentimento quanto ao evento, mas se lermos a carta como um texto sem destinatário específico, o texto assume caráter de carta ao mundo, de texto literário escrito para atingir muitos destinatários, isto é, os muitos leitores de João Antônio — os de então e os futuros. O pacto da carta, então, é, mais uma vez, na escrita do autor, um pacto ambíguo, em que se comunicam os teores autobiográfico, literário, autoral.

a correspondência do escritor João Antônio. Orientação de Ana Maria Domingues de Oliveira. Tese de doutorado em Letras. Faculdade de Ciências e Letras de Assis, Unesp, 2009, pp. 229-230.

${ }^{493} \mathrm{O}$ teor de balanço seguirá nos trechos suprimidos na citação, pois o escritor alude às suas mudanças de cidade e à chegada ao Rio de Janeiro, mais de vinte anos antes. 
A permanência da importância do pai para João Antônio pode ser constatada em outras de suas cartas já publicadas.

A correspondência com Fábio Lucas registra algumas referências sugestivas do autor ao pai. Em outubro de 1990, escreve: "Alguns me acham elegante escrevendo. Creio que aprendi isso com meu pai, grande inspirador de elegâncias, inda mais no comportamento e no conviver. Um grande humilde, que com certeza v. teria alegria em conhecer" ${ }^{494}$ Em carta ao mesmo destinatário, já no último ano de vida, o pai volta a ser evocado, em lembranças que se relacionam à literatura e à música: "Metáfora é metáfora e não devo abusar. Mesmo nas minhas licenças poéticas, que v. tão bem conhece e, segundo sei, aprecia. Sem entrar em detalhes e sem contar o segredo, a verdade é que estou consumindo cocaína e heroína ao mesmo tempo. Descobri baratos incomensuráveis. Nesse momento, ouço Franz Liszt, Concerto para piano e orquestra $n^{\circ} 4$ e a palavra admirável é fraquinha. Compreendo na alma, agora, por que meu pai tanto admirava o compositor e pianista húngaro. Trata-se de um canalha a ser amarrado a um pelourinho e sovado de modo exemplar para largar a mão de ser zombeteiro. Trata-se de um intimorato sacanocrata. Um ousado." 495

As lembranças do pai, relatadas em carta, indicam que a figura paterna se relacionava fortemente à sensibilidade estética do autor. Na primeira das duas menções ao pai, em 1990, João Antônio liga a pretensa elegância de sua escrita à pretensa elegância do comportamento paterno. Ecoa, aqui, dois anos depois da morte do pai, a ideia de refinamento, ligada à música e à arte, que era uma das características fortes de João Antônio Ferreira, como os textos autobiográficos já indicavam. A segunda menção, em 1996, a poucos meses de sua morte, é ainda mais sugestiva, pois o escritor diz ter entendido por que o pai gostava de Liszt. A formulação expressa contradições que dizem respeito a pai e filho. João Antônio descobre que Liszt é um “zombeteiro", e conclui, brincalhão, que o compositor deveria ser castigado por isso. A afirmativa sobre o compositor húngaro reflete, obviamente, a relação entre ele e João Antônio Ferreira. Zombeteira, a personalidade do filho contrasta com a personalidade austera, sentenciosa, severa do pai. Merecia ser castigado por isso, por ser "ousado", um "intimorato sacanocrata". Aqui, é

\footnotetext{
${ }^{494}$ Carta de João Antônio a Fábio Lucas, datada de 17 de outubro de 1990. Cartas aos amigos Caio Porfírio Carneiro e Fábio Lucas. op.cit., p. 118.

${ }^{495}$ Carta a Fábio Lucas, 31 mar. 1996. In: Cartas aos amigos Caio Porfírio Carneiro e Fábio Lucas, p. 132.
} 
João Antônio que adere ao ponto de vista do pai, sem deixar de ser João Antônio, o zombeteiro e ousado, intimorato sacanocrata, isto é, alguém irônico, destemido e partidário da sacanagem, que aos olhos paternos deveria ser castigado, para deixar de sê-lo. E João Antônio não deixou de sê-lo, como sabemos e voltamos a verificar nesta carta. Aqui, a ironia desbocada do autor localiza a ousadia e a sensualidade do compositor e goza, com folga, aquilo que o pai censuraria no compositor, isto é, em Liszt, aqui identificado com ele mesmo, “compositor" João Antônio, ele mesmo um intimorato sacanocrata até os últimos dias. $^{496}$

As cartas a Fernando Paixão, enviadas no último ano de vida, dizem da mesma persistência de espírito bonachão e inquieto, ainda disposto a pensar, refletir, ler novos autores, escrever e se indignar com os problemas do país e da literatura. As cartas falam da disposição do autor em trabalhar — e reclamar disso: "Não gosto de trabalhar de graça num domingo, creio que ninguém gosta". ${ }^{497}$ A mesma carta mostra a permanência do espírito inflamado e do comportamento arredio às rodas literárias.

Quero ficar só com as coisas minhas. Muito mais que lindas, diria o poeta. Tenho boas companhias por aqui. Desde os caquis que vou comendo, pois a temporada é deles, até alguns ensaios supimpos que tenho lido graças à Maria José de Queiroz, que escreve elegante e límpido, é culta e não bota banca, dá uma de vagamunda e é uma senhora ensaísta. Ensina-me e me convida a pensar. Tão diferente da gentalha ou gentarada que gosta de aparecer e encher as medidas e desmedidas. Egões, conforme v. mesmo diz. Quero distância deste festival das vaidades arreganhadas. E dos anseios ressentidos. Deus me livre e guarde e toda a casa de Davi me salve. De assim, quero ir cada vez menos aos lugares frequentados pela curriola dita letrada. Hei de fugir deles como o diabo da cruz. E, em os vendo, me persignarei três vezes - na testa, na boca e no peito. O ambiente dos letrados está pra lá de Deus me livre. Imagino um sujeito barbado, magro e alto, com um relho na mão invadindo esses ambientes infectados e descendo o relho em todos os asquerosos. $\mathrm{E}$ aos gritos quase bíblicos:

\footnotetext{
${ }^{496}$ As cartas a Fábio Lucas, a quem João Antônio chama algumas vezes de Sábio Lucas, trazem ainda mais uma menção ao pai do escritor, anterior a todas estas comentadas. Em dezembro de 1984, o autor conta a Lucas que o pai teve de ser operado várias vezes e amputou a perna esquerda. Esta informação biográfica se torna ainda mais importante, e pungente, se lembrarmos como o caminhar é algo importante para a obra de João Antônio. Ganham também dimensão mais sofrida as dedicatórias de Lambões e de Ô, Copacabana!: respectivamente "Para João Antônio Ferreira - meu pai —, ainda firme na luta" e "Para João Antônio Ferreira / meu pai / firme ainda / e também andejo".

${ }^{497}$ Carta de João Antônio a Fernando Paixão, 12 mar. 1996. PAIXÃo, F. "João Antônio: cartas de desabafo". Revista IEB, n. 51, mar/set 2010, p. 163.
} 
— Ímpios e fariseus, ide lamber sabão com a vossa acrimônia! E o Diabo os tenha para todo o sempre, mediocrões e ignorantaços! Não passais de reles preguiçosos a dormir no travesseiro de Satanás. ${ }^{498}$

Como se vê, apesar de ainda manter enlevo pela própria verve, cultivando o estilo e a ironia, as imagens e as construções metafóricas, o autor não tinha mais paciência com as rodas literárias, com a patota da literatura, com os círculos (infernais) da "curriola dita letrada".

Mais adiante, na mesma carta de março de 1996, vituperava ainda mais uma vez contra os literatos:

Falei, Fernando, talvez até pelos cotovelos. Mas só completar para você o que eu entendo ou faço um desdobramento necessário, a meu ver - ao redor daquilo que v. chamou de carneirismo. E, concordo, está difícil conviver com esse ambiente. Não sei até onde vai o obscurantismo atual e começa uma gananciosa safadeza.

Machado neles. Lima neles. É preciso que o espírito desses dois negros volte e baixe. Com a força estrondosa das arriadas de Ogum.

A dívida da chamada arte brasileira cresce diante do que vemos por aí.

Você sabe, e muito bem, que não me excluo da cambada de fariseus. Também eu tenho dívidas com a realidade que já vi e não passei para o papel. Ninguém é perfeito, tenho muitas dúvidas e miasmas. Muita vez, diante do meu texto, tenho a consciência de que estou perante uma boa merda. Filho de quem sou, desconfio como meu pai - a idade faz velhos e não sábios. Mas me recuso a viver num corre-corre pela própria promoção, a frequentar tudo quanto é festinha de coiós e farsantes só pra ganhar notinha no jornal, a só me preocupar com o meu umbigo que, a bem dizer, é uma das partes mais sujas do corpo. ${ }^{499}$

De novo, a menção ao pai vem acompanhada de reflexões sobre sua própria escrita, ainda que não se vincule diretamente a ela, pois a lembrança é de uma daquelas sentenças paternas proverbiais, que lembram aforismas, ditos populares: "A idade faz velhos e não sábios”. A asserção entretanto vem misturada a uma espécie de mea culpa sobre as pretensas dívidas com a "realidade" que, assim como a "arte brasileira", ele diz também

\footnotetext{
${ }^{498}$ Idem, ibidem, p. 165.

${ }^{499}$ Idem, ibidem, pp. 167-168.
} 
manter. Ele não se exclui da "cambada de fariseus". E ainda assume que muitas vezes acha o próprio texto uma "boa merda".

Recorrer a uma das sentenças paternas permite, sob o manto da sapiência do pai, reafirmar a culpa, expressar certa humildade e até menosprezo pela própria obra, mas tudo isso para justificar sua ausência das rodas artísticas, seu apartamento dos círculos literários. É de novo o pai atuando, na memória e na escrita de João Antônio, para a um só tempo justificar, engrandecer e diminuir seus feitos literários.

Também naquela que possivelmente seja a última carta de João Antônio, há nova referência a João Antônio Ferreira.

Copacabana, 10/10/1996 e não é novidade nenhuma dizer o quanto passa, arisco, professor rápido, o tempo. Já ouvi isso em Hamburg e em outros lados do mundo.

Myltainho. Prezado.

Esse Grieg é um monstro da delicadeza com este "Amanhecer" que vou ouvindo neste horário de verão às quase oito da matina. Delicadeza e elegância. Com magia fina.

Espero que v. já esteja na ilha abençoada e que aí em Florianópolis estas o alcancem em paz e contentamento, gozo de boa saúde e de apetites gerais. Fêmeas há, que sei.

Quanto à telefonia, eu a entrego a Deus. (Grieg é um monstro delicado.) Como deixei gravado na sua secretária eletrônica em São Paulo, acabou-se a possibilidade de falar telefonicamente com quem quer que seja após a chegada da secretária eletrônica.

Adorno teria razão com os seus sentimentos de horror diante das máquinas?

Rapaz, como o estive procurando aí em São Paulo no final da semana passada! É que meu irmão Virgínio ajeitou, amorosamente, um churrasco no domingo que passou, 6/10, convidou músicos. Barão, quase noventa anos, e mais Ascendino Theodoro Nogueira, o maestro, estiveram lá. Mais um bandolim esperto na melodia. É por isso, Myltainho, que me cobro tanto. Rodou uma roda de choro o dia todo. E seu Ascendino tocou valsas inesquecíveis no violino. Valsas do interior.

O Barão, figura lendária, acompanhou no violino. E havia um bandolim chamado Pacífico. Que roda v. perdeu, Myltainho.

Agora, esse Grieg, já saiu da gruta do rei da montanha e vai no lamento de Ingrid, enquanto sua dança árabe não vem.

Mas em Presidente Aluno, na casa que v. conhece e em que meu irmão Virgínio montou um churrasco, amorosamente, o espírito de meu pai esteve presente. $(. . .)^{500}$

\footnotetext{
${ }^{500}$ Carta de João Antônio a Mylton Severiano. In: Severiano, M. Paixão de João Antônio. op.cit., pp. 28-29.
} 
O churrasco na casa do irmão Virgínio reúne alguns músicos, que executam composições ao bandolim e ao violino - choros, presume-se, ainda que o autor fale em valsas. É por isso que o autor dirá que o espírito do pai esteve presente, pois o pai, como sabemos, tocava bandolim, foi também chorão e possivelmente colega dos instrumentistas presentes, Ascendino e Barão, além de Pacífico, que parece não ser da intimidade do autor. Ao escrever para Myltainho, João Antônio relembra o churrasco recente, fala dos músicos, de Grieg e, na sequência da carta, de Mozart, do amigo Maneco Müller, que the elogiou o último livro, Dama do encantado, e de outros assuntos, como a miséria dos camelôs no Largo de Pinheiros em São Paulo e a péssima distribuição de livros no Brasil, "um país que sofre de melancolia da escravidão e em que somos tratados como massa de manobra". E termina de modo prosaico: pede que Myltainho, morando em Florianópolis, lhe compre pijamas da marca catarinense Hering.

O espírito do pai, este fantasma paterno, cumpre de novo sua função inconsciente de aguçar a sensibilidade artística do escritor e de infundir-lhe, mais uma vez, a culpa: "É por isso, Myltainho, que me cobro tanto", escreve ele ao amigo. O que cobra João Antônio de si próprio? O fato de não ter seguido a carreira musical e sim a literatura? Mais uma vez, o escritor não formula a culpa que sente e que vincula à figura paterna. Se a presença do pai, quando o pai era vivo, era uma presença inibidora, o fantasma do pai, o espírito do pai morto, continua a assombrar o escritor, até o fim.

João Antônio morreria alguns dias depois. Foi encontrado morto no apartamento da praça Serzedelo Correia, em Copacabana, no dia 31 de outubro de 1996. Presume-se que tenha morrido um dia depois de ali escrever esta última carta ao amigo Mylton Severiano.

As derradeiras cartas do autor divulgadas até aqui demonstram, assim, que João Antônio, apesar da saúde debilitada que o levou finalmente à morte, mantinha, em seus últimos meses uma vitalidade intelectual e uma inquietação - que beirava a indignação bastante afiadas. A morte veio cedo e abreviou uma trajetória de escritor que ainda poderia ter evoluído. Mesmo que a última década de vida de João Antônio tenha sido marcada por reedições, as cartas permaneceram um espaço privilegiado de atividade e reflexão literárias, inclusive sobre os temas que marcaram sua própria obra, para além do que registram suas entrevistas, crônicas e reportagens, publicadas em vida. Para os que estudam e apreciam a obra do autor, a extensa atividade de missivista do autor ainda reserva um campo de estudo 
e análise promissor. E, como pretendemos mostrar neste trabalho, também a obra ficcional e autobiográfica do autor permanecem desafiadoras e fonte de inspiração para a crítica.

As relações entre personagens e figuras paternas, narrador e protagonistas, autor e mundo narrado, escritor e o pai, desdobram-se na obra de João Antônio, encenando impasses e promessas de resolução, que anunciam ações e seus limites. Para a obra literária do autor, essas contradições renderam a criação de um realismo singular, ancorado na tradição literária e renovado, feroz e trágico, violento e lírico, de forma rematada mas experimental, com impulsos latentes que esgarçam os limites do conto. Para a biografia do escritor, as relações com o pai foram determinantes, até os últimos momentos. Além de informarem sua literatura, também mantiveram acesas - na memória, nos fantasmas e na fantasia imaginativa do autor — ambiguidades que o constituíram e que João Antônio soube desafiar e ultrapassar, reinventando a si próprio, sem deixar de ser ele mesmo. 


\section{Bibliografia}

\section{BIBLIOGRAFIA DO AUTOR}

AnTÔNIO, João. Malagueta Perus e Bacanaço. São Paulo: Cosac Naify, 2004. . Cartas aos amigos Caio Porfírio Carneiro e Fábio Lucas. Cotia/SP: Ateliê

Editorial. São Paulo: Oficina do Livro Rubens Borba de Moraes, 2004.

- Leão-de-chácara, São Paulo, Cosac e Naify, 2002.

. Ô, Copacabana!, São Paulo: Cosac e Naify, 2001.

. Os melhores contos. Prefácio de Antonio Hohlfeldt. $2^{\mathrm{a}}$ edição. São Paulo:

Global, 1997.

. Dama do encantado. São Paulo: Nova Alexandria, 1996.

_. Patuléia. Gentes da rua. Série Rosa dos Ventos. São Paulo: Ática, 1996.

. Sete vezes rua. São Paulo: Scipione, 1996.

- Um herói sem paradeiro. Vidão e agitos de Jacarandá, o poeta do momento. São Paulo: Atual, 1993.

_. Guardador. 2ª edição. Rio de Janeiro: Civilização Brasileira, 1992.

. Meninão do caixote. $6^{\mathrm{a}}$ edição. São Paulo: Atual, 1991.

Malagueta, Perus e Bacanaço, São Paulo, Ática, 1987.

. Malagueta, Perus e Bacanaço incluindo Malhação do Judas carioca. São

Paulo: Clube do Livro, 1987.

_. Abraçado ao meu rancor. Rio de Janeiro: Editora Guanabara, 1986.

_. Meninão do caixote. $2^{\mathrm{a}}$ edição. Rio de Janeiro: Record, 1984.

_. Dedo-duro. Rio de Janeiro: Record, 1982.

_. Lambões de caçarola (Trabalhadores do Brasil!). Porto Alegre: L\&PM, 1977.

Calvário e porres do pingente Afonso Henriques de Lima Barreto. Rio de Janeiro: Civilização Brasileira, 1975.

. (org.) Extra - Realidade Brasileira, especial Malditos Escritores!, nº .4 , ano I, março de 1977. 
. Casa de loucos. Rio de Janeiro: Civilização Brasileira, 1976.

. Malhação do Judas carioca. Rio de Janeiro: Civilização Brasileira, 1975.

\section{BIBLIOGRAFIA SOBRE JOÃO ANTÔNIO}

Aguiar, Flávio. "Evocação de João Antônio ou do purgatório ao inferno". Remate de Males, $\mathrm{n}^{\circ}$ 19. Revista do Departamento de Teoria Literária do Instituto de Estudos da Linguagem. Unicamp, Campinas, 1999.

. "A palavra no purgatório". In: A palavra no purgatório. Literatura e cultura nos anos 70. São Paulo: Boitempo Editorial, 1997.

Azevedo Filho, Carlos Alberto Farias de. Hibridismo e ruptura de gêneros em João Antônio. Tese de doutorado. Unesp, Assis, 2008.

. João Antônio: Repórter de Realidade. João Pessoa: Idéia, 2002.

Barbosa, João Alexandre. "Malagueta, Perus e Bacanaço", in Opus 60 - Ensaios de crítica, São Paulo, Duas Cidades, 1980.

BosI, Alfredo, "Um boêmio entre duas cidades". Prefácio a ANTÔNIO, João. Abraçado ao meu rancor, Rio de Janeiro: Guanabara, 1986.

CANDIDO, Antonio. "Na noite enxovalhada". In: Antônio, J. Malagueta Perus e Bacanaço. São Paulo: Cosac e Naify, 2004.

. "Um banho incrível de humanidade". In: Dedo-duro, Rio de Janeiro: Record, 1982.

ChiAPPINI, Ligia. "O Brasil de João Antônio e a sinuca dos pingentes". In Brasil, país do passado?. Organização de Ligia Chiappini, Antonio Dimas e Berthold Zilly. São Paulo: Edusp/Boitempo, 2000.

CORTÁZAR, Julio. Valise de cronópio. $2^{\mathrm{a}}$ edição. São Paulo: Perspectiva, 1993.

DURIGAN, Jesus Antonio. “João Antônio e a ciranda da malandragem”, In: Roberto Schwarz (org.), Os pobres na literatura brasileira. São Paulo: Brasiliense, 1983. . "João Antônio: o leão e a estrela”. In: ANTÔNIO, João. Leão-de-chácara. $7^{\mathrm{a}}$ edição. São Paulo: Estação Liberdade, 1989.

HoHLFELDT, Antônio. "Pra lá de Bagdá". In: ANTÔNIO. J. Os melhores contos. Seleção de Antônio Hohlfeldt. São Paulo: Global, 1997. 
LACERDA, Rodrigo. João Antônio: uma biografia literária. Tese de doutoramento em Letras. Orientação de Joaquim Alves de Aguiar. São Paulo: Departamento de Teoria Literária e Literatura Comparada (DTLLC), FFLCH-USP, 2006. . "O primeiro amor de João Antônio". In: Malagueta, Perus e Bacanaço. João Antônio. $4^{\text {a }}$ edição rev. Cosac e Naify, 2004, encarte anexado ao livro, em separata. . Pingentes: João Antônio e Lima Barreto. Disponível em: http://www.rodrigolacerda.com.br/pingentes-joao-antonio-e-lima-barreto. Último acesso: 2 jun. 2012.

LAFETÁ, João Luiz. “João Antônio e sua estética do rancor”. In: A dimensão da noite. Organização de Antonio Arnoni Prado. Duas Cidades/Editora 34.

MACÊDO, Tania. "Malandros e merdunchos". In: ANTÔNIO, J. Leão-de-chácara, São Paulo, Cosac e Naify, 2002.

MARTIN, Vima Lia. Literatura e marginalidade: um estudo sobre João Antônio e Luandino Vieira. São Paulo: Alameda Editorial, 2008.

MoRAES, Renata Ribeiro de. João Antônio de pés vermelhos: a atuação do escritorjornalista em Panorama. Dissertação de mestrado. UEL, Londrina, 2005.

MiYAKe, R. Cidade, malandros e Capital: uma leitura dos contos de Malagueta, Perus e Bacanaço. Dissertação de mestrado. São Paulo, Universidade Presbiteriana Mackenzie, 2004, p. 71.

Oliveira, Ana Maria Domingues de, Ornellas, Clara Ávila, Silva, Telma Maciel da (orgs.). Papéis de escritor: Leituras sobre João Antônio. Assis: FCL - Assis - Unesp Publicações, 2008.

OliveIra, Ana Maria Domingues de; Silva, Telma Maciel da. "Memória e ficção na correspondência do escritor João Antônio". Teresa. Revista de literatura brasileira [8] [9]; São Paulo, p. 356-371, 2008. 2011.

ORnellas, Clara Ávila. João Antônio, leitor de Lima Barreto. São Paulo: Edusp, . O conto na obra de João Antônio: uma poética da exclusão. São Paulo: LinearB/FFLCH USP, 2008.

PAES, José Paulo. "Ilustração e defesa do rancor". O Estado de S. Paulo, 21 mar. 1987. 
PAIXÃO, Fernando. “João Antônio: cartas de desabafo”. Revista IEB, n. 51, mar/set 2010, pp. 157-180.

PEREIRA, Jane Christina. Estudo crítico da bibliografia sobre João Antônio (19631976). Dissertação de mestrado. Orientação de Ana Maria Domingues de Oliveira. Assis: Faculdade de Ciências e Letras da Universidade Estadual Paulista, Unesp, 2001.

PRADO, Antonio Arnoni. "Lima Barreto personagem de João Antônio”. In: Remate de males $\mathrm{n}^{\mathrm{o}} 19$, Revista do Departamento de Teoria Literária do Instituto de Estudos da Linguagem. Unicamp, Campinas, 1999.

RIBEIRO, Joana Darc. Vozes em ruínas. Experiência urbana e narrativa curta em João Antônio e Rubem Fonseca. Tese de doutorado em Letras, Assis, Unesp, 2007.

SANTOS, Simone Paulino dos. Nas esquinas do desejo. Um estudo do tema da busca nos contos de João Antônio. Dissertação de mestrado em Letras. DTLLC. Universidade de São Paulo, 2009.

SeVeriano, Mylton. Paixão de João Antônio. São Paulo: Editora Casa Amarela, 2005.

SILVA, Telma Maciel da. Posta restante: um estudo sobre a correspondência do escritor João Antônio. Orientação de Ana Maria Domingues de Oliveira. Tese de doutorado em Letras. Faculdade de Ciências e Letras de Assis, Unesp, 2009.

ZENI, Bruno Gonçalves. Fachada, sinuca e afasia. Alcântara Machado, João Antônio e Fernando Bonassi. São Paulo, ficção no século XX. Dissertação de mestrado em Letras. DTLLC. Orientação de Joaquim Alves de Aguiar. FFLCH-USP, 2004.

ZILLY, Berthold. "João Antônio e a desconstrução da malandragem”. In: Brasil, país do passado? Organização de Ligia Chiappini, Antonio Dimas e Berthold Zilly. São Paulo: Edusp/Boitempo, 2000.

\section{BIBLIOGRAFIA GERAL}

ABDALA JÚNIOR, Benjamin. Literatura, história e política: literaturas de língua portuguesa no século XX. Cotia: Ateliê Editorial, 2007. 
ADORNO, Theodor W. "Posição do narrador no romance contemporâneo". In Notas de literatura I. Trad. de Jorge de Almeida. São Paulo: Duas Cidades, Editora 34, 2003.

. Minima moralia. Reflexões a partir da vida danificada. São Paulo: Ática, 1992.

AgUIAR, Flávio. A palavra no purgatório. Literatura e cultura nos anos 70. São Paulo: Boitempo Editorial, 1997.

AndRADE, Mário de. Contos novos. $13^{\text {a }}$ edição. Belo Horizonte/Rio de Janeiro: Vila Rica, 1990.

. O empalhador de passarinho. $3^{\text {a }}$ edição. São Paulo: Livraria Martins Editora; Brasília: INL/MEC, 1972.

ANDRADE, Oswald de. "Manifesto antropófago". In: . A utopia antropofágica. $4^{\mathrm{a}}$ ed. São Paulo: Globo, 2011.

ARRIGUCCI JR., Davi. “O mundo misturado. Romance e experiência em Guimarães Rosa", Novos Estudos, Cebrap, n. 40, nov. 1994, pp. 7-29.

. "Jornal, realismo, alegoria: O romance brasileiro recente". In: Outros achados e perdidos. São Paulo: Companhia das Letras, 1999.

. "Fragmentos sobre a crônica". In. A Crônica: uma bibliografia comentada. Boletim Bibliográfico Biblioteca Mário de Andrade. Vol. 46, n. 1/4, p. 43-53, jan./dez. 1985.

ARrudA, Maria Arminda Nascimento. Metrópole e cultura. São Paulo no meio século XX. Bauru, SP: Edusc, 2001.

AzEVEDo, Ana Vicentini de. A metáfora paterna na psicanálise e na literatura. Editora da UnB/Imprensa Oficial, 2001.

BaKhtin, M. A cultura popular na Idade Média e no Renascimento: o contexto de François Rabelais. São Paulo: Hucitec, 1987.

BENJAMIN, Walter. "O narrador. Considerações sobre a obra de Nikolai Leskov”. In: Obras escolhidas. Magia e técnica, arte e política. vol. 1. $4^{\mathrm{a}}$ ed. S. Paulo: Brasiliense, 1985.

_. "Experiência e pobreza". In: Documentos de cultura, documentos de barbárie (Escritos escolhidos). Sel. de Willi Bolle. São Paulo: Cultrix/Edusp, 1986. 
BosI, A. "Reflexo e reflexão em história literária", in: Literatura e resistência. São Paulo: Companhia das Letras, 2002.

. "Situações e formas do conto brasileiro contemporâneo". In: O conto brasileiro contemporâneo. $4^{\mathrm{a}}$ edição. São Paulo: Cultrix, 1981.

Bosi, Ecléa. Memória e sociedade. Lembranças de velhos. $3^{\mathrm{a}}$ ed. São Paulo: Companhia das Letras, 1994.

BuARQue, Chico. Tantas palavras. Todas as letras e reportagem biográfica de Humberto Werneck. São Paulo: Companhia das Letras, 2006.

CANDIDO, Antonio. O albatroz e o chinês. Rio de Janeiro: Ouro sobre azul, 2004. . Ficção e confissão. Ensaios sobre Graciliano Ramos. Rio de Janeiro: Editora 34, 1992.

. "Jagunços mineiros de Cláudio a Guimarães Rosa". In: Vários escritos. 4" edição. São Paulo/Rio de Janeiro: Duas Cidades/Ouro sobre azul, 2004.

. “A vida ao rés-do-chão". In: Recortes. $3^{a}$ edição revista pelo autor. Rio de Janeiro: Ouro sobre Azul, 2004.

. "A nova narrativa", in: A educação pela noite \& outros ensaios. $3^{\mathrm{a}}$ edição. São Paulo: Ática, 2003.

. "Dialética da malandragem". In: $O$ discurso e a cidade., São Paulo: Duas Cidades, $2^{\text {a }}$ ediç̧ão, 1998.

- "A revolução de 30 e a cultura". In: A educação pela noite e outros ensaios, Ática, $2^{a}$ edição, São Paulo, 1989.

. (org.). A personagem de ficção. $5^{\text {a }}$ edição. São Paulo: Perspectiva, 1976.

_. "The Brazilian family". In: SMith, T. L. e Marchant, A. (orgs.), Brazil, portrait of a half continent. New York: The Dryden Press, 1951.

CARone, Modesto. “Anotações sobre o conto”. In: Boa Companhia - Contos. São Paulo: Companhia das Letras, 2003

CORTÁZAR, Julio. "Do conto breve e seus arredores". In: Valise de cronópio. $2^{\mathrm{a}}$ edição. São Paulo: Perspectiva, 1993.

. “Alguns aspectos do conto". In: Valise de cronópio. $2^{\mathrm{a}}$ edição. São Paulo: Perspectiva, 1993. 
CARVALHO, Herbert. "A MPB canta e conta a nossa história", In: Revista Problemas Brasileiros, $\mathrm{n}^{\mathrm{o}} 385$, jan/fev 2008.

CAscudo, Luís da Câmara. Antologia do folclore brasileiro. $5^{\text {a }}$ edição. São Paulo: Global, 2001.

_. Contos tradicionais do Brasil. $8^{\text {a }}$ edição. São Paulo: Global, 2000

_. Dicionário do folclore brasileiro. $5^{\mathrm{a}}$ ed. Belo Horizonte: Itatiaia, 1984.

_Literatura oral no Brasil. $3^{\mathrm{a}}$ ed. Belo Horizonte: Itatiaia/ São Paulo: Edusp, 1984.

DAMATTA, Roberto. Carnavais, malandros e heróis. Rio de Janeiro: Rocco, 1997.

FAusto, Boris. Getúlio Vargas: o poder e o sorriso. Coleção Perfis Brasileiros. São Paulo: Companhia das Letras, 2006. pp. 122 a 127.

FERnANDES, Florestan. Sociedade de classes e subdesenvolvimento. São Paulo: Global, 2008.

FORSTER, E.M. Aspectos do romance. Trad. de Sérgio Alcides. $4^{\mathrm{a}}$ edição revista. São Paulo: Globo, 2005.

FREUD, Sigmund. A interpretação dos sonhos. Rio de Janeiro: Imago, 1999. . “A dissolução do Complexo de Édipo". In: Obras completas, volume 16. O Eu e o Id, Autobiografia e outros textos (1923-1925). Trad. de Paulo César de Souza. São Paulo: Companhia das Letras, 2011. . "Dostoiévski e o parricídio". In: O futuro de uma ilusão, O mal-estar na civilização e outros trabalhos (1927-1931). Edição standard Brasileira das Obras Psicológicas Completas de Sigmund Freud, vol. XXI, R. de Janeiro: Imago, 1996. . "Romances familiares". In: "Gradiva” de Jensen e outros trabalhos (1906-1908). Edição standard brasileira das obras psicológicas completas de Sigmund Freud. Vol. IX. Rio de Janeiro: Imago, 1996.

_. "Totem e tabu". In: Totem e tabu e outros trabalhos (1913-1914). Edição standard brasileira das obras psicológicas completas de Sigmund Freud. Vol. XIII. Rio de Janeiro: Imago, 1996.

. "Luto e melancolia." Edição standard brasileira das obras psicológicas completas de Sigmund Freud. Vol. XIV. Rio de Janeiro: Imago, 1996. 
FrYe, Northrop. Anatomia da crítica. Trad. de Péricles Eugênio da Silva Ramos. São Paulo: Cultrix, 1973, p. 44.

HolandA, Sérgio Buarque de. Raízes do Brasil. 26 edição. São Paulo, Companhia das Letras: 2000.

HomeM, Wagner. Histórias de canções: Chico Buarque. São Paulo: Leya, 2009.

JoANIDES, Hiroito de Moraes. Boca do Lixo. São Paulo: Labortexto, 2003.

JoLLES, André. Formas simples. São Paulo: Cultrix, 1976.

KAKFA, F. Carta ao pai. Trad. Modesto Carone. São Paulo: Companhia das Letras, 2002.

KeHL, Maria Rita. "Existe uma função fraterna?", in Função fraterna, Rio de Janeiro: Relume Dumará, 2000, p.35

LEJEUnE, Philippe. Le pacte autobiographique. Nouvelle Édition Augmentée. Éditions du Seuil, 1975, 1996.

. "Autobiografia e ficção". In: O pacto autobiográfico. De Rousseau à internet. Trad. de Jovira Maria Gerheim Noronha e Maria Inês Coimbra Neves. Belo Horizonte: Editora UFMG, 2008.

Levine, Robert M. Pai dos pobres?: O Brasil e a Era Vargas. São Paulo: Companhia das Letras, 2001.

LAFETÁ, J. "Três teorias do romance: alcances, limitações, complementaridade". In: A dimensão da noite. Organização de Antonio Arnoni Prado. Duas Cidades/Editora 34. São Paulo: 2004.

LuKÁCS, Georg. A teoria do romance. São Paulo: Duas Cidades/Editora 34, 2000. . "A fisionomia intelectual dos personagens artísticos". In: Marxismo e teoria da literatura. $2^{\mathrm{a}}$ edição. São Paulo: Expressão Popular, 2010.

Matos, Cláudia Neiva de. Acertei no milhar: samba e malandragem no tempo de Getúlio. Rio de Janeiro: Paz e Terra, 1982.

MAZZARI, Marcus Vinicius. Romance de formação em perspectiva histórica. São Paulo: Ateliê Editorial, 1999.

. "Apresentação" a Os anos de aprendizado de Wilhelm Meister, de J.W. Goethe. Trad. Nicolino Simone Neto. São Paulo: Editora 34, 2006. 
OTsuKA, Edu Teruki. "Espírito rixoso: para uma reinterpretação das Memórias de um sargento de milícias", Revista do IEB, n. 44, fev. 2007, pp. 105-124.

PAES, José Paulo. "O pobre-diabo no romance brasileiro". In: Armazém literário. São Paulo: Companhia das Letras, 2008.

PAZ, Octavio. "Verso e prosa". In: Signos em rotação. $3^{a}$ edição. Organização de Celso Lafer e Haroldo de Campos. São Paulo: Perspectiva, 2003.

PASTA JR., José Antônio. “O romance de Rosa. Temas do Grande sertão e do Brasil”. Novos Estudos Cebrap, n ${ }^{0}$ 55, 1999, pp. 61-70.

PoE, Edgar Allan Poe. "Filosofia da composição". In: Poemas e ensaios. Trad. Oscar Mendes e Milton Amado. São Paulo: Globo, 1999.

RAmOS, Graciliano. Vidas secas. 80 tiragem. Rio de Janeiro: Record, 2000. Linhas tortas. $21^{\text {a }}$ edição. Rio de Janeiro: Record, 2005.

REIMÃo, Sandra. Repressão e resistência. Censura a livros na ditadura militar. São Paulo: Edusp/Fapesp, 2011.

ROBERT, Marthe. Romance das origens, origens do romance. São Paulo: Cosac Naify, 2007.

Romero, Sílvio. Contos populares do Brasil. São Paulo: Landy, 2000.

Rosenfeld, Anatol. "Literatura e personagem". In: Antonio Candido (org.). A personagem de ficção. $5^{\text {a }}$ edição. São Paulo: Perspectiva, 1976.

RIBEIRO, Renato Janine. "Meu nome é ninguém (sobre o canto IX da Odisseia), disponível em: http://www.renatojanine.pro.br/Cultura/cultura.html

SchnAIDERMAN, Boris. "Vozes de barbárie, vozes de cultura. Uma leitura dos contos de Rubem Fonseca”. In: Fonseca, R. Contos reunidos. São Paulo: Companhia das Letras, 1994.

SCHWARZ, Roberto. Martinha versus Lucrécia. Ensaios e entrevistas. São Paulo: Companhia das Letras, 2012. . Que horas são? São Paulo: Companhia das Letras, 1997. . (org.). Os pobres na literatura brasileira. São Paulo: Brasiliense, 1983. . "Cultura e política 1964-1969. Alguns esquemas". In: O pai de família e outros estudos. $2^{\mathrm{a}}$ edição. Rio de Janeiro: Paz e Terra, 1978. 
SkidMORE, Thomas E. Brasil: de Getúlio a Castello (1930-64). São Paulo: Companhia das Letras, 2010.

SouZA, Gilda Mello e. O tupi e o alaúde. Uma interpretação de Macunaíma. $2^{\mathrm{a}}$ edição. São Paulo: Livraria Duas Cidades/Editora 34, 2003.

SÜSSEKIND, Flora. Literatura e vida literária. Polêmicas, diários e retratos. Rio de Janeiro: Jorge Zahar Editor, 1985.

TCHEKHOv, A. Sem trama e sem final. São Paulo: Martins Fontes, 2007 . A dama do cachorrinho e outros contos. São Paulo: Editora 34, 1999.

TRILLING, Lionel. "The Princess Casamassima”. In: The liberal imagination. Essays on literature and society. Nova York: The Viking Press, 1950.

Vernant, Jean-Pierre. O universo, os deuses, os homens. Trad. de Rosa Freire d'Aguiar. São Paulo: Companhia das Letras, 2000.

VIDAL, Paulo. "Freud e a nostalgia do pai". In: Bernardes (org.), Angela C. $10 x$ Freud. Rio de Janeiro: Azougue Editorial, 2005.

WATt, Ian. Ascensão do romance. Trad. de Hildegard Feist. São Paulo: Companhia das Letras, 1990.

WISNIK, José Miguel. “O famigerado”. In: Sem receita. Ensaios e canções. São Paulo: Publifolha, 2004, pp. 131-132. 
Apêndice 


\section{LIVROS DE JOÃO ANTÔNIO E CONTOS QUE OS CONSTITUEM}

MALAGUETA, PERUS E BACANAÇO (1963)

Contos gerais

Busca

Afinação da Arte de Chutar Tampinhas

Fujie

Caserna

Retalhos de Fome numa Tarde de GC

Natal na Cafua

Sinuca

Frio

Visita

Meninão do Caixote

Malagueta, Perus e Bacanaço

\section{LEÃO-DE-CHÁCARA (1975)}

Três contos do Rio

Leão-de-chácara

Três Cunhadas - Natal de 1960

Joãozinho da Babilônia

Um conto da Boca do Lixo

Paulinho Perna Torta

\section{MALHAÇÃO DO JUDAS CARIOCA (1975)}

Problema

Mariazinha Tiro a Esmo

Galeria Alaska

Pingentes

Polícia

Carlinhos, o inconveniente

Conto-reportagem

Cais

Especial

Lapa acordada para morrer

Gente

40 Anos de Profissão - Paulo Gracindo

Costumes

Pequena História Matreira da Fila Carioca

Sinuca 
Malhação do Judas carioca

Futebol

É uma revolução

Corpo-a-corpo com a vida

\section{CASA DE LOUCOS (1976)}

Protesto

Olá, Professor, há quanto Tempo!

Comportamento

55 anos de casados

Música Popular

Nelson Cavaquinho

Noel Rosa, poeta do Povo

Costumes

Merdunchos

As Virgens Blindadas do Footing

Futebol

Raul, meu Amor

Uma Banana para os Valentes

Gente

A Morte e as Vidas de Sérgio Milliet

Habitação

Testemunho de Cidade de Deus

Vida

A morte

Drama

Casa de Loucos

CALVÁRIO E PORRES DO PINGENTE AFONSO HENRIQUES DE LIMA BARRETO (1977)

\section{LAMBÕES DE CAÇAROLA (1977)}

Ô, COPACABANA $(1978,2001)$

Ô, Copacabana

Viva o Bicho

Carioca da Gema

(os dois último contos publicados apenas na reedição de 2001)

\section{DEDO-DURO (1982, 2003)}

Tony Roy Show

Dois Raimundos, um Lourival

Milagre Chué

Excelentíssimo

Uma Memória Imodesta no Coração da Pouca Vergonha 
Paulo Melado do Chapéu Mangueira Serralha

Dedo-Duro

Bruaca

\section{MENINÃO DO CAIXOTE (1983)}

Frio

Lambões de Caçarola (Trabalhadores do Brasil!)

Bolo na Garganta

Meninão do Caixote

\section{CONTOS ESCOLHIDOS (1983)}

Afinação da Arte de Chutar Tampinhas

Fujie

Retalhos de Fome numa Tarde de GC

Natal na Cafua

Leão-de-chácara

Joãozinho da Babilônia

Tony Roy Show

Milagre Chué

Dedo-Duro

Bruaca

\section{ABRAÇADO AO MEU RANCOR (1986)}

Guardador

Maria de Jesus de Souza (Perfume de Gardênia)

Publicitário do Ano

Televisão

Abraçado ao meu Rancor

Sufoco

Uma força

Eguns

Amsterdam, Ai

Tatiana Pequena

\section{OS MELHORES CONTOS (1986)}

Bolo na Garganta

Frio

Dois Raimundos, um Lourival

Três Cunhadas - Natal de 1960

As Virgens Blindadas do Footing 
Mariazinha Tiro a Esmo

Olá, Professor, há quanto Tempo!

Testemunho de Cidade de Deus

Merdunchos

A Lapa Acordada para Morrer

Visita

Paulinho Perna Torta

Paulo Melado do Chapéu Mangueira Serralha

\section{ZICARTOLA (1991)}

No Morro da Geada

Feira

Santas Teresas

Zicartola

Querida Praça Quinze XV

E que Tudo mais Vá para o Inferno!

Vibrações, Poeiras e Pulgueiros

\section{GUARDADOR (1992)}

Tatiana Pequena

Retalhos de Fome numa Tarde de GC

Guardador

Joubert - Maringá

Tuareg

Morre o Valete de Copos

É uma Revolução

PAULINHO PERNA TORTA (1993)

UM HERÓI SEM PARADEIRO: VIDÃO E AGITOS DE JACARANDÁ, POETA DO MOMENTO (1993)

\section{AFINAÇÃO DA ARTE DE CHUTAR TAMPINHAS (1993)}

\section{PATULÉIA (1996)}

Milagre Chué

Sufoco

Malhação do Judas Carioca

Meninão do CAixote

Fujie

Televisão 
Natal na Cafua

Afinação da Arte de Chutar Tampinhas

Paulinho Perna Torta

\section{SETE VEZES RUA (1996)}

Milagre Chué

Flagrante Pequeno da Miniguerra do Metrô

Mariazinha Tiro a Esmo

Busca

Dois Raimundos, um Lourival

Mendigos e Mafueiros

Morro da Conceição

\section{DAMA DO ENCANTADO (1996)}

Meus tempos de Menino

Fera

Almas da Galera

Garrincha Impossível

Pingentes

Antes que o Poeta Fizesse Oitenta anos

Leão de Juba Grande

Joubert - Maringá

Dalton Exporta a Lua Pálida dos Vampiros

Encantador e Lúcido João do Rio

Romancista com Alma de Bandido Tímido

Ajuda-me a Sofrer

Dama do Encantado 


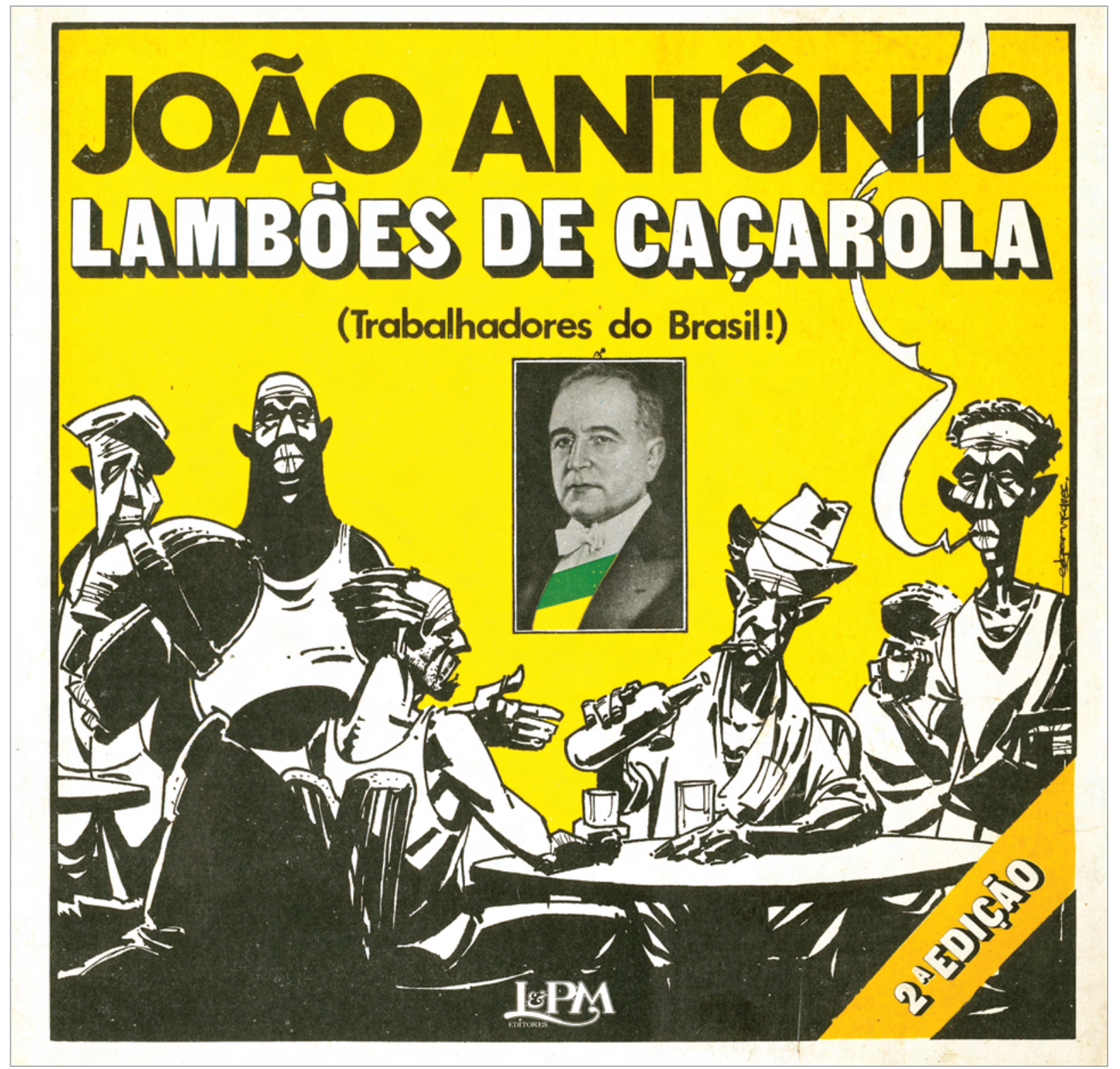

Capa de Lambões de caçarola (Trabalhadores do Brasil!). Porto Alegre: L\&PM: 1977. 


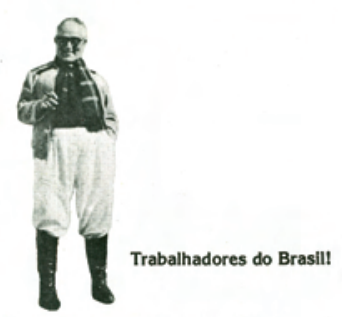

Isto entalado na garganta. E bem. Dofa. Desde o tempo de moleque, a gente no Navio Negreiro. Um
dia, meu velho rebatizou aquele pedaço de Beco da Onça. Cris.

Mou.s. Creio que aquele povo amargue a dúvida e a castração. Gana de cobrança, de forra. Que de um jeito ou outro, querendo empatados. Somos órfáos e viưvos do velhinho. Até agora.

JOÃO ANTONIO
COpacabana, $1 .{ }^{\circ}$ de maio de 1977

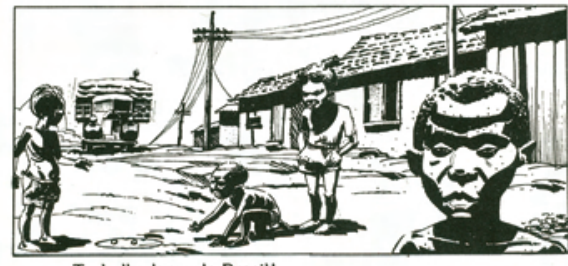

- Trabalhadores do Brasil!

Pé no chåo, barriga de fora, nariz moncoso, cabeça despen. molecada negra passa o dia debaixo do sol, na rua de terra. Remexe, apronta e perturba com carrinho de rolema, papagaio. tudo. Uma misturaç̧o. Nå havendo trocos de brincar tempo de com algum gato ou cachorro. Os moleques, entâo, se espojam na terra fóa da beirada da rua.

Encostou um caminháo das Indústrias Reunidas Francisco Matarazzo para a entrega do açucar em pacotes de meia arroba. empilhavam uns quatro daqueles nas costas, iam ligeiros, ganhan do ritmo, o movimento corridinho. Traquejo. Biceps enormes,

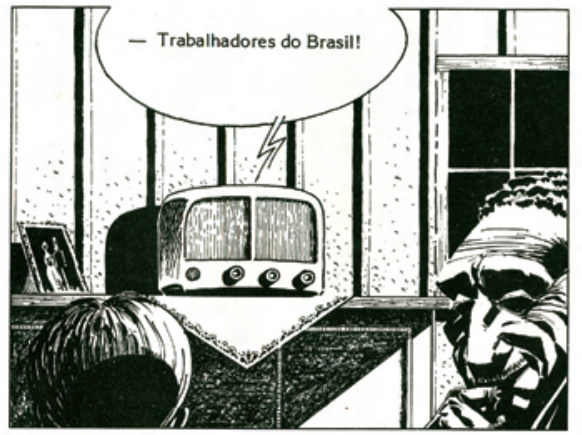
O fanatismo, o fascínio ferviam. Um puxando o outro. Sorriso Baixote, barrigudinho, fotografias nào o traziam de óculos. Era vistoso, simpático. Remexia a gente:
Um dia, baixou em Såo Paulo. A crioulada, a mestiçada do Beco da Onça, foi ver. La defronte à refinaria, num pavilhào. ne Feira das Naçoes Unidas. Hoje, ali se planta um supermagazine. limpinho e sem graça, vendendo de um tudo. De alfinete a carro ne luxo. de rupas

A gente se aprontou. Duanas e becas domingueiras nos varais. ao vento. escovadas, tomaram sol. Fomos de banho tomado sair, Enao os de andar em casa, como nossas maes diziam.

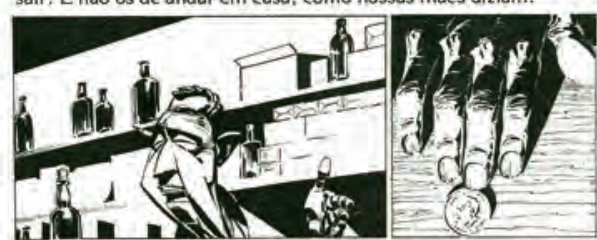

Atolado de lirabalho na vendinha do comeco da Rua Caiovas. um desprendimento esparramado. Entào, alguém poderia perder oportunidade de ver Getúlio? Im cara assim estava bem acima da maioria. Aina nos encabulou!

- Eu vejo ele na moedinha. nova, desconhecida, de ancas fornidas que mexem, indo, vindo e requebrando, os homens desencostam do balcao, vao para a porta do botequ

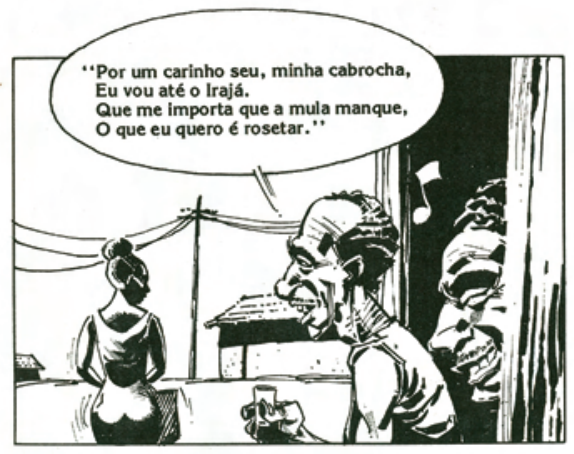

Uns quarenta anos. Nas rodas, esquinas e botequins, nas fábricas, na andança, na rua, meu pai ouviu discussóes sobre ali:

- Gostos e bofetadas sáo diferentes.

$\star \star \star$

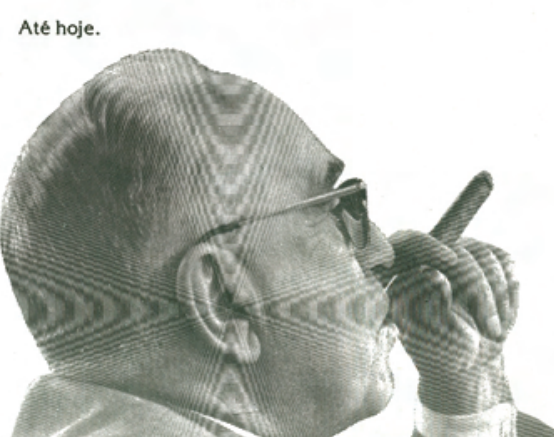

Páginas internas de Lambões de caçarola (Trabalhadores do Brasil!). 


\section{SUMARIO}

Duas Palavras $\ldots \ldots \ldots \ldots \ldots \ldots \ldots \ldots, 11$

Toni Roy Show $\ldots \ldots \ldots \ldots \ldots \ldots \ldots \ldots, 13$

Dois Raimundos,

Um Lourival ...................... 49

Milagre Chué $\ldots \ldots \ldots \ldots \ldots \ldots \ldots \ldots \ldots \ldots \ldots \ldots$

Excelentissimo $\ldots \ldots \ldots \ldots \ldots \ldots \ldots \ldots \ldots, 71$

Uma Memória Imodesta no Coração da Pouca

Vergonha

Paulo Melado

do Chapéu Mangueira Serralha ......... 79

Dedo-Duro $\ldots \ldots \ldots \ldots \ldots \ldots \ldots \ldots \ldots, 131$

Bruaca $\ldots \ldots \ldots \ldots \ldots \ldots \ldots \ldots \ldots \ldots, 161$

O sumário da primeira edição de Dedo-duro (1982) não distingue os contos do autor do texto "Duas palavras", prefácio de Paulo Rónai, e não inclui a "Apresentação", texto de Jorge Amado que vem imediatamente antes do texto de Rónai.

Além disso, a seção "Uma memória imodesta no coração da pouca vergonha" parece se referir aos três últimos contos, mas é possível (como sustentamos no capítulo 1) que diga respeito apenas ao conto "Paulo Melado do Chapéu Mangueira Serralha". 


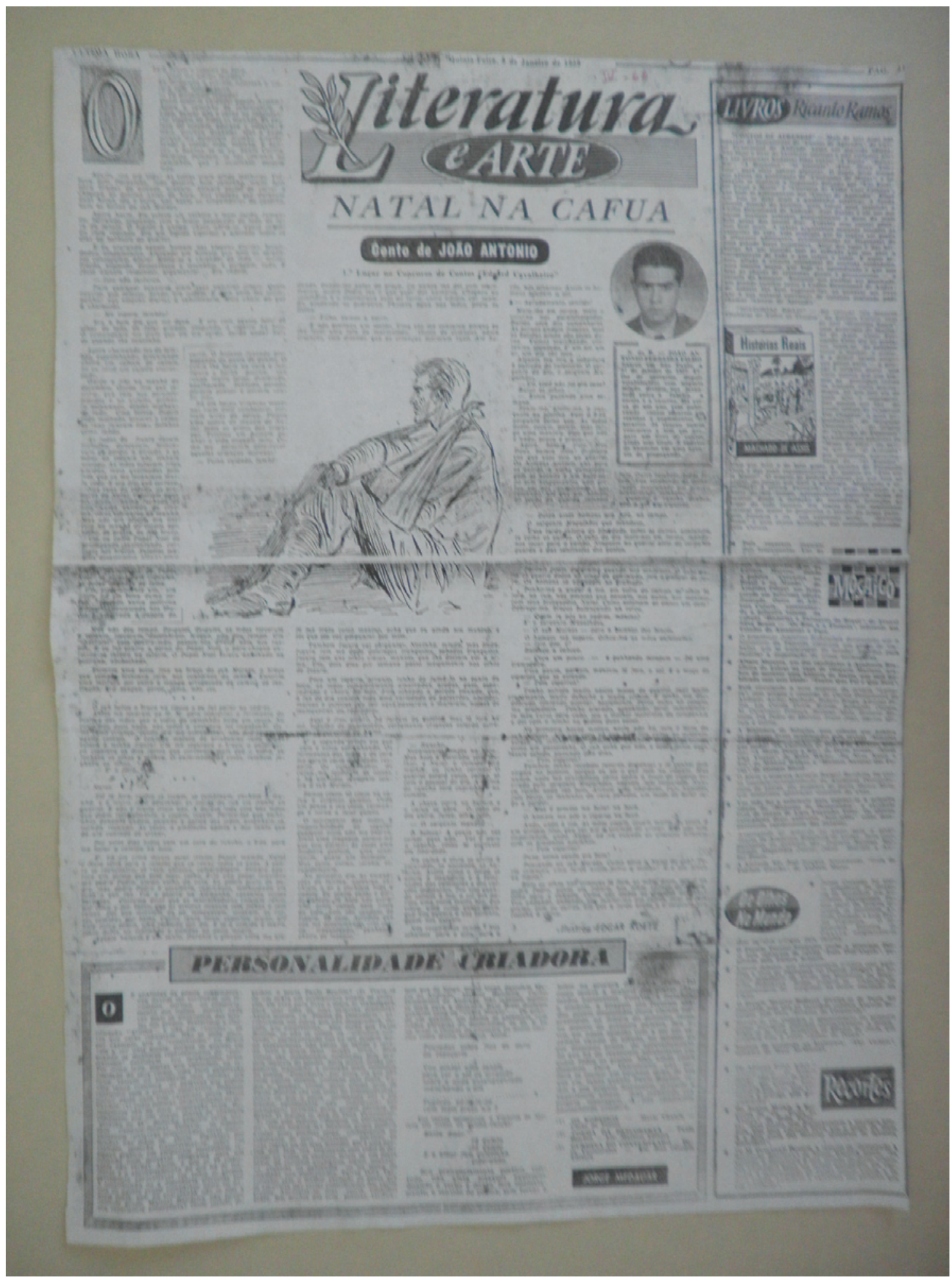

Reprodução da página do jornal Última Hora com a publicação do conto "Natal na cafua", em 8 jan. 1959.

Fonte: Acervo João Antônio, Cedap, Faculdade de Ciências e Letras da Unesp de Assis. 


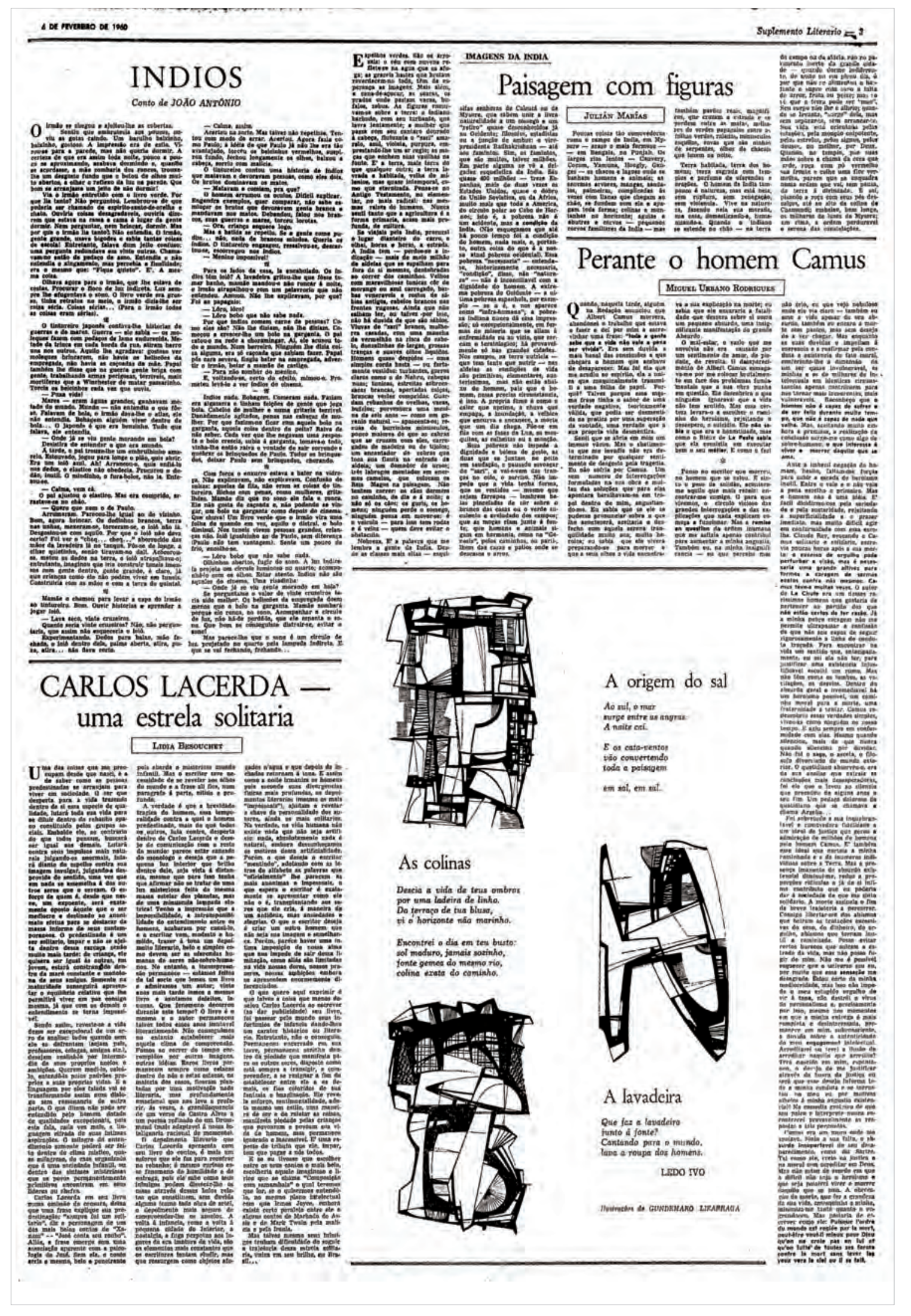

"Índios", um dos primeiros contos do autor, foi publicado no Suplemento Literário de $O$ Estado de S. Paulo em 6 fev. 1960. Fonte: Acervo on-line do jornal.

Renomeado para "Bolo na garganta", foi publicado em Meninão do Caixote (1983). 


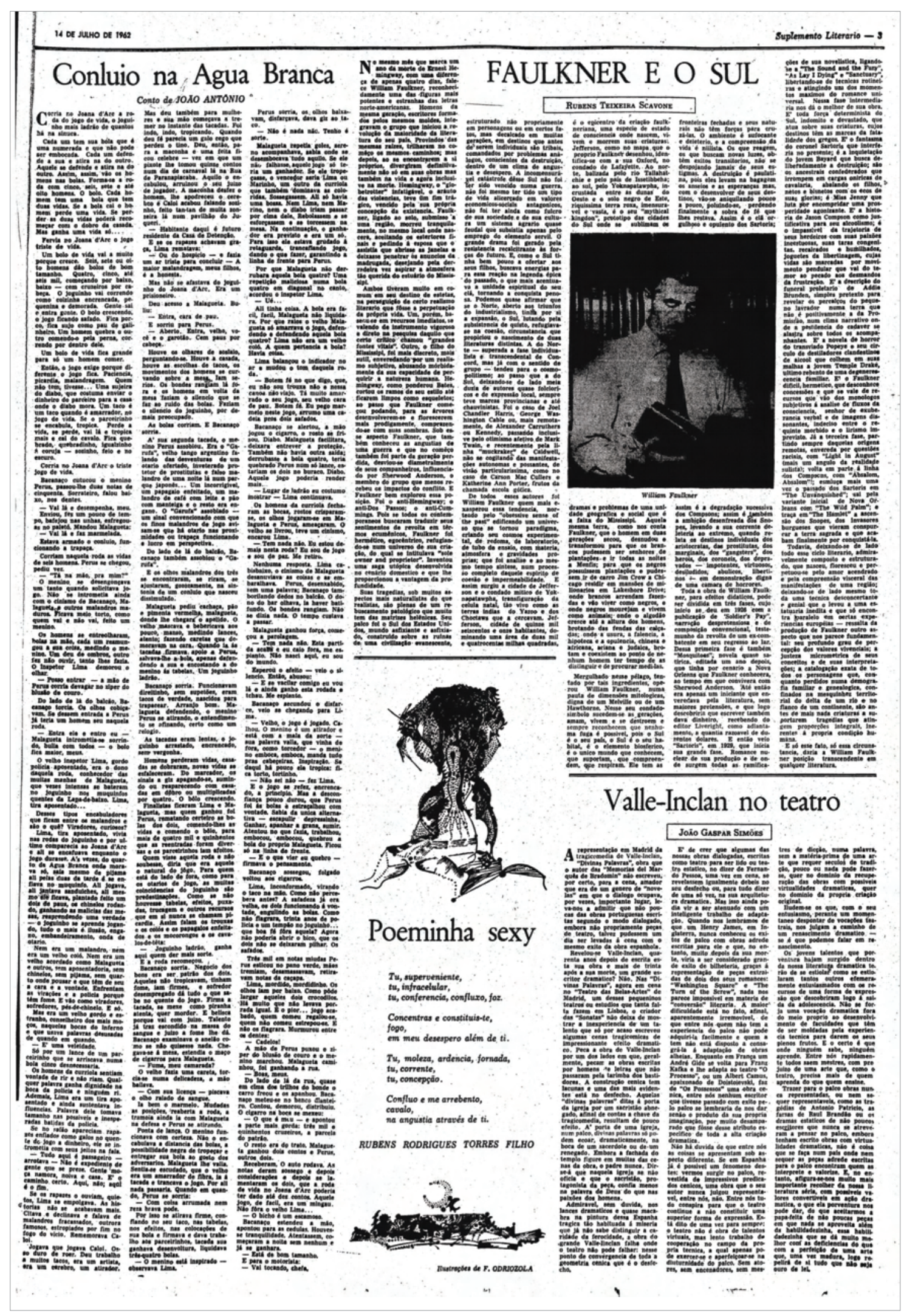

O conto "Conluio na Água Branca” (Suplemento Literário de O Estado de S. Paulo, 14 jul. 1962), depois incluído na versão final de Malagueta Perus e Bacanaço (1963).

Fonte: Acervo on-line do jornal.

Os protagonistas já têm seus nomes definitivos. Curiosamente, no final do mesmo ano o autor publicaria outra parte do conto, no mesmo jornal, com outros nomes para os protagonistas. Ver a reprodução na página seguinte. 


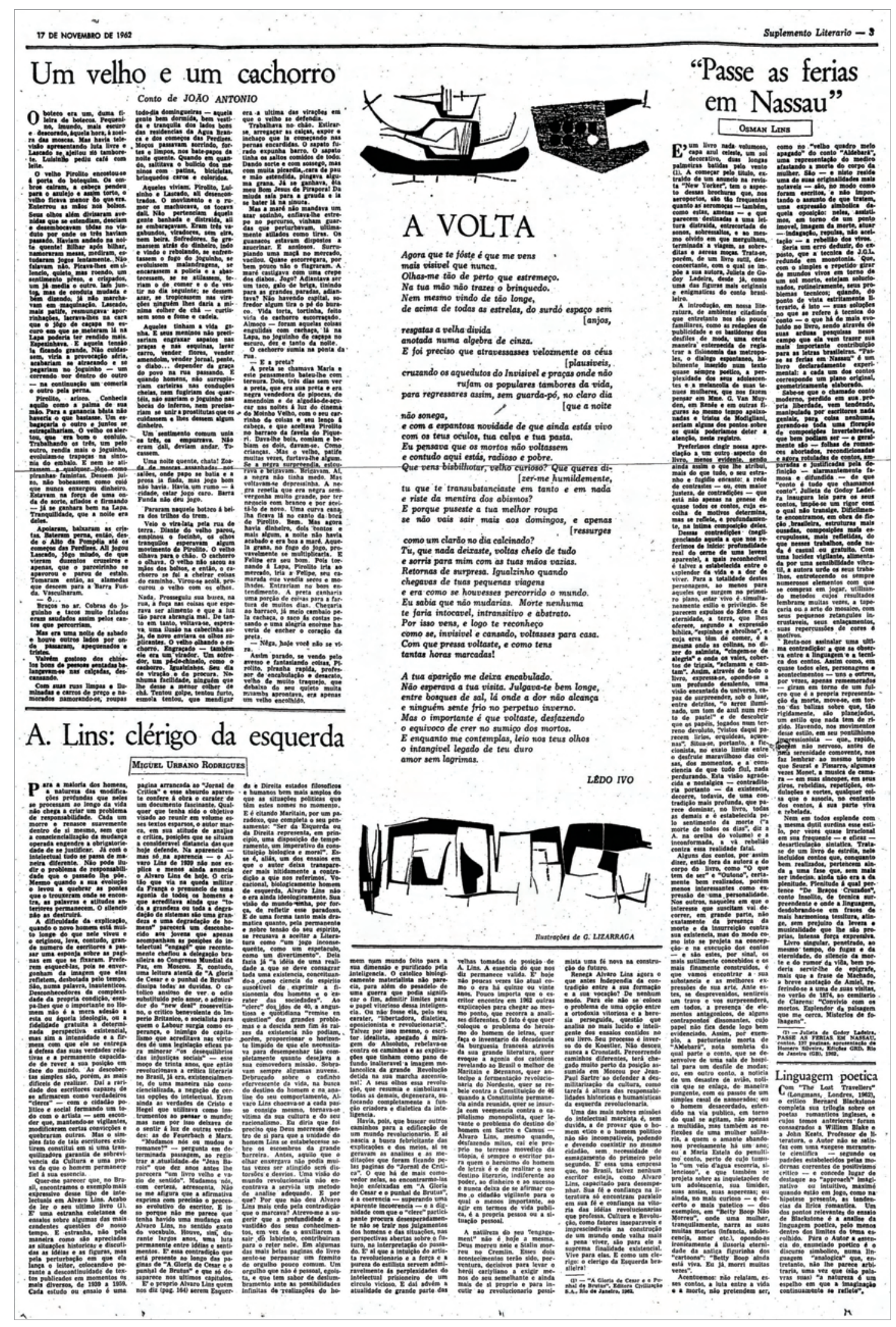

O conto "Um velho e um cachorro" (Suplemento Literário de O Estado de S. Paulo, 17 nov. 1962), depois incluído na versão final de Malagueta Perus e Bacanaço (1963). Fonte: Acervo on-line do jornal.

Aqui, os protagonistas se chamam Pirolito, Luisinho e Lascado, depois renomeados para Malagueta, Perus e Bacanaço. 


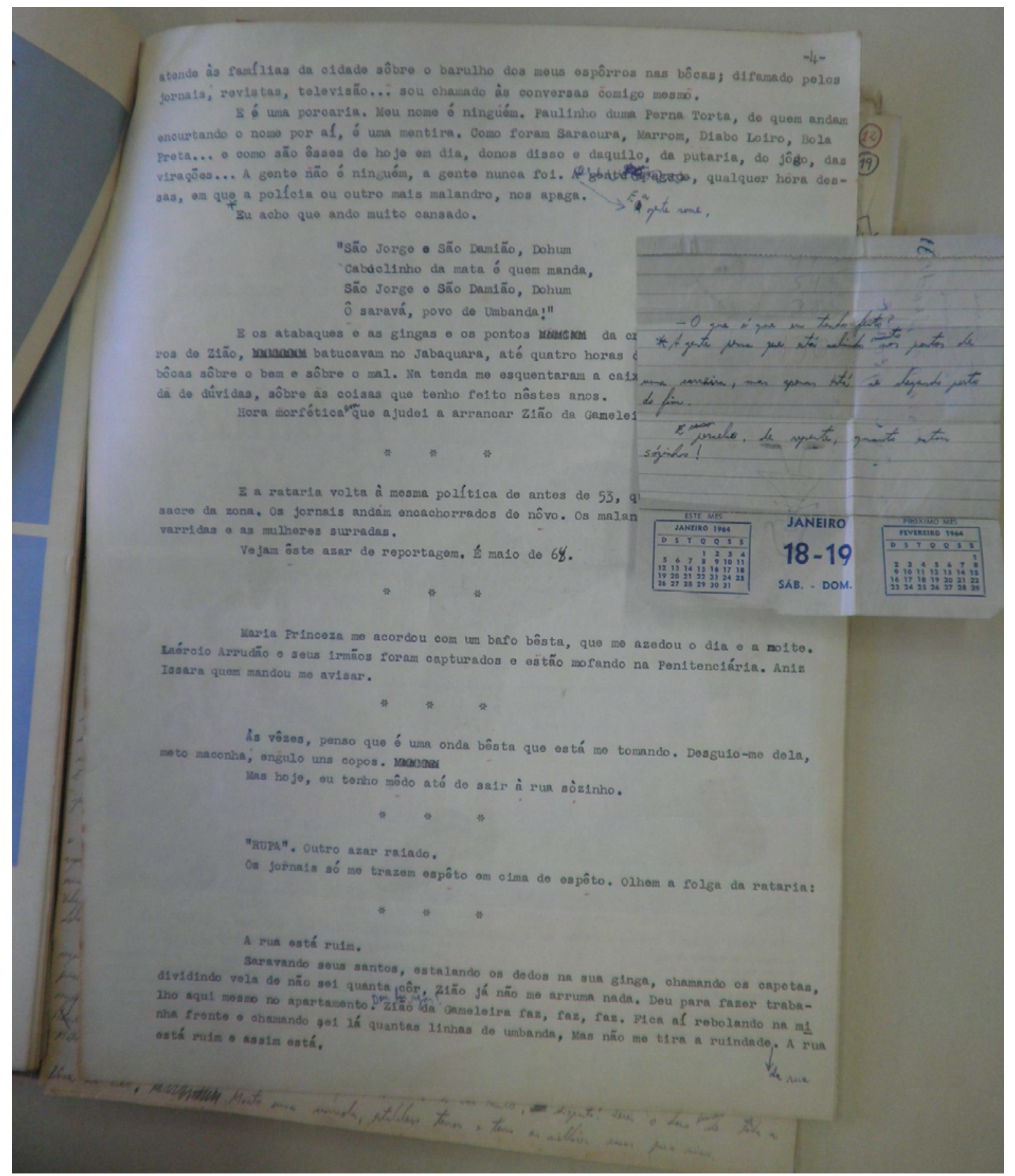

Página do datiloscrito de "Paulinho Perna Torta". O trecho reproduzido acima, do final do conto, traz um adendo manuscrito (colado no centro da página) que foi de fato aproveitado na composição final do conto. Fonte: Acervo João Antônio, Cedap, Unesp de Assis. O trecho manuscrito confirma que há um erro na última edição em livro do conto (como indicado no capítulo 4). Na página a seguir, o trecho em destaque. 

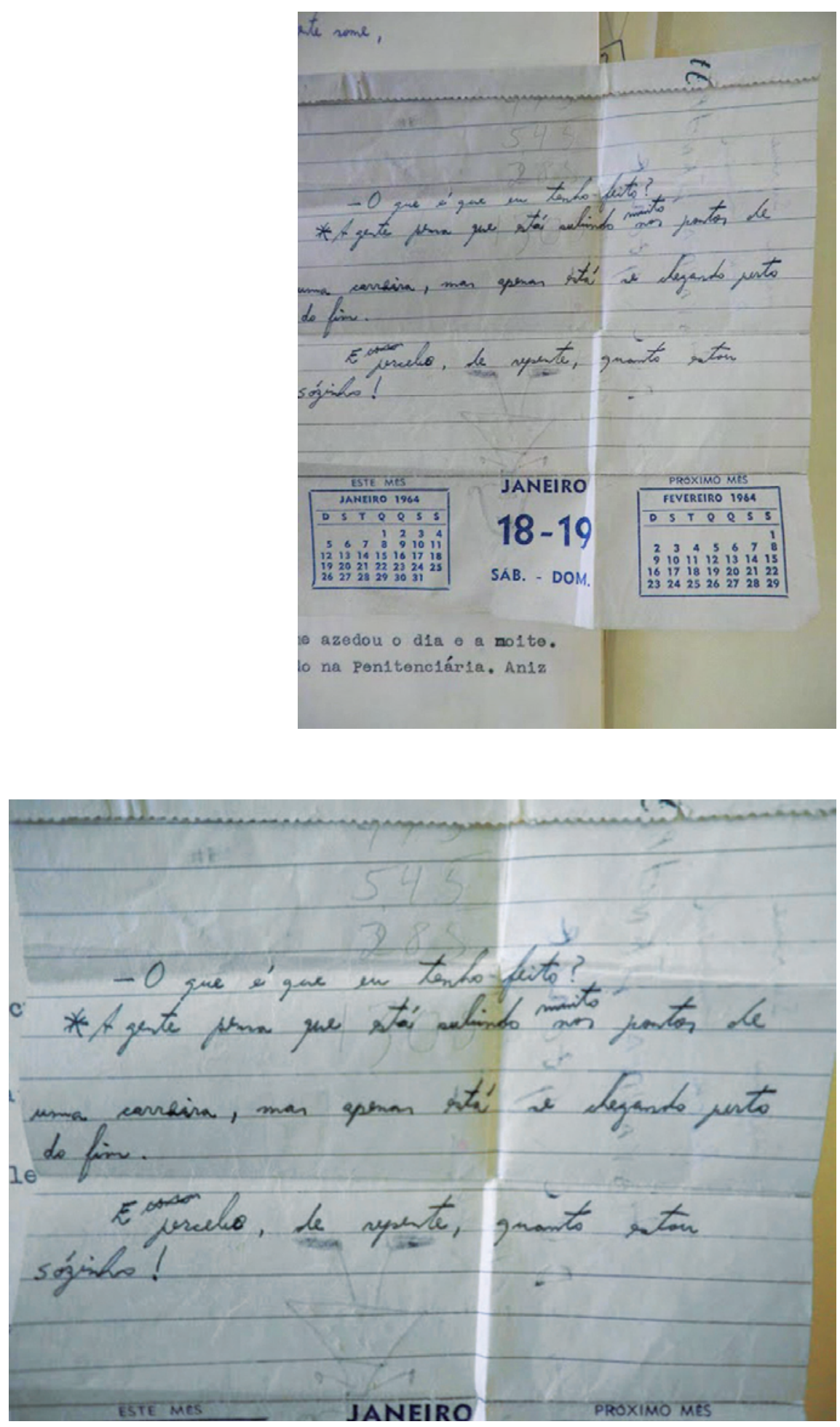

Trecho do conto "Paulinho Perna Torta", em detalhe do trecho do manuscrito do autor. Esta reprodução e o cotejo com edições anteriores do conto comprovam que a palavra correta é "quanto" e não "quando" na frase: "E como percebo, de repente, quanto estou sozinho!". Fonte: Acervo João Antônio, Cedap, Unesp de Assis. 
Faz hoje seis meses que estou na Alemanha.

Afeito às mudangas, tenho vivido em algumas capitais e cidades do meu pais, não por beleza o, sim, por necessidade. Quando parei no Rio, no começo da década de Sessenta, quando o Bio náo tinha aínda quatrocentos janeiros e era na verdade a Cidade Maravilhosa, então, sim, foi um ca so de paixão. Sm minhas andanças, nao sou dado a raclumaçóes fuleíras. Afinal, sempre me movi com as próprias pernas, escrevo com o meu pró prio texto pago as contas que faço. Da mesma forma, dírei que vão posso transferir para a Alemanha o sol que ela não me deu em seis meses, como ainda não posso passar aos alemães um calor humano, ura alegria de viver, uma elezância uma generosidade, um espírito de humor e de esperanca na vida que eles desconhecem. Sequer desconfiam o que seja isso. E não serei eu que $v a ́$ descer às funduras antropológicas explicar eetas lacunas. Ŝma questão de ancestralidade.

A 13 dd fevereiro, sábado de Carnaval, morreu meu pai em São Pau 10. Su soube com dez horas de diferença. Foi uma porrada seca, rente, grossa e redonda como poucas levei em vida. Tive que parar o que estava fazendo - chorar. Passei, a partir dali, a viver dois dramas. A perda de um pai i nesquecivel, basta ler os meus livros para sentir o tamanho de meu pai; a impossibilidade de viajar imediatamente ao Brasil. Bu estava em Berlim e era Carnaval. Berlim não tem Carnaval como não tem outras explosões referentes à alegria e ao entusiasmo espontâneo de viver, como também não tem vôos díre tos para o Brasil. Espécie de ilha metida a capitalista, um capitalismo singular enfiado entre o que se chama esquerda e direita hoje, no mundo atual, um capitalismo rodeado de DDR por todos os lados e, por isso mesmo, ostensi vo. Bu precisaria me mandar para Frankfurt e de lá tentar entrar no Brasil. Mas chegar ao Brasil durante um Carnaval é façanha praticamente inatingivel. Consegui contornar o meu desespêro com telefonemas para minha mãe, dona Ire ne, uma forģa humana de caráter e resistência e Virginio, irmão mais moço dez anos que eu, atual chefe da farilia pequena. B grande, 0 meu pessoal me enche de um orgulho humilde e altaneiro. Ali, naquele meio, ara-se.

Claro que não sou tão incauto a ponto de cometer a ingenuidade, - que me custaria alto en termos de decepgão humana, de contar aos alemães a morte de meu pai.

De uns dias para cá, amijos tệ me telefonado de são Paulo e Rio. Amigos valiosissimos me trazendo solidariedade, um recado de amor. Reconforta.

Estou vivendo uma fase dura. , claro, certas dores não se podem confiar a qualquer um. Só àqueles que as merecem. 1e texto. São como alguns textos. Não basta ao sujeito saber gscrever aque

B, também, é tudo como Deus quer.

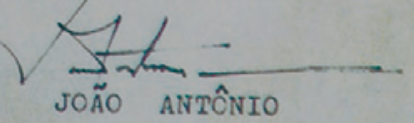

\footnotetext{
Wha tambem tenhor

me dado coniorto e nuita solidar aqui alemães que, com grandeza humana, têm inesquecivel, uma das personalidades Claro, há o vazíc da perda de um pai conheci. Mas há um aprendizado de víla más ricas, humanas e talentosas que já Virginio, mou no dia-a-dia duro de Presidente conheceu meu pai milimetricamente e o a to unico de amor filial. Minha mãe, ditino, me fez uma carta que é um momena dignidade e a coragem daquola mul her.

Deus abenģoe a todas essas boas almas que me confortaram.
}

Cópia de carta escrita por João Antônio por ocasião da morte de seu pai, João Antônio Ferreira, ocorrida em 13 fev. 1988, como indica o texto. Fonte: Acervo João Antônio, Cedap, Unesp de Assis. 